\title{
De functie van de vrijheid van meningsuiting in beide Duitse staten : een rechtsvergelijkend onderzoek in het licht van het Internationaal Verdrag inzake Burgerrechten en Politieke Rechten
}

Citation for published version (APA):

van Rijn, A. B. (1985). De functie van de vrijheid van meningsuiting in beide Duitse staten : een rechtsvergelijkend onderzoek in het licht van het Internationaal Verdrag inzake Burgerrechten en Politieke Rechten. [Doctoral Thesis, Maastricht University]. Tjeenk Willink. https://doi.org/10.26481/dis.19850329ar

Document status and date:

Published: 01/01/1985

DOI:

10.26481/dis.19850329ar

Document Version:

Publisher's PDF, also known as Version of record

Please check the document version of this publication:

- A submitted manuscript is the version of the article upon submission and before peer-review. There can be important differences between the submitted version and the official published version of record. People interested in the research are advised to contact the author for the final version of the publication, or visit the DOI to the publisher's website.

- The final author version and the galley proof are versions of the publication after peer review.

- The final published version features the final layout of the paper including the volume, issue and page numbers.

Link to publication

\footnotetext{
General rights rights.

- You may freely distribute the URL identifying the publication in the public portal. please follow below link for the End User Agreement:

www.umlib.nl/taverne-license

Take down policy

If you believe that this document breaches copyright please contact us at:

repository@maastrichtuniversity.nl

providing details and we will investigate your claim.
}

Copyright and moral rights for the publications made accessible in the public portal are retained by the authors and/or other copyright owners and it is a condition of accessing publications that users recognise and abide by the legal requirements associated with these

- Users may download and print one copy of any publication from the public portal for the purpose of private study or research.

- You may not further distribute the material or use it for any profit-making activity or commercial gain

If the publication is distributed under the terms of Article $25 \mathrm{fa}$ of the Dutch Copyright Act, indicated by the "Taverne" license above,

Download date: 26 Apr. 2023 
De functie van de vrijheid van meningsuiting in beide Duitse staten 



\section{De functie van de vrijheid van meningsuiting in beide Duitse staten}

een rechtsvergelijkend onderzoek in het licht van het Internationaal Verdrag inzake Burgerrechten en Politieke Rechten

\section{Proefschrift}

ter verkrijging van de graad van doctor in de rechtsgeleerdheid aan de Rijksuniversiteit Limburg te Maastricht, op gezag van de Rector Magnificus, Prof.Dr F.I.M. Bonke, volgens het besluit van het College van Dekanen, in het openbaar te verdedigen op vrijdag, 29 maart 1985 , om 16.00 uur

door

\section{Arie Bernardus van Rijn}

geboren te Alphen aan den Rijn in 1956

W.E.J. Tjeenk Willink

Zwolle 
Promotor

Referenten
Prof.Mr C. Flinterman

Prof.Mr Th.C. van Boven (Maastricht) Prof.Mr F.J.M. Feldbrugge (Leiden)

Dit proefschrift is ook verschenen in een handelseditie bij W.E.J. Tjeenk Willink - Zwolle in de Rechts Reeks onder ISBN 9027123373 


\section{Voorwoord}

Klassieke grondrechten $z 1 j n$ de jurldische vertaling van de speelruimte, die ledere mens tenminste nodig heeft on zichzelf te kunnen ontploolen. De taak van het recht is, ervoor te zorgen dat de overheld, het collectlef warvan wij deel uitmaken, deze speelrulmte respecteert. Dit is een verantwoordelifkheid met een zeer grote praktische relkwijdte. Zonder het te beseffen maken wij limmers allen dag in dag utt ontelbare malen van onze grondrechten gebruik.

De overtulgingskracht van de grondrechten is nlet op de laatste plaats te danken an de eenvoud van de filosofte, die aan de grondrechten ten grondslag 1igt, namelijk dat zij de individuele ontploofing dienen. Iedereen hoeft alleen maar bij zichzelf te rade te gaan om te begrijpen, hoe vanzelfsprekend deze vaststelling 1s. Dit proefschrift bevat een pleidooi de fllosofle van de grondrechten eenvoudig te houden. Het w11 waarschuwen voor opvattingen, die menen dat grondrechten andere doelen dienen dan enkel de individuele ontploollng, ook al zijn dat verheven doellen zoals de democratle. Zulke opvattingen brengen de grondrechten onvermifdelljk schade toe en dat mag niet gebeuren. De grondrechten hebben het al moeflijk genoeg in een wereld, waar vrifheld voor het grootste deel van de mensheld, vanwege honger, onderdrukking of on welke reden dan ook, een leeg woord is.

De gevaren, welke onze vrifheld bedrelgen door opvattingen, die de traditionele fllosofle van de grondrechten ter discussie stellen, worden geschetst aan de hand van een vergelijkend onderzoek naar aard en functie van het grondrecht op vrijheid van meningsulting In de Bondsrepubliek Duitsland en in de Duitse Democratische Republlek. Dit onderzoek heb ik gedurende een perlode van twee jaar an de Rheinibche FriedrichWithelme-Universität in Bonn verricht. Mifn dank gaat ut naar de Deutscher Akademischer Austauschdienst, die mij hlertoe in staat heeft gesteld. Dankbaar heb Ik tevens gebrulk gemaakt van de faclliteiten van de Bundesanstalt fir Gesantdeutsche Aufgaben, die is gevestlgd in Bonn en West-Berlifn. Speciale vermelding verdfenen de geweldige loglstleke ondersteuning van Marle-Loulse Coninx, de waardevolle, stimulerende suggesties van Martke Dewina en Martina Conrads en de 
Steun en wriendschap, die $1 \mathrm{k}$ van mijn promotor Rees linterman heb mogen ondervinden. Dit boek draag ik op aan mijn ouders, aan wie th zo veel te danken heb.

Hoewel hun mening niet de mijne 1s, wil ik op deze pllats tevens mijn respect betuigen aan allen, die op grond wan hun persoonliljke ervaringen met Hitlers dictatuur tot de overtuiging alln gekomen dat de grondrechten niet slechts individuele vrijheidsrechten $z 1 j n$, maar bovendien tegenover de democratie een taak te vervullen hebben. Dat doe $i k$ in de persoon van Gerhard Leibholz. Deze eminente jurlst, vanwege zljn. joodse afkomst zelf het slachtoffer van de racistische waanzln van het Derde RIjk geworden, had de kracht na de oorlog naar Dultsland terug te keren on zlch in te zetten voor de totstandkoming van een levenswatbare democratie.

Het onderzoek geeft de stand van literatuur en rechtspraak op 1 oktober 1984 weer.

Ar jen van $\mathbb{R} i j n$. 


\section{Inhoud}

Afkortingen 1 j $1 \mathrm{st}$

XII

1. Grondirechten en democratie

1.1. Inleiding

1.2. De receptie van de westerse opvatting over grondrechten in de Bondsrepubllek Duitsland

1.2.1. De discussie over de betekenis van de grondrechten

1.2.2. Enkele histor ische achtergronden

1.2.3. Een democratische taak voor de vrijheld van menlngsuiting in de Bondsrepubliek?

1.3. De soclalistische opvatting over grondrechten

1.3.1. De receptie van de sociallstische opvatting in de Dultse Democratische Republiek

1.3.2. Een dewocratische taak voor de vritheid van meningsulting in de Dultse Democratische Repub11ek?

1.4. Het internationale onder zoekskader

1.4.1. Het Internationaal Verdrag Inzake Burgerrechten en Politieke Rechten

1.4.1.1. De garantie van de vrljheld van meningsufting

1.4.1.2. Beperkingsmogel1 jkheden

1.4.1.3. Grenzen aan de beperk1ngsmoge 11 jkheden

1.4.1.4. Het controlemechanisme

1.4.2. Het Grondslagenverdrag

1.5. Probleemstelling en opzet van de overige hoofdstukken

2. De democratieche taak van de umijheid van meningauting in de Dutise Democratische Republiek

2.1. Inleidung

2.2 . Het marxistisch-leninistische vritheldsbe$\mathrm{gr} \mathbf{1 p}$

2.2.1. Vrijheld As inzicht in de noodzake11jkheid

2.2.2. De Inhoud van de objectleve wetmatigheden

2.2.3. De soclalistische opvatting van demacratie

2.2.4. Het klassenkarakter van de vrijheid 
2.3. De consequenties van het marxistisch-1en1nistische vrijheldsbegrlp voor de socialistische opvatting over grondrechten

2.3.1. Het klassenkarakter van de soclalistische grondrechten

2.3.2. De betekenis van de socialistische rechtsopvatting voor de groudrechten

2.3.3. De grondrechten als soctalistische persoonli jkheldsrechten

2.4. De vrijheld van meningsulting

2.4.1. Waarheldsvinding

2.4.2. De democratische taak

2.5. Middelen ter verwezenlijking van de democratische taak

2.5.1. Het polltleke strafrecht

2.5.1.1. Art. 6 lid 2 Verf. van 1949

2.5.1.2. Tegen de staat gerichte ophitsing

2.5 .1 .3 . Openbare klelner ing

2.5.1.4. Delicten tegen de vrede en tegen de menseli $\mathrm{jkheid}$

2.5.2. Andere middelen

2.6. De persuritheid

2.6.1. Het vergunningenstelsel

2.7. De vrifheid van informatie 73

2.8. Hor 1 zontale werking

2.9. Conclusie

2.10. Het Internationaa1 Verdrag inzake Burgerrechten en Polltleke Rechten

2.10 .1 . Vergelijking tussen art. 27 Verf en art. 19 ICCPR

2.10.1.1. De kring van adressaten

2.10.1.2. De Inhoud van de vrijheid van meningsuiting

2.10.1.3. De beperkingen

2.10 .1 .4 . Art. 20 ICCPR

2.10.2. Het effect van art. 19 ICCPR op de interne rechtssfeer

2.10.3. De controle op de naleving van art. 19 ICCPR

2.11. Het Grondslagenverdrag

3. De democratiache taak van de vrijheid van meningeuiting in de Bonderepubliek Duitstand

3.1. In leiding

3.2. De conceptie van de strijdbare democratle

$3.2,1$. Achtergronden

3.2.2. De "fretheit1iche demokratische Grundordnung"

3.2.3. Strijdbaarheld naar twee zijden 94

3.2.4. De part1fverboden 96

VIII $3.2 .4 \cdot 1$. Het partijenprivilege 
3.2.5. Verwerking van grondrechten

3.2.6. Het veranderende karakter van de strijdbare democratie

3.2.7. De consequentles van de conceptie van de strijdbare democratie woor de vrijheld van meningsulting

3.3. Nogmaals: het dubbele karakter van de grondrechten

3.4. De vrijheld van meningsulting

3.4 .1 . Het Lüth-arrest

3.4 .2 . Horizontale werking

3.4.3. De wisselwerkingstheorie

3.4.3.1. Het begrip "allgemelne Gesetze"

$3.4 \cdot 3.2$. De rechtsgoederena fweging

3.4.3.3. De andere beperkingen van art. 5 lid 2 GG

3.4.4. De omvang van de garantie van art. 5 lid $1 \mathrm{GG}$

$3 \cdot 4.4 .1$. Wat is een meningsulling?

3.4 .4 .2 . Verelsten aan inhoud en vorm van de meningsulting

3.4.4.3. De zin van de vrijheld van mentingsulting

3.4.5. De "schlechthin konstituterende" betekenis van de wijheid van meningsulting

3.4.5.1. De publieke opinte

3.4.5.2. De twee-componentenleer herontdekt

3.5. Het instituut vr 1 je pers

3.5.1. Rechtspraak

3.5.2. De opvatting van Ridder

3.5.3. De openbare taak van de pers

3.5.4. De institutionele garantie

3.5.5. Kritiek

3.5.6. De stellingname van het Bundeswerfassungsgextcht in het Iicht van de verschillende stromingen

3.5.7. Praktische consequenties van de institutionele garantle

3.5.7.1. De omvang van de garantie

3.5.7.2. De privileges van de pers

$3 \cdot 5.7 .3$. Organisatievrijheld

3.5.7.4. Het recht op informatle

15.4

3.5.7.5. De pluriformiteit van de pers

154

3.5.7.6. Het verschoningsrecht van journalisten

3.5.7.8. De bescherming van persoonsgegevens

3.5.7.9. De behartiging van gerechtvaardigde belangen door de pers

3.5.7.10. Spectale plichten van de pers: de zorvuldigheidsplicht 
3.5 .7 .11 . Het recht op antwoord

3.5.7.12. De colofonplicht

3.5.7.13. De Splegelaffaire

3.5.8. Balans.

3.5.9. De omroepuritheid

3.6. Beperkingen van de vrifheld van meningsutting

3.6.1. Het recht inzake de persoonlijke eer

3.6.1.1. De persoonlijke eer als onderdeel van het per soon 11 jkheldsrecht

3.6 .1 .2 . Persoonlijkheidsrecht en kumstur 1 fheld

3.6.2. Commun1st1sche men1ngsultingen

3.6.3. Neo-nazistische menlngsultingen

3.6.4. Meningsultingen betreffende het thema geweld

3.6.5. Het aanzien van de staat

3.6.6. Militairen en ambtenaren

184

187

195

3.7. Conclusie

3.8. Het Internationaal Verdrag inzake Burgerrechten en Polltieke Rechten

3.8.1. Vergelifking tussen art. 5 GG en art. 19 ICCPR

3.8.1.1. De kring van adressaten

3.8.1.2. De inhoud van de vrijheld van meningsulting

3.8.1.3. De beperkingen

3.8 .1 .4 . Art. 20 ICCPR

3.8.2. Het effect van art. 19 ICCPR op de interne rechtssfeer

3.8.3. De controle op de naleving van art. 19 ICCPR

3.9. Het Gronds lagenverdrag

4. Het karakter van de vrijheid van meningautting: een vergelijking

4.1. De democratische taak van de vrijheid van meningsulting in belde Dultse staten

4.1.1. Premissen voor een vergelijking

4.1.2. Overeenkomst

4.1.3. Versch11

4.2. Het karakter van de vrijheid van meningsulting in de belde Dultse staten als gevolg van haar democratische taak

4.2.2. Bondsrepubliek Duttsland

4.2.4. De vrifheld van meningsuiting als individuele ontplooting en als deel van de objectleve orde

4.2.5. Beperkingen en de democratische taak 
4.3. Het karakter van de vrijheid van meningsulting in het licht van het International. Verdrag inzake Burgerrechten en Polltieke Rechten

4.4. Enkele opmerkingen ten aanzien van Nederland

4.4.1. De stand van de discussie over de grondslag van de vrljheld van meningsuiting

4.4.2. Partijver boden

4.4.3. De individuele antplooilng als enige grondslag

Noten bif hoofdstuk 1

Noten bij hoofdstuk 2

Noten bij hoofdstuk 3

Noten b1j hoofdstuk 4

Literatuurlifst

Rechtspraakregister

Zakenreg1ster

Curriculum vitae 


\section{Afkortingenlijst}

\begin{tabular}{|c|c|}
\hline Ab1. & Antsblatt \\
\hline Abs: & Abschnitt \\
\hline $\mathrm{ADN}$ & Allgemeiner Deutscher Nachrichtendienst \\
\hline $\mathrm{AG}$ & Antsger 1 cht \\
\hline $\mathrm{ACB}$ & Arbeitsgeseczbuch \\
\hline AJIL & American Journal of International Law \\
\hline AöR & Archlv des öffentlichen Rechts \\
\hline art. & artikel \\
\hline artt. & artikelen \\
\hline BAG & Bundesarbeitsgertcht \\
\hline BayBS & $\begin{array}{l}\text { Bereinigte Sammlung des bayerischen Lan- } \\
\text { desrechts }\end{array}$ \\
\hline BG & Bezirksgericht \\
\hline$B G B$ & Bürgerlliches Gesetzbuch \\
\hline BGB 1 . & Bundesgeset $z$ blatt \\
\hline BGH & Bundesgerichtshof \\
\hline BGHSt & $\begin{array}{l}\text { Entscheldungen des Bundesgerichtshofs in } \\
\text { Strafsachen }\end{array}$ \\
\hline $\mathrm{BGHZ}$ & $\begin{array}{l}\text { Entscheidungen des Bundesgerichtshofs in } \\
\text { zivilsachen }\end{array}$ \\
\hline BVerff & Bundeswerfassungsgericht \\
\hline BVerfGE & $\begin{array}{l}\text { Entscheidungen des Bundesverfassungsge- } \\
\text { richts }\end{array}$ \\
\hline BVerwG & Bundesverwa 1 t ungsger icht \\
\hline BVerwGE & $\begin{array}{l}\text { Entscheidungen des Bundesverwaltungsge- } \\
\text { richts }\end{array}$ \\
\hline BW & Burger $1 i j \mathrm{k}$ Wetboek \\
\hline $\begin{array}{l}\operatorname{cog} \cdot \\
\operatorname{csu}\end{array}$ & $\begin{array}{l}\text { Casu quo } \\
\text { Christlich-Sozlale Union }\end{array}$ \\
\hline $\mathrm{DA}$ & Deutschland Archiv \\
\hline DAP & Deutsche Aussenpolitik \\
\hline DDR & Deutsche Demokratlsche Republik \\
\hline $\mathrm{DdU}$ & Dokumente des Unrechts \\
\hline DöV & Die öffentllche Verwaltung \\
\hline DRIZ & Deutsche Richterzeitung \\
\hline DVb1 & $\begin{array}{l}\text { Deut sches Verwaltungsblatt } \\
\text { Deutsche Zeitschrift fü Philosophie }\end{array}$ \\
\hline $\begin{array}{l}\text { DZP } \\
\text { EA }\end{array}$ & $\begin{array}{l}\text { Deutsche Zeitschrift für Philosophie } \\
\text { Europa-Archiv }\end{array}$ \\
\hline ECRM & $\begin{array}{l}\text { Europees Verdrag tot bescherming van de } \\
\text { Rechten van de Mens en de Fundamentele } \\
\text { Vrijheden }\end{array}$ \\
\hline duGRz & $\begin{array}{l}\text { Europäische Grundrechte-Zeitschrift } \\
\text { en volgende }\end{array}$ \\
\hline
\end{tabular}


EdGo

GAOR

GB1.

GB1./DDR

$G C^{*}$

GRUR

GVB1.

$\mathrm{HR}$

HuSt

ICCPR

ICJ-Reports

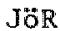

JR

IZ

KG

$\mathrm{KGe}$

Ku

KPD

LG

MDR

m. n.

NDP

$\mathrm{NE}$

$\mathrm{NJ}$

NJ

NJB

NJCM

NJW

NPD

nt.

NTRR

NVU

NWwZ

NWU

NYIT

o.a.

OG

OGSt

OLG

OVG

P.

par. fretheltliche demokratische Grundordnung

General Assembly offlclal Records

Gesetzblatt

Gesetzblatt der Deutschen Demokratischen

Repubitik

Grundgesetz für die Bundesrepublik

Deutschland

Gewerblicher Rechtsschut 2 und Urheberrecht

Gesetz- und Verordnungsblatt

Hoge Raad

Hochverrat und Staatsgefahrdung

International Cowenant on Civil and Polltical Rights

International Court of Justice, Reports of Judgements, Advisory Opinions and Orders

Jahrbuch des öfentlichen Rechts

Jur 1stische Rundschau

Juristenzeitung

Kreisgerlcht

Kammergericht

Kritische Justiz

Kommuntstische Partel Deutschlands

Landgericht

Monatschrift für Deutsches Recht

met name

Neue Deutsche Presse

Meve Folge

Nederlandse Jurisprudentie

Neue Justiz

Neder Lands Juristenblad

Nederlands Juristencomité voor de Mensenrechten

Neue Juristische Wochenschrift

Nattonaldemokratische Partei Deutschlands nowt

Nederlands Tijdschrift voor Rechtsfllosofie en Rechtstheorie

Neder landse Volksunte

Neue Zeitschrift für Verwaltungsrecht

Nederlandse Wolksunie

Nether lands. Yearbook of Internat1onal Law onder andere $(n)$

oberstes Gerflcht

Entscheidungen des Obersten Gerichts in Straf sachen

Ober landesger licht

Oberverwaltungsgericht

paglna ('s)

paragraaf 


\begin{tabular}{|c|c|}
\hline $\mathrm{Rb}$. & Recht bank \\
\hline RGB1. & Retchsgesetzblatt \\
\hline Rndnr. & Rand nummer \\
\hline ROW & Recht in Ost und West \\
\hline RvdW/KG & Rechtspraak van de Week/Rort Geding \\
\hline SED & Elaheitspartel Deutsch- \\
\hline SG & Soldatengesetz \\
\hline $\mathrm{Sr}$ & Wetboek van Strafrecht \\
\hline $\begin{array}{l}\text { St } A G \\
\text { St BG }\end{array}$ & $\begin{array}{l}\text { Stratrechtsanderingsgesetz } \\
\text { Stadtbezlrksgericht }\end{array}$ \\
\hline StEG & Strafrech $t$ siergänzungsgeset $z$ \\
\hline StG & Stadtgericht \\
\hline StGB & Strafgesetzbuch \\
\hline SEPO & Strafprozessordnung \\
\hline StuR & Staat und Recht \\
\hline $\operatorname{Tr} b$. & Tractatenbilad \\
\hline Uas & Unrecht als System \\
\hline Uf 1 ta & $\begin{array}{l}\text { Archiv für Urheber-, Film-, Funk- und } \\
\text { Theaterrecht }\end{array}$ \\
\hline Verf. & $\begin{array}{l}\text { Verfasisung der Deutschen Demokratischen } \\
\text { Republik }\end{array}$ \\
\hline vgl. & vergeli jk \\
\hline VG & Verwa 1 t ungsger tcht \\
\hline VGH & Verwal tungsger $\Perp$ cht shof \\
\hline VN & Zeitschrift für die Vereinten Nationen \\
\hline VWDStRL & $\begin{array}{l}\text { Veröffentlichungen der Verelntgung der } \\
\text { Deutschen Staatsrechtslehrer }\end{array}$ \\
\hline W & Weekblad van het Recht \\
\hline WRV & Welmarer Reichsverfassung \\
\hline WWV & Wet Vereniging en Vergadering \\
\hline $20 B$ & Zivilgeserzouch \\
\hline 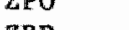 & Livilprozeissorrang \\
\hline ZRP & Ze1tschrift für Rechtspolftik \\
\hline
\end{tabular}




\section{Grondrechten en democratie}

\subsection{Inteiding}

Tussen grondrechten(1) en de democratische staatsvorm bestaat een nauwe band. Zonder de ultoefening wan grondrechten is geen levensvatbare democratie mogelijk en omgekeerd.

Hoewe1 deze vaststelling geen problemen oplevert, roept wel de vraag, of en in hoeverre de samenhang tussen grondrechten en democratle jur 1 dische erkenning verdient, problemen op. Het is van belang bif die vraag stil te staan, omdat daarachter de fundamentele kwestie schuilgaat van de verhouding tussen enerzljds de individu en anderzijds het collectlef, waarvan de ind Ividu dee 1 uitmakt.

In de traditionele opvatting worden grondrechten op de eerste plaats verstaan als Individuele vrijheidsrechten; het zijn afweerrechten tegenover de staat die een ruimte creëren, waarin elke individu zijn vrijheid naar elgen belleven kan gebrulken, en die waarborgen wormen tegen overheidsinmenging(2). De vrijheid wordt niet door de staat verleend, maar gaat aan de stat voorult. De inhoud en de wijze van gebrulk van de grondrechten kan de overheid niet aan regels onderwerpen. De enige functle van de overheld is garanties voor hun respectering te scheppen.

Deze opvatting is ontleend aan het naturrecht. Vanuit het natuurrecht is de idee afkomstig, dat ledere individu is uitgerust met gelijke en onvervreemdbare rechten. John Locke baseerde zich nog op de natuurtoestand, waarin alle individuen gelijk en onafhankelijk zijn; latere fllosofen zochten de bron van de vrijheid in de natuur, in het wezen van de mens zelf(3). Via de twee grote 18 e euwse documenten die aan deze idee praktische ultidrukking gaven, de Amerikaanse Onafhankelljkheidsverklarlng en de Franse Verklaring van de Rechten van de Mens en de Burger, is de natuurrechtelifke opvatting in de westerse wereld tot gemeengoed geworden.

Sinds de rechten van de mens voorwerp van finternationale zorg $\mathrm{zijn}$ geworden is voor het leggen van het ideologische fundament eveneens teruggegrepen op natuurrechtelijke beginselen(4). Behalve de Universele Verklaring van de Rechten van de Mens van 1948 spreken 
ook de preambules van de belde vN-Mensenrechtenverdragen van de "gelijke en onvervreemdbare rechten van alle leden van de wereldgemeenschap" en erkennen "dat deze rechten voortvloefen ult de inherente wardigheld van de menseli jike persoon" $(5)$.

Grondslag van de westerse opvatting is dus een mensbeeld, dat de verwezenlijking van de persoonlijkheid zoekt in de eigen Individualiteit en niet in buiten de individu staande normen.

Wettegenstande de erkenning, dat grondrechten 1nd1viduele vrijheidsrechten $z i j n$, kan niet worden ontkend dat de individuele gromdrechtsuitoefening tegelijkertijd wel degelijk betekenls heeft voor het functioneren var de democratie. Dat blijkt het duidelijkst bij het grondrecht op vrijheid van meningsuiting. Pas door het gebruik maken van dit grondrecht functioneert het democratleche proces, dat is gebaseerd op woord en wederwoord.

Tot zover roept deze constatering geen bezwaren op. Anders wordt het, indien ult de bijzondere betekenis van de vrltheld van meningsulting voor de democratie gevolgtrekkingen op het constitutionele vlak worden getrokken, dat wil zeggien als ten behoeve van de democratie de bescherming of de intensiteft van de bescherming wan de vritheld van menlingsulting van bepaalde voorwarden afhanke11jk wordt gemaakt. Dan namelijk is het gevaar aanwezig, dat het karakter van het grondrecht als afweerrecht wordt arigetast.

Dit onderzoek houdt zich bezig met de vraag, of zo"n ingreep in het karakter van het grondrecht op vritheld van meningsuiting van overheldswege te verantwoorden is, en wel speclaal in het licht van de meningsverschillen tussen oost en west in de internationale mensenrechtendiscussle over het karakter van de grondrechten.

Dok in de socialistische staat bestaat limers een nawe band tussen grondrechten en democratie, $z i j$ het dat het in dit geval een van de traditionele conceptle afwijkende opvatting over grondrechten betreft en dat onder democratie in het soclalisme eveneens lets anders wordt verstaan. De in oosteuropese staten bestaande juridische en ldeologische band tussen grondrechten en democratie, die nu Juist voortvloeit ult de afwljkende wardering van de grondrechten, stuit in het Westen op kritilek. Het is geen overbodige luxe zich expliciet in deze band te verdlepen. Dat kan ons helpen onze elgen ldeëen ten aanzlen van het karakter van de grondrechten scherper te gaan zlen.

Om bovengenoemde reden heeft het onderzoek een rechtsverge 11 jkend karakter. Het gat de aard en functie van 
het grondrecht op vrijheid van meningsulting in de Bondsrepubliek Dultsland en in de Dultse Democratische Republlek (DDR) Ma. De Duitse context garandeert dat het gehele spectrum van de ter discussil staande problematlek aan de orde wordt gesteld. De ldeologlsche tegenstellingen tussen de belde Dultse staten enerzijds en de vele gemeenschappelijkheden en onderlinge afhankel1jkheden anderzijds leveren daarvoor het geschlkte en tevens boelende kader.

1.2. De receptie van de westerse opvatting over grondrechten in de Bandsrepubliek Duitstand

In het westelijk deel van Duitsland vervulden de grondrechten een belangr 1 jke identitelt werlenende functie In de totstandkoming van een nieuwe constitutionele orde na de ineenstorting van het Derde Rljk. Het gewicht, dat de grondrechten in deze nleuwe orde kregen, moest de breuk met het cecente, gruwelljke, mensonterende verleden tot uitdrukking brengen. De grondwet van 1949 opende met een grondrechtencatalogus, voor eens en voor altijd de mens in het middelpunt van de nileuwe orde stellend: "Die Würde des Menschen 1st unantastbar. Sie zu achten und zu schitzen 1 sit Verpflichtung aller staatlichen Gewalt. Das deutsche Volk bekennt stch darum zu unverletallehen und unveräusser11chen Menschentechten als Grundlage jeder mensch11chen Gemelnschaft, des Frledens and der Gerechtigkelt In der Welt" (6). De grondwet heeft met deze canstatering aangeknoopt aan de liberale, op de natuurrechtelijke filosofie teruggaande traditie(7). De kwalltelt van de gxondrechten is ibberpositiv, aldus het Bundesverfassungsgemicht ( 8$)$. Zowel wit de historisch-f110sofische ontwikkeling als utt de historische gebeurtenissen, die tot de opname van de grondrechten in de constituties van de verschillende staten hebben geleid, volgt dat de grondrechten in de eerste platas bedoeld $z i j n$ om de vrijheidsseer van de individu tegen inbreuken door de staat te beschermen; het zijn afweerrechten tegenover de stat(9), ultuloeisel van het beginsel dat de individuele vrijheld principleel onbegrensd 1s, terwijl de bevoegdheld van de staat om in deze seer in te grijpen principleel gelimiteerd is $(10)$.

Daarmee is nog niet alles gezegd. Naast de erkenning van de natuurrechtelijke oorsprong van de grondrechten valt namelifk direct de verblnding op, die in de Westdultse grondwet is gelegd tussen de grondrechten en de democratische staatsvorm. De grondwet heeft een strijdbare democratie in het leven geroepen, die af- 
Gchaffing van de denocratle, zoals in 1933 is gebeurd, in een vroeg stadum moet kunnen verhinderen. De strljubare democratie $1 \mathrm{~s}$ een beschermingsmechanisme ten behoeve van die constitutionele beginselen, die onontbeerlijk zijn voor het proces van democratische beslultvorming. Deze beglnselen wormen tezamen de fre the it iche democratioche Grundordnung, wat ongeveer zoveel betekent als de vrije democratische rechtsorde. Door middel van het beschermingsmechanisme worden pogingen zowel van onderat als van bovenaf, om deze orde ult de weg te rulmen, afgeweerd. Dok het respect voor de in de grondwet geconcretiseerde mensenrechten behoort tot de fundamentele beginselen van de vrije democratische rechtsorde, aldus het Bundesverfassungsgerioht(11), daarmee erkennende, dat zonder grondrechten geen levensvatbare democratle mogelijk is. Aldus vomen grondrechten en democratie in de Bondsrepubliek door widdel van het instrumentarium, dat de strijdbare democratle ter beschlkking stelt, een onverbrekelijke eenheid, welke nlet kan worden opgeheven(12).

\subsubsection{De discusatie over de betekents van de grond- mechten}

Tegen de achtergrond van de verbinding die de grondwet heeft gelegd tussen grondrechten en democratle ls het verklaarbaar, dat in de naoorlogse Westdultse rechtswetenschap een ultgebreide discussie over betekenis en functie van de grondrechten in de moderne stat op gang is gekomen, ondanks de in beginsel duidelijke stellingname in art. 1 GG, dat de grondxechten vanult hun tradltionele betekenis moeten worden begrepen. Deze discussie is getnspireerd door en wordt gevoed vanuit de erkenining, dat de grondrechten behalve alweerrechten tevens objectleve normen zijn, op grond van het feit dat $z i j$ onmisbaar zifn voor de instandhouding van de democratische rechtsorde. Hesse spreekt In dit verband van het dubbele karakter van de grondrechten: "als subjektive Rechte bestimmen und slchern sie den Rechtszustand des Einzelnen in selnen Fundamenten; als (objektive) Grundelemente der demokratischen und rechtsstatichen ordnung figen sie thn in diese ordnung ein, die threrselts erst durch die Aktualisierung jener subjektiwen Rechte Wirklichkelt gewtnnen kann"(13). De subjectief- en objectiefrechtel1jke zljde van de gromarechten staan in wederzljdse afhankelijkheld ten opzichte van elkaar. En daarbly is de subjectlefrechtelijke kant geenszins het oorspronkelijke gederlte. Hesse ontkent namelijk het bestamn van een naturijke wrijheid. De vrijheid ontstaat pas 4 door de objectleve orde( 14$)$. 
De constitutioneel gegarandeerde grondrechten kunnen dan ook nlet eenwowligweg als een erkenning wan een vorstaatitche of naturlijke vrijheld worden gezien. Voor Hesse berust hum existentie op het felt dat zil deel van de positieve staatsorde ultmaken(15). Met andere woorden: pas d6ór hun objectieve normgehalte worden $z i j$ subjectleve rechten, terwijl anderzijds de objectieve orde pas door de garantle van de subjectleve rechten tot werke11jkheld kan worden.

Ter onderbouwling van de objectiefrechtelijke zijde van de grondrechten heeft men voor ex deel kunnen aanslulten aan de tijdens de Weimar-republiek ontwikkelde theorleën van smend en Huber. Zo beschourde Huber de in de constitutle van Welmar opgenomen grondrechten niet wezenlijk als subjectleve rechten, maar in de eerste plaats als objectleve beginselen(16); de grondrechten waren "nicht mehr Ind1ulduelle Frethetten der selbstherrlichen Persönlichkelt, sondern Ordnungsprinziplen im Rahmen eines demokratischen Volksstaates" (17). Maar afgezlen van het bestaan van zulke aanknopingspunten heeft de gedachtenvorming in de Bondsrepubliek haar eigen loop genomen.

Men vroeg zlch af, wat in de huidige tijd het wezen van de grondrechten ultmakt, in het 1 lcht wan de erkenning van de objectiefrechtelfjke dimensie van de grandrechten. Toen bleek, dat de antwoorden die hierop werden geformuleerd niet zonder ultwerking bleven op de rechtspraak van het Bundesverfassungegericht en op de rechtspraktijk, is men tn het begin van de jaren zeventig 1 juer $1 \mathrm{~g}$ begonnen de stand van de discussle te inventariseren en zich te bezinnen op de weg de was ingeslagen. In 1974 heeft Böckenförde de in onloop $z i j n d e$ meningen tot een vijftal grondrechtstheorieën ultgekristaliseerd(18). Zifn indeling is algemeen aanvaard als richtingwijzer door het oerwoud van bijdragen, die het mogelijk makt te begrijpen waar het nu elgenlijk om gat (19). Naat de hiervoor reeds besproken klassieke 11 berale grondrechtstheorle en de sozialstaatliche theorle, die vooral betrekking heeft op de problematiek van de soclale grondrechten en die daarom bulten beschouwing zal blifven, ondat het onderhavige onderzoek zich beperkt tot het vraggstuk van de klassleke grondrechten(20), onderscheldt Böckenförde tussen de institutionele theorie, de Werttheorie en de democratisch-functionele theorle.

De Wertheomie gat terug op de integratieleer van Smend(21). Deze leer vat het staatsleven op als een continu integratleproces op weg maar én belevenis-, cultuur en wardengemeenschap. De tn de grondwet van Welmar gegarandeerde grondrechten zijn in dat integra- 
teproces de toonaangevende factoren. Z1j leggen de fundamentele gemeenschapswarden vast en proclameren een cultursysteem, een Wertghatem, wardoor de mensen in staat worden gesteld zlch tot volk te integreren (22). De grondrechten hebben in deze leer het karakter van objectieve normen a angenomen. Het gevolg kan $21 \mathrm{jn}$, dat de grondrechtel1jke vrijheld wordt tot een vrijheld ter reallsering van de 1 in de grondrechten uitgedrukte warden in het kader wan het door de grondrechten opgerlchte Wertaystem.

Dirig heeft de draad opgenomen en de grondrechtencatalogus van de grondwet van 1949 eweneens geInterprem teerd a1s een Werteystem(23). Centraal in dit systeem staat de tot objectleve rechtswarde geworden zedelljke warde der menselljke wardigheid in art.I GG, het "oberste Ronstltutionsprinzip" van het gehele objecLeve recht(24). U1t de menselijke waardigheld volgt dan het recht op viltheid (art.2 11d 2 GG) en op gelifkheld (art.3 lid 1 GG), warult op hun beurt de af zonder 11 jke grondrechten voortv1oelen( 25$)$.

Het beroep op de grondrechten als Wertbystem wordt gedaan ter legltimerlng van het objectleve normgehalte van de grondrechten. Waar deze warden vandaan komen b11jft in de lucht hangen. Dat bl1jkt ook in het Lith arrest. In dit arrest heeft het Bundesverfassungagemicht de Wertheorie omarma. Het erkent dat de grondrechten nast afweerrechten tevens objectleve normen zijn op grond wan de laconteke constatering dat de grondrechten warden zijn. Tezamen vormen ze een waardensysteem, in het mlddelpunt warvan de zlch binnen de soclale gemeenschap vrij ontplootende persoon $1 \mathrm{ljk}$ held en har wardigheld staat. Het Bundeswerfassungsgemicht beschouwt de grondrechten in hun totalitelt als een objektive Wertordnung (26). De grondrechten worden aldus tot "wertentscheldende Grundsatznormen" (27). Dat kan met zich meebrengen dat de oorspronke11jke functle van de grondrechten op de achtergrond drelgt te raken. Een voorbeeld levert het Mephistoarrest. Daran noemde het Bundesverfassungagemicht de bepaling die de kunsturijheid garandeent (art.5 lid 3 GG) "nach Wortlaut und sinn zunachst elne objektive, das Verhaltnis des Berelches Kunst zum Staat regelnde wertentscheldende Grundsatznorm. Zugletch gewährlelstet die Bestlmming jedem, der in dlesem Berelch tatig lot, efn Individuelles Freitheltsrecht" $(28)$. Zo'n benadering laat de functie van het grondrecht in kwestie als afweerrecht welhast tot een bljkomende factor silnken.

De erkenning, dat het niet alleen meer gat on de garanderlug van bepaalde rechten, maar on de realisering van een Hertordnung, kan zowel viljheidsverculnend als 
vrijheldsbeperkend werken(29).

De grondrechten vormen als objectieve normen een wardensysteem, dat als "verfassungsrechtliche Grundentscheidung für alle Berelche des Rechts"(30) geldt. Dat opent de mogelijkheid tot de erkening van de horizontale werking van de grondrechten in het privatrecht. Aan de andere kant bergt een Wert-georienteerde benadering gevaren in zich. Beschouwt men een grondrecht immers als waarde, den wordt het bepalen van de inhoud van het desbetreffende grondrecht een kwestie van het proberen te vinden van de zin van de in het grondrecht uitgedrukte waarde. Bovendien moet de aldus vastgestelde warde worden ingevoegd in het waardensysteem van de grondrechten. Hoe verhoudt zich bijwoorbeeld de waarde, die het grondrecht op vrijheid van meningsuiting vertegenwoordigt, ten opzichte van het persoon1ijkheidsrecht als waarde? De oplossing kan volgens Böckenförde alleen worden gevonden door correlatie met het contemporaine geestelijk-culturele wardenpatroon. Voor hem zijn de gevolgen dan voorspelbaar: "Dem Einströmen zeitgebundener und gegebenfalls rasch wechselnder Wertauffassungen und Werturtelle in die Grundrechtsinterpretation ist damit -bewusst- die Tür geoffnet"(31). De bescherming van grondrechten wordt in dat geval afhankelijk gemakt wan de vraag of het vrijheidsgebruik met de bestaande waardepatronen correspondeert.

Inherent aan de transformatie van grondrechten tot waarden is tenslotte, dat bij de verwezenliflking ervan een belang ontstaat. Dat kan tot gevolg hebben, dat de staat daaraan een bijdrage dient te leveren. Met betrekking tot de kunsturijheid is die concluste inderdaad getrokken; als "objektive Wertentscheidung für die Freiheit der Kunst" stelt art.5 lid 3 GG de stat voor de taak een vrij kunstleven in stand te houden en te stimuleren(32). De volgende stap zou kunnen zifn ook van de Individu een bijdrage ter verwezenlijking van de grondrechten te verwachten. Geheel ondenkbaar is zoiets niet. Het Bundesverfassungsgericht motiveerde destijds de grondwettigheid van de in 1955 ingevoerde dienstplicht met een beroep op het mensbeeld dat aan de waardegebonden orde van de grondwet ten grondslag 1igt. Dat is niet het mensbeeld van de souvereine individu, maar dat van de persoonlijkheid, die midden in de gemeenschap staat en veelvuldige verplichtingen tegenover die gemeenschap heeft(33). Daarom kan het niet in strijd met de grondwet $z 1 j n$ de burger tot bescherming van deze orde te verplichten. Via een analoge redenering zou ook een bijdrage van de Individu a an de verwezenlijking van het abjektive Wertigstem van de grondrechten verwacht kunnen worden. 
Het objectleve normgehalte van de grondrechten treedt nog duldelifker op de voorgrond in de instltutionele theorie( 34 ). Deze opvatting is in het bijzonder uitgewerkt door Häberle(35). Z1j heeft niets te maken met de door Schmit ontwklkelde leer van de "institutionellen Garantien der Verfassung"(36). Sahmit las in de grondrechtencatalogus van de grondwet van weimar nast de garantie van de individuele vrijheidsrechten tevens de verzekering van een complex van publiekrechtelijke inrichtingen (de elgenlijke institutionele garantles, zoals de gemeentelifke en de universitaire autonomie en de beginselen van het ambtenarenrecht) (37) en de garantie van - privaltrechtelijke- rechtsinstituten $1 \mathrm{~m}$ de zin van typische, traditioneel gegroelde normen- en rechtscomplexen (de zogenalamde instituutsgaranties, zoals het elgendomsrecht en het erfrecht) (38). ook de individuele vrijheidsrechten konden volgens deze onderschelding wel institutionele garanties bevatten, maar dat was volgens Schmitt in concreto alleen bif het eigendomsrecht het geval. In hun algemeenheld bevaten de vrijheidsrechten echter geen Institutionele garanties: "So ist mit der Gewährlelstung der persönlichen Freiheit natirlich kein Rechtsinstitut gewährleistet, denn die Freiheit ist kein Institut"( 39$)$.

Häberite verwijt Schmitt door zijn tegenover elkaar stellen van de vrijheldsrechten en de institutionele garanties, de institutlonele zljde van de grondrechten zelf aan het oog te hebben ontrokken(40). Als constitutleve bestanddelen van de in de grondwet opgerichte rechtsordie - omdat door het vrijheldsgebrulk van allen deze orde zlch steeds opnieuw constitueert(41) - en als deel van het "objektive Wertsystem der Verfassung" (42) hebben de grondrechten nast hun afweerfunctie immers ook een soclale functie(43), namelijk "lebendige Menschen zu einem politischen Gemeinwesen zusammenzuordnen" $(44)$. De grondrechten $z i j n$ niet alleen marar ten behoeve van de individuele gerechtigden gegarandeerd, maar ze zijn tegelijk toestand, verzakellijkt, objectleve normencomplexen voor het gehele rechtsstelsel. In dit verband spreekt Habberle van de institutionele zljde van de grondrechten(45): "Die individuelle Frelhelt bedarf der institutionell gewahrleisteten Lebensverhutulsse, der institutionelien selte der Grundrechte, sowie der diese anrelchernden Normencomplexe. Diese geben thr Richtung und Mass, Sicherhett und Geborgenheit, Inhalt und Aufgabe. Die Spontanltät des Individuums bliebe ohne Normencomplexe ... kungslos. Die individuelle Frethelt bedarf objektiver ordnungen, in denen sie sich bewähren und entfalten kann"(46). En even verder: "Dle Individuelle Frethelt 
Eindet die Fretheit als Institut vor" (47). De vrijheld als instituut treedt de individuele whijheid als objectief gegeven tegemoet. Dat 11 alet zeggen dat Baberle de functle van de grondrechten als afweerrechten geringschat. De individueelrechtelijike en de institutionele zijde staan principieel in een gelijkwaardige verhouding ten opzlichte van elkaar. (48). Maar uit de manter, warop hij de wisselwerking die tussen belde 2 ifden plaatsuindt definieert ("Den Schöpferkraften der einzelnen und der durch dlese erfolgende Aktualisierung von Wertvorstellungen bleibt Raum in den objektiven Rahmen, der durch die Grundrechte als objektive Institute vorgezejchnet ist"(49)) b11jkt, dat Häberle de institutionele zijde toch als het oorspronkelijke gegeven zlet, waraan het individuele wrijheidsgebruik zich dient aan te passen. Het primaat van de institutionele zijde wordt bevestigd door de opmerking, dat beperkingen van de grondrechten als Individuele rechten eventueel geoorloofd zijn in het belang van de grondrechten als instituten, zomis omgekeerd uit de grondrechten als instituten individuele rechten moeten ontspringen terwille van een versterking van de objectieve levensverhoudingen en hum institutionele betekenis(50). Centraal staat dus de instandhouding van de grondrechten als instituten(51). Niet de onbegrensde liberale vritheid is het voorwerp van zorg, maar een geobjectiveerde en institutioneel geordende vritheid.

De consequentie van zo'n benadering is een vergroting van de speelruimte, die wetgever en rechter hebben ter bepaling van de inhoud van de grondrechten. Dat is ook wat Häberle voorstaat. Door de institutionele benadering wil hij berelken, dat wettelijke beperkingen van grondrechten niet langer als ingrepen worden gezien, maar julst als het scheppen van normencomplexen ter concretisering van de vriftheld als instituut(52). Door deze normencomplexen worden de grondrechten in felte pas verwezenlijkt. De in de grondwet gegeven beperkingsmogelijkheden zijn ultdrukking van de Gemeinachaftabesogenheit der grondrechten en behoren in Habertes visie daarom tot het wezen wan de grondrechten(53). Zo kan het objectleve belang van de vrijheldsrechten, bljvoorbeeld voor de democrate, de staat ertoe verplichten om de vrijheid, waar deze in gevaar komt, actief te ondersteunen en te beschermen en de institutionelle Sicherung der presse als elnes der Träger und Vertreter der öffentlichen Melnung im Interesse efner frelen Demokratie" (54) de overheld ertoe brengen ter bescherming van het instituut vrije pers matregelen te nemen om de persconcentratie tegen te gaan. Dat is geen kwestie van beperken, maar van 
concretiseren. Dit voorbeeld legt de zin van de institutionele theorle bloot, namelifk de vrijheid zelf net verloren te laten gaan. Maar het neveneffect kan ziln, dat de vrijheld op een bepaald doel wordt vastgepind, namelifk de realisering van de institutioneelobjectleve zin van de vrltheidsgaranties. Door beperkingen van grondrechten als concretisering van de objectieve zin van het desbetreffende grondrecht te zien kan een te weinig kritische houding in de hand worden gewerkt tegenover beperkingen, die onder de invalshoek van de liberale theorie ontoelaatbaar zouden $21 j n(55)$.

Böckenförde wifst op twee tendenzen, die een institutilonele opvatting kan veroorzaken(56). In de eerste plaats het risico van verstarring, het beschermen van de status qua, dat is de weg van de vrijheld via de institutionele vritheid nar het privilege. In de tweede plaats het inbinden van de individuele vrijheid in het institutionele raamwerk, dat is de weg van de wrijheld via de institutionele vrijheid naar de plicht $(57)$.

Blijft in de Wert theorie en de institutionele theorie de vrijheid als matstaf gelden, zij het waarde-georiënteerd respectievelijk geobjectiveerd, in de democratisch-functionele theorie wordt de vrijheid als maatstaf losgelaten. Matstaf is in deze theorie het democratische politieke proces. De grondrechten worden bezien vanult hun polltieke functle, namelijk als constitutieve factor 1 in het proces van democratische besluttvorming(58). Op de voorgrond staan dan ook die grondrechten, die in dat proces onontbeerlijk $z i j n$, zoals de vrijheid van meningsuiting en het recht tot vereniging, vergadering en betoging(59). De bescherming van deze grondrechten vindt hoofdzakelijk plaats om dit proces mogelijk te maken en veilig te stellen. De vrijheld wordt volledig geinstrumentaliseerd en getransformeerd van vrijheid sec in een vrijheid tot. De inhoud van de vrijheid wordt bepald door haar functie. In deze $11 \mathrm{jn}$ ligt de volgende uitspraak van het Bundesverwaltungagemicht, de hoogste Westduitse administratieve rechter: "Die Grundrechte sind dem Staatsbürger nicht zur freien Verfügung eingeräumt, sondern in seiner Elgenschaft als Glled der Gemeinschaft und damit auch Im biffentlichen Interesse" $(60)$. ook de democratisch-functionele opvatting is geinspireerd door Smend en diens omschrijuing van de grondrechten in hun "integrale, staatshervorbringende, soziale, wertsetzende, also entgegen der 1 iberalen Auffassung nicht nur schrankenzlehende Funktion" $(61)$. Het meest zulver is zif herkenbaar in Ridders democra- 
tisch-functionele interpretatie wan de vrijheid van meningsuiting(62) en in Krïgers 'Allgemeine statslehre'(63). Krigger merkt op dat de definitle van de grondrechten als afweerrechten slechts voor de in de eigenlijke zin van het woord te verstane privesfeer opgaat en dat de grondrechten "Im Berelch der Gesellschaft nicht einen "staatsfrelen", geschweige denn einen staatlich "negativen", sondern im Gegentell elnen Raun der Staatshervorbringung umschrelben"(64). Een impuls voor een functionele benadering vanuit niet- juridische invalshoek heeft de soctoloog Luhman geleverd(65). Hij beschouwt de grondrechten als een institutle in sociologische $z 1 n$. Het gat hem erom de sociale functie van de grondrechten in de moderne samenleving bloot te leggen(6.6): "Dle Garantle von Freiheiten ist nichts als eine Garantle von Kommunikationschancen"(67). Weliswar speelt Luhmanns theorle een geringe directe rol in de actuele grondrechtendiscussie, maar wel heeft hif, door te wijzen op de maatschappelijke functle van de grondrechten, bijgedragen tot de inburgering van de gedachte van de multifunctionaliteit van de grondrechten(68).

De consequenties van de democratisch-functionele opvatting $z i j n$ tweeledig en vergelijkbaar met die van de institutionele theorle. Het functionele aspect kan het recht om van de grondrechten gebruik te maken ontoveren tot een plicht. Krüger heeft daarmee geen moeite: "Der Bürger hat von seinem Grundrecht Gebrauch zu machen. Dass hinter dieser Meinung keine staatiliche Sanktion stehen kann, schllesst nicht aus, dass dle Gesellschaft mit thren elgenartigen Ordnungs- und Zuchtmitteln auf die Beachtung dieser ihrer Meinung hinwirkt"(69). In de tweede plaats is het niet meer onverschi1lig, hoie de vrijheldsrechten worden gebruikt: het politieke gebrulk kan een bevoorrechte positfe claimen ten opzlichte van het gebruik voor privedoeleinden. De stap naar een inhoudelijke beoordeling van het vrijheldsgebruik behoeft van hier niet groot meer te zijn, de grondrechtelijke vrijheld kan verworden tot de vritheid de grondrechten in dienst van de democratie uit te oefenen. Het stellen wan de vrifheid in dienst wan de democratle kan tenslotte leiden tot opheffing van de vritheid zelf. Isensee waarschuwt: "Rousseau hat das unsterbliche, verbluffungswirksame Argumentationsmuster gefertigt: Zunächst wird dile Frethelt des Individuums versprochen, diese sodann gegen die Frelhelt des Kollektivs ausgetauscht, also der 1 iberale Fretheitsbegriff durch den demokratischen ersetzt. Schliesslich wird die Individualfrelheit dazu verurtellt, sich in der demokratischen Ganzheit aufzulösen. Welgert sie sich, so setzt das Ge- 

(70).

Wertheomie, institutionele en derocratisch-functionele theorie vertonen onderling tal van raakviakken. Alle drle exkennen zij het objectieve normgehalte van de grondrechten: behalve afweerrechten tegenover de stat zijn zij tevens elementen van de objectleve rechtsorde. Deze objectlefrechtelijke zijde wordt door elk van de drle theorieen onder een ander aspect be1lcht. De Werttheomie levert een verklarende, legitimerende bijdrage; de institutionele theorle wil de grondrechten als objectieve beginselen versterken door een structureel kader; in de democratisch-functionele opwatting worden de grondrechten wanwege hun objectieve nor formeerd. Onder de indruk van de prominente rol, die de objectlefrechtelijke zijde wan de grondrechten speelt, spreken Friesenhahn en Rupp van een "Wandel des Gr undrechtsverständnisses" $c . q$ * "Wandel der Gr undrechte"(71). Rupps elfgen opmerking dat "dle crundrechtswerbirgungen der Verfassung ... primär objekt1vrechtliche Normen"( 72 ) 21 jn geeft Inderdaad aanleidlng tot deze veronderste11ing. 06senbihl(73) merkt echter op, dat de grondrechten in beginsel niet anders worden ultgelegd dan vroeger; zoals voorheen blijven zij in eerste instantie afweerrechten. Het is niet de bedoe1ing van de nleuwe stromingen dit afweerkarakter op te heffen, maar veeleer de grondrechten met nieuwe dimensies te verrifken ten einde hun effectiviteit te vergroten, te optimaliseren. Dat ook zon verrijking gevaren in zlch bergt is in de literatuur ondertussen ultvoer lg uiteengezet. Zowel een waarde-georiënteerde als een institutionele en een functionele benadering bergen - elk op haar eigen wijze - het risico in zich dat aan het afweerkarakter van de grondrechten afbreuk wordt gedaan. Desondanks vindt het voorstel, de grondrechten uitsluitend als afweerrechten te beschouwen en voor wat betreft hun betekenis als objectieve normen (die niet wordt ontkend) te vertrouwen op het vrije spel dex matschappelifke krachten, geen luide echo. In een groot deel van de aan de grondrechten gewijde verhandelingen, die sinds het midden van de jaren zeventig zijn verschenen(74) wordt dan ook naarstig verder gespeurd naar een oplossing voor een vernuftig evenwicht tussen subjectief- en objectiefrechtelijke zijde van de grondrechten, zonder dat een van beide kanten te kort kont. 
Voor een goed begrip van de kwaliteit van de discussie $21 j n$ enkele kanttekeningen van historische aard op hun plaats. De Iichtvoetigheid, waarmee in de discussie door de Westduitse staatsrechtsgeleerden met het karakter van de grondrechten wordt ongesprongen, berust niet alleen maar op de zorg voor de prille democratie. $Z 1 j$ wordt tevens vergemakkelijkt door het feit, dat in Duitsland tot het einde van de Tweede Wereldoorlog nooit een grondrechtentraditie zoals bijwoorbeeld in de Verenigde Staten en Nederland heeft bestaan, noch in het denken, noch in de praktijk van het staatsbeste1. De jonge Biondsrepubliek beschikte derhalve niet over een historisch gegroelde vanzelfsprekende aanvaarding van de grondrechten als individuele vrijheidsrechten. Als er al lets historisch gegroeid was, dan hoogstens een diep geworteld bewustzijn, dat grondrechten de staat aangaan. De geschiedenis van de grondrechten in Duitsland $พ 66 \mathrm{r} 1933$ heeft er zeker toe bijgedragen dat het dubbele karakter van de grondrechten in de Bondsrepubliek vrijwel als een onwrikbaar gegeven wordt geaccepteerd.

Ter legitimatie van het dubbele karakter van de grondrechten in de Bondsrepubliek wordt in Westdultse besprekingen nogal eens gewezen op de politieke functie van de vrijheidsrechten in de geschiedents van andere staten, met name Engeland en de Verenigde Staten. Gesteld wordt, dat de grondrechtengaranties in die landen tot doel hadden de deelname aan het politleke leven mogelijk te maken en dat het beroep op de natuurrechtelijke oorsprong van de grondrechten slechts diende als ideologische ondersteuning van concrete polftieke eisen (75). Men wijst erop, dat het historisch niet juist is de grondrechten ultsiluitend als afweerrechten te beschouwen, maar dat ze tevens steeds bewust als "Mittel weitgreifender Verfassungspolitischer Zielsetzungen" hebben gediend en dus een ordnungepolitische component bevatten(76). Gewezen wordt met name op de Virginia Bill of Rights, die een bijzondere rang inneemt vanwege het felt, "dass die aus einem einheitlichen naturrechtlichen Ansatz heraus unveräusserliche Rechte vor und im Staat anerkennt, dass die aus diesen durchgängig Individualistischen Ansatz sowohl Freiheiten des Einzelnen als auch Grundprinzipien der staatlichen ordnung, nathmlich die Volkssouveränität und dle Gewaltentellung, ableltet" (77).

of uit de ontwikkelingsgeschieden is van de grondrechten in West-Europa en Noord-Amerika het dubbele karakter van de grondrechten Inderdaad blijkt, kan hier in 
het midden porden gelaten. In Duftsiland in leder geval waren de grondrechten tot 1918 noch het een noch het ander. Z1j werden noch als afweerrechten noch als leidende beginselen wan de staatsorde beschouwd. Deze andersgeaarde ontwikeling hangt naw samen met de orstandighefd, dat de grondrechten in Duitsland niet zijn ontstaan in verbinding met een burgerilifke revolutie en niet als grondslag van een nieuwe democratisiche orde hebben gefungeerd(78).

In de Duitse staten bleef ook na het napoleontische tijdperk de op het beginsel van de souvereiniteit van de vorst gebaseerde staatsorde voortbestaan. Weliswaar bestond er een burgerlijke beweging, die streed voor politleke emancipatie en grondrechten, zich baserend op natuurrechtelijke postulaten, maar het lukte haar niet deze eisen kracht bij te zetten. Zelfs de tijdens de revolutie van $1848 / 49$ in de Paulskirche te Frankfurt opgestelde grondrechtencatalogus als grondslag voor een nieuwe polltieke en sociale orde(79) bleek nlet meer dan een intermezzo te zijn. Het burgerlijke emanclpetiestreven eindigde definltief met het ontstaan van het Duitse Keizerrijk in 1871. De burgerlijke klasse werd met succes ingekapseld in de statsvorm van de constitutionele monarchle. Een staatsvorm, waarin alle macht van het volk uitging, maakte geen kans. Wel had in de loop van de negentlende eeuw een modificatie plaatsgevonden in die $z 1 n$, dat onder de groelende invloed van het constitutionalisme het principe van de souvereliniteit van de vorst had plaatsgemaakt voor het beginsel van de staatssouvereiniteit. Dat hield in, dat niet langer alle macht bij de vorst berustte, maar bij de als rechtspersoon opgevatte staat. Onder deze formule werden bepalde bevolkingsgroepen betrokken bif de ultoefening van het staatsgezag, echter zonder dat het volk de souverein werd. De vorst bleef het hoogste milsorgaan van de staat. Aan hem werd de normatieve kracht ontleend van de wetten, die door de cooberatie van de vorst met de tot de besluitvorming toegelaten bevolkingsgroepen waren totstandgekomen ( 80$)$.

Net als in absolutistische tifden was het ook met het princlpe van de staatssouvereiniteft niet verenigbar de grondrechten als natuurlifke, voretadtiche rechten te beschouwen. De entge legitimatiebron kon immers slechts de onpersoonlijke staat (zoals vroeger de vorst) $z i j n$. Individuele rechten werden derhalve door de staat verleend. 21j waren niet meer dan een bepaa1de concessie van de overheid aan de individu, reflexrechten, "da jedes Recht seiner objektivitat nach nur elne Konstituante der staatlichen Ordnung ist"(81). 14 Zo verklaarde Laband, een van de meest gezaghebbende 
statsrechtsgeleerden tijdens het Dultse kelzerrijk, grondrechten tot normen voor het staatsgezag, de het staatsgezag zichzelf gaf; zij stelden grenzen aan de machtsuitoefening van de overheid, garandeerden de individu zijn natumlijke vrijheid van handelen in zekere omvang, mat creéerden geen subjectieve rechten van de statsburger(82). Zij waren niets anders dan het zogenaamde rechtsstatsbeginsel van de gesetzmat sige Vemwltung: een verbod tot lingrijpen in de aan de individu verleende vitheid zonder wettellike grondsilag $(83)$.

De grondrechten werden vanuit het perspectlef van de stat als objectieve normen beoordeeld, die de executieve bonden.

Aan deze objectivering van de grondrechten heeft het vruchtbare denkwerk van de negentiende-eevwse Duitse filosofen de nodige ondersteuning verleend. Gevoed door de Aufkzärung, die in de $18 \mathrm{e}$ eeuw had getracht de absolute monarchie te verzoenen met de groelende belangstelling voor de in het naturrecht gefundeerde grondrechten, relativeerde Fichte hun naturrechtelijke oorsprong en definteerde hen als het positieve recht van de staat. Ook wolgens Hegel kan er geen sprake $z i j n$ van natuurlijke rechten, maar slechts van zekere door de staat vastgestelde rechten. Wel erkende hij een persoonlijke vrijheidssfeer; deze stond echter niet tegenover de staat, mar vormde julst de grondsilag van de stat(84). Fichte en Heget leverden de beslifsende bijdrage tot de positivering wan het naturrecht in Duttsiland.

Het is de verdienste van Jellinek de 1 n Duftuland heersende opvatting, dat grondrechten objectleve normen voor het staatsgezag waren, te hebben doorbroken en het subjectieve moment te hebben benadrukt. In zijn werk "System der subjektiven offentlichen Rechte'(85) definieerde hij de grondrechten als subjectieve rechten van de burger.

Jellinek nam als uitgangspunt, dat de mens slechts drager van rechten, dat wil zeggen persoonlijkheld, kan worden doordat hij deel uitmaakt van de staat (86). Uit het wezen van de mens volgt dat een recht tegen de staat niet bestaat.

De mogelijke betrekkingen warin de mens ten opzichte van de staat kan staan plaatsen hem in een serte juridisch relevante situaties. De anspraken die ult deze toestanden voartvioeien noemde Jellinek "subjektive offentliche Rechte"( 87$)$. Hij onderscheidde drie toestanden, dile aan de heerschapplj van de staat grenzen stellen. Behalve de positleve status (de basis voor aanspraken op positieve prestaties door de owerheid) en de actieve status (waruit het recht op het uitoe- 
Fenen van de polltieke rechten in engere zin voortyloelt, zoals het kiesrecht) ls dat de negatieve status: "Dem Staatsutgliede kommt daher ein status zu, in dem er herr $1 \mathrm{st}$, elne statsfreie, das Imperium vernelnende Sphare. Es 1 st die der individuellen Freiheitssphäre, des negativen Status, des status 1 ibertatis, in welcher de stremg individuellen Zwecke durch die frele Tat des Individuums thre Befriedigung fin$\operatorname{den}^{\prime \prime}(88)$.

De rechten wan de negatieve status omvatten de klassleke individuele vrijheidsrechten. Hoewel Jelinek deze dus "subjektlve öffentliche Rechte" noemde staat afjn onschrijwing voor het overige in de traditie van het constitutionele denken. Het betreft hier namelijk niet de erkenning door de staat van vomatatiche, onvervreendbare rechten, maar de toekenning van een staatsvrlje sfeer, een statusverlening door de overheid, wat dus ook de bevoegdheid van de stat impliceert de rechten, die ult deze status voortwloelen, naar belleven te normeren. In het kader van de door het constitutionalisme ontwikkelde scheiding tussem stat en samenleving dienen de grondrechten de realisatie wan een van de politieke macht afgescheiden sfeer, waarin de burger zlin individuele belangen mag nastreven ( 89 ).

Tifdens de Welmar-republlek bleef de grote omwenteling in het denken over de grondrechten uft. Sinds 1918 was de staatsorde formeel gebaseerd op het principe van de volkssouvereindtelt. Deze nieuwe staatsrechtelijke legitimatle, dat alle macht van het volk uitgaat, leed evenwel een kwljnend bestaan(90). De staatsvorm was veranderd, maar de staat als jurldisch fenomeen werd door de staatrechtswetenschap niet anders beschouwd dan tijdens de constitutionele monarchle(91).

In plaats van aan de vorst of aan zichzelf ontleende de staat voorthan zijn gezag dan wel aan het volk, de souvereiniteit werd echter onverminderd als een eigenschap van de staat zelf en ajet van het volk gezien. Het staatsgezag bleef bijgevolg als onbeperkt gelden, niet gebonden an vorgtaatliche rechten(92).

Zo amblvalent als het principe van de volkssouvereiniteit in de praktijk werd omgezet en afgezwakt, zo tweeslachtig was ook de benadering van de grondrechten. De grondwet van Welmar bevate in tegenstelling tot de constitutie van het keizerrijk wellswar een zeer ultgebrelde catalogus van klassieke en saclale grondrechten en ook -plichten, waar dit deel van de grondwet vormie niet de onbetiste grondslag voor de nieuw opgerfchte staatsorde. De heersende leer beschouwde de individuele vrijheidsrechten van de nega- 
Lieve status niet anders dan Jellinek: als een algemene furldische aanspraak op vritheld overeenkomstig de wet, als het princlpe der Gesetmäasigkeit dew Veraxitung (93). Een normatieve binding voor de wetgever an de 1 ineidsrechten bestond niet.

Tegen deze reductle van de vrijheldsrechten keerden zich Smend, Schmitt en Huber. Smend trachte het gehalte van de vrijheidsrechten op te vijzelen door ze in zijn integratieleer te bestempelen als het culturen wardensysteem, waraan de staatsorde hat $z$ in en legitlmiteit ontleent en wardoor de in de stat levende burgers zich tot volk integreren(94). Sehmitt op zijn beurt ging dan wel uit van Jeltineks definitie van de vrijheidsrechten als een staatswrije sfeer, mar hij wees de idee van een door de stat aan de indiwidu toegekende vrijheid af. De mens treedt de staat Immers ult hoofde van een eigen natuur $11 \mathrm{jk}$ recht tegemoet, dat "vor- und uberstaat1ich" is(95). De grondrechtelijke wrijheid, aldus sohmitt, is daarom principleel onbegrensd, terwijl de bevoegdheid van de staat tot normering begrensd is. Dit houdt in, dat een wettelijke normering nooit de inhoud van een vrijheidsrecht kan bepalen, hoogstens bepaalde beperkingen vastlegt. Een grondrecht mag daaron nooit zodanig worden uitgehold dat het in feite opgeheven is. Huber deelde deze opvatting, maar stelde cegelijkertijd vast, dat onder het regime van Weimar de grondrechten praktisch gezien wel degelijk ter dispositie van de staat stonden $(96)$. De Rijkspresident bezat bijvoorbeeld de bevoegdheld (ex artikel $4811 \mathrm{~d} 2$ WRV) de grondrechten buiten werking te stellen. Wat de grondrechten waard waren, bleek meedogenloos aan het elnde van de Weimar-republiek. Door de verordening van de Rijkspresident ter bescherming van volk en staat van 28 februari 1933 en de machtigingswet van 24 maart 1933 werd het lot van de grondrechten definitief bezegeld(97). Tijdens de dictatuur van het Derde Rijk was de afweerfunctie van de grondrechten overbodig geworden. In de ideologie van de national-socialistische staat was een tegenstellling tussen de belangen van volk en stat tmers uitgesioten. Ironisch genoeg was het juist Sohmitt, de grote verded 1 ger van de burgerlifjke wrijheden tijdens de Welmar-republiek, die de nationaal-socialistische machtsovername en de daaropvolgende actuviteiten van het nazi-reglme van een stats- en volkenrechtelifke legitimatie heeft voorzien $(98)$.

Deze korte historische schets makt duide11.jk dat tot na de Tweede Wereldoor $10 \mathrm{~g}$ de grondrechten in Duftsiand mooit constituerende elementen voor de stat zifn ge- 
weest. De grondwet van 1949 heeft 1 h een react le daarop de verblinding tussen grondrechten en democratie expluclet vastgelegd. Een gegeven dat grote invloed heeft op de gedachtenwisseling in de Bondsrepubliek over de functie van de grondrechten. Ult elgen bittere ervarlng weet men hoe onmisbaar grondrechten zijn als voorwarden voor de democratie. Het ontbreken van het element van vanzelfsprekendheid in de nog jonge democratische polltieke culturr draagt er wellicht toe bij dat het noodzakelifk wordt geacht de objectlefrechte11jke zijde van de grondrechten steeds zo nadrukkel1jk ten tonele te voeren, hetgeen des te lichter valt, aangezlen een traditie wan de grondrechten als individuele vrijheidsrechten in het verleden ontbroken heeft, terwijl men wel al lange tijd is gewend aan de ldee wan grondrechten als reflexrechten - "nur elne Konstituante der staatlichen Ordnung" (Laband) -, als culturu - en waardensysteem, waraan de staatsorde haar zin en legitimiteit ontleent (Smend), of als "Ordnungsprinziplen $1 \mathrm{~m}$ Rahmen elmes demokratischen Volksstaates" (Huber). Altljd had de staat wel lets met de grondrechten te maken en zo is het ook in de naoor logse democrat 1 siche Westdultse staatsorde gebleven.

1.2.3. Een democratiache taak voon de vrijheid van meningauiting in de Bandsrepubtiek?

Het is niet toeval11g, dat in de Westduitse discussie over betekents en functie der grondrechten voor de democratie het grondrecht op vrijheid van meningsulting een cemtrale plaats inneemt. De vrifheld van meningsulting is conditio sine qua non voor het functioneren van de democratie. Zonder dit grondrecht kan de democratie niet bestaan. De gehele problematiek, zoals dile hierboven geschilderd is aan de hand van de verschillende theorleën, die Böckenförde onderscheiden. heeft, vindt men derhalve weersplegeld in de rechtspraak van het Bundeaverfassungsgemicht met betrekking tot de vrijheid van meningsulting en de reacties daarop vanult de literatuur. De vrijheid van meningsuiting staat daarom in het middelpunt van het onderhavige onderzoek. Het doel is na te gaan, welke uitwerkingen de erkenning van het objectleve normgehalte van de vritheid van meningsulting heeft op de functie van dit grondrecht als afweerrecht, en in hoeverre tot deze consequenties een bepaalde verplichting van de wrijheld van meningsulting tegenover de democratische staatsworm behoort. Ik noem deze verplichting: de democratische taak van de vrlyheld van mentngsulting. Voor wat betreft de Bondsrepubliek luldt de vraagste1ling dus, of en in hoeverre het grondrecht op vrijheld 
van meningsulting in deze staat een democratische taak dient te vervulien.

Vanwege de omvang van het gebied, dat door dit grondrecht wordt bestreken, is een beperking van het onderzoeksveld geboden. Geen aandacht zal worden besteed an die grondrechten, die weliswar tot de vrijheld van meningsuiting in ruime zin behoren, maar zelfistandige betekenis hebben. Dat zijn het recht tot vereniging, vergadering en betoging. Binnen het berelk van de vritheid van meningsulting in enge $z$ in concentreert het onderzoek zich op de algemene garantie van de vrijheid van meningsuiting en op de persvrijheid. Bij een bespreking van de algemene garantie komt het vraagstuk van de verhouding tussen de beide componenten van het grondrecht ten principale aan bod, terwij1 de bespreking van de persvrijheid een additionele dimensie oplevert doordat zij institutionele en democratisch-functlonele aspecten tot leven brengt. Aan de informatievrijheid, de omroepvrijheid en de filmwrijheid zal hoogstens zijdelings worden gerefereerd.

Repercussies op de garantle wan het grondrecht op vrije meningsuiting in West-Berlijn, die voortvloeien wit de specialle status van deze stad binnen het constitutionele bestel van de Bondsrepubliek, worden in dit ander zoek bulten beschouwing gelaten.

\subsection{De sacialistische opvatting over grondrechten}

In tegenstelling tot de klassieke liberale opvatting ontkent de socialistische conceptie over grondrechten elke natuurrechtelijke oorsprong of vorstaatitiche gelding van de grondrechten (99).

Grondrechten zijn geen aangeboren rechten, maar zlj ontlenen hun gelding aan positleve rechtsnormen, die de verhouding tussen burger en stat in de socialistische samenlewing regelen. Karl Marx legde het klassenkarakter van de zogenaamde mensenrechten bloot. Zoals zij In zijn tijd optraden zag hij ze als rechten van de bekrompen, op zichzelf gefixeerde individu van de burgerlijke samenleving(100) - een voor de eerste helft van de negentiende eeuw warschijnlijk nilet van inzicht ontblote inschatting van de toemalige relkwijdte van de grondrechten. Wel erkende Marx de functie van de grondrechten als instrument In de emancipatiestrijd wan de burgerlijke klasse tegen de resten van de feodale matschappif. Dok tegenwoordig nog wordt door de marxistisch-leninistische leer hun belang voor de ontwikkeling van de mensheid $\mathbb{1 n}$ het toenmalige stadium van de geschiedenis erkend(101). Pas in de huidige fase van de ontwkkeling van de menshedd 
echter, In de overgang van kapltalisme naar socialisre, 1 verwezenlljking van de grondrechten voor het eerst echt mogelijk. Woortvloeiend "aus den Notwendigkeiten der ökonomischen Entwicklung der Gesellschaft und den Moglichkeiten der Diktatur des Proletariats" komt met behulp van de grondrechten het "historisch notwendige Befrelungsprozess der Gesellschaft" tot

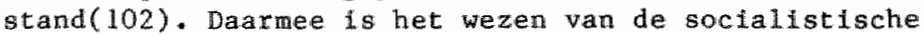
grondrechten omschreven: het zijn geen individuele vijhelistechten, die naar elgen inzicht kunnen worden gehanteerd, maar zij dienen te worden ingezet ten behoeve van de opbouw wan de socialistlsche samenleving, conform de objectleve wetnatigheden van het marxismeleninisme, die, zoals wij nog zullen zien, concreet door de partij van de arbeldersklasse worden vastgesteld. Individuele ontplooiling kan pas plaats vinden wanneer en doordat de soclalistische samenleving tot stand gekomen is.

In de socialistische staten bepalt de verhouding tussen burger en stat de normatieve inhoud van de grondrechten, dit in tegenstelling tot de westerse democratleën, war de traditionele opvatting over grondrechten wordt gevolgd en die met zich meebrengt dat de normatieve inhoud van de grondrechten de verhouding tussen individu en stat bepaalt (103).

In hoofdstuk 2 wordt dieper op de socialistische opvatting ingegaan.

1.3.1. De receptie van de socialistische opvatting in de Dutise Democratische Republiek

In de $\mathrm{DDR}$ hebben de grondrechten hun vorm gekregen conform de socialistische opvatting en zijn zij in dienst gesteld van de opbouw van het socialisme, zij het dat zulks pas langzamerhand $z i j n$ weerslag heeft gevonden in de Dostduitse grondwet. De grondrechten vloeien niet voort uit een autonome bron, maar zijn door de staat verleend(104). Hun uitoefening dient plaats te vinden in het kader van de in de oostduitse grondwet vastgelegde doelen. De opvatting over grondrechten, die de grondwet weerspiegelt, "sucht nicht die vorgegebene Frelhelt des abgesonderten Individuums des Menschen zu postulieren. Ste grundet die Frethelt auf der Verblndung des Menschen mit den Menschen, auf der Gemelnschaft des Handelns der M1tglieder der Geselischaft zum Wohle der Allgemeinheit wie des einzelmen"(105). Net vritheid van de staat, maar vrijheid in de stat is de maxime. In de DDR zijn de grondrechten voor de burger leldraden, hoe hij(106) zich in de samenlewing dient te gedragen. 

meningowiting in de Duitse Democratische Republiek?

Dat geldt ook voor de vrijheid van meningsulting. Dit grondrecht mag ultsiuitend ten behoeve van de opbouw van de socialistische samenleving worden gebruikt. Individuele betekenis heeft het slechts als uitvlaeisel van deze taak doordat het, "wie alle Grundrechte der Verfassung, der Stärkung und Welterentwicklung der sozialistischen Persönlichkeit dient"(107). In aanmerking genomen, dat het marxisme-leninisme onder democratie iets anders verstaat dan de westerse staatsleer, kan men stellen dat de vrijheid van meningsuiting een verplichting tegenover de socialistische democratie heeft en dat deze verplichting zelfs tot het wezen wan het grondrecht behoort. Net als bij de Bondsrepubilek noem ik ook met betrekking tot de DDR deze verplichting: de democratische taak van de vrijheid van meningsuiting. De socialistische opvatting over de grondrechten laat zo weinig ruimte voor twijfels over, dat reeds op deze plaats kan worden gesteld dat de vritheid van meningsuiting in de DDR een democratische taak te vervullen heeft. Hetgeen niet betekent dat daarmee alles gezegd is. In hoofdstuk 2 zal een nauwkeurige balans worden opgemalkt van de ideologische achtergronden van de democratische taak, van de invloed van de democratische taak op het karakter van de vrijheld van meningsulting en van de wijze, waarop de taak in de praktifk functioneert. Toch kan, rekening houdende met het bovenstaande, de vraagstelling voor wat betreft de DDR reeds worden gemodificeerd. De vraag luidt niet: of, maar: in hoeverre en op welke wijze het grondrecht op vrijheld van mentingsuiting een democratische taak dient te vervullen. Dok hier is een beperking van het onderzoeksveld geboden. Het onderzoek concentreert zich op de algemene garantie van de vrijheid van meningsuiting en op de persvrijheid, dit on tot een synchrone afbakening met het Westduitse onderzoeksveld te komen. Wel wordt aan de informatievrijheid aparte aandacht besteed, vanwege de speclale Duits-Duitse problematiek, die hier de kop opsteekt. .

Met de resultaten, die het onderzoek naar de democratische taak van de vrijheid van meningsulting in de DDR oplevert, zal vervolgens de Westduitse garantie van het grondrecht worden vergeleken.

Vila deze vergelijking kan een oordeel worden gevormd over het feitelijke karakter van de vrijheld van meningsufting in de Bondsrepubliek. Kan het grondrecht worden beschouwd als een afweerrecht in klassiek-11berale zin? Zo nee, is de wijze, waarop de vrijheld van 
meningsulting in de Bondsrepubliek dan wel is gegarandeerd, aanvaardbaar in het licht van de internationale mensenrechtendiscussie? Dit zal worden nagegaan aan de hand van het International Verdrag inzake Burgerrechten en Politieke Rechten.

\subsection{Het intemationale onderaakakader}

1.4.1. Het Intemationaal Verdray inzake Burgenrechter en Politieke Rechten

Als referentiekader voor het onderzoek naar de democratische taak van de vrijheid van meningsulting in beide delen van Dultsland fungeert het in 1976 in werklng getreden Internationaal. Verdrag inzake Burgerrechten en Polltieke Rechten(108), ondat het de meest vergaande algemene garantie van de vrijheid van meningsuiting op international niveau bevat en beide staten jurldisch bindt. Nagegaan zal worden, in hoeverre de democratische taak van de vrijheld van meningsulting, voorzover daarvan in de Bondsrepubliek en de DDR sprake Is, verenigbaar is met de ult het Verdrag voortvloeiende rechten en plichten.

Zowel de Bondsrepubliek als de DDR zijn tot het Verdrag toegetreden, zodra zij lid van de Verenigde $\mathrm{Na}-$ ties waren geworden(109). Kort na elkar hebben $21 j$ elind 1973 het Verdrag geratificeerd(110). Aan de onderhandelingen over het Verdrag heeft geen van beide staten deelgenomen. Nadat de voorwarde van het verelste aantal ratificaties van 35 was vervuld trad het Verdrag op 23 maart 1976 in werking(111). Het is een volkenrechtelijke overeenkomst. Door de iawerkingtreding zijn rechten en verplichtingen tussen de verdragspartijen in het leven geroepen.

Op grond van art. 2 IId 1 ICCPR is ledere staat, die partij $1 \mathrm{~s}$ bij het Verdrag, verplicht de in het Verdrag erkende rechten te eerbiedigen en deze aan een leder, die binnen zijn grondgebied verblifft en aan $z i j n$ rechtsmacht is onderworpen, te verzekeren zonder onderscheld van welke aard ook. Lid 2 van hetzelfde artikel verplicht ledere verdragsstaat, langs de door zljin statsrecht voorgeschreven weg en in overeenstemming met de bepalingen wan het Verdrag alle wettelijke en andere matregelen te nemen, die nodig zijn om de In het Verdrag erkende rechten tot gelding te brengen, voorzover daarin niet reeds door bestande wetcelljke regelingen of anderszins is voorzien.

1.4.1.1. De garantie van de vmijheid van meningeuiting 22 In art. 19 lid 1 en 2 ICCPR wordt het recht op vrlj- 
heid van meningsuiting gegarandeerd. Dit onvat het recht een mening te koesteren alsmede de vrijheid on ongeacht grenzen Inlichtingen en denkbeelden te garen, te ontrangen door te geven:

1. Everyone shall have the right to hold oplnions without interference.

2. Everyone shal1 have the right to freedom of expression; this $r$ ight shall include freedom to seek, receive and $\mathbb{I m p a r t}$ information and 1 deas of all kinds, regardless of frontiers, elther orally. in writing or in print in the form of art, or through any other media of his cholce.

\subsubsection{Beperkingsmogetijkheden}

Art. 19 Iid 3 ICCPR laat de mogelijkheld toe dit recht aan bepaalde beperkingen te onderwerpen:

3. The exercise of the rights provided for in paragraph 2 of this article carries with it speclal dutles and responsibilities. It may therefore be subject to certaln restrictions, but these shall only be such as are provided by law and are necessary:

(a) For respect of the rights or reputations of others;

(b) For the protection of national security or of public order (ordre public), or of public health or morals.

Dit derde lid geeft de verdragsstaten een aanzienIljke speelruimte voor een nadere concretisering van de vritheid van meningsulting en de mogelijkheld de relkwijlte van het grondrecht aan te passen aan de eligen nationale behoeften, die in oost en West mogal verschilien.

Vage criteria als het belang van de nationale veiligheid, de bescherming van de openbare orde, de volksgezondheid en de goede zeden bleden hiertoe volop gelegentheid.

Nast de beperklingsmogelijkheid van art. 19 11d 3 sub b ICCPR bestaat tevens in een aantal gevallen voor de overheid de verptichting tot beperking over te gaan. zo wordt de $1 \mathrm{n}$ art. 19 11d 3 sub a ICCPR opgenomen beperkingsmogelijkheid in het belang wan de rechten of de goede naam wan anderen aangevuld door de bepaling van art. 17 lid 1 ICCPR, dat nlemand mag worden onderworpen onder meer aan onwettige aantasting van zljn eer en goede naam. Hierult volgt een a ansprak op overheldsbescherming, als het tot $20^{\prime \prime} n$ antasting komt.

Vooral van belang 1 s echter de verplichting, die voortvloeit ult art. 20 ICCPR. Dit artikel is als beperking vam het recht op wrijheld van meningsutting 
bedoeld, zoals uit zijn plats direct achter art. I9 ICCPR en uit de ontstaansgeschieden is biljkt(112):

1. Any propaganda for war shall be prohiblted by 1.a.

2. Any advocacy of national, racial or religious hatred that constitutes incitement to discrimination, hostillty or violence shall be promibited by Law.

B1J de onderhandelingen over art. 20 ICCPR bestond in westelijke kring de vrees, dat regeringen vooral dit artikel zouden kunnen gebrulken om censur voor alle vormen van meningsuiting in te voeren en oppositionele meningen te onderdrukken(113). Meer dan een derde van de landen, die a am de onderhandelingen deelnamen, watander alle westerse, stenden tegen deze bepaling of onthielden zich van steming(114). Enlge westerse staten hebben on voormelde reden blj ratificatie een voorbehoud ten aanzien van art. 20 ICCPR gemakt c.q. mangekond $1 \mathrm{gd}(115)$. Zo heeft Nederland ultdrukkelijk verklaard de verplichting ex art. 20 ICCPR niet te zullen accepteren(116). Noch de Bondsrepubliek noch de DDR hebben evenwel een voorbehoud ten aanzien van dit artike1 gemakt.

\subsubsection{Grenzen aan de bepenkingsmogetijkheden}

Een zekere grens aan de bevoegdheld c.q. verplichting tot het beperken van de vrijheid van mentingsulting stelt art. 5 lid I ICCPR. Deze bepaling verbledt een staat, groep of persoon om het even welke bepaling van het Verdrag zodanig uit te leggen, dat deze het recht zou inhouden enlge activiteit te ondernemen, die ten doel heeft de in het verdrag erkende rechten en vrijheden te vernietigen of deze rechten en vritheden meer te beperken dan bij het Verdrag is voorzien. De effectleve bescherming, die van art. 5 lid 1 ICCPR ultgaat, hangt ulteraard af van de vraag, wamneer een beperking verder gaat dan bij het Verdrag is voor $z_{i e n}$.

Uit de voorgeschiedenis blijkt, dat art. 5 lid 1 ICCPR in de eerste plats bedoeld is om bescherming te bieden tegen een ultholling van de rechten en vrijheden van staatswege. Wel houdt de bepaling tegelijkertijd het verbod in voor groepen en personen (die bijvoorbeeld fasclstische, nazistische en totalitaire ideologieên aanhangen) on van de in het Verdrag gegarandeerde rechten en vrifheden gebruik te maken met het doel ze op te teifen $(117)$.

Tot zover de bepalingen, dle relevant zljn voor een toetsing van de democratische taak van de writheid van meningsuiting aan het Verdrag. 


\subsubsection{Het controtemeahanisme}

Van belang is ook het controlemechanisme ter bescherming van de in het Verdrag gegarandeerde rechten en viljheden. Het belangrijkste is het comite voor de Rechten van de Mens (art. 28 ICCPR). Dit Comlte bestudeert de rapportage, die de tot het Verdrag toegetreden staten verplicht zijn uit te brengen over de door hen genomen matregelen ter Implementatie van de in het Verdrag erkende rechten, alsmede over de berelkte voruitgang met betrekking tot het genot van die rechten (art. 40 ICCPR). Daarnaast bestaat er een statenklachtrecht (art. 41 lid 1 ICCPR) en een Individueel klachtrecht, dat in een Facultatief Protocol geregeld is(118). Het statenklachtrecht en het individuele klachtrecht bestaan slechts voorzover deze door de afzonderlijke verdragsstaten expliciet erkend $\mathbf{z} \mathbb{1} j \mathrm{n}$.

\subsubsection{Het Grondstagenverdrag}

Het 1 igt voor de hand nog te denken aan de slotacte van Helsinki(119) als een passend kader voor het onderzoek. Dit document komt daarvoor echter niet in aanmerking ondat het niet met zoveel woorden een algemene garantie van de vrijheld van meningsuiting bevat (120) en ook geen wolkenrechtelijke overeenkomst is (121). Wel zal moeten worden stilgestaan bij het in 1972 tussen de Bondsrepubliek en de DDR gesloten Grondslagenverdrag(122), waamee de normalisering van de betrekkingem tussen beide staten werd ingeluid en dat de grondslagen vastlegt op basls waarvan de betrekkingen worden onderhouden. Hoewel dit bilaterale verdrag evenmin een algemene garantie voor de vrijheld van meningsulting bevat alls de slotacte, kent het belangrifke wederzijdse verplichtingen op het vlak van de persuritheld, die met name voor de informatieverschaffing in de DDR van grote praktische betekenis zijn. Een bespreking van het Grondsiagenverdrag is onontbeerlijk woor een beter begrip van de verhouding tussen de twee Duitse staten en de rol wan de vrijheld van meningsuiting daarin.

\subsection{Probleemstelting en opzet var de overige hoofd- Gukken}

Kan in het licht van de democratsche tak ran de vrijheld van meningsulting in de DDR, mutatis mutandis worden gesproken van een vergel1jkbare democrat 1 sche taak van de vrijheld van meningsuiting in de Bondsrepubliek Dutsland en zo ja, is deze taak, gezlen zijn repercussies op het karakter van de vrijheid van me- 
ningsulting, aanvaardbaar met het oog op de meningsverschillen tussen oost en West in de internationale mensenrechtendiscussle over het karakter van de grondrechten?

Uitgaande van deze probleemstelling zljn de overige hoofdstukken als volgt opgezet.

In hoofdstuk 2 wordt de democratische tak van de vrl theld wan menlngsulting in de DDR onderzocht. Speclale aandacht krijgen de 1 deologische grondslagen vam de soclalistische grondrechtenconceptie, ondat pas tegen deze achtergrond adequat kan worden beoordeeld, wat met het begrip democratische taak wordt bedoeld. Het hoofdstuk sluit af met een toetsing van de democratische taak van de vrljheld van meningsulting aan het Internationale Verdrag inzake Burgerrechten en Polltieke Rechten en het Grondslagenverdrag.

Een handilcap bij de bestudering van het soclalistische recht is de beperkte toegankelifkheid tot de jurisprudentie. Het gevolg is, dat verhoudingsgewijs meer nadruk wordt gelegd op de rechtsliteratuur. Deze aanpak laat zich rechtvaardigen met de constatering, dat voor een onderzoek naar het geldende recht in een soclalistisch land de rechtspraak als zelfstandige rechtsbron niet van zulk doorslaggevend belang is als in ons rechtgstelsel. Het leidinggevend monopolle van de Sozialistische Einheitspartei Deutschlands in de DDR staat er garant voor dat de juridische literatur ongeveer even nauwkeurig het geldende recht weergeeft als de ultspraken van de rechterlijke instanties, die tenslotte uit dezelfde bron gelaafd en gecontroleerd worden.

In hoofdstuk 3 komt de vraag aan de orde, of en in hoeverre de vrljheld van meningsuiting in de Bondsrepubllek aan een democratische taak is onderworpen. Vertrekpunt is de in de grondwet neergelegde onverbrekelljke eenheid tussen grondrechten en democratle. ook dit hoofdstuk elindigt met een toetsing aan de hierboven genoemde verdragen.

De in dit hoofdstuk te ondernemen speurtocht concentreert zich op de jurisprudentie van het Bumdesverfabsungegericht, dat als constitutionele rechter niet alleen in de beginjaren van de Bondsrepubliek, maar ook daarna een ongeêvenaarde invloed heeft gehad op het constitutionele leven in het algemeen en op de bescherming en verwezenlijking van de grondrechten in het bifizonder (123).

In hoofdstuk 4 worden de resultaten van de twee voorgaande hoofdstukken met elkaar geconfronteerd. Nadat de premissen voor deze confrontatie zijn geformuleerd zullen eventuele overeenkomsten en verschillen wordea gelocaliseerd en zal een oordeel worden ultgesproken 
over het karakter van de vrijheid van meningsuiting in beide Duitse staten. Vanuit de invalshoek vam het Internationaal Verdrag inzake Burgerrechten en Polltieke Rechten zullen vervolgens ten principale enkele conclusies over het karakter vam de vrifheid van meningsuiting en de relatie tussen dit grondrecht en de democratische staatsvorm worden getrokken. Aan de hand van deze conclusles zal ter afsluiting een uitstapje worden gemaakt naar Nederland en kort worden ingegaan op de discussie over de grondslag van de vrijheld van meningsuiting en het vraagstuk van de partijverboden. 


\section{De democratische taak van de vrijheid van meningsuiting in de Duitse Democratische Republiek}

\subsection{Inleiding}

Ewenals de andere grondrechten is de vijheid van meningsulting in de DDR een grondrecht in marxistischlemintstische $z$ in. Allereerst is daarom de vraag an de orde wat vijheld, onder die invalshoek gezien, eigendijk inhoudt en wat de consequenties van deze visie zijn op de in de DDR gehuldigde opvatting over democratie en grondrechten. Aan de hand van deze informatie kan een beeld worden gevormd onder welke voorwarden het grondrecht op wrijheid van meningswiting in de DDR is gegarandeerd.

De gevonden resultaten worden getoetst aan het Internatlonal Verdrag inzake Burgerrechten en Politieke Rechten en aan het Grondslagenverdrag.

\subsection{Het marxistisch-teninistische vrigheidabegrip}

\subsubsection{Vrijheid als inzicht in de noodaakelijkheid}

De marxistisch-leninistische opvatting over vrijheid is gebaseerd op de door Hegel gelegde onverbrekelijke verbindlng tussen vrijheid en noodzakelijkheid, in diens filosofische verhandeling over de geschiedenis van de wereld ( 1 ).

De wereldgeschiedenis is volgens Heget het zich noodzakelifkerwijs voltreklkende bewustwordingsproces van de menselijke geest. In cegenstelling tot de materie, die haar substantie buiten zichzelf zoekt, behoort thet tot de natuur van de geest $z i j n$ lnhoud niet buiten zlchzelf, maar in zichzelf te zoeken. De geest heeft zichzelf tot inhoud, net andere worden $t s$ zill elgen object. "Dle Materie hat Ihre Substanz ausser ihr; der Gelst dagegen 1 st das Belstchselbtstsein, und dies eben lst die Frelheit. Den wenn lch abhängig bin, so bezlehe ich mich auf ein anderes, das lch nicht bin, und fich kann ntcht ohne solch ein Ausseres sein. Fref bin ich, wenn ich bel mir selbst bin"(2). De geest is vrlj, ondat hij bij zlchzelf is en van zijn ongeving onathanke $1 \mathrm{ijk}$ is.

Maar hoewel de geest "an und fur sich" vij $1 \mathrm{~s}$, is het toch eerst de gewarwording van de vrijheid, die wer- 
kelijk vrij make(3). Vrijheid is het zich $z i j n$ vrijheld bewust $z i j n$. Dit bewustzljn is een onmisbar element van de vrijheid zelf en omdat het tot de natuur van de geest behoort vrij te $21 \mathrm{jn}$ is dit bewustzifn tevens een noodzakelijk element.

De wereldgeschiedenis is de voortgang in dit bewustzijn van de vrifheid, "ein Fortschritt, den wir in selner Notwendigkeit $z u$ exkennen haben ${ }^{\prime \prime}(4)$. Het is een noodzakelijk proces omdat de geest zich met niets anders kan bezighouden dan te willen weten wie hij is, zijn eigen waarheid te leren kennen en te verwezenlijken: "die Weltgeschichte ist die Darstellung des göttlichen Prozesses, des Stufenganges, in dem der Geist sich selbst, seine Wahrheit weiss und verwirklicht" (5). Het doel van dit proces staat vast, namelijk "dass der Geist zum Wissen dessen gelange, was er wahrhaft ist, und dies Wissen gegenständlich mache, es zu einer vorhandenen Welt verwirkliche, slch als objektiv hervorbringe" (6).

Het begrijpen van de noodzakelijke, objectieve wetmatigheden van de wereldgeschiedenis, het bewustwordingsproces van de geest, dat is het inzicht in de noodzakelijkheid. De uitkomst wan het bewustwordingsproces is het besef, dat de geest bij zichzelf is: de vrijheid. Aldus leidt het tngicht in de noodzakelijkheid tot vrijheld; vrijheid is inzicht in de noodzakelijkheid.

Deze vrijheid, het bij zichzelf zijn van de geest, is zoals het woord al ultdrukt een geestelijke vrijheid. De vrijheid beperkt zich tot het begrijpen van het verloop van de wereldgeschiedenis. Consequenties uit deze kennis heeft Hegel niet getrokken. De marxistische kritiek op Hegel richt zich op dit feit, namelifk dat de vrijheld bij Hegel een geestelijke gebeurtenis blijft en dat Hegel geen wegen aangeeft deze geeste1ijke vxijheid on te zetten in concrete vrijheld. ook de marxistisch-leninistische filosofie zlet de geschiedenis als een reeks van objectleve wetmatigheden. Het inzicht in dit proces vormt weliswaar een noodzakelijke, maar onvoldoende voorwaarde voor de vrijheld. Zij moet daarom worden angevuld met de mogelijkheid en de geschiktheld terzake kund $1 \mathrm{~g}$ te beslissen en overeenkonstig te handelen. Het geestelijk monent wordt dus aangevuld met een praktfsch moment. Als dat laatste ontbreekt kan van werkelljke vrl gheld geen sprake aijn. Engels heeft daarover in 'Anti-Dühring" gezegd: "Nicht in der geträumten Unabhanglgkeit von den Naturgesetzen liegt die Frelheit, sondern in der Erkenntnis dieser Gesetze, und in der damit gegebenen Möglichkeit, sle planmässig zu bestimmten Zwecken wirken $z u$ lassen ... Fretheit des Willens helsst 
daher nichts anderes als die Fahigkelt, mit Sachkenntnis entschelden zu könmen. Je freter also das urtell des Menschen in Beziehung auf einen bestimmten Fragepunkt ist, mit desto grösserer Notwendigkeit wird der Inhalt dieses Urtelis bestimt sein; wathrend die auf Unkentnis beruhende Unsicherkeit, die zwischen vielen verschiedenen wil Idersprechenden Entscheidungsmög11chkeften scheinbar wllikülich wählt, eben dadurch thre Unfretheit beweist, thre Beherschtsein won dem Gegenstände, den sle grade beherrschen sollte. Frelheit besteht also in der, auf Erkenntnis der Naturnotwendigkelten gegründeten Herrschaft tiber uns selbst und Uber die atusere Natur" $(7)$.

Aan deze omschrljuing slutt het huidige in de DDR gehuldigde vrithelisbegrip an: "Fretheit ist die auf Wissenschaftllcher Erkenntnis der Gesetzmässigkelten der Natur und der Gesellschaft beruhende Herrschaft der Menschen tiber die Matur und uber die geselischaftlichen Verhältnisse. Sie ist der Fähigkelt der Menschen zu elner auf sachkundiger Entschefdung beruhemden Gestaltung ihrer Lebenswerhaltnisse entsprechend der Erkenntnis der objektiven Gesetzmässigkeiten" (8): Het kemnen van de wetten van natuur en siamenleving is het inzicht in de objectieve noodzakelijkheden. De vrijheld betekent dus niet, dat men kan doen wat men w11. Z1j betekent, dat de mens dient te handelen conform de objectleve wetmatigheden, hij kan zelfs alleen maar zo handelen, angezien niemand zich aan die wetmatigheden met succes kan onttrekken.

In de costduitse 1 deologie makt dit gegeven de mens nog niet tot een willoos wezen. De objectieve wetten van de geschiedenis sluiten het actleve handelen van de mens immers niet uil, maar in: zonder het mensel1jk handelen laten zij zlch niet realiseren(9). Ter verklarling van de verhouding tussen objectileve wetten en actief tandelen wordt veelvuldig naar de naturkundige wetten verwezen: men moet hun werklng kennen, er in de praktijk rekening mee houden, mar ze tegelijk bewust voor zijn doelen in beweging zetten en zo aan de ontwikkeling vorm geven. Te ver voor postdultse verhoudingen gat echter de 1964 door Havemann geformuleerde opvatting: "Fretheit ist nicht in dem Sinne Einsicht In die Notwendigkeit, dass man jewells nur elne elnzige notwendige Sache tun kann. Sondern wahre Frelheit haben wir erst, wenn es fur unser Tun und Lassen eine breite Skala von Möglichkeiten glbt. Je mehr man nicht tun darf, um sa weniger Frethelt. Wir wollen eine Welt schaffen, In der allen Menschen itmer mehr Moglichkelten offenstehen, so dass jeder ganz nach seinem individuelien streben handeln kann, nicht beschnitten und 30 eingeengt durch Anordnungen, Befehle und "Grundsätze""' 
(10).

Zulke vijheidsopvattingen worden niet getolereerd ondat $z i j$ het monopolie van de marxistisch-1eninistische partif ten aanzien van het inzicht in de noodzakelijkheid doorbreken(11).

\subsubsection{De inhoud wan de objeatieve wetmatigheden}

Tot het inzlcht, welke de objectleve wetmatigheden zijn, leldt de in de DDR als onaantastbare waarheid geldende filosofle van het marxisme-lentnisme, die is ontwikkeld door Marx, Engels en Lenim(12). Hoewel het zeker nilet de bedoeling is deze filosofie hier uitvoerig te bespreken, zal kort worden ingegaan op enkele voor het onderhavige thema relevante punten.

De marxistisch-leninistische filosofie is gebaseerd op het axioma, dat het werkelijk zifnde slechts het materiele zijn is en dat het geestelijke een reflex van het nateriële zijn is, een afsplegeling van de materiële werkelifkheid, welke concreet medebepaald wordt door de heersende produkt leverhoudingen. De door Marx en Engels ontwikkelde soclale theorie en historische filosofie ontmoeten elkaar in het zogenaamde historisch-materialisme oftewel de materialistische geschledenisopvatting. De grondslagen hiervoor hebben ze gelegd in hun gemeenschappelifke werk 'Deutsche Ideologie': "Diese Geschichtsauffassung beruht also darauf, den wirklichen Produktionsprozess, und zwar von der materiellen Produktion des unmittelbaren Lebens ausgehend, zu entwicklen und die mit dieser produktionsweise zusammenhängende und vor thr erzeugte Verkehrsstrom, also die bügerliche Gesellschaft in thren verschledenen Stufen als Grundlage der ganzen Geschichte aufzufassen und sie sowohl in ihrer Aktion als Staat darzustellen, wle die sämtichen verschiedenen theoretischen Erzeugnisse und Formen des Bewusstselns, Religion, Philosophie, Moral, etc. etc., aus thr zu erklären und ihren Entstehungsprozess aus thmen zu verfolgen"( 13$)$. Het historisch-materialisme wil dus de sociale drijfveren van het historische proces blootleggen en daarmee de algemene structuur en de ontwikkelingswetten van de menselijke samenleving. Het maatschappelijk leven wordt teruggevoerd tot zljin materiële basis, dat $z i j n$ de produktieverhoudingen, wellke tot stand komen door de verbinding tussen Produktivkräfte (produktiefactoren: mens, grondstoffen, enz.) en Produktionsfaktoren (produktiemiddelen: de hulpmiddelen van de mens bij zijn werk). De produktieverhoudingen worden gekarakteriseerd door de vorm van de arbeid (huisarbeid, fabrieksarbeid) en door een bepalde verdeling van de produkt lemiddelen (grond, 
machlnes), waarult een zekere elgendonsorde en sociale geleding van de matschapplj - de klassenstructurr voortvloelen (14).

In het voorwoord wan zijn werk 'Zur Kritik der politischen oekonomie" (1859) heeft Marx de belangrijkste princlpes van $z$ ijn theorie samengevat: "In der gesel1schaftichen Produktion thres Lebens gehen die Menschen bestlmmte, notwendige, von ihrem Wilen unabhängige Verhälnisse eln, Produktionsverhaltnisse, die elner bestimten Entwicklungsstufe ihrer materiellen Produkt1vkrafte entsprechen. Dle Gesamthelt dieser Produktionsverhaltnisse bildet die ökonomische struktur der Gesellschaft, de reale Basis, worauf sich ein juristischer und polftischer veberbau erhebt, und der bestiminte gesellschaftliche Bewusstselnsformen entsprechen. Die Produktionsmelse des materiellen Lebens bedingt den sozialen, polltischen und geistigen Lebensprozess uberhaupt. Es ist nich das Bewusstsein des Menschen, dass thr Bewusstsein bestimmt"(15). Marx gaat daarop voort: "Auf elner gewissen Stufe ihrer Entwicklung geraten die materielien Produktivkräte der Gesellschaft in Miderspruch ult den vorhandenen Produktionsuerhälnissen oder, was nur ela jurlstischer Ausidruck dafur ist, mit den Elgentumsverhaltnissen, Innerhalb deren sie sich bisher bewegt hatten. Aus Entwicklungsformen der Produktivkrafte schlagen diese Verhälnisse in Fesseln derselben um. Es tritt dann elue Epoche sozlaler Revolution ein"(16).

Marx heeft de geschiedenis in viff fasen ingedeeld, die met elkaar door zo'n soclale revolutie verbonden zijn: de oersamenleving, warln nog geen prive-elgendom aan produktiemiddelen bestond; de slavenhoudersmatschappij, met eigendom an werktuigen en slaven; het feodalle tijdperk, met elgendom aan grond en $11 \mathrm{jf}$ eigenen; en het kapitalisme, met privé-elgendom aan kapitaal, machines en menselijke arbeidskracht. In toenemende mate nu staan deze stadia de waarlifk menselijke emancipatie in de weg. Zij hebben integendeel gelefd tot de uitbulting van de mens door de mens. De privé-elgendón aan produktiemiddelen heeft de mens tenslotte gedegradeerd tot handelswaar, als gevolg van het felt dat de mens van $z 1 j$ jin arbeld is vervreend.

Arbeld(17) is voor Marx een objectief gegeven, nodlg voor het produceren van de goederen die elke mens ter bevred1glng van $z 1 j n$ behoeften nod $1 \mathrm{~g}$ heeft. In het product wan de arbeid wordt menselijke energle geconcretiseerd, er vindt een vervreemding plaats, welke weer wordt opgeheven doordat de produceerde war verbruikt wordt. Deze cyclus, die in het oorspronkel1jke arbeldsproces, warin geestelijke en handenarbeld nog. 32 verenlgd waren, een gesloten proces vormde, $1 \mathrm{~s}$ verbro- 
ken door de arbeidsverdeling, die overigens vanwege de voortschrijdende ontwikkeling onvermijdelljk is. Als de arbeldsverdeling zover is voortgeschreden, dat de productie boven de onmiddellijke verzekering van de existentie uitgaat, kan prive-eigendom aan produktiemiddelen ontstaan. Deze prive-eigendom is het produkt van de vervreemde arbeid. Op het culminatiepunt van de ontwikkeling van de prive-eigendom blijkt echter dat de prive-eigendom tegelijkertijd het middel is, waardoor de arbeid zich van de mens vervreendt, het realiseert de vervreemding(18). Er ontstaat een vicieuze cirkel.

Voorwaarde voor een waarlijk menselijke samenleving, waarin de vervreemding weer wordt overwonnen, is dus dat de prive-ejgendom aan produktiemiddelen, die tot de vervreemding leidt en die schuld is aan de uitbuiting in de kapitalistische samenleving, wordt afgeschaft. Burgerlijke elgendomsverhoudingen dienen plaats te maken voor de vermaatschappelijking van de elgendom aan productiemiddelen, waardoor de weg wordt vrijgemaakt voor de klasseloze matschappij.

Met de overgang van kapitalisme naar communisme treedt de viffde en laatste fase in de geschiedenis van de mensheid in. Ook deze overgang vindt plaats door middel van een sociale revolutie, warin de arbeldersklasse een historische rol speelt. $21 \mathrm{j}$ vestigt tijde$1 i j k$ de dictatur van het proletariaat en voltrekt de economische omwenteling. Deze overgangsfase wordt gekenmerkt door het socialisme. Is de owergangsfase voltooid, dan ontstaat de klasseloze communistische samenleving.

De loop wan de geschiedenis is geen open ontwikkeling, maar een proces waarvan begin en elnde zijn vastgelegd en dat doelgericht, noodzakelijk, wetmatig plaatsvindt. Het inzicht in de noodzakelijkheid van dit proces is bij Marx de vrijheld. Deze vrijheld wordt geconcretiseerd in de medewerking aan de uitvoerling van de objectieve bistorische wetmatigheden, in de vestiglng van socialistische eigendoms- en produktieverhoudingen. Hoe actiever en doelgerichter het handelen van de mensen, des te hoger is het tempo van het historische proces in de richting wan socialisme en communisme, des te sneller ook vindt de daarmee verbonden vergroting van de reële vrijheld plaats.

\subsubsection{De socialistische opvatting van democratie}

Volgens de Oostduitse literatuur is van democratie sprake, als de heerschappij van de arbeidersklasse over de produktiemiddelen tot stand gekomen is en soclalistische produkteverhoudingen bestaan. Democra- 
tie ls de ultoefening wan de polttieke macht door de atbeldersklasse en har bondgenoten, gericht op de vertegenwoordiging van thar belangen en op het stimuleren van de arbeiders tot bewuste vormgeving aan hun matschappel 1 jk leven conform de historische noodzakelijkheden(19). of dewocratie heerst, hangt in de soclalistische visie dus niet van formele kenmerken af, maar van teriele, namelijk van het karakter van de samenleving, warin de wormem zijm ingebed(20).

De opbouw van de soclalistische democratie is geen spontaan proces, zaals vastgesteld, maar vereist bewustwording, die slechts kan worden bereikt door erkenning van de leidende rol van de partij van de arbeldersklasse(21). Als enige klasse in de samenleving, wier belangen ldentlek zijn met de objectleve wetmatigheden van de matschappelijke ontwikkeling, is de arbeldersklasse in stat zonder wooroordelen het objectieve verloop van die ontwikkeling op te sporen (22). Het interpretatemonopolie van dit bif de arbeldersklasse berustende lnzlcht in de noodzakelijkheld 1 s echter voorbehouden aan de marxistisch-lentnistische partif als "bewusste und organisierte Vortrupp der Arbelterklasse und des merktatigen Volkes" (23), warin de meest vooruitstrevende krachten van de arbeldersklasse, de boeren en de intelligentia zich hebben verenigd . De partij is de georgandseerde uitdrukking van de verblnding van de ervaringen van de arbefdersklasse in hun strijd tegen de uthuiting met de wetenschappelijke theorle van het soclalisme, die de uitweg uit uitbulting en onderdrukking aangeeft. De geschledents bewljst dat zonder de partijen haar leiding de arbelders niet in staat zijn zich te beurijden van de heerschappij van het kapitaal en de nieuwe sociallstische orde op te richten(24). Het is de rol van de partif het proletariaat met de realisatie van zijn historlsche taak te helpen door de "Wlrkungsmechanismen der objektiven Gesetze der Gesellschaftsentwicklung im Sozialismus fortschreitend zu verkennen" (25). In de DDR is dat de Sozialiatische Einhettsparm tet Deutschlande (SED). Aan haar komt de leidende rol In staat en samenleving toe. Art. 1 Verf. heeft deze leidende rol constitutioneel vastgelegd. Zij wordt ook erkend door de andere politieke partijen(26), die de DDR heeft op grond van het feit dat officieel een meerpartijensysteem bestaat. Doordat de zetels in het Dostduitse parlement, de Volkskommer, volgens en vaste sleutel $z i j n$ verdeeld, wormen de overige partijen geen bedrelgling voor de leidende positie van de SED. Bovendien is de Volkskammer als geheel gebonden aan de objectieve wetmatigheden van de matschappelij34 ke ontwikkeling (art. 47 lid 1 Verf.) en het inzicht 
darin 1 voorbehouden aan de SED.

Waarom het nu juist alleen mar de partij van de arbeidersklasse is die in laatste instantie het objectieve inzicht kan verwerven blijft onduidelijk. De Westultser Wadrion onderscheldt in zijn kritische analyse wan de rol wan de SED in de DDR tussen en functioneel en een historisch-dialectisch argument. Op de eerste plaats is een hoogste autoriteit vanuit het oogpunt van socialistische planing al noodzakelijk, op de tweede plaats kan de partij har monopolie clatmen op grond van het feit dat de arbeldersklasse pas door de partij als medium iberhaupt tot bewustrording komt. De partij vormt dus het elgenlijke bewustzijm van de arbeiders(27). De pretentie van de partij a1s enige in staat te zijn de objectieve matschappelijke wetmatigheden te herkennen berust uiteindelijk op een mystilek argument. Het praktische gevolg is dat alleen de partij - en volgens de regels van het democratisch centralisme dararbinen de partijleiding(28) - uhtmakt warlin de vrijheid voor de burger concreet bestaat.

\subsubsection{Het kaboentarakter van de vritheid}

Aangezlen het inzicht in de objectieve wetmatigheden (hetgeen de vrijheid is) ultsluitend bij de arbefdersklasse en wel in het bijzonder bij haar partij berust, is ook de vrijheid klassegebonden. De vrijheld als inzlcht in en realisering van de objectleve wetmatigheden is een kwestie van de economische macht, en hieraan gekoppeld de politleke macht, van de ene klasse over de andere(29). Volgens het historisch-materialisme is het de werkende klasse, die in overeenstemming met hat historlsche rol op revolutionaire wijze de noodzakelijke overgang van kapitallsme naar socialisme tot werke11jkheld lat worden en socialistische produktieverhoudingen tot stand brengt. Door het veroveren van de macht heeft de arbeldersklasse de vijhell verworven. In de klassenmatschapplj kan geen vrijheid voor allen bestaan. Daar negeert de vrijheid van de uttbuiters de vrijheid van de arbeidende massa"s en omgekeerd. De vrifheid van de arbeider en de vil theid van de bourgeols sluiten elkat wederijds uft(30). In het soctilisme is de arbelder vrlj, voor tegenstanders wan het sociallsme kan geen wrijheld bestaan. Het marxisme heeft overigens noolt vrijheid voor ledereen beloofd, aldus KLennep(31).

De vrijheld van de werkende klasse 18 tegelljk de basis voor de persoonlijke vrijheld. $21 \mathrm{j}$ hangt dilect van de vritheid van de klasse af(32). Daarom ook is in het socialisme een individuele vrijheld in burgerlijke zin niet mogelijk, maar slechts een persoonlijke vrij- 
held, die in de soclale lewensomstandigheden van de arbeldersklasse is geworteld en het persoonlifk belang met het belang van de klasse en de samenleving verbindt. De individu vindt $z 1 j n$ vrijheld derhalve niet anafhankelij $\mathrm{k}$ van de samenleving, of zelfs tegen haar gerlcht (het verwijt aan de burgerlijke vrijheidsopvatting), maar juist in vaste verbinding met staat en samenleving, in de bewuste medevormgeving van de sociale ontwikkeling, in de medeverantwoordelijkheid voor het geheel, die tot uiting komt in actieve medewerking(33). Werkelijke wrijheld beleeft de individu, wanneer hij handelt in overeensteming met de objectieve wetmatigheden. Het individuele element aan deze persoonlifke vrijheid bestaat in de omstandigheid, dat iedere mens zijn individuele karaktereigenschappen en talenten op zijn efgen wijze kan inzetten ten behoeve van het algemeen belang. Niet in het doel, maar in de middelen komt de individualiteit tot uitdrukking.

2.3. De consequenties van het maxistisch-leninistische urijheidsbegrip voor de cocialtstische opvatting over grondrechten

Reeds de eerste grondwet van de DDR van 7 oktober $1949(34)$ bevatte een uftgebreide grondrechtencatalogus, warln zowel de klassieke als de sociale grondrechten een plaats vonden. De formuler Ing van de klassieke grondrechten leek sterk op de fortalering die werd gebezigd in de constituties van de Weimar-republiek en van de Bondsrepubliek Duitsland(35). Aan de klassleke grondrechten van 1949 lag nog de ldee ten grondslag van grondrechten in de zin van individuele vrijheidsrechten( 36 ), hoewel het officlele handboek 'Staatsrecht der DDR' dit bestrijdt. De grondrechtencatalogus van 1949 zou al zijn gecreeperd vanult de socialistische conceptie van de grondrechten, met het doel de burgers er toe te bewegen actief aan het maatschappelijk leven deel te nemen en de eenheid van staat en burgers te ontwikkelen: "Das bedeutet die Absage an die bürgerliche Lehre von den Grundrechte, die den Bürger als isoliertes Einzelwesen betrachtet und thm eline "statisfrele" Sphäre sichern soll"(37). Hoe het $21 \mathfrak{J}$, vanaf het begln wees de praktijk u.t, dat het gebruik van de grondrechten alleen in de zin der grondwet mogelijk was en dat $z$ Lj niet voor imperlalistische, militaristische en fascistische doeleinden mochten worden aangewend.

De discrepantie tussen de formulering van de grondrechten en de praktijk werd opgeheven door de grondwet van 6 apri1 1968(38), waarin de nleuwe realiteiten van 
de ontwikkelde socialistische samenleving werden vastgelegd. In de gehele constitutle kwam nu de dialectsche eenheld van socialistische machtsultoefening en de vrije ontplooling van de persoonlifkheld tot uilting. De grondrechten waren definitief van hun oude gedante bevrijd en tot socialistische persoonlijkheidsrechten gewarden.

De grondrechtencatalogus uit 1968 is onveranderd in de derde grondwet van de DDR van 7 oktober 1974 (39) owergenomen. Direct na het eerste hoofdstuk over de economische grondslagen hebben de klassieke en sociale grondrechten (een indeling die overigens in de 0ostduitse rechtswetenschap njet wordt gehanteerd) een plaats gekregen onder de titel "Grundrechte und Grundpflichten der Büger" ter ultevoering van de in art. 2 Verf. gegeven algemene opdracht, dat de mens in het middelpunt staat van alle inspaningen van de socialistische samenleving en de staat.

De Oostduitse rechtstheorie besteedt vrij veel aandacht aan de grondrechten. Dit is te danken aan de omstandigheid dat men zich voortdurend onder druk voelt gezet on de socialistische interpretatie van de grondrechten te legitimeren tegenover aanvalien vanuit de Westduitse rechtswetenschap, die zich intenslef met de ontwikkelingen in de DDR bezighoudt(40). Sinds het begin van de jaren zestig is sprake van een voortdurende stroom van oostduitse publicaties over de grondrechten(41). Men probeert systematisch het gehele terrein van de grondrechten te dekken met de achterliggende gedachte, de superioriteit van de sociallstische grondrechten te bewijzen( 42 . Het hoofdverwijt dat richting Westen wordt gemakt is, dat men zich daar onvoldoende rekenschap geeft van de ideologische en economische grondslagen van de socialistische grondrechtemconceptile en dat de oostduitse praktijk uitsluitend nar westerse matstaven wordt beoordeeld. DIt verwijt kan ook in de richting van het onderhawige onderzoek worden gemaakt. Weliswar wordt in dit hoofdstuk getracht, een zo objectilef rogelljke beschrijuing te geven van het marxistisch-leninistische vritheidsbegrip, de soclalistische grondrechtsopvatting en de functie van de vrijheid van menlngsulting, zoals deze 1 in de DDR zelf worden gezien (wat mitet uitsluit dat ook kitische postduitse opvattingen an bod komen). Maar de officiele oostduitse interpretatie van de writheid van meningsuiting zal uitelndelijk niet aan een beoordelling ontkomen. De invalshoek voor deze beoordeling kan als ideologisch bepald worden afgedaan in zoverre, dat wordt uitgegaan van het oorspronkelijke karakter van de grondrechten. Afgezien van het feit, dat voor deze keuze goede historisch-fi- 
losofigche gronden zijn aan te voeren, mot echter worden benadrukt, dat de beoordeling gebaseerd is op het Internatlonale Verdrag inzake Burgerrechten en Polltieke Rechten, dat door de DDR is geratificeerd en warin het oorspronkelijke karakter van de grondrechten eveneens wordt erkend $(43)$.

\subsubsection{Het kassenkarakter van de socialistische grondrechtern}

W1t het klassenkarakter van de vrijheld volgt dat de grondrechten, als middel dat speciflek de burger in staat stelt bij te dragen aan de verwezenIijking van de objectieve wetmatigheden $(44)$, eveneens klasserechten $21 \mathrm{jn}$.

Die ult het natuurrecht afkomstige opvatting, dat grondrechten absolute, eeuwlge en onveranderlijke rechten ziln, wordt afgewezen(45). Grondrechten zi jn daarentegen altijd het produkt van concrete matschappielijke constellaties. "Der Gedanke der Menschenrechte ist fur die christlithe Welt erst im vorigen Jahrhunthert entdeckt worden", aldus Marx. "Er ist dem Menschen nicht angeboren, er wrd vielmehr nur erobert in Kampfe gegen die geschichtilchen Traditionen, in denen der Mensch bisher erzogen wurde. So sind die Menschenrechte nicht ein Geschenk der Natur, keine Mitgift der bisher1gen Geschichte, sondern der Preis des Kampfes. gegen den Zufal1 der Geburt und gegen die Privileglen, welche die Geschichte won Generation auf Generation bis jetzt vererbt hat. Sie sind das Resultat der Buldung, und derjenlge kann sie nur besttzen, der sie erworben und verdient hat" (46).

In de burger lijke samenleving zijn de grondrechten de rechten wan de heersende bourgeolsie. Zij berusten op de heerschappij van de prlve-eigendom, die economische en politleke onderdrukking en uitbuiting door de beattende klasse tot gevolg heeft. De burgerlijke grondrechten hebben slechts tot doel de werkelijke verhoudingen te versluieren. De socialistische grondrechten $z \mathbb{1} j n$ daarentegen wële rechten. Zij komen woort ult de door het soclalisme geschapen matschappelifke verhoudingen zelf; zij zijn niet geschonken of werleend, mar door de arbeidersklasse weroverd. In het soclallisme zijn het zodoende rechten van de arbelders. 213 worden doon hun behoiefen en door hun eisen bepald(47) en spelen een belangrijke rol bij de verwolmaking van het soclallsme. Het klassenkarakter timpliceert dat zij nilet an ledereen en te elken tijde een bepald minimum aan writheid gunnen max dat dit a thankelijk is van de elsen van de samenleving * Dadat de grondrechten noch onvervreemdbare, noch universele 
rechten zijn maar in een bepaalde fase van de geschiedenis door een bepalde klasse, namelijk de arbeiders en hun bondgenoten, $21 j n$ veroverd, heeft hum opneming in de grondwet geen declaratoir, mar een constitutief karakter, en is hum reikwijdte tevens beperkt tot diegenen die behulpzaan worden geacht te zijn bij de opbouw van het soclalisme, namelijk de burgers van de DDR. Deze visie kont tot ulting ln art. 19 Verf, dat aan de elgenlijke grondrechtencatalogus vooraf gaat. Lid 1 luldt: "Dle Deutsche Demokratische Republik garantient allen Bürgern die Ausibung lhrer Rechte" (48). De formulexing makt duldelijk, dat de garantie van de grondrechten in de DDR nilet het karakter van een erkennlug, mar van een toekenning heeft.

De soclalistische grondrechten zijn van een principleel andere orde dan de burgerlijke grondrechten. In tegenstelling tot deze laatste, die in soclalistische ogen de burger juist van de politieke macht scheiden, betrekken de soclalistische grondrechten de burger wel bil de uitoefening van de politieke macht. Die tegenstelling moet onder meer blijken ait de garantie van het socialistische recht op medezeggenschap en medevormgeving (art. 21 Verf.) en het kiesrecht (art. 22 Verf.). Vanult dit gezichtspunt is het dan ook vanzelfsprekend dat bijwoorbeeld het Initial Report van de DDR aan de Secretaris-Generaal van de Verenigde Naties ex art. 40 lid 1 sub a ICCPR grotendeels is gewijd aan een bespreking van juist die rechten(50).

Zelfs indien burgerlijke en socialistische grondrechten op dezelfie wijze zijn geformuleerd gat het toch om grondrechten van verschillende kwaliteit, die niets met elkaar te maken hebben. Zo wordt ook de finhoud van het recht op vrifheid van meningsuiting door tegengestelde klassenbelangen bepaald(51). Al worden overeenkomsten tussen de burgerlijke en de soclalistische grondrechten ontkend, niet miskent men dat de, door de jonge bourgeoisie in strijd tegen het feadalisme geformuleerde, grondrechten positleve trekken bevatten, warop de door de arbeldersklasse verworven soclalistische grondrechten voortbouwen(52). De burgerlifke grondrechtencatalogi uit de achttiende evw waren utingen van de historlsche menselijke voorultgang naar hogere maatschappifvormen, zif het dat zil later


behoeve van de heerschapplit van de bourgeolsie. Voorzover deze echter de progresilewe en humalstische tradjties van de menshell vertolken zll $3 \mathrm{n}$ zj in de socialistische grondrechten en -vrijheden, "wie sie die sozialistische Entwficklung der DDR hervorbrachte" (53), geincorporeerd. Voor wat betreft de Dultse bij- 
drage hebben volgens Klenner met name Fichte en hegel wtstekende prestaties verricht, die niet mogen worden genegeerd $(54)$.

2.3.2. De betekenis wan de socialietische rechtsopvatting voor de grondrechten

De rol van de grondrechten in het soclalisme is uitvloeisel van de socialistische rechtsopvatting.

Zoals in het maxkisme-leninisme de vrijhefd het inzicht in en de vormgeving aan de objectleve wetmatigheden is, zo is het recht het instrument, waarmee de vri fheld kan worden verwezenlijkt. Deze instrumentele benadering komt voort uit een princlpieel andere waardering van het recht in vergelifking met het traditionele westerse rechtsdenken. In de democratische rechtsistat normeert het recht het politieke proces en het politiek handelen; thet recht staat min of meer neutraal tegenover de in concreto nagestreefde politheke doeleinden. In de socialistische staat normeert de polltiek het recht. Als deel van de zogenaamde bovenbouw wordt het recht door de materiële basis, dat wil zeggen door de produktieverhoudingen bepald(55). Het recht dient de belangen van de arbeidersklasse en brengt haar will op adequate wijze tot uiting. Het soclalistische recht is het middel ter verwezenlijking van de politieke doeleinden van de arbeldersklasse (56). "Von seinem Klassencharakter her impliziert deshalb auch das sozialistische Recht ein bestimntes Verhalten zu den objektiven Gesetzen. Grundzätzlich gilt: Die Forderung, den K1assencharakter des sozlalistischen Rechts auszuprägen, schliesst ein, die Erfordernisse der objektiven Entwicklungs- und Strukturgesetze möglichst adäquat Im soziallstischen Recht widerzuspiegeln; je adäquater dies geschieht, un so witkungsvoller dient das socialistische Recht der Durchsetzung der Klasseninteressen der Arbeiter"(57). Het recht is een onontbeerlijke factor in de werkingsmechanismen van de objectieve wetmatigheden en de ontwikkeling van de soclalistische samenleving, omdat het de belangen van de arbeidersklasse tramsformeert in de wil wan de stat( 58 , die de dwangmiddelen bezit om aan het recht effectiviteit te verlenen.

Maar ondanks politisering en instrumentalisering van het recht bestaat ook in het socialisme behoefte aan orde en aan zekerheid, dat w1 zeggen van het recht moet toch enfge normativiteit uitgaan(59). Witdrukking van deze behoefte is het principe van de sosialistiache Gesetalichkeit(60): regelgeving daar, waar die nodig is en vervolgens strikte naleving van de regels 4.0 door alle burgers en overheldsorganen. Strikte nale- 
ving is immers strijd on de verwezenlfjking van de in het recht uitgedrukte politiek van de arbeldersklasse en har partij. Maar ook de aouialisticehe Gesetaliahkeit moet uiteindelijk wijken voor het instrumentele karakter van het recht, als $z 1 j$ de verwezenlijking van de objectieve wetmatigheden in de weg blijkt te staan. Zif moet daarom steeds worden uitgelegd en ontwikkeld vanuit de matschappelijke doelstellingen, die in de partijbesiuiten zijn vastgelegd(61). Waruit blijkt dat alle rechtsnormen in laatste instantie ondergeschikt zijn aan de besluiten van de SED. Het is van belang, deze politieke relativering van het socialistische recht in het oog te houden. Zij geldt met gelijke kracht voor de socialistische grondrechten.

2.3.3. Grondrechten ats sacialistische persoontijkheidsrechten.

De grondrechten maken deel uit van het socialistische recht. Evenals het overige recht zijn zif instrument ter verwezenlijking van de objectleve wetmatigheden, van reele vilfheid in marxistisch-leninistische zin. In onderscheid tot andere rechtsregels zijn de grondrechten die in de grondwet vastgelegde rechtsnormen, die de betrekkingen tussen de burgers en de stat en de burgers onderling regelen en die er speciflek op gericht zijn de individu bij de wormgeving aan de socialistische samenleving te betrekken(62). Het accent ligt op het engagement van de individu voor het collectief. Het wezen van de grondrechten $1 . \mathrm{lgt}$ "In nichts anderem ... als In der allseitigen Entfaltung der schöpferischen Kräfte der Menschen beim Aufbau der sozialistischen Gesellschaftsordnung" (63).

Het beklemtonen van de matschappelifke dimensie van de grondrechten berust op Marx' afwijzing van de 11 berale opvatting van de wijheidsrechten als afweerrechten tegen de staat in zijn jeugdwerk 'Zur Judenfrage'. In zijn kritiek op de mensenrechtsopvatting van de Franse Revolutie constateert hij, "dass die sogenannte Menechenrechte, die droits de t'homme, Im Unterschied von den droits du citoyen, nichts anderes sind als die Rechte des Mitglieds der burgeritchen Gesellachaft, das helsst des egolstischen Menschen, des vor Menschen und vor Gemelnwesen getrennten Menschen" (64). Het in artikel 6 Verklaring van de Rechten van de Mens en Burger neergelegde mensenrecht van de vrljheld is in zij 1 n ogen niet gebaseerd op de verbinding van de mens met de mens, mar op de scheiding van de twee. "Es Ist das Recht dieser Absonderung, das Recht des beschränkten, auf sich beschränkten Indlviduums" $(65)$.

De meest pregnante ultdrukking van deze individualis- 
thishe 1 theldsopvatting is volgens Marx het recht op prive-elgendom, het recht om w11ekeurig, zonder rekening te houden met andere mensen, onafhankelijk van de samenleving, wan $z i j n$ vermogen te genteten en erower te beschikken, het recht van het elgenbelang. Dit recht vormt de grondslag van de burgerlijke samenleving $(66)$.

De burgerlifke vrijheden verlenen geen werkelijke vr 1 jheden behalve voor de geprivilegleerden. On werkeIljke vrijheld te creêren is het nodig, dat de mens zichzelf niet langer opsplitst in enerzijds de egoistische, onafhankelijke lndiwidu (hem mogelijk gemakt door de "drolts de 1 "home"), die zich terugtrekt in een statsurije sfeer, en anderzijds in de statssurger, die well deelneemt aan het matschappelijk leven (door middel van zijn "droits du citioyen"). De mens moet zichzelf als Gattungbuesen zien. "Erst went der whlleh lndividuelle Mensch den abstrakten Staatsbüger in sich zurücknimint and als individueller Mensch in seinem empirischen Leben, in selner individuelien Arbeit, In selinen individuellen Verhältnissen, Gattungewesen geworden ist, erst wenn der Mensch seine "forces propres" als geseltachaftliche Krafte erkannt und organistert hat und daher die gesellschaftliche Kraft nicht mehr in der Gestalt der politischen Kraft von sich trennt, erst dann ist die menschliche Enamzipation vollbracht" $(67)$.

In deze traditie Lis het staatsrecht van de DDR geworteld. De grondwet behandelt de mens als sociaal schepsel. Zo zoekt ook de in de grondwet neergelegde grondrechtsopvatting de verwezenlijking van de vrijheld nitet door de lsolering van de afgezonderde individu, maar door hat betrekken yan de individu bij de samenleving. "Die Fretheit des Menschen kann nicht in der Isolferung des einzelnen, sondern nur durch die tätige Mitwirkung bel der Gestaltung des Lebens der Gese11schaft verwirklicht werden. Wahre Freihelt kann nicht Freiheit won stat und Gesellschaft, sondern nur Freiheit im staat und in der Gesellschaft sein. Nicht der vom Statsbürger getrennte Mensch lst frei, sondern der Staatsbirger, der als solcher selne menschilche Qual1titen zu entfalten vermag ${ }^{\prime \prime}(68)$.

Daarom neent $1 n$ de grondrechtencatalogus van de grondwet het recht op nedezeggenschap en medevormgeving (art. 21 lid 1 Verf.) een centrale plaats in:

Jeder Burger der Deutschen Demokratischen Republik hat das Recht, das politische, witschaftiche, sozlale und kulturelle Leben der sozlalistischen Gemeinschaft und des sozlalistischen Staates umfassend mitzugestalten. Es gilt der Grundsatz "Arbeite mit, plane mit, regiere mit!". 
Het geldt als het meest omvatende en belangiljkste grondrecht en is richtiljn voor le ultoefening van alle andere grondrechten. Daarnaast worden uiterard het recht op arbeld (art. 24 verf.) en opleiding (art. 25 Verf.) als verdere kerngrondrechten worden beschouwd (69).

Verkeerd zou het echter zijn, aldus de of rie, de matschappelijtke functie van de socialistische grondrechten te interpreteren als een wolledige uniformering van de individu en zijn belangen(70). Het is niet de bedoeling dat de individu in de massa ondergat( 71$)$. Behalve het doel de individu via de grondrechten te betrekken bij de vormgeving van de socia11 stische samenleving staan deze de individu tevens ter beschikking ten behoeve wan de vilje en ongehinderde ontplooilng van de elgen persoonlijkheid en $z i j \mathrm{~m}$ persoonlijk leven ( 72$)$. Vanzelfsprekend kan het evenmin de bedoeling zijn "einen Schutzraum für die Launen von Einzelgängern oder elne spielwlese threr Willkür zu errichten"(73). De individuele ontplooiling is element van de matschappelijke ontwlkkeling, niet haar tegenpool. De grondrechten bleden daaron de burger de mogelijkheid $z i j n$ persoonlijk leven vorm te geven, met dien verstande dat zulks volgens de socialistische principes, in overeensteming met de objectieve wetmatigheden geschiedt $(74)$. Vrije ontplooling van de persoonlijkheid vornt een dialectische eenheld met de ontwlkkeling van de samenleving(75). In een voortdurende wisselwerking sterken beide elementen elkaar. Zij hebben voordeel van elkaar. Slechts dan 1 s sprake van volledige individuele ontplooiling als socialistische persoon 1ijkheid(76). Uit deze wisselwerking volgt bijna vanzelt, dat wie van zijn grandrechten geen gebruik makt, niet alleen zichzelf schaadt, maar ook de socialistische gemeenschap. Dlt impliceert dat ieder grondrecht tevens de verplichting inhoudt er daadwerke11jk van gebruik te maken: "Gesellschaftlich notwendig ist es, dass der Birger seine grossen, gewachsenen Rechte in untrennbarer Einheit mit den statsbürger 11chen Pflichten erkennt und verwirklicht"( 77$)$. Een rechtsplicht tot ultoefening van de grondrechten bestaat evenwel in het algemeen niet. Het blifft blj een morele plicht, warvan de burgers door onderwijs in de soclalistische moral doordrongen moeten worden (78). Een uitzondering is bijvoorbeeld de dienstplicht (art. 23 lid 1 Verf.): het recht on het soclalisme gewapenderhand te verdedigen is hier tegelijk rechtsplicht.

De dialectische eenheld die tussen de ontplooilng van de elgen persoonlijkheid en de maatschappelijke ont- 
whkeling bestaat, berust op de princlplele overeensteming dile bestat tussen de belangen wan de burger en de belangen van de socialistische samenleving(79). De socialistische stat is het machtsinstrument van de werkende klasse en hil oefent de macht volgens haar wil en belangen uit. Er 1 g geen verschil tussen wat de individu en wat de samenleving w11. Een individuele vritheidssfeer tegenover de staat is daaron overbodig. In $20^{*} n$ opvatting, die uitgaat van een ldentiteit van belangen tussen individu en samenleving, is voor het beschouwen van de grondrechten als subjectieve rechten in burgerlijke $z i n$, als afweerrechten, geen plaats. Als men al spreekt van subjectleve rechten is het uitsluitend in dife zin, dat de individu subject is van de in de grondwet neergelegde rechten en vrijheden is, dat $\mathbb{H}^{j}$ door hem kunnen en - als sazialistische Gebtaltungamechte - ook moeten worden ultgeoefend, dat $21 j$ de tegenstelling tussen individu en samenleving oplossen doordat zij"den einzelnen auf die Durchsetzung der gesellschaftichen Exfordernissen als in seinem persönlichen Interesse liegend ... orientieren" (80).

De laatste Jaren is het besef doorgebroken, dat deze beperkte uitleg van het begrip subjectieve rechten niet onder alle omstandigheden kan worden gehandhatid, mart dat er wel degelijk belangentegenstellingen tussen ladividu en collectief mogelijk zijn, die het noodzakelijk maken de grondrechten als subjectleve rechten In de in het Westen gebruikeldjke zin te zien, dat w11 zeggen als rechten, warmee een bepalde aanspraak tegenover de overheld geldend kan worden gemakt.

Met name Poppe heeft zich woor een meer genereuze ultleg sterk gemaakt. Reeds in 1963 gaf hij de mogelijkheid van het bestaan van objectieve belangentegenstellingen tussen Individu en collectlef toe. Hij sprak zich er tegen uit de idee van subjectieve rechten tot burgerlijk overblijfsel te verklaren, daar alj ook in de soclalistische samenleving de functle hebben de burger tegen ongerechtvaardigde ingrepen in zijn act1vitelten te beschermen $(81)$. Deze opvatting wordt nu algemeen geaccepteerd. In "Staatsrecht der DDR" staat geschreven: "Die in der sozlalistischen Gesellschaft geschaffene prinzipleile vebereinstimung von gese11schaftichen und individuellen Interessen schliesst die Berecht1gung won Ansprüchen des elnzelnen nicht aus, sondern elin. Die Bejahung der Grundrechte als subjekt Ive Rechte dient der positiven Verhaltensorientherung des elnzelnen staatichen oder gesellschaft11chen organs bzw. Funktionärs oder auch des elnzelnen 44 Bügers wie auch der Lösung partieller Widerspruiche, 
einzelner Konflikte zwischen Partnern, die an der Grundrechtsverwirklichung beteiligt sind"(82). Wat niet inhoudt dat de burgerlijke opvatting is geaccepteerd. Het doel van de vertuling van het begrip is namelifk njet de grondrechten een afwerifunctie te verlenen, maar door het onderkennen en oplossen van nu eenmad voorkomende conflicten de belangenidentiteit op een hoger miveau te herstellen.

Het subjectieve karakter van de grondrechten als (beperkte) claims tegenover de stat geldt bovendien niet voor alle grondrechten, maar is voorbehouden aan die grondrechten, die zelfs in soclalistische ogen tot de strikt persoonliflke levenssfeer van de individu behoren, zoals bijvoorbeeld de godsdiensturijheid (art. 20 Verf.), de gewetensvrijheid (art. 39 Verf.) en het recht op onschendbatheid van de woning (art. 37 Verf.). De rechten en viltheden met een onmiskenbaar politleke dimensle, waaronder mast de gelijkberechtiging van man en wrouw (art. 20 verf.), het recht tot verenigting (art. 29 Verf.) en het recht tot vergadering en betoglng (art. 28 verf.), ook het recht op vril jheid van meningsuiting (art. 27 Verf.) valt, beschermen geen persoonlijke levenssfeer, maar dienen de individu uitslutend tot ontplooling van zijn socialistische persoonlijkheid in de samenleving(83). Deze rechten zijn derhalve niet subjectlef in de hilerboven bedoelde zin.

Al Is dus de hypothese van volledige belangenidentitelt tussen individu en collectivitelt losgelaten en wordt de mogelifkheid van uiteenlopende belangen schoorvoetend erkend, de praktische betekenis daarvan Is ulterst gering. Dit wordt met name duldelijk bij een blik op de garanties, warmee de grondrechtem in de DDR zijn omgeven. Art. 19 11d 1 Verf. garandeert alle burgers van de DDR de ultoefening van hun rechten. Ex wordt onderscheld gemaakt tussen polltieke, idedlogische, economische en juridische garanties, warvan de erste drie de doorslaggevende $21 \mathrm{jn}(84)$. De politieke garantie bestaat in de uitoefening van de macht door de arbeidersklasse, de Ideologische garantie bestaat in de leer van het marxisme-leninisme en het soclalistische staatsbewustzi jn, en de economische garantie in de soclalistische eigendomswerhoudingen (85). De matschappelijke orde zelf is dus de hoogste garantie. Zli schept echter eerder de voorwarden voor de uttoefening van de grondrechten (bintnen de aangegever gxenzen) dan dat zij rechtsbescherming in westerse zin verleent. Hierin zouden de jurldische garanties kunnen voorzien, die vam secundalr belang zijn en warvan ondertussen wordt toegegeven dat zij een beschermingsfunctle hebben( 86$)$. De rechtsbescherming in 
haar algemeenhetd en de bescherming van de grondrechten in het bijzonder is in de DDR evenwel zeer zwak ontwikkeld(87), zelfs in vergelijking met andere staten van het Dostblok(88). Als belangrijkste juridische garantle wordt het feit genoend dat de grondrechten in de grondwet zijn vastgelegd(89). Een constitutionele rechter ontbreekt, evenals een algemene rechtsgang tegen rechtsschendingen van overheldswege, zoals blyvoorbeeld in de Bondsrepubliek het geval is $(90)$. Voorzover via afzonderlijke wetgeving voor bepalde gebieden een administratieve rechtsgang is geopend, heeft deze voor de bescherming van de klassieke grondrechten geen praktische betekenis. Een factor dle de rechtsbescherming bovendien in de weg stat is het feit dat de rechterlijke macht niet onafhankelijk opereert, maar door de overheld wordt gecontroleerd (art. 94 Verf.), zodat het een waar woord mag $z i j n$, "dass jedes Grundrecht dem allseitigen Schutz durch die Macht des Vo1kes uberantwortet ist und niemand es wagen darf, es in seiner Zlelrichtung und Substanz anzutasten oder zu verändern. Die Realität dieser auf alle Grundrechte sich erstreckenden Garantie gründet sich auf die prinziplelle Uebereinstimung der Interessen der sozialistischen Gesellschaft, ihres Staates und seiner Bürger" (91).

Beperkingen van de grondrechten worden gelegitimeerd door het objectief gefundeerde belang van de gemeenschap en de burgers zelf $(92)$. Deze belangen ziln in de grondwet vastgelegd. De grondrechten dlenen in overeenstemming met de principes en de doelen van de grondwet gebruikt te worden(93). Relevant in dit kader 1s de constatering in de preambule, dat het volk van de DDR vorm geeft aan de ontwikkelde socialistische samenleving en vervuld is van de wil de weg van het saclallsme en het commisme verder in te slaan; verder is wan belang art. 2 lid 2 Verf., dat de soctalistische eigendom van de produktiemiddelen en de maatschappelijke ontwikkeling volgens de inzichten van het marxisme-leninisme tot grondslag van de matschappe$1 i j k e$ orde verklaart. In sommige artikelen, die garanties van grondrechten bevatten, $z 1 \mathrm{jn}$ concrete verwijzingen te vinden naar deze bepalingen, die algemene beperkingen aan hun ultoefening stellen, zoals bif het recht tot vereniging: "in Uebereinstimmung mit den crundsatzen und Zlelen der Verfassung" (art. 29 Verf.), en het recht tot vergadering en betoging: "1m Rahmen der Grundsätze und Zlelen der Verfassung" (art. 28 Verf.). Ook thet recht op vrijheid van weningsuiting (art. 27 Verf.) bevat zo'n beperking. Voorzover de afzonderlijke artikelen niet een zodanige formulering bevatten, is hun gebrulk toch aan de socialistische 
Resumerend kan het wolgende worden gesteld. Soclalistische grondrechten $z i j n$ geen absolute rechten, maar rechten die voortkomen uit de concrete matschappelifke context. Het zijn geen universele rechten, maar rechten die in het socialisme toevallen aan de arbeidersklasse en haar bondgenoten. Zij zijn geen individuele vrijheidsrechten, maar zij zijn juist bedoeld on de burger bij de samenleving te betrekken; voorzover zij tevens ruimte bieden voor individuele ontplooling is dit het geval, ondat en mits deze ontplooilng de matschappelijke ontwlkkeling bevordert. De wijze warop en de grenzen warbinnen de burger via de grondrechten kan deelnemen aan de vormgeving van de samenleving, wordt door de partij van de arbeidersklasse bepaald.

\subsection{De vritheid wan meningsutiting}

De vrijheld van meningsulting is gegarandeerd in art. 27 Verf.:

1. Jeder Bürger der Deutschen Demokratischen Republik hat das Recht, den Grundsätzen dleser Verfassung gemäss seine Melnung frei und öffentlich zu äussern. Dieses Recht wird durch kein Dienst- oder Arbeitsverhältnis beschränkt. Miemand darf benachtefligt werden, wenn er von diesem Recht Gebrauch macht.

2. Die Freihelt der Presse, des Rundfunks und des Fernsehens ist gewährleistet.

Inhoud en functie van het recht op vrifheld van meningsuiting worden bepaald door de geschetste opvattingen over vrijheid en recht, welke $z 1 j n$ weerspiegeld in de soclallstische benadering van de grondrechten. ook de vrijheid wan meningsulting is ingebed in het grotere geheel van constitutionele normen, die de objectieve wetmatigheden van de ontwikkeling van de socialistische samenleving weergeven; de zinsnede: "den Grundsätzen dieser Verfassung gemäss" legt dit duideliftk vast. Deze normen objectiveren het recht op vrijheid van meningsulting en maker het naar soclam listische overtuiging pas reeel, omdat het pas tn het soclalisme mogelijk wordt de objectleve wetmatigheden te herkennen en zich op grond van deze wetmatigheden een juiste mening te vormen: "Die Erkenntnis der Notwendigkeit, der Gesetznässigkeit aller Entwicklung und thre bewusste Anwendung als elner Entscheldung mit Sachkenntnis eröffnet dem Bürger erst dle Freiheit seiner Meinung" (94). 
Twee aspecten woeten worden onderscheiden. In de eerste plaats is de vrljheld van menlingsulting zelf woorwarde voor het herkennen van de objectieve wetmatigheden, dat wl zeggen het vinden wan de warheid. In de treede plaats dient de vrijheld van mentingsuting met die gevonden warheld blj te dragen aan de verdere opbouw van de soclalistische samenleving.

\subsubsection{Warheidevinding}

De vritheid van meningsulting in het socialisme is het recht van de burger bij te dragen an het herkennen van de warheid als objectieve grondslag van matschapelljk julst handelen. De dlepere zin wan dit grondrecht is niet het voorhanden $\mathrm{z}$ jn ran verschillende meningen, maar de totstandkoming van één juiste mening, die de werkelijkheid exact weergeeft(95). Door de warheld te vinden $1 s$ het mogelijk de socialistische orde sneller en beter tot stand te brengen(96). Het grondrecht omvat alle vormen van meningsuiting, die tot het vinden van de warheld bijaragen(97).

Hieblinger en Menaet hebben zlch diepgaand beziggehouden met de relatie tussen vrijheld van meningsuiting en warheidsvinding(98). Volgens hen levert het marxisme-leninisme als wetenschappelijke filosofie de mogelifkheld de objectieve realitelt te herkennen. War 1s, wat deze objectieve realiteit exact weerspiegelt. De vrijheld van meningsulting is het middel, wardoor de warkeld aan de opperwakte kan doordringen. Ook in het marxisme-leninisme is het herkennen van de objectieve realiteit echter een probleem, ondat de mens in laatste instantie het herkennende medium is. Zonder de mens is er geen herkenning en dus ook geen waarheid. Dat zou kunnen leiden tot de conclusie dat het critertum voor de warheld in de mens zelf 1 igt, namelijk dat een mentng subjectief war is, wanneer degene die de mening koestert zelf van de juistheid ervan overtuigd is. De confrontatie met andere meningen leidt dan tot een matschappelijke concensus. Deze loglca wordt evenwel door Hieblinger en Menzel als burger 11jke opvatting afgewezen. Hoewel zonder de mens geen herkennen mogelijk is, zeggen zij, hangt de inhoud van het herkennen niet van de mens af. Warheid Is geen eigenschap van de objectieve realitelt. De realitelt staat vast, ongeacht de menselijke interpretatle. Waar of fout kan siechts de mentng, de kople van de objectleve realitelt in het bewustzijn van de mens zifn. De toetssteen voor de warheld $11 \mathrm{gt}$ bulten het denken, in de objectieve realitelt, en alleen het marxisme-Ieninisme is daartoe in staat (99). 
het marxisme-leninisme is een produkt van de menselijke geest, evenzo als de intexpretatle en praktische verwezenlijking van deze theorie mensenwerk 1 . Hetzelfde geldt voor het oordeel over het warheldsgehalte van een mening. Altijd is op een gegeven ogenbllk als medium de mens nodig en blifft er dus een subjectief moment in het spel. Het subjectieve moment wordt verdoezeld door een beroep op het monopolle van de SED betreffende het inzicht in de objectieve wetmatigheden.

Een ander probleem is, dat het niet valt vast te stellen of een mening waar is of niet, alvorens deze geult wordt. Zelfs kan het $\mathbb{Z}^{i} \mathrm{jn}$ dat een objectief onjulste mening ex toe kan leiden dat de warheld wordt gevonden. Hoewel de vrijheld van meningsuiting de warheidswinding dient, kan daarom niet worden geconcludeerd dat alleen de meningen die zelf war zijn door dit grondrecht worden beschermd. "Ir PrInzip darf das Grundrecht abweglge, irrige, selbst falsche Meinungen, die zweifel oder Fragen beinhalten, nicht ausschliessen. Im streitgespräch, im Meinungsaustausch können auch sie zu einer tieferen Erkenntnis füren und dazu beltragen, dass die objektive Wahrheit offenbar wird" $(100)$.

Al is de algemene overtulging, dat de zin van de vrijheid van meningsuiting niet $11 \mathrm{gt}$ in het voorhanden zijn van tien verschiliende meningen, maar 1 n de totstandkoming van én juiste mening, ook algemeen wordt erkend dat de warheld slechts in een confrontatie van meningen kan gedijen(101). Door kritlek en zelfkritlek, door de ultwisseling van ervaringen en voorstellen kunnen tegenstrijdigheden worden opgelost en gebreken overwonnen(102). Ook thet obenste Gericht heeft uitgesproken dat het in het algemeen belang is, dat serieuze kritiek op mateschappelijke misstanden wordt geuit, als men van het bestaan van die misstanden overtufgd is (103). De burger moet de gelegenheid hebben, aldus Haney, actief aan de algemene meningsvorming mee te werken, als recht op en plicht tot matschappelifke controle en kritiek aan misstanden en als het recht on klachten te uiten over onrechtvaardigheden, subjectlvisme en egolsme(104). Als voorwarde voor het viden van de warheld wordt dus wel als noodzakell jk gezien dat een confrontatie van mentngen platsvindt, maar alleen en slechts dan als deze confrontatie de opbouw van het soclallsme constructief dient. De objectieve wetmatigheden van het marxismeleninisme mogen niet in twijfel worden getroffen. De opdracht, die de grondwet aan de vrijheld van meningsuting heeft meegegeven, laat daarover geen onzekerheid bestaan. 
Het recht op vrijheid wan meningsuiting is een dochterrecht wan het recht op medezeggenschap en medevormgeving(105). Vanult de burger gezien is het grondrecht middel om mee te werken aan alle matschappelifke ontwikkelingsprocessen, aan de vorngeving van de gemeenBchap en het soclalistische leven. Vanuit de overheid gezien is het grondrecht instrument on de burger te betrekken bij de opbouw van het socialisme en de realisering van de objectieve wetmatigheden. Zoals van alle grondrechten is het ook de taak wan de vritheid van meningsuiting de burger ertoe te brengen, zijn matschappelijk en persoonlijk leven in soclalistische zin vorm te geven. Uiteraard is het onder deze invalshoek nlet in het belang wan de samenleving, noch in dat van de burger, dat ledereen elke mening kan verkondigen die hij wll(106). Dat zou de ontwikkeling van de socialistische persoonl1 jkheid niet dienen. "Niemand kann daran interessiert sein, dass beispielsweise unter Vortâluschung freter Mellnungsäusserung nach Artikel 23, anstatt konstruktive Meinungen über die Lösung der gesellschaftichen und staatichen Aufgaben und Probleme auszutauschen oder selbst lösungen $z u$ finden, anstatt sachliche Kritik an aufretenden Mängeln zu uben, destruktiv und absichtlich die sozlalistische Demokratie, der Afbau des Soztalismus geschädigt wird" (107). De uitoefening van de vrijheid van meningsuiting draagt pas tot meer vrijheid bij, als men door middel van de vrijheid van meningsuiting uitdrukking geeft aan de objectleve verelisten van het menselijk samenleven in het socialisme, als men zich het marxistisch-ieninistische wereldbeeld eigen makt en het verbreidt. Het recht op vrijheid van meningsuiting wijst de burger op de objectleve wetmatigheden. Het helpt ledere spontanitelt in denken en handelen te overwinnen en het richt de aandacht van de burger op die doelen die zowel in het belang van hemzelf als van de samenleving liggen. "Insofern sind die Funktionen des Grundrechts auf frele Meinungsäusserung die auf das Grundrecht bezogene Politik von Partei und Staatsmacht zur Entwlcklung der sozlalistischen Persönlichkelt und zur Entwicklung threr Freiheft"(108). Aldus impliceert de vrijheid van menlngsulting een handelen in overeenstemming met de objectleve wetnatigheden, gericht op de opbouw van het soclalisme, conform de leer van het marxisme-leninisme, zoals deze door de partlj van de arbeldersklasse wordt uitgelegd.

In aanmerking genomen dat in het socialisme onder democratie de verwezenlijking van de objectieve wetmatigheden wordt verstan(109), kan deze functie van de 
vrijheld van meningsulting de democratische taak wan de vritheid van meningsulting worden genoemd.

De spectfieke functie van de vrijheid van meningsuiting ter verwezenlijking van de objectieve wetmatigheden in vergelifjking met andere grondrechten $11 \mathrm{gt}$ in de ontwkkeling van het socialistische bewustzijn, doordat dit grondrecht de voorlichting en de overtuiging van de burgers van de socialistische staat volgens het marxistisch-leninistische wereldbeeld door propaganda en agitatie in de vorm van het geschreven en gesproken woord bewerkstelligt, bevordert en waarborgt(110). Hoewel hier zeker ook een taak ligt voor elke indiwiduele burger treedt dit aspect vooral op de voorgrond bij de persurijheid(111).

Tegelijkertijd is de vrljheid van meningsuiting voor de staat het middel om er achter te komen, wat de burger denkt en voelt, wat hem in de gelegenheld stelt waar nodig corrigerend op te treden en het socialistische bewustzijn wan de burger bij te sturen(112). Bij zo'n uitleg moet worden gevreesd dat het grondrecht zich definitief tegen de burger keert.

De democratische taak drukt zo zeer haar stempel op de vril jheld van meningsulting, dat het grondmecht vrijwel geheel in deze taak opgaat. Miet alle meningsuitingen. vallen onder art. 27 1id l Verf. Van een meningsulting is slechts sprake, als deze een "persönliches Verhältnis zu einer bestimten gesellschaftichen Erscheinung" uitdrukt(113). Alleen een mening met een maatschappelifke dimensie, dat is een mening dile een verbinding legt met de matschappij waar 1 in $z i j$ wordt geuit, is als grondrecht relevant (114). Alleen politleke uftingen, die aan de democratische taak voldoen, kunnen derhalve aanspraak maken op de constitutionele bescherming, die van art. 27 lid 1 juncto art. 19 lid 1 Verf. uitgat. Alle andere uitingen worden niet gedekt door art. 27 Verf., zij zijn eenvoudig non-existent, want niet nuttig voor de opbouw van het socialisme.

De verbinding tussen de garantie van de vrijheid van meningsuiting en het nut dat het grondrecht voor de democratie heeft komt ook tot uiting in een andere belangrijke onderscheiding, namelijk die cussen openbare en niet-openbare meningsuitingen. Alleen de mening die "öffentlich" (art. 27 lid l eerste zin Verf.) geuit wordt is een meningsuiting in de zin van art. 27 lid 1 Verf. Niet-openbare meningsuitingen worden niet ter kennis genomea. Niet-openbare meningsultingen zijn echter niet hetzelfde als in privekring gedane meningsultingen. Het criterium van de openbaarheld wordt in de rechtspraak zeer ruim geinterpre-teerd. Wat onder openbaar verstaan wordt, moet worden vastgesteld 
naar analogie van de interpretatie wan het criterium In par. $220 \mathrm{stGB}$, op grond warvan de staat onwelgevallige meningsultingen als stataverdeumdung $\mathrm{c} . \mathrm{q}$. offentlihe Herabuindigung bestraft(115).

Uit het feit dat onder art. 27 lid 1 Verf. slechts die meningsuitingen met een matschappelijke dimensie, die bovendlen in het openbaar gedaan zijn, vallen, moet worden afgeleld dat in het geval van art. 271 id 1 Verf. geen sprake 1 s van een in algemene bewoordingen gesteld grondrecht, mar dat dit recht precies zo ver en niet verder relkt als het voor de ondersteuning van het overheidsbeleid van nut is.

De democratische taak wan de vrijheid van meningsulting wordt gewaarborgd door de in art. 27 11d 1 Verf. opgenomen zinsnede: "den Grundsätzen dieser Verfassung gemäss". Daarmee is ook formeel vastgelegd dat dit grondrecht dient te worden ultgeoefend ten behoeve wan de verdere opbouw van de sociallstische samenleving. Dit onvat tevens de plicht iedere propaganda, die de grondslagen van het systeem bedreigt, te verhinderen (116). Poginger on onder de dekmantel van de witheid van mentingsuiting antisocialistische propaganda te bedrijven hebben met de functie van dit grondrecht niets gemeenschappelljk. Voor zulke tegen de socialistische matschappijorde en tegen de vritheld van alle burgers gerichte activiteiten kan geen vrijheid van meningsulting bestaan. "Das gilt fur die verbreitung konterrevolutionatrer Ideologie(117) ebenso fir militaristische und reuanchistische Propaganda, Kriegshetae, Bekundung von Glaubens-, Rassen- und Volkerhass sowie fur stadtsfeindliche Hetze, die nach Artikel 6 der Verfassung bzw. gemäss Paragraph 106 StGB als Verbrechen verfolgt werden. Der Schutz der sozlalistischen Gesellschaft, wie der Schutz jedes ihrer Bürger gebieten es auch, jegliche offentizche Herabüirdigung der staatichen Ordnung, der staatlichen organe, Einrichtungen, geselischaftlichen organisationen usw. sowie die Verächtlichmachung oder Verleumdung eines Birgers entschieden vom Grundrecht auf frele Meinungszusserung abzugrenzen und mit den erforderlichen staatlichen und gesellschaftichen Mitteln auszuschllessen bzw. zu ahnden"(118). Deze afbakening vindt plates door middel van het strafrecht.

De in 1982 overleden communtst en DDR-burger Robert Havemanm heeft een andere interpretatie van de zinsnede "den Grundsätzen dieser Verfassung gemäs"s" gegeven. Moeten de coegestane meningsuitingen overeensteumen met de beglinselen wan de grondwet, wroeg hij zich af, of beantwoordt het aan de beginselen van de grondwet, dat de DDR-burgers het recht hebben, hun mening vilje52 lijk en openbar te uiten? Hif concludeerde, dat de 
laatste interpretatie juist was op grond van de derde zin van art. 27 lid 1 Verf.: "Niemend darf benachtelligt werden, wenn er von diesem Recht Gebrauch macht". Want wile zou nu benadeling te vrezen hebben als hif slechts meningen uit, die overeenstemmen met de beginselen van de Verfassung! De ult leg, dat de meningsultlngen moeten overeenstemmen met de beginselen van de grondwet, zou de derde zin tot een loze uitspraak maken. Havemann meende daarom, dat het in de DDR is toegestaan ook meningen, die van de officlële mening afwijken, vrijeli jk en openbaar te uiten. "Der ganze Artikel 27 Absatz 1 wäre sonst nichts anderes als eine verlogene Phrase $z$ ur Täuschung der Bürger über thre verfassungsmässigen Rechte" (119).

Deze opvatting wordt begrijpelijkerwijs door de oostduitse grondrechtswetenschap niet gedeeld. Het mag integendeel als een verrijking worden gezien dat de vrif theid van meningsulting haar grenzen vindt in de socialistische orde, want daardoor wordt iedereen in staat gesteld zich op wetenschappelijke wijze een mening te vormen, die niet nadelig wordt belnvloed door soctale afhankelijkheid, monopolies van meningen (persconcentratie) en kapitalistische propaganda.

2.5. Middeten ter verwezentijking van de democratiache taak

\subsubsection{Het politieke strafrecht}

De uit de zinsnede "den Grundsätzen dieser Verfassung gemäss" voortvloeiende grenzen van de vrijheid van meningsuiting worden geconcretiseerd door verschillende bepalingen van het politieke strafrecht $(120)$.

Functle van het socialistische strafrecht in de DDR is de bescherming en bevelliging van de soclalistische rechtsorde alsmede de opvoeding van de burgers tot soclalistische persoonlijkheden (121). Als onderdeel van het socialistische recht is het instrument in de politleke strijid van de arbeldersklasse(122). Het strafrecht heeft daardoor naast een juridische een uitgesproken polftieke dimensle. Dat geldt net zo goed voor de strafrechtspraak. Rechter 11 jke beslissingen in strafzaken zijn politieke besilssingen, die in de eerste plaats de bescherming en de vormgeving van het socialisme dienen.

Het strafrecht gaat uit van de plicht van ledere burger tot trouw aan het soclallstische vaderland, de plicht zich zowel in binnen- als in buitenland (wat dat laatste betekent zal nog blijken(123)) zodanig tie gedragen dat hil de DDR geen schade toebrengt(1.24). 
Ook de bepalingen die tot doel hebben de meningsuitingen van DDR-burgers te reguleren zijn op deze beginselen geënt. Deze bepalingen zijn ultwerkingen van de door de democratische taak an de vrijheid van mentingsuiting gestelde grenzen, zij het dat niet alle bepalingen aan de naleving van de democratische taak met dezelfde intensiteit bijdragen. Een centrale ral spelen de voorschriften die tegen de stat gerichte ophitsing (stactsfeindtiche Hetze) en openbare kleinering (offentiche Herabuindigung) strafbaar stellen (par. 106 c.q. 220 StGB). Van additionele betekenis $z i j n$ de bepalingen die het onwettig opnemen van contacten (ungesetzliche Verbindungeaufnahme - par. 219 $11 d 2 \mathrm{StGB}$ ) en het doorgeven van landverraderijke inlichtingen (Landesvernatemische Nachmichteribermitttung - par. 99 StGB) strafbaar stellen. Andere voorschriften die grenzen stellen aan de vrijheld van meningsulting zijn verder bijwoorbeeld: kleinering van buitenlandse persoonlijkheden (Herabwïrdigung auständischer Pereönlichkeiten - par. 221 StGB) en minachting voor de symbolen van de staat en van de samenleving (Missachtung statiticher und gesellschafticher Symbole - par. 222 StGB). Niet alleen op de verwezenlijklng van de democratische taak gericht, maar ook op de bescherming van humanitaire waarden, is de strafbaarstelling van ophitsing tot oorlog en oorlogspropaganda (Kriegshetae und -Propaganda - par. 89 StGB) en van misdaden tegen de menselijkheid (Verbrechen gegen die Menschlichkeit - par. 91 stGB).

Vanaf de stichting van de DDR - in 1949 - tot 1957 werd de strafbaarheid van niet met de democratische taak te verenligen meningsuitingen rechtstreeks op een bepaling in de grondwet gebaseerd. Art. 6 lid 2 Verf. (van 1949) stelde ophitsing tot boycot (Boykothetze) strafbaar. Tevens kon men steunen op een voorschrift van de geallleerde controleraad, dat verheerlijking van fascisme en militarisme respectievelijk verspreilding van geruchten die de vrede in gevaar brengen strafbaar stelde( 125$)$.

In 1958 trad ter vervanging van deze zeer onuitgewerkte bepalingen een aanvulling op het Wetboek wan Strafrecht in werking(126). Par. 19 StEG stelde staatsgevarlijke ophitsing (staatsgefahrdende Hetae), par. 20 StEG stelde laster jegens de staat (Staatsverleumdung) strafbar. Art. 6 lid 2 Verf. gold vanaf 1957 alleen nog als reserveartikel. Sinds 1968 speelt dit artikel, In dat jaar in licht gewijzigde vorm teruggekeerd in art. 6 lid 5 van de nleuwe grondwet van de DDR, praktisch geen rol meer. Sinds de lnwerkingtreding van het nieuwe Wetboek van Strafrecht in 1968 (127) heeft de rechter namelijk een sluitend geheel van bepalingen 
ter beschikking, wartoe naast par. 106 StgB (de opvolger van par. 19 StEG) en par. 220 StGB (de oprolger van par. 20 StEG) ook par. 89 en 92 StGB behoren.

\subsubsection{Art.6 6 id 2 Verf. van 1949}

De afbakening tussen geoorloofde en ongeoorloofde meningsultingen wond plats tijdens de beginjaren van de republiek. Julst in deze periode bestond de behoefte duidelijkheld te scheppen over de verwachtingen die de staat aan $z i j n$ burgers stelde. Met harde hand werden afwiljkende menlngsultingen bestraft. De bestrafflng vond, zoals gezegd, a anvankelijk plaats op grond van art. 6 lid 2 verf.:

2. Boykotthetze gegen demokratische EIntichtungen und Organisationen, Mordhetze gegen demokratische Politiker, Bekundungen von Glaubens-, Rassen-, völkerhass, militaristischer Propaganda sowie Krilegshetze und alle sonstigen fandlungen, die sich gegen die Glelchberechtigung richten, sind Verbrechen im Sinne des Strafgesetzbuches. Austabung demokratischer Rechte im sinne der Verfassung 1st keine Boykotthetze.

Hoewel dit artikel noch een delictsomschrijuing moch een strafmat bevatte, verklaarde het oberste Gericht dat het als rechtstreeks toepasbare strafrechtelijke bepaling an te wenden was. Alle in het Wetboek van strafrecht voor misdrijf toegelaten straffen, namelijk de doodstraf, levenslange en tijdelijke gevangenisstraf mochten al nar gelang de ernst van het delfct worden opgelegd(128). Het ontbreken van een concrete delictsomschrifving zette uiteraard de deur open voor zeer rulme interpretatiemogelijkheden. Bestraft werden onder meer opmerkingen, die het democrat1sche karakter wan de DDR in twiffel trakken, opmerkingen dat de arbeliders $\mathbb{i n}$ de DDR nog sterker werden uitgebult dan ten tijde van de nazi's en de vraag waarom de Soziatdemokratiache Partei Deutschlands verboden was(129). De vraag hoe men kon stemmen als er maar é̃n $11 j \mathrm{st}$ was bracht volgens de rechter de vrede van het Duitse volk en van de wereld in gevaar:

"Die Justiz der DDR ist im Mamen der 800 ML11Lonen

Friedenskämer der Welt verpflichtet, gegen solche Elemente harte aber gerechte Urtelle zu falIen' $(130)$.

De straf bedroeg in totaal 15 jaar gevangenis. In het geruchtmakende proces, dat in 1950 leidde wot een verbod van de Jehova's getudgen, concludeerde het oberste Gericht onder andere tot Boykothetze vanwege de oproep, door de Jehova's getuigen gedaan, om niet deel te nemen aan de verkiezingen van oktober 1950 (131). 
Ontoelaatbar merd het geacht comunisten te betitelen is misdadigers, warkens of parasieten(132). Evenzo de menlug dat de arbeldersopstand van 17 funl 1953 in Oost-Berlijn niet door Amerlkaanse agenten, maar wel degelljk door de arbelders zelf was georganiseerd (133), de verwelkoming van de opstand in Hongarije (134), het zingen van liederen na de dood wan stalin (135), het tappen van politiake moppen(136), kritiek op de prijs van bier en worst(137), kritlek op de Levensomstandigheden in de DDR in nar de Bondsrepubliek gezonden brieven (4 tot 6 jaar gevangenis)(138), het shrifven van een artikel over de toestand in de DDR in eer Westdultse krant(139), het invoeren en verspreiden van Westdultse kranten en tijdschritten (140), of het opvangen en verbreiden van via westelijke zenders opgevangen mieuws (141).

Met 5 jaar tuchthuis werd een studentenpastor ut Leipzig bestraft, die boeken ult het westen invoerde en bovendien studenten aanspoorde uit de Freie Deutsche Jugend, de Jeugdorganisatie van de SED, te treden $(142)$. Zelfs een oostduitse handelsrelziger, die in een $\mathbb{D}$-trein tussen Neurenberg en Stuttgart textiel en schoenen van 0ostdultse make11 $j$ bet4telde als "Dreck" ontkwam nitet aan de lange arm van de DDR-justitie (143).

\subsubsection{Tegen de stad gerichte ophitsing}

Sinds de inwerkingtreding van de derde wijziging van het Wetboek van strafrecht in 1979 (144) luidt par. 106 StGB als volgt:

1. Wer die verfassungsmässigen Grundlagen der sozialistschen Staats- und Gesellschaftsordnung der Deutschen Demokratischen Republik angreift oder gegen sie aufwiegelt, Inden er

(1) die geselischaftichen Verhältnisse, Repräsentantem oder andere Bürger der Deutschen Demokratischen Republik wegen deren staatlicher oder gesellschaftlicher Tätigkeit diskriminiert;

(2) Schriften, Gegenstände oder Symbole zur DIskriminferung der gesellschaftlichen Verhaltnisse, von Repräsentanten oder anderen Bürgern herste11t, einfuhrt, verbreitet oder anbringt;

(3) die Freundschafts- und Bundnlsbeziehungen der

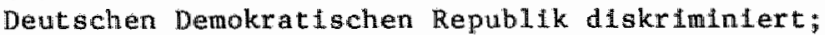

(4) Verbrechen gegen den Staat androht oder dazu a ufordert, Widerstand gegen die sazialistische Stats- und Gese11schaftsordnung der Deutschen Demokratischen Republik zu lelsten;

(5) den Faschismus oder Militarismus verherritcht oder Rassenhetze treibt,

wird mit Freiheitsstrafe von elnem bis zu acht 
Jahren bestraft.

2. Wer zur Durch fuhrung des Verbrechens mit organisationen, Elnrichtungen oder Personen zusamenwirkt, deren Tåtigkeit gegen die Deutsche Demokratische Republik gerichtet lst oder das Verbrechen planmässig durchfuhrt, wid mit Freiheitsstrafe von zwei bls zu zehn wahrea bestraft.

(3) Vorbereltung und Versuch sind strafbar.

In het officiele comentaar op het Wetboek van Strafrecht wordt de stadsfeindliche Hetze onschreven als een aanval op de constitutionele grondslagen van de soclallstische staat en samenleving. Zil is een subversieve activiteit die de matschappij ln gevar brengt en Immanent bestanddeel van de imperialistische ideologische sabotage, die het soclalistische bewustzijn van de oostdutitse burgers in verwarring wil brengen en tot doel heeft onzekerheid en ontevredenheid te strooien(145). Deze sabotage veroorzakt de Hetze. Normale ideologische discussies, onduidelijkheden, politieke domheden of vergissingen zijn geen Hetze.

De omschrijving van het delict is zo rulm gesteld, dat ledere ulting, op wat voor wijze ook gedaan, exdoor wordt gedekt (met name par. 1061 id 1 sub 1,2 en 5 StGB). Onder de in par. $1.06 \mathrm{lid} 1$ sub 2 stgB genoemde geschriften, voorwerpen en symbolen worden onder andere verstaan: alle vormen van drukwerken - waarbij het nlet relevant is af men zelf de auteur $1 \mathrm{~s}(146)-$, alle afbeeldingen, plastleken, vlaggen, tekenen, emblemen en gebaren $(147)$.

Hetze is eer misdrijf, omdat het zich richt tegen de ldeologische en politleke grondslagen van de staat zelf en daarom bifzonder ernstig moet worden genomen. Dit in tegenste1ling tot het delict Staatsverieumbung, dat geen misdrijf is, mar in een lichtere categorie valt, ondat het de staat zelf niet in gevar brengt, mar hoogstens het aanzien van de socla listische staat schade toebrengt $(148)$.

In de eerste jaren na de inwerkingtreding van de aanvulling op het toenmalige Wetboek van Strafrecht (1957) heeft de rechter zich intensief bezig gehouden met de afbakening tussen Hetze en Staatsventeumdung. Als criterium is ontwikkeld of de dader al dan niet een viyandige 1 instelling tegenower staat en matcschappif heeft en het oogmerk de staat schade toe te brengen of er tegen op te rulen. BIj de beoordeling of sprake is van Betze kan niet van de woordelljke inhoud worden uitgegaan; doorslaggevend zljn de innerlijke onstandigheden, welke tot de uiting hebben gelieid en opheldering geven over de intentie(149). Het nagegtreefde doel is doorslaggevend:

"Wer gegen unseren Staat und gegen die Sowjetunton 
hetzt und dabei auch noch Resonanz bel anderen Burgern anstrebt, begeht nicht statsverleundung* sondern statsgefahtende Propaganda und Hetze (150).

Op grond wan deze rechtspraak werd de intentie in 1968 opgenomen in de delictsomschrijwing(151), maar er in 1979 weer wit verwijderd(152), nat men mag aamnemen on de bewijsvoering woor de offlcher wan Justitie niet onnodig moeill $1 \mathrm{jk}$ the raken.

Valt een uiting zowel onder par. 106 stGB als onder par. $220 \mathrm{StGB}$, dan vindt veroordeling plats op grond van het zwardere delict(153).

Veroordelingen wegens Hetze werden ultgesproken tegen Jehova"s Getulgen vanwege 1 llegale invoer en wersprelding van geschriften van deze groepering(154), tegen studenten die een politieke discussie gevoerd hadden (155), vanwege een opmerking dat staken nodig was a $1 \mathrm{~s}$ te lage lonen werden uitbetaald (156) en dat de partijbonzen lule varkens waren die zich op kosten van de arbeiders voedden(157). Twintig maanden tuchthuis licaste de opmerking" "Du Lump, Du Held der Arbeit, Dich erwischen wir schon noch einmal" tegen een burger dle met de onderschelding "Held wan de arbeld" was beloond (158). Bestraft werd eveneens de opvatting dat de oprichting van de Berlijnse mutr vergezeld was gegaan van progroms en 1ynchpartijen(159). Naar aanlelding van dezelfde gelegenheid werd iemand veroordeeld, "indem er sich gegeniber dem Zeugen sowie auch anderen Personen mit angeblichen Erlebnissen beil der Durchfinrung der sicherheitsmassrahmen vom 13.8. 1961 brustete. Er erzählte, dass dle Wolkspollzed in elnem Kanal In Berlin Menschen wie die Hunden abgeschossen habe, dass die Angehörigen der S1cherheltsorgane selbst nicht mit diesen Massnahmen einverstanden seien und mit weisser Fahne nach West-Berlin tiberlaufen. Selne Hetze gegen unsere bewaffneten Organe gling so welt, dass er erzählte, ein oberst der Volkspolizei häte einen Brief liber die Mauer nach West-Berlin geworfen, dessen Inhalt gegen den Vorsitzenden des Staatsrates, Walter U1bricht, gerlchtet war" (160).

Onder verheerlijking van het fascisme (11d 1 sub 5) is verstaan het zingen van het Deutbohtandlied ("Deutschland, Deutschland, uber alles")(161), llederen uit de nazitifd of het brengen van de fascistische groet (162). Verheer $11 j k i n g$ van het fasclsme heette ook het kijken naar een serie Westdultse ultzendingen over de aanslag op Hitler van 20 Juli 1944(163). De problematlek rond het kijken en luisteren naar Westduitse zenders vormde in de eerste jaren na 1958 een zeker 
zwatepunt in de rechtsprak net betrekking tot Het20. Daarop wordt nog teruggekomen(164).

Op grond vam par. 106 lid 2 StGB werkt strafvet warend het samenwerken met organisaties, inrichtinger of personen, wiler activitelten tegen de DDR gericht zijn, alsmede het planmatig te werk gaan. Dit ls het geval wameer men naar westelijke zenders kijkt of luisturt met het doel op deze manler verkregen informate am derden door te geven(165).

$\mathrm{Bij}$ mondelinge meningsultingen (par. $10611 \mathrm{~d} 1$ sub 1 StGB) Is Hetze aanwezig als zij tegen de stat, zijn vertegenwoordigers of andere burgers wegens hun activiteiten noor staat of samenleving(166) gericht is. Bij meningsultingen wia geschriften, voorwerpen of symbolen, die immers een veel bredere werking kunnen hebben, is geen adressaat verelst (167).

De bouw van de Berlijnse mur leldde tot een zekere stabilisering van de verhoudingen in de DDR. De behoefte om de eigen socialistische ldentitelt te pas an te onpas te benadrukken nam af, de noodzaak zich tegenower de Bondsrepubliek af te grenzen werd tets minder en de DDR-burger zelf vormde waaxschijnlijk ten minder grote bedreiging voor de overheid(168).

Sinds het begin van de jaren zeventig valt weer een verscherping van het strafrecht net betrekking tot de vrijheid van meningsuiting te constateren, in oostdults jargon onschreven als verwolmaklng van de sozialistische Gesetzlichkeit( 169$)$. Deze verscherpling hangt samen met de door het Grondslagenverdrag van 21 december 1972(170) in gang gezette liberalisering van de betrekkingen tussen de Bondsrepubliek en de DDR. Men poogde het gevaar van intenslever wordende contacten tussen 0ost- en West-dultsers te bezweren door drie opeenvolgende wetswijzlgingen, die leidden tot verdergaande restricties van de vrijheld van meningsuiting (171). In 1979 is de maximumstraf voor staatofeindlihe Hetze verhoogd van viff tot acht jaar( 172), nadat in 1977 de strafverzwarende omstandlgheden, die een maximumstraf tot 10 faar toelaten, waren uitgebreid (173). Had het vór die datum behalve het planmatig begaan ran Hetze en strafverzwarende werking, wanneer men "Publikationsorgane oder Elnrichtungen benutzt, die einen Kampf gegen die Deutsche Demokratische Republik fuhren"(174), sinds 1977 kwam voor strafuerzwaring in aamerking degene, die "mit organisationen, Elnrichtungen, Gruppen oder Personen zusamenwirkt, die einen Kampf gegen die Deutsche Demokratische Republik fuhren", een aanzien 1 ijke uttbreidlng, die in de praktijk de mogelijkheid opent voor de autoritelten am elk ongewenst contact van DDR-burgers met westduitsers 
en andere ult het Westen afkomstige bezoekers te bestraffen. Bowendien speelt in de nieuwe formulering, zoals reeds opgemerkt, de Intentie geen rol meer. Daarvoor is nu in de plaats gekomen de formulering dat de gewrakte meningsulting zich tegen de constitutionele grondslagen van de 0ostultse matschappijorde moet richtem, w1 er van Hetze sprake zijn. Daaruit zou kunnen worden afgeleld dat alet elke opruilng tegen de soclalistische orde meer strafbaar zou zijn, maar alleen die ophitsing, die tegen de grondslagen van die orde gerlcht is, en dan nog slechts voorzover die in de grondwet zijn neergelegd (175). Een dubbele inperking, dle echter gezien de ruime formuleringen, die in de grondwet worden gehanteerd, geen praktische betekenls hoeft te hebben. Wel kont nu in par. 106 StGB duldelijker dan tot dan toe tot uiting dat het er om gat meningsultingen die niet aan de demacratische taak voldoen te bestraffen(176). Hoe streng deze taak nog steeds wordt uitgelegd toont een oordeel ult 1979 , dat werd ultgesproken vanwege het opnemen en doorgeven van liederen van de 1 n 1976 van het oostduitse statsburgerschap beroofide chansonnier Wolf Biermann(177). In 1982 werd een dichter en blueszanger veroordeeld, die had meegewerkt in protestantse kerkdiensten in Oost:-Ber $11 \mathrm{jn}(178)$, evenals twee leden van een dissidente marxistische groep met Albaanse sympathleën wegens het verspreiden van materlaal met onvriendelijke opmerklngen over de manier, warop het soclalisme In de DDR in praktijk wordt gebracht ( 179$)$.

Onverminderd strafbaar is het sturen van brieven met voor de DDR onvriendelijke linoud nat het westen (180). Ook het schrijven van een brief aan Honecker, de voorzitter van de Staatsraad van de DDR, door een veroordeelde die beweerde onschuldig in de gevangenils te zitten werd bestraft (181).

Een betrekkelijk recente tendens is de aanwending van par. 106 StGB in geva11en, waarin DDR-burgers de autoriteiten om een uitreisvisum naar het westen verzoeken. Dit komt steeds vaker voor sinds de ondertekening van de Slotacte van Helsinki en de lnwerkingtreding van het Internationaal Verdrag Inzake Burger echten er. Polltieke Rechten. In de emigratieverzoeken wordt dan bljwoorbeeld een beroep gedaan op att. 12 11d 2 ICCPR, dat het recht van een teder erkent, zijn elgen land te verlaten. Het schriftelijke emigratieverzoek wordt in deze gevallen gewardeerd als statsfeindliche Hetie en met meerdere Jaren gevangenis bestraft (182).

Hetzelfde lot onderging de schrijver van een toneelstuk, dat de dialoog tot thema had, die zich had ontsponnen tussen de indiener van een emigratieverzoek en de verantwoorde11jke autoritelten (183). 


\subsubsection{Openbare kleinering}

Sinds de inwerkingtreding van de derde wijziging van het Wetboek van Strafrecht in 1979(184) luidt par. 220 StGB als volgt:

1. Wer in der Oeffentlichkelt die staatiliche Ordnung oder staatliche organe, Einrichtungen oder gesellschaftliche Organisationen oder deren Tätigkeit oder Massnahmen herabwürdigt, wird mit Freiheitsstrafe bis zu drei Jahren oder mit Verurteilung auf Bewährung, Hafstrafe, Geldstrafe oder nit offentilichen Tadel bestraft.

2. Ebenso wird bestraft, wer Schriften, Gegenstände oder Symbole, die geelignet slind, die staatliche oder offentilche Ordnung zu beeinträchtigen, das sozlalistische Zusamenleben $z u$ stören oder die staatliche oder gesellschaftliche ordnung verächtlich zu machen, verbreitet oder in sonstiger Weise anderen zugänglich macht.

3. Ebenso wird bestraft, wer in der Geffentilichkeit Aeusserungen faschistischen, rassistischen, militaristischen oder revanchistischen Charakters kundtut oder Symbole dieses Charakter verwendet, verbreltet oder anbringt.

4. Wer als Bürger der Deutschen Demokratischen Republik die Tat nach Absatz 1 oder $3 \mathrm{im}$ Ausland begeht, wird mit Freiheitstrafe bis zu füf Jahren, Verurtellung auf Bewährung oder mit Geldstrafe bestraft."

Reeds is naar voren gebracht dat de offentliche Herabwirndigung (het openbaar kleineren), of zoals het delict vroeger heette Stativerleumdung (laster jegens de staat)(185), in vergelifking met Hetze minder ernstig is, omdat zij niet tegen de staat zelf is gericht, maar siechts het aanzien van de stat schaadt, bijvoorbeeld door het uiten van onwaarheden of het doen van onbewijsbare beweringen. Daardoor wordt wantrouwen tussen burger en overheid gezaatd, wat de ontwikkeling. van het socialisme remt, maar niet in gevaar brengt. Het minder serieuze karakter van de offentliche Herabwiürdigung in vergelijking met Hetale komt tot uiting in de geringere zwarte van de opgelegde straffen.

ook bif de herabwiliniging is de manier waarop de mening kan worden geuit schier onbegrensd. Voorwaarde voor strafbaarheld ex par. 220 lid 1 StGB 1 s het criterlum van de openbaarheid. In zijn oordeel van 18 oktober $1957(186)$ bepalde het Oberite Gericht dat een meningsuiting openbaar is, wanneer $z i j$ door een onbepaalde kring van personen ter kennis kan worden genomen. Deze voorwarde gat in ieder geval in vervulling in openbare gelegenheder, op de openbare weg, in openbare verwoersmiddelen en dergelijke. Ook bij mondeling 
of schrlftelijk gedane uitingen die aan overyeldsinstellingen zifn gertcht of die in een dienstrulute vorden gedaan is an de voorwarde van openbaarheld voldaan. Zo werd lemand tot twee jaar gevangenisstraf veroordeeld, die een protest had ingediend tegen een welgerling van de autoriteiten een ultrelsvisum te verstrekken(187). Als de witing in de privéfeer, bijvoorbeeld in de eigen woning, wordt gedaan, maakt deze omstandigheld de ulting niet automatisch tot een prive-ulting Dat hangt af van de betrekkingen tussen de aanwezigen. Wellswar moet de plats war de mededeling wordt gedaan in aanmerking worden genomen, maar darnaast ook de relatie tussen degene die de mening uit en degene die har aanhoort:

"Die Voraussetzung der Oeffentlichkeit ist aber auch dawn gegeven, wemn in einer an sich nicht als "fffentliche oertichkelt zu bezelchnenden Umgebung, wile privaten Wohnraumen, Werkstatten und derglelichen, die persönliche Atmosphäre durch den Charakter der betreffenden Aeusserungen und der vö111g unpersönlichen Beziehtmgen, in denen sich der Kundgebende und der Empfanger der Mittellung gegenuber stehen, beseitigt 1st. Es ist hierbei zu denken an fremde Personen - wobel "fremd" nicht glelchzusetzen 1st mit "unbekannt" -, die in der Austibung staatlicher oder gesellschaftlicher Tatigke1t, aber auch zun Beispiel aus persönlichen oder geschäftichen Grunden in den privaten Räumen des Täters weilen und von diesem genötigt werden, slch staatsverleumderfsche Erklärungen anzuhören." $(188)$.

Geen openbarheid 1 s a anwezig, waneer de ulting uitsluitend tegenover naaste verwanten (echtgenoten, broers en zusters en verwanten 10 de rechte 1 ijn) gedaan 1s. De royale uttleg van het begrip openbaarheld is ook in de DDR op kritiek gestoten. Frenzet heeft gewaarschuwd voor een al te grote rechterlijke 1 jiver een privé gedane uiting als bedrelgend te zien en voor een striktere interpretatie gepleit(189). Har mening is echter niet gevolgd.

De door de rechtspraak in het kater van par. 220 stGB verrichte albakening van het begrip openbaarheld is op gelifke wljze van toepassing op het criterlum van de openbaarthedd in art. 27 lid 1 verf.

Veroordelingen vonden plates op grond van de volgende ultingen, waryar over lgens opwalt dat velle identlek alf atn uithingen die ook genoeg reden hebben opgeleverd voor een veroordeling op grond van Hetze: "Schelsse aut den Sozialismus, so wie es jetzt ist 62 kann es in der DDR nicht weltergehen, bei euch ist 
alles Scheisse"(190), de snerend bedoelde uiting dat ulbricht alwetend zou $z 1 j n(191)$, de oprerking dat in het partijorgaan van de SED, Neues Deutschtand, soms leugens zouden staan(192), politleke moppen over de toenmalige staatspresident Pieck, minister-president Grotewohl en diens plaatsverwanger vibricht(193); een uitroep van vreugde over de dood van Pieck(194), kritiek op de SED en haar functionarissen (195) en op de bouk van de Berlijnse mur (196). Tot zeven maanden werd een vrow veroordeeld die de pedagogische capaciteiten van de 0ostduitse leraren in twijfel trok(197). Dat de veroordelingen in deze gevallen werden uitgesproken op grond van staatsveroteumdung in plaats wam op grond van Hetze is te danken aan het felt dat de Instelling van de verdachten niet vijandig tegenover de staat zelf was. Deze instelling is af te leiden uit het gedrag wan de dader, zijn opstelling tegenover de arbeiders- en boerenmacht, bijvoorbeeld in het arbeldsproces, en uit de stand van zijn bewustzijnsontwikkeling, alsmede uit de beweegredenen, die aan zijn handelen ten grondslag lagen(198). In de meeste geva1Ien is de Staatsverteundung terug te voeren op emotionele opwinding, ergernis of (opvallend vaak) dronkenschap. Komt op grond van deze - In socialistische ogen verzachtende - omstandigheden geen veroordeling wegens Hetze, mar wegens staatsverleumdung in aanmerking, dan heeft deze geen vergeldende, mar veeleer een opvoedende functie. De reden van bestraffing is:

"dass die Strafe unbedingt notwendig ist, un den Angeklagten dahingehend zu erziehen, dass er sein Verhalten in der Zukunft iberprüft und ändern muss, un wirk1ich eln geachtetes Mitglied in unseren sozilalistischen Gesellschaft zu $\operatorname{sein}^{\prime \prime}(199)$.

Wie Hetge bedrijft ontpopt zich tot vijand van de socialistische staat wordt afgeschreven. Van degene, die zich aan Staatsverdeumdung schuldig makt wordt nog een min of meer positieve houding tegenover het socialisme verondersteld. De belastering van de staat beschouwt men als een eenmalige ontsporing, zoals die nu eenmaal kan voorkomen zolang de slechte Invloeden van het kapitalisme nog niet geheel zijn overwonnen, aldus de teneur van de rechtspraak rond 1960. In zulke gevallen kan een veroordeling soms zelfs achterwege blijven, ondat zij niet altijd de geëlgende weg is om de delinquent weer op het rechte spoor te brengen en voor thet soclalistische ideall terug te winnen. In 1962 - kort na de bouw van de mutur - sprak het Oberite Gericht zich uit voor een restrictieve toepassing van wat tegenwoordig par. 220 StGB 1s. Het betrof een verdachte, die in lagere instantie veroordeeld was vanwege de opmerking, dat de DoR een 
staat was van boeven en ploerten, terwijl hij tevens had angekondigd Walter ULbclcht een brief te zullen schrijuen on hem van de in de DDR heersende toestanden op de hoogte te stellen. Het oberbte Gericht concludeerde dat in casu van Staatsverlewndung geen sprake kon $21 \mathrm{jH}$,

"schon deshalb, well die won thm gebrauchten Worte nur zum Teil elnen abfalligen Charakter tragen, 1 m ibrigen aber erkennen lassen, dass er den Vorsitzenden des Statsiates der DDR, als dem fihrenden Staatsmann der Deutschen Demokratischen Republik, Walter Ulbricht, grosses Vertrauen entgegenbringt" (200).

Hetgeen toch duldelijk een blijk van vertrouwen in de soclalistische samenleving als geheel is. Het Obemste Gemicht vervolgde met de constatering,

"dass sich im Handeln des Angeklagten nicht eine Straftat, sondern ein Verstoss gegen die ihm als Burger der Deutschen Demokratischen Republik obliegenden morallschen Pflichten und gegen die Staatsdisziplin offenbart. Wegen dieses Verhaltens hatten sich dte Kollegen und der Partelsekretär sofort mit dem Angeklagten auselnandersetzen mis$\operatorname{sen}^{\prime \prime}(201)$.

Het is dus niet de zaak wan de justitie de burger te corrigeren in alle gevallen, dat een de stat onwelgevallige mening geuit wordt, maar de medeburgers hebben evenzeer een verantwoordelijkheid in dezen.

Wiet alleen burgers van de DDR worden wegens kritische opmerkingen verwolgt. Een leder die zlch op liet terr tolk wan de DDR bevindt, dient zich te houden aan de oostduitse ufteg van de vrijheid van meningsuting $(202)$.

Ook de bepallngen van par. 220 StGB zijn rajddels de wetswijzigingen in de jaren zeventig(203) verscherpt. In 1979 werd de maximumstrat verhoogd van twee tot drie Jaar. De offentltche Herabuirdigung door middel van geschriften, voorwerpen en symbolen werd analoog aan par. 106 StGB expliclet strafhaar gesteld. Bovendien werd een nleuw $11 d 4$ ingevoerd, dat het door oostduitsers in het bultenland begaan van dit delict strabar stelt en bedrelgt met vritheldsstrat var maxlmat 1 wif jaar, bewaring of geldboete(204). Het viterde lid is lingevoerd met het oog op de steeds wder verbreid rakende gewoonte van oostduitse anteurs an hun werk in de Bondsrepubliek te laten uitgeven, als dit in de DDR zelf niet mogelijk is(205). Zelis als deze handeling in concreto geen öffentiche Herabwindigung of Hetze inhoudt is zij tegenwoordig strafbaar, ondat in 1979 tegelijk met de invoering van 
par. 220 Ild 4 StGB, tevens een algemeen verbod op priblicatie in het buitenland van kracht is geworden door die toevoeglng van een miew tweede en derde lid aan par. 219 StGB, dat het 111 egaal opnemen van contacten strafbaar stelt (206). De tekst van par. 219 11d 2 en 3 StGB luidt:

2. Ebenso wird bestraft

(1) wer als Burger der Deutschen Demokratischen Republik Nachrilchten, die geeignet sind, den Interesien der Deutschen Demokratischen Republik zu schaden, in Ausland verbreitet oder verbreiten lassist oder zu diesem $Z$ weck Aufzelchnungen herstellt oder herstellen lasst;

(2) wer Schriften, Manuskipte oder andere Materialien, die geelgnet sind, den Interessen der Deutschen Denokratischen Republik zu schaden, unter Ungehung von Rechtsvorschriften an Organisationen, Einrichtungen oder Personen im Ausland ubergibt ader ubergeben 1assit.

3. Der Versuch ist in Falle des Absatzes 2 ziffer

2 strafbar.

De actuele aanlelding voor de invoering van par. 219 $11 d 2$ en 3 StGB en par. 22011 d 4 StGB vormde een conflict tussen de oostduitse autoriteiten en de schrijver Stephan Heym.

Heym was kort daarvoor veroordeeld wegens overtreding van de 0ostduitse deviezenwet(207), In werkelijkheid echter vanwege publicatle van een boek in de Bondsrepubliek. Hij had namelijk zonder toesteming van het In 0ost-Berilin gevestigde bureau voor auteursrechten een contract met een Westduitse uitgever afgesloten. Ondat die toesteming ontbrak reglstreerde het bureau ook de wit het contract voortvloeiende deviezentransacties niet, met als gevolg dat Heym tegen wil en dank de deviezenbepalingen, die anmelding van zulke transacties verplicht stellen(208), schond. Ondat men inzag dat dit onelgenlijke gebruik van de deviezenwet om onwelgevallige meningsultingen te bestraffen een onhoudbare toestand was, die veel $\mathrm{kritiek}$ in het westellfke deel wan Duitsland uitlokte(209), werd par. 219 1id 2 StGB ingevoerd, daarom ook wel de lex Heym genoend (210). Aldus kan men thans rechtstreess tot bestraffing van publicatie in het buttenland overgaan.

Bowendien kan de bepaling ook in andere gevallen worden aangewend. Zo werd in 1981 lemand veroordeeld wegens het 11 legal apnemen van contacten, die een brief aan ziln moeder in de Bondsrepublliek had geschreven, dat hij een uitreisvisum op grond van familieherentging had aangevraagd $(211)$, en In 1984 een vrouw, die een telefoongesprek met vrlenden in West-Ber $11 \mathrm{jn}$ had gevoerd. Wat de inhoud van het gesprek was, is niet 
bekend, mar de veroordeelde was $11 d$ van een gesprekskring. die bijeenkwam in een kerk in Weimar, en $21 j$ nam deel aan activitelten ten behoeve van de wrede (212). Verder 1 . de veroordeling bekend van een arts, van wie op cassette opgenomen wredesliederen waren afgespeeld op de Hestduitse televisle, en van twee personen, die zouden hebben geprobeerd contact op te nemen met vedeggroepen in West-Europa(213).

De normale maximumoogte van de straf, warmee in geval van overtreding van par. 220 StGB wordt gedreigd Is 3 Jaar, bij par. 219 StGB is dat 5 jaar. Moet daarult worden geconcludeerd, dat de costdultse autoritelten het ernstiger vinden als een van hun burgers schade aan het aanzien van de DDR in het buitenland berokkent, dan wanneer dit binmenslands gebeurt?

Net over de gehele linle heeft de verscherping wan de strafrechtelijke bepalingen geleid tot een repressievere praktijk. Zo is het in tegenstelling tot de eerste decennla van het bestaan van de republiek sinds het bewind van Erich Honecker in leder geval niet meer gevaarlijk politleke moppen te vertellen die voor de staat onvriendelijk uitvallen(214). Wel $11 \mathrm{gt}$ de discretionalre bevoegdheld over de al dan niet toelaatbaarheid van meningsuitingen als vanouds bif de overheld. Elke liberallserling en versoepeling blijte het karakter behouden van een geschenk aan de burger. Het blifft onmogelijk princlpiele kritlek te leveren op de socilistische orde in de DDR.

2.5.1.4. Detioten tegen de vrede en tegen de menseitukheid

Additionele betekenis voor de verwezenlifking van de democratlsche taak van de vrijheld van meningsuiting kumnen de par. 89 en 92 StGB hebben.

Het in art. 6 1ld 5 Verf. constitutioneel vastgelegde verbod van ophitsing tot oorlog en oorlogspropaganda is tegenwoordig geconcretiseerd door par. 89 StGB. onder propaganda voor een aanvalsoorlog, een andere daad van agressie, het gebruik van kernwapens of andere massavernietigingswapens wordt verstaan de systematische verbrelding van standpunten, die er op gericht zljn onder minachting van de regels van het volkenrecht de bevolking van de eigen stat of van andere staten ideologisich te betnvloeden, om mensen voor de doelen van imperlalistische agressiepolitiek te winnen of hen te intimideren(215). Het verschil met par. 106 StGB is dat achter de propaganda een agressieve intentie moet steken, terwijl aan de andere kant de ulting niet speclaal tegen de oostdultse staats- en maatschappijorde gericht hoeft te zijn. Kriegshetze werd in 1950 bij Jehova's Getuigen vastgesteld, die zich 
keerden tegen het verzamelen van handtekeningen tegen de atoombom, zij het vanwege de begeleidende omstandigheid dat zij tegelijkertijd de rechtvaardige oorlog ankondigden, aldus de rechter(216). Recente gepubliceerde veroordelingen op grond van par. 89 StGB zijn niet bekend.

Dok een constitutionele basis heeft het delict fascistische propaganda, ophitsing tegen volkeren en rassen (Fabchitische Propaganda, Vökem und Rassentetze par. 92 StGB). De strafbaarheid van zulke uitingen wordt voor een deel reeds gedekt door par. 106 ild 1 sub 5 stGB(217). Voor een vervolging ex par. 92 stGB is als extra vereiste nodig, dat de ulting geschukt is on op te ruien tot het voorbereiden of begaan van een misdaad tegen de menselijkheid(218). Uit de opmerking in het officiële commentaar op het Wetboek van Strafrecht, dat Völker und Rassenhetze vaak dienst doen als instrumenten van reactionaire ideologieën(219) blijkt dat het voorschrift tevens kan fungeren om makoming van de democratische taak van de vrijheid van meningsuiting te verzekeren.

\subsubsection{Andere middelen}

Ondanks de bepaling in art. 27 lid 1 Verf., dat het recht op vrijheid van meningsutting door geen dienstverband beperkt wordt, is de realiteit dat het niet voldoen aan de democratische taak van dit recht bestraft kan worden met ontslag. Art. 55 AGB laat ontslag op staande voet toe in geval van zwaarwegende schending van de staatsburgerlijke plichten(220). onder schendingen kumnen ook meningsuitingen worden verstaan die nlet aan de democratische taak voldoen. Weliswaar heeft het Oberste Gericht utgesproken dat ontslag op staande voet niet lichtvaardig als sanctie mag worden aangewend(221), maar toepassing van dit middel vindt nog altijd plaats(222).

Voor hen die in overheidsdienst werkzaam zijn gelden speciale voorschriften. Van de ambtenaren(223) wordt onvoorwaardelijke trow aan de arbeldersklasse, de marxistisch-leministische partij en de socialistische staat geëist(224): "Das Denken und Handeln der Mitarbelter des sozialistischen Staatsapparates ist von den Wesenszigen der Arbeiterklasse und deren wissenschaftlicher Weltanschauang, dem Marxismus-Lenintsmus, bestimnt; thre gesamte Tätigkeit ist darauf gerichtet die ziele des sozlalistischen und kommunistischen Aufbaus zu verwirk1lchen"(225). Naast de normale ambtelijke taken dienen de ambtenaren tevens politiekideologisch overtulgingswerk te verrichten en het socialistische bewustz1jn te sterken(226). Schenden 
z15 hun plichten, opzettelifk of uit nalatigheld, wat dus ook het geval is als $21 j$ hun wrijheid van meningswiting niet conform de democratische taak ultoefenen, dan kunnen de ambtenaren worden berispt of op staande voet ontslagen(227).

De democratische taak van de vrijheld van meningsulting werd massaal genegeerd in 1982. Onder de groelende invloed van de vredesbeweging ook in de DDR gingen steeds meer - voornamelijk jonge oastduitse burgers ertoe over openlijk stickers op hun kleding te dragen met het opschrift: "Schwerter 2u Pflugscharen" (zwaarden tot ploegscharen), dat een afbeelding omlijstce van het geschenk van de Sowjet-Unie aan de Verenigde natles. De autoriteiten vatten deze ult het bijbelboek Micha 4 afkomstige tekst op als een bedreiging van het offlctële overheidsstandpunt over de wijze waarop internationale vrede dient te worden bereikt. Ook de door de oostduitse vredesbeweging gebruikte leus: "Frieden schaffen ohne Waffen" (vrede tot stand brengen zonder wapens) gold als een doorkruising van het officleel gepropageerde vijandbeeld, dat berust op de stelling, dat soclalisme en vrede enerzijds en kapita11 sme en oorlog anderzijds een onverbrekelijke eenheid vormen, en die alleen de conclusie "Der Frieden muss bewaffnet seln" (de vrede moet bewapend zijn) toelaat (228). De jongeren werden onder druk gezet de stickers van hun kleding te wexwijderen met de dreiging, anders van school te worden verwijderd of de opleidingsplaats te verllezen(229). In september 1982 besloot de Evangelische Kerk in de DDR, een van de steunpilaren van de vredesbeweging, om wille van de lieve vrede af te zien van het gebruik van de sticker, hoewel men aan de inhoud van de woorden onverkort wil vasthouden (230). Het diffuse karakter van de vredesbeweging en de ondersteuning vanuit kerkelijke kring makt het de oostdultse autoriteiten ondanks dreigementen erg moeilijk de dissidente mentingsuttingen met de gebruikelijke middelen te bestrlfden. In het ulterste geval wordt daarom ook van het middel gebrulk gemaakt vredesactivisten uit de DDR uit te wijzen en over de grens naar de Bondsrepubliek te zetten(231).

De toepassing van de gebrulkelijke middelen stuit eveneens op bezwaren als de meningen afkomstig zijn van persoonlijkheden, die in het Westen bekend zijn. Robert Havemann probeerde men onschadelijk te maken door hem te isoleren van de samenleving. De laatste jaren van $z i f n$ leven was hij onder hullsarrest gesteld. Andere oostdultse auteurs en dissidenten, zoals Wolf Blermann, Reiner Kunze en Rudolf Bahro, rakten hum staatsburgerschap kwijt en werden naar de Bondsrepublitek ultgewezen. 
Art. 27 lid 2 Verf. is de lex speclalls van art. 27 1id 1 Verf. De in dit tweede lid gegarandeerde persvrijheld heeft daarom dezelfde inhoud en functles, en is aan dezelfde beperkingen onderworpen, als het it 11d 1 algemeen geformuleerde grondrecht op vrijheid van meningsulting. Ook de sanctles, die dreigen als men zich niet houdt an de democratische taak van de vritheid van meningsuiting, zijn op de persvrijheld van toepassing. Ondat lid 2 de lex speclalis van lid $\mathbb{1}$ is, heeft het geen betekenis, dat de zinsnede "den Grundsätzen dieser Verfassung gemäss" hier nlet opgenomen is. Dok de media moeten zich naar de beginselen van de grondwet richten(232).

De in art. 27 lid 2 Verf. genoemde media, drukpers, radio en televisle zijn de middelen bij uitstek, met behulp warvan meningen geuit en verbreld wordem. Dit gegeven makt de persvrijheid tot een belangrijke garantie van de vrijheid van meningsuiting, tot een noodzakelijk instrument in het bijzonder als het om de openbaarheid wan de meningsuiting gaat. Veel sterker dan deze bemiddelende rol treedt echter een andere functie op de voorgrond, namelijk de zelfstandige meningsvormende functie van de massamedia. Het gat er nlet alleen or, de burgers in hun meningsvorming, de ontplooling van hum socialistische persoonlijkheid en hun soclalistische bewustzijn te begeleiden. Het felt dat de massamedia matschappelijke krachten van een geheel eigen kwaliteit zijn brengt een bijzondere verantwoordelijkheid met zich mee, die boven het begeleiden ultgaat. Dat is de polltieke functie van de persvrijheld, die wordt uitgeoefend door de massamedia; de functle niet alleen an de publieke oplnile te articuleren en naar buiten te brengen, maar tevens en In de eerste plaats, deze publieke opinie te vormen en te sturen.

Hermann formuleert het zo: "Bekanntlich erfüllen unsere sozialistischen Medien thre Funktion als kollektive Agitatoren, Propagandisten und organisatoren bef der Reallsierung der Politik von Partel und Reglerung. Diese Polltik wlederum gibt dem Interesse der Arbeiterklasse und aller Werktätigen unseres Landes richtig Ausdruck. Wir fördern Parteinahme für die Sache des Sozlalismus und aktive Betelligung eines Jeden ... Es ist daher elne kämpferische Aufgabe, der wir uns widmen, wenn wir die Wahrheit uber uns, uber den Sozia11smus, tiber seine gesellschaftliche Wirkllchkeit verbreften"(233). Er kan geen twijfel over bestaan, dat ook de persurijheid een klasserecht is(234) en dat de pers een politiek verlengstuk van de macht van de 
arbeidersklasse is (235). In Oostduitse ogen is onafhankelijkheid van de massamedia een fictie(236). De vritheld van de massamedia kan niet onafhankeli jk van, maar net als bij de vrijheid van meningsuiting in het algemeen jufst alleen door de matschappelijke orde worden gerealiseerd. Het is de taak van de massamedila deze orde te ondersteunen en mede vorm te geven aan de verwezenlijking van de objectieve wetmatigheden. Omdat de marxistisch-leninistische filosofie een materialistische fllosofle is, ligt een zwartepunt van de taak van de media in de economische sector. De massamedia dienen de economische competitie in het sociallsme te stimuleren( 237 ).

De actieve rol in de opboun van het socialisme houdt ook in dat het de taak van de journalist is het hele onmenselifice kapitalistische systeem bloot te leggen en zijn slinkse bedoelingen aan de oppervlakte te brengen(238). De massamedia dragen een grote verantwoordelijkheid in de strijid tegen de burgerlijke ideologie. Dit verantwoordelijkheldsbewustzijn wan de media tegenower de samenleving, hun daaruit voortvloeiende plicht tot het verstrekken van warheidsgetrouwe en zakelifke informatie, dit alles brengt met zlch mee dat de burgers van een "partelliche Berichterstattung" (239) verzekerd mogen $\mathrm{zIjn}$. "Aus der der Freihelt entspringenden Verantwortung für Presse, Rundfunk und Fernsehen heraus kann ein Missbrauch der Massamedien für die Verbreitung bürgerlicher Ideologien nicht geduldet werden. Vlelmehr richten sie ihre Tätigkelt auf die Verbreitung der marxistisch-lenlnistischen Ideologie, fördern den schöpferischen Meinungsaustausch der Werktätigen und organisieren unter Führung der Partei der Arbeiterklasse das gemeinsame Handeln und die Persönlichkeitsentfaltung der Bürger in allen Bereichen des gesellschaftlichen Lebens. Das fordert entsprechend der grossen Ausstrahlungskraft der Massamedien hohe gesellschaftliche Eigenverantwortung, grosse po1itische Reife und Erfahrung, Klugheit und tiefes Wissen derer, denen diese Frethelt anvertraut ist." (240)

Bij de vitheld van mentingsulting in het algemeen, die in art. 27 lid 1 Verf. gegarandeerd wordt en, gezien in relatie met de in lid 2 gegarandeerde persvrijheid, speciall voor de burger als individu bedoeld is, wordt de democratische taak langs strafrechtelijke weg afgedwongen. Deze weg heeft een sterk repressief karakter. Hoewel deze strafrechtelijke drelging ook woor de uitoefening van de perswrijheid op de achtergrond aanwe$z \lg$ is(241), wordt de democratische taak hier via een andere methode gewaarborgd, die bij uitstek geschlkt is vanwege de organisatorlsche voorwaarden, warmee de 
persurifheid verbonden 1s. Dit is de methode van een wil Jwel perfect verguningenstelsel, dat er voor zorgt dat schrijwende pers, radio en televisie onder volledige controle van de staat staan. Juist op het gebled wan de persvrijheid, warap de overheld nu eemmal wollediger grip kan krijgen dan op de vrijheid wan meningsulting, die zich op het individuele viak afspeelt, komt de democratische taak het meest onverbloemd tot uitting *

\subsubsection{Het vergunningenstelsel}

Censurur bestaat niet in de DDR, aldus het eenstemige oordeel in de oostdultse rechtswetenschap. Sinds de beëlndiging van de kapltalistische uitbulting wordt de persvritheid niet meer bedreigd door monopolles, die In de kapitalistische samenleving de eigenlijke censumr vormen. Deze monopolies zorgen ervoor dat alleen die meningen aan bod komen die de stat en de heersende klasse, de bourgeolsie, niet bedreigen. Zij manlpuleren de massa's en stroolen hun zand in de ogen door een pluriformiteit van meningen voor te schotelen, die in werkelijkheid helemal niet bestaat. Door de vermatschappelljking van de produktiemiddelen is de voorwarde voor reële persvrijheid vervuld. De instrumenten warmee censuur kan worden utgeoefend $z 1 j n$ geẻlimineerd(242). De garantie voor de persvijheld ligt in de matschappelijke orde zelf. Daarom is ook een 1 in de constltutle neergelegd censurverbod overbodig. Tot 1968 heeft de grondwet overigens wel een censuurverbod bevat (243).

Havemann beoordeelde de realitelt anders: "Obwohl es kelne Zensurbehörde gibt, kömnen in der DDR weder in Zeitungen und teitschriften noch itn Rad1o oder Fernsehen, nicht im Theater und Kino, auf elner Kulturveranstaltung, nicht einmal belm Kleingärtnerverein Immergrün auch nur eln Wort und eine Zelle gesagt oder gesungen werden, die nicht direkt oder indirekt der Filter der stats- und Parteikontrolle durchlaufen haben, Und dieser Filter ist sehr streng." $(244)$.

Censurur is Inderdaad overbodig, omdat de staat zlch er vooraf van vergewist heeft dat geen enkele van het offlclele paxtijstandpunt afwljkende mentng gepubliceerd wordt, namelijk door middel van het tot in de inesses uitgewerkte vergunningenstelsel.

Alle in de DDR perlodiek verschijnende drukwerken, war ronder dag- en weekbladen en tijdschriften, zijn op grond van een verordenfing wit $1962(245)$ aan een vergunnling gebonden. Een verguming kan worden verleend als het karakter van het drukwerk overeenstemt met de weten van de DDR én indien de voor vervaraliglng 
benodigde materialen in het kader van de economische planning beschikbar zijn (par. $311 d$ sub a en b). Een aansprak op verlening van de verguning bestat niet. De bevoegdheld tot het al dan niet verlenen van de licentle ligt bij het Persbureau van de voorztter van de Minfsterraad (par. 4 11d 1).

Alle dagbladen worden door de SED, de onder controle varu de SED staande andere partljen of door de massaorganisaties uitgegeven $(246)$. De uniformitelt van de dagbladpers wordt gewarborgd door de aanijzinger, die de Afdellng agitatie en propaganda van het centrale Comite van de SED aan de dagbladen verstrekt $(247)$. Voor het verkrijgen van hun informatle zijn de dagbladen aangewezen op de enlge persdienst die de DDR rijk is, de AZIgemeiner Deutachem Nachmichtendienst (ADN), een overheldsinstelling die onder het gezag van de voorzltter van de Minlsterraad staat, welk gezag door diens Persbureau wordt uitgeoefend(248). De ADN heeft tevens het monopolie voor wat betreft de berlchtgeving ult het bultenland(249). Richtiljn voor het handelen van de medewerkers van de $\mathrm{ADN}$ is de verwezenlijking van de politlek wan de $\operatorname{SED}(250)$.

De activitelten van witgevers van tijdschriften en boeken, kunst en muzlek $z i j n$ eveneens centraal geregeld (251). Dok hier geldt de voorwarde dat voor de uftoefening van het uitgeversvak een vergunnning moet $z 1 j n$ verleend (252). De ultgevers dienen hun werkzaamheden te verrichten binnen het raamwerk van jaarplannen, die door het minlsterie van Cultuur moeten worden goedgekeurd. Het minlsterle kan de uitgevers tevens verplichten bepalde werken in hun plannen op te nemen (253). Vele Dostduitse auteurs, voor wie het op grond van de geldende bepalingen niet mogelijk 4 s hun boeken in de DDR te laten uitgeven, publiceren hun werk in de Bondsrepubliek. Vanzelfsprekend riskeren zij daardoor strafvervolging *

Alle andere drukwerken, ultgezonderd dienstaanwijzingen, circulaires en ander ultsiluitend voor intern gebruik door overheldsorganen bestemd material, zijn eveneens aan de verlenlng van een vergunning gebonden (254).

Voor een additonele controleschijf zorgt het ministerie wan PTT, dat de bevoegdheld bezit al dan niet toesteming te verlenen foor de distributie van drukwerken (255). Het $1 \mathrm{~s}$ ntet coegestaan drukwerken inet adresbandjes eromheen te verzenden, en het paksgewijs versturen van drukwerk is aan strenge controle onderworpen(256). Evenmin is het toegestaan zich te abonneren op drukwerken ut het bultenland(257). op grond van deze bevoegdheden kan de post distributie van niet gewenste drukwerken woorkomen. 
Radio en televisie zijn instellingen in handen van de soclalistische staat. Aan het hoofd van elk vam deze media staan overheidscomites, die rechtstreeks onder de Ministerraad ressorteren(258). Deze comites zorgen erwoor dat radio en televisie de belangen wan de arbeildersklasse vertegenwoordigen( 259 ).

\subsection{De vmitheid van infomatie}

Nar westerse matstaven is de vrljheid van informate Integraal bestanddeel van de wrijheld van meningsulting, omdat men zonder informatie moellijk een mening kan vormen. De schrijuende pers, radio en televisie hebben uiteraard een belangrijke functie in de informatleverstrekking.

In de grondwet van de DDR is de vrijheid van informathe niet gegarandeerd. De media aldaar geven uttslultend de informatile die onombeerlijk is voor de vorming van het socialistische bewustzijn. De vrijheid van meningsulting is immers gericht op de totstandkomilng van kên juiste mening, welke in overeenstemming is met de objectleve wetmatigheden. Deze meningsvorming moet plaatsulnden op basis van slechts die informatie, die voor socialistische verhoudingen celevant 1s. De informatiestroom moet daarom gericht 21 jn op meningsvorming die overeenstemt met de beginselen en de doelstellingen wan de grondwet. Volledige informatievrijheid zou zelfs in strijd met de grondwet zifn, zif zou leiden tot manipulatie van de masa's en tot w11ekeur (260). 21 zou het herkennen van de objectieve wetmatigheden en de vorming van de socialistische persoonlijkheid belemmeren. Woor een snellere verwezenlijking van de soclalistische doelstellingen is het Integendeel noodzakelijk verkeerde meningen ult de informatiestroon te filteren en aldus de objectiewe berichtgeving te warborgen(261). "Dass die Arbelterpresse den Klassentmhalt ihrer Information niemals abstreitet, sondern mit allen Mitteln zu verstärken und betonen versucht, ist jedem Leser bekannt. Die


- * de a

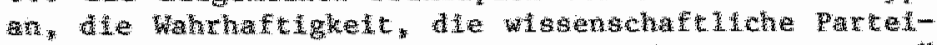

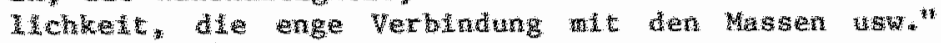
(262) Me Swa bepar



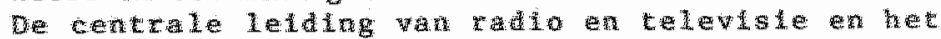

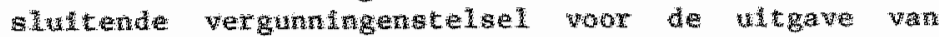



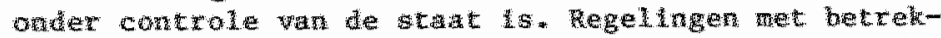




vla deze kanalen ongewente informate de burger berelkt. De verkoop en het in voorraad houden van "anthumanistische" 11teratuur 1 s verboden(263). De bibliotheken die door particulieren worden geexplofteerd (gewemblahe Leihbichemeien) mogen ook geen boeken bevatten die antlhumanlstisch zijn, burgerlijk reactionalre ideologleën verbreiden of op andere wijze in strljd zijn met de beginselen van de socialistische ontwikkeling(264). Boeken die tegen deze criterla zondigen kunnen wit de roulatie worden genomen. Bij zware overtreding kan de explottatlevergunning worden ingetrokken. De opembare bibliotheken dienen hun werkzaamheden ult te oefenen conform hun taak de "Meisterung der wissenschaftlich-technlschen Revolution und der sozlalistischen Oekonomie" te ondersteunen, de "Schaffung elnes wissenschaft11chen Vorlaufs besonders in den strukturbestimenden Zweigen der Volkswirtschaft" te bevorderen, bij de "Durchsetzung moderner Leftungsmethoden" behulpzaam te zijn en de "Gelst und die Durchfuhrung der Aufgaben der sozlalistischen Landesverteldigung" te stimuleren(265), dat w1 zeggen zich geheel In dienst te stellen van de economische en milltalre prioritelten, die voor de oostdultse samenleving typierend zijn.

Het informatlemonopolle van de SED is sinds de oprichting van de DDR continu doorbroken door berlchtgeving vanutt het westen en wel in het bijzonder vanult de Bondsrepubiliek.

Tot de bouw van de Ber 11 jnse muur in 1961 konden Westdultse kranten en andere drukwerken zonder moelte via West-Berlijn in de DDR worden ingevoerd. Het bezit daarvan was weliswaar moreel verwerpelijk, mar niet strafbaar. Wanneer echter "zu den Besitz von Westzeitungen noch Umstande hinzutreten, die erkennen lassen, dass diese Zeltungen zu hetzerlschen oder boykottierenden Handlungen benutzt werden oder benutzt werden sol1ten"(266), was sprake van Boykothetze ex art. 6 $11 d 2$ Verf. Zo werd lemand die in 1952 een artikel ult een Westdults tijdschrift verspreid had, waarin de oprichting wan een demarcatielljn tussen de sovjetzone (DDR) en de drle westelijke zones (Bondsrepubliek) werd angekondigd, vanwege deze leugenachtige beweringen gestraft met drle jaar tuchthuls, hoewel een mand na $z$ ljn veroordeling de dewarcatlelijn lnderdaad werd opgericht(267). Het oordeel werd niet vernilet 1 gd. Nifet alleen kranten betekenden toentertijd een gevaat. Zelfs het annemen wan een voedselpakket uit West-Ber1.1n werd in de begintijd van de republiek beschouwd als het verspreiden van een gerucht dat de vrede in gevar bracht $(268)$. De bouw van de mur heeft een 
effectleve rem gezet op de invoer van uit het Westen afkomstig drukwerk. Sindsdien zijn de oostaultsers voor hun informatie aangewezen op de Westdultse radio en tellevisie, welke de mur natuurlijk nitet heeft kunnen tegenhouden.

In het grootste deel van de DDR worden deze media probleemloos ontvangen. Hoewel hun ontvangst niet te verhinderen en daarom op zichzelf miet verboden is, is het well strafbaar ze openlijk te ontvangen(269) of de ultzendingen voor andere personen toegankelijk te maken( 270$)$, ondat op deze wijze subversieve informatie kan worden verspreid. Bovendien is het verboden via westelijke zenders ontvangen informatie aan anderen mee te delen(271). Al deze handelingen zijn staatsfeindliche Hetze (par. 106 StGB). Drelging met straf en intimidatie hebben de populariteit van de Westduitse media echter nlet kunnen verhinderen, integendeel. De berlchtgeving uit de Bondsrepubliek is een belangrijke informatiebron zowel voor de bevolking als voor partijfunctionarlssen. Zelfs Erich Honecker ontkent niet dat hij kijkt. Uit onderzoek is gebleken dat de Westduitse nfeuws- en actualiteitenultzendingen door oostduitsers relatief beter worden bekeken dan door de Westduitsers zelf(272). Hoe groot de invloed van de Westduitse televisle is toont een voorval uit 1978. In een actualiteitenuitzending werd kort aandacht besteed aan mogelifke veranderingen van het systeem van de zogeheten Intershops, die het de Oostiduitsers moellijker zou maken in de toekomst tegen harde valuta westerse waren te kopen. De volgende dag stonden tlendulzenden DDR-burgers voor de Interehops in de rif om nog snel hun slag te slaan. Zulke incidenten, aldus een in Dost-Berlijn geaccrediteerde Westduitse televisiecorrespondent, maken de angst van de oostduitse autor1telten voor de Westdultse media begrijpelijk. H1j vroeg zich af hoe fervent de informatievrijheid in de Bondsrepubliek nog zou worden verdedigd als de oostduitse televisie door een dergelifke uitzending de Westduitsers in scharen de strat op zou weten te krijgen(273).

Een nfeuwe barriere voor de informatievrifheld vornt de strafbaarstelling in 1979 van het verzamelen en doorgeven van berichten, die wellswaar niet gehellm $z i j n$, maar de DDR kunnen schaden. De tekst van par. 99 StGB luldt:

1. Wer der Gehelmhaltung nicht unterliegenden Nachrichten zum Nachteil der Interessen der Deutschen Demokratischen Republik an de in par. 97 (274) genannte Stellen oder Personen überg1bt, fur dlese sammelt oder ihnen zugänglich macht, wird mit Fretheltsstrafe von $z$ wel bis $z u$ zwölf Jahre 


\section{bestrat.}

2. Vorbere1tung ader Versuch sind strafbar.

De bepallng heeft de aandacht getrokken door het gehelre proces tegen een Westdultse student, die in 1982 tijdens een bezoek aan vrlenden in de DDR werd gearresteerd en vervolgens tot wijf en een half jaar werd veroordeeld wegens overtreding van par. 99 StGB, onder andere op grond van het werwijt dat hij bezig was geveest zlch op de hoogte te stellen wan de matschappelifke ontwlkkelingen in de DDR om te bezien, of de contrarevolutionaire gebeurtenissen in Polen onder de regie wan de vakbond Solidariteit zich als model voor de DDR leenden(276). Onder druk van de westduitse publieke opiale werd de man drle weken na zijn veroordellng vrijgelaten $(276)$.

Net als par. 219 lid 2 stgB kan ook par. 99 stGB overigens worden gebrulkt on publicatie door schrijuers wan hum boeken in het buitemland te bestraffen (277)*

In verband met emigratieverzoeken kan par. 99 StGB worden toegepast, als de indiener van zo"n verzoek (al dan nlet door elgen toedoen) in het Westen in de publiciteit is gekomen $(278)$.

\subsection{Homizontate werking}

Uit het felt, dat het recht als instrument wordt gezien ten behoeve van de opbouw van de socialistische samenleving rolgens de objectleve wetmatlgheden, volgt al dat de vraag naar de horlzontale werking van de vritheid van meningsuiting in feite overbodig is. Niet alleen in de verhouding tussen burger en staat, maar ook in de verhouding tussen individuen onderling zijn de beginselen van het marxisme-leninisme hoogste norm (279). Als de socialistische grondrechten op die verhouding Inwerken, dan niet als afweer tegenover aanspraken van derden maar als instrument ter verwezen11 jking van de marxistisch-leninistische beginselen. Dat blijkt reeds uit de sancties die een werknemer boven het hoofd hangen als hij zich niet houdt aan de democratische taak van de vrijheld van meningsuiting (280). Hetzelfde geldt voor privat- en strafrechteLijke voorschriften die de persoonlijke eer beschermen(281). Deze bepalingen moeten in het Licht van de functie van het privaatrecht(282) respectlevelijk het strafrecht (283) in het socialisme worden uitgelegd. Dit kan bijwoorbeeld betekenen dat niet wan belediging (par. 137 StGB) sprake is, wanneer kritische uitlatingen in de pers verschijnen in het kader van het recht op nedeverantwoordelijkheid voor de leiding van matschappelljke en statsaangelegenheden en ten be- 
hoeve van the opvoeding van andere burgers(284). Evento kan een schending van het door par. 327 ZGB beschermde persoonlijkheldsrecht worden gerechtvaardigd door de noodzaak tot medewerking aan de bescherming van de soclallstische stats- en rechtsorde( 285$)$.

Ontbreekt bij een meningsulting de verbinding met de democratische taak, dan is de vrijheid van meningsulting ook niet in het geding en kan aij logischerwijs geen horizontale werklng ontvouwen.

\section{9. conclusie}

De garantie van de vrijheld van meningsuiting in de DDR biedt geen enkele bescherming tegen overheldsingrijpen. Het grondrecht gaat geheel op in zljn democratische taak en wordt dardoor gedegradeerd tot een richtlijn ten behoeve van de opbouw van de socialistische stat. De uitoefening van de vritheld van neningsulting stat uitsluitend in dienst van de verwezenlijking van de objectleve wetmatigheden, zoals die door de marxistisch-leninistische fllosofle zijn vastgestelld en door de SED worden uitgelegd. Die ultieg wordt bepald door overwegingen van opportuniteit. De naleving van de democratische taak wordt hoofdzakelijk afgedwongen door het politieke strafrecht. Voor wat betreft de persvrijheld stat het vergunningenstelsel voor de naleving garant.

In de praktijk kan de democratische takk niet voor honderd procent worden gerealiseerd. Dat geldt nlet zo zeer voor de media, die getrouw een 1 dea 1 beeld van de socialistische verworvenheden in de DDR Leveren, maar wel voor de individuele uitoefening van de vrijheid van meningsulting. Storende factor is hier namelijk de doorbreking wan het informatiemonopolle van de soclalistische staat door de Westduitse medla, wat de vorming van het soclalistische bewustzijn, on in DDR-termen te spreken, natuur $11 j k$ danig 1 in de weg staat. Het gevolg is een kloof tussen de offlcielle en de nietofficlête meningsvorming, warbij de officiele verste niet altijd aan het langste eind trekt. Het voorbeeld van de vredesbeweging toont, hoe de offlctele mening zich tegen zichzelf kan keren. Door de enthousiaste ondersteuning van de vredesbeweging in West-Europa om daardoor de oorlogszuchtige bedoelingen van de kapltalisten aan de kaak te stellen heeft men mede het fundament gelegd voor het ontstaan en de popularitelt van de vredesbeweging in elgen land en voor het ontstan van standpunten die ingaan tegen de democratische taak van meningsuiting, althans tegen de verkrampte uitleg die de $S E D$ eraan geeft. 
De democratische taak wan de vrijheld van meningsulting makt dit recht tot een massen meus als men ervan utgat dat grondrechten de individu dienen en niet de staat.

Men kan $z 1 c h$ afvragen of de Oostduitse prakt $11 \mathrm{k}$ datgene $1 \mathrm{si}$, wat Mor of Engels voor ogen stond (286). Marx is zelf journalist geweest bil de Reulse Fheiniache Zeitung $(1842 / 43)$ en hoofdredacteur van de Neue Pheintache Zeitung ten tide van de revolutie van 1848/49. In 1842 schreef hij" "Das wesen der frelen Presse 1st das Charaktervolle, verninftige, sittliche Wesen der Frelheit. Der Charakter der zensierten Presse lst das charakterlose Unwesen der Unfrelheit, sle 1st ein zivilistisches Ungeheuer, eine parfümerte M1ssgeburt"(287). En in 1892 schreef Engels vanult Londen aan de Dultse socialist August Bebel over de noodzaak binnen de elgen soclalistische partij een onafhankel1jke pers te hebben, "die 1n der Lage 1st, Innerhalb des Programms und der angenommenen Taktik gegen elnzelne Partelschritte ungeniert Opposition zu machen und Innerhalb des Partelanstandes auch Program und Taktik fref der kritik zu unterwerfen"(288). En ook Havemann(289) meende dat in het echte soclalisme ideẻen en meningen nlet langer meer onderdrukt mogen worden, maar dat in plaats daarvan in een socialistlsche samenleving een onbeperkte zakelljke confrontatie van menlngen moet bestaan, maaran allen deelnemen, zonder dat lemand voorrechten kan claimen. Niet meer de belangen van de heersers, maar de betere argumenten zullen dan de doorslag geven. "Wann wird es uns gelungen sein diesen Sozlalismus in der DDR zu verwirklichen? Das ist schwer zu sagen. Eins kann man aber mit Sicherhelt schon heute sagen: Wenn es sowelt seln wird, dann können wir die Mauer meistbietend versteigern."'(290)

2.10. Het international Verdrag inzake Burgerrechten en Politieke Rechten

2.10.1. Vergelijking tussen art. 27 Verj. en art. 19 ICGPR

2.10.1.1. De kming van admesaten

Art. 19 11d 1 en 2 ICCER garandert het recht op wrijheld van menlngsulting aan ledereen, terwij1 art. 27 Verf. dit recht alleen an burgers van de DDR garandeert. Wellswar bepalt het Dostdultse Austandergesetz dat 1 n de DDR verblijvende buitenlanders dezelfie rechten hebben als oostduitsers, maar daaraan is toegevoegd dat dit slechts geldt voorzover deze rechten 
alet aan Oostdultsers zifn voorbehouden(291). Dat nu is in art. 27 Verf. ultdrukkelijk het geval. Wel zijn bultenlanders verplicht de grondwet te respecteren en zlch aan de in de DDR geldende rechtsvoorschriften te houden(292). Gezlen de wijze warap de vritheld van meningsuiting in de DDR is georganiseerd betekent dit dat buitenlanders met zo an de democratische taik van het grondrecht zijn gebonden als oostdultsers en dat hun positie niet van die van hen verschilt. Desalniettemin is het van belang te constateren dat art. 19 ICCPR in beginsel een grotere kring van personen aanspreekt dan art. 27 Verf.

2.10.1.2. De inhoud van de vmitheid van meningautiting In vergelijking met art. 27 Verf. voegen art. 19 lid en 2 ICCPR twee elementen aan de garantie van de vrijheid van menlingsuiting toe.

In art. 19 lid 1 ICCPR wordt afzonderlijk het recht erkend een mening te koesteren. Dit recht is in art. 27 Verf. niet opgenomen. Zelfstandige betekenis heeft deze erkenning echter niet, omdat men ervan uit mag gaan, dat art. 27 Verf. dit recht impliciet garandeert op grond wan de stelregel dat de bescherming van het meerdere ook de bescherming van het mindere omvat. Zonder de erkenning van het recht een menling te koesteren, zou het recht op vrijheld van meningsulting inhouds loos zijn(293).

In tegenstelling tot art. 27 Verf., waarin de vritheld van informatie niet expliciet is opgenomen, garandeert art. 19 lid 2 ICCPR de informatievrijheid ultdrukke$11 \mathrm{jk}$, en wel in ledere gewenste vorm, door middel van elk gewenst medium en ongeacht gremzen. De rulmte die aam de informatievritheid wordt besteed in vergel1jking met de ruimte, die voor de vrijheld van meningsulting in het algemeen is ultgetrokken, taont het belang dat aan de informatievrijheid als onwerbrekelijke voorwaarde voor de vrijheld van meningsuiting wordt gehecht. Vanwege de garantie van de informatievrijheid biedt art. 19 1id 2 ICCPR dus een grotere bescherming dan art. 27 Verf. De praktische betekents van het extra dat art. 19 ICCPR ten opzichte van art. 27 Verf. biledt valt echter niet ult de formulerlng van het grondrecht af te lezen. De werkelijke orvang van de in art. 19 lid 1 en 2 TCCPR gegarandeerde grondrechten hangt af van de ultleg die wordt gegeven aan de beperkingsmogelijkheden, die art. 19 ifd 3 ICCPR biedt. vritheid van menlingsulting toe, mits dit geschledt bij 
wet en mits dit nodig is in het belang van de rechten of goede naam yan anderen, in het belang van de natlonalle welligheld of ter bescherming van de openbarie orde, de volksgezondheid of de goede zeden $(294)$.

De democratische taak, die in de DDR aan de vrijheld van meningsulting is toegetacht, de functie die het recht dient te verwullen bij de verwezenlijking van de objectieve wetmatigheden van het marxisme-1eninisme, kan in principe worden gezien als een binnen deze ruime formuletingen vallende beperking van dit grondrecht. Deze taak moet als een geoorloofde beperking worden beschouwd. Neemt men dat aan, dan is de inhoud van art. 27 Verf. ook niet in strijd met de inhoud van art. 19 ICCPR(295). Wanneer de democratische taak van de vrijheid van meningsulting een toelaatbare beperking is in de zin van art. 19 lid 3 ICCPR, is immers ook de informatievrljheld daaraan gebonden en verandert de in besinsel rulmere bescherming van art. 19 lid 3 TCCPR feitelijk niets an de praktijk in de DDR. De democratische taak is evenwel alleen een toelaatbare beperking als op de eerste plats de voorwaarde, dat beperkingen slechts bij wet mogen plaatsuinden, wordt nageleefd. Het is op de tweede plaats noodzake$1 \mathrm{ijk}$ de structuur van art 19 ICCPR in het oog te houden. Eerst wordt de vrijheld geconstateerd en pas daarna, als daarvoor een rechtsgrond bestaat, worden beperkingen toegelaten. De vrifheld is de regel, de beperking is de uitzondering. De beperkingen mogen bovendien niet zo ver gaan, dat de vil fheld in felte geheel wordt opgeheven. Dat verbledt een redelijke uit leg van art. $5 \operatorname{ICCPR}(296)$.

Art. 27 Verf. laat twijfels ontstaan of zijn formulering in voldoende mate an deze structuur voldaet. In tegenste1ling tot art. 19 ICCPR worden in deze bepaling de garantie van de vrijheld van meningsuiting en de regeling van de beperkingen namelljk riet ult e1kaar gehouden. Weliswar wordt de vrijheid in haar algemeenheld in art. 271 d 1 Verf. gegarandeerd, maar reeds in die garantie zelf 11 gt de beperking "den Grundsätzen dleser Verfassung gemäss" besloten. Regel en ultzonderlng worden niet van elkar gescheiden, maar vioelen in elkaar over. Van concrete criteria, op grond warvan beperkingen geoorloofd zjjn, is verwolgens geen sprake. De vaagheid van de beperkingsmogelijkheid, mamelijk dat de vrijheld van meningsuiting in overeensteming met de beginselen van de constitutie moet worden ultgeoefend, geeft de staat een blanco volmacht. Bovendien is angetoond dat de manier warop deze beperking is ultgewerkt de substantie van het grondrecht aantast $(297)$. 
11d 1. Verf. slechts in overeensteming met de grondslagen van de grondwet worden uitgeoefend. Deze democratische taak wordt gevaarborgd door een vergunningenstelsel, dat de uitoefening van de persvritheid in al haar schakeringen afhankelijk maakt van overtheidstoestemalng. In beginsel geldt het verbod tot uitoefening wan de persvrifheld, tenzif een vergunning wordt verleend(298). De beperking is dus de regel, de vrijheld is de ultzondering. In plaats van de door art. 19 ICCPR geêiste volgorde: ja, tenzij, is de persvrijheid in de DDR geregeld volgens het principe: nee, tenzij. Deze structuur wordt bevestigd door het felt, dat de verlening van een vergunming niet plaatsvindt aan de hand van in de desbetreffende regelingen opgesonde criteria. De bevoegde autoritelten kunnen naar elgen inzicht beslissen of $z i j$ een vergunning verstrekkem (299). In een klachtenprocedure is niet voorzien.

De reglementering van de persvrijheld in de DDR is niet in overeenstemming met art. 19 ICCPR. De verdragsbepaling laat geen rulmte voor een algemeen verbod onder voorbehoud van toesteming. Wel dient te worden toegegeven dat de vraag, in hoeverre een vergunningenstelse1 voor de pers in beginsel geoorloofd. is, een stuk minder absoluut kan worden beantwoord, als de bedoeling van de verdragspartijen bij de uitleg wordt betrokken. Uit de discussie in de derde commissle van de Algemene Vergadering van de Verenigde $\mathrm{Na}-$ ties aver art. 19 ICCPR tifdens de opstelling van het Verdrag blijkt dat ten aanzien van deze vraag geen eensgezindheid bestond. Wel was men het erover eens, dat de beperkingsmogelijkheid in art. 19 Iid 3 ICCPR In het belang van de openbare orde het recht van een staat insluit, om informatieverstrekkende media aan een vergunning te onderwerpen(300). Westerse delegaties hadden hiermee welliswaar uitsluitend radio en televisie op het oog(301), maar vele andere delegaties dachten tevens aan de schrijvende pers(302). Vanwege deze uiteenlopende opvattingen is het onmogelijk op grond van de travaux préparatolres vast te stellen of het de bedoeling van de verdragspartijen was een vergunningenstelsel voor de schrifvende pers als toelaatbaar te beschouwen of nlet. Uttsluitend op de tekst afgaande moet echter worden geconstateerd dat het vergunningenstelsel voor de pers in de DDR niet in overeensteming is met art. 19 ICCPR, temeer dar dit een uftholling van de perswrijheld met zich meebrengt, die art. 5 lid 1 ICCPR verbledt.

Een tekstuele interpretatie leldt dus tot de conclusie dat twijfels bestaan, of de versmelting van garantie en beperking in art. $2711 d$ l Verf. in overeensteming 1 set de structuur van art. 19 ICCPR en dat het ver- 
gunningenstelsel wan de pers apert met art 19 ICCPR in stifd is.

Op grond van art. 2 lid 2 ICCRR 1 s de DDR verplicht haar wetgeving an te passen, indien deze in strijd is met de bepalingen van het Verdrag. Op de DDR rust de verplichting an de harmoniseringswetgewlng tot stand te brengen die nodig is om een duldelijker onderscheld te maken tussen garantle en beperking van het algemene recht op vill jheld wan meningsulting en om het vergunningenstelsel, dat met art. 19 ICCPR in strijd is, op te heffen en te vervangen door een stelsel, dat ean algemene garantie van de persuritheid als grondslag heeft, die onder bepaalde onstandigheden en wolgens vaste crlterla kan worden beperkt. Hoewel het $11 \mathrm{jkt}$ alsof de burger door de vervanging van het ene stelsel door het andere van de regen in de drop raakt, heeft de Westduitser Mampel opgemerkt dat er wel degelijk praktische voordelen $z i j n$, omdat het een verschil makt of alles geoorloofd is tenzij het verboden is in plates van de huldlge toestand dat alles verboden is tenzlj het geoorloofd is. Tevens dwingt een ander stelsel de autoritelten tot het motliveren van hum beslissingen, hetgeen hun discretionaire bevoegdheld inperkt ( 303$)$.

Tot dusver heeft harmonisatie van de wetgeving niet plaatsgevonden.

2.10.1.4.Art. 20 ICCPR

De DDR gaat ex van uit door de strafbaarstelling van Kriegahetae und-Propaganda (par. 89 StGB) en Faschistische Propaganda, Völker und Rassenhetze (par. 92 StGB) (304) haar verplichtlingen uit hoofde van art. 20 ICCPR te zijn nagekomen( 305 ).

2.10.2. Het effect van art. 19 ICCPR op de inteme rechtsifeer

In de Oostduitse wolkenrechtsleer(306) worden nationaal en internationaal recht als twee nast elkaar vestaande gelijkwaardige normenstelsels beschouwd, die belde voortkomen ult dezelfde bron, namelijk de souvereiniteit van de stat.

Dat betekent enerzijds dat een stat zlch niet aan de nakoming van de door hem aangegane volkenrechteligke verplichtingen kan onttrekken door een beroep te doen op zijn interne wechtsorde, anderzijds werken de volkerrechtelljke normen ndet onmidde111jk op het interne recht in, omdat aj slechts rechten en verplichtirgen voor de staat 1 in thet leven roepen.

Om aan volkenrechtelijke normen interme rechtskracht

te verlenen moeten $z i j$ eerst in national recht worden 
amgezet. Daarvor is ratiflcatie alleen niet voldoende, er is een speclale wetgevende handeling voor nodig. In het geval yan tegenstrijdigheid tussen mationale en internationale rechtsmormen $1 \mathrm{~s}$ de stat volkenrechtelijk verplicht de verelste wetgevende matregelen te nemen om de interne met de internationale rechtsnormen in overeensteming te brengen(307). Voor het verkrijgen van interne rechtskracht is geen uitdrukkelijke transformatie in national 1 recht verelst, indien de internationale rechtsmormen tot volkenrechtelijke normencomplexen behoren, die door de rechtsorde van de stat al in hun algemeenheld in national recht zijn getransformeerd (308).

Zo"n normencomplex zijn bijvoorbeeld de algemeen erkende regels wan volkenrecht, die de vrede en de vreedzame samenwerking tussen de volkeren dienen. Art. 81 id 1 Verf. verklaart deze regels voor ledere burger verbindend.

De vraag is, of de bepalingen van het Internationaal Verdrag inzake Folitieke Rechten en Burgerrechtem ook behoren tot deze narmencomplexen, die de vrede en vreedzame samenwerking tussen de volkeren dienen. Met betrekking tot de Universele Verklaring van de Rechten van de Mens vermeldt 'Staatsrecht der DDR" in ieder geval wel uitdrukkel1 jk dat deze verklaring de vrede en de vreedzame samenwerking tussien de volkeren dient, $z i j$ het dat de Verklaring geen regel van volkenrecht $1 \mathrm{~s}(309)$. Vanwege het ontbreken van rechtskacht kan de Verklarlng niet ander de werking van art. 8 11d 1 Verf. vallen. Deze handicap kleeft echter niet aan het International Verdrag. Dit Verdrag, dat een voortzetting van de Unlversele Verklaring $1 \mathrm{~s}$, is een volkenrechtelijke overeenkomst en dient analoog aan de Verklaring de vrede en de vreedzame samenwerking tussen de volkeren. Dit laat de conclusie toe, dat het Verdrag in tegenstelling tot de Verklaring wel "Innerstaatilch verbindliches Recht fur alle Staaten"(310) kan worden.

In aanmerking genomen dat het Verdrag overeenkomstig de vereisten van art. 8 IId 1 Verf. de vrede en vreedzame samentiverking tussen de volkeren dient zou men zich op het standpunt kunnen stellen dat een ultdrukkelljke transformatie van het Verdrag niet vereist is on het interne rechtskracht te verlenen. Deze constatering zou de weg openen voor burgers van de DDR zlch diect te beroepen op bepalingen van het Verdrag, voorzover deze tenminste rechtstreeks toepasbaar zijn. Bovendien wordt $1 \mathrm{n}$ de DDR-1 theratuur benadrukt dat de oostdultse praktijk alle in belde vN-Verdragen opgenomen grondrechten reeds constltutloneel verankerd en verwezenlijkt heeft en dat het nationale recht de 
burger zelfs meer grondrechten garandeert dan welke de VW-Verdragen in het leven roepen(311). Gewezen wordt bijworbeeld op het recht op medezeggenschap en medevormgeving(312). Schuld aan het achterblilven van de va-verdragen vergeleken bif de nationale bescherming van de grondrechten is dat aan de Verdragen niet de soclallstische conceptie van de grondrechten ten grondslag $11 g t(313)$, maar de opvacting van de Verenigde Naties, die een compromis tussen 0ost en West is (314). Als met deze vaststelling gezegd mil worden dat het Verdrag Inzake Burgerrechten en Politieke Rechten slechts tot uitdrukking brengt wat door de grondwet reeds lang tot formeel recht geworden 1 s en nageleefd wordt, is ex althans inhoudelijk evenmin reden om het verdrag interne rechtskracht te ontzeggen.

of bepalingen van het Verdrag self-executing karakter hebben hangt af van de vraag, of de verdragstekst $z$ lch voor rechtstreekse toepassing leent en of de wil van de verdragspartijen erop gericht was dat de bepalingen rechtstreeks toepasbar zouden zijn(315).

Een verdragstekst leent $z$ tch voor rechtstreekse toepassing als de formulering voldoende nauwkeurig en geprec1seexd $1 \mathrm{~s}(316)$. Dat is wat art. 19 ICCPR betreft het geval.

De wil van de verdragspartijen moet in eerste instantie worden afgeleid uit de verdragstekst(317). De Commlssle van deskundigen van de Raad wan Europa heeft een onderzoek verricht naar de w1 van de verdragspartijen met betrekking tot de rechtstreekse of nietrechtstreekse toepasbaarheld van de bepalingen van het Verdrag. De Commissle baseerde dit onderzoek op art. 2 lid 1 en 2 ICCPR (318) en constateerde dat deze bepalingen geen uitsluitsel geven over het al dan niet self-executing karakter(319). In dat geval zijn die travaux préparatolres van belang( 320$)$. Deze bieden evenmin argumenten om te kunnen concluderen tot de rechtstreekse toepasbaarheid wan de bepallngen dile zich daartoe lenen ( 321$)$.

Dat uit het Verdrag zelf niet ondubbelzinnig het selfexecuting karakter van verdragsbepalingen kan worden afgeleld behoeft een verdragspartijer niet van te weerhouden zelf bepalingen rechtstreeks toepasbaar te verklaren. Door de DDR wordt rechtstreekse toepasbaarheld echter ontkend(322). Het Verdrag ropt geen rechten voor de individu in het leven, mar slechts volkenrechtelijke verplichtingen voor de staten, die verdragspartif zijn. Dat zijn vooral verplichtingen tot bepalde vormen van samenwerking op het gebled van de mensenrechten tussen de verdragsstaten. 
nisering van wetgeving weliswaar bestaat, maar dat dit slechts kan geschieden met inachtneraing van de bestaande maatschappelijke context, die van land tot land verschilt (323). Reeds is opgemerkt, dat art. 27 Verf. nlet aan art. 19 ICCPR is aangepast.

De aarzeling om de bepalingen van het Verdrag rechtstreeks toepasbaar te verklaren berust op de stelling dat alle aangelegemheden betreffende mensenrechten in principe tat de competentie van de individuele staten blijven behoren. De respectering en bescherming van de mensenrechten blijft een interne aangelegenheid van de staten, zolang deze niet door een systematische minachting de internationale vrede en veiligheid in gevaar brengen. In alle andere gevallen wordt bemoelents door derden beschouwd als een inmenging in de interne aangelegenheden van de staat (324).

Hoewel ex dus goede gronden $\mathrm{z} l \mathrm{j}$ on aan te nemen dat art. 8 lid 1 Verf aan het Verdrag inzake Burgerrechten en Politieke Rechten interne rechtskracht verleent en de bepalingen die zich daartoe lenen rechtstreeks. toepasbaar zouden kunnen $z i j n$, biedt het Verdrag zelf voor deze laatste gevolgtrekking onvoldoende aanknopingspunten en ontkent de DDR rechtstreekse toepasbaarheid uitdrukkelijk. Een direct beroep op art. 19 ICCPR is derhalve uitgesloten.

2.10.3. De cantrole op de naleving van artiket 19 ICCPR

De DDR heeft geen verklarfing ex art. 41 lid 1 ICCPR afgegeven, dat zij het statenklachtrecht erkent.

Evenmin heeft de DDR het Facultatieve Protocol, behorende bij het Verdrag, ondertekend, dat individuen in de gelegenheid stelt een klacht over beweerde schending van het Verdrag bij het Comite voor de Rechten van de Mens in te dienen.

De controle op de naleving van art. 19 ICCPR blijft zodoende beperkt tot de in het comite gevoerde discusstes naar aanleiding van ingeleverde rapporten. In dit Comité, dat is samengesteld ult onafhankelijke deskundigen, hebben zowel een Westduitser als een Oostdultser zitting(325). De DDR interpreteert de taken van het Comite restrlctief. Zij gat er wan uit dat het doel van de gedachtenwisseling bestaat th het ondersteunen van de lidstaten bij de verwezenlijking van de In het Verdrag erkende rechten( 326 ). Terughoudendheld in het leveren van kritiek is verelst om de vriendschappelfjke betrekkingen tussen de staten niet 1 in gevaar te brengen.

De DDR heeft in 1977 haar Initial Report Ingeleverd en daarmee voldaan aan haar verplichting, binnen een jaar. 
na inwerkingtreding van het Verdrag verslag uit te brengen aan het comltê over cen eerste de matregelen die zif heeft genomen ter implementatie van de in het Verdrag erkende rechten en ten tweede de vooruitgang die valt war te nemen in het genot van die rechten

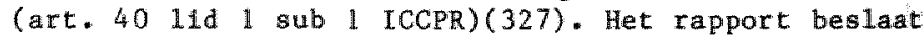
negen bladzijden. Het beperkt zich hoofdzakelijk tot een opsomming van de wetgevlng met betrekking tot de grondrechten, maar lat de furidische werkelijkheid bulten beschouwing. Voor wat betreft art. 19 ICCPR is volstaan met een samenvatting van de tekst van art. 27 Verf. (328), voor wat betreft art. 20 ICCPR met een verwjzing naar par. 89 en par. 92 StGB(329).

Tljdens de mondelinge toelichting op het rapport werd door de vertegenwoordiger van de DDR evenmin ingegaan op de rechtsprakt $1 \mathrm{jk}(330)$.

Het Comitelid Tamopolaky stelde de vraag of het voor de burgers mogelljk is lets anders dan het sociallsme te propageren en wat de beperking "den Grundsätzen dLeser Verfassung genäss" betekent(331). Het Comitelld Tomuchat sprak de vrees ult dat deze zinsnede niet in overeensteming is met art. 19 ICCPR(332). Hij wroeg tevens of men zich in de DDR vrijelijk op kranten utt het Westen en andere Oosteuropese staten kan abonneren.

De vertegenwooralger van de DDR ging niet op deze vragen $1 n$. Hij gaf slechts een algemeen antwoord, namelijk dat "it should be pointed out that a number of leglsiative provisions on these subjects had been put before the people and had been approved by majoritles amounting in many cases to more than 90 percent of the vote" (333). Hil benadrukte tevens dat de grondwet geen censuurbepaling kent en dat de invoer van (hoofdzakelijk wetenschappe1ijke) publicaties uit de Europese kapitalistische landen de ultvoer naar het Westen overtreft (334).

Verdere discussites naar aanleiding van de vrijheid van meningsulting vonden niet platis.

Op grond wan een besluit van het Comite ult 1981(335) is de DDR verplicht vijf jaar na inlevering van het eerste rapport een vervolgrapport voor te leggen(336). BLj dle gelegenheld moet speclaal worden Ingegaan op die problemen, die bij de bespreking wan het Initial Report in het Comite zijn opgeworpen, maar nlet uitputtend $z i j n$ behandeld(337). Het vervolgrapport 1 is in 1983 verschenen( 338 ). Ten aanzien van de vrijheid var menlngsulting. is wederom volstaan met entige algemene opmerkingen, name11jk dat het grondrecht in de DDR aan ledere burger het recht garandeert zijn mentng vij te uten, dat persurijheid bestaat, dat het grondrecht stevig is verankerd in het soclalistische systeem en 
naw verbonden is met het recht deel te nemen an de opbouw van de socialistische democratie. Bovendien is opgemerkt dat het Dostduitse rechtssysteem volledige bescherming bledt tegen misbrulk van het recht op Informatie, dit teneinde het respect voor de in art. 19 IId 3 ICCPR genoemde normen (waronder de nationale velligheld en de openbare orde) te verzekeren(339). Met deze speclale vermelding van het recht op informatie wil men waarschijnlijk zeggen dat dit recht in de DDR net zo goed is gegarandexd als de andere in art. 19 ICCPR genoemde grondrechten, hoewel de informatievritheid niet in art. 27 Verf. is opgenomen. De garantie geldt conform de soclalistische matstaven, dat W1 zeggen dat de informatievr jheld opgat in har democratische taak. Deze benadering komt in het vervolgrapport duidelijk cot ulting, doordat alet de garantie van de informatievrijheid als zodanig wordt vermeld, mar de garantie tegen misbrulk van het grondrecht in het middelpunt stat( 340$)$. In het vervolgrapport is niet ingegaan op de hierboven vermelde vragen van Tamapalsky en Tomusahat (341).

Over de warde die de DDR zelf aan het Verdrag hecht heeft het lostaltse $11 d$ van het comite Graefrath gezegd: "Sozlalistische Grundrechte werden ... nicht an unlversellen internationalen Konventionen, sondern an den Gesetzmässigkelten des Aufbaues des Sozlalismus gemes $\operatorname{sen}^{\prime \prime}(342)$.

\subsection{Het Grondalagenverdrag}

Het Grandslagenverdrag(343) bepaalt dat de Bondsrepubliek en de DDR zich bij de ontwikkeling van normale betrekkingen zullen laten leiden door de 1 h het VNHandvest neergelegde doelen en beglnselen, waaronder In het biljzonder de respectering van de mensenrechten (art. 2). In het Aanvullend Protocol(344) hebben de verdragspartijen $z$ ich verplicht onderhandelingen te voeren met het doel het wederzljds betrekken van boeken, tijdschriften, radio- en televisieprodukten ult te breiden. Deze anderhandelingen zijn nog altijd niet afges loten.

Tot het Grondslagenverdrag behoort ook de Brilefwisse$1 \mathrm{lmg}$ van 8 november 1972 over de arbeldsmoge1ljklieden voor journalisten(345). Deze briefwlsseling is van belang voor de viltheid van menlngsulting. Daarin heeft de DDR $z$ lich onder meer verplicht, "1m Rahmen threr geltenden Rechtsordnung Journalisten aus det Bundesrepublik Deutschland und deren H1lfspersonen das Recht zur Ausubung der berufllchen Tätigkelt und der frelen Information und Berichterstattung" te garande- 
ren.

Dit houdt inter alla in: het recht op gelljke behandeling als cortespondenten van andere staten; arbeidsen beweglngsmogelijkheden, Inclusief de onverwllde doorselulng van nieusbierichten, meningen en commentaren; het recht de voor de openbarhedd en de media algemeen toegankel1jk gemakte ambtelijke informatie te verzamelen en het recht informatle van de daarto gevolmachtigde personen en autoriteiten in te winnen. De Briefwisseling legt de DDR wellswar de verplithting op journalisten uit de Bondsrepubliek toe te laten en te accrediteren, max de garantle dat deze ongestoord hun werk kunnen verichten geldt slechts in het raamwerk van de geldende rechtsorde, hetgeen betekent dan dat ook wan hen wordt verwacht dat zij hun werk verrlchten met inachtneming van de soclalistische beglnselen.

Ter nadere regeling van de verplichtingen die uit de Brlefulsseling voortvloeien trad begin 1973 een nleuwe fournalistenverordening in werking, die overlgens ook voor correspondenten uit andere staten dan de Bondsrepubllek geldt(346). Deze verordening verplicht de journalisten zlch te houden aan de algemeen erkende normen van het volkenrecht en aan de in de DDR geldende rechtsvoorschriften, belastering (Verleumdung) van de DDR en de met haar verbonden staten achterwege te laten, warheidsgetrouw, zakelijk en correct te verslaan en geen kwadwillige vervalsing van felten toe te laten( 347$)$. Overtreding wan deze richtilfinen kan worden beantwoord met een warschuwing, uitwijzing van de journalist en tenslotte met de sluiting van het kantoor wan het persorgaan, waarwoor de journalist werkt(348). Verscheidene malen zijn de oostduitse opvattingen over persurijheld reeds gebotst met de activiteften wan Westduitse correspondenten. Sancties bleven niet uit. zo werd in 1975 werd een redacteur van het weekblad de Spiegel ultgewezen op grond van Verlewndung. Aanlelding was een artikel over adoptiepraktijken in de DDR, dat hij overigens niet eens zelf had geschreven( 349 ). In Januari 1978 werd het kantoor van de spiegel in Dost-Berlijn geslocen, want dit tIJdschrift had 1 in de latste maanden "in standig stelgenden Masse die Deutsche Demokratische Republik und thre verbundeten bösw1111g verleumdet und vorsätz$11 \mathrm{ch}$ den Versuch unternommen, durch erfundene Nachrichtem und Berichte die Beziehungen zwischen der Deutschen Demokratischen Republik und der Bundesrepublik Deutschland zu vergiften"( 350$)$. In 1983 werd de correspondent van Sterm uitgewezen vanwege een artikel, walin hlj beweerde dat een moordaanslag op Honecker was gepleegd(351). 
Kort na de televilsie-ultzending over de Interghopg (352) trad in 1979 eeen aanvulling op de journalistenverordening in werking(353). Deze bevatte nieuwe beperkingen. Het houden van interviews en enquêtes werd aan de verlening van een vergunnlng gebonden( 354$)$. Verder moeten journalisten hum relzen butiten oost-Ber1ijn een etmal van te voren aanmelden met precieze opgave wan reisdoel en redenen( 355 ).

Deze restricties waren een reactle op de uitzending over de Intershops. Darin waren namelijk ook oostduitsers geintervlewd, hun mening over de maatregelen hadden gegeven. De bepalingen hebben tot doel de correspondenten in het vervolg te hinderen bij de verzameling van informatie, die nodig is voor een verslaggeving naar westerse matstaven. De beperkingen passen in de socialistische opvatting over de vritheid van meningsuiting, welke 1 s gericht op het vinden van de enige Julste mening. Verkeerde informatle kan de vorming van die ene mening en dientengevolge de ontwikke1 ing van het sociallsme doorkrulsen of 1 in ieder geval vertragen. Door het houden van interviews en enquetes ar een vergunning te binden kan worden voorkomen dat de buitenlandse journalist onjuiste informatie vergaart, namelijk wan burgers, die dikwljls een subjectleve visie hebben en de objectieve matschappelijke samenhang van bepaalde gebeurtentssen uit het oog verliezen, zoals in de ogen van de oostduitse autor ceiten bij de interviews over de verandering van het systeem van de Intershops overduidelijk gebleken is (356).

De oostduitse auteur Stefan Heym omschreef de nieute bepalingen als censuurmatregelen, die de voorschriften van de feodale vorstendomet jes, waruit Duits land eens bestond, aan geestelijke bekrompenheld nog ver overtreffen(357). Kort na de inwerkingtreding van de bepallngen werd een Westdultse journallst ultgewezen op grond van de beschuldiging deze Heym zonder toesteming geinterviewd te hebben. Hij had Heym de gelegenheid gegeven voor het Westduitse televisiekanaal Zweites Deutaches Eernsehen een verklaring voor te lezen ower de methode van de DDR-autoritelten om oostdultse auteurs, die hun boeken in de Bondsrepublitek laten ultgeven, te strafen wegens overtreding van de devilezenwetgeving(358).

Sinds 1982 worden weer vergunningen tot het houden van interviews en enquetes verieend( 359 ).

De in 1979 ingevoerde restricties zifn niet in strijd met de Briefwisseling van 1972 , omdat het recht algemeen toegankelijke informatie te verzamelen niet wordt angetast. Voor het verzamelen van informatie, gegeven door overheidsinstellingen, is geen toestemming ver- 
elst. Dok de anmeldingsplicht voor relzen butten oost-Berlijn is toelaatbaar. De mogelijkheld voor journallgten zich vrlj te bewegen wordt weliswar bemoellijkt, maar nlet verhinderd.

De plicht van Westdultse journallisten zlch te houden aan de soctalistische spelregels, zoals geconcret1seerd in de journalistenverordening van 1973 en de aanvulling van 1979, kan niet worden opgevat als een schending van het Grondslagenverdrag. De clausule "in Rahmen ihrer geltenden Rechtsordnung" stelt de DDR in staat naar elgen inzicht de grenzen voor de fournalistieke activitelten van Westduitse journalisten te trekken. Hun positle verschilt in dit opzlcht niet van die van journalisten ult andere staten, die in de DDR geaccrediteerd zijn.

Ondanks alle beperkingen is de accreditering van journalisten ult de Bondsrepubliek in de $D D R$ per saldo een risico voor de 0ostduitse autoriteiten, waarvan de gevolgen niet zijn te controleren. Noor de Dostduitsers zelf is de verslaggeving door Westduitse correspondenten vanuit de DDR over gebeurtenissen in dit land via de Westdultse radio en televisie uitgegroefd tot een belangrijke additlonele bron van informatie en een welkome correctle op de officlële meningsvorming. In zoverre heeft het crondslagenverdrag de mogelijkheden voor Dostduitsers tot het verzamelen van informatle vergroot $(360)$. 


\section{De democratische taak van de vrijheid van meningsuiting in de Bondsrepubliek Duitsland}

\subsection{Inteiting}

Dok de beantwording wan de vragg, in hoeverre de vrljhelid van meningsulting in de Bondsrepubliek Duitsland(1) een democratische taak dient te vervullen, beglnt bij een onderzoek naar de onderlinge verhouding tussen vrifheld, grondrechten en democrat1e. Deze ontmoeten elkar in de zogenamde conceptle van de strijdbare democratie, dile de basls van de Westultse constitutile vormt en een erkenning is van de wetenschap dat vrijheid van menfngsulting en democratie alles met elkar te maken hebben. Na een analyse van de mechantsmen, die de grondwetgever ter concretsering wan deze relatie ter beschikking heeft gesteld, wordt de invloed van hun onderlinge verhouding op het In art. 5 GG gegarandeerde grondrecht op vrifheld van menlingsulting zelf onderzocht.

Tenslotte worden de gevonden resultaten getoetst aan het Internationaal Verdrag inzake Burgerrechten en Politieke Rechten en aan het Grondslagenverdrag.

\subsection{De conceptie van de strijdbare democrative}

\subsubsection{Achtergronden}

De Hestduftse grondwet van 29 mel 1949 is een reactie op dertig jaar Dultse geschledenis. De grondwetgever, de Parlementalre Rad, was vastbesloten te verhinderen dat op Dultse bodem opnieuw een totalitalre stat zou kunnen ontstaan. Men wilde voorkomen dat ooit weer mensen en menselijke wardigheld zouden worden vertrapt en voor de toekomst ultsluiten dat nogmals een man als Hitler an de macht zou kunnen komen. Een constitutionele orde werd opgericht, warin de mens en zljn wardigheld centraal werden gesteld, een democratlsche orde, met alle kenmerken en warborgen yan een parlementalre democratie in westerse zin, vrlj in de zin van anti-totalitair.

De Parlementalre Raad was ervan overtulgd dat een van de oorzaken, dat het tot een nationat-soclalistische detatuur had kunnen komen, lag in het neutrale karakter wan de grondwet van Welmar (1919) en ln zijn tole- 
rantle ook tegenover antldemocratische krachten die de democratle princlpieel bestreden, zolang deze zlch mar aan de formele regels hielden(2).

Varwege deze neutralltelt hadden Hitler en zijn NSDAP de Welmar-Republiek opealijk en met legale middelen kunnen begtrijden en waren ulteindelijk zelfs an de macht gekomen via Hitlers correcte benoeming tot Rijkskanselter op 30 janwar1 1933 en vervolgens (op minder correcte wjze) het annemen door de Rijksdag van de machtiglngswet (23 mart 1933), die Hitler vier farix lang met onbeperkte voluachten uitruste en de weg nar de dictatuux opende( 3 ).

Dndertussen is vrif algeneen het inzlcht gegroeld, dat het mischien niet zozeer het neutrale karakter van de vooroorlogse constitutie was alswel veeleer het ontbreken van een werkelljke democratloche gezindheld in brede lagen van de bevalking, wat tot de machtsovername heeft geleld(4). Ook Welmar was - zij het in beperkte mate - ultgerust met instrumenten om antidemocrat 1 sche tendenzen te bestrijden. Er is alleen nilt vastberaden genoeg gebrulk van gemaakt(5). In leder geval heeft de grondwetgever het in 1949 nodig geacht constlutionele garanties te scheppen am te voorkomen dat de kern van het in de nleuwe grondwet vastgelegde democratische systeem, de freitheitliche demokratisohe Grundomdnung, zou kunnen worden afgeschaft. De grondwet werd voorzien van de linstrumenten, nodig om ant1democratische tendenzen reeds in een vroeg stadium te kunnen tegengaan en ontmantelen. Dit is het principe van de strlfabare democratie(6). Het is de 11 tot zelfverdediglng, die wil voorkomen dat de democratie met democrat sche middelen wordt ultgehold, die intolerantle met intolerantie beantwoordt onder het motto: "Kelne unbedingte Fretheit fur die Felnde der Freihelt"(7). Zo"n strijdbare houding verkeert uiteraard op slechte voet met het vrljheldsbeginsel, dat julst het levenselyxer voor elke democratie is. Daarvan dloordrongen heeft de grondwetgever de strijdbaarheld bewust beperkt tot de kernelementen van de in 1949 opgerichte wardegebonden en constitutionele orde, dat wil zeggen die elementer, zonder welke democratie absolutut nlet mogelifk is(8).

\subsubsection{De "freiheitliche demoknatische Grumdordinung"}

De "oberste Grundwerte des frethettlichen demokratschen Verfassungsstaates" vormen tezamen de freithettLiohe denoknatiache Grundondnung, aldus het Bundesver faboungagericht in het SRParrest(9). Aan deze orde ligt de voorstelling ten grondslag, dat de meris in de 92 schepplng een elgen zelfstandige warde bezit en dat 
Writheld en gelljkheld blijvende fundamentele warden van de staatseenheld zijn. Deze orde, die in de grondwet haar beslag heeft gevonden, Is het tegendeel van de cotalitaire staat, dle menselijke wardigheid, vil theid en gelijkheid afwijst.

"So lasst sich die frelheltliche demokratische Grundordnung als elme ordnung bestimen, die unter Ausschluss jeglicher Gewalt- und Wllkürherrschaft elne rechtsstatllche Herschaftsordnung auf der Grundlage der Selbstbestlmung des Volkes nach dem Willen der jewelligen Mehrhelt und der Frelheit und Gleichheit darstelit. Zu den Prinzipien dieser ordnung stad zumindestens zu rechnen: die Achtung vor den Im Grundgesetz konkretisierten Menschenrechten, vor allem vor dem Recht der Persönllchkelt auf Leben und freie Entfaltung, die Volkssouveräniteit, die Gewaltenteilung, die Verantwortllchkelt der Reglerung, dle Gesetzmässigkeit der Verwaltung, die Unabhänglgkelt der Gerlchte, das Mehrpartelenprinzip und die Chancenglelchhelt fir alle politischen Parteien mit den Recht auf verfassungsmässige Bildung und Ausubung elmer opposi$\operatorname{tion} "(10)$.

Het woord "tenminste" geeft an dat het Bumdesvemfasbungegericht geen uitputtende opsoming heeft bedreven. Wat precles tot de freineitiche demakratioche Grundordnung behoort, blijft onzeker(11). Belangrljk ter bepaling van haar inhoud is daarom vooral de achterliggende gedachte, die voor het eerst is geformuleerd (in 1951) door Leibhota, aan wiens opstel het Buniteaverfaseungsgericht zijn omschrljulng van de freiheitiche demokratische Grundordmung ontleend heeft $(12)$.

Leibhotz zlet de onaantastbaarheld van de freiheitliche demokmatische crunciordnung als het instrument om het volk ervoor te behoeden, dat het met behulp van democrat sche middelen en methodes weer vrijwl11. de politieke macht afstand doet, zoals in 1933 gebeurde. De freiheitiche demokratische Grundordnung moet een vrljheld garanderen die an het fasclsme geen kans meer geeft. Tegelijkertijd is zij echter een reactie op de actuele ervaringen met de volksdemocratie in de toenma11ge: Sovjetrusische bezettingszone. Deze gedachte $1 \mathrm{~s}$ teruggekeerd in de doox het Bundeoverfascungagentcht gebruikte formulering, dat de uitslutting van de heerschapplj van geweld en willekeur het doel van de freiheitiche demokratische Grundordinug 1s. De freiheitiche demokratisohe cmudondmung moet worden opgeyat als het tegengestelde van een totalitalr systeem(13). Haar inhoud wordt nlet bepald door wat $z j$ wel is, mar door de voorstelling hoe deze fundamente- 
le orde nlet dient te zija: "Der Begriff der freiheltlichen demokratlschen Grundordnung erglbt slch elnfach: daraus, was wit von "fruher" und von "druben" als politische ordnung unbedingt nicht wollen" (14).

\subsubsection{Stmijbaarheid naat twee aijden}

Men kan de antitotalitalre strekking van de freineittiche demokratische Grumdordinung positief vertalen door te stellen dat haar inhoud wordt gevormd door datgene wat absolutu nod1g is om een blijvende open. denocratische besluitworming te verzekeren. De strijdbare democratie weert de gevaren af die deze besluitworing bedrefgen. De strijdbaarheid rlcht zich zowel tegen totalitaire tendenzen van boven als van beneden (15).

In art. 79 11d $3 \mathrm{GG}$ wordt de fretheitliche demokratieche Grumdordnung tegen de staat in bescherming genomen. Deze bepaling verbledt elke grondwetswijzlging, die de erin genoemde principes aantast. (Hoewel de fretheitliche demokratische Grundordnung in dit voorschrift niet met zoveel woorden genoemad wordt(16), wordt aangenomen dat de hler opgesonde elementen inderdaad tezamen de freiheitliche demokratische Grundordnung ultmaken(17).) Zelfs tegen een met gekwallficeerde meerderheid hadelende wetgever wordt de freiheitliche demokratiache Gmandordnung aldus beschermd. Het Bundeaverfassurgsgericht wakt over de naleving. Als uiterste afweerniddel tegen pogingen van zowel boven- als onderaf om de freiheititiche demoknatische Grundordinung ult de weg te rulthen geeft art. 20 11d 4 GG aan alle Dultsers het recht op verzet, als een andere weg niet meer mogelifk is. Deze pas in 1968 ingevoerde bepaling moet gelden als tegenwlicht tegen het toen tevens ingevoerde staatsnoodrecht (19).

De voorschriften, die ultsluitend tegen antidemocratische tendenzen van onderaf gericht $z \mathbb{1} j \mathrm{n}$, dragen het meeste bij tot het de ulterlijke kenmerken van de strijdbare democratie en worden min of meer als haar centrale bestanddelen gezfen(18): het ziln de bepalingen die een collectlef $\mathrm{c} . \mathrm{q}$. Individueel misbruik van bepalde grondrechten ter bestrijding van de freiheitliche demokratische Grundordnung bestraffen. Verenlgingen, dle tegen de verfaseungemäsaige ordnung (20) opponeren zijn verboden (art. 9 11d 2 GG). Hie de vritheid van meningsulting, de vritheid wan onder ijs, het recht tot vereniging, het recht tot vergadering en betoging, het brief-, post- en telefoongehelm, het eigendomsrecht of het asielrecht misbrulkt ter bestrijding van de freiheitliche demokmatiache Grundordnung verwerkt deze grondrechten (art. 18 GG). En tenslotte 
zljn partijen die erop uit zijn, aan de frethettitohe demoknatische Grindordnung afbreuk te doen of har ult de weg te ruimen of de bestendigheid van de Bondsrepubllek in gevaar te brengen, ongrondwettig (art. 21 lid $2 \mathrm{GG}$ ). Of dit het geval is, wordt bezien aan de hand van hun doelstellingen en het gedrag van hun aamangers.

De bepalingen dienen ter afweer van geweldloze, maar desalniettemin als gevaarlijk beschouwde polltieke activitelten, die de openheld van het proces van politieke Hisvorming ter discussie stellen(21). Behalve de hier genoende kernvoorschriften heeft het Bundesverfaseungagericht nog andere bepalingen tot de strijdbare democratie gerekend(22).

In de twee artikelen die drelgen met de verwerking van grondrechten en een partijverbod koat tot ultdrukking dat strljdbare democratie en fretheittiche demoknatisohe Grundordnung twee zijden van een en dezelfae medaille zijn: het is julst ter bescherming van de fretheitliche demoknatische Grundordnung dat (reeds in een vroeg stadium) wordt opgetreden tegen hen die deze arde bestrijden. Uit de context, warin de freiheititche demokratische Grundordnung genoemd wordt (in de grondwet is van het begrip verder uitermate spaarzaam gebruik gemakt, aan een omschrifving heeft de grondwetgever zich bovendien nlet gewaagd), volgt dat zij geen zelfstandige betekenis heeft, maar de grens markeert, wanneer de staat tot de ter beschlkking staande represailles mag overgaan, namelijk slechts indien de essentielle bestanddelen van het democratische stelsel worden aangevallen. De freiheitliche demokratiache Grundordinang moet dienen als een garantie dat de overheld niet lichtvaardig van haar bevoegdheden in het kader van de strijdbare democratie gebrulk makt, het begrip noopt tot terughoudendheid, heeft aldus een restrictleve functle(23). Een andere garantie ligt in het felt, dat de competentle on tot verwerking van de in art. 18 GG genoemde grondrechten over te gaan c.q. een partij voor ongrondwettig te verklaren uftsluitend blf de constitutionele rechter berust. De enige malen

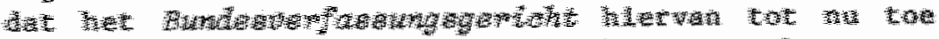

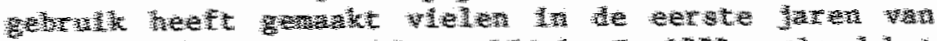

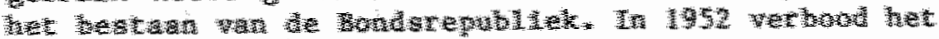

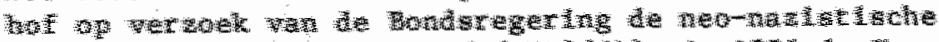

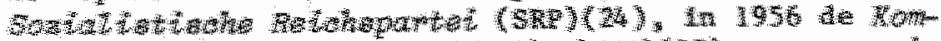

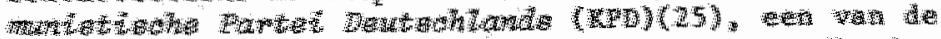

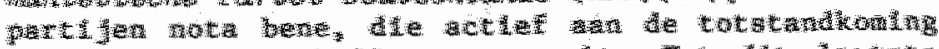


70:

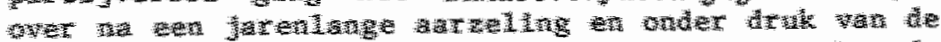

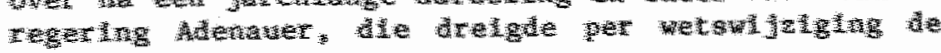


competentle tot het uitspreken van een verbod van de bevoegde maar tegenstribbelende senat naar een meer gerillige senat van het Bunderverfassungsgericht over te hevelen (26).

In het SRP-arrest en in het KPD-arrest heeft het Bundesverfaraungagericht het begrip freiheitliche demokratiche Grundordnung nader ingevuld en de leer van de strifdbare democratie ontwikkeld.

\subsubsection{De partijuerboden}

\subsubsection{Het partijenprivilege}

De politieke partijen nemen in het Westduitse staatsbestel een geprivilegleerde positie in. In tegenstelling tot vroeger is in de grondwet van 1949 hun betekenis voor het staatsleven uitdrukkelijk erkend. Zij 21Jn ult de polltlek-soclologische sfeer gehaald en tot instituties van constitutlonele rang verheven. Dit op grond van de medewerking die de partijen verlenen aan de polftleke wlisvorming van het volk (art. 21 lid 1 GG) (27). Aan deze wilsvorming werken $z 1 j$ voorname$11 \mathrm{jk}$ mee door hun deelname aan de verkiezingen, die zonder de partijen nlet plaats zouden kunnen vinden, aldus het Bundesverfassungsgericht ter verduidelijking In het Parteifinanzieming $I I$-arrest(28). Bovendien vormen $z i j$ de schakel tussen individu en staat, zij zijn spreekbuis van het volk, instrumenten waardoor de wil van de burger ook tussen de verkiezingen in kan worden verwezenlijkt. Zowel regeringspartijen als oppositle leveren hiertoe hun elgen bijdrage. De partijen nemen deel aan het proces van openbare meningsvorming. Zij zijn de verzamelplaats van de op politieke macht en op de ultoefening daarvan gerichte meningen, belangen en doeleinden tenelnde die in het gebled van de statelijke wllsworming tot gelding te laten komen. Tevens oefenen de partifen beslissende invloed uft op de bezetting van de hoogste staatsambten(29). Een van de belangrijkste taken van de partijen is het de burgers van de juistheld van hun doelstellingen en de weg die daarheen voert te overtuigen.

De constitutionele erkenning, dle de partijen on voormelde redenen ten deel is gevallen, gaat evenwel nlet zover dat zif tot de hoogste staatsorganen behoren. zij blijven het karakter behouden van vrij tot stand gekomen, in de samenleving wortelende groeperingen (30). Het $z 1 \mathrm{jn}$ verenigingen, $z 1 \mathrm{j}$ het dat hun interne organlsatie in een speclale wet op de politieke parthen geregeld is(31).

3.2.4.2. Het KPD-arreat

96 Het felt, dat ledere burger polltieke vrijheld van 
meningsulting en de vrijheld van vereniging ook van politieke aard geniet en dat de partijen een integrerende rol in het staatsbestel spelen, leldt tot de conclusie dat aan de vorming en de activiteiten van politleke partijen geen grenzen mogen worden gesteld.

In het SRP-arrest en later in het RPD-arrest zag het Bundesverfasungsgericht zich echter voor de vraag gesteld, of die absolute writheld niet gebonden zou moeten $z i j n$ aan de erkenning van de fundamentele democratische beginselen en of niet partijen, die met formele middelen de democratie willen opheffen, uit het polttleke leven zouden moeten worden geëlimineerd (32). Deze vraag heeft het hof bevestigend beantwoord. Uit de plaats die de grondwet in art. 21 GG de politieke partijen in het staatsbestel heeft toegewezen wolgt:

"dass an der "Inkorporation" der Partelen In das Verfassungsgefüge "polttisch sinnvoll" nur die Partelen tellhaben können, dle auf dem Boden der freiheitlichen demokratischen Grundordnung stehen ... Wenn die Vielvalt der Weltanschaungen und Interessen nicht die Bildung elnes elnheitlichen Staatswillens überhaupt unmöglich machen soll, dann muss bel denen, dle zur Mitwlrkung an dieser Willensbildung berufen sind, wenigstens Elnmitigkeit der Bejahung der verfassungsrechtlichen Grundwerten bestehen" $(33)$.

Het is wellswar denkbar dat partijen die deze fundamentele waarden verwerpen als maatschappe11jke groepering voortbestaan, maar van de constitutloneel gegarandeerde medewerking aan de statelijke wilsworming roeten zij worden ultgesloten( 34 ).

Tot zover is de argumentatle van belde partifwerboden identlek. Op dit punt aangeland heeft het Bundeaver fassungsgericht in het KPD-arrest evenwel een nieuwe dimensie an de problematiek toegevoegd. Het heeft geen halt gehouden bij het bevestigen van de legitimitelt van de verwachtingen die de Westdultse grondwet aan de politieke partijen stelt en de constatering dat deze zwaarder wegen dan het gebrulk van grondrechten, dat met de activiteiten van de politieke partijen verbonden is. Tevens heeft het namelifk de spaning onderkend, die ondanks de erkenning van de verwachtingen van de constitute jegens de partijen blijft bestaan tussen partijuerbod en vrifheld van politieke meningsulting, "ohne Frage elnen der vornehmsten Rechtsguter jeder frelheltlichen Demokratle" $(35)$. Een stat die zijn rechtsorde "frelheltilch-demokratisch" noent moet uit het grondrecht op vrijheld van meningsuiting een principieel recht op vrije politleke activitelt en daarmee ook op de vrije vorming van politie- 
ke partijen ontwikkelen. Hant het behoort tot de fundamentele opvattingen van de liberale democratische rechtsstaat,

"dass nur die ständige gefstige Auselnandersetzung zarischen den einander begegnenden sozialen Kräften und Interessen, den politischen Ideen und damit auch den sie vertretenden politischen Partelen der richtige Weg zur Bildung des Staatswillens ist" (36).

Niet in dle zin, dat deze weg alty jd objectlef julste resultaten oplevert, want $h i j$ is een "process of trial and error", maar toch 20 , dat hif door de voortdurende wederzijdse controle en kritlek de beste garantie geeft voor een fuiste politieke $11 \mathrm{jn}$ als uitkonst van het proces dat zich tussen de in de staat werkzame politieke krachten afspeelt ( 37 ).

Dit alles neemt niet weg, dat het Bundesverfasiungegemicht bif het hierop volgende onderzoek naar de verenlgbaarheid van een partijverbod ex art. 21 11d 2 GG met het door art. $5 \mathrm{GG}$ gegarandeerde recht op vrijheld van meningsulting niet van zijn eerdere in het SRP-arrest ingenomen standpunt afwl jkt.

Onvoorwaardelijke tolerantie en neutralitelt tegenover alle partijen was misschlen wroeger nog mogelijk, maar met het opkomen van de totalitalre partijen na de Eerste Wereldoor $\log$ is deze sitwatle radicaal veranderd. Tegenover zulke partijen kan de democratie, die de menselljke waardigheid moet verdedigen en garanderen, zich geen neutrale houding meer permitteren. De houding van de grondwet moet worden bezlen tegen de achtergrond van de recente ervaringen met het total1talre systeem. De grondwet

"nimmt aus dem Pluralismus von Zielen und Wertungen, die in den politischen Partelen Gestalt gewonnen haben, gewisse Grundprinziplen der Staatsgestaltung heraus, die, wenn sle elnmal auf demokratische Welse gebllifgt sind, als absolute Werte anerkannt und deshalb entschlossen gegen alle Angriffe verteldigt werden sollen; sowelt zum Zwecke dieser Verteidigung Elnschränkungen der polit1schen Betätigungsfrelhelt der Gegner erforderlich sInd, werden sle In Kauf genommen. Das Grundgesetz hat also bewusst den Versuch elner Synthese zwischen dem Prinzlp der Toleranz gegenüber allen politischen Auffassungen und den Bekenntnis zu gewissen unantastbaren Grundwerten der Staatsordnung unternommen. Art. 21 Abs. 2 GG steht somit wicht mit ellnem Grundprinzlp der Verfassung in Widerspruch; er ist Ausdruck des bewussten Verfassungspolltischen Willens zur Lösung elnes Grenzproblems der fretheitlichen demokratischen staats- 
ordnung, Niederschlag der Erfahrungen eines Verfassungsgebers, der in elner bestimten historischen Situation das Prinzip der Neutralltat des Staates gegenüber den politischen Partelen nicht mehr rein verwilklichen zu dirfen glaubte, Bekenntmis zu einer - In alesem sinne - "streitbaren Demokratie". Diese verfassungsrechtliche Entscheldung 1st für das Bundesverfassungsgerlcht bindend" (38).

Het principe van de strijdbare democratie is dus de synthese van de spanning, die bestat tussen het recht op vrijheld van meningsuiting enerzijds en de noodzaak tot het verbleden van totalitaire partijen ter bescherming van de democratie anderzijds(39). Deze strildbaarheid is in de ogen van het Bundesverfassungsgericht niet militant, want het gewicht van de vrljheld van meningsulting noopt tot terughoudendheid tegenover de aanwending van een partijuerbod. De strijdbaarheld wordt tot het absolute minimum gereduceerd: op de eerste plaats is een dergelifk verbod silechts gerechtvaardigd ter verdediging van die fundamentele beginselen, die tezamen de vrije democratische rechtsorde vormen; op de tweede plaats is een partij ook niet reeds dan ongrondwettig, als zij deze beginselen niet erkent, ze afwijst en er andere tegenoverstelt. Er moet veeleer een actleve, strijdbare, agresaleve houding tegenover de bestaande orde bljkomen. De partij moet systematisch afbreuk doen aan het functioneren van deze orde en in het verdere verloop de orde zelf uit de weg willen ruimen( 40$)$. De stat stelt zlch dus defenslef op, hil weert slechts aanvallen af, maar neemt nlet zelf het inftiatief.

Deze defensieve houding wordt weer enigsins teniet gedaan doordat het doel van een partijuerbod is, reeds in een vroeg stadium totalitalre strevingen te verhinderen. Vanwege dit preventieve karakter is niet het bestaan van een acuut gevaar vereist. Doorslaggevend is of de politlieke koers van een partij bepaald wordt door de intentle, de freiheitiche demokratische Grundordnung principieel en continu te bestrifden(41). Een belangrijke anwijzlng daarvoor zijn de doelstel1ingen van een partij. De KPD werd verboden ondat het nagestreefde doel, het vestigen van de dictatuur van het proletarlaat, nlet met de freinettiohe demokratisohe Grundordnung verenlgbaar was(42). Het berelken van dit doel zou de belangrijkste polftieke grondrechten, waaronder het recht op vrije meningsvorming en -uiting, onmogelijk maken met de daaruit voortvloeiende repercussies voor het meerpartijensysteem en het recht op georganiseerde politieke oppositie wandien (43). 
Wij hebben de strijdbare democratie nu leren kennen als methode om het conflict op te lossen tussen uitaefenlng wan grondrechten en de bescherring van de grondbeginselen van de democratische staat. Dile afweging valt wellswar in het voordeel van de freinettliche demokratiache Grundordnung uit, maar door de formule van de freihe itliche demokratische Gmudordrung wordt tegelijkertijd getracht de schade voor de uitoefening van de grondrechten tot het noodzakelijke minimum te beperken. Dat wordt nog eens bevestigd door de additionele voorwaarde, dat slechts mag worden ingegrepen als er sprake is van een actieve, strijdbare houding. De zo opgevatte strijdbare democratie heeft tot doel het proces van democratische besluitworming open te houden.

De mogellijkheid wan een partijwerbod is het aan de overheid ten dlenste staande beschermingsmiddel tegenover politiek actleve groeperingen, dil zich reeds in het constitutionele bestel hebben ingenesteld. Ten behoeve van groeperingen, die zich nlet als politieke partif georganiseerd hebben staat het verenigingsverbod ter beschlkking. Art. 21 lid 2 is de lex specialls tegenover art. 91 id $2 \mathrm{GG}(44)$. In tegenstelling tot de politieke partijen, die als logisch uitvloelsel van hun geprivilegieerde positie uitsluitend door het Bundesvemfasangagemicht kunnen worden verboden, is het verbleden van een vereniging een administratieve matrege1(45).

\subsubsection{Verwerking van grondrechten}

Z1j, die de freiheitltahe demoleratische Gmondordnung niet in verenigings- of partijverband, maar individueel bestrijden en daarbif misbrulk maken van de in art. $18 \mathrm{GG}$ opgesonde grondrechten, worden met verwerking van die grondrechten bedrelgd(46). Ook ult deze bepaling blijkt dat het doel wan de strijdbare democratie bestaat in het openhouden van de democratische besluitvorming. Verwerking is namelijk alleen mogelijk van die grondrechten, die met de vrijheid van meningsuiting te maken hebben, politleke activiteit eerst mogelifk maken en dus voor het besluitvormingsproces in het bijzonder een gevaar kunnen opleveren(47). De vrijheid van meningsuiting, in het bijzonder de persvritheid, de onderwijsurijheld, het recht tot vereniging en het recht tot vergadering en betoging $21 \mathrm{jn}$ alle grondrechten die de vrljheid van meningsuiting in rulmere $z$ in betreffen(48). Voor de overige, het brief-, post- en telefoongeheim, het elgendonsrecht en het astelrecht is het verband minder duidelijk. Zij hebben echter een ondersteunende rol. De communicatie- 
rechten beschermen het averbrengen van meningsuitingen, door het asfelrecht wordt voor bultenlanders de mogelifkheld geschapen van hun vrijheld wan meningswiting gebrulk te maken, het elgendonsrecht verleent de nodige breedtewerking aan de vritheid wan meningswiting (geld, technische hulpmiddelen)(49). SohmittGlaeser heeft ex dan ook met recht op gewezen dat in de verwerkingscatalogus van de in art. $18 \mathrm{GG}$ genoemde grondrechten het zwartepunt "uberhaupt und Insgesamt" bif de vrijheid van meningsuiting $11 \mathrm{gt}(50)$, zifnde het grondrecht bif uitstek, waarmee de moderne vijand van de constitutie(51) zijn geweldloze strijd tegen de democratische rechtsorde voert( 52$)$.

Van misbrulk is sprake, wanneer lemand niet "Jene unabdingbare Wertbasis unangefochten lasst, ohne deren selbstverständlichen Exlstenz eine Integrierende Rraft des Melnungprozesses ausgeschlossen 1st"(53). Deze Wertbasis, de fretheithiche demokratische Grundordnung, moet worden getolereerd, desnoods als noodzake1ijk kwaad worden aanvaard, maar mag in leder geval niet in haar totaliteit worden afgewezen, wil men $z 1 \mathrm{ch}$ niet schuldig maken aan het perverteren van de functle van de grondrechten, die op integratie gericht is. Dat misbruik niet zo snel wordt aangenomen of wellicht in de praktijk moeilijk is vast te stellen, blijkt ult het felt dat het Bundesverfasaungsgericht nog geen enkele mal een grondrechtsverwerking heeft uitgesproken ( 54$)$.

Interessant is het dat in het bowen aangehaalde cltaat de integrerende werking van het proces van meningsvorming in verband met de bescherming van de freiheitliche demokratische Grundordnung eenzelfde rol speelt als in de beide door het Bundesverfassungsgericht uitgesproken partijuerboden. In het geval van SRP en KPD lag voor het Bundesverfassungsgerioht de reden van een verbod in de overweging dat partijen niet zinvol kunnen functioneren als ze miet de fundamentele waarden van de constitutle delen, omdat anders "die B11dung eines einheitlichen Staatswlilens uberhaut unmöglich" is. De achterliggende zorg is dus elgenlifk de integrerende functie van het proces van meningsvorming, namelifk voorzover de partifen hieraan bijdragen. Factoren, die deze integratie van de matschappelijke krachten in de stat, (die culmineert in de totstandkoming van de statswil) storen, dienen te worder opgeheven. Deze - Intrinsieke - doelstelling 1s ook weer verklaarbaar vanult de ervaringen met de We1mar-republiek. Een van de oorzaken, dat deze republiek niet functioneerde, was het ontbreken van een basisconsensus tussen de politleke partijen, wardoor het voor de stat nauwelljks mogelljk was te functioneren. 
als overkoepelende instantie, de identitelt en samenhang verleende(55).

Wil zullen deze integratledoelstelling nog vaker tegenkomen als maatstaf voor het grondrecht op vrlijhefd. van menlingsuft $\mathbb{1 n g}$.

3.2.6. Het veranderende karakter van de stmijabare demoenatio

Na het werbod yan de KPD konden natuur lijk conflicten niet witblijven over de juridlsche gevolgen die het verbod zou dienen te hebben voor voormalige aanhangers van de communistische partij, die zlch na 1956 in de 11 legalitelt gedrukt zagen. De in het $K P D$-arrest ontwikkelde conceptie van de strijubare democratie moest worden geoperationaliseerd.

De eerste beslissing, die het Bundesverfassungsgemicht terzake heeft genomen(56), toont aan met welke rigorositeft het berefd was individuele consequenties uft het KPD-verbod te trekken, nlettegenstaande het defensleve karakter van de strijdbare democratie(57).

Na 1956 de uitkering van een voormalig functionaris van de KPD stopgezet, dle hij tot dat tijdstip had ontwangen als schadeloosstelling voor zijn vervolgling door de nationaal-soclalisten vanwege zijn communfstische activiteiten. Het Bundesverfassungagericht achtte de stopzetting rechtmatig "angesichts der in Art.9 Abs. 2, Art. 18, Art. 21 Abs. 2 zum Ausdruck gekommenen Grundsatzentscheldung des Verfassungsgebers für eine Bekämpfung der aktiven Feinde der demokratischen Wertordnung" (58).

Op grond van art. 42 jo. 46 BVerfGG was de opzettelljke overtreding van het KPD-verbod strafbaar. De vraag rees, wanneer een meningsulting zo'n overtreding betekende. Het Bundesverfassungegericht(59) bepaalde, dat een partijuerbod nlet alleen de bestraffing toelaat van leden van de desbetreffende partij of van een vervangende organisatie, maar ook van bultenstaanders, die denkbeelden van gelijke inhoud als van de verboden partif propageren, mits de van een buitenstaander afkomstige meningsulting een onmiddel1ijk ondersteunend effect voor de verboden partij heeft. Ontbreekt dat effect evenwel, dan is de meningsulting nlet strafbaar. Het gat immers nlet aan alle communistische meningsultingen sec te criminaliseren: "Eine solche den Gesiantverständnis des Grundgesetzes entsprechende restrikt1ve Auslegung des Art. 21 Abs. 2 GG widerspricht nicht dem Grundzug der Verfassung als "streitbare Demokratie"l" $(60)$.

Interessant in deze uitspraak is dat het begrip 102 strijdbare democratle hier niet meer als procedure 
wordt aangehaald, zoals in het KPD-arrest, matr als zelfstandig kenmerk van de constitutie gezlen. Reeds wordt het begin zlchtbaar van een nieuwe bemadering, die ultelndelijk tot een volledige verzelfstandlging wan de conceptie van de strijdbare democratie heeft gevoerd.

Een andere wraag warmee de constitutionele rechter werd geconfronteerd was, in hoeverre grondrechtsbeperkende matregelen tegen indiduele aanangers van een werboden partif binnen de hierboven getrokken grenzen elgenlijk principleel geoorloofd zijn als ultvioeisel wan een partijverbod ex art. 21 lid 2 GG. Betekenen zulke maatregelen niet een uithol11ng van art. 18 GG?

Han een voormalig KPD-1id was in 1962 wanwege zijn lddmatschap van de verboden partij het verbod opgelegd, voor de duur van vijf jaar het beroep van redacteur en u1tgever u1t te oefenen. Dit Berufsierbot steunde op een bepaling uit het Wetboek van strafrecht (61). Het verbod werd door het Bundesverfassungsgewoht rechtmat1g bevonden(62). Hoewel deze beperking van de perswrijheld feltelijk praktisch aan een verwerking van grondrechten in de $\ln$ van art. $18 \mathrm{GG}$ gelljkstond, overwoog de rechter dat de klager zijn activiteiten niet als individu, mar in het kader van zijn KPD-11dmatschap had uitgeoefend en het Berufsverbot derhalve kon steunen op het KPD-verbod. Bovendien komt de strijdbare democratie in gelijke mate in art. 21 lid 2 en art. $18 \mathrm{GG}$ tot ulting. Beide bepa11ngen dienen de bevelliglng van de rechtsorde tegenover vijanden van de constltutle(63). Deze overweging suggereert, dat het er blijkbaar niet op aankomt of het Beruf avembot in concreto nu op het ene of op het andere artikel berust. De gevolgen van deze uitleg zifn verstrekkend. De bescherming, dile art. 18 GG a an individuen biedt is door het Bundesverfassungsgericht buiten werkling gesteld voorzover het aamangers van eem verboden part $1 j$ betreft. Wat materleel een verwerking van grondrechten is hoeft nlet meer door de constitutionele rechter te worden ultgesproken, maar behoort tot de competentle van de normale strafrechter, die daartoe is gelegttimeerd door een partijuerbod (64). Het karakter van de stridbare democratie als grondrechtsgarantie verwatert.

De consequenties van de twee latste ultspraken $21 \mathrm{jn}$ groot geweest. Tot 1968 hebben in groten getale strafrechtelijke beperkingen van de vrijheld van meningsulthig bestaan, die het karakter hadden van een verwerking van grondrechten, mar door het KPD-verbod werden gelegltimeerd. Ze troffen niet alleen ex-leden van de KPD, maar ook bultenstaanders met communistische overtulglingen. 
In het KPD-arrest is de strijdbare democratie geintroduceerd als een methode om de spanning tussen de grondrechtea en de behoefte aan bescherming van de freineititine demokmatibche Grundordmung in het voordeel van de latste, mar wel restrictlef angewend, op te lossen. Reeds tijdens haar operatlonalisering in conflicten, die ult het KPD-verbod woortvloelden, was een zekere verzelfatandigfing en positiverlng van de conceptie te bespeuren. In de jaren zeventig heeft deze ontwikkeling doorgezet en is de strijdbare democratie van methode tot zelfstandige warde met een elgen inhoud geworden.

B1 1 een discussthe in 1968 had een onderofficier in aanwezlgheid van soldaten de mening ten beste gegeven, dat de vrlje meningsulting in de Bondsrepubliek en in het leger door represallles werd ingeperkt, dat geen rechtsmiddelen bestonden tegen schendingen van het briefgeheim en telefoonaflutsterpraktijken, dat van soctale rechtvaardigheld geen sprake was en dat hif persoonlijk rechtmatlge bevelen in het kader van een binnenlandse inzet van het leger zou welgeren(65). Bestraft met drie dagen arrest en ontslag op staande voet utt het leger ging het slachtoffer in beroep bll het Bundesverfasingagericht wegens schending wan zijn grondrecht op vrltheld van meningsulting. Het Bundesverfassungsgemicht ooxdeelde echter:

"Die Bundesrepublik Deutschland ist elne Demokratie, die von thren Bürgern elne Verteidfgung der fretheitllchen ordnung erwartet und elne Missbrauch der Grundrechte zum Kampf gegen diese ordnung nicht hinnimmt (Art. 9 Abs. 2, 20 Abs. 4, 18, 21 Abs. 2, 98 Abs. 2 und 5 GG). Dieses Prinzip der streitbaren Demokratie gilt auch fïr die innere Ordnung der Bundeswehr. Es 1st deshalb elne Grundpflicht der Soldaten, durch Ihr gesamtes Verhalten fü die Erhaltung der fretheitlichen ordnung einzutiten ... Ein auf das Prinzip der streltbaren Demokratie gegründetes Gemelnwesen kann es nlcht dulden, dass selne frelheltiche ordnung bel pol1tischen Dlskussionen Innerhalb der Truppe und whrend des Dienstes von militärischen Vorgesetzten In Frage gestellt, geschwelge denn bekämptt wird" (66).

Het stelde vervolgens vast, dat de man door zijn ultIngen de vrije democratische rechtsorde had belasterd (67). In werkelljkheid echter was de kritlek van de onderofficter niet tegen de fretheittiche demokratibehe Gmudordnung als zodanig gericht. HIj had zlch slechts uitgelaten over concrete toestanden, die in zijn ogen niet in orde waren. Hij verwerp niet de beginselen van de freiheitiche demokratische crund- 
ordrung, mar richte zlch tegen de 1 jns lnziens verkeerde manier, warop die la de prakt1 Jk werden gelniterpreteerd.

Het Bundesverfassungsgemioht werd op grond van dere ultspraak verweten concrete polftieke en soclale verhoudingen, zoals die zlich op een bepald moment voordoen, op een $11 \mathrm{jn}$ te hebben gesteld met een constitutionee1 princ1pe, de democratische rechtsorde(68). Dat het de militair aan loyaliteit tegenover ajn regering ontbrak is mogel1jk, dat het hem aan loyalltelt tegenower de beginselen ontbrak, die het fundamemt wormen van de constitutie, daarvoor bestonden geen arwijzlngen(69). Opvallend is tevens dat In dit arrest de strijdbare democratie zo wordt uitgelegd, dat daaruit kennelljk de plicht wolgt voor alle burgers tot verdediging van de fretheititiche demoknatische Grundordnung, hetgeen van de restrictieve ult leg in het KPDarrest nlet veel meer overlat.

In het omstreden Abhow arrest van 15 december $1970(70)$ moest het Bundesverfassungsgemicht de grondwettigheld toetsen van een grondwetswijziglng, die het mogelijk makte voortaan in het belang van de staatsvelligheid brieven te openen, telefoongesprekken af te luisteren en telexberichten mee te lezen zonder dat dit aan de betroffenen zou behoeven te worden meegedeeld (art. 10 $11 d 2 \mathrm{GG})(71)$. De grondwetswijzlging werd met een beroep op de strijdbare democratie geoorloofd geacht. De rechter wees er op dat

"die Verfassung der Bundesrepubilk Deutschland sich fur die "streitbare Demokratie" entschieden hat ... Verfassungsfetnde sollen nlcht unter Berufung auf Erelhelten, dLe das Grundgesetz gewährt und unter thren Schutz die Verfassungsordnung oder den Bestand des Staates gefährden, beeinträchtigen oder zerstören dür"fen"( 72 ).

Duldelijk is: zowel in het Soldaten als in het Abhör arrest is de strijdbare democratie tot een zelfstandige warde getransformeerd.

Op dezelfde wijze heeft het Bundesverfasingsgemicht de strijdbare democratie ook in het Radikaten-arrest (73) als volmacht gehanteerd om de belangen van de staat boven de grondrechten van de burger te laten prevaleren.

Ten elnde te komen tot meer eensluldendheld met betrekking tot de criterla ter beoordeling van personen op hun geschiktheld voor een functie tn overheldsdienst hadden de bondskanselier en de minister-presidenten van de afzonder11jke deelstaten in 1972 het zogenaande Extremistenbesluit getroffen, beter bekend onder de betteling Radikalenerlass(74). Art. 1 van dit besluit bepaalt dat voor een functie in overheids- 
dienst slechts dlegene in aanmerking komt, die "Gewathr dafür bletet, dass er jederzeit für die fretheitliche demokratische Grundordnung im Sinne des Grundgesetzes eintritt". Tevens zijn ambtenaren verplicht zich zowel binnen als buiten dienstverband voor de instandhouding van de rechtsorde in te zetten. Ten aanzien van sol11citanten vermeldt art. 2 onder meer, dat het 1 idmatschap van een organisatie met anticonstitutionele doelstelling twiffels doet rijzen, of de sollicitant zlch wel ten allen tijde woor de freiheititiche demokratische Gmundordnung zal inzetten. Deze twiffels rechtwaardigen in de regel een afwijzing van de sollicitatie.

De in het Extremistenbesluit verwoorde interpretatle van het vereiste van de Verfasaungstreue, de plicht van trouw van ambtenaren (art. 33 11d 5 GG) was vanaf het begin orstreden. In 1975 was het woord aan het Bundesverfassungsgemicht. Aan de hand wan een gelljklufdende bepaling in de ambtenarenwet van de deelstat Sleeswijk-Holstein(75) moest het een uitspraak doen over de grondwettigheid van het in art. l van het Extremistenbesluit opgenomen criterium. In verband hiernee overwoog het Bundesverfassungagemicht, dat de vanouds bestaande plicht van trouw van ambtenaren onder het regime van de grondwet van 1949 een bijzonder gewloht heeft verkregen door de omstandigheid, dat deze constitutie nlet waarleneutraal is; $z i j$ heeft voor bepalde fundamentele warden gekozen en door matregelen ter bescherming van die waarden te nemen, een "wehrhafte Demokratie" opgericht:

"Dlese Grundentscheldung der Verfassung schllesst es aus, dass der staat, dessen verfassungsmässiges Funktionieren von der frelen 1nneren Blndung se1ner Beamten, an die geltende Verfassung abhängt, zum Staatsdienst Bewerber zulässt und $\mathbb{1}$ Staatsdienst Bürger belässt, die die frelheitllche, demokratische, recht- und sozlalstaatliche ordnung ablehnen und bekämpfen" $(76)$.

Tot de plicht van trouw behoort daarom terecht een positleve instelling tegenover de fretheittiohe demokmatische Grundordmung. Een neutrale houding is niet voldoende( 77 ). Ambtenaren moeten zlch door hun hele gedrag voor de vrije democratische rechtsorde inzetten, sollicltanten die op dit punt twijfels doen rijzen dienen ult de overheidsdienst geweerd te worden (78). In de beoordeling van de sollicitant op zifn geschiktheld moet zljn gehele persoonlijkheid worden betrokken en nlet ultsluitend afzonderlijke beoordelingsmomenten, zoals het lidmaatschap van een als anticonstitutioneel beschouwde organisatie( 79$)$. Hoewel volgens de constitutionele rechter natuurlijk nlet te 
loochenen $1 \mathrm{~s}$, dat julst dat latste veel over de persoionlif theid van de sollicitant verraadt(80).

Het Bundesverfaseungagemicht acht de in het licht van de stmijabare democmatie uitgelegde pliaht van tronw niet in strijd met de in de grondwet gegarandeerde grondrechten, zoals bijwoorbeeld het in art. $311 d 3$ GG gegarandeerde gelijkheldsbeginsel: "Nierand darf wegen ... seiner ... politischen Anschauungen benachtelligt oder bevorzugt werden". Het is uitgesloten dat de grondwet, die de Bondsrepubliek vanuit de bittere ervaringen met het lot van de democratle van Welmar als een strijdbare democratie heeft geconstitueerd, deze zelfde Bondsrepubliek met behulp van het gelijkheidsbeginsel aan zijn vijanden wll uitleveren(81), aldus het Bundesverfassungegericht. Het gelijkheldsbeginsel is aldus aan het princlpe van de strijdbare democratie ondergeschikt gemakt ( 82$)$.

Evenmin is de plicht van trouw in strifa met de vrijheld van meningsulting. Een politieke meningsulting is slechts door de garantie van de vrifheid van mentngsuiting in art. $5 \mathrm{lld} 1 \mathrm{GG}$ gedekt, als ze nlet onverentgbaar is met de plicht van trouw van de ambtenaar. Deze plicht van trouw en de daarmee samenhangende rechtsvoorschriften $z i j n$ toelaatbare beperkingen van de vritheid van meningsulting in de $z$ in van art. 5 lid 2 GG(83). De verplichting het ten allen tijde voor de fretheititche demoknatische Grundordnung op te nemen bepaalt dus de grenzen van de vrijheld van meningsulting van ambtenaren en van hen, die vroeger of later ambtenaar willen worden.

Hoewel het Radikalen-arrest geen onzekerheid lat bestaan over de rang van de plicht van trow in het geheel van constitutionele normen, heeft het nlet precles duldelijk gemaakt, welke consequenties nu met betrekking tot de aanstellingscriterla voor ambtenaren uit de uitspraak moeten worden getrokken, met name welk gewicht het 1 idmaatschap van een anticonstitutionele organisatie concreet heeft in de beoordelling van solifitanten op hun geschiktheid( 84$)$. Overheid en rechtspraak tonen zlch van de nuances, die het Radikaien-arrest bevat, weinlg onder de indruk. Zodra het 11dmatschap van een anticonstitutionele parti」 1s vastgesteld, bestaat an andere beoordelingmomenten nauwel1jks behoefte meer.

Aanvankelijk was de strijdbare democratle als "Ausdruck des bewussten verfassungspol1tischen W11lens zur Losung eines Grenzproblems der freiheitlichen demokratischen Grundordnung" (85) een methode om twee tegengestelde belangen met elkaar te verzoenen. Wellswar stond het belang gevaren voor de rechtsorde af te 
weren worop, mar tegel1jkertijd schiep de oorspronkelljhe conceptle varborgen dat die gevarenafwer niet ten koste zou gaan van omnodige beperkingen wain de Indilduele grondrechtem. Dit voor de strijubare democrat le karakterlstieke evenwicht $11 \mathrm{jkt}$ intussen te zijn prijggegeven. De beschermende werking jegens de grondrechten is verifiderd, de werdediging van de rechtsorde is in aanzlen gestegen. De conceptle van de strijdbare democratie dient er niet meer uitsluitend toe on gevaren af te weren 1 n het geval dat de rechtsorde actlef bestreden wordt. In het afgelopen decennium $1 \mathrm{~s}$ zI geworden tot een zelfstandige warde en daardoor tot een argument om in beginsel van ledere burger, mar in de prakt1jk alleen van milltalien en ambtenaren te werlangen, dat $z 1 j$ zlch ten allen tijde actief voor de democratische rechtsorde inzetten. Het gevalg van deze nteuwe benadering is, dat de strijdbare democratie tot een loutere beperking van de vrijheld van mentingsulting wam militalren en ambtenaren is geworden. Hlerop wordt later teruggekomen( 86 ).

De door het Bundesverfasungagemicht voltrokken accentverschulving wordt zeker nllet algemeen toegejulcht (87). Het str1jdbare karakter van de Westduitse constitutie als zodanig stat ook bij hen die een kritisch geluid latem horen niet ter discusste(88). Wel wijen degenen, die krttiek hebben, de priortteltsverschuiving af. Zij uiten de vrees, dat het precaire evenwicht, warop de strijdbaarheld berust, woorgoed verloren gat en dat ult het oog wordt verloren, dat tot de rechtsorde ook bet respect woor de grondrechten behoort. De bescherming van de frethettitche demokratische Grundordnung beoogt niet in de laatste plaats de bevelliglng julst van de grondrechten. De verwaarlozing van dit aspect zou er gemakkelijk toe kunnen voeren, dat de strijdbare democratie niet meer de gehele rechtsorde, inclusief de grondrechten dient, maar filft tot een blanco volmacht voor de staatsralson. Op dit gevaar gat ook het minderheldsvotum van drle rechters in het $A b$ höp-arrest in:

"Denn die "streitbare Demokratle" vertefdigt die bestehende rechtsstatliche verfassungsordnung, deren integraler Bestandteil die Grundrechte sind. Der Gesetzgeber, auch der verfassungsändernde, hat daher bel Regelung det Gefahrenabwehr ... die Rechtsgüter gegeneinander abzuwägen unter Berückslchtigung des Wertes, den das Grundgesetz den Indivlduellen belmisst. Die "Staatsralson" ist kein unbedingt vorranglger Wert. Werkennt der Gesetzgeber die Schranken, so kehrt die "streitbare Demo"kratie" slch gegen sich selbst" ( 89$)$.

108 De rechters wijzen er op, dat de strijdbare democratle 
zlch, behalve in de trits van de artt. 9 11d 2,18 en 21 lid 2 GG, eveneens in art. 79 lld 3 GG manifesteert, dat onder andere het respect voor de menselijke wardigheld tot onaantastbare basis van de grondwet heeft verklaard. Ook deze bepaling is een norm ter bescherning van de constitutle. Het 1 s een contradicto in re als men ter bescherming van de constitutie onvervreendbare principes van de constitutie zelf prijsgeeft $(90)$.

In deze afwijkende mentng is thet dilema van de strijdbare democratie haarscherp blootgelegd: zij bevat het risico dat de warden, die de strijdbare democratie beschermt, het moeten afleggen tegenover de strifdbaarheid zelf. Het kind wordt met het badwater weggegooid.

Uit de meest recente uitspraak met betrekking tot deze problematiek blijkt dat het Bundesverfassungegemicht dat toch ook niet 11 . De constitutionele rechter wees een klacht af van de Nationaldemokratische Partei Deutschtands (NPD), de opvolger van de SRP, dat de minister van binnenlandse zaken het partijenprivilege zou hebben geschonden(91). Deze had nameltjk ondanks het ontbreken van een partijverbod in zijn jamrverslag "Verfassungsschutz 1973" de NPD als rechtsradical, rechtsextreem, vijand van de vrijheid en een gevaar voor de democratische rechtsorde betiteld(92). Zo"n meningsulting van de minister - het Bundesverfabsungsgemicht noemt har eufemistisch: zakelijk gehouden(93) - moet echter volgens het hof als geoorloofd worden beschouwd. Want niettegenstaande dat de Bondsrepubliek een strijdbare democratle is, blifft zlj toch primalr op de vrlije lntegratie van alle politieke meningen en krachten in het kader van de grondbeginselen van de constitutie gertcht. De strljd tegen anticonstitutionele partijen noet in de eerste plaats met politieke en niet met juridische middelen worden gevoerd. Het is daarom legitiem als de staat in plaats van direct het Bundesverfassurgagemicht te verzolken, een partij die hij als strijdig met de grondwet beschouwt te verbleden, haar door middel van argunenten onschadelijk probeert te maken; daardoor wordt een verbod eventueel overbodlg. Ook met deze tactlek vervult de staat reeds aljo opdracht de frethettitiohe demoknatische Grundondnung te verdedigen( 94$)$. Ook in een strifdbare democratie gaat het dus niet aan om de doelen an de middelen op ce offeren. Teurghoudendheld b11jtt het parool.

Het NPD-arrest 11 lustreert de veranderende opvatting van de overheld, op welke wljze de democratische rechtsorde het meest effectlef zou kunnen worden beschermd. In plaats wan te grijpen nat het meest rigoreuze rechtsmidde1, het patijverbod, acht de staat 
het om tedenen van opportuniteft verstandiger de strljd tagen de vijanden van de democratie op een ander wlak an te blinden, namell jk vla het ambtenarenrecht (dus helemal niet alleen mar door middel van argumenten, zoals in het NPD-arrest zo fraal wordt gesuggereerd). De ultieg van het verelate van trou aan de constitutie in het licht van het Extremistenbeslut makt het mogelijk aanhangers van partijen die de staat als anticonstitutioneel definieert, te weren ult de overheldsdienst. Aangezien enerzijds het verleden van de sollicltant mede in aanmerking wordt genomen en anderzijds de overheldsdlenst 1 in de Bondsrepubliek een zeer vertakt geheel is, moet worden aangenomen, dat de preventieve werking die van de Radikatenenias ultgat groot is. Bovendien blifft het effect niet beperkt tot (ex-)leden van NPD en DRP (de opvolger van de KPD). Ook het lidmatschap wan tal van andere organlsaties kan twijfels doen rijzen over de Verfataungtreue van de (aankomende) ambtenaar.

De beleldsombulging van de overheld 1 s nlet van het Bundesverfaoungsgemicht ultgegaan. Wel heeft de constltutionele rechter de ombulgling gesanctioneerd daor de conceptle van de strijdbare democratie uit het KPD-arrest te transformeren tot een zelfstandige warde. De nleume conceptie kan aldus als legltimatle voor het veranderde beleid dienen.

3.2.7. De consequenties van de conceptie van de stmidbare democratie voor de vmijheid van meningsuituing

Uit het strijdbare karakter van de Westdultse democratie wolgt dat de vrijheid van menlngsuiting in de Bondsrepubliek aan een democrat lsche taak is onderworpen in die $z i n$, dat dit grondrecht niet mag worden ultgeoefend om ex de fretheitliche demoknatische Grundordiung mee te bestrijden, dat w1 zeggen die fundamentele beginselen, die de democratische beslultvorming garanderen en die voorkomen dat totalitaire strevingen een kans krifgen. Zowel art. I8 als de artt. 9 lid 2 en 21 lid 2 GG verbleden een dergelijk gebrulk van de vritheld van mentngaulting.

Weliswar $1 \mathrm{~s}$ van de mogelijkheid van art. $18 \mathrm{GG}$ on een verwerking ult te spreken nog noolt gebrulk gemaakt. De Interpretatle van het KPD-verbod toont echter aan dat ook een uitspraak op grond van art. 21 11d 2 GG grote gevolgen voor de vrijheid van meningsulting kan hebben en niet alleen voor de collectleve uitoefentag van het grondrecht, In partijuerband. Dok kon met het KPD-verbod in de hand individuen veelvuldig de uit- 
oefentng wan de vritheld van meningsulting worden ontzegd op een wijze dle praktisch met verwerking vergel1 jkbaar was (95).

De tramsformatie van de strifdbare democratie van methode tot warde heeft roor de individu geen verschulving met zlch nee gebracht ran de grenzen, die het Westduitse recht ter bescherming van de denocratie aan de vritheld van meningsulting stelt. Hoewel het Bundegverfasiungsgericht in het Soldaten-arrest heef vastgesteld dat ledere burger de pllcht heeft tot de verdediging van de vilje democratische rechtsorde, Is het juridische belang van deze ultspraak nihil. Voor milltalren en ambtenaren heeft deze pllcht echter wel repercussies op de vrljheld van mentmgsuitlug. De uitoefenling van het grondrecht moet verenlgbaar $z 1 j n$ met hun plicht zicht te allen tijde voor de rechtsorde La te zetten (96).

Tot dusver was dit hoofdstuk gewljd aan de conceptie van de strijdbare democratie. Het ging om de vraag, in hoeverre beperking van bepaalde grondrechten in de Bondsrepubllek aanvaardbaar wordt geacht ten behoeve van de bescherming van de democratische rechtsorde. Dieze vraag heeft het Bundeaverfasangsgemiaht beantwoord vanuft de exkenning van de wardegebondenheld van de Westdultse democratie. In het geheel van de striljdbare democratle bleek de vrljheld van meningsuting een centrale plaats in te nemen en vanwege die wardegebondenheld an bepaalde beperkingen onderworpen te zijn. Daarmee l1jkt de vraag, of de vrijheld van menlngsulting een democratische taak vervult, reeds te zijn beantwoord voordat het grondrecht zelf goed en wel is onderzocht. Toch zou het op zijn zachtst gezegd onbevredigend zijn hier op te houden. Het Is immers nauwe11jks aan te nemen, dat de centrale betekends van de vrljheld van meningsuitlng voor het democratische beslultvormingspraces - die biljkt ult de beperkingen, die het grondrecht zich in het kader wan de strijdbare democratie moet laten welgevallen gerulsloos aan de kern van het grondrecht zelf zon voorbljgaan.

Als de grondwet vanwege de waardegebondenheld van de denocratie al een afweerreactle paraat heeft voor het geval de vil theid van mentngsulting wordt gebrulkt met het doel de democratie op te heffen, warom zou men dan aan de andere kant nlet het gebrull van het grondrecht wllen belomen als dit op positleve wijze geschiedt, dat w11 zeggen als daardoor juist een b1jdrage aan de politieke besluitvorming wordt geleverd?

Op het eerste gezicht 11 jkt en speclale reactie op positlef gebrulk (conform de bedoeling, zo men wil) 
niet geboden. Weliswaar is door de strijdbare democratie de vritheld van menlngsulting aan bepalde beperkingen onderhevig, maar blijft het gebruik van het grondrecht binnen de gestelde grenzen, dan gaat het de staat eigen 1 ijk niet aan, overeenkomstig de opvatting. die ook in de Bondsrepubliek wordt aangehangen, dat de grondrechten afweerrechten van de individu tegenover de staat zijn. De grenzen die de strijdbare democratle aan de uitoefening van de vrijheld van meningsuiting stelt, zet het afweerkarakter van het grondrecht al meer dan genoeg onder druk. Bovendien zou men kunnen zeggen, dat de bescherming wan de uritheid van rieningsuiting als deel van de freiheitliche demokratische Gmundordnung $\mathbb{i n}$ het kader van de strijdbare democratie voldoende erkenning is van het belang van de grondrechten voor de democratie. Een speciale bescherming of statusverhoglng van de vrijheld van mentingsufting in geval van een voor de democratie nuttig gebruik lijkt daarom ongewenst en onnodig.

Het vervolg van dit hoofdstuk is aan de vrijheld van menlngsulting, zoals die blnnen de randvoorwarden van de strljdbare democratle bestaat, gewljd. Bezien zal worden, of en In hoeverre de mate van bescherming van dit grondrecht ook blnnen de hierboven vastgestelde grenzen wordt beinuloed door de betekenis van het grondrecht voor het functioneren van de democratie.

3.3. Nogmaals: het dubbele kamater van de grondrechten

De in de grondwet neergelegde conceptie van de strijdbare democratie toont aan, hoezeer grondrechten en democratie als een twee-eenheld worden beschouwd. Het een kan nlet zonder het andere bestaan.(97). Tezamen vormen grondrechten en democratie de piflers van het Westduitse constitutionele bestel. Beiden vloelen zij dwingend voort ult de onaantastbaarheld van de menselijke wardigheid als hoogste princlpe van de in 1949 opgerichte rechtsorde (art. $\mathbb{1}$ IId $1 \mathrm{GG}$ ).

De mens bezit in de schepplagsorde een eigen, zelfstandige watrde; $h 1 j$ is een persoonlijkheld uitgerust met het talent om $z i j n$ leven $\mathbb{1 n}$ eigen verantwoording gestalte te geven. Omwlle van zljn waardigheld moet hem een zo mogelijk vergaande ontplooling van zijn persoonlijkheid gegarandeerd worden (art. 2 1id 1 GG)(98). Daartoe dienen de overige in de Grondwet geconcretiseerde inensenrechten, die onschendbaar en onvervreendbaar zijn (art. 1 lid 2 GG)(99). Zij garanderen dus de Individuele ontplooiling. Hun belang wordt 112 onderstreept door de plaats van de grondrechtencatalo- 
gus, namelijk aan het begin van de grondwet, nog v6rr de bepalingen, die de grondbeginselen van de statsinrichting vastleggen. De in deze catalogus opgesonde grondrechten binden de wetgevende, uitwoerende en rechtsprekende macht (art. 1 lid $3 \mathrm{GG}$ ). In afzonderIijke gevallen is wettelifke beperking van de grondrechten wellswar toegestaan, maar hun essentle mag in geen geval worden aangetast (art. 19 11d 2 GG). De bescherming van de grondrechten wordt gecompleteerd door de omstandigheid, dat de dispositle over art. I GG aan de competentie van de wetgever is onttrokken in het kader van de strijdbare democratie (art. 79 lid 3 GG)(100) en dat ledereen, die meent dat zijn grondrechten door de staat $z 1 j n$ geschonden, een klacht kan Indienen bij het Bundesverfassungsgericht (art. 93 11d $4 a G G)(101)$.

Uit het primaat van de menselijke waardigheid volgt tevens dwingend het democratische princlpe (art. 20 Iid 1 GG). De ontplooiling van de eigen persoonlijkheid is slechts mogelijk als men ook mee kan werken aan de beslissingen van het collectlef(102) en kan deelnemen aan de totstandkoming van de volkswll. De volkssouvereiniteit is gebaseerd op de menselifke waardigheld.

Maar de democratie is niet enkel het noodzakelijke uitvloeisel van de individuele persoonll jkheidsontplooilng, die mogelijk wordt gemaakt door de in de grondwet opgenomen grondrechten, dat wl1 zeggen democratie is niet alleen dwiwngende voorwaarde voor individuele vrijheid. Net zo goed $z i j n$ de individuele vrijheidsrechten voorwaarde voor het functioneren van de democratie. Dat geldt in de eerste plaats voor de grondrechten die garanderen,

"dass der geistige Kampf, dle Auselnandersetzung der Ideen frei ist, dass mit anderen Worten geistiger Freiheit gewährleistet wird. Die Geistesfrelheit ist für das system der freiheitlichen Demokratie entscheidend wilchtig, sie list geradezu elne Voraussetzung für das Funktionieren dieser Ordnung; sie bewahrt es insbesondere vor Erstarrung und zelgt die Fülle der Lösungsmöglichkeiten für die Sachprobleme auf"(103).

De grondrechten dienen dus nlet alleen de individuele ontplooling, maar zif constitueren ook de democratie. Daarom behoren de grondrechten net zo goed als de meer expliciet procedurele rechtsnormen tot de door de strijdbare democratie beschermde belangrijkste grondbeginselen, die teamen de freiheitliche demoknatiache comindordnung vormen; zif danken hun bijzondere bescherming in het kader van de strifdbare democratie zowel aan het feit dat zij uit het postulaat van de menselifke wardigheid voortvloeien als aan het feit 
dat $z 1 \mathrm{l}$ omontbeerlifk zijn voor de democratle, die op haar beurt weer onontkonelljk ult de menselljke waardigheld wolgt. Belde karakterelgenschappen waken die grondrechten tot de spil van de wardegebonden orde, dle door de grondwetgever - als reactle op Weinar - is opgericht. Het Bundebverfabeungagemicht heeft het dubbele karakter van de grondrechten en hun plaats in de vardegebonden orde als volgt omschreven:

"Ohne Zwelfel and die Grundrechte in erster Linle dazu bestlmat, die Freiheltsaphäre des elnzelnen vor Eingriffen der offentilchen Gewalt zu sichern; sie sind Abwehrrechte des Burgers gegen den Stat - Diesen Simn haben auch die Grundrechte des Grundgesetzes, dass mit der Vorstellung des Grundrechtabschnlts den Vorrang des menschen und selner Wüde gegeniber der Macht des Staates betonen wo1te *.. Ebenso richtig ist aber, dass das Grundgesetz, das kelne Wertneutrale ordnung seln will ..., In selnem Grundrechtsabschnitt auch eine objekt Ive Wertordnung aufgerlchtet hat und dass gerade hierln elne prinziplelle Verstärkung der Geltungskraft der Grundrechte zum Ausdruck komm. Dieser Wertsystem, dasi selnen Mittelpunkt in der Innerhall der sozialen Gemelnschaft sich frei entfaltenden menschllchen Persönlichkeit und ihrer Wurde flndet, muss als verfasingsrechtliche Grundentscheldung für alle Berelche des Rechts gelten; Gesetzgebung, Verwaltung und Rechtsprechung empfangen van thm Rlchtinten und Impulse" (104).

In deze erkenning dat de grondrechten, omdat zij waarden $z i j n$, behalve subjectieve rechten tevens objectieve rechtsmormen $21 \mathrm{jn}$, die hun uftstrallng op de gehele rechtsorde hebben(105), heeft het Bundesverfassungsgemicht alch de Wertheorie elgen gemakt(106). Deze erkenning van het objectieve normgehalte van de grondrechten heeft hav ultwerking op de wiljheld van meningsulting alet gemist.

\subsection{De urijheid wan meningeuting}

In de Wentomdnung der grondrechten neemt de vrijheld van meningsulting een vooraanstaande plats $1 \mathrm{n}$. In art. 5 11d 1 GG wordt dHt grondrecht gegarandeerd, terwlj1 in art. 5 11d 2 GG is geregeld, in welke gevallen tot beperking van de vrltheld wan meningsulting mag worden overgegaran:

1. Jeder hat das Recht, selne Meinung 1 n Wort, Schrift und Blld frel zu äussern und zu verbrelten und slch aus allgemeln zugänglichen quellen unge- 
hindert zu unterrichten. Die pressefreiheit und die Frelheit der Berlichterstattung durch Rundfunk und Film werden gewathrleistet. Elne zensur findet nicht statt.

2. Diese Rechte finden thre Schranken in den Vorschriften der allgemeinen Gesetze, den gesetzlichen Bestimmungen zum Schutze der Jugend und in dew Recht der persönlichen Ehre.

Gegarandeerd worden de Informatievrijheid, de vrifheld van meningsulting en -verbreidlng in het algemeen, de persvrlyheid, de omroepvrijheld en de fllmorijheld. Bovendien is een ultdrukkelijk censuurverbod opgenoimen *

De genoende grondrechten worden an iedereen gegarandeerd. De natlonalitelt wan degene die ze uitoefent speelt in beglinsel geen rol (107). 0ok blnnenlandse rechtspersonen behoren tot de kring der gerechtigden (108).

\subsubsection{Het luth-amest}

De belde partijuerboden bulten beschouwing gelaten moest het Bundesverfassungsgemint zich voor het eerst ultgebreid met de vrijheid vam meningsulting bezlghouden in 1958. Het ult dit jarar daterende Lithrarrest (109) is nog steeds hoogst actueel vanwege de hiler voor het eerst gebrulkte en tot op de huldige dag toegepaste methode ter oplossing van conflicten, warbij de vrijheid van meningsuiting betrokken is, met inachtneming wan de dubbele status van dit grondrecht. Het betrof overigens niet een conflict tussen individu en overheid, maar een private rechtsstrijd ter discussie stond in de eerste plats, inhoeverre het recht op vrifheld van mentngsulting tegenover een andere Individu kon worden ingeroepen. Het arrest 1s daarom net zo goed woor belang voor de vraag naar de hor lzontale werking van de wrijheld van mentngsuiting.

Erich Lüth, officiele woordvoerder van de Senate van de hanzestad Hamburg, had in 1950 in het openbar opgeroepen een nleuwe $f 11 \mathrm{~m}$ van de vroegere nationaalsoclalistische regisseur Velt Harlan (berucht vanwege zijn in het Derde Rifk gedraalde productle "Jud suss") te boycotten, ondat de vertoning van diens f1lm in de Duftse bloscopen volgens Lith het morele aanzen van. Duitsland in de wereld opnleuw zou ruineren. Nadat lagere instanties Luth het recht om tot een boycot op te roepen hadden ontzegd als zijnde in strljd met de goede zeden, hief het Bundesverfassungsgemicht dit verbod op wegens strijd met het grondrecht op vrije meningsulting(110). Dit naar a anlefding van de uitstraling die de grondrechten als objektive Wemtordnung 
ook op het priwatrecht hebben(111). Ook de wrijhell van meningsulting make deel wit van deze Hemtondnumg; 21j heeft behalve haar karakter als subjectlef recht teven betekenis als objectiewe norn:

"Das Grundrecht auf frele Melnungsusserung ist als unittelbarster Ausdruck der wenschlichen Persönllchket in der Gesellschaft elnes der vornehrster Wenschenrechte uberhaupt (un des droits les plus prếcleux de 1 homme nach Artikel 11 der Erk1:rung der Menschen- und Bürgerrechte von 1789). Fur elne frelheltich-demokratische staatsordnung Ist es schlechthin konstitulerend, denn es exing1lcht ert die standige gelstige Auselnandersetzung den Kampf der Melnungen, der thr Lebenselement ist (BVerfGE 5, 85 (205)). Es ist in gewissent sitn dle Grundlage jeder Fretheit iberhaupt, "the matrix, the indispensable condition of nearly every ather form of freedom" (Cardozo)"(112).

U1t deze objectleve zijde, de eminente betekenis van de vrijheld van mentingsulting voor de liberale democratlsche rechtsstat, heeft het Bundesverfassungsgemicht consequentles getrokken die nlet alleen voor de derdenwerklng van dit grondrecht, maar ook voor de werhouding individwoverheid wan belang zijn.

Vanult constitutioneel standpunt bezien zou het nfet


de vritheld van meningsulting naar belleven per algemene wet, zoals 1 art. 5 lid 2 GG yoorzien, zou kunnen worden gerelativeerd.

Tenelinde zulks the voorkomen gelden spectale criteria om vast te stellen of een wet, die pretendeert de vrljheld van menlngsulting te kunnen beperken, wel algemeen 1 s. Onder algemene wetten zijn die wetten te verstaan,

"die "nicht elne Meinung als solche verbieten, die slch nicht gegen die Aeusserung der Melnung als solche richten", die vielmehr "dem Schutze eines schlechthiln, ohne Rücksticht auf eine bestimmte Melnung, zu schitzenden Rechtsguts dienen", den Schutze elnes Gemelnschafswerts, der gegenuber der Betatlgung der Melnungsfretheit den Vorrang hat" (113).

Is wolgens deze criteria een wet een algemene wet ten dus in principe als beperking toelaatbaar, dan is de volgende overweging van toepassing:

"dle allgemelnen Gesetze missen in threr das Grundrecht beschränkenden Wirkung threxselts in Lichte der "Badeutung dileses Grundrechts gesehen und so interpretlert werden, dass der besondere Wertgehalt dieses Rechts, der in der freiheit11chen Demokratie zu einer grundsätzlichen Vermutung 
fur die Frethelt der Rede in allen Berelchen, namentlich aber im offentlichen Leben, fuhren muss, auf jeden Fall gewaht blelbt. Die gegenseltige Bezlehung zwischen Grundrecht und "allgenelnem Gesetz" Ist also nicht als elnseltige Beschränkung der Geltungsikraft des Gruadrechts durch die "al1gemelnen Gesetze" aufzufassen; es findet vielmehr elne Wechselwirkung 1 n dem Sinne statt, dass die "allgemelnen Gesetze" zwar dem Wortlaut nach dem Grundrecht Schranken setzen, ihrerselts aber aus der Erkenntnis der wertsetzenden Bedeutung dieses Grundrechts tm frefhelt1ichen denokratischen Staat. ausgelegt und so in threr das Grundrecht begrenzenden Wirkung selbst wieder eingeschränkt werden müissen" (114).

De algemene wet, die de vrijheld van meningsulting beperkt, moet dus zelf in het licht van de bljzondere betekenis van dit recht voor de democratie worden beoordeeld en beperkt.

De ultschakeling van de algemene wet als automatische beperking van de uritheid van menlngsulting door deze wiselwerkingstheorite vergt een nieuwe procedure om vast te stellen waneer de viljheid van menthgsulting dan wel mag worden beperkt. Het Bundesvenfasinugggemicht heeft daartoe als nleuw beperkingsmechanisme een rechtsgoederenafweging gefntroduceerd, aan de hand warvan van geval tot geval dient te worden vastgesteld of de vrljheld van menlagsulting de voorrang verdient boven een door een algemene wet beschermd rechtsgoed:

"D1e ... Meinungsäusserung 1st als solche, d.h. In threr rein gelstigen wirkung, frei; wenn aber durch sie ein gesetzlich geschutztes Rechtsgut eines anderen beelnträchtigt wird, dessen Schutz gegeniber der Meinungsfretheit den Vorrang verdient, so wird dieser Elagriff nlicht dadurch erlaubt, dass er mittels efner Melnungsäusserung begamgen wird. Es wird deshalb elne "Giterabwägung" erforderlich: Das Recht zur Melnungsäusserung muss zur ucktreten, wenn schutzwürdige Interessen eines anderen von höherem Rang durch die Betätigung der Melnungstretheit verletzt wirden. ab solche iberwegender Interessen anderer vorllegen, ist auf Grand aller Umiände des Falles zu ermitteln" (115).

Deze afweglngsmethode met inachtneming van de w1sselwerkingstheorle is sinds het lith arrest vaste rechtspraak (116).

Voor het Bundegverfassungagericht was voor de concrete afweging tussen de writheid van mentmgsulting (warop 
Lïth een beroep deed) en de persoonlifke eer van Harlan (die zlch berlep op par. $826 \mathrm{BGB}$, welke bepaling: privaatrechtelijke bescherming biedt tegen aanvallen die in otrljid met de goede zeden $z i j n$ en een algenene wet in de zin van art. 5 11. 2 GG is) van doorslaggevend belang de overweging, dat de vrifheid van meningsulting in casu niet ten behoeve wan een privégetinte twist werd gebruikt, maar dat Lïth in eerste instantie aan de vorming van de publieke opinie wilde bifdragen. Het private rechtsgoed moest voor de vrijheld van menlngsuiting wijken, ondat het niet "um elne unittelbar gegen dieses Rechtsgut gerichtete Aeusserung im privaten, namentilch im wirtschaftilchen Verkehr und in Verfolgung elgennütziger ziele, sondern um einen Beftrag zum gelstigen Meinungskampf in einer die Oeffentlichkelt wesentlich berihrenden Frage durch einen dazu legitimierten" ging(117).

Het conflict werd beslist, niet door de betekenis van de vrifheid van meningsuiting als subjectief recht, maar door haar betekenis als van de Wertordinung deel uitmakende objectleve norm:

"der Wert, den das Grundrecht der frelen Melnungsäusserung gerade dadurch besitzt, dass es dile öffentliche Diskussion über Gegenstände von allgemelner Bedeutung und ernstem Gehalt gewährlelstet ... Wenn es darum geht, dass sich in einer für das Gemeinwohl wichtigen Frage elne offentliche Meinung bildet, miissen private und namentlich wirtschaft1lche Interessen grundsätzlich zurücktreten" (118).

\subsubsection{Homizontale werking}

Wellswar zag het Bunderverfarsungsgemicht in het geval van lïth naar efgen zeggen geen aanleiding in volle onvang op de kwestle van de horlzontale werking van de grondrechten in te gaan(119), maar met een beroep op de betekenls van de grondrechten als objektive Wertordnung en de vritheid van menlngsuiting daarin als garant voor de vorming van de publleke opinfe heeft het in ieder geval de middel1ijke horlzontale werking van de vrijheid van meningsulting erkend: geen privaatrechtelljk voorschrift mag met deze objektive Wertordnung in strijd zijn en elk voorschrift dient in haar geest te worden ultgelegd(120).

Ter realfsering van de invloed van de groudrechten op het privaatrecht kunnen vooral de algemene rechtsbeginselen dienen(121). Houdt de rechter in de burgerlijke rechtsstrijd onvoldoende rekenlng met de uitstraling van de vrifheld van meningsuiting op het privaatrecht, dan is er sprake van een schending van 
dit grondrecht wan overheldswege (122). De vritheid van weningsulting stat immers in directe samenhang met de in art. 1 GG gegarandeerde menselijke waardigheid en thet is ex art. 1 lid 1 in 2 GG de verplichting van alle overheldsorganen deze te respecteren en te beschermen(123).

Sinds het BZinkfilemarrest(124) kan over de horizontale werking van de vrijheid van meningsuiting geen twijfel meer bestaan. Aan dit arrest lag een conflict tussen de krantenmagnaat Axel Springer en het tifdschrift Blinkfuer ten grondslag.

Nal de bouw van de Berlijnse mur riep springer het publiek op om geen kranten meer te kopen die Oostduitse tw-programma's afdrukten. Hij kon zijn boycotoproep kracht bijzetten doordat de meeste verkooppunten van kranten in de Bondsrepubliek in zijn handen waren en hil op die wijze de distributie kon verhinderen van kranten die het afdrukken van aankondigingen voortzetten. Het Bundesverfassungsgericht overwoog dat de boycotoproep niet door art. 5 Iid I GG beschermd werd, ondat de daarmee gepaard gaande economische druk in strijd was met de kansiengelfjkheld in het proces van meningsvorming en ook met zin en wezen van het grondrecht op vrije menlingsulting, dat alleen de geestel1 jke strijd van menlngen beschermt. De economische druk was integendeel gericht op het verhinderen van die geestelijke strijd van meningen(125). Nlet alleen was een beroep op de vrligheid van meningsuiting ter rechtvaardiging van de boycotoproep niet op zijn plaats, bovendien schond de boycotoproep de persvrijheld van de ultgever van Blinkfiter, ondat gepoogd werd de concurrentie van meningen door economische druk ult te schakelen. Het doel van de persvrijheid, de vorming van een publieke opinte te vergemakkelijken en te garanderen, verelst dat de pers tegenover zulke pogingen in bescherming wordt genomen(126).

Met deze ultspraak is het Bundesverfaseungegericht een wezenlijke stap verder gegaan dan in het Luth-arrest. Het was hier niet de lagere rechter die door onvoldoende rekenting te houden met de uitstraling van de grondrechten op het burgerlifjk recht de persivijheid schond; het Bundesverfaseungegericht bepaalde dat Springer zelf de perswrijheld had geschonden. Het verzuim van de rechter bestond dit keer daarin, dat deze had nagelaten die schending te berispen.

Het Blinkfiem-arrest is een aanschouwelljk voorbeeld van de intensiteft, wartmee de horizontale werking van de vrijheld van meningsulting haar invloed doet ge1den. Het Bundesvenfassungsgericht is daarna weer teruggekeerd naar de in het Lïth-arrest gebezlgde formulering(127). 
Het In art. 5 lid 1 GG gegarandeerde grondrecht op vrl fheld van menlngsulting kan worden beperkt door de voorschriften van de algemene wetten, de wettelijke beperkingen ter bescherming van de jeugd en het recht Inzake de persoonlfjke eer. Via de toetsing van de vritheld van meningsuiting aan deze in art. 5 lid 2 GG opgenomen beperkingmogel1jkheden kan in geval van een confllct, waarblj een meningsulting 1 s betrokken, worden vastgesteld of sprake is van een schending of van een toelaatbare beperking van het grondrecht.

Hoewel deze drie begrippen ona fhankell jk van elkaar en naast elkaar bestaande beperkingen $21 j n(128)$, overlappen zif elkaar onderling voor een deel(129). De bescherming van de jeugd en de persoonlijke eer kunnen via een algemene wet een beperkende werking op de writheld van meningsuiting hebben. Daarnaast kunnen zij evenwel, in tegenstelling tot andere rechtsgoederen, doordat zij apart zljn genoemd, ook door een bijzondere wet de vrijheld van meningsuiting beperken. De persoonlijke eer wordt in de praktijk echter voornamelijk beschermd door bepalingen uit het Burgerlifk Wetboek en uit het Wetboek van Strafrecht, die als algemene wetten worden gezien(130), zodat de praktische betekenis van het recht lnzake de persoonlijke eer als apart genoemde categorle niet groot 1s. Wij zullen dan ook zlen dat conflicten tussen de vrijheld wan meningsulting en de persoonlljke eer voor een groot deel via het begrip algemene wet worden ultgewochten. De bescherming van de jeugd als beperkende factor zal in dit verband verder bulten beschouwing blifwen, omdat zij zowel over het geheel genomen als met betrekking tot het hier te onderzoeken thema geen rol wan betekenis spee1t(131).

\subsubsection{Het begrip "allgemeine Gesetze"}

De belangrijkste beperkingsmogelijkheid die art. 5 lid 2 GG bevat is die op grond van de algemene wetten. Het begrip "a11gemeines Gesetz" stamt uit art. 118 lid 1 In 1 van de grondwet van Weimar: "Jeder Deutsche hat das Recht, Lnnerha1b der Schranken der allgemeinen Gesetze selne Melnung durch Wort, Schrift, Druck und Blid oder in songtiger Welse frel zu äussern" (132). Wat de toenmalige grondwetgever ermee bedoeld heeft kon reeds in die tijd nlet meer worden vastgesteld (133).

De heersende menling vatte algemene wetten echter op als in tegenstelling staande tot bljzondere wetcen. Zif mochten qua lahoud en doel niet speclaal tegen de wrijheid van meningsulting zijn gericht, dat w1 zeg- 
gen tegen een menlng als zodanig ("Melnung als solche") of tegen een bepaalde mening ("bestimite Meinung $)(134)$, mar $z i j$ moesten een andere intentie hebben. Dat was het geval als de desbetreffende wet bedoeld was ter bescherming van een niet met de vrijheld van menlagsuiting samenhangend rechtsgoed. In deze zin zijn algemene detcen: "Gesetze, die dem Schutze eines schlechthin, ohne Rüksicht auf eine bestimnte Meinung $z u$ schützenden Rechtsgutes dienen" (135).

Deze opvatting had tot consequentie, dat de vritheid van meningsulting in geval van conflict had te wijken voor leder ander rechtsgoed, al was het nog zo onbeduldend, mits dit maar in de vorm van een algemene, nilet speciaal tegen dit grondrecht gerichte wet gegoten was. Zo zou bijvoorbeeld een wet, die een drukprocede met behulp wan bepalde machines met directe lingang uht velilgheidsoverwegingen zou verbieden, met het gevolg dat kranten en tijdschriften voorlopig niet zouden kunnen verschijnen, totdat niewwe machlnes waren geinstalleerd, geen ontoelaatbare beperking van de vritheid van meningsulting betekenen, ondat zo" $n$ wet als algemene wet moest worden beschouwd, dit hoewel de writheid wan menlngsuiting ernstig in het gedrang zou komen(136). Een dergelijke uitholling van de vel theid van meningsulting door middel van eenvoudige wetgeving ter bescherming van andere rechtsgoederen, zoals tijdens de Weimar-republiek mogelijk was geweest (137), wilde het Bundesverfassungagemicht na 1949 verhinderen. De reikwijdte van de vrijheid van meningsufting zou niet mogen worden overgelaten aan ledere gewenste relativering door middel van normale wet, wond de constitutionele rechter(138). Het Bundesver fasaungagericht koos voor dit standpunt ondanks het feft dat de grondwetgever klaarbl1jke11 jk met de opname van de beperkingsmogelijkheid door middel van algemene wetten in art. 5 GG wel bij de in welmar heersende ultleg heeft willen ansluiten en eenzelfde werking voor ogen heeft gehad(139). On deze werking te vermijden knoopte het Bundesverfassungsgericht echter an bij de door Smend tijdens Weinar verdedigde, net door de toenmalige heersende leer gedeelde vilste op het begrip algemene wet: "Allgemelnhelt ist die materilelle Allgemelnheit der Aufklarung: die Werte der Gesel1schatt, dle offentliche Ordnung und Slcherhelt, dhe konkurrierenden Rechte und Freihelten der Anderen. Allgemeine Gesetze sind also Gesetze, die deshalb dem Vorrang vor Art. 118 haben, weil das von thaen geschitzte gesellschaftiche Gut wlchtiger $1 \mathrm{st}$ als die Melnungsfreiheit" (140). Op deze wijze wilde het Bundesverfassungsgemicht vermljden dat elk rechtsgoed 
automatisch voorrang boven de vrijheid van meningsulting zou verkr1jgen. Deze formulering van Smend heft inderdaad het automatisme op, maar voorkomt nog niet, dat de algemene wet een speclaal tegen de vrifheld van menlngstiting gerlicht voorschrift kan $21 \mathrm{fn}$. Daarom heeft het Bumdesvenfasaungsgericht tegelijkert 1 jd nlet de in Weimar gebruikelljke opvatting losgelaten, dat een algemene wet nlet speclaal tegen dit grondrecht gericht mag $z 1 j n$. Het wilde als het ware het beste ult de verschillende opvattingen met elkar combineren. Zo kwam het in het Lüth-arrest tot een soort synthese van formele en materiele criteria(141), warin alle bovengenoemde elementen terugkeren(142): een algemene wet is een wet, die niet tegen een mening als zodanig of tegen een bepaalde menling is gerlcht en dle bovendien een rechtsgoed beschermt, dat belangrijker is dan de vril jhetd van mentingsulting.

Het laatste, op Smend teruggaande gedeelte van deze omschrifving, het materfiele criterium, impliceert dat een afweging dient plats te vinden tussen de vritheld van meningsulting en het andere in het geding zijnde rechtsgoed, wardoor het aorspronkelijke automatisme van de algemene wetten als beperkende voorschriften door broken wordt.

Het eerste deel van de omschrijuing, het formele criterium, dat de wet nlet tegen een menfing als zodanig, tegen een bepaalde mening mag $z i j n$ gerlcht, is in de praktijk volledig in de schaduw van het materfële criterium komen te staan. Hetzij wordt namelijk het formele criterium bij de beantwoording, of een wet algemeen $1 \mathrm{~s}$ en dus de vrijheld van meningsulting in princlpe kan beperken, genegeerd(143), hetz1j wordt vastgesteld, dat de wet niet tegen een bepaalde mening is gerlcht, zonder dat deze vaststelling bevredigend wordt gemotiveerd(144). Als het gaat on het onschade$11 \mathrm{jk}$ maken van het formele criterium kent de fantasie van het Bundesverfassungsgericht geen grenzen. ZO stelde het eens:

"Die Vorschrift richtete sich nicht gegen eine bestimmte Melnung, sondern gegen al.te, u.u. auf ganz verschiedene politische Ueberzeugungen beruhenden verfassungs feindlichen Bestrebungen" (145).

Hier is een bijzonder originele draal aan het criterlum bepaalde mentng gegeven: een mening is blifkbaar geen bepalde mening meer, als $z 1 \mathrm{j}$ maar voor ledereen, ongeacht de politieke overtuiging, taboe $1 \mathrm{~s}$.

Slechts een mal, nanelijk In het Südkurier-arrest, is door het Bundesvenfassungsgericht op grond van het formele criterfum vastgesteld dat een wet geen algemene wet in de zin van art. $511 d 2$ GG was, en wel niet eens omdat het voorschrift in kwestle (het behelsde 
en publicatleverbod voor vacatures op de bultenlandse arbeldsmarkt in persorganen, die in de deelstat Baden-Wirttemberg verschenen) een bepaalde mening verbood, maer omdat de publicatie la kwestie alleen de pers en niet ledereen verboden was (146).

Door de uitholling van het formele criterlum hangt de beoordeling of een wet algemeen is en dus een coelaatbare beperking van de vrijheid van meningsulting elgenlljk uitslultend af vaw de afweging, die nodig is om te bepalen of In casu de vrijheid van menlngsuiting of een andere Gemeinsehaftswemt de voorrang verdient.

\subsubsection{De rechtsgoederenafweging}

Deze rechtsgoederenafweging, in het Lith-arrest geintroduceerd en sindsilen vaste rechtspraak, is geen abstracte afweging tussen writheid var meningsuiting en andere rechtsgoederen in de $z i n$ van Smend; veeleer moet op grond van alle omitandigheden van het geval worden vastgesteld of vilheid van menlngsulting moet wijken voor belangen van een ander, welke het beschermen ward en van een hogere rang $z 1 j n(147)$. Van geval tot geval moet dus worden vastgesteld of het door algemene wet beschermide rechtsgoed of de vrlyheid van meningsulting de roorrang verdient.

Als belangrifkste leldraad voor deze ad hoc afweging heeft het Bundesverifasungsgericht de wlssilwerkingstheorie ingevoerd. De bijzondere kwallteit vat de vrijheld van mentngsulting leldt in de vrije democratie tot een principieel vermoeden vo6r de "Freiheit der Rede" op alle gebleden, met name in het openbare leven. Daarom vindt een isselwerking plaats tn die zin, dat de algemene wetten wellswar letterlijk gezien het grondrecht beperkingen opleggen, maar dat deze julst vanult de erkennlng van de bijzondere betekenis van de vritheid van meningsulting in de dewocratische staat ultgelegd en zodoende 1 in hum beperkende werklng zelf weer beperkt moeten worden( 148$)$.

Deze rechtsgoederenafweging met inachtneming van de wisselwerking tussen de beperkende wet en de vrijheid van menlngsulting is door de Westduitse juristen, die niet aan casuistiek gewend zijn, niet zonder moeite geaccepteerd $(149)$.

Als systematisch zwak wordt de cirkelredenering gezien, die de wisselwerkingstheorle in felte is: lid 1 van art. 5 wordt door het tweede lid ingeperkt, daarentegen het tweede lid weer door 1fd 1(150). Die cirkelredenering brengt onzekerheden in de interpretatie en de uitleg van de in art. 5 11d 1 GG gegarandeerde grondrechten met zich mee.

Heraog weert deze kritlek af met het argument dat deze onzekerheid biljkbar inherent is an de in de grond- 
wet gekozen systematiek van de grondrechten en dat de grondwet zelf dit bezwaar reeds heeft willen opwangen door de bepaling ( $1 \mathrm{n}$ art. 19 lid 2 GG) dat in geren geval de essentie van de grondrechten mag worden aangetast(151). Dat werplicht het Bundesverfassungegephicht te onderzoeken of een algemene wet, die de viljheld van meningsulting beperkt, deze kern daadwerk$11 j$ kantast wat nu juist het doel wan de wisselwerklngstheorle lifut te zijn; die wll immers "dass der besondere Wertgehalt dieses Rechts ... aul jeden Fall gewahrt blefbe"'(152).

Bif de afweglng zelf ontstat de moellijkheld dat materie matstaven. meten worden gewonden aan de hand warvan die afweglng kan worden verrlcht. Hoe kan men vastsellen of een Gemeinschaftswemt meer gewicht In de schaal legt dan de urijheld van meningsuiting of julst niet? Dat 4 . al moelijk bij de afweging tusisen de wifheid van meningsulting en een ander rechtsgoed van constitutionele rang, want de constitutionele orde is wellswar een Wertordnung, mar geen Wertrangondnung(153). B1jzonder dubleus is de afweging als deze Gemeinachaftawert niet in de grondwet, mar elders in het rechtsistsel verankerd 1 (s (154), bijwoorbeeld als norm van burgerlijk of administratief recht.

Het Bundeaverfassunggenicht heeft in het Lüh-arrest echter wel enlge aanwijzingen voor de afweging gegeven. Door het grondrecht enerzijds als meest onmidde1lijke ultdrukking van de menselijke persoonlijkheid te eren, anderzijds as constituant van de vrije democratische statsorde(155), ligt het voor de hand aan de vrijheid van meningsulting een zwaarder gewicht toe te kennen, naarmate het meer een van deze warden dient (156), met dien verstande, dat met name de meningsulting, die een bijdrage aan de vorning van de publieke opinie en daardoor aan de democratie levert, zwar weegt.

Het principiele bezwaar, dat tegen de afweglngsmethode wordt aangevoerd 18 , dat $z 1 \mathrm{j}$ op een afweglng van gewal tot geval ultloopt(157), die ten koste van de rechtszekerheld zou gaan. Er vindt geen afweglng tussen twee conflicterende rechtsgoederen meer plaats, mar een beoordeling van het gedrag van twee partijen: een belangenafweglng. Deze belangenafweglng bllfft nog inzoverte met een zekere abstracte afweglng verbonden dat constante leidraad de bljzondere beteken 1 s van de vrltheid van menlagsulting voor de democratile monet bilfven. Blj de afwegling spelen aldus zowel abstracte normen als concrete momenten een rol, marr uitelindelifk geldt: "Die Entscheldung kann nur aus einer Gesantanschauung des Elnzelfalles getroffen werden. EIne unrtcht1ge Abwägung kann das Grundrecht Cop vritheld 
van menlingsulting) verletzen und so die Verfassungsbeschwerde zum Bundesverfassungsger lcht begründen" (158). Aanleiding voor de ingevoerde methode was tat het Bundesverfassungsgericht de beslissing over de beperkingen van de vrijheld van meningsulting nilet aan de wetgever wilde overlaten. Het gevolg is nu, dat deze competentie naar de rechter is overgeheveld. Zij gaat zelfs verder doordat de afweging niet tot een abstracte beperkt blfjft(159). De rechter heeft bij de afweging volledig de vrife hand, zolang hif maar aannemelifk maakt dat hij de bijzondere betekents van de vrijheid van meningsulting heeft meegewogen. Het Bundesverfassungsgericht toetst de rechterlijke beslissing slechts marginaal $(160)$.

Met de invorering van de wisselwerkingstheorie en de ad hoc afwegling heeft het Bundesverfassungsgericht willen voorkomen dat de vrijheid van meningsulting nat believen zou kunnen worden beperkt als maar aan de formele voorwaarden was voldaan; in die opzet is het Btondesverfassungsgericht zeker geslaagd(161).

\subsubsection{De andere beperkingen van art. 5 lid $2 \mathrm{GG}$}

Voorzover het recht Inzake de persoonlijke eer en de voorschriften ter bescherming van de jeugd nast het begrip algemene wet zelfstandige betekenis hebben als beperking van de vrijheld van mentngsuiting(162), is deze niet van belang voor het bepalen van de verhouding tussen deze beperkingen en de in art. 5 lid $1 \mathrm{GG}$ gegarandeerde grondrechten, want ook zij moeten in het licht van de bijzondere betekents van de vrljheld van menlngsulting voor de democratie worden gezten en uitgelegd en aldus in hun de vrijheld van meningsuiting beperkende werk1ng weer worden beperkt(163), wat tot uitdrukking moet komen in de concrete afweging tussen de meningsuiting en het recht inzake de persoonlijke eer of het voorschrift ter bescherming van de jeugd, die vervolgens plaatsvindt. Zodoende makt het voor de uitslag van de afweging niet ut of deze tussen de vrijheid van meningsuiting en het recht inzake de persoonlijke eer c.q. het voorschrift ter bescherming van de jeugd rechtstreeks of via een algemene wet geschledt.

3.4.4. De omvang van de garantie van art. 5 did 1 GG

\subsubsection{Wat is een meningsuiting?}

De eerste zin van art. 5 11d 1 GG garandeert aan een leder het recht, zijn mending vrij te uiten(164). De onvang van deze garantie hangt af wan de ultleg, die aan het begrip mening gegeven wordt. De heersende leer is, dat niet elke uiting als een meningsuiting kan 
worden beschowwd. Een felt, dat wil zeggen lets dat reeel exlsteert of een gebeurtenis, valt niet onder het begrip menling. De mededeling van felten, berichten, nleuws, informatieverstreklking, zo wordt gesteld, is derhalve geen meningsulting en wordt niet door art. 5 11d I GG beschermd(165). Meningsultingen zifn witsluttend waarderingen, oordelen, beoordelingen, opvattungen, 1nschattingen en dergelijke(166). Als criterium ter onderschelding tussen felten en wardeoordelen dient de bewljsbarheid: de juistheld van felten kan men bewijzen, die van wardeoordelen niet (167).

Een minderheld huldigt de opvatting, dat een onderscheld tussen de mededeling van feiten en het leveren van waardeoordelen onmogelijk is(168). Enerzijds bestaat er nauwelijks een gefundeerd wardeoordeel, waarin niet een of meer feiten verweven $z i j n$, zonder dat het een van het ander kan worden geschelden, anderzljds $1 \mathrm{~s}$ er geen berlchtgeving denkbaar, die geheel wan het elgen waardeoordeel is losgekoppeld. Zelfs de keuze, welke felten men vermeldt, houdt al een waardering in(169). Afgezien van deze praktische overwegingen zlet Herzog bovendien princlpleel geen reden de garantie van de vrljheid van mentngsulting te beperken tot producten van de eigen denkarbeid. Hij zlet het grondrecht als een erkenning van een alomvattende menselifke mededellingsbehoefte(170). Art. 5 lid 1 GG garandeert daarom $z$ jns inzlens een "Recht der frelen Rede", inclustef het recht van de Individu tot wrije mededeling an anderen in de breedste $z$ in van het woord (171).

Het Bundesverfassungsgericht houdt een onderscheiding wel voor geboden, hoewel art. 51 id 1 GG niet uitdrukkellilk tussen waardeoordelen en feitenweergaven differentleert. Het hof leidt de noodzaak tot het maken van een onderscheld echter af utt de zin van de meningsult1ng: geestelijke werking op de wereld om ons heen ut te laten gaan, meningsvormend en overtuigend te werken(172) en die $z$ in is bif de strikte mededeling van feiten niet a priorl aanwezig. Hoe de grens tussen felten en waardeoordelen precles dient te worden getrokken heeft het Bundesverfassungsgericht onlangs in het Meinungsäusserung im Hahlkampfarrest ult de doeken gedaan(173). Aanlelding was een conflict tussen de chrlsten-democratische partij van Beleren, de Chmistlich-Soziale union (CSU), en een afgevaardigdle van de Sostatdemoknatische Partei Deutschtands th het Europese parlement. De parlementariër had tijdens de campagne voor de verklezingen van de Bondsdag in 1980 de cSU uitgemakkt voor de NPD van Europa. Het Bundesverfassungagemicht oordeelde dat deze ultspraak mede een 126 waardeoordeel inhleld en dus in principe door art. 5 
11d $1 \mathrm{GG}$ beschermd werd(174). De toelaatbaarheld moest dan vervolgens aan de hand van de wisselwerkingstheorie en een concrete afwegling tussen de vriljheld wan meningsulting en het recht inzake de persoonilijke eer worden vastgesteld.

Waardeoordelen, had het Bundesverfassungegemicht al in het Strafvollaug-arrest overwogen, zijn altijd beschermd. Niet van belang is, of zo"n utting wardevol of waardeloos, julst of fout, emotioneel of rationeel gefundeerd $1 \mathrm{~s}(175)$. Een differentiatie naar de zede$11 j k e$ kwalltelt van een mening zou de bescherming ontoelatbaar relativeren. In een pluralistische staat is tedere mening het beschermen waard, ook diegene, die van heersende voorstellingen afwljkt(176). Bij mededelingen van feiten $1 \mathrm{igt}$ dat anders. Deze zifn geen meningsuitingen in strikte $\mathrm{zin}$ en daarom hangt hun bescherming af van de vraag of $z i f$ voorwaarde voor de vormen van meningen $21 \mathrm{jn}$. De bewuste weergave van onjuiste feiten en onfuiste citaten worden derhalve in geen geval door art. $5 \mathrm{lld} \mathrm{l}$ GG beschermd, omdat $\mathrm{zlj}$ niet aan de meningsworming kunner bijdragen, of, zoals dit in het Böl-arrest werd geformuleerd, "well sie der verfassungsrechtlich vorausgesetzten Aufgabe zutreffender Meinungsbildung nicht dienen" kunnen(177). In tegenstelling tot de eigenlijke meningsulting komt het er bij de mededeling van feiten dus op de jufstheid van de mededeling aan(178).

Dit alles in aanmerking genomen moet het begrip mening ruim worden uitgelegd, aldus het Bundesverfassungsgepicht in het Meinungeäusserung im Wahlkanpf-arrest. Overheerst het element van stellingname, overtulging of menen, dan verdient een ulting bescherming, ook wanneer deze elementen $z i j n$ verbonden of vermengd met elementen, die de bewering of de mededeling van feiten inhouden. Dat geldt in ieder geval, wanneer beide elementen niet van elkar te scheiden zljn en het feitelljke tegenover het waarderende element op de achtergrond treedt(179). De bewering, dat de csil de NPD van Europa is, was in casu zo'n mengvorm.

Recapitulerend kan het volgende worden gesteld. Beschernd worden door art. 5 lid 1 GG wardeoordelen. Felten worden beschermd als zif met wardeoordelen verbonden $z 1 \mathrm{jn}$, beide elementen nlet van elkar te scheiden $z i j n$ en het warderende element overheerst. In deze constellatie speelt het warheidsgehalte van de felten geen rol.

Worden nlet-ware feften beweerd en gat deze bewering bovendien nlet van een wardeoordeel vergezeld dan is geen sprake van een menlngsulting en valt de ultspraak. niet onder de bescherming van art. 5 lid 1 GG. Het gevolg is dat bepalingen, die zulke (door art. 5 lid 1 
GG niet bescherrde) ultingen strafbar stellen als ze laster of smaad Inhouden(180), ook niet als beperkingen van de vrijheid van meningsultig in de zin wan art. 5 lid 2 GG worden beschouwd en dus niet in het 1.cht van de schlechthin konstitwerende betekends van dit grondrecht moeten worden gezien. Hetzelfde geldt voor bepalingen, die de basis vormen voor privartrechtelljke anspraken die ult de bewering of de mededeling van niet-ware felten voortvloelen(181). Dit in tegenstelling tot het dellct belediging (182), dat ultspraken strafbaar stelt die een wardeoordeel bevatten en dus wel een beperking van de vrljheid van menlngsulting betekent, alsmede cot bepalingen die de privaatrechtel1jke grondslag wormen van aanspaken, die op wardeoordelen $z 1 j n$ gebaseerd(183). Deze beide laatste categorlieen moeten derhalve wel in het licht van de bifzondere betekents van de vrijheld van meningsulting worden beoordeeld. Wij zullen nog zien diat in dat geval voor en bescherming van de persoonlijke eer weln $1 g$ plaats $1 \mathrm{~s}$ als de openbare meningsvorming in het geding 1 (s $(184)$.

3.4.4.2. Vereisten aan vorm en inhoud wan de mentingsuiting

Zaals al blifkt ult de opmerking van het Bundesverafassungagericht, dat het niet aangat een menting op haar zedelijke kwallelt te beoordelen, worden aan de inhoud van eet ulting, die volgens de hlerboven ulteengezette matisaven onder de garantie van art. 5 ldd 1 GG vallen, geem beperkingen gesteld(185).

We1 heeft het Bundesverfassungsemicht reeds lang geleden opgemerkt, dat de grote betekenis die de vrijheld van meningsulting in de democratie heeft, niet met zlch meebrengt, dat men zifin mening in ellke vorm en met elk middel mag uiten(186). We1iswar omwat art * 5 Iid 1 GG in principe ook de vrijheid zelf te besilssen hoe een gedachte wordt geformuleerd, maar de bijzondere beteken 1 s van dit grondrecht ligt vooral in de bescherming die het aan de substantie van meningsultingen verleent. Strafworschriften, die ter bescherraing van het aanzien van derden of van de staat grenzen aan de formulering stelien, gelden niet als ontoelat bare beperklngen is de geestelljke lnhoud van de ulting ook door middel yan een andere, niet krenkende uttrukkingsvorm kan worden verbreld (187).

Zo werd door het Bundesverfasamgagemint in het $D G B$ arrest de letterlijke herhaling, maar niet de ldentleke omschrijulng van het tijdschrift Deutschtand-Magazin met de woorden "rechtsradika les Hetzblatt" voor de toekomst verboden (188). 
zlch afgevraagd, hoe zonder gebrulknaking van deze omschrijuing een inhoudelijk gelifkluldende kritiek valt te leveren. Een differemtelering tussen formulering en inhoud van een meningsulting is in haar ogen nitet door te woeren, zonder dat zlj tepercussies heeft op de Inhoud van de meningsulting zeif. Een censurerlag van de formulering loopt uft op bevoogding van de burger. Gezien de sinds het Lith arrest erkende princtpide betekents die de vrijheid van meningsulting en de openbare discussle voor de democratie heeft(190), zou de te licht bevonden formulering zeker nlet diemen te wiken voor de persoonlijke eer van het tijdschrift nu $\mathrm{ij}$ was gebezigd in het kader van een repllek van de Westduitse vakbond op beschuldigingen an het adres van de vakbond in het Deutschzand-Magazin, die ook nlet bepald zachtaardig geformuleerd waren(191). Het Bundesverfassungsgericht was toch julst de overtulging toegedaan, dat zo'n tegenaanval bevorderend 1 s voor de mentingsvorming? In dat geval zou er geen aanlelding mogen bestaan aan de gekwetste eergevoelens wan het tifdschrift, dat de tegenaarual had uitgelokt, de voorrang te gewen (192).

Getullge de jurisprudentie na het DGB-arrest schijnt het Bundesverfassungsgemiaht de uiteenzetting van Fupp-von Brinneck over de gevaren, die een beoordeling van de formulering van een meningsuiting oproept voor de Imhoud, ter harte te hebben genomen. Het standpunt luidt thans:

"Betrlfft eln Beltrag zur Melnungsbildung eine die Deffentlichkett wesentlitch berihrende Frage, so durfen bel der Auslegung der die Melnungsfretheit beschränkenden Gesetze an die Zulassigkeit öffent11cher krit:k kelne iberhöhten Anforderungen gestellt werden" (193).

Dat geldt ook voor de formulering, zowel voor het gesproken woord als voor utingen in de pers:

"Im Interesse freier Rede, für deren Zulässlgkelt die Vermutung spricht ...., müssen in EInzelfallen Schärfen und Jeberspitzungen des offentlichen Me1nungskampfes hingenommen werden. Die Befürchtung, wegen ellner wertenden Aeusserung elnscheldenden gerlchtlichen Sanktionen ausgesetzt zu werden, trägt die Gefahr in sich, offentliche thitik und offentliche Diskussion zu lahmen oder elnzuengen und damit Witkungen herbelzufthren, die der Funktion der Metnungsfretheit in der durch das Grundgesetz konstituterten ordnung zuwlderlaufen"( 194 ). Hoewel dus aan de formulering van een mentngsulting geen overdreven eisen meer mogen worden gesteld, bestat nog vanuit een andere hoek gevaar voor een inhoudelifke beoordeling van meningsultingen. De irhoud 
van een meningsulting kan namelijk wel degelijk een rol spelen in de afwegingsprocedure tussen de vrijheld van meningsuiting en een met dit grondrecht in conflict geraakt rechtsgoed. Bif gebrek aan formele criteria ter bepalling van de voorrang van een bepaald rechtsgoed voor de urijheld van menlngsuiting ja of nee, is die afweging dikwijls bijna onmogelijk zonder dat tot een inhoudelijke beoordeling wordt overgegaan. De inhoud van de meningsuiting in kwestle is alleen dlaarom al niet irrelevant, omdat moet worden vastgesteld, of zij tot de openbare meningsuorming bijdraagt.

In dit opzicht heeft het Lüth-arrest precedentenwerking gehad. Het ging hier on twee tegenover elkaar staande meningsuitingen: de film van Harlan tegenover de boycotoproep van Lith. Terwijl thet belang van Harlan bif een ongestoorde circulatie vam zijn film werd afgedaan als het nastreven van economische en baatzuchtige doelen(195), werd de boycotoproep gevierd als een bifdrage aan de meningsvorming in een kwestie, die voor het algemeen welzijn van belang was (196). Hoevel eigenlijk niet is in te zien waarom Harlans film geen bijdrage aan de menlngsvorming vormde, werd hierover met geen woord gerept. Harlans prlvébelangen moesten wijken voor de meningsulting van Lïth. De doorslaggevende motivatie van het Bundesverfassungsgemicht is verhelderend: Liiths mening was waardevoller dan die van Harlan; hij had het gelifk aan zijn kant, want de overweldigende meerderheid van de publieke opinie stond achter hem(197). Het Bundeavenfassungsgemicht wees op de massale bijval die een parlementarier in de Bondsdag kreeg toen hij partij koos voor Lüth:

"Für die Beurtellung des Verhaltens des Beschwerdefuhrers kann die hier zum Ausdruck gekommene Auffassung des repräsentativen Vertretungsorgans des deutschen Volkes nicht gleichgültig sein. Sie macht es unmöglich, in den Aeusserungen des Beschwerdeführers einen Verstoss gegen die Auffassungen der verständigen, billig und gerecht denkenden Bürger zu sehen" (198).

Een mening die zelfs door de gehele Bondsdag wordt gedeeld is kennelijk de waardevollere mening. Inhoudelijke overwegingen hebben aldus bepald welke van de twee meningsultingen aan de meningsvorming bifdraagt en dus de voorrang verdlent.

Een ander arrest, waaruft blijkt dat de inhoud van een mentingsulting een rol in de beoordeling kan spelen, betrof de mentingsulting van een dienstplichtig soldaat, die in een gesprek met de DDR-radio melding had gemaakt van het aantal dienstwelgeraars in de Bondsrepub1lek(199). Hoewel de ciffers algemeen bekend waren 
stelde het leger dat de soldaat zijn gehelmhoudingsplicht had geschonden. In de daaropvolgende afweging overwoog het Bundesverfassungegericht, dat tegenover het belang van het leger bij geheimhouding het belang wan de soldaat bij mededeling "gerade an elnen gegen die Bundesrepublik Propaganda treibenden Sender der DDR ohne jede billigenswerte Bedeutung" was, "Insbesondere nicht für die Bildung einer offentllchen Melinug" $(200)$. Met andere woorden: wat de soldaat te vertelien had, was niet interessant. De inhoud van de meningsuiting was aldus van direct belang voor de beoordeling van de toelaatbaarheid.

\subsubsection{De ain van de vmigheid van meningsutting}

Achter de opmerking van het Bundeoverfassungsgemioht, dat de bewering of mededeling van niet-ware feiten niet door art. 5 lid 1 GG wordt beschermd, gaat een bepalde opvatting over de zin van de vrijheld van meningsulting schuil. In dit verband is de mening van Ridder interessant. Volgens Ridder is de "slttiche Leitidee der Melnungsfreiheit" : waarheidsvinding(201). De $z i n$ van de vrijheld van meningsulting zou bestaan in het zoeken naar en het vinden van de waarheid. Nu kan men de vrijheld van meningsuiting niet zonder meer aan dit doel ondergeschikt maken. Men kan slechts hopen dat uit de confrontatie van verschillende meningen met elkaar een waarheid te voorschijn zal komen. Het grondrecht op vrijheid van mentngsuiting stelt dit proces vellig. Ondat de julstheid van waardeoordelen nu eenmal niet is vast te stellen, worden $z i j$ in princlpe allemal bescherma (202). Met felten $1 \mathrm{ggt}$ dan anders; daarvan kan objectief worden vastgesteld en bewezen of $z 1 \mathrm{f}$ war $z 1 \mathrm{jn}$ of nlet. Het zou daarom in strijd $z 1 j n$ met de $z$ in van de vrijheld van meningsulting de waarheidsvinding, de mededeling of de bewerling wan nlet-ware felten door art. 5 lid 1 GG te laten beschermen. Om dit te vermijden dienen volgens Ruthers alle weergaven van feiten van de bescherming te worden uitgesloten (203).

De relatie tussen de neiging het begrip mening restrictief te interpreteren en het annemen van een warheldsdoelsteling als bittiche Leitidee van de wrijheid van meningsuiting komt ook naar voren in het Schmitarrest, dat de persvrijheld tot onderwerp heeft (204). In het kader van de zogenaamde institutionele garantie van de persvrijheld(205) wordt het gehele complex van persactivitelten door art. 5 lid l GG beschernd, dat wil zeggen niet alleen de verbrelding van een eigen mening, maar ook reeds de verstrekking. van pure informatle, waronder ulteraard felten(206). In het sohmidarrest heeft het Bundeoverfasaungsge- 
wicht, als tegenprestatle voor de bescherming van feltenweergaven die door viddel van de institutionele garantie aan de pers verleend $1 s$, en plicht tot bierlchtgeving overeenkomstig de warheid in het leven geroepen(207), een plicht die juist de nieuwsverstrek$\mathrm{king}$ op het oog heeft. De grotere bescherming gaat dus gepaard van een plicht tot warheldsgetrowwe weergave van feiten, opdat de zin wan de vrl theid van meningsulting nlet in gevaar kont. Daarom ook kennen de perswetten van de meeste deelstaten de zorguldigheidsplicht, dat is de pllcht nieuwsberichten op hun julstheld, Inhoud en herkomst te toetsen(208). Ondanks de institutionele garantie wordt overigens ook het bewust beweren van niet-ware feiten in de pers niet door de meningsvr 1 theld beschermd(209).

Verhelderend is tevens het standpunt van Hesse(210). Naast de eigen stellingname (waardeoordelen) beschouwt hil wellswar ook de mededeling van felten als meningsulting in de zin van art. 5 1id $1 \mathrm{GG}$, daarentegen echter niet de weergave van onjuiste feiten, en ondat de daarop gebaseerde mentng noodzakelijkerwljs een onjuiste moet zijn. De bezorgdheld, die hem tot de onderscheiding noopt, betreft nlet zozeer de onjuistheld van de felten zelf als wel het gevolg daarran, dat onjuiste informatie leidt tot een onjulste meningsvorming. Dat is precles de redenering van het Bundesverfassungsgericht, met dien verstande dat de constitutionele rechter onjuiste meningsvorming niet gewenst acht expliciet met het oog op de democratische besluitvorming. Gezien het belang van het proces van openbare meningsvorming is het beweren van onjulste felten, het geven van onjulste informatle, waaronder het onjuist citeren valt, onder de invalshoek van de vrl theld van meningsulting het beschermen niet waard, "well sle der verfassungsrechtlich vorausgesetzten Aufgabe zutreffender Melnungsbildung nicht dienen kann"(211). Het hof neemt dus kennelifk aan, dat het de taak allas de $z$ in van de urijheld van meningsulting is, voor een julste meningsvorming zorg te dragen (212).

Dit leidt tot de conclusie, dat achter het gemaakte onderscheid tussen felten en waardeoordelen en achter het straf- en clvielrechtelljke waarheldsbegrip, dat ten behoeve van de beoordeling van beweringen en weergaven van feiten wordt gehanteerd, nog een constitutloneel waarheidsbegrip schullgat.

Het Bundesverfassungsgericht verwacht blijkbaar van the vrijheld van meningsuiting dat deze leidt tot een meningsvorming, die van voldoende kwaliteft fs om hat functle in het democratische proces te kunnen vervul132 len. Uitspraken, warvan vaststelbaar is dat zij niet 
kloppen, behoren daarom nlet beschermd te worden. Niet In de eerste plaats omdat zij, vanuit de individu gezilen, afbreuk zouden kunnen doen aan de menselijke wardigheid van degenen, die het slachtoffer van die ultspraken $z i j n$, maar vooral ondat zil een vervalsende werking hebben op het democratische proces.

Betekent de opmerking dat de vritheid van meningsulting tot taak heeft woor een juiste meningsviorming zorg te dragen dan ook dat het in de democratle op het vinden van die ene waarheld aankomt? Roelleoke warschuwt tegen zo'n interpretatie van de vrifheld van meningsuiting: alleen totalitalle regimes kennen julste menfingen (223).

Samengevat ontstaat het volgende beeld. Het Bundesver fassungsgemicht heeft de waarheidsvinding als sittliche Leitidee van de vrijheld van meningsuiting geaccepteerd(214). Deze zingeving hangt niet samen met de behoefte an bescherning van de menselijke waardigheid, maar met de betekenis van de vrijheid van meningsuiting voor het functioneren van het democratische proces. De bewering en de weergave van onjuiste feiten leveren geen bijarage aan dit proces en genfeten daarom geen bescherming. Uitingen die een wardeoordeel bevatten zijn daarentegen meningsultingen in de zin van art. 5 lid 1 GG en mogen daarom niet door de rechter op hun juistheid worden getoetst. Indirect kan een beoordeling van de inhoud echter plaatsvinden tijdens de goederenafweging tussen de vrijheld van meningsuiting en een daarmee in conflict verkerend rechtsgoed. Dit geschiedt dan door de vaststelling of de desbetreffende meningsuiting aan de openbare memingsworming bijdraagt en daarom bij de afweging extra gewicht krijgt.

3.4.5. De "sohlechthin konstituierende" betekenis van de vrijheid van meningouiting

De horizontale werking van de vrijheld van meningsulting heeft haar uftwerking niet gemist. Steevast is in privaatrechtelijke geschilien, waarbij een meningsuiting in het geding was - meestal wegens aantasting van de persoonlifke eer door een meningsulting(215) - de achlechthin konstituterende betekenis wan de vrljheld wan meningsulting expliciet ter sprake gekomen of st1lzwijgend verondersteld door de verwijzing naar het belang van het proces van openbare menlngsvorming (216). Het is geen wonder dat in deze civielrechtel1jke context de primaire betekenis van de vrijheid van meningsuiting volledig op de achtergrond is geraakt. Speelt dat grondrecht inmers in deze sfeer een rol, dan slechts op grond van zijn gehalte als deel wan de 
Wertordinung. De aandacht woor de vrljheld van meningsuiting als afweerrecht is in deze context orgekeerd evenredig an de andacht voor dit grondrecht als objectleve norm, namelijk nilh11. Dat de afweerfunctle de aorspronkelljke is, lijkt in het Echtemach-arrest zelfs geheel vergeten, als het Bumdeaverfasangagemicht de vritheid van meningsulting "in seiner Kembedeutung" een "fur elne freiheitliche demokratische Staatsordnung schlechthin konstituierendes Grundrecht ${ }^{\text {g }}$ noemt $(217)$.

Hoewel de wrijhell van meningsuiting als objectieve norm voor het eerst is aangehaald in het kader van de uitstraling van de grondrechten op het burgerlijk recht, is de vermelding van de objectiefrechtelijke zijde geenszins tot uitspraken op dit gebled beperkt gebleven. Evenzeer treedt deze zllyde op de voorgrond bij klassleke conflicten met de vrïheld van meningsuiting als inzet: tussen burger en overheid. Ook dan is het enlige wat het Bundesverfassungsgericht kwelt, of bij de vraag, of dit grondrecht door de overheid is geschonden, voldoende rekening is gehouden met de "für die fretheitliche ordnung schlechthin konstitulerende Bedeutung der Meinungsfretheit"(218). De verwaarlozfing van de subjectiefrechtelijke zijde in het gemeenschappelijk kenmerk van alle in art. 5 lid 1 GG gegarandeerde afzonderlifke grondrechten, zowel van de algemene garantie van de vrijheid van meningsuiting als van de separate garanties, de informatiewrijheid, de perswrit jhetd en de omroepwrijheid.

De subjectiefrechtelijke zijde wordt weliswaar genoemd In de eerste an de perswrijheid(219) respectievelifk omroepvri jheid(220) gewl jde uitspraken, maar de rechtspraak is gefixeerd, op hun betekents als objectieve norm. Op de persvritheld als aanschouwelijk voorbeeld van een scheefgegroelde twee-componentenleer wordt hierna apart(221) ingegaan.

Bij de informatievrijheld valt de meeste nadruk eveneens op de objectiefrechtelijke component. De Informatievrijheld vormt een zelfstandig grondrecht(222). Anders dan de vrljheld van mentngsuiting, waarbij de ontvanger een onontbeerlijke functie vervult(223), is de Informatievrijheld juist naar binnen gerlcht, zij is het recht zlchzelf te informeren(224) en wel ult algemeen toegankellijke bronnen(225). Zif is bovendien de prenisse voor de uitoefening van het recht op ville meningsulting(226). Want alleen omvangrifke lnformatle ult voldoende informatlebronnen makt pas vrije menligsworming en -uiting mogelijk, zowel voor de individu als voor de gemeenschap (227). De pers heeft hlerIn de belangrijke taak, "durch umfassende Informatio134 nen den Bügern die Aufgabe zu erleichtern, slich Mei- 
numgen $z$ u bliden und polltische Entscheldungen za treffen (228). Gellet op deze verwijzing naar de betekents van de informatlevr theld voor de meningsvorming In werband net de politleke beslutevorning zal het nilet verbazen dat van de twee componenten die het karakter van dit grondrecht bepalen de objectlefrechtell Jke zijde als eerste wordt genoemd:

"Elma1 ist es der Bezug zum demokratischen Prinzip des Art. 20 Abs. 1 GG: EIn demokratischer Staat kann nicht ohne freie und möglichst gut informlerte öffentilche Melnung bestehen. Dameben weist die Informationsfretheit eine lndividualrechtilche, aus Axt. 1, Art. 2 Abs. 1 GG hergeleltete Komponente auf. Es gehört zu den elementaren Bedür fnlssen des Menschen, slch aus möglichst vieLen Quellen zu unterichten, das elgene Wissen zu erweltern und sich zo als Persönlichkeit zu entfalten" $(229)$.

De conclusie spreekt wanzelf: evenals het recht op vrije meningsuiting $1 \mathrm{~s}$ de informatievrijheld "elne der wichtlgsten Voraussetzungen der frefheltichen Demokratle" $(230)$, die de burger in stat stelt in democratische zin verantwoordelijk te kunnen handelen. Zelfs als het gaat om de individuele persoonlijkheidsontplooling staat het democratische nut ondubbelzinnig op de voorgrond in de overwegingen die an de informatievrijheld als subjectief recht gewijd zijn. Wat betekent namelijk de informatlevrijheld voor de persoon1fjkheldsontploailng: de burger herkent de wisselwerklng tussen de politlek en zijn elgen bestaan, zijn vritheld tot medeverantwoordelijkheld en kritiek groeit, enz. (231).

\subsubsection{De publieke opinie}

De schlechthin Konstituterende betekenis van de vrijheld van meningsuting voor het functioneren van de democratische orde bestat in het felt dat dit grondrecht de garantie vormt voor de vrije vorming van de publleke opinie. Daarmee is de publieke opinie tot het eigenlijke argument geworden in een reeks van uitspraken ten gunste van de vijheld van meningsulting. Wat Is prectes de raarde wan de publleke optule roor de democratie(232)? De publieke oplate, aldus het Bundesverfasoungsgemeht in het Volksbefragungarrest (233), speelt in de moderne democratie een beslissende rol. De publieke opinie is het resultad van de vrije openbare discussie over onderwerpen van algemeen belang. dle in de samenleving plaatsvindt en waraan de meest uiteenlopende matschappelljke krachten, inditiduen en groepen, deelnemen. $Z 1 j$ is een integratleproces (234), een gebeuren dat nlet tot de statssfeer behoort en 
van owerheldsingrijpen verschoond dient te blifven (235).

Wel is de publieke opinfle voor de staat relevant, want "dle ln der "öffentilchen Meinung" zum Ausdruck kommenden Tendenzen und Stellungnahmen $\mathrm{zu}$ politischen Fragen mag man als "Vorformung der polftischen W1lensbildung des Volkes" bezeichnen" $(236)$. Via deze "Vorformung" is de publieke oplnie met de politleke besluftvorming verbonden: "Der permanente Prozess der Mefnungs- und Willensblldung des volkes mündet ein in den fir dle Hillensbilidung im stat entscheldenden thet der Parlamentswahl" $1^{\prime \prime}(237)$. In het democrat emodel van het Bundesverfassungsgericht is de publieke opinie dus het krigtallisatiepunt van de in de samenleving levende opvattingen; alvorens deze wia verkiezingen in de besluitvorming op overheidsniveau tot gelding komen en tenslotte in de wil van de staat worden omgezet. Bovendlen belnvloedt de publieke oplnie tussen de verklezingen in de beslissingen van de statsorganen (238). Deze plaatsbepaling van de publieke opinie vertoont een treffende overeenkomst met de functie, die het Bunderverfabiungsgericht woor de polltieke partijen in de democratie zlet weggelegd(239), zij het dat vanwege die functie (art. 21 lid 1 GG: "Die Partelen wirken bel der polltischen Willensbildung des Volkes mit") de partijen tot constitutionele instituties zijn verheven, terwijl de vorming van de publieke oplnile slechts in het kader wan de vrljheid van meningsulting is gegarandeerd als ultoefening van een grondrecht $(240)$.

Cakjka (241) heeft erop gewezen dat de nauwe verbinding, die het Bundesverfassungsgericht tussen publieke oplnie en staatswil heeft gelegd, parallellen vertoont met het door Leibholz ontworpen model van de plebiscitalre democratie(242). Deze stelt, dat de parlementalre besluitvorming in de moderne denocratie in feite 1 s vervangen door partij-interne beslultvorming. In een functionerende partijendemocratie wordt de w11 van de partijmeerderheld in regering en parlement met de volonté générale geidentificeerd(243). Leibholz gaat ervan ult dat de bevolking zich met de actleve staatsburgers, de partifleden die dus de beslutten nemen, kunnen identificeren(24.4). Langs deze weg will hij de Ldentiflcatle tussen volk en stat redden. Leibhola neent echter volgens Caajka door deze redenering zlly toevlucht tot een fictie, want de partijleden representeren helemaal niet het volk en overlgens hebben de partifen niet eens de pretentle dat het zo zou zijn. Dearom bliffe alleen al de toesteming van de bevolking in de vorm van parlementsverklezingen noodzake$11 j k$. 
Voorzover de partijen nu te kort schleten in het tot stand brenged van een identiflcatle tussen volk en staat en de theorle van Leibholz dus doodloopt korat de publieke aplnie te hulp. De publieke opinle wult het tekort an identiflcatie, dat de partijen niet kunnen overbruggen, aan; zlf vervult een "plebisaltäre Ersatzfunktion" $(245)$. Vooral Ridder lijkt door deze gedachte gecharmeerd te zijn. Hij wil namelljk de pers als belangrijkste factor in de vorming van de publieke opinie zelfs een gelijke positie in het constitutioneel bestel geven als de partijen(246).

Het Bundesvenfassungsgericht gaat niet zover, maar wel wordt duldelijk dat het de sterke behoefte heeft aan een zo groot mogelijke democratische legitimatle van het overheldshandelen. Voorzover de vrijheid van meningsuiting daaraan bijdraagt, doordat dit grondrecht de vorming van de publieke opinte ibberhaupt mogelifk makt, verdient zij blijkbaar bijzondere erkennling.

\subsubsection{De twee-componententeer herontdekt}

Wellicht als reactie op de overaccentuering van de in art. 5 11d I GG gegarandeerde grondrechten als objectleve normen - wat het Bundesverfassungsgerioht het verwijt opleverde dat de vooropstelling van de subjectlefrechtelijke zijde in het Liith-arrest slechts een belijdenis met de tong was(247) - heeft de constitutlonele rechter recentelljk een ultspraak over de onroepvrifhedd aangegrepen om $z i j n$ in het Lütharrest neergelegde visle nog eens op te frissen. Deze hernieuwde stellingname moet worden gezlen tegen de achtergrond van een passage ult het Mitbestimmungarrest, warin exaan wordt herinnerd dat de in de grondwet opgenomen grondrechten in de eerste plaats individuele, mensen- en burgerrechten $z 1 j n$. De functle van de grondrechten als objectieve beginselen, die bestaat in de princlplële versterking van hun gelding, heeft haar wortels in deze primaire betekenis. Deze functie laat wich niet tot een geheel van abjectleve normen verzelfstandigen, waarin de oorspronkelijke en blifvende zin van de grondrechten op de achtergrond verdwifnt (248). In dit perspectief de volgende overweglng uft het aan de omroepvrijheld gew1 jd arrest:

"Indem Art. 5 Abs. 1 GG Melnungsäusserungs-, Me1nungsverbreltungs- und Informationsfrethelt als Menschenrechte gewährlefstet, sucht er zugleich diesen Prozess verfassungsrechtlich zu schutzen. Er begründet insowelt subjekt Ive Rechte; Im Zusammenhang damit normlert er die Meinungsfrelhelt als objektives Prinzip der Gesamtrechtsordnung, wobel. subjektiv- und objektivrechtliche Elemente einander bedingen und stuitzen"(249). 
Wat kan uit deze ultspraken worden afgeleld met betrekkIng tot de betekenis van de vel theid van wentngoutung? Voorop staat de functle van de vritheld van weningsulting als afweerecht tegenover de stat. In het licht van deze afweerfunctle moet de schlechthin Konstituiepende betekenls van de vrljheid van meningsulting worden gezien. De betekents van de vritheld van meningsulting voor het functioneren van de democratsche rechtsorde moet dus tegen de achtergrond van de af freer functle worden ultgelegd.

Daarnaast belnvioedt echter ook de functie van de vilheld van meningsulting als objectleve norm (de sehlechthin konetituienende betekenis) op har beurt de status van de vrijheld van menlngsuiting als subjectlef recht. Inzoverre heeft het feit, dat de vrljheid van meningsuiting voor het functioneren van de democratie onontbeer $11 \mathrm{jk}$ is een versterkende ultwer$\mathrm{klng}$ op de vrljheld van meningsulting als mensenrecht. Niet ultgesloten is evenwel, dat dit tweerichtingsverkeer niet alleen tot wederzijdse versterking leldt, maax dat het objectleve gehalte tevens inhoudeliflk vat krijgt op de vrljheid van meningsulting als afweerrecht, met andere woorden dat het afweergehalte stijgt of daalt met de bijdrage die een door art. 5 lid 1 GG beschermde renlngsulting feltelljk levert aan het functioneren van de democratische rechtsorde. ofschoon het karakter wan de vrijheld van meningsulting als mensenrecht voorop staat, $11 \mathrm{kkt}$ door de redenering van het Bundesverfassungsgemicht het gevar, dat de benadrukling van de objectlefrechtelijke zijde repercussles heeft op deze primalre betekenls, niet denkbee1dig.

\subsection{Het instituut vmije pems}

\subsubsection{Rechtepraak}

Het elgen gewicht van de vrifheld van mentngsuiting als constituante van de democratie kont tot volle ontplooling bij de perswrijheld. Als het grondrecht op vrltheld van meningsulting voor de vrlje democratie schlechthin konstituiemend 1s, dan moet dat net zo voor het grondrecht op persuritheld gelden, "well die Pressie zur polltischen Melnungsblldung entscheldend belträgt", aldus het Bundesverfaesungsgemicht in 2 in eerste an de persvrijheld gewijde aitspraak, het Nordrhein-Westfatenarrest van 1959(250). Omdat de pers naast radio en televisle het belangrifkste instrument bij de vorming van de publleke opinie is gentet de persuritheld volgens art. 5 itd 1 zin 2 GG 
specifieke grondrechtsbescherming (251). De perswrijheld wordt als een apart grondrecht beschouwd, dat naast de algemene garantle van de vrlyheld van meningsuiting staat, maar betekent tegelljk ook een meer, ondat zij een institutionele dimensle bevat.

"Dleses Grundrecht erschöpft sich nicht in der berelts in Art. 5 Abs. 1 Satz 1 GG erhaltenen Garantie der frelen Meinungsäusserung und -verbreitung mittels der Presse. Es ist mehr als nur eln Unterfall der Meinungsfrellheit, da daruber hinaus die institutlonelle Eigenständigkelt der Presse ron der Beschaffung der Information bis zur Verbreitung der Nachricht und der Meinung gewährlelstet ist" (252).

Deze Institutionele garantie van de pers als een van de dragers en verspreiders van de publleke oplnie in het belang van een vrije democratie (253) is een vast bestanddeel van de rechtspraak van het Bundesverfasaungsgericht geworden. Naast de institutionele zelfstandigheld van de pers(254) is ook de term finstitutionele vrijheid gebrulkt(25.5), totdat de rechter te beginnen met het spiegel-arrest tenslotte is gaan spreken van het "Instltut" Frele Presse""(256). Dit instituut omvat het gehele organisatorische en redactlonele gebeuren in het persbedrijf. Ook het advertentledeel wordt door de persvritheld beschermd(257). Uit de institutionele garantie van de persurijheid volgt bovendien de bescherming van de vertrouwelljkheld van de redact lewerkzaamheden(258).

Het Instituut vrije pers vertegenwoordigt de objectiefrechtelijke zljde van de persuritheid(259). Daarnaast kent de persvrijheid ook een subjectiefrechtelijke kant, hoewel deze aanvankelljk enlgszins verwarlloosd werd. In het Nordrhein-Westfalen-arrest stelde het Bundesverfassungsgericht nameli jk vast dat de institutionele garantie van de pers "das subjektive öffentliche Recht der Im Pressewesen tätigen Personen ein(-schllesst), thre Meinung in der thnen geeigneten Form ebenso frell und ungehindert zu ausseren wie feder andere Bürger" $(260)$, daarmee wel het subjectlefrechte11 jke karakter van de persuri theld degraderend tot een soort reflexrecht, dat ult de institutionele garantle wordt afgeleld. Deze opvatting heeft in de 11teratuur veel kritiek ultgelokt(261), omdat zis het karakter van de perswritheid als originair grondrecht verloren laat gaan. Zfj is verklaarbaar door de eenzijdige aandacht die het Bundesverfasaungagemicht aan de persvrijheld - in leder geval in de hem voorgelegde conflicten - heeft besteed in haar betekenis voor de democratie als factor in het proces van openbare meningsvorming(262) en warbij het er niet voor terugge- 
schrokken is te constateren dat de pers met het oog op hat functie In de democrat1sche stat openbare belangen behartigt(263). In het spiegel-arrest heeft het Bundeaverfasaunggemicht deze te eenz1jdige nadruk op de objectiefrechtelijke kant gecorrigeerd. Met de persurijheld wordt in de eerste plats - corresponderend met de systematische positle van art. 5 GG en hoe het tradltioneel wordt opgevat - een subjectlef grondrecht gegarandeerd, $21 \mathrm{f}$ het dat op dit subjectieve grondrecht slechts de in het perswezen werkzame personen en ondernemingen aanspraak kunnen maken (264). Hoewel dus een erkennlng van het karakter van de persvrijheld als orlginalr grondrecht, blijft dit grondrecht met het institut vrije pers eer eenheid wormen.

De beweegreden voor de versterking van het grondrecht op persuritheid met een institutionele garantle ter bescherming van het gehele persgebeuren is zonder thijfel dat de pers "Wesenselement des fretheitlichen Staates" 1s; "1nsbesondere 1 st elne frele, regelnassig erschelnende politische Presse für die moderne Demokratle unentbehrlich"(265). Zij is een bellangrifke factor blj de totstandkoming wan de publieke oplale, die op haar beurt, als het cesultat van een wrij gewoerde openbare discussie over zaken van algemeen belang en staatspolitleke betekenis, in de moderne democratle een besl1ssende rol speelt. Door har deelname aan dit proces geeft de pers aan de burger informatle door, dle hem in stat stelt, de meningen van anderen te leren kennen en te coetsen, zijn elgen standpunt te vinden, aan de openbare discusisie deel te nemen en politieke beslissingen te nemen.

De persvr1jheld vormt aldus in de moderne democratsche staat een wezenlijke vootwarde voor de vrije politlieke wilsvorming van het rolk(266). Het Bundesverfassungsgemicht spreekt in dit kader van een "öffent1lche Aufgabe der Presse", een openbare taak van de pers. Woor het eerst in het Schmid-arrest gebrulkt (267), wordt deze openbare taak in het Spiegel-arrest nader omschreven. Deze taak vervult de pers door haar bljdrage an de publleke oplnie die voor het functioneren van het democratische proces noodzakelijk $1 \mathrm{~s}:$ de pers houdt de discussle op gang door infarmatle te verstrekken, neent zelf stelling en werkt daardoor zelf als orlenterende kracht an de openbare discussie mee; in de pers articuleert de publieke oplnie zich (268). Mar meer nog. Tege11jkert1jd fungeert de pers als voorturende verbindingsschakel en continu controleorgam tussen het volk en $z 1 \mathrm{fm}$ gekozen vertegenwoordigers in parlement en regerlng; $z i j$ vat de meningen en elsen, de in de samenleving onophoudelijk opnlent 
worden gevormd, kritisch samen, bespreekt deze en brengt ze ter kennis van de relevante overheldsorganen, die op deze fifze hum beslissingen steeds kunnen toetsten an de in het volk levende opvattingen(269). Door mildel van een vrlje openbare discussie van burgers dle zlch van hun verantwordelljkheld bewast $z 1 \mathrm{fn}$, behoort de perswritheid bovendlen de verzakellyking van de politlek te dienen( 270 ).

Het walt op hoezeer aan de pers dezelfde taak in het statsleven wordt toegedacht als an de partijen. Nietterin - of misschien julst daaron - onthoudt het Bundesverfassungsgericht zich ervan de pers enige positie in het constitutiomele systeem te verlenen die wergelijkbaar zow zijn met die van de partijen.

De openbare taak van de pers is weliswaar zeer gewichtig, maar zlj kan niet van overheidswege worden vervuld. De pers moet van overheldsinvloed verschoond blijven en zich in het matschappelijke krachtenveld bewegen(271). De pers is privaatrechtelijk georganiseerd en werkt wolgens de principes van de vrije markt economle (272).

\subsubsection{De opvating wan Ridder}

In de erkenning van een openbare taak van de pers en de daaraan gekoppelde institutionele garantie van de persvrillyelld stat het Bundesverfassungsgerioht niet alleen. Deze benaderling mag $\mathbf{z l c h}$ tevens $1 \mathrm{n}$ de Westdultse 11teratur in een geweldige populariteit verheugen(273). Reeds dertig jaar lang ts het vraagstuk van de Institutionalisering van de pers, waarin zlch de gehele discussle over de functie van de grondrechten weersplegelt, een van de centrale en neest controversiele thema's van het constitutionele recht(274). Enkele bijdragen dateren reeds ult de tijd, voordat het Bundesverfassungsgemicht zich over de persvrljheld had geult (275), het grootste deel 1 s echter een reacthe op de ontdekking door het Bundebverfaseungegemiat van het instituut vrije pers. Hierdoor gestimuleerd hebben sommige voorstanders van de nleuwe leer zlch laten verlelden tot gewagde constructles, on te bewiljen dat de persurifheid geen grondrecht in de traditlonele zin zou zijn(276).

Een van de meest extreme positles, die nar het zich laat aanzlen op de conceptle van het Bundesuerfassungsgericht grote invloed heeft gehad, 16 in 1953 ontwikeld door Ridder(277). Hij toont zlch woorstander van de functionallsering van bepaalde grondrechten, waronder de persvrijheid (278). Deze wordt noodzakel1jk vanwege de verandering van de 190 eeuwse llberale representatieve democratie (die in Duitsiand 
overigens niet eens heeft bestaan) in een moderne plebiscitalre masadenocratie, warin de partijen een wezenl1jke col spelen(279). Maar de partijen zijn nlet de enlge factor in het proces van democratische 11 vornlng. Julst ondat partijen een relatief gering aantal leden hebben, die bovendlen nlet altijd in de gelegenheld verkeren vootdurend controle op hun bestuurders (die de meningen wormen) ult te oefenen. kent Ridde met het oog op de wllsworming van het volk aan de publieke oplnie een minstens even grote betekeris toe in het democratische proces als an de partijen( $(280)$. Het nedium bij ultstek voor de articulering van de publieke oplinie $\mathbb{1}$ s de politieke pers. Hij maakt daarom de persur 1 theld als "offentliche Melnungsfrelhelt" 108 van het individuele grondrecht op vilje menlngsulting(281). Blifte dit grondrecht zelf ook in Ridders ogen behoren tot de klassieke individuele vijheidarechten van de negatieve status(282), bedoeld woor privégebruik, de perswrifheld is in de moderne democratie geworden tot een politlek burgerrecht wan de actleve status(283) en heeft een institutioneel karakter angenomen(284). De betekenis van de pers voor de democratle verefst logischerwijs eenzelfde constitutionele garantie voor de pers als voor de partijen: "Art. 21 GG gibt mithin fü die Verfassung der Bundesrepublik die Haupt- und Grundnorm der institutionellen offentlichen Meinungsfreihelt des modermen Partelenstates ab, die bedenkenlos in den entsprechenden Versionen auf die politische Presse ... angewendet werden kann. Es wäe also etwa zu lesen: "Die politische Presse wirkt bet der politischen Melnungs- und W1llensbildung des Volkes mit. Die Gründung von politischen Zeltungen ist frel. Die lnnere Ordnung des Pressewesens muss demokratischen Grundsätzen entsprechen. Die Zeitumgen mussen iber die Herkunft ihrer Mittel öffent1lch Rechenschaft geben * " $(285)$. Met het klassieke grondrecht heeft deze garantie niets meer te maken, want ajj dient niet de vrlje ontplooiIng van de individuele persoonlijkheld(286). De perswrijheld hoort daarom niet meer thuls in de grondrechtencatalogus van de grondwet, wam ryan ook art. 5 11d 1 GG deel ultmaakt, mar in het organlsatorlsche deel, wartoe art. 21 GG behoort. De persvrijheid wordt slechts gegarandeerd vanwege de openbare tak van de politleke pers (287). De pers mag niet zijn gerlcht tegen de fretheitliche demokmatische Grundoranung of tegen de bestendigheid van de Bondsrepubllek(288). Vart de pers mag worden verwacht dat $z$ lif het gemeenschappelijk welaljn dient, dat tenslotte het doel van het: politieke meningsproces is: "Von der salus rei publi142 cae als dem Zielgut des polltischen Meinungsprozesses 
her erglbt slich, dass die Tellnehmer an diesem Prozess von thren ehrlichen und redlichen Vorstellungen voin erstrebten politischen gemeinen Besten gelenkt werden miüssen" (289).

De openbare taak van de pers is dus een democratische taak, onwille waarvan de pers tot institutie van constitutioneel kaliber verheven dient te worden.

omdat de geInstitutionaliseerde persvrijheid niets meer met art. $5 \mathrm{GG}$ te maken heeft, kan ook de Individuele meningsulting van een medewerker bij een persorgaan niet op de traditionele bescherming van de individuele vrijheid van meningsuiting gebaseerd $21 \mathrm{jn}$, maar slechts op de aan de andersgeaarde functie van de pers tegemoetkomende bescherming van de persvrijheid (290). Dat wil zeggen: "Die öfentliche Meinungsfreiheit verleiht kelne subjektive Freiheltsrechte; aber es kann sich auf ihren Rechtsreflex gegebenfalls berufer, wer am Melnungsprozess tellnimi"(291). Ridders gellijkstelling van partijen en pers en $z j j n$ verwerping van elk subjectief karakter van de perswrijheid loopt dus uit op het verlies van subjectleve rechtsaanspraken zelfs van hen, die in het persbedrijf werkzaam $z 1 j n(292)$.

Ridders gelifkstelling van de pers met de partijen is op vrijwel algemene afwijzing gestoten(293). De formele onhoudbaarheid van $z 1 j n$ constructle blijkt alleen al ult het systeem wan de grondwet, waar de persvrifheld een plaats heeft gekregen in de grondrechtencatalogus, terwij1 de positle van de partijen is neergelegd in het gedeelte van de grondwet, dat de staatsopbouw regelt( 294$)$. Het moge juist zijn dat belde een functie vervullen bij de polltieke wlisvorming van het volk en bij de vorming van de publieke oplnie, daarnaast zijn er ook op het matertële vlak verschillen aanwijsbaar. In tegenstelling tot de partijen, die op de verovering van de statsmacht ult $z \mathbb{1} j \mathrm{n}$, blijft de pers bulten de machtssfeer van de staat, haar activiteiten spelen $z 1 \mathrm{ch}$ in het matschappelifk veld af (295). Voor de pers bestaat niet het gebod zich te rlchten naar het algemeen welzijn(296). De medewerking van de partijen aan de vaststelling van de wil van het volk wordt gelegitimeerd door verklezingen, bif de pers is dat nlet het geval $(297)$. Bovendien beperkt de pers haar activitelten niet uitsluitend tot haar medewerking aan de totstandkoning van de publieke oplnie, maar vervult $z i j$ daarnaast nog een scala van andere functies, zoals informatleverstrekking en verstrooling, die door de consument misschien nog wel veell belangrijker worden gevonden(298). Deze plurfformiteit aan functies laat het niet toe de pers slechts vanult haar betekenis voor de democratie te beoordelen en te 
beschermen. De perswrifheld hoort in haar hele spectrum beschernd te worden, art. 5 GG bledt daarvoor de julste premise (299).

\subsubsection{De openbare taak van de perg}

Wa het eenstemige oordeel dat Ridderg voorstel te ver gat en dat de pers bulten de statssfeer moet wordem gehouden schelden de geesten zlch evenwel. De opvatting dat de pers een openbare taak te vervullen heeft, heeft namelifk wel grote resonanthe gevonden. Ondile darvat spreekt voor velen de institutionallsering van de persvrljheid als logische consequentie vanzelf, zij het in het kader van art. 5 GG en met wselende intensitell. Een minderheld heeft alch tegen Institutionalisering ultgesproken.

Wettelijke erkenning heeft de openbare taak van de pers gevonden in alle ult het midden van de zestiger jaren daterende ( 300$)$ perswetten van de afzonder lljke deelstaten(301), ultgezonderd die van de deelstaat Hessen. Riddews visie op de openbare tak als medewer$\mathrm{klng}$ aan de polltieke wlisvorming analoog aan die van de partifen wordt daarin niet gedeeld. Voorop staat ultdrukkel1jk: "Die Presse ist frel"(302), howel direct darop reeds volgt dat $21 j$ de freiheitliche demoknatische Gmudordnung dient(303), in teder geval behoort te dienen(304), ertoe beroepen is har te dienen(305) of kortweg plichten tegenover de vrije democratische rechtsorde heeft ( 306$)$.

Doet deze vermaning nog enigszlns aan Ridder denken, voor wat betreft de onschrijulng van de openbare taak Is toch een geheel andere rlchting ingeslagen(307). In Sleeswijk-Holstein vervult de pers een openbare taak "dadurch, dass sie Nachrlchten beschafft, vierbreitet, Stellung nimmt oder Kritlk libt", in Hamburg en MoordRljaland-Westfalen ook nog als zill "auf andere Welse an der Melnungsblldung teilnimmt" in de Hanzestad bovendien als ze "der Blldung dient". In Baden-Wurttemberg, Neder-Saksen, Rijnland-Palts en Saarland tenslotte luldt de formulering: "Die Presse erfült elne offentllche Aufgabe, wenn sle In Angelegenheiten von $\delta f f e n t 1$ chen Interesise Nachrichten beschafft und verbreltet, stellung nimmt oder af andere Weise an der Melnungsblidung mitwirkt". Deze laatste orschrijving bevat de reallstische erkenming, dat de pers niet altljd per se het openbar belang moet dienen, marr dat ze 1 lechts een openbare taak vervult, voorzover ze zlch met angelegenheden van openbaar belang bezlghoudt (308).

Aan deze in de perswetten gekozen benaderlng slult de heersende menling $1 \mathrm{n}$ de 11 teratur zlch ar. 
Weliswar laat de relatie tussen pers en stat c.q. samenleving de gemoederen niet met rust. Zo bekleedt de pers walgens Löffler een "von der Werfassung tbertragene Position Im Staat" $(309)$, en wervalt gij wolgens stamler "diejenfgen Funktonen, die die Presse Innerhalb und unittelbar fur das Verfassungsgefuge des Grundgesetzes als politischer Ordnung des Gemelnwesens hat" $(310)$; haar openbare taak vervul1en betekent openbare belangen behartlgen, aldus sohneidep (311). En al gat het anderen te ver de privebelangen van de pers geheel met de openbare belangen te ldentficeren, zij winden well dat hum "ganze Arbelt sich ausrichten soll am Gemeinwoh " $^{\prime \prime}(312)$. "Im Vorfeld der polit Ischen Entscheldung, in der Herstellung des 1eg1timlerenden Rontakts zwischen der politischen Lettung und dem Volk, in der von $1 \mathrm{hr}$ bewirkten Permanenz bffentlicher kritik und Kontrolle liegt die öffentliche Aufgabe der Presse im demokratischen staate. Die demokratische Verfassung lebt nich nur in den institutionellen Wilensentscheldungen von Wablerschaft und Staatseinrichtungen" (313).

Tegelijkertijd wordt er echter voor gewaarschumd ult deze beschrijoring een posttie roor de pers als consttutioneel organ af te leiden en wordt een benadering van de openbare taak van die pers beplett, die op de staat gefixeerd is. De openbare taak ligt niet in het averhelds- maar in het matschappelijke vlak(314), 1 s aldus geen normatleve, mar een soclologische inventarisati van de functie van de persvrl jheid in de democratie(315). In deze visie bestaat de openbare taak in de verwulling door de pers van har specifieke functie als communicatiemiddel (316), in het creeren wan de openbaarheid in de zin van algemene toegankelijkheid (317). De pers schept een communicatiemarkt door de publlcatie van felten en menlingen; $z 1 j$ heeft een vormende taak doordat zIj zelf deelneemt an de opinievorming; $z i j$ heeft een platformfunctie doordat $z i j$ medium van de publieke oplnie 1s; tenslotte heeft zij een controlerende functie, zij is "das krttische Gegenuber" (318). Door Löffler wordt zij met een beroep op Rousseau zelfs werde macht lin de stat genoend, die vanwege de vervlecht 1 ng van parlement en regerlng, als uitvioelsel van het partifensysteem, praktisch de enige lnstantie is, die nog werkelijk controle ap de overheld kan uftoefenen(319). De pers vornt zijns inzlens de noodzakell jke nleuwe matschappelijke dimensie in de trias politica.

\subsubsection{De inetitutionele ganantie}

\footnotetext{
"Institutionalisierung", "Institutionelle Garantle",
} 
"Instltutsgarante", "Einrichtungsgarantie" of "Inst1tut "Prelle Presse" "' (320) worden nodig geacht omdlat men aanneemt dat de persvrijheld als individueel grondrecht, dat deel van het algemene grondrecht op wrifheld van meningsulting uitmaakt, nlet voldoende bescherming bledt om haar hoge taak(321) te kunnen vervullen.

Opdat de pers haar functle voor de democratle daadwerkelljk kan vervullen acht men een (additionele) garantie onvermijdelijk, die voor sommlgen wel, voor anderen nlet uit het oorspronkelfjke grondrecht voortvloelt(322). De gemeenschappelijk drijfveer voor de erkenning van een institutionele garantie is de zorg on de tere blaem die democratle heet en de behoefte de positie van de grondrechten als integraal bestanddeel en kenmerk julst van die democratische orde te versterken. De grondrechten zijn niet alleen maar een Magna Charta van urifheden en rechten van de individu tegenover de staat. Tegenover de individueelrechtelifke zljde der grondrechten als afweerrechten staat een "positive Gestaltungsfunktion des Staats"(323). Met name Stanmiers enthouslasme is alet te remmen. H1j ziet de politieke grondrechten ultsluitend als een garantie voor de deelmame van de individu aan het democratische proces. Zif zijn nlet omwille van de Individu, maar omwille van de "Funktionsfähigkeit der frelheltlichen Demokratile gewährleistet - wobel der ind ividualrechtliche gegenuber dem funktionalen Aspekt zurücktritt"(324). Dat valt vooral bif de persvrl jheld op. Uit het felt dat zonder persurijheld geen democratie mogelijk is en dat de pers een speciflek af te perken tastitutle zou zljn, die als zodanig een wezen$\mathbb{1 i j k}$ bestanddeel van de grondwet als politleke orde 1s(325), leidt hij af dat de persvrijheid op grond van haar betekenis uitsluitend instrumenteel karakter heeft ten behoeve van een "Dienstleistung an der Al1gemeinheit"(326). De persurfjheld is slechts omwille van de openbare taak van de pers gegarandeerd(327). De geschiedenis van de perswrifheid bewijst volgens Stamiler dat de karakterisering van de persvrijheld als algemeen mensenrecht pure flctle is(328). Een dergelijke verstrengeling van de persvrijheld met de openbare tak van de pers leldt bijna automatisch tot de vraag, wat de jurldische consequentles $z 1$ jn van het ntet naar behoren vervullen van die taak. Hlerover zwi jgt stammler echter.

De institutionalisering van de persvrifheid, door stammier tot het ulterste doorgevoerd, wordt volgens de voorstanders van een institutionele garantie bevestigd door de tekst van art. 5 lid 1 GG, waaruit zou blijken dat de persuritheid een zelfstandlg, van de 
klassleke individuele vrl jheld van meningsulting afgeschelden grondrecht is: de persuritheld is in de tweede zin van dit artikel een speciale garantle waard.

Met deze garantie wordt bedoeld: "dle bestehende Institution Presse ... Eine der Meinungsfrethelt glelchartige Formulierung müste lauten: Jeder hat das Recht, seine Meinung und Tatsachen durch die Presse ... bekanntzumachen" $(329)$. Nu dit er niet staat, kan alleen maar een institutionele garantle bedoeld $z 1 \mathrm{jn}$. overigens nemen de meesten een minder extreen standpunt dan Stammier in. Zij erkennen dat het grondrecht zowel een individueelrechtelijk als een institutioneel. element bevat. De institutionele garantie heeft vanuit dit gezlichtspunt vooral een versterkende functie(330). Binnen de groep, die erkent dat de persurijheid op twee pijlers rust zijn twee richtingen te onderscheiden.

2o wordt er enerzifds uitgegaan dat de persvrijheld weliswaar een indlvidueel grondrecht in klassleke zin 1s, een afweerrecht van de individuele gebruiker van de persvrifheld tegenover de staat, maar dat zich los daarvan een institutionele garantie heeft ontwikkeld (331), die accentueert dat de persurijheid een op democratische participatie gericht grondrecht is, een recht van de individu als staatsburger, dat hem de gelegenheld geeft an het polftieke leven deel te nemen(332). Een natuurrechtelijke wortel heeft deze garantie niet(333): deze objectieve zljde van de persvrljheld is met de democratie meegegroeld en in de loop van de tijd steeds meer op de voorgrond getreden. Een andere opvatting is, dat de garantie geen zelfstandig karakter heeft, maar als deel van het individuele recht en daruit voortsprultend moet worden ultgelegd en ingevuld in de wetenschap dat de persvrifheid als onderdeel van de algemene garantie op vrijheid van meningsulting in de eerste platis en exclusief een individueel recht is(334). In deze visie betekent de garantle vooral dat nlet alleen $z i j$, die In enge zin van de persvrljheld gebrulk maken zich op dit grondrecht kunnen beroepen, maar allen die in het persbedrijf als soclaal-economische organisatie werkzaam zijn.

De latste opvatting loopt dus uit op een uftbrelding wan de werkingssfeer van dit grondrecht met behoud van zijn afweerkarakter. Beschouwt men darentegen de Institutionele garantle als nast het oorspronkelijk gronarecht bestaand en niet erult voortvloellend, dan heeft dat als gevolg dat de bescherning van hen, die in het persbedrijf werken, niet zozeer ult het individuele grondrecht voortvloeit, maar uit de institutie zelf. Daardoor is de persurifheid in feite niet meer 
dan een reflexrecht van de institutionele garantie en verllest har karakter als ind wdueel recht. Die tendens kan bl Ridolep reeds worden wargenomen en aok het Bundesverforsungsericht deelt in het WominheinWestalen-arrest deze consequentile (335).

op deze manter kan de individu zlich slechts dan op de perswr theld beroepen als hij in het persbedrijf aerkt (336). Defent lemand wan buiten het persbedrijf actvitelten uft, die in de ogen van de poorstanders wart een ultslutend Ind widueelrechtil fke benader Ingsw yze van de perswritheld wel degelijk als het gebrulkaiken van de vrijheld van drukpers worden gezlen, dan is dat volgens de redenering wan hen die de institutionele garantle beamen kennelijk geen ultoefening van de persvelfheld, mar van de individuele vrijheid van menlngsulting, genoend in de eerste zin wan art. 5 lid $1 G G$, zodat $z i j$ ook geen aanspraak kunnen maken op de privileges, die met de perswrifheid als institutionele garantle verbonden zijn. Het mogelijke gevolg liat zich voorspellen: de sanctionering van bestaande structuren in de perswereld en de discriminatie vam Indivduelle activitelten op dit gebied.

Het $1 \mathrm{~s}$ in deze benaderlng bovendien verleidelijk nog verder te gaan en te stipuleren dat degenen die in het persbedrijf werkaam z1jn zich op de persviljheld alleen kumnen becoepen, als zif hun activitelten verrlchten in de zla van de garantle, dat wil zeggen, wet het oog op de openbare taak (337). De persurijheld, aljnde een reflexrecht, zou dan doelgericht raken en nilet meer ter vrije dispositie stan(338).

De onvermijdelijkheld van de institutionalisering van de perswrijheld ten behoeve van de openbare taak wan de pers moet blljken utt de volgende argumenten. Het lad widuele grondrecht op vrijheld van mentngsultling zou slechts meningsuitingen beschermen, terwill door de institutionele garantie van de persuritheld tevens felten, verslagen, advertenties etc. bescherming genleten (339).

Pas dankzif de garantle wordt nlet degene die de menimg ult, matr het gehele persbedrljf "von der redaltomellen und technlschen Herstellung und Herausgabe bls zum Vertrleb, zur Beförderung und Verbreitung des Presseerzeugnisises" beschernd ( 340 ).

Pas de garante $20 u$ pas bepaalde privileges voor de pers mogelijk maken, die zij nodig heeft om haar openbare taak te vetvullen $(341)$.

Een belangrijk argument van de woorstanders van de Institutionele opvatting ls tenslotte dat hierdoor problemen kunnen worden opgelost, wartegenover men 148 anders machteloos zou staan, zoals de In de Bondsrepu- 
bllek vanouds brandende kwestle wan de persconcentratie (de Springer-pers) (342).

\subsubsection{Kmitiek}

Hoewel de institutionele opvatting in verbinding met de openbare taak van de pers grote weerklank in de literatuur heeft gevonden wordt $z 1 j$ nlet door ledereen gedeeld (343). Afgewezen wordt het gebruik van de term openbare taak, ondat het ongerechtvaardigde verwachtingen zou wekken en maar al te gemakkel1jk de persvrijheld "vom Recht uber die Institution zur pflicht" (344) of tot een taakgebonden privilege(345) zou kunnen omturnen, warult plichten zouden kunnen worden geInterpreteerd(346). Hoe de institutile daarbif de nodige hulp verleent toont Gross. Zij constateert dat ult de openbare taak zelf wellswar geen plichten kunnen worden afgeleid, maar dat wel plichten voortvloelen ult de institutie (die let wel op haar beurt is gegarandeerd vanwege de openbare taak)(347). De plicht, die zij aanneemt, om de lezer over gebeurtenissen te informeren is daarvan wel de origineelste. De critici van de institutionele opvatting wifzen erop dat alleen al de tekst van art. 5 GG (voorzover relevant: "Die Pressefreiheit und ... werden gewährlelstet") een institutionalisering niet toelaat (348). De persvrijheid heeft hier geen zelfstandige betekenis, maar moet worden gezien als een onderdeel van de algemene garantle op vrifheid van meningsulting met dien verstande dat $21 \mathrm{f}$ natuurlijk daarin van oudsher een dominante positie inneemt en meer hulpmiddelen vergt. Dat en de recente ervaringen met de onderdrukking van de perswrijheid in het Derde Rijk is voor de grondwetgever aanleiding geweest de persurijheld mog eens extra te noemen. Maar dat is niet meer dan een redactionele kwestie(349). Een en ander zou blijken uit de formulering van art. $18 \mathrm{GG}$. In dit verwerkingsartikel wordt gesproken van "die Fretheit der Melnungsäusserung, insbesondere die Pressefreihelt"(350). Tegen een zelfstandige betekenis van de persvrijheld spreekt tenslotte ook het felt, dat de uitdrukking persurijheid in de loop van de tijd meestal gebruikt is in de zin van een aan iedereen gegarandeerd recht, om zijn mening door middel van de drukpers te ulten en niets meer betekende dan precies dat(351). Nhet is in te zien, waarom plotseling in art. 5 lld 1 GG niet meer de individu zou $z 1 \mathrm{jn}$ aangesproken, maar alleen het Instituut vrije pers. Deze argumenten lefiden volgens de tegenstanders van de institutionalisering tot de conclusie dat de persvritheid slechts een uitdrukkfngswijze van de viljheld van menlngsulting is en dat 
de speclale vermelding in de tweede zin van art. 5 lld 1 GG te verklaren $1 \mathrm{~s}$ ut $z 1 j \mathrm{n}$ ontstansgeschiedenls en de bijzondere arbeldsomstandigheden van de pers. onbestreden blijft bil alle kritlek ook bilj de tegenstanders de bijzondere betekenls van de persvr 1 theld voot de democratie (352), matr er wordt op gewezen, dat deze objectieve zljde de resultante van het grondrecht is. Zij heeft geen zelfstandig gewicht, maar is slecht een aspect van het subjectieve recht. Een Instltutionele garantie $1 \mathrm{~s}$ nlet nodig ondat en vilje discusslerulmte in de democratie ook zo tot stand kont door de massale wijze warop het recht dagel1yks wordt gebrulkt en warult spontaan een continue openbare ultisiseling van menlngen ontstat. De subjectieve rechten hebben, met andere woorden, hoewel $z 1$ geen objectleve normen zijn, wel degelljk eren objectieve rex 1 rg (353): "Indem das Individuum sein Recht ausubt, dlent es glelchzeit1g der Demokratie" (354). Deze functhe wordt al woldoende gewaarborgd door de bescherming die de grondrechten in hun algemeenheld in het consttutionele stelsel genleten door art. 19 lid 2 en art. $7911 d 3 \operatorname{GG}(355)$.

De afwifzing van de institutionele opvatting leldt tot de concluste, dat zowel zif die van hun indlviduele vrljheld van menlmgsulting als zij die van de persvrltheid gebrulk maken in princlpe gelijk te behandelen zijn. Beiden hebben dezelfde rechten en dezelfde plichten. Voorzover de bijzondere arbeidwomstandigheden van de pers (1n neutrale ztn bedoeld) dit vere1sen, is een verschillende behandeling evenwel op zijn plaats. Zo $1 \mathrm{~s}$ er or organisator 1 sche redenen een verhoogde behoefte aan bescherming en kunnen aan de beoefenars van de persvril theid bijwoorbeeld hogere zorgvuldigheldselsen worden gesteld vanwege de grotere potentielle gevaren die door de massalltelt van de uitingen voor anderen kunnen ontstaan, maar deze kunnen ook zonder een lnstitutionele garantie worden verwezeniljkt (3.56).

Omdat eventuele speciale regelingen verband houden met de elgenardigheden van het persgebeuren, die bif de ind Ividuele vrl theid van mentingsulting nu eenmal nlet bestaan (zodat ook niets te beschermen valt) kan moellijk van discriminatie worden gesproken, aldus degenen de de Institutonele garantle fijzen(357).

3.5.6. De stezthgrame van het Bundesverfassungsgemicht in het liwht van de verschiliende stromingen

B1j een vergelijking van de uitspraken van het Bundegverfasaungsgemiat met de verschlliende opvattingen 150 die hierboven $z 1 \mathrm{fn}$ geInventariseerd kunnen $1 \mathrm{j}$ vast- 
stellen dat de constitutionele rechter een middenweg heeft gezocht tussen volledige institutionalisering en volledige subjectivering van de perswritheid. De vroege ultspraken aljn niet glashelder, maar doen vermoeden dat het Bundesverfassungsgerioht in de persvrifheld zowel een subjectief recht als een institutionele garantle waarneemt. De passage in het Nordihein-Weatfaten-arrest, dat de persvrijheid mếr is dan slechts een onderdeel van de vrifheld van meningsulting(358), moet dan wel zo worden gelezen dat daarmee niet bedoeld wordt dat ze dus helemaal geen onderdeel van de vrijheid van meningsuiting is, maar juist dat ge daar wellswaar enerzljds deel van uitmaakt, maar anderzljds tegel1jkert1jd een meer bevat. Het Bundesvenfasaungsgement beperkt zlch vervolgens in dit arrest tot dat meer - de institutionele zelfstandigheid - en schept verwarting door vast te stellen dat daarult als een reflexrecht een subjectlef recht voor de in het persbedrijf werkende personen voortvloelt. Hierdoor wordt de Indruk gewekt dat de persurl jheid uitsluitend als een institutionele garantie is te beschouwen, maar gezien het laslaten van de reflex-constructie in het Spiegel-arrest, waar de persivifheid ultdrukkelijk eerst als subjectlef recht en pas in de tweede plats als Instituut wordt omschreven(359), heeft het Bundesverfasaungagericht dat kennelifk niet bedoeld. Voor een deel blijft de onduidelijkheld bestaan, doordat het subjectleve recht in het Spiegei-arrest alleen aan een beperkte personenkring gegarandeerd wordt, nare$11 j k$ an hen die in het persbedrijf werken(360). Blijkbaar denkt het Bundesverfassungsgemieht bif het begrip persvrijheid niet aan een in de hulskamer geInstalleerde stencilmachine. De nadruk blijgt liggen op de institutionele, de objectlefrechtelijke zijde.

ook in latere arresten is de aandacht eenzljdig gerlcht gebleven op de Institutionele zljde van de persvrifheid. Wel heeft het Bundesverfassungsgemicht in entge recente arresten gepoogd de eenzijdige objectiefrechtelifke beklemtoning van de persvritheid enfigszins te corrigeren(361) en de persuritheld omschreven "sowohl als Grundrecht des Elnzelnen wie als Garantle des Instituts "Frele Presse" (362). Een beperking van het subjectieve recht tot de in het persbedrijf werkzame personen komt nlet meer voor. Men zou deze arresten kunnen zien als de bevestiging dat het Bundeaverfassungsgericht is overgestapt naar een meer gematigde institutionele opvatting, die ervan ultgat dat de instltutionele garantie van de persvrijheid utt het individuele grondrecht voortkomt en $z i c h$ in haar effect eligenlijk vooral beperkt tot het beschermen van de organfsatorlsche kant(363). 
Lichten wif de visle van het Bundesverfassungegerident op de openbare taak door, dan is de tendens te bespenren van het hinken op twee gedachten. Enerzijds wordt ferm bevestigd dat de pers vrij is en zich uitslutend in het vrije veld der maatschappelifke krachten beweegt, en wordt er, woorzover een openbare taak ontward wordt, keur $1 \mathrm{~g}$ blj de in de literatuur clrculerende soclologische benadering aangeknoopt, anderzljds verslikt het Bundeaverfassungsgemicht $z$ ich in dezelfde galop an hoge democratische idealen, waarblj de pers prompt als verbindingsschakel en controleorgaan en wat dies meer $z 1 \mathrm{f}$ in het parlementaire leven wordt gevierd en van haar wordt gevergd maatstaf van de in het volk daadwerkelijk vertegenwoordigde opvattingen te kunnen zijn(364). Kritisch wordt het als de persvrijheld, zoals in het splegel-arrest geschledde, in dienst wordt gesteld van het "Bestand der Bundesrepubllk Deutschland, den es $z u$ schützen und zu erhalten gilt" (365), maar in latere arresten heeft het Bundesvenfassungsgericht zlch weer bescheidener over de openbare taak van de pers uftgelaten(366).

\subsubsection{Praktibche consequenties van de institutionele garantie}

Wat zljn nu de praktische consequenties van het aannemen van een institutionele garantie van de persvrijheid onwlle van de openbare taak van de pers?

\subsubsection{De omvang van de gamantie}

Allereerst dringt de vraag zich op naar de gevolgen voor de omvang van de garantie van de persurt jheld. In von Mangoldt-Klein wordt een eng persbegrip gehuldigd, warin inhoudelf jke criterla de ruimte krijgen (367). Deze opvatting rekent tot het begrip pers a1leen die persprodukten, die het openbare belang dienen en een openbare functie vervullen. "Presse in diesen Sinne 1st nur die Veröffentlichung polltisch-kulturell-weltanschalicher Nachrichten und Stellungnahmen sowle die sonstige sachliche Berichterstattung in Zeitungen und Zeltschriften"( 368$)$. Het Bundesverfabaungagerioht heeft zich van elke benaderlng, dle deze kant op gaat, gedistantieerd. Het begr1p pers moet breed en formeel worden ultgelegd. Het kan niet van een waardering van het drukwerk afhankelijk worden gemaakt. De persvitheid is ntet tot de serleuze pers beperkt (369). Ook de sensatiepers wordt door het grondrecht beschermd. Het Bundesverfassungsgericht hanteert dus het rulme persbegrlp, dat ook in de perswetten van de deelstaten wordt aangehangen( 370 ). Beschermd worden 152 alle geschriften, geluidsbanden, uttbeldingen met en 
zonder schrlft en muzlkale composities met tekst of rerklarlng, dle door middel van de drukpers of andere roor massapraductle geschikte vermenlguvidiglngsmethoden $z i j n$ vervaardlgd en voor verbrelding bestemd $z i j n$. De onvang ran de garantie wordt nlet door de inhoud van het persproduct, maar uitsluitend door de vervaar AgIngsmethode bepaald. Met Inachtneming van de andere grondrechten van de context, warin de persvi ijheld in art. 5 11d 1 GG gegarandeerd 1 , deflaleert Loffler de persvifheid dan ook als het aan een leder ter beschlkking staande, met individueelrechtelljke en $1 \mathrm{n}-$ sititutionele garantie ultgeruste grondrecht, on ongehinderd persprodukten van ledere aard te vervaludigen en te verbrelden, zich daarin in woord, schrift en beeld vrif te uiten, zulke producten te ontvangen en zich er ult te informeren alsmede ongestoord alle activiteiten te verrichten, die deze doeluen dienen (371).

Dat het begrip pers ruim mot worden uitgelegd betekent voor het Bundesverfassungsgemicht overlgens niet dat leder persorgaan altijd en voor elke inhoud van zijn uitlngen op gelijke wijze zou worden beschermo:

"Be1 der Abwägung zwischen der Pressefrethett und anderen verfassungsrechtlich geschitzten Rechtsgiter kann bericksichtigt werden, ob die Presse im konkreten Fall elne Angelegenhelt von offentlichem Interesse ernsthaft und sachbezogen erörtert, damit den Informationsanspruch des Publikums erfullt und zur Blldung der öffentlichen Melnung belträgt oder ob sie lediglich das Bedurfnis efner mehr oder rinder breiten Leserschicht nach oberflachlicher Unterhaltung befrledigt" ( 372$)$.

\subsubsection{De privileges van de pera}

Uit de garantie van het instituut vrije pers volgt: "Der staat ist - unabhängig von subjektiven Berechtigungen Elnzelner - verpfilchtet, In selner Rechtsordnung tiberal1, wo der Geltungsberelch elner Norm die Presse berihrt, dem Postulat ihrer Freihelt Rechnung zu tragen", aldus het Bundesverfassungegericht in het Splegel-arrest(373). Deze plicht heeft de wolgende beteken 1 .

\subsubsection{Ongantisatievmigheid}

De oprlchting van persorganen is vrij. Een toelatiagsvergunning of een 11 centie is nlet nodig( 374$)$. Er bestart vrlje toegang tot de persberoepen, dat wil zeggen dat een leder zonder vergunning persactivitelten kan wloefenen(375). De persvrljheld brengt met: zich mee dat beroepsorganisatles met verpllicht $11 \mathrm{~d}-$ matschap en bekleed met de beyoegdheld tot het nemen 
van disclplinalre maatregeten niet zijn toegestaan (376). Dit verbod is expliclet vastgelegd als reactle op de exwaringen, die men tijdens het Derde Rijk net de Retohspreseekcumer had opgedaan(377). Er bestaan echter een antal beropsorganisaties, die een 1ldmaatschap op basis van wrijwilligheid kenten(378). Vertegenvoordigers van deze organisaties wormen tezamen de twintig leden van de Deutsche Pressemat (voor de helft journal1sten-, woor de helft ultgeversvertegenwoord1gers), het zelfcontrole-orgaan wan de Westduitse schrijuende pers. Deze raad moet waken over de persvrljheid en over het aanzlen van de pers. De raad kent een klachtencommissie, die klachten behandelt tegen persorganen, die door ledereen kunnen worden 1ngediend. Deze comisste kan vermaningen uitdelen, heeft echter geen juridische sanctiemogelijkheden ter beschikking. In 1973 heeft de Pressent een Pressekodex opgesteld, warin het respect voor de warheid en de warachtige informering van de openbarheld als het hoogste gebod van de pers worden genoemd(379).

\subsubsection{Het mecht op informatie}

Owerheidsinstellingen zijn verplicht tot het verstrekken aan de pers van informatle(380). Deze aflelding van de Informatieplicht door het Bundesverasaungagemont ult de persil theld is in de literatur omstreden(381). Voor Ricker(382) volgt deze pllcht reeds uit de samenhang, die bestaat tussen de aanspraak op 1nformatie van de pers en de individuele informatievijheld uit openbaar toegankelijke bronnen (art. 5 11d I eerstie zin GG). Deze laatste zou ontoelatibarar worden ultgehold als de pers, die toch verult de belangrijkste informatiebron voor de individu is, geen aanspraak op 1 informatle zou kunnen doen gelden.

In leder geval roepen de perswetten van de deelstaten een informatleplicht voor overheldsinstellingen in thet leven(383). Informatie kan echter gewelgerd worden, voorzover een zorgvuldige rechtspleging dit verelst, gehelmhoudingsvoorschriften dit verbleden of een ander openbaar of prlwat belang, dat zwarder weegt, zou worden geschonden( 384$)$. In geval van conflict kan nakoning van de informatieplicht via een administratleve procedure worden afgedwongen( 385 ).

\subsubsection{De plumifomiteit van de pers}

Gezien de institutionele garantie "liesse sich etwa auch an elne PIIcht des states denken, Gefahren abzuwehren, die elnew Pressewesen aus der Bildung von Meinungsmonopolen erwachsen könnten" "aldus het Bundesverfasingsgemicht in het Spieget-arrest (386). De 15.4 overheid heeft dus de taak voor een systeem wan con- 
currerende massacommunicatieniddelen zorg te dragen en monopoliseringstendenzen te bestrijden als de pluriformitelt van meningen in gevaar komt( 387 ).

Mis anwalling op de algemene kartelwet van $1957(388)$, die een horizontaal en verticaal kartelverbod bevat alsmede een controle op fusies en een discriminateverbod - welke voorschriften ook voor de pers gelden is In 1976 een specilale regeling in werking getreden ten behoeve van de controle op fusles in het perswezen (389). Volgens die wet geldt voor fusles tussen persondernemingen reeds een aanmeldingsplicht en overeenkonstge controle als het gevolg een overheersende narktpositie 15 , Indien de gezamenlijke omzet de 25 mijoen DM overschrijdt in plates van de gebruikelljke 500 miljoen DM. Toesteming voor fusle is nodig als tenminste twee wan de betrokken ondernemingen een jaaromzet van 50 miljoen hebben (de grens voor andere ondernemingen ligt bij Een mil jard DM) (390).

Bezwaren wanult de Bondsraad tegen de geschetste rege11ng, dat het hier een speciale tegen de pers gerlchte wet betrof, het voorschrift nlet an de formele criterla voar algenene weten voldeed en dus geen toelaatbare beperking in de zin van art. 5 11d 2 GG was, werden door de regering en Bondsdag afgewezen met het argument dat de wet de vrijheld van de pers niet beperkte, maar juist ter bescherming van de pers diende en dat de criterla van art. 5 11d 2 GG dus niet wan toepassing waren(391).

Her is de institutionele benadering gevolgd. Men gaat er kennelijk wan ult, dat de institutionelle garantie nodig is on speciale wetgeving op dit punt te legitimeren(392). Een speciale, tegen de persconcentratie gerlchte wet, zou immers lnderdaad geen algemene wet in de zin van art. 5 11d $2 \mathrm{GG}$ kunnen zijn, omdat zo'n wet uftsluitend met het $00 \mathrm{~g}$ op de pers zow worden ultgevaardigd(393). Toetsing aan de criterla van art. $511 d 2$ GG kan in dit geval worden orzeild door in een antlconcentratiewet geen beperking, maar een nadere inhoudelijke vormgeving van de persvritheld als ultvloeisel van de institutionele garantie te zlen(394).

Valgens Herzog is het echter niet nodig een interventlebevoegdheid van de overheld te baseren op de institutionele garantie, omdat een anticoncentratlewet de toets van art. 5 lid 2 GG wel degelljk kan doorstaan, tamelifk door een beroep te doen op het la art. 20 GG nergelegde democratische principe, wartoe in zijn ogen ook een pluriforme pers behoort vanwege hav rol in het proces van meningsworming en har betekenis voor de democratie(395). De redenering is dan als volgt. Betreft het een kartel woorschrift, dat niet ult zorg on puur economisch machtsmisbrulk, mar uit zorg 
on butengewone publlcitaire invloed van mediaglganten 1s Ingegeven, dan is nu eenmal sprake van een voorschrlft dat de persvijheid beperkt en an de criterla van art. 5 lid 2 GG getoetst moet worden. De horde wan het formele criterium kan worden genomen, omdat het voorschrift zlch nlet tegen een bepalde rening of een mening als zodanig richt, max tegen economische structuren die de pluriformitelt en daarom de democratie bedrelgen. Toetsing aan het materiele criterlum kan de antlconcentratlewet verwolgens ook doorstaan, want b11jkt bij de afweglng werkelijk gevaar te bestaan dat het vrije maatschappelijke proces wan oplnievorming door menlngsionopolles vervalst wordt, dan 1s het voorschrift, gemeten aan het materlele criterlum, een terechte beperking: "es verhllft dem höherwertigen Rechtsgut der Demokratle zar Geltung"(396); het dient "dem Schitz elmes Gemelnschaftswerts (neergelegd In art. $20 \mathrm{GG})$, der gegeniber der Betätigung der Metnungsfreihett den Votrang hat" ( 397 ).

De door Heraog bepleite legitimering van de antipersconcentratiewetgeving door middel van het democrat $1-$ sche principe in plaats wan door de institutionele garantie heeft tot voordeel dat de mogelijkheld van een rechterlijke toetsing wolgens de methode van het Lith-arrest b11.jet bestaan $(398)$.

Zoals de Instltutionele garantie de staat verplicht tot het verhinderen van monopolles van meningen, zo moet ter bescherming van het instituut vrije pers ook de onathankelljkheld van persorganen tegenover interventle van economisch machtlge groeperingen met onevenredige middelen in de produktle en de verbrelding van petsproducten worden gewarborgd. Hoewe1 het Bundesverfassungsgericht in het Lith-arrest in principe had vastgesteld, dat een boycot uit ideologische motleven anvaardbar kan aljn, heeft het later, in het $B$ tinkfilem-arrest, bepaald dat de pers, onwile van de bijdrage die zil aan de mentngsvorming levert, moet worden beschernd tegenover pogingen, om de concurrente van meningen door ecomouische pressiemiddelen ut te schakelen (399). Een boycotoproep die gepard gaat met econonlsche druk is dus ontoelaatbaar.

Een speclale belagting voor de pers is niet geoorloofd (400), mar wel is de verlening van belastinguoordelen ter behoud en versterking van de plurifornttelt van de pers toegestan $(401)$.

\subsubsection{Het vemehoningereoht van joumalisten}

Als consequentle van het felt dat tot de institutione- 
Anformatle behoort(402) en dat deze alleen maar kan functioneren als informatlebromen rijkelljk vloelen, is een zekere bescherwing van de vertrouwensialate tussen pers en prive-1aformanten noodzakel1jk. De Informant moet er van op aan kunnen, dat het redactlegehelin wrat geêrbledigd(403). Daaros behoort tot de Institutlonele garantie ook bet verschomingsrecht van hen, die in het persbedrljf werkman zijn, op grond warvan $z i j$ onder bepaalde orstandigheden kumen weigeren getulgenis af te leggen over de 1 nhoud van mededellngen en de persoon van de informant(404).

Het verschoningsrecht is wettelijk geregeld op federaal niveau, nadat het Bundesverafasungsgericht in 1974 de strafprocessuele regeling van het verschoningsrecht, die was opgenomen in de uit het midden van de jaren zestig daterende persweten van de deelstaten, voor nletig had verklaard, ondat de deelstaten. hitermee hum wetgevende competente hadden overschreden (398). Sinds 1975 kunnen zich nu zowel in een strafa1s civielrechtelijke procedure op het verschonlngsrecht beroepen: "Personen, die bel der Vorbereltung, Herstellung oder Verbretiung won perlodischen Druckwerken oder Rundfunksendungen berufsuäsig mitwirken oder mitgewilkt haben, Uber die Person des Verfassers, Einsenders oder Gewăhrmanns von Befträgen und Interlagen sowle uber die thnen Im Hinblick auf 1hre Tat thkeit gemachten Mitteilungen, sowelt es sich um Belträge, Unterlagen und Mittellungen für den redaktionellen Teil handelt" (406).

Het verschoningsrecht heeft betrekking op periodleke drukwerken, niet op boeken of andere geschriften. Niet slechts personen, die meewerken of hebben meegewerkt aan de vervaardiging en de verbrelding, kunnen zlch er op beroepen, maar ook $z 1 j$ die bij de voorberelding. betrokken zijn. Ook de drukker heeft dus eem verschoningsiecht. Voor alle categorieün geldt, dat de medewerking beroepsmatig dient te geschieden, dat wil. zeggen met de bedoeling ult die medewerking door herhaalde uitoefening een voortdurende of in leder geval. steeds terugkerende bezigheid te maken(407).

Getuigen 1 mag worden gewelgerd over de person van de auteur, de inzender of de informant, en over de intioul van de mededeling, mar dit laatste slechts voorzover het byjdragen voor het redactionele deel war het perlodiek betreft. Het verschoningsrecht geldt dus in beginsel niet voor de lnhoud van bijdragen aan het advertentiedeel, aldus de tekst van de wet, mar nadat het Bundesvemfasungsgemicht reeds in het sudkurier arrest had bepaald dat het advertentledeel eveneens door de perswitheid beschernd wordt(408), heeft het 1t 1983 daarult de consequentie getrokken, dat het 
verschoningsrecht ook op het advertentledeel betrekking heeft, met name op advertenties onder numer, als deze een bijdrage leveren aan de vorming van de publieke opinle(409). Het staat aan de gerechtigde zelf vrij te bepalen of $h i j$ een beroep op het verschoningsrecht wil doen. Het verschonlngsrecht ontslat hern niet wan de plicht aangifte te doen als hil kennis neemt van te voorberelding van een zwaar delict(410). in verbinding met het verschoningsrecht stat het verbod wan inbeslagname van geschriften en dergelijke, die $z$ ich in bewaring bevinden van hen, die zlch op het verschoningsrecht mogen beroepen en zover het verschonlngsrecht reikt. Hetzelfde gelldt woor de daarop betrekklng hebbende stukken, die zlch op de redactle, de uitgeverij of de drukkerif bevinden(411). In gelijke omvang en onder dezelfde voorwaarden bestaat een doorzoekingsverbod van de betrokken personen, ruimten en zaken ( 412$)$. Een belangrijke beperking van het verbod van Inbeslagname $c . q$. het door zoeklingswerbod is de toelaatbaarheid, wanneer degene, die zich op het verschoningsrecht mag beroepen, verdacht wordt van medeplichtigheld aan een strafbaar felt, strafverijdeling of heling, of als het voorwerpen betreft die voor het plegen van een dellct gebruikt of bedoeld zijn, uit het delict zijn voortgekomen of er hun oorzaak in hebben(413). Hetzelfde geldt als $\| 1 j$, die voor het verschoningsrecht in aanmerking komt, zelf van een strafbaar feit wordt verdacht, omdat in dat geval het verschoningsrecht zelf ook niet bestaat( 414 ).

Van de hierboven genoemde matregelen moet worden onderschelden de zelfstandige regeling betreffende de Inbeslagname van persprodukten in de perswetten van de deelstaten(415), die inbeslagname van de gehele oplage wan een drukwerk toestaat, als er dringende redenen zljn om aan te nemen dat hun tntrekklng zal plaatsvinden, ondat hun Inhoud een strafbaar feit oplevert (416), alsmede de doorzoeking met als doell de opsporing van verdachten en bewijsmateriaal in verband net een strafproces(417). Een algeheel doorzoekingsverbod en een verbod van inbeslagname kan uit de garantle vam de persvrijheld namelijk niet worden afgeleld(418).

\subsubsection{De verjaring van persdelicten}

Een andere bevoorrechte positle voor de pers in thet strafrecht bestaat in een kortere verjaringstermfjn voor dellcten, die door middel wan een drukwerk worden began(419). Deze kortere termy onstandigheld dat een persdelict openlijk wordt begaan en gedurende een langere tifd aan ontdekking is blootgesteld, nameligk zolang de af zet durt(420). 
3.5.7.8. De bescherming van peraoonsgegevens

ook het Bundesdatenschutzgesetz (421) kent een privilege voor de pers. Omdat de bescherming van persoongiegevens een beperking van de informatievritheld inhoudt, is daarin uitdrukkelijk opgenomen dat de wet geen persoonsgegevens beschermt, die door pers-, omroep- en filmonderneningen voor elgen publieltaire doeleinden worden werwerkt (par. 1 lid 3 ). Wel zijn deze ondernemingen verpllcht de nodige technische en organlsatorlsche matregelen te treffen om misbruik te voorkomen (par. 1 lid 3 jo. par. 6 1id 1).

\subsubsection{De behartiging van gerechtvaardigde betangen} door de pers

Aangezien uitingen die in de pers worden gedaan in de regel tot de worming van de publieke opinie wilen bijdragen moet in beginsel van hun toelaatbaarheid worden ultgegaan. Daarom moet ledere inperking van de persivil jheld worden verhinderd, die niet uit conslderatie voor tenminste gelijkwand\#ge rechtsgoederen absoluut geboden is. De objectiefrechtelijke, Institutionele zijde van de persvrijheid treedt hier in het bijzonder op de voorgrond (422). De strafrechter geeft zich hiervan rekenschap door in het geval van een delict jegens de persoonlijke eer, dat is begaan in verband met de vervulling van de openbare taak, deze behartiging van openbare belangen door de pers inet oog op haar functie in de democratische staat te erkennen als "berechtigte Interessen", welke een offlclele rechtvaardigingsgrond is (par. 193 StGB) (423). Het beroep op de openbare taak van de pers kan aldus ontslag van rechtsvervolging tot gevolg hebben. Deze rechtvaardigingsgrond is tevens criterium voor de ultslag van een op privaatrechtelijke niveau uitgevochten conflict tussen de persoonlijke eer en de persvrl jheld(424). Een beroep op par. 193 StGB wordt echter niet gehonoreerd als het een feitenweergave: betreft, zodra vaststaat dat deze niet juist is. Maar voor het zover is speelt par. $193 \mathrm{StGB}$ een gewichtige ro1, omdat een beroep op deze bepaling leldt tot de opheffing van de bewljslast voor de pers ten alanzien van de juistheid wan de melding. De behartiging van gerechtvaardigde belangen als rechtvaardigingsgrond is daarom vooral van belang met betrekking tat het dellct Ueble Nachrede (laster - par. 186 StGB), dat de bewering of verbrelding strafbaar stelt van feiten, die de eer krenken. De verdachte gat normal1ter slechto wrijuft, als hij kan bewijzen dat zifla bewering waar is (425). Omdat de aard van de werkzaamheden van de pers met alch meebrengt, dat veel meldingen worden gepubliceerd, terwijl niet vooraf kan worden gecontro- 
leerd of deze kloppen, zou deze verdeling van de bewjolast het persbedrije venIjnig kunnen raken. Het beroep op par. 193 StGB heft deze onvoordellge uitgangsposttie voor de pers op. De rechtvaardigingsgrond 1s daarom van grote praktische betekenis voor de bescherming van de pers in haar nlewwsverstrekkende functie(426). De pers hoeft niet in te staan voor de juistheid van haar meldingen, zolang is voldaan aan de in de reglonale perswetten opgenomen zorguuldigheldspllcht. Als de zorgvuldigheidsplicht is geschonden, wordt een beroep op de gerechtvaardigde belangen echter niet gehonoreerd (427).

Niet alleen het persbedrijf als geheel, maar ook $z i j$ die er 1 werkzaam $z 1 j$ proflteren wan de ult de instltutionele garantle voortvloelende voorrechten. Uitdrukkelijk heeft het Bundesverfassungsgericht vastgesteld, dat een bijzondere rechtspositie an hen enkel en alleen vanwege de openbare taak van de pers en slechts in het kader van die taak is toegekend. Het betreft geen persoonlijke privileges(428). In zoverre bestaat de extra rechtsbescherming, die uit de institutionele garantie voortvloeit omwille de vervulling van de openbare taak van de pers, uit reflexrechten en nlet uit originalice rechten.

3.5.7.10. De speciale plichten van de pers: de zorgvuldigheidsplicht

Uit de openbare taak van de pers kunnen geen rechtsplichten voor de pers worden afgeleid, maar wel impliceert de vervulling van die taak een verhoogde verantwoordelijkheid. In het Schmid-arrest overwoog het Bundegverfasgungagericht:

"Mit der Pressefreiheit gehen pflichten einher, die um so ernster genommen werden missen, je höher man das Grundrecht der Pressefretheit einschätzt. Wenn die Presse von fhrem Recht, die Oeffentlichkeit zu unterrichten, Gebrauch macht, lst sie zu wahrheitsgemässen Berichterstattung verpflichtet. Die Erfüllung dleser Nairheitspflicht wird nach gesicherter Rechtsprechung schon un des Ehrenschutzes des betroffenen gefordert. Ste ist zugleich in der Bedeutung der öffentlichen Melnungsblldung in Gesantorganismus elner frelheitlichen Demokratie begrïndet. Nur dann, wenn der Leser Im Rahmen des Möglichen - zutreffend unterrichtet wird, kann sich die offentliche Meinung rlchtlg bilden. Die Presse 1st daher um threr öffentlichen Aufgabe bel der offentllchen Melnungsbildung gehalten, Nachrichten und Behauptungen, die sie weitergibt, auf thren Wahrheitsgehalt zu prïfen"(429). 
Dezelfide openbare taak brengt echter tegelijk wet $z$ Lch mee, dat bij de concretisering van de waarheldsplicht mat 1 ing moet worden betracht; aldus het Bundesverfasaungrgericht in het Böll-arrest:

"Bine Ueberstelgerung der Wahrheitspflicht und die daran anknüpfenden, unter Umständen schwerwiegenden Sanktionen könnten zu efner Einschränkumg und Lähmung namentlich der Medlen fthren; diese könnten thre Aufgabe, insbesondere diejenige offentlicher Kontrolle, nicht mehr erfüllen, wenn thnen ein unverhaltnismässiges Risiko auferlegt würde" (430).

Deze stelregel in aanmerking genomen is het evenwel niet geboden ook de bewering van onjulste feiten, waaronder onjulste citaten, te beschermen. Het hanteren van deze matstaf verzwaart of doorkrulst nlet de openbare taak van de pers(431). Integendee1, onjuiste informatie is vanult het perspectief van de vrijheld wan meningsuiting juist niet het beschermen waard, aangezien zij de meningsvorming nlet kan dienen:

"Was ... nicht zur verfassungsmässig vorausgesetzten Meinungsbildung beitragen kann, ist nicht geschützt, insbesondere die erwlesen oder bewusst unwahre Tatsachenbehauptung" (432).

Het Bundesverfasaungagerioht notiveert in het Schmidarrest de waarheidsplicht zowel met de betekenis van de openbare meningsvorming voor de democratie als met de rechten van derden.

Het aannemen van een waarheidsplicht in verband met de betekenis van de meningsvorming voor de democratie is problematisch ondat het met het karakter van de vrijheid van meningsuiting, waartoe ook de persvrijheid behoort, onverenlgbaar is meningsultingen op hun warheidsgehalte te beoordelen, zoals het Bundesverfassungagemicht zelf trowwens toegeeft(433). Uit de waarheidspllicht is voor de pers dan ook slechts een beperkte consequentie getrokken. In de meeste reglonale perswetten is uitsluitend een zorgvuldigheidsplicht opgenomen, die bovendien alleen op feiten en niet op waardeoordelen betrekking heeft. De zorgvuldigheidsplicht is de plicht, verbreide nieuwsberichten op hun julistheid, Inhoud en herkomst te veriflëren(434). De rechter hanteert bij de uitleg van het zorgvuldigheidsbegrip het privaatrechtelifke criterlum, dat van de in het matscheppe11jk verkeer vereiste zorguldigheid ultgaat(435). Deze maatstaf is bovendien glifdend: hoe zwaarder de lnbreuk, die een publicatie op andermans rechten makt, des te hoger zijn de elsen die aan de zorgvuldigheld worden gesteld(436). Het gaat dus om de naar omstand 1 gheden geboden zorgvuldigheld(437). De zorgvuldigheldsplicht van de pers is 
aldus nlet anders dan dile van elke andere burger( 438 ). Z1j ls de publicitalre vertaling van normale aansprakelijkheldsregels. Het juridische gewolg van een schending van de zorgvuldigheidsplicht is, dat de pers zlch in dat geval niet op de bijzondere rechtsbescherming van de persvritheld ex art. 5 lld 1 tweede zin GG respectlevell jk op de rechtvaardigingsgrond van par. 193 StGB (de behartigling wan gerechtvaardigde belangen) kan beroepen (439).

\subsubsection{Het recht op antwoond}

Met de nleuwswerstrekkende functie van de pers hangt de Gegendarstellungsanspruch samen. De perswetten van de meeste deelstaten(440) kennen de plicht van de verantwoordelijke redacteur of van de ultgever van een perlodiek drukwerk, om de reactie af te drikken wan personen, groepen, organisaties en dergelijke, die zelf geraakt $z i j n$ door een in het periodiek gedane bewering van felten(441). Het recht op antwoord geldt niet woor wardeoordelen. Het weerwoord moet zich beperken tot feitelijke gegevens en mag geen strafbare inhoud hebben(442). Het moet onverwij1d, maar ulterlifk binnen drie manden, worden ingezonden(443) en verschijnt gratis in het eerstvolgende nummer na ontvangst van het antwoord, dat nog niet persklaar 1s, en wel in het gelijke deel en in dezelfde opmaak als waar de oorspronke11 jke tekst was geplaatst (444). Het weerwoord mag niet langer zijn dan de tekst, waarop wordt gereageerd. Sommige perswetten erkennen tevens het recht te reageren op advertenties, die niet exclusief commercieel $z 1 \mathrm{fn}(445)$, andere erkennen dit recht ten aanzien van alle advertenties, $z 1 j$ het tegen betaling (445). Het recht op antwoord volgt, behalve uit het persoonl1jkheldsrecht (447), wit het recht van de burger op medewerking aan de openbare meningsvorming (448).

Van het recht op antwoord wordt in toenemende mate gebrulk gemaakt(449). Naar opvatting van Ricker ls de Gegendargtellungaanspruch een algemene wet in de $z$ in van art. 5 1Id $2 \mathrm{GG}$, omdat het een rechtsgoed beschermt, dat voorrang heeft boven de vrijheid van meningsuiting (450).

\subsubsection{De colofonplitht}

De regionale perswetten hebben tenslotte een aantal plichten van administratieve aard opgenomen. Daarvan is met name de colofonplicht te noemen: de plicht voor elk drukwerk enige vaste gegevens op te nemen over de herkomst van het drukwerk, waaronder de naam van de verantwoordelifke redacteur, als het een perlodiek drukwerk betreft( 451$)$. 
Ben millpaal op de weg naar de erkenning van het instituut vilje pers vormt het reeds verscheidene malen aangehaalde spiegel-arrest(452), gewezen naar aanlelding van de beroemde Splegelaffaire. Deze deed in 1962 veel stof opwalien. Het gelijknamige, in Hamburg verschifnende weekblad had in een artikel stelling genomen tegen de uitrusting van de Westduitse krijgsmacht met nucleaire wapens en in plaats daarvan geplelt voor een sterkere conventlonele bewapening. Het tljdschrift stond met deze opvatting $11 \mathrm{fnrech}$ tegenover de mening van de toenmalige minister van defensie Franz-Josef Strauss. Het artikel bevatte detalls over de militalre planning van de NAVO en het Westduitse leger en was voorzten van foto's van nleuwe wapens. Hierop doorzocht het openbaar ministerle in een nachtelljke overval de redactieruimten van de spiegel. De uitgever, Rudolf Augstein, werd op beschuldiging van het verraden van staatsgeheimen gearresteerd(453). De actie, waarvan werd vermoed dat zij was veroorzakt door een persoonlijke vete tussen Strauss en Augstein, leidde tot een regeringscrisis en het aftreden van straus (454).

Op grond van de toenmalige par. 99 StGB kon reeds het publiceren van een artikel, dat door het samenvoegen van bekende en openbaar toegankelijke deta $11 \mathrm{~s}$ lezers en potentiële tegenstanders nieuwe Inzlchten verschafte, landverraad $z 1 j n(455)$. Op deze moza Tektheorle was de actie tegen de Spiegel gebaseerd.

Hoewel thet Bundesverfassungsgericht de ondeugdelijkheid van de mozalektheorie vaststelde met het oog op de betekenis van de persvrijheld(456), meende het dat onder het geldende recht de verdenking tegen de spieget de beslissing tot doorzoeking van de redactierulmten kon dragen(457). Het doorzoekingsbevel leverde geen schending van de persvrijheid van Augsteln op.

Het Bundesverfasaungsgericht nam de gelegenheid ten baat $z 1 \mathrm{fn}$ ldeëen over de verhouding tussen persvrifheld en staatsvelligheid op tafel te leggen (458). De bepaling, die het verraden van staatsgeheimen strafbaar stell (459), moet als beperking van de vrijheld van meningsulting in het llcht van de bijzondere betekenis van de persvrtheid voor de democratie worden utgelegd. Dat houdt echter niet in dat de persurifheid automatisch voorrang heeft voor belangen inzake gehelmhouding. Immers: "Das Korrelat der Pressefreihelt ist elne verantwortungsbewusste Presse (BVerfGE 12, $113(130))$. Wamentlicht steht $1 \mathrm{~m}$ frelhelt11ch-demokratischen Staat der Pressefreiheit die Mitverantwortung der Presse für die Staatssicherheit gegenüber" (460). De noodzaak tot militafre gehelmhouding in het 
belang van de statsvelligheld en de persvritheld $z 10 n$ geen tegenstellingen die elkaar uitsluiten: "Belde sind vielmehr durch das höhere Zlel, den Bestand der Bundesrepublik Deutschland - Im Recht verstandemen Sinne - zu sichern, elnander zugeordnet" (461). Onder de bestendlgheid valt niet alleen de organlsatorlsche structuur var de staat mar ook haar fretheitliche demokratische Rechtsordnung (462). Van de pers wordt dus in of meer verwacht dat $z i j$ haar steent je aan het behoud van de organisatorische en politieke structuur van de staat bijdraagt.

De ultspraak van het Bundesverfarsungsgemicht was voor de wetgever anlelding het begrip statsgeheln opnieu te definiëren en wel zo, dat de mozalektheorle niet meer zou kunnen worden gehanteerd. Staatsgehelmen zijn voortaan uitsluttend: "Tatsachen, Gegenstande oder Exkenntnisse, die nur elmem begrenzten Personenkreis zuganglich sind und vor elner fremden Macht gehelmgehalten werden missen, om die Gefahr elnes schweren Nachtells für die äussere Sicherheit der Bundesrepublik Deutschland abzuwenden"(463). Op grond van deze omschrijving kan het schrijven van een artikel onder gebrulkmaking van openlijk toegankelijke informatte geen landverraad meer opleveren(464).

\subsubsection{Bazans}

De passages ult het Spiegel-arrest over de medeverantwoordelijkheid van de pers voor de staatsvelligheid hebben veel stof doen opwaalen en geleld tot een kritische evaluatie van de institutionele benaderlng van de persvrithedd $(465)$.

De in het Spiegel-arrest gevolgde redenering toont het gevar dat ontstaat, Indien de persvritheid steeds maar vanult de objectlefrechtelijke invalshoek, tegen de achtergrond van haar bljdrage an de meningsworming en aan de democratie, wordt bellcht: het gevaar van een identiflcatie van belangen van pers en staat. De institutionalisering van de persvrijheid loopt op die manler uit op de oprichting van een "Ersatzstaatlichkelt" butten het ressort van de stat, warschuwt Schmtt-GLaeser (466). Omdat normale meningsullingen net zo goed aan de meningsvorming kunnen bljdragen alls persultingen vreest hij bovendlen een ontwikkeling in de richting van een institutionalisering van de gehele vritheld van mentngsuiting(467).

Een muchtere beschouwling van de consequenties, die uit de instltutlonele garantie $\mathbf{i j n}$ getrokken, leert echter dat deze het oorspronkelijke karakter van de persvritheid als indluidueel afweerrecht niet werkelijk 164 hebben angetast. De verbinding van de institutlonele 
kant net de subjectlefrechtelijke zijde, onlangs door het Bundesverfasoungagericht weer nam voren gehaald, $14 j k t$ een losiaten van de afwerfunctie effectlef te kunnen verhinderen. De wijze, waxop an het instituut vilje pers gestalte wordt gegeven, toont dat de instcutionele garantie bedoeld is ter versterking van de vilueld. De privileges en de plichten van de pers worden In de meeste gevallen dan wel vanult de openbare taak van de pers gerechtvaardigd, mar grosso modo houden zij verband met de organisatorische voorwarden, die nu eenmal met de elgen ard van de pers samenhangen. Ook vanult een benaderlng, die meer recht doet an de afweerfunctie van de persuritheid, zijn de gecreëerde privileges en speclale plichten niet abject. Dat geldt voor het verschonlngsrecht, maar ook voor maatregelen die de pluriformitelt van de pers in stand beogen te houden. Net zo goed zouden het nlet beschermen van nilet-ware felten en het recht op antwoord verklaarbaar zijn vanuit de Invalshoek van de persoonlljkheldsontplooilng van derden, die nlet in het gedramg mag komen. De zorgvuldigheldsplicht van de pers is zelfstandig bezien weliswaar nlet toe te julchen, maar in de praktifk fungeert zijals correctiemechanisme op de bevoorrechte positie van de pers, die bljvoorbeeld voortvloeft uit de interpretatie van par. 193 StGB. De gegeven bescherming wijkt per saldo niet veel af van de bescherming, die de algemene garantie van de vrijheid van meningsuiting biedt. En ook de gedachten, die het Bundesverfasengsgemicht heeft ontwikkeld ower de medeverantwoordelijkheid van de pers voor de staatsvel11gheld, zijn op de keper beschouwd nitets anders geweest dan een hulpmiddel bif een afweging tussen de persvrijheid en de staatsvel1.lgheld, die reeds in het teken stond van de bljzondere betekenis van de persvrijheld voordat de afwegling goed en wel gestart was.

Zolang de privileges en de speciale plichten van de pers, voorzover zif éen van de 1 in art. 5 lid 1 GG gegarandeerde grondrechten beperken, dan ook als beperkingen In de zin van art. 5 lid 2 worden beschouwd kan de wisselwerkingstheorie teminste een corrigerende functie vervullen.

\subsubsection{De ommoepvmijheid}

Op de In art. 5 ild 1 GG eveneeng gegarandeerde omroepuriftheid zall hier alet worden ingegaan. Gewezen zif slechts op de overeenkomsten in de benadering van de persurijheld en de omroepurijheld. Ook de omroepvrithedd kent volgens het Bundesverfasaungsgericht twee componenten. 
Zij 18 "primair elne der Relheit der Melnungsbilding in ihren subjektiv- und objekt urechtlichen Elementen dienende Frethelt" $(468)$, en mag wich evenals de persvrltheld verheugen in een institutionele garantie(469) en een openbare taak(470), wat allet verbazingkekkend Is gezlen het feit dat radio en televisie natst de pers het belangrljkste instrument bij de apenbace meningsvorming $21 j n(471)$. Een en ander is toegesneden op de structurir van de ararapen als publiekrechtelljke organlsatle. Deze rechtsvorm is gekozen als warborg voor de verwezen11 jklag en handhaving wan de constitutioneel gegarandeerde omroepwrijheld, die immers bedrefgd is door de randvoorwarde, dat om financiele en technische redenen het antal zendgemachtigden naar verhouding klein dient te bLIjven(4/2).

Het karaker van de omroepvijheld als afweerrecht garandeert dat de omroeprorganisatles hun taak desalniettemin vif wan overheidsinmenging kumen vertichten(473). Tegelijk bxengt de schlechthin konatituierende betekents van de omroepvrljheld voar de democratie met zich mee dat de nodige voorzientigen worden getroffen die garanderen dat de pluriformitelt van meningen bij de omroep gewarborgd $1 \mathrm{~s}(474)$.

Met het oog op het relatief kleine antal zendgemachtigden enerzljds en de taak van de omroup voor een vrlje en breed aangelegde mentngsvorming zorg te dragen anderzijds, mogen ter bescherming van deze plariformitelt de omroeporganlsaties niet éen bepaalde richting aanhangen, maar moeten ze $1 \mathrm{a}$ principe alle mentngen de ruimte geven. "Insoweit unterscheiden stch. die Gebote der Rundfunkfreihelt won denen der Pressefrelhe1t, welche die Frethelt unfasst, die Grindrichtung elner zeltung unbeeinflusst zu bestimmen und zu verwirklichen" (475).

\subsection{Beperkingen van de vrijheid van meningsuting}

Beperkinger van de vritheld van meningsuiting zifn mogelifk op grond van art. 5 11d 2 GG(476). Z1j vinden plate tem behoeve van de rechten van derden en in het algemeen belang. Reeds is vastgesteld dat $z 1 j$ in het 1 leht van de schlechthin konstitutemende betekents van de vritheld van mentingsulting voor de derocratle moeten worden gezlen. Aangezlen die bijzondere betekentis bestat in de bijdrage die het grondrecht levert aan de vorming van de publieke oplnte betekent dat, dat de beperkingen in de 2 in wan art. 5 lid 2 GO concreet in hun werking worden beperkt als de vritheid van meningsulting, die met zo"n beperking in conflict is ge166 komen, ten behoeve van de openbare menting wordt inge- 
zet. Het valt bulten het kader van dit onderzoek alle beperkingen afzonderlijk na te gaan. Slechts enkele vootbeelden zullen worden aangehaald, met de bedoellng. de verbanden te conen, die bestaan tussen wisselwerkingstheorie, de aard van de beperklngen en de conceptie van de strljdbare democratle. Dit zal worden gedaan aan de hand van een besprekling van achtereenvolgens beperkingen ten behoeve van het recht inzake de persoondijke eer, beperklngen die tot 1968 communtstsche meningsultingen strafbaar stelden, beperkingen. de meningsultigen van natlonal-soclalistische aard strafbaar stellen, beperkingen van de vritheid van menlngsulting. die betrekking hebben op het thema geweld, beperkingen die het aanzlen wan de stat beschermen en nogmaals(477) beperkingen van de vrijheld wan mentngsulting van militairen en ambtenaren.

\subsubsection{Het recht inzake de persoontijke eer}

Bif conflicten tussen de vrifheid van meningsulting en het recht inzake de persoonlijke eer wordt de persoonlijke eer minder beschermd narmate de meningsulting meer aan de meningsvorming bijdraagt. Reeds in het Luth-arrest moest het door par. $826 \mathrm{BGB}$ beschermde privébelang van tarlan voor de boycotoproep wijken. Deze werd niet in strijd geacht met de goede zeden vanwege de bljdrage die hierdoor werd geleverd aan de meningsvorming in een kwestie die voor het algemeen welzijn van belang was(478). Het ging fmmers om het aanzlen van de Bondsrepubliek in het bultenland. De wereld moest er zeker van zijn, dat het Dultse volk het nattonal-soclalisme had afgezworen en de gruwelijke vervolging van de joden verwierp. De 11 jn van het Lith-arrest werd in latere arcesten doorgetrokken. In het Schmid-arrest ging het om een zekere rechter Schnid, wiens oorlogsverleden door het weekblad der Spiegez op provocerende wijze was tentoongesteld. Schmid voelde zich in 21 jn eer gekwetst, mar de eer moest wilken voor de persvrijheid. De ulting droeg in casu tot de vorming van de publieke opinie bij(479). De Spiegel behartigde gerechtvaardigde belangen (par. 193 StGB) $(4.80)$. Bovendien had Schmid de splegel al in een andere krant van repliek gedlend(481).

ook in het Tonjligerarrest was een kritlsche meningsulting in de pers gedekt door par. 193 StGB, "wetl die Aeusserung im Rahmen elner bffent1lchen, der al.1geme1nen Melnungsblldung dienender Auselnandersetzung gefallen ist und es stch um eine adequate Reaktion auf elinen anderen Vorgang handelte", terwijl het een ter algemene d1scussie staand probleem betrof $(482)$.

In het Echtemach-arrest had een mentngsulting voor- 
rang, ondat met de vil iheld wan mentingsulting geen prive- of zelfzuchelge doelen werden nagestreefd, war het de bedoeling was een bijdlrage aran de openbare po11tieke menlingsstrijd te leveren(483). In het Runtkwtik-arrest werd een meningsulting toelaatbaar geacht, omdat $z 1 \mathrm{j}$ een bljdrage vormde aan de "offentichem gelstigen Auselnandersetzung auf elnem Geblet. das nicht minder von der Freiheit wer Gedanken lebt als die Pollt1k" (484). Bovendien werd een beroep op the persoonlifke eer door het beginsel van repliek gerelatweerd. Wie vrljulllig aan de meningsvorming deelneemt en zlch darmee an de matstaven ondermerpt, die in de openbare strijd van meningen gelden, moet: als hil zelf zware kritleken heeft gespuld een scherpe reactile op de koop toe nemen, ook als deze zijn aanzien vermindert (485). Zoals reeds opgemerkt mogen an de toelaatbaarheld van openbare kritlek geen overdreven elsen worden gesteld(486).

Samenvattend kan worden gezegd, tat blj de afweglng tusisen persoonl1jke eer en vrijheld van meningsulting steeds in armerking moet worden genomen of de ulting een bijdrage vormt aan de geestelljke strijd van meningen, die de openbaarheid wezen11jk raakt (487), wat overlgens aan de rechter ter beordeling blifft $(488)$. Is wan zo'n bijdrage sprake, dan verhoogt deze omstandigheld de tolerantlegrens met betrekking tot de formulering van de ulting aanztenlijk(489). Het evenredigheldsbeglnsel verelst wel dat de reactle adequat is. Whe bovendien zelf tot een reactie a a leiding heeft gegeven kan zich vervolgens nilet meer op de persoon $11 j k e$ eer beroepen(490).

In het with-arrest is voor het eerst de zinsmede gebruikt, dat de vrijheid van menligsuiting boven een ander rechtsgoed pxewaleert als het een bijdrage betreft aan de geestelljke strijd der meningen in een kwestle die de openbarheid wezenijik raakt * "hier spricht die Vermutung für die Zulässlgkeit der frelen Rede"(491). In het Me Znungsausemung im Wahlkampf-arrest heeft het Bundeaverfassungsgemicht aan deze ultspraak nieuwe actualitelt verleend. In bijzondere mate geldt het vermoeden als het discussies tijdens eem verklezingsstrijd betreft, dus in sttuaties, warin de politieke strijd tot het uiterste gelntensiveerd 1 s. Dit volgt uit de speclalle taak van de politieke partijen met betrekking tot de politieke wilsworing (492). Sohnitt-GLaeber merkt op, dat het Bundesvenfabsungegewicht hler een part lJenprivilege van bijzondere aard heeft geintroduceerd(493), voor hem het laatiste bewlifs voor een onverantwoordelijke witholling wan het recht inzake de persoonlljke eer. Tenzij onjulste feiten beweerd worden of cltaten onfuist worden weergege- 
Ven vindt volgens hem een bescherming wan de persoon$11 j k e$ eer in geval wan twijfel niet meer plats(494).

3.6.1.1. De persoonlijke eer ats onderdeet van het algemene persoonlijkheidsrecht

Tot dusver enkele malen heeft het Bundesverfassungsgericht in arresten, die de vrijheid wan menlingsulting betroffen, gerefereerd aan het zogenaamde persoon $11 \mathrm{jk}-$ heldsrecht. Dit algemene persoonlijkheidsrecht is door het Bundesgerichtohof ontwikkeld uit de garantie van de menselijke waardigheld (art. 1 lid 1 GG) en het recht op vrije ontplooling van de persoonlijkheld (art. 2 lid 1 GG)(495). Het Bundesverfassungsgericht heeft zich aanvankelijk terughoudend opgesteld en zich niet aan een oraschrifving gewaagd, maar is evenmin aan de ontdekking van dit nieuwe grondrecht voorbijgegaan. zo heeft het, als daartoe aanlefding bestond, het persoonlijkheidsrecht van geval tot geval in stelling gebracht en bepaald dat in teder geval het recht op eerblediging van de persoonlijke levenssfeer ertoe behoort, alsmede de persoonlijke eer, het beschikkingsrecht over de uitbeelding van de eigen persoon, het recht op de elgen beeltenis en het eligen gesproken woord en onder bepalde amstandigheden het recht, verschoond te blifven van de toedichting van niet gedane uitingen(496). In het Eppler-arrest merkte het Bundesverfasaungagericht op, dat het persoonlijkheidsrecht de in de grondwet opgenomen speciale vril jheldsrechten aanvult. De taak van dit recht is het de persoonlijke levenssfeer in engere zin en wat daarvoor voorwaarde is te garanderen, hetgeen door middel van de traditionele vrijheldsgaranties niet geheel moge$11 \mathrm{jk}$ is; de noodzaak hiertoe bestaat met name met het oog op moderne ontwikkelingen en de daarmee verbonden gevaren voor de bescherming van de menselijke persoon11 jkheld (497).

Ontstat een conflict tussen het persoonlifkheldsrecht en de vrijheid van meningsulting, dan wordt het persoonlijkheidsrecht als "sonstiges Recht" in de zin wan par. 823 lid 1 BGB, beschouwd als een beperking van het grondrecht ex art. 5 1यd 2 GG. Wettelifke voorschriften die afzonderlijke aspecten van het persoon11 jkheldsrecht beschermen $z i j n$ evemeens toelatbare beperkingen ex art. 5 lid 2 GG(498).

Het Bundesperfasoungagericht vertichte 21 in eerste afweging tussen een aspect van het persoonlijkheidsrecht en de vritheid van menlingsuiting in het somaya-arrest (499). Het voorwerp van de strijd was een in een tijdschrift verschenen interview met prlnses soraya, de ex-vrouw van de toenmallge sjah van Iran, dat verzonnen bleek te $z 1 j n$. De fantasierijke fournallst beriep 
zich op zijn perswrifheld, maar die wlieger ging niet op. Het Bundesverfabungsgemiht achtte het verzonnen interview een ontoelaatbare schending wan het persoonlijkheldsrecht van soraya(500), daarmee beslissende dat het persoonlijkheldstecht ook het recht onvat, van de toedichting van nlet gedane ultingen verschoond te blifven. De afreging vond plaats via par. 8231141 $B G B(501)$. Hoewel deze als algemene wet in het $11 \mathrm{cht}$ van de bijzondere betekenis wan de persveifheld voor de democratle moest worden ultgelegd, trok de journaIlst aan het kortste elnd. Van beslissende betekenis was in dit verband, dat soraya de openbarheid niet had gezocht, max zlch integendeel afzildig had gehouden wan de arena, war de openbare strljd van meningen plaatswindt.

De constellatle 1 in het Lebach-arrest(502) is vergelijkbar met die van het Soraya-arrest. Naam en foto wan een man, dle was veroordeeld wegens deelname aan de roofmoord op een antal soldaten, waren vermeld in een televisiespel dat an deze gebeurtentis gewijd was. Hoewel zulks in beglnsel door de omroepvrithell beschernd was, achtte het Bundesverfassungagemiat de vernelding een ontoelaatbare inbreuk op het beschikkingsrecht van de delinquent over de ultbeelding van $21 \mathrm{jn}$ elgen persion( 503$)$.

Hoevel dit aspect van het persoonlijkheidsrecht door een algemene wet werd beschermd en derhalwe an de wisselwerklngstheorle zou moeten worden onderworpen, overwoog het Bundesverfassungsgerioht dat het door de algemene wet beschermde belang van de delinquent onmiddelijk versterkt werd door de constitutionele garantle van de persoonlijkheldsbescherming(504). Bij de oplossing van het conflict tussen de vrijheid wan meningsulting en het persoonlijkheidstecht moest er daarom van worden witgegaan, dat geen van beide Ver fassungswerte en princlplële voorrang kon clatmen; er diende een rechtstreekse afweging plaats te vinden (505). Het persoon11jkheidsrecht kwam daaruit als de sterkste te voorschijn. Net als soraya had ook de delinquent de openbarheid niet gezocht. Uit het Lebacharrest volgt dat de wilsselwerkingstheorle an betekenis verllest als de vrijheid van meningsulting in conEllct ralakt met het persoonlijkheidsrecht, ondat dit constitutionele rang heeft. Door rechtstreeks af te wegen wordt de wisselwerklngsmethode gepasseerd.

Deze gevolgtrekklng wordt bevestigd door een recent arrest, warin sprake was van een conflict tussen de omroepvritheid en de Gegendarstellungsanspruch (506). De regelling van de Gegendarstet Zungamepmich werd nilet gezien als algemene wet, die aan de wisselwerkingstheorte 1 s onderworpen, mar de rechter liet het recht 
op antword utt het persoonlijkheldsrecht yontwloelen, dat het recht op zelfbesteming over de ultbeelding wan de elgen persoon beschernt en dus ook het recht Impliceert, te reageren op de ultbeelding wan de elgen persoon door een ander. De Gegendapstellingsanspruch had derhalve constitutionele rang en diende rechtstreeks tegen de omroepvri jheld te worden afigewogen. Het ontzeggen van het recht op antwoord aan een Turkse culturele verenlging, die op de televisle met een terrorlstenorganisatle in verband was gebracht, later dan twee weken na de oorspronkelijke ultzending, betekende een onevenredige inbreuk op het persoon $11 \mathrm{fk}-$ heidsrecht van de veren 1 ing $(507)$.

De drie genoemde arresten hebben gemeenschappellij, dat niet de persoonlifke eer in het geding was, maar andere aspecten van het persoonlifkheldsrecht. Tevens is het van belang vast te stellen dat zowel Soraya alls de soldaat van Lebach zlch van thet openbare leven afzijdig hadden gehouden en dat ook de Turkse vereniging de publicltelt niet had gezocht. Twee omstandigheden, die kennelijk opwegen tegen de betekenls van de vrijheld van meningsulting voor de democratie, wellke door de wlsselwerkingstheorle wordt gehonoreerd. Dit duldt erop, dat het Bundeoverfasaungsgemicht niet van plan is in het verlengde van de uitholling van het recht Inzake de persoonlljke eer ook de bescherming van de rest van de persoonlijke levenssfeer an de vrijheld van mentngsulting ondergeschikt te maken.

Het Böll-arrest (508) had ook een conflict tussen het persoon11 jkheidsrecht en de vrljheid van mentngsuiting tot onderwerp, maar dit keer had de rechtsstrijd een ander verloop, wardoor het nlet tot een afweging kwam. In een commentaar naar a aleiding van een doox de Rote Ammee Fraktion gepleegde moord beschuldigde een medewerker van de Sender Freies Berlin de schrijver Helnrich Böll ervan een van de geestelljke wegberellders te $z 1 j n$ geweest van de terroristische beweging, die in de faren zeventig West-Duitsiand op stelten zette. H1j halde in dat comnentaar enlge cltaten van Böll aan, warutt zIjn beschuld 1 ging zou moeten blifken. In een clvielrechtelijke procedure elste Böll schadevergoeding wegens aantasting van $21 j \mathrm{j}$ recht op het elgen woord. Vast kwam te staan dat een van belde citaten niet fulst was en dat het andere volledig uit zijn verband was gerukt - het was afkomstig uit een in 1966 gehouden lezing, lang voordat de bakens op terroristische storm stonden. In de daarop volgende veroordeling tot schadevergoeding wan de omroepmedewerker zag het Bundesverfassungsgericht geen schending van de vrijheld van meningsulting, omdat van een mentugsul- 
ting geen sprake was(509). Onjulste citaten worden namel1 jk nlet door het grondrecht beschermd(510).

In het Böl-arrest kwan het bijgevolg nlet tot een afueglng tussen persoonlijkheldsrecht en vrljheld van menlngulting, mat het resultat was uitelndelijk hetzelfde als in de andere arresten. Langs andere weg: 1 In casu aan het persoonlljkheldsrecht woorrang verleend en is de wisselwerkingstheorle buiten werklng gesteld, namelljk door het meergeven van onjuiste feiten van de vrijheid van meningsulting ult te zonderen (511).

Een interessante vraag is, hoe de afwegling zou zijn verlopen, als het Bundesverfasaungsgemicht had vastgesteld dat de gewraakte citaten (bljvoorbeeld op grond van begelelidende omstandigheden, zoals het verbonden21 jn met ardeoordelen) meningsulting zouden worden beschermd. Zou dan weer een rechtstreekse afweging hebben platsgeronden, zoals in het Lebach-arrest, of zou het persoonlijkheldsrecht in dit geval zijn bezien via art. 5 1/d 2 GG, dat wil zeggen in het licht van de schlewhthin kongtituierende betekents van de vrijheld van meningsuiting en daarom minder gewlcht tegenover dit grondrecht hebben gehad? De constellatie in het Böll-arcest verschilde in teder geval in zoverre van die in de voorgaande arresten, dat Böll in tegenstelling tot Soraya en de delinquent van Lebach bewust aan het openbare leven had deelgenomen. Hy zou daarom geacht kunnen worden meer te incasseren.

\subsubsection{De kunstomijheid}

Conflicten tussen het persoonlijkheldsrecht en de vrijheld van menlngsuiting worden evenmin via de wisselwerkingstheorie, dus met inachtneming van de bijzondere betekenils van het grondrecht voor de democratie, opgelost als de meningsulting in kwestle wordt beschouwd alls een kunstuiting en derhalve niet wordt beschermd door art. 5 11d 1 GG, mar door art. 5 1.d 3 GG, dat onder weer het grondrecht op kunstvrljheid garandeert. De kunsturi jheid wordt niet als onderdeel van de vitheld van mentingsulting beschouwd, maar als een apart grondrecht met een elgen gezlcht. Wel blijkt wt de plasting van de garantle direct na de vrijheid van meningsulting, namelljk in art. 5 lid 3 GG, de onidddellijke band tussem de twee grondrechten.

Problematisch is natuurlijk de onderscheiding tussen kunstuftingen en mentingsutingen, en dit des te meer daar de vraag, of een ulting een kunstulting dan wel een meningsulting is, van groot praktlsch belang 1 s. Op de kunstvrijheld als lex specialis van de vrijheid van menlngsulting zijn immers de beperkingen ven art. 
5 lid 2 GG niet van toepassing(512). Die kunst hoeft zich dus van de beperkingen van art. 5 Hid 2 GG niets aan te trekken(513). Dieze verhoogde bescherming van de kunsturifheid moet worden verklaard uit de behoefte een misbrulk van de kunst, zoals deze onder nationaalsoclallsme plaatsvond, voorgoed te verhinderen(514).

In het beroemde Mephisto-arrest (515) heeft het Bundesverfassungsgericht zich bezig gehouden met de vraag, of de kunstvrijheld dan uberhaupt kan worden beperkt en vervolgens vastgesteld dat de grenzen van de garantie van de kunstvrijheid alleen in de constitutie zelf te vinden zijn. Conflicten tussen de kunstvrijheld en andere constitutionele normen moeten "nach Massgabe der grundgesetzlichen Wertordnung und unter Berïckslchtlgung der Elnhelt dieses grundlegenden Wertsystems" worden opgelost (516). Zo'n andere constitutionele norm is bijwoorbeeld het persoonlijkheidsrecht.

De door Klaus Mann geschreven en reeds in 1936 bij Querido in Amsterdam verschenen roman Mephisto werd in de Bondsrepubliek na zijn verschljning in 1970 verboden ondat de hoofdpersoon een niet te loochenen gelijkenis vertoonde met de toneelspeler Gustaf Gründgens, die ult carrlèreoverweglngen na 1933 met de nazl's had samengewerkt en het tensilotte tot algemeen directeur van het Prulsische Staatstheater gebracht had. Klatis Mann had zich Inderdaad door Gründgens, zljn ex-zwager, laten inspireren, $z i j$ het dat hij naar eigen zeggen niet de bedoeling had hem als persoon aan de schandpaal te nagelen. Klaus Mann wilde slechts door mlddel van de persoon van Gründgens het prototype uitbeelden van de meelopers, die niet de grote misdaden begaan, maar wel van het brood der moordenaars eten, die niet doden, maar wel de hielen der machtigen 1.tkken, ook als deze hlelen in het bloed der onschuldigen waden $(517)$.

Naar aanlelding van het conflict, dat door de publicatie van de roman was ontstaan, ontwikkelde het Bundesverfassungsgemicht enige criteria on te bepalen of lets kunst is. Het wezen van de kunst, aldus het hof, is de vrije creatieve vormgeving, warln indrukken, belevenissen en ervar1ngen van de kunstenaar aanschouwelljk worden gemaakt. De gekozen worm zelf speelt daarbij als medium een belangrijke rol. De artistieke activitelt bestaat ult bewuste en onbewuste processen, die niet van elkaar te scheiden $z 1 \mathrm{jn}$. ZIj is een cooperatie van intultie, fantasie en verstand. Kunst is niet primair een mededeling, maar ultdrukking van de Individuele persoonlf jkheld van de kunstenaar(518).

Mephisto moest in casu worden beschouwd als een werk van vertelkunst. Dat de roman aan de historische wer- 
kell jkheld aanknoopte deed hieraan niets af. Al beschreef de kunstenaar gebeurtenissen ut het werkelifke leven, de artistleke factor stond op de voorgrond (519). Het zou niet gepast zijn bepaalde delen uit de samenharg van de roman los te maken en als meningsultingen in de $z$ In wan art. 5 IId 1 GG te beschouwen ara then zadoende onder de beperkingen van het tweede Iid te laten vallen(520). Het gehele werk moest volgens het Bundesverfabaungegericht als kunst worden beordeeld. Hel moest de kunstvrijheld vervolgens terugtreden voor de door art. 1 lid 1 GG bescherrade menselijke waardigheid van - de inmiddels overigens gestorven Grindgens(521). De helft van het college van rechters kon $z$ llch niet met deze ultspraak verenigen(522). Op zlchzelf al een teken hoezeer de uitkomst van de afweglng een kwestle van persoonlijke smaak was. De dissidente rechters pleitten voor een afweging die in het voordeel wan de kunstwrijheid zou hebben moeten uitvallen.

Was de roman nu nlet als kunst maar als menlngsuiting opgevat, dan had de uitkomst er wellicht anders uitgezlen. De menselijke wardigheld van Grïndgens werd namelljk door een privaatrechtelijke rechtsnorm, dus door een algemene wet, beschermd. Een afweging tussen de vrifheld van meningsuitting en de menselijke waardigheld met inachtneming van de wisselwerkingstheorie was in dit geval misschien in het voordeel van de menlngsulting ultgevallen. Gezlen de beroemdheld van Grüdgens en de reeds lange tijd bestaande controverse over $z 1 \mathrm{jn}$ rol in het Derde Rijk betrof het hier zeker een "die Deffentlichkelt wesentlich berührende Frage"; men vergeliljke de constellatle in het Lüth-arrest (523). Het is dus nlet gewaagd te veronderstellen dat de kunsturijheld, hoewel in beginsel onbeperkt gegarandeerd, in het onderhavige geval juist minder bescherming heeft geboden dan de aan beperkingen onderworpen vritheid van meningsuiting. Het voorbeeld van het Mephisto-arrest geeft een 1 dee van het belang van de wisselwerkingstheorle.

Mephisto werd overligens in 1980 voor de tweede mal ultgegeven. De ultgever verdedigde zich door te wijzen op een brief van Mann, die ondertussen boven tafel was gekomen en waarult zou blifken dat Mann zifn boek niet ult persoonll jke wrok geschreven had, maar de lnspirathe voor $z i j n$ werk in eerste instantle van buitenaf had gekregen(524). Tegelijkertijd werd een verfilming uitgebracht.

Uit het Mephisto-arrest volgt dat zowel voor de beslissing, of een uiting een kunstulting is, als voor de besllssing, of een kunstulting in geval van con174. Flict plaats moet maken voor een ander recht van con- 
stltutlonele rang, bepalend is of en in hoeverre een transformatle van de werkelijkheid heeft platsgewonden, dile als ultakking van de Individuele persoon1ijkheid moet worden gezlen.

on met het latste te beginnen, doorslaggevend woor het gewlcht dat de kunsturijheld tegenover andere rechtsgoederen van constitutionele rang, bijvoorbeed het persoonlijkheldsrecht, in de schaal legt $1 \mathrm{~s}$ de mate, warln een kumstwerk aan de soclale werkelljkheid aanknoopt. Blj Mephlisto was naar de mening van het Bundeswerfasungsgerioht wellswar sprake van een kunstuerk (in zoverre had dus wel een transformatle plaatsgewonden), maar tegelljkertijd was toch te weinitg van de persoon van Grindgens geabstraheerd. Op dezelfde redemering beruste een arrest nar anleiding van het toneelstuk Der Geist von obersut, warin een met name genoemde onderneming werd verweten de machtsovername van Hitler ondersteund en winst uit de oor log geslagen te hebben. Het Bundesgerichtahof achtte een ontoelaatbare schending van het persoonl1jkheidsrecht van de onderneming anwezig, ondat de kunstenar in zijn artistleke arbeld de realitelt - die de noodzakelifke bron van inspiratie $4 s_{\text {, dat }} 1$ niet voldoende had getransformeerd in kunst. Hij was integendeel op het niveau van de soclale werkelljkheid blijven steken en had de verbinding met de realiteit fulst als middel tot artistleke vorngeving ingezet (525).

Andere uftingen struikelen reeds over de vobrvraag: kunst of menligsulting en blijven op die manter van het voorrecht van een afweging op constitutioneel niveau verstoken. $Z 1 j$ moten met een gewone afweging langs de 11jnen van de wisselwerkingstheorle genoegen nemen. Zo llep ook een conflict af om het boek Unsere Siemens-Welt, waarin op satirische wijze de arbeldsomstandigheden in het gelljknanlge concern op de hak werden genomen. De gedagden werd verweten bewust meningsultingen, die onderworpen ztjn an de beperkingen wan art. $511 d 2$ GG, aan kunstultingen te hebben gekoppeld, die nlet a an beperkingen zoals in het tweede 11d genoend zifn onderworpen, on op deze manler de menthgsultingen an de normale toetsing te kunnen onterekken. Hoewel het Bundesverfasengsgerioht in het Mephisto-arrest heeft opgemerkt, dat het nlet gepast is bepaalde dellen van een boek, dat als kuntwerk lo erkend, ult de samenhang log te maken en als meningsutting te beschowien, achte de rechter het in het onderhavige geval toch geboden, de afzondet lijke omstreden ultingen te beoordelen naar het critertum of 2ij op het niveat van de soclale werkelijkheld lagen en zo jal deze het karakter van een kunstulting te 
ontzeggen, met als gevolg dat z1j aan de regels van de vritheld van menigsulting te meten waren(526). Wetzelfale lot als de onstreden gedeeltes in Unere Stemens-Welt onderging een afflche met de boodschap: "De cljken moeten nog rijker worden - daarom cDu". De rechter(527) overwoog dat nlet voldoende van de real1telt was geabstraheerd on van kungt te kunnen spreken. Het afflche was in de eerste plaats bedoeld als middel ln de polltieke strijd; het was verspreld tijdens dieelgtat verkiezlngen ( 528$)$.

Howel het warschijnlijk voor de ultgever van Mephioto van voordeel was geweest, als de roman als meningsuting in plaats van als kunstulting zou zijn beschond vanwege de betekents van het boek voor de openbare meningsvorming, in het geval van uncere siemens-Welt en ook in het conflict rond het affiche werd de bljdrage an de vorming van de publieke oplnie julat inlet belangrijk genoeg geache on tot bescherning van de meningsultingen over te gaan.

De bereltheid om een uiting toelaatbaar te achten is in het algemeen toch groter, als deze als kunst erkend wordc(529), zodat het de molte ward is te proberen eeri ulting als kunst te verkopen, ook al valt het voordeel van de wisselwerklngstheorle ln dat geval weg $(530)$.

\subsubsection{Communiatische meningsuitingen}

Nadat de geallieerden gedurende de eerste jaren na de Tweede Wereldow $10 g$ alle bestaande voorschriften op het gebled van de bescherming van de stat had opgeheven(531), zag de Bondsdag het als een van zijn eerste taken in de ontstane leemte te voorzien(532). Een belangr $1 \mathrm{jk}$ gedeelte van de nleuwe strafbepalingen, die in 1951 werden ingevoerd(533), was bedoeld on polltileke activiteiten te verhinderen, die de geweldioze omwenteling van de bestaande politieke orde in het vizier hadden inclusief die activitelten die het land voor de omwenteling rijp zouden moeten maken( 534 ).

Deze activiteiten werden gebundeld onder de nomer staatsgevariflk. De catalogus van voorschriften dle zulke activitelten strafbar stelden was zeer omwangrijk. Dit was een logisch ultvloeisel van het strijdbare karakter van de Westdultse democratle( 535 ).

Strafbar waren in de eerste plats activitelten, die waren gericht tegen de souverelnitelt van de Bondsrepubliek of tegen bepaalde beginselen van de constitutle, die deel van de frethetitiche demakratische Grundordnung ultmaken (par. 89-90a jo. 8B StGB), waaronder de oprichting van en verfasaungaverräteribche 176 verenlging vie1 (par. 90a 10. 88 StGB). Strafbar was 
verder de schending van een partijwerbod en de oprichting van een vervangende organisatie (art. 42 jo. 47 BVerfGG)(536). Ook was strafbaar het vervaardigen, vermenlgvuldigen, verbrelden of het met het oog op vermenigvuldiging, verbreiding in voorraad houden, betrekken of invoeren van verfassungeverriterische publicatles: geschriften, plaatopnamen, afbeeldingen en beschrijvingen, "durch deren Inhalt Bestrebungen herbelgefüht oder gefördert werden sollen, die darauf gerlchtet stad, den Bestand der Bundesrepublik Deutschland zu beelnträchtigen oder zur Unterdrückung der demokratischen Fretheit einen der in par. 88 bezelchneten Verfassungsgrundsätze zu beselltigen, ausser Geltung zu setzen oder zu untergraben" (par. 93 StGB) (537). De strafbaarheld van vervaardiging in de Bondsrepubliek zelf werd pas in 1953 toegevoegd(538).

Verder zijn te noemen: laster (Vommglimpfung) jegens de bondspresident (par. 95 StGB), jegens de staat en zljn symbolen (par. $96 \mathrm{StGB}$ ) en jegens staatsorganen (par. 97 StGB), alsmede de strafbaarheid van het in het openbaar, tijidens een vergadering en in geschriften gebruiken van kentekens van verboden verenigingen en partijen respectievelifk van voormalige nationalsoclalistische organisaties (pax. 96a StGB)(539). De meeste van deze bepalingen betekenden een beperking van de vrijheid wan meningsuiting.

Hoewel de voorschriften neutraal van opzet waren en ook ter bestrijding van nationaal-socialistische strevingen zijn toegepast( 540$)$, kregen aij onder invloed van de ontwikkellingen in de $D D R$ en de koude oor $\log$ een voornamelijk anticommun1stisch karakter. De bepalingen ter bestrifding van geweldloze maar desalniettemin staatsgevaarlifk geachte actiwiteiten werden samen met andere bepalingen ter bescherming van de staat ingezet In het kader van de vervolging van communisten, die tot 1968 heeft geduurd. Dankz⿺j veranderde inzichten, gestabiliseerde verhoudingen in de Bondsrepubliek zelf en onder Invloed van de algehele intermationale ontspanning tussen oost en West heeft in dat jaar name1ijk een herworming van het politieke strafrecht plaatsgevonden, waardoor aan de communistenvervolging de strafrechtelijke basis werd onttrokken( 541 ).

Tussen 1951 en 1968 werden door middel wan het politieke strafrecht communistische meningsultingen verregaand onderdrukt. Von Brünneck heeft de toenmalige praktijk minutleus geInventariseerd(542). Niet alleen van de bepalingen ter bestrijding van staatsgevaari1jke activitelten werd gebruik gemakt, men kon ook teruggrijpen op de voorschriften fnzake hoogverraad om staatsgevaarlijke meningen(543) te bestrijden. Strafbaar waren de voorberelding tot hoogverraad (par. 81 
StGB) en de wervardiglng en verbrelding van hoogwerraderlijke publicaties (par. 84 stGB). Zo vonden op grond van par. 81 StGB veroordelingen plaats wegens de verbrelding ran en de propaganda voor een door de KPD utgegeven progranma voor de nationale herenting yan Duth sland(544). Dat geschledde nog voordat de KPD verboden werd.

Von Brünneck toont aan dat de justltiele prakt 1 jk ten aanien van communistische mentngsultingea was geconcentreerd op de vervolging van commulstische persprodukten en andere publicaties en dat slechts hier en daar mondellnge menlngsultingen werden bestraft. Van enkele ultzonderingen afgezien ging het er de justltie bowendien an de vervolging te beperken tat menligsuttinger, die 1 in de politieke context van de KPD waren $\operatorname{gedaan}(545)$.

Centrale betekents had par. 93 StGB, dat zo werd ultgelegd, dat niet geschriften, die $z$ lch met de dagelijkse politlek bezlghlelden, mar alleen geschriften, die direct of indirect voor de invoering van het communistische systeem ierven, erdoor getroffen werden (546). Op grond van dit artikel was ook de invoer, opslag en distributie van alle In de DDR verschijnende polltieke publicaties, in het bijzonder de dagbladen en polltieke tijdschrlften, strafbaar(547). Dankzij het partijenprivilege vielen partijpublicaties van de KPD thot 1956 nlet onder de strafbepaling in par. 93 StGB. DLt veranderde echter door het KPD-verbod (548).

Door het KPD-verbod antstond na 1956 bovendien een extra mogelljkheld om communtstsche meningsultingen te vervolgen, namelijk op grond van het KPD-verbod rechtstreeks (ex art. 42 jo. 47 BVerfGG), doordat het Bundesgerichtshof onder de overtreding van dat verbod elke steun aan de KPD, "auf Irgendelne Welse" gedaan, verstond(549). Beslissend was de intentile of een ulting gedragen werd door de wll daardoor de KPD te ondersteunen (550). Ook menlngsultingen die niet met par. 93 StGB in strijd waren konden zodoende strafbarar $z 1 J n(551)$. Deze uft het KPD-verbod afgelelde strafbaarheid trof aanvanke $1 \mathbb{j k}$ vooral ult de DDR afkomstige publicaties, later echter ook Westdultse communisten, die weer waren overgegaan tot de ultgave van elgen t1jdschr1ften ( 552$)$.

Ower de grondwettlgheld van de aan art. 42 BWerfGG gegewen ult leg bestonden grate twijfels, mar in 1969 bevestigde het Bunderverfargungsgemint de prakt ij $\mathrm{k}$ in grote 11 jnen. Het voorschrift, dat vervolging van meningsultingen als overtreding van het KPD-verbod toestond moest als een algemene wet, dile de vrifheld van menlngsulting beperkte, weliswar in het 1 icht van de bijzondere betekenis van dit grondrecht worden 
uitgelegd: "Dile strafvorschrift schüzt wor allem .." die frelheitliche demokratische Grundordnung. Fur sie ist aber die Melnungs frethelt schlechthin konstitulerend. Wenn gerade dieses Grundrecht zurückstecken soll, dann wuss dies durch besondere Notwendigkelten dieser ordnung gerechtfertigt sein"(553) - maar dle biljzondere noodzalk, de bescherming van de stat door middel van een partijverbod, was hier anwezig. Omdat het partijverbod een objectief gevaar wilde afweren warem niet alleen matregelen tegen leden van de verboden part j of van een vervangende organlsatie geoorloofd, maat ook tegen buitenstaanders die meningen utten, die gelljk waren aan die wan de verboden partij.

Wel knoopte het Bundesverfassungsgericht aan het door het Bundeageriohtahof toegepaste intentiecriterlum nog de voorwaarde vast, dat de ulting een onalddellijk ondersteunend effect moest hebben(554). Het hoefde echter geen van de aangevochten veroordelingen(555) wegens niet-lmachtneming van deze voorwarde op te heffen. Overlgens had de ultspraak van het Bundeswer fassungsgericht geen praktische warde meer, omdat het woorschrift in 1968 reeds was afgeschaft.

Behalve dat de lavoer en de distributle van oostduitse publlcaties op grond van par. 93 stcB strafbar was, bestond bovendlen de mogelijkheid on de uit de DDR afkomstige communistische stroom van publicaties, vooral kranten, aan de grens te confisqueren(556) en reeds daardoor versprelding in de Bondsrepubliek te verhinderen. Dit rechtsmiddel was met name zeer praktisch, omdat het ook mocht worden ingezet als geen bepalde persoon vervolgd of veroordeeld kon worden (557). Van de nadellge gevolgen die de rigoreuze handhaving van de confiscatiepraktijk had, speciaal ook vanuit het oogpunt van de behoefte die in de Bondsrepubliek bestond an informatie uit het oostblok zelf over de ontwikkelingen aldaar, werd men zlch pas langzamerhand bewust. Nadat het Bundeagerichtshof reeds in 1964 de Invoer van communistische lectuur had mogel1 jk gemaakt als een gerechtvaardigde behoefte an Informathe bestond(558), duurde het nog tot 1969, voordat het Bundesverfassugsger lcht de confiscatle van een 0ostdultse krant voor ongrondwettig verklaarde(559). Een ulteg van de configcatiebepalingen $1 \mathrm{n}$ het 1 lcht wan de bljzondere betekents van de informatlevrijheld voor de democratle lefide tot de conclusie dat door de confiscatle de Informatlevrijheid was geschonden van de abonnee van de Leipziger VolkBgeztung, welke abonnee 1 mex "nach der Vorstellung des Grundgesetzes mündig und dazu berufen 1st, an der öffentlichen W11Lensbildung te11zunehmen" $(560)$. De ultspraak wan het 
Bundeaverfabungagericht was wederom mosterd na de malltyd; de wetgever had de conflscatiemogelifkheld reeds in 1968 afgeschaft $(561)$.

De schiechthin konstituierende betekenis wan de informatlevrljheld vanwege haar rol in de openbare meningsvorming was voor het Bundesverfarsungsgemicht echter geen reden om de eveneens bestaande controle op de Invoer van fllms - wit het Dostblok - als ongrondwettig te beschouren( 562$)$. Alle in de Bondsrepubliek Ingevoerde fllms moesten volgens het Vebemochungsgebetz wan $1961(563)$ ter goedkeuring an een interdepartementale beoordelingscomissle worden voorgelegd. F11ms warvan vervolgens werd vastgesteld, dat $z 1 j$ qua lnhoud geschlkt waren als propagandamiddel tegen de fretheitliche demoknatische Grundordnung (of tegen de gedachte van de toenadering tussen de volkeren - art. 5 11d 1), kregen een distrlbutieverbod opgelegd (art. 5 lid 4 ). Tussen 1961 en 1966 werden 28 van de circa 1800 voorgelegde films door zo" nerbod getroffen (564), alle afkomstig uit de DDR en oost-Europa. Het Bundegverfassungsgemicht besloot in 1972 dat de rege11 ing niet ongrondwettig was, $z 1$ j het dat het criterlum op grond warvan tot een verbod kon worden overgegaan restrlctief most worden ultgelegd(565). De regellng werd niet in strijd geacht met het censuurverbod van art. 5 lild $1 \mathrm{GG}$ ("Eine Zensur flndet nicht statt"), ondat d1t slechts een verbod van cansuur vooraf inhoudt. Alleen "elnschränkende Massnahmen vor der Herstellung oder Verbreltung elnes Gelsteswerkes, Insbesondere das Abhäng1gmachen von behördlicher Vorprüfung und Genehnigung selnes Inhalts (Verbot mit Erlaubnisvorbehalt)"(566) zijn op grond van het censuurverbod onrechtmatig. Als het geestesprodukt eenmaal 1 in de openbaarheld is gekomen, dan gelden de normale regels betreffende de vritheld van meningsulting en ook de beperkingsmogel1.jkheden ex art. 5 11d 2 GG. Deze zouden volledig uttgehold zijn als censur achteraf eveneens verboden zou $21 j n(567)$.

De pllcht om eren film aan de bevoegde autoritelten voor te leggen, overwoog het Bundesverfassungsgemicht, was vanut deze Invalshoek gezien geen censuurnatregel, omdat zij de filmagent niet verhinderde de film te publiceren en te distribueren totdat een eventueel. verbod werd ultgesproken (568). Dat bloscopen het nlet aandurfolen een flim te draaten voordat hif was goedgekeurd, zodat de procedure an censuur gell Jk kwam, vond thet Bundesverfassungsgemicht nlet relevant(569). De rechters Rupp-von Brimneck en Simon zagen daarentegen in de regeling wel een ontoelaatbare beperking van de vitheid van meningsulting, omdat zij wel erg veel 180 op censuur vooraf leek(570). In hun afwijkende mening. 
wezen $21 j$ er bovendien op dat de fundamentele betekenis van dit grondrecht voor de democratie het hun inziens niet toeliet de spanning, die bestaat tussen de noodzaak de staat te beschermen en de politieke vritheldsrechten in het onderhavige geval en iberhaupt al te snel in het voordeel van de eerste te slechten:

"Nach dem Wertsystem des Grundgesetzes dient eben der politischen Staatsschutz nicht der Absicherung irgendeiner beliebliger, sondern ganz speziell derjenigen polftischen ordnung, für die Mefinungs-, Presse- und Informationsfreiheit konstitutiv sind. Daraus folgen im Berelch des polftischen Staatsschutzes unverkennbare Schwierigkelten, die thn von Vorschriften zum Schutz anderer Rechtsgüter charakteristisch unterscheiden: Je perfekter der Schutz wird, je stärker also jene Grundrechte elngeschränkt werden, desto mehr wächst die Gefahr, dass ungewollt das Schutzobjekt selbst erstlckt wird" $(5,71)$.

De onderhavige regeling vonden belde rechters ook praktisch gezlen welnig zinvol ter bescherming van freiheitliche demokratiache Grundordnung, ondat het toch niet mogelijk is deze te verdedigen door de ogen en oren van de burger - die toch als mondig wordt beschouwd - voor van bulten komende favloeden te beschermen $(572)$. Zij werd overigens twee jaar later, in 1974, door de wetgever opgeheven(573). Niet opgeheven werd de rest van het Uebemuahungsgesetz, waarvan de regeling deel ultmaakte. Op grond hlervan hebben de douaneautorfteiten nog altijd de taak ervoor te zorgen, dat geschriften worden tegengehouden, waarvan de Inhoud een overtreding oplewert van een strafvoorschrift dat invoer of distributie uit overwegingen van staatsvelligheld verbiedt. De met de naleving van deze taak samenhangende controle levert volgens het Bundesverfassingsgemicht geen ontoelaatbare beperking van de informatievri jheid op (574).

De jurisprudentle toont aan, dat het Bundesverfassungsgericht in de pertode tussen 1951 en 1968 geen stokje heeft gestoken voor de vervolging van communistische meningsultingen op grond van de overweging dat de strafvoorschriften die dit mogelijik makten in het licht van de sohtechthin konstituierende betekenis van de vril jheld van meningsulting een ontoelaatbare beperking van het grondrecht zouden opleveren. De enige keer dat het Bundesverfasoungegericht zover ging - ten behoeve van de Informatievrijheid - was de vaststelling nutteloos, omdat de wetgever door middel van de hervorming van het politfeke strafrecht in 1968 de discutabele bepalingen al had afgeschaft. Deze hervorming ging vergezeld van een algehele amnestie(575). 
De metgever heet echter met de hervorming net het princlpe van de strijdbare denocratie ook ln het polltleke strafrecht opgegeven. Zo 1 s de voortzetting van een ongrondwettlg verklaarde partij en de schending van een vereniglngsverbod onverminderd strafbar gebleven (par. 84 en 85 StGB). Hlerult volgend 1 s (voor de vrltheld van meringsulting relevant) het wersprelden wan propagandariddelen van ongrondwettige organ1satles strafbaar gesteld (par. $86 \mathrm{stGB}$ ) , sinds 1974 met de regtrictie dat deze bepaling niet is aan te wenden tegen kranten en tijdachriften die buiten de Bondsrepubliek regelmatlg verschljnen en daat algemeen en openbar worden. ged1stribueexd(576). Onder propagandamiddelen worden geschrlften verstaan, warvan de Inhoud tegen de fretheittiche demokmatische Grondorinung 1 is gericht. Bovendlen $1 \mathrm{~s}$ in par. 86 11d 3 StGB de zogenaamde SozialadaquanzkLasel opgenomen: dat w1 zeggen dat geen strafbarheid bestaat, als het propagandamiddel of de handeling de stats burgerll jke voor1llchting, de afweer van ongrondwettlge strevingen, de kunst of de wetenschap, het onderzoek of het onderwils, de bertchtgeving over actuele of historlsche gebeurtenfssen of dergel1jke doelen dient (577).

Nast par. 86 StGB is in par. 86 a stgB de in 1960 ingevoerde strafbaarheld blijven bestaan van het $\mathrm{in}$ het openbaar, tIjdens vergaderingen en in geschriften gebrulk maken van kentekens van ongrondwettige organisaties $(578)$.

In gemodifflceerde vorm zifn ook de beledigingsdelicten, die de bondsprestdent, de stat en de constitutionele organen op het oog hebber (par. 90, 90a en 90b StGB), b1ljwen bestaan.

De KPD bleef ook na 1968 verboden en het Bundesgepichtehof beval zelfs in 1975 nog de conflscatle van een nieuw ultgegeven partijprogramm van de verboden KPD (579), steunend op de nieuwe par. 86 StGB, maar de oprichting van een nleuwe communistische partij in de herfst van 1968, de Deutache Kommuistibche Partei, werd niet verhlnderd.

\subsubsection{Neo-nazistiache meningsutingen}

Door de toenemende popularltelt van de neo-nazi"s heeft de strijd tegen meningsultingen met nationalsoclalistische strekking aan betekenls gewonnen. Deze strljd wordt gevoerd met behulp van de strafbepallngen dle de vervardiglng, de distributie en de invoer verbleden van propagandamiddelen, die qua lahoud bedoeld zifn, strevingen van een vormalige nationaal-soclalistische organlsatle woort te zetten (par. 86 1id 4 182 sub 4 stGB), alsmede het gebrulk van kentekens van on- 
grondwettige organfsatles (par, 86a StGB). Op beide bepallngen is de boven genoemde Sazialadäquansklauset ran toepasslng. Twijfel kan bestaan of deze voorschriften algemene wetten $z 1 \mathrm{jn}$ in de zin van art. 5 11d $2 \mathrm{GG}$, omdat $z 1 \mathrm{j}$ bepalde meningen verbleden. Ten anzien van par. 86 StGB heeft het Bundeagementishof in leder geval verklaard dat deze bepaling grondwettig is, aangezien zij uitrloelsel is van de in axt. 21 lid 2 Go ultgedrukte keuze tussen vril jheid van meningsuiting en de behoefte aan bescherming van de frethettiohe demokmatieche Grundordnung in het voordeel wan de laatste $(580)$. Conform de in het KPD-arrest genoende crlteria, die voor een partijuerbod gelden, moeten deze propagandamiddelen dan wel een agressieve tendensi hebben; doorslaggevend is, of $z 1 \mathrm{f}$ qua inhoud geschikt aifn in het algemeen voor het national-soclalistische regime te werven en $\mathrm{zl}$ jn ldeologie te verheerlifken. De tmhoud van een drukwerk of een plaatopname moet werkelijk tot doel hebben strevingen van een voormalige national-soclalistische organisatle voort te zetten(581), wat bijwoorbeeld het geval is als een nieuwe "Fihrerstaat" wordt geëist of tegen joden wordt opgehitst(582). Het in het openbaar aanbieden van v6бr 1945 gedrukte exemplaren van het boek Mein Kampf is nilet strafbaar, omdat een boek uit dle tijd nog niet tegen de sinds 1949 pas bestaande freiheitliche demokratische Grundordnung kon zijn gericht(583).

Als ongrondwettige kentekens in de $z$ in wan par. $86 a$ StGB zijn beschouwd: de buste van HAtler(584), het zingen wan het national-socialistische Horst Wesse1lied(585), het gebruik van de tiljdens het Derde Rijk gebrulke1ijke groet(586); net zo min is de kreet "Hefl Hitler" geoorloofd(587). Het gebruik van het hakenkruis is eveneens verboden, ook als het op kinderspeelgoedvliegtuligjes is aangebracht; het verbinden van vriendelijke assoctaties met dit teken moet worden voorkomen (588). In beperkte mate geoorloofd is het gebrulk echter, als daarmee julst wordt uitgedrukt dat men tegenstander van de achter het hakenkruis schullgaande ldeologie is(589), bijuoorbeeld als het de karikaturistische afbeelding van een menselijk lichaam In de vorm van een hakenkruls betreft (590). Geoorloofd was ook het uitstallen van national-soclallstische kentekens in het kader van een velling, die was georganiseerd door een international erkende specta11st op dit gebled(591).

Tegen joden gerichte meningsultingen kunnen niet a1leen op grond van par. 86 lid 4 sub 4 StGB, maar ook op grond van het delict volksopruling (Volksverhetzung, par. $130 \mathrm{StGB}$ ) worden vervolgd, namell jk als ze tevens geschikt $z i j n$ de openbare orde te verstoren, 
bijvoorbeeld de opmerking in een ingezonden brief aan een krant dat een dode jood een goede jood 1s(592), of het bekladden van een verkiezingsaffiche van een kandidaat voor het burgemeesterschap met het woord jood en de eis dat alle joden van openbare ambten moeten worden bultengesloten(593), maar niet een pamflet, waarin het vermoorden van joden in het Derde Rijk een leugen wordt genoemd, omdat deze bewering nilet wan kwallficerende opmerkingen tegenover de joden vergezeld ging(594). Tegen zulke opmerkingen kan dan well een aanklacht wegens belediging worden ingediend(595).

\subsubsection{Meningsuitingen betreffende het thema gewezd}

Het justitielle optreden tegen neo-nazistische meningsuitingen wordt algemeen geaccepteerd. Anders ligt dat met de alanwending van strafvoorschriften, die de vrijheid van meningsulting beperken, in samenhang met de bestrljding van het linksextremlstische terrorisme, in het centrum warvan de Rote Ammee Fraktion stond. In het middelpunt van de kritiek heeft de herontdekking gestaan van de bepaling die belediging van de staat en zljn symbolen strafbar stelt (par. 90a StGB)(596). Maar ook het speclaal met het oog op de toenmalige actuele situatle gecreëerde delict atlconstitutionele bepleiting van strafbare feiten (verfiassungsfeindliche Befïrwortung von straftaten - par. 88a StGB) heeft een controversleel bestaan geleid, totdat de bepaling in 1981 weer werd ingetrokken. De activiteiten van de Rote Armee Fraktion hadden de wetgever er in 1976 toe gebracht dit artikel in te voeren samen met enkele andere voorschriften, zoals éen betreffende de vorming en ondersteuning van terroristische verenigingen en de werving ervoor (par. 129a StGB)(597), de aanvulling op een reeds bestaande strafbepaling met betrekking tot criminele verenigingen in het algemeen (par. 129 StGB). Dok deze beide laatste bepalingen hebben hun invloed op de vrlfheld van mentingsulting vanwege de strafbaarstelling van werving, waartoe de leuzen "Leve de RAF" en "de RAF zal overwinnen" worden gerekend (598).

Uit par. 88a StGB blifkt het duldelijkste het motief achter het optreden tegen bepalde meningsultingen in verband met de bestrijding van het terrorisme. Men wilde nameliflk voorkomen dat in de Bondsrepublitek een politlek klimat zou ontstaan, warlin gewelddaden zouden gedtjen en worden nagevolgd. Met par. 88a StGB wilde men meningsultingen verhinderen, die de bereidheid julst van jonge mensen zou kunnen bexorderen, het gebruik van geweld als toelaatbar polltiek middel te 
beschouwen(599). Deze bepaling moest het instrument $z 1 \mathrm{jn}$, warmee reeds in een vroeg stadium met strafrechtelijke middelen zou kunnen worden opgetreden tegen geweldacties, die de openbare orde zouden verstoren (600).

Strafbaar was, wie een geschrift, warin een dellet met een sterk gewelddadig karakter $(601)$ werd bepleit, en dat er toe bestemd was alsmede naar de onstandigheden geschikt was, bij anderen de bereldheid te bevorderen, zich door het begaan van zulke delicten voor strevingen tegen de bestendigheid of de velligheid van de Bondsrepubliek of tegen constitutionele beginselen in te zetten, 1. verbreidde, 2. in het openbaar tentoonstelde, aansloeg of op andere wijze toegankelijk makke of 3. produceerde, betrok, leverde, in voorraad had, a anbood, aankondigde, aanprees, poogde in te voeren of ult te voeren, on dit geschrift of delen daarult in de zin van de nummers 1 of 2 te gebruiken of lemand anders het gebruik mogelijk te maken(602). Wat onder deze delictsomschrijuing zou kunnen worden verstaan deed een regeringsvertegenwoordiger tijdens de parlementalre behandeling van het wetsontwerp uit de doeken; bepleiting van geweld kon geschieden door middel van indirecte uftnodiging, schifnbare distantiëring, beschrifving van strafbare handelingen met nawolgingseffect, de goedkeuring van een historlsche gebeurtenis met het doel deze gebeurtenls te presenteren als een voorbeeld dat het navolgen waard was, de aankondiging of voorspelling van gewelddaden tnet de ondertoon dat deze het navolgen waard waren en het afdrukken van vreemde mentngen (die de auteur zich elgen makkte) om een bepaalde indruk te bewerkstelligen (603).

De bepaling had een uitstraling die ver uitging boven het elgenlijke doel, namelijk de bestrijding van het terrorisme. Het venijn zat vooral in de mogelijkheld die door par. 88a StGB geschapen werd on tot Inbeslagname en huiszoeklingen over te gaan op grond van de enkele verdenking van overtreding van par. 88a StGB. Het gevolg was, dat ook boeken 1 in beslag werden genomen, die met de beplefting van geweld weinig meer te maken hadden, zoals een documentatie over onlusten in het Chlicago van 1886 en een dissertatie over derde-wereld-vraagstukken. Men vroeg zich af of par. 88a StGB. niet de deur opende voor een soort censurr vooraf (604). Deze inbeslagnamepraktijk kwam overigens sinds het voor jaar van 1978 , na massale kritlek en het afzwakken van de golf van terrorfstsche aanslagen, die In 1977 zi jn hoogtepunt had berelkt, niet meer voor. Van de 103 tot medio 1979 ingestelde voorlopige onderzoeken op grond van par. 88a StGB werden ex 85 wegens 
gebrek aan bewljs gestaakt. Aangeklaggd werden ultelndelijk zeven personen, warop slechts in vijf gevallen cen veroordeling in eerste instante volgde(605). Een reden voor de geringe effectivitelt wan pat. $88 \mathrm{a}$ st6B 1 ag ln de dubbele voorwarde, dat zowel strafbare felten bepleit als antconstitutionele strevigen tegen de Bondsrepubllek of de fretheitziche denokrat 2 che swundordnung bevorderd moesten worden. War die dubbele voorwaarde in vervulling glng was bovendlen de auteur vak onbekend of kon nlet worden bewezen dat de boekhandelaars, die de publicaties verkochten, van de Imhoud op de hoogte waren(606). Omdat par. $88 \mathrm{a}$ StGB in de prathilfk geen extra middel ter bestrijding van het terrorlsme bleek te $21 j n$ en tot moellijkheden had gevoerd In samenhang met hulszoekings- en inbeslagnamematregelen, zodat per saldo de rechtszekerheld er niet op voorult was gegaan, werd de bepaling in 1981 weer afgeschaft (607).

Belangrijk voor het onderzoek is de constatering, dat het Bundeggenichtahof par. 88 a StGB, ondanks alle deels constitutionele-bezwaren die tenslotte weer tot de afschaffing hebben geleid, niet als een ontoelaatbare beperking van de vrljheld van meningsulting beschouwde. Lapldalr gtelde het wast dat par. 88 a StGB een algemene wet in de 2 in van art. 5 ild 2 GG was en dat voldoende rekening was gehouden met de uitstra1Ingswerking van art. $511 \mathrm{~d} 1 \mathrm{GG}$, doordat par. $88 \mathrm{a}$ 11d 3 StgB het strafwoorschrift in $z$ lifn werking beperkte door de regeling dat de Sozialadäquanzk Lausel van par. 86 lid 3 StGB ook op par. 88 a stGB van toepassing was $(608)$.

Het Bundesverfassungsgerlcht heeft geen gelegenheld gehad zlch over de grondwettigheld ult te spreken.

Tegen de achtergrond van de vrees dat de samenleving in gevaar wordt gebracht doordat een psychlsch klimat wordt geschapen, waarin zware gewelddadien gedijen (609), moet aok de toepassing worden gezlen van par. 140 StGB, die de goedkeuring wan geweldsdelicten op een wljze die geschlkt is de openbare orde te verstoren strafbaar telt(610). Zo werd in 1975 in de Bondsrepubliek net boek the alles anfing in beslag genomen. Hierin beschrijft de ex-terrorist Michael "Bommie" Baumann $z i j n$ ontwikkeling tot stadsguerlllero, mar ook hoe hlj ulteindelljk het terrorisme de rug toekeerde. De ultgever van het boek werd vervolgd ex par. 140 StGB, maar in 1978 door het Bundesgerichtshof vr1Jgesproken(611). Dat deed nlet af an het felt dat het boek zelf moest worden beschouwd als een goedkeuring van geweld, hoewel het hoofdzakelifk gebeurtenissen beschreef, en we1 "well der Darstellende, teils 
erklärter sympathlsant der Täter lst und sich nicht ausdricklich von den Taten distanzlert", aldus het Bundesgerichtshof in een eerdere ultspraak(612). In dit geval betekende het zich niet uitdrukkelijk distantiêren dus al goedkeuring van geweldsdelicten(613). of ook het ultgeven van een dergelijk boek zonder voorafgaand commentaar een strafbaar felt is llet het Bundeagenichtahof, onverlet de vrijspraak in het anderhavige geval, in het midden(614), zodat uitgevers van zulke boeken zich nog steeds aan een risfico blootstellen(615). Desondanks is het boek opnieuw ultgegeven en heeft de justitie geen actle meer ondernomen. Met een beroep op zowel de par. 88a, 140 als 129 a StGB werden vier personeelsleden veroordeeld van een drukker $\mathbb{1 j}$, waar een informatiebulletin was gedrukt met RAF-teksten erin opgenomen(616). Hen werd verweten de teksten klakkeloos te hebben afgedrukt. Hoewel het Bumdeagerichtshof erkende dat het uitbreiden van de strafbaarheld (door middel wan medeplichtigheld) ook tot personen die binnen het drukkerljbedrijf slechts bij de technische vervaardiging van een geschrift meewerken, problematisch kan $21 \mathrm{jn}(617)$, hief het de veroordeling ntet op. Een beroep op de persvrijheid hielp de drukkers niet. Het doel van dit grondrecht, een volledige vrije discussie in de openbaarheid moge$11 \mathrm{jk}$ te maken, maakt publicaties, "die sich nach Form und Inhalt als verfassungsfeindliche Befurwortung von Straftaten und als Bllligung von Straftaten sowle als Werbung für terroristische Verelnigungen darstellen" nog nlet tot een toelatbare berichtgeving van een persorgaan $(618)$.

\subsubsection{Het aanzien wan de staat}

Door par. 90a StGB wordt het aanzien ran de staat en zijn symbolen bescherma. Het eerste lid luidt als voligt:

Wer öffentlich, in einer Versammlung, oder durch Verbreiten von Schriften (par. 11 Abs. 3)

1. die Bundesrepublik Deutschland oder elnes threx Länder oder thre verfassungsmäsigige ordnung beschlimpt oder böswillig verächtlich macht oder

2. die Farben, die Flagge, das Wappen oder die Hyme der Bundesrepublik Deutschland oder elnes ihrer Länder verunglimpte,

wird mit Fretheitsstrafe bis zu drel Jahren oder mit Geldstrafe bestraft.

In het tweede lid wordt de verwijdering, vernietiging. en beschadiging van een in het openbaar getoonde vlag of andere in het openbar angebrachte officlele tekens strafbaar gesteld. 
Dit strafvoorschrift kan bogen op een rifke geschledenls en heeft alle statsordes gedfend, die Dultsland deze eew heeft gekend, zij het steeds angepast an de specifleke omstandigheden(619). Het heeft de hervorang van het polltieke strafrecht van 1968 overleefd en mag zich sinds 1972 meer in een bijzondere popularitelt verheugen. Sinds die tifd is het hoofdzakel1jk tegen 11nksextremistische menlngsultingen ingezet $(620)$.

De afschaffing van de bepaling is meermals bepleit wegens bedenkingen van const1tutionele aard(621). Het Bundesverfabaungrgertaht heeft beslist dat in leder geval par. $90 a$ lid I StGB nlet in strijd is met het grondrecht op vrijheld van menlngsulting en een algemene wet is ln de zin van art. $511 d 2 \mathrm{GG}$

"Sle richtet slch nicht gegen eine bestimnte Melnung, sondern stellt jeden unter strafie, der - unabhänglg von elner polltischen Ueberzeugung - öfFentlich die Bundegrepublik Deutschland oder thre ver fassungsmässige ordnung herabwürdigt. Dabel ist Jedoch par. 90 a $5 t G B$ In Lichte der besonderen Bedentung des Grundrechts der Frefen Melnungsäusserung für den fretheitlichen demokratischen Rechtsstaat auszulegen"( 622$)$.

De argumentatie van het Bundesverfasmungigemicht is dus, dat par. 90a nlet tegen een bepalde menting is gerlcht, ondat het voorschrift an ledereen het ulten van deze mentng verbledt, onafhankelljk wan $z 1 j n$ overtulging. De bepallng is evenwel volgens de critcici (623) we1 tegen een bepalide menlng gerlcht, nameli jk tegen een menling die de staat beledigt. Bowendien kan men stellen dat par. $90 \mathrm{a}$ StGB geen algemene wet 1 s, als het beschermde rechtsgoed iberhaupt slechts door meningsultingen kan worden geattacqueerd, zaals blj het aanzien van de staat het geval is, want in het Luth-arrest heeft het Bundesverfassungsgemicht juist gezegd dat een wet die een mening als zodanig beperkt, ontoelaatbaar $1 \mathrm{~s}$. Vandaar dat bij belediglngsdelicten jegens personen alt $1 \mathrm{jd}$ nog kan worden teruggegrepen op de $1 \mathrm{n}$ art. $511 \mathrm{~d} 2 \mathrm{GG}$ opgenonem beperkingsmogeli jkheid cen behoeve wan de bescherning van het recht inzake de persoonllfke eer, watwoor de formele voor warden van de lgemene wetten nlet gelden.

Voot de bescherulng van het anzlen van de stact bestat deze ultandering echter nitet. Grinuald concludeert darult, "dass es elnen Ehrenschutz filr den Stat oder fü Institutionen nicht geben darf"(624). Door par. 90a StGB ondanks de aangevoerde bezwaren als een lgemene wet te beschouwen heeft het Bundeaverfabsungagemicht de grondwettigheld van deze bepallng, die 18 6 bllykbar en rechtsgoed beschermt, dat tegenover de 
ultoefening van de vritheld van mentngsulting de voorrang verdlent, bevestigd.

Het doel van par. 90a StGB is het aanzien van de stat bij zljn burgers te beschermen(625). of door de strafbaarstelling van meningsultingen met bespottende of verachtelijk makende inhoud jegens de stat dit affect wordt berelkt, wordt echter betwijfeld. De dader zal In $z$ ijn veroordeling ererder een bevestlgling zien ran zijn mening over de Bondsrepubliek, luidt de kritlek, terwijl het voorschrift als zodanig de twijfels van de burgers voedt of de stat het grondrecht op wrije meningsuiting wel respecteet (626).

Zowel het aanzien van de staat als de rechtsorde worden tegen beledigende ultingen beschermd. Het onderscheld is van weinig praktisch belang. Enerzljds wordt de stat slechts beschermd in zijn gedante als vife representalleve democratie(627), anderzllow wordt het belasteren van de fretheitithe demokmatische Grundordnung ook als het belasteren van de staat gezlen (628). Stat en rechtsorde vormen dus miln of meer een eenheid. Voorzover de frotheititohe demokratioche Grundondrung door dit voorschrift in bescherming wordt genomen, is par. 90a StGB een rellct uit de tijd voor de hervorming wan het politleke strafrecht. vo5r 1968 ging men ervan ult dat tegen de freiheitliche demoknatische Grundordnung gerlchte mentngsultingen altijd strafbaar waren(629), terwlj1 sindsdien de mening veld gewonnen heeft, dat tegen de fretheittiche demokmatisohe Grundordnung gerlchte menlngsuitingen via een verenlglings- of partijuerbod of via grondrechtsverwerking dilemen te worden tegengegaan. Het strafrecht zou slechts als hulpmiddel ter naleving van zulke matregelen in aanmerking komen(630). Inderdaad heeft een beroep op het partijenprivilege in geval van vervolging wegens overtreding van par. 90a StGB regelmat1g succes(631), maar de mogelifkheid zulke meningsultigen te bestraffen wordt door par. $90 \mathrm{a}$ stGB ndet princlpileel verhinderd (632).

Met een beroep op het Radikalen-arrest, warin het Bundesverfassungagemicht heeft vastgesteld, dat het partifenprivllege van art. 21 ild 2 GG een vaststel$1 \mathrm{ing}$ en rechterlijke beoordeling van anticongtitutionele strevingen van een nog niet verboden partij nitet In de weg staat (633), heeft het Bundesgepichtohof bepaald dat art. 21 11d $2 \mathrm{GG}$, dat aan het Bundegverfassungsgemicht het monopolle om een partijverbod ult te spreker toekent, geen rechtvaardiglingsgond is in geval van overtreding wan par. 90b stGB (Vemfasoungsfeindliche Verunglimpfung von Verfassungsorganen) door een partij of in partijverband(634). Men kan aannenen dat hetzelfde geldt voor par. 90a StGB, aangezien voor 
dit delict niet eens verelst is, dat de meningsuiting anticonsticutioneed moet $z 1 \mathrm{~J} n$.

Van wб6̈r 1968 en vбةr het Lith-arrest dateren nog veroordelingen vanwege de meningsulting, dat het staatscomplex van Bonn er utzag als een frisgeschilderde Coca-cola kiosk(635), en de menlngsulting dat een stad die bepalde matregelen ten ultwoer fiag brengen geen rechtsstat reer 1s, maar een onrechtsstaat 1 s (636). In deze belde gevallen kwamen de mentngsuitingen over 1 gens ult de rechtsextremistische hoek.

In het Unrechtobtad-arrest heeft het Bundesgemichtshof een belangrijke beperklng gesteld an wat onder een bespotting in de zin van par. 90a StGB moet worden verstaan, met als gevolg dat alleen de overtulgde systeencritici worden blootgesteld aan criminalisering: een meningsulting is nlet beledigend, als zij ult treve1, onnademkendheid of oppervlakklgheid voortspirult, zonder dat de strekklng van de uitung volledig begrepen 1 s $(637)$.

In recenter $t 1 \mathrm{jd}$ is het betitelen wan de Bondsrepubllek als staat wan onderdrukkers en van de bondsdagverklezlngen als oplichterstruc goed geweest voor een veroordellng, evenals de bewerlng dat $1 \mathrm{n}$ de Bondsrepubliek wllekeur en terreur heerst, dat de staat, de politie en de justitle alch niet aan wet en recht houden en dat de Bondsrepubllek geen rechts- maar een onrechtsstat is, warop men niet trots mag $z 1 j n(638)$. Volop 1 n de belangstelling kwar par. $90 a$ StGB te staan toen op het hoogtepunt van de terroristische beweglng in 1977 de Mescaleroaffatre de gemoederen in bewegling bracht(639). Deze affalre toont, hoe verschillend aan de hand wan én enkel strafvoorschrift de bijzondere betekenls van de vrijheld van mentngsulting voor de denocratle wordt gewardeerd. Ondertekend met de naam Mescalero werd in aprl1 1977, enkele weken na de moord op Siegfried Buback, de procureur-general van het Bundesgemichtehof te Karlsruhe, in het tijdschrift van het studentenparlement te Göttingen een in memorlian voor Buback gepubliceerd. Het begin: "Meine unmittelbare Reaktion, meine "Betroffenhe1t" nach dem Abschuss von Buback ist schmell geschildert: Ich konnte und wollte (und will) eine klammelmilche freude nicht verhellen. Ich habe diesen Typ oft hetzen hören, lch welss, was er bel der Verfolgung, Kriminalisterung, Folterung von limken fü eine herausagende Rolle spie1te. Wer sich in den letzten Tagen nur elnmal genau sein konterfiel angesehen hat, der kann erkennen, welche zuge diester Rechtsstat trät, den er in so hervorragender Welse Werkörperte. Und der kennt dan auch schon eln par zïge von den Gesichtern jener aufrechten Demokraten, dle Jetzt wle eln Mann empört 
wind betroffen aufschrelen"(640). Hij kwam na ver 1 wikken en wegen tot de conclasle dat geweld geen zinwal middel is on de samenlewing te veranderen: unser Zweck, elne Gesellschaft ohme Terror und Gewalt (wenn auch nicht ohme Agression und Milltanz), elne Gesellschaft ohne Zwangsarbeit (wenn auch nicht ohne Plackerel), elne Gesellschaft ohne Justiz, Knast und Anstalten (wenn auch nicht ohne Regeln und Vorschriften oder besser: "Emptehlungen) dieser 2 weck heillgt eben nicht jedes Mltel, sondern nur manches. Unser Weg aum Sozlallstaus (wegen mir: zur Anarchle) kann nicht mit Lelchen gepflastert werden"( 641$)$.

Een aaklacht volgde wegens Verunglimpfung van de herinnering aan een gestorvene (par. 189 StGB). In het vooronderzoek werd onder meer ook par. 90 a StGB betrokken. Het incident groelde ult tot een nationale affalre toen na een golf van verontwardiging in de pers over het artikel en na een grootscheepse hulsaoking bif de leden van het studentenparlement het art1kell in het gehele land door ongeveer honderd groepen en individuen werd gepubliceerd, meestal om de burger te informeren, waarom het nu elgenllik ging. Onder hem bevond zlch een groep van 47 professoren en advocaten uit Berlijn en het noorden van de Bondsrepubliek. 21j publiceerden het artikel als document, omdat de volledige tekst nergens was afgedrukt en de in de pers gectteerde brokstukken naar hun mening geen recht deden aan de intentie van het artikel - de afwijzing van geweld. Z1f verklaarden dat de onderdrukking en de vervolging van het artikel zelf ultarukking was van de in de samenleving heersende moral ten aanzlen van geweld: "Wahrend jeder Ansiatz sozialistischer Krlt1k und Praxis erstickt werden soll, können sich faschistolde Tendenzen ungehlndert breitmachen"( 642 ).

De schrijwer van het artikel werd wegens Verunglimpfung van het aandenken aan een gestorvene veroordeeld, omdat zijn ultingen die Buback als persoon betroffen noch door de behartiging van gerechtwardigde belangen (par. 193 StGB), noch door de vrljheid van meningsuiting gerechtvardigd werden. Wellswar behartigen uttigen in eren tijdschrift inzoverre gerechtvaradigde belangen, dat tijdschriften in het kader van hum openbare taak het publiek moeten informeren en krittek moten kunmen uitoefenen, zelfs in drastische vorm ook tegen gestorven personen. Mar $1 n$ casu was de ulting geen redelijk middel tot en redelijk doel, namelijk een discusste ovet het cerrorlsme an te zwengelen. Aan de onrechtmatlgheid verandert ook een ultleg van de bepalingen betreffende de bescherming van de persoonlifke eer in art. 5 lid 2 GG in overeensteming met de constitutie niets $(643)$. 
Tevens had de schrijuer:

"die Bundesrepublik Deutschland, Insbesondere thre werfassungsmäsige Ordnung, beschimpte (par. 90a I, Nr. 1 StGB), inden er ... anführt, wer slch das (verbrecherlsche) Konterfel (Bubacks) angesehen habe, könne erkennen, "welche Züge dleser Rechtsstat trägt, den er $1 \mathrm{n}$ so herworragender Welse verkörperte". Da der Verfasser das Geslcht des Toten später verhohnt, llegt darin alcht nur eine Verunglimpfung elns Antsträgers. Der Text erglbt, dass diese besonders verletzende und rohe missachtung auch die Bundesrepublik Deutschland als Staatswesen treffen soll. Der hieraus entlehnte Vorwurf, auch der Rechtsstaat trage das Gesicht ellnes Verbrechers, ist elne in der Form und Inhalt besonders verletzende Aetusserung der Missachtung, also ein Beschlmpten im Sinne des par. 90a I Nr. I StGB ... Diese Beschimpfung richtet sich gegen die Bundesrepub1ik; denn der Rechtsstaat 1st ein charakteristisches Zelchen der konkreten Gestalt dieses. Staates und seiner verfassungsmässigen Ordnung als fretheitlich-repräsentative Demokratie" (644).

De rechter overwoog, dat de bespotting van de Bondsrepubllek niet gerechtvaardigd was. Het staat wellswaar ledere staatsburger vilj, ingrepen van de staat te kritiseren; als actieve burger is hij daartoe zelfs verplicht. Op zlchzelf is daarom politieke kritiek nooft strafbaar, ook als zilf hard en scherp is en, zoals dat bij politieke polemiek snel het geval is, kennelijk ongerechtvaardigd. Juist het voorschrift betreffende de bescherming van de eer van de staat moet daarom in overeensteming met de rechtspraak van het Bundesverfassungsgemieht in het licht van de bljzondere betekenls van de vrijheld van meningsulting worden uitgelegd. De daaruit voortvloeiende beperking van de strafrechtelijke bescherming van de eer ten gunste van de vrijheid van meningsuiting leverde voor de schrijuer wan het in memorlan echter geen rechtvaardiging op. De grens van de strafbaarheid wordt overschreden als - zoals hier - de kritiek ongedifferentleerd, dat wil zeggen zonder entge zakelijke verklaring geleverd wordt en daarom alleen maar bespot. Dan is er geen sprake meer wan geoorloofde polltleke polemlek $(645)$.

Tegen de meeste verantwoordelljken voor het afdrukken van het artikel elders in den lande werden eveneens strafrechtel1jke stappen ondernomen(646). De rechter1ijke ultspraken liepen ulteen(647). Doordat het voor de berechting van de verdachten nodig was ook vast te stellen of de Inhoud van het originele artikel straf192 baar was, kwam allereerst het verschil in beoordeling 
van het orlgineel naar voren. Door somige rechters werd het origineel zelf wel $(648)$, door een andere rechter niet als overtreding van par. $90 a$ stcB beschouwd(649). Vervolgens werd ook het overnemen van het origlneel als een overtreding van par. 90a StGB gezlen(650), of ook julst niet, dankzlj de aanwezligheld van een begeleidend commentar(651). Soms zorgde dat begeleidende commentaar evenwel julst voor het aannemen van strafbaarheld(652). In somige gevallen volgde vrijspraak(653), eenmal met een beroep op de openbare taak van de pers:

"Es liegt gerade 1 in den Zugänglichmachen solcher, berelts öffentlich diskutierter und von in öffentlichen Leben stehenden Einzelpersonen kommenterter Vorgänge und Dokumente der Zeitgeschichte für dle breite Bevölkerung ine der fundamentalen Voraussetzungen fur die Lebensfühigkelt eines demokratischen Gemeinwesens. Wenn ein Presseorgan stich der Erfullung thm $1 \mathrm{n}$ dfesem Zusammenhang grundsätzlich zugewiesener Aufgaben widmet, so kann daraus nur gefolgert werden, dass thm bel der Ko1lision mit strafrechtlichen Bestimungen insowe1t der Rechtfertigungsgrund des Artikels 5 GG zur Sette steht" $(654)$

De 47 professoren en advocaten wit Berlijn en NoordDuftsland werden vanwege het bljgevoegde commentaar van overtreding van par. 90a StGB verdacht. Het Kammergemicht Berlin opende de strafprocedure op grond van de gerechtvardigde verdenklng dat ij $z 1 c h$ ook zelf aan een overtreding van de bepaling hadden schuldig gemakkt vanwege hun opmerking over de houding van de staat tegenover socialistlsche kritlek en fascistische tendenzen. Wel werd de bljzondere betekents van de vrljheld van meningsuiting voor de publieke opinie erkend. "Es steht thnen aber nicht zu, dem staat deswegen Willkir und faschistoide Tendenzen und die unterdrickung der Meinungsfreihet vorzuwerfen"( 655$)$. rijdens de elgenlijke procedure kwam het Isandgemicht oldanburg evenwel tot een andere conclusie. Het overwoog, dat par. 90a stGB "letzlich doch wleder "Im Lichte der Bedeutung dieses Grundrechts (nanelljk de vrthetd van mentingsuiting) in elnem fretheltichen demokratichen stat" guszulegen und folglich restrikt1 anzuwenden 1 s.t". Zulks geldt la het blyzonder "wenn es sich um die Beuttellung vom öffentlichen Aeusserungen handelt, die elnen Beltrag lnnerhalb des gelstigen Meinungskampites in einer die Deffentllchke1t wesent 11ch ber thrende Frage darstellen". Daarult wolgt dat "politische Kritik niemals elnen straftatbestand exfullt", tenzij "dlese Krltik beleldigt, beschinpft oder bösw1111g verachtllch macht und zum blossen Mit- 
tel einer allein beabsichtigten Verunglimpfung inlsbraucht will". Maar omdat hilervan in dit geval geen sprake was, sprak het de werdachten urij(656). Well liet de rechter $z$ lch de gelegenheid niet ontgan vast te stellen, dat de kritlek van de professoren op de stalat, waarom het hier ging, "elnfach nicht wahr" was $(657)$.

Een bielangrighe factor voor de beantwoording van de vraag of ook het overnemen van het artlkel over Buback een owertreding wan par. 90a stGB inhleld, was of de verdachte zich de in het artlkel verkondigde mening elger had gemalkt. Daarbij werd verschillende malen gekeken naar de omstandigheld, hoe de ultingen op een doorisneelezer zouden overkomen:

"Der stat wird durch die Wiedergabe beschimpiender Aeusserungen, die der wledergebende stch zu elgen macht, und sel es nur "zwischen den Zellen", ebenso werunglimptt wie durch die wiedergegebene Aeusserung selbst. Das Grundrecht der freien Meinungsäuserung findet hier selne Grenze. Die Frage, ob der Wiedergebende sich die Aeusserung zu elgen gemacht hat, ob er also selbst den objektiven Tatbestand des par. 90a 5tGB erfullt hat, ist nur danach $z u$ beurteilen, wie dle Aeusserungen auf den Durchschnittsleser wirken und von thm verstanden verden" (658).

In een latere procedure werd er echter op gewezen dat dit criterlum bij de beoordeling geen rol mocht spelen, ondat tot de persvritheid ook de vri jheld behoort zelf te bepalen, of een afgedrukte tekst als Informatle, als elgen mening of als vreemde mening wordt doorgegeven(659). Het Bundesverfasaungsgerioht acht het namelijk dubleus on de inhoud van een meningsulting aan de hand van de doorsmeelezer te bepalen. In leder geval verbledt art. $5 \mathrm{GG}$ het on de lnhoud van een lnformatie met behulp van de matstaf van de vluchtige lezer te bepalen, wanner de informatie in een concreet geval julst uitgaat van een duldelijk geinteresseerde en andachtige lezer en zich tot hem richt(660). Men zou kumen stellen dat zulks b1j het in menorlam toch het gewal was. De verdachten werden vri jgesproken.

Ook In het geval van par. 90a StGB kan een beroep op de kunstvrifheid effect hebben, war een beroep op de vritheld wan meningsulting niet zou hebben geholpen. In 1978 werd een fotomontage verbreld, wamop tegen de achtergrond van de bondsadelaar enlge gevangenen achter tralles te zlen waren met het onderschrlft, dat in 194 de gevangenlssen van de Bondsrepubllek door 1 solatle 
werd gefolterd. De rechter stelde vast dat geen sprake was van bespotting van de Bondsrepubliek als onrechtsstat en van Verunglimpfung ran de bondsadelaar als symbol wal de staat, omdat de fotomontage het karakter van een kunstwerk had (661). Met een beroep op en beslissing van het Bundesverfassungsgericht ult 1972, dat bij een schending van het invoerverbod wan anticonstitutionele fllms een beperking van de kunsturifheld slechts zou zijn toegelaten in het geval van schending wan de grondbeginselen van de constitutie (662), overwoog de rechter dat in dit geval wan een aanval op een van dle grondbeglnselen niet kon worden gesproken.

Aan een fotomontage, waarop acht militalren de Duitse vlag vasthielden terwill een man op de vlag urineerde en die als omslag wan een antimilitaristlsche tijdschrift diende, ontzegde een andere rechter echter elk artlstlek karakter(663). Deze overtreding van par. 90a StGB moest nar de matstaven van de vrifheld wan menlngsulting worden beoordeeld.

\subsubsection{Militairen en ambtenaren}

Art. 17a 11d 1. GG staat speciale wetten toe, die de rrltheid van milttalren en vervangend dienstpltchtgen, on hun menling in woord, schrift en beeld te ulten en te verbreiden (art. 5 lid 1 eerste $21 n$ GG) beperken. Reeds op grond van art. $17 a$ l1d 1 GG ziln daarom disclplinalre voorschriften uit het soldatengesetz (664) toelaatbaar, d1e repercussies hebben op de wrijheid van menlingliting, bifvoorbeeld de plicht van militairen zich voor de instandhouding van de freiheitliche demokratische Gmondordnung in te zetten (par. $8 \mathrm{SG}$ ), de plicht van meerderen tot terughoudendheid bif meningsultingen, zowel blnmen- als buiten dienstverband (par. 10 11d 6 SG), de gehelmhoudingspilicht (par. 14 11d 1 SG), het verbod van politieke activitelten ten gunste van een bepalde richting t1jdens de dienst (par. $1511 \mathrm{~d} 1 \mathrm{SG}$ ), de beperking van de vrlje mentingsulting door de regels van de kameraadschap (par. 15110 2 SG) en de plicht tot het bewaren van de disclpilne en tot het respecteren van de positile van de meerdere binnen en bulten dienstverband (par. 17 11d 1 SG).

De verhouding tussen art. $511 d 2$ GG en art. $17 a$ 1dd 1 GG is lange tijd onduidel1jk geweest. De vraag was, of voorschriften die de vrifheld van menlinguiting van millairen beperken algemene wetten in de $z$ in van art.

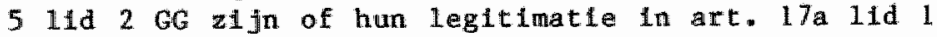
GG vinden.

In het reeds eerder ter sprake gekomen Sotdaten-arrest 
(665) heeft het Bundesverfabangsgemoht deze vraag Liks Iaten 1iggen. Het owerwog sechts, dat de plicht van de meerdere tot terughoudendheld wellswar als zadanig in het llcht van de bchechthin konatituierende betekenis van de viljheid van meningsulting wost worden ultgelegd(666), maar dat art. 5 lid 1 GG reeds daram mocht worden beperkt, omdat ult het princlpe van de strijdbace dewocratie de plicht van militalcen volgt, zich woor de Instandhouding wan de vrlje rechtsorde in te zetten $(667)$. Daarmee ls onverenigbar dat (onder-)offlcieren "bel polltischen Diskussioner whrend des Dienstes die frelheltiche ordnung in Frage stellen"( 668$)$. Ironlsch genoeg was dat in casu Julst gebeurd door de opmerking dat men in de Bondsrepubliek zijn menlng niet vrij kon uiten(669). Het Bundesverfassungsgericht concludeerde uit het principe wan de strijdbare democratle abstract en rechtstreeks de voorrang van het voorschrift warop de beperking van de vrijheid van meningsulting beruste (par. 10 $11 \mathrm{~d} 6 \mathrm{SG})$. Het belang van de bescherming van het super-rechtsgoed freineititihe demoknateche Grundordnung, makte het owerbodig in concreto te onderzoeken of de menlngsulting een bfjdrage aan de meningsvorning leverde. Bif de abstracte afwegling tusisen de strijdbare democratie en het grondrecht werd de omstandigheld, dat het grondrecht zelf deel van de freiheitiche demoknatische Grundardmung ultmakt, geheel onder de tafel geveegd $(670)$.

Reeds op dfezelfde dag echter verrichtte het Bundesverfaseungigericht in een ander arrest warin het de meningsuiting van een militalr betrof, de afweglng ntet meer abstract vila de strijdbare denocratie als warde, maar interpreteerde het de desbetreffende bepaling ult het soldatengesetz weer concreet in het licht van de schlechthin konstituierende beteken is wan de vrithefd van meningsuiting(671). Het overwoog, dat een disclplinalre straf, aan een miltair ultgedeeld omdat deze in een ingezonden brief in de pers een toesprak van $z 1 j n$ meerdere had bekritiseerd, een ontoelaatbare beperking van diens grondrecht betekende. De brtef, als "anerkanter Faktor der offentllehen Melnungablldung" vornde immers een bljdrage aan de algemene apenbare discussie 672$)$.

In latere ${ }^{2}$ resten werd deze lifn doorgetrokken. Hoewel art. $17 \mathrm{a}$ 11d 1 GG beperkingen van de vrijheld van menlngsulting van militairen op zichzelf al voldoende legltimeert, moeten beperkingen $\mathrm{ln}_{\mathrm{n}}$ de $z \mathrm{in}$ van art. 5 IId 2 GG als algemene wetten worden beschouwd als $21 j$ aan de formele criteria voldoen, zodat zij in dat geval in het $11 \mathrm{cht}$ tan de bijzondere betekenls van de 196 vrljheld van meningsulting voor de democratie moeten 
worden uitgelegd(673). Dat woorkomt echter nog nlet, dat in de daarop volgende concrete afweging wel rekening wordt gehouden met de spectale plichten, die de militair tegenover de democratische rechtsorde heeft.

Net anders ligt het voor ambtenaren. In het RadikaZen-arrest heeft het Bundesverfasingsgerioht bepald dat de plicht van trouw wan de ambtenaar, zoals die slnds het Extremistenbesluit wordt geinterpreteerd, en de daarmee samenhangende voorschriften van het ambtenarenrecht en het disciplinaire recht, algemene wetten ziljn in de zin van art. 5 1id $2 \mathrm{GG}(674)$. Dat betekent, dat bif een afweglng, waarin moet worden vastgesteld of een polltieke menlngsulting van een ambtenaar verenigbaar is met zijn plicht van trow, deze plicht van trouw in het licht van de schtechthin kanstituterende betekents van de vrijheid van meningsuiting moet worden uitgelegd(675).

In de prakt1jk van de Radikaleneriass is daarvan echter weinig te merken. Door rechters die moeten oordelen in conflicten tussen (aankomende) ambtenaren en overheldsinstanties, die menen dat nlet aan het vereiste van de plicht van trouw is voldaan, is de vrijheid van meningsuiting als toetsingscritertum en haar betekents voor de democratie als factor bij de darmee samenhangende afweging tot dusver zeer verwarloosd (676). Op de verontachtzaming van dit grondrecht in verband met de interpretatie van de plicht van trouw heeft de Europese Commissle voor de Rechten van de Mens gewezen, toen zij in 1984 uitspraak moet doen in een conflict tussen een lerares en de Westduftse dee1staat Noord-Rijnland-Westfalen - de eerste mal overigens, dat een orgaan van de Raad van Europa een schending door de Bondsrepubliek vaststelde van art. 10 van het Europees Verdrag tot Bescherming van de Rechten van fe Mens en de Fundamentele Vrijheden, dat de vrijheld van menlingsulting garandeert (677).

De deelstat had in 1974 de vaste aanstelling van de lerares als ambtenaar ingetrokken, nadat in de krant een ingezonden brief van haar was verschenen. In die brief ging zij in op een verklaring, door haar afgelegd om ambtenar te kunnen worden, dat zij geen lid van de KPD was. De lerares wees erop, dat daaruit nlet mocht worden geconcludeerd, dat $z 1 j$ zlch wolledig van de KPD en de politiek van deze partij distantieerde. Zij ondersteumde onder meer het streven van de KPD tot oprichting van een internationale volkskleuterschool in haar woonplaats(678). Tien jaar na dato, nadat alle nationale rechtsmiddelen waren uitgeput, had de Commissie aan de hand van het voorliggende conflict de gelegenheld te oordelen over de verenigbaarheid van de 
plicht van trouw, zoals die in de Bondsrepubllek rordt utgelegd, wet de vrl theld van mentingsulting.

De Comisise stelie vast, dat de plicht van trou in beglngel een geoorloofde beperking wan de vifherd wam mentrgsuting in de 2 in van art. 10 ild 2 ECRM Is, want zif is nodig in een dewocratische samenieving (679), zij is in het belang wan de matlonale vellit held (namelijk ter verdediglng van de democratie (680)), en zij dient ter bescherming van de rechten van derden (681).

Het belang van de nathonale velligheld heeft extra gewloht vanwege de historlsche ervaring vari de Duttsers met het national-soclalisme(682). De toetsing wan de plicht wan trouw an de vrijheld van meningsulting in het concrete geval verrichtte de Commisile net Hnachtneming wan alle omstamdigheden van het specifleke geval(683) en van de vitale roll, die de bescherming van de vrltheid van meningsulting speelt in de democrat 1 che structur van de 11 dstaten wan de Raad van Europa 684 ).

In het $11 \mathrm{cht}$ hlervan concludeerde $\mathrm{z}$ il, dat de reactie van de deelstat Noord-RIjnland-Westfalen op de brief van de lerares disproportoneel was geweest en dat derhalve sprake was van een schending wan art. 10 $\operatorname{ECRM}(685)$.

Met deze beslissing heeft de Europese Comissile voor de rechten van de mens niewwe actualitelt verleend aan de pasage in het Rodikalen-arrest, warin de plicht wan trouw wellswar als een geoorloofde beperking van de wrifhelld van meningsulting wordt beschouwd, mar tegelijkertifd de geldigheid van de wisselwerkingstheorle wordt onderstreept, ook net betrekking tot menlngsuitingen wan (aankoinende) ambtenarer, dile twilfels aan hun Verfasungstreue doen ontstaan(68.6). De hantering wan het proportionaliteltsbeglnsel door de Commissle komt neer op de rechtsgoederenafweglng (die overwegend een belangenafwegling $1 \mathrm{~s}(687)$ ), welke in het verlengde van de wisselwerklngstheorle wordt toegepast door de Westdultse rechter in conflicten, warbif de yritheld van menlngsulting betrokken is.

De ulsprak van de Commlssie kan worden opgevat als een vingerwifzlng an de natlanale instantles, in het vervolg weer meer a andacht aan dit aspect te besteden. Hoe verschllend een meningsulting van een ambtenaar, dle botst met een ambtenarenvoorschrift, kan worden beoordeeld tonen tenslotte taee uitspraken naar aanleiding van het dragen van een speld "Atomkraft - Nein danke" tljdens de les door leraren. In het ene geval. stelde rechter vast dat een lerares haar plicht tot terughoudendheld door het dragen wan de badge had geschonden (688), In het andere geval julst niet(689). 
Zowel de grenzen die de strijdbare democratie an de vrifheld van menlngsuiting stelt als de speciale posithe die het grondrecht inneemt zolang het zlch binnen deze grenzen beweegt komen voort uit dezelfde bron, namelijk de erkenning, dat dit grondrecht voor het functioneren van de democratle onontbeerlijk is en derhalve objectieve norm is. Vanult de optiek van die onontbeerlitkheid gezien zija de wisselwerkingstheorie en de afwegingsmethode, die het Bundesverfaseungsgewoht in het Lüth-arrest heeft geIntroduceerd, een welkome versterking van de vrijheld van meningsuiting. Die versterking kan worden toegejulcht, daar de mogelijkheld om de vrijheld van menlngsulting wettelijk te beperken door middel van algemene wetten groot is en van die mogelljkheid door de wetgever daadwerkelijk tamelljk uiltgebreid gebruik wordt gemaakt. Dat de neiging om het grondrecht an beperkingen te onderwerpen zo groot is, kan op de gedachte van de strijabare democratie worden teruggevoerd. Dezelfde gedachte, die reeds in de artt. 9 lid 2,18 en 21 lid 2 GG is weersplegeld.

Weliswar heeft het Bundesverfassungsgericht criteria ontwlkkeld, waaraan een algemene wet in de zin van art. 5 lid 2 GG dient te voldoen, maar de praktijk toont aan dat in teder geval de formele criteria geen belemmering inhouden voor voorschriften, die de vrijheld van meningsuiting beperken. Zelfs par. 88a en 90a StGB zijn als algemene wet beschouwd. Een werkelijk beletsel vormt net zo min het materiële criterfum, dat het beperkende voorschrift een rechtsgoed moet beschermen, dat de voorrang verdient boven de ultoefenlng van de wrijheid van meningsulting. In een strijdbare democratle wordt al gauw aangenomen dat een beperkend woorschrift in het belang van de algemeenheid een rechtsgoed beschermt dat de voorrang verdient en dus toelaatbaar is als beperking van de vrijheld van meningsulting(690).

De wisselwerkingstheorie vormt derhalve een welkon tegenwicht tegen de vele beperkingen, waaraan het grondrecht in de Bondsrepubliek onderworpen 1s. De vrijspraak van de 47 professoren en advocaten in de Mescalero-affaire is een duldelljk voorbeeld dat de achleohthin konstituierende betekenis wan de vrijheid wan meningsuiting geen lige formule is, al toont dezelfde Mescaleroaffalre ook de speelrutmte die de rechter desondanks heeft (691).

De wisselwerkingstheorle $1 \mathrm{~s}$ ook een werktuig om de scherpe kantjes af te sl1jpen van de gevolgen van de conceptle van de strijdbare democratle voor de vrij- 
held wan meningsulting van willtalren en amberenaren. Hellswar zadelt de strlfdbare democratie hen met spectale pllchten tegenover de vilje denocratische recht orde op "mar de wisselwerklngstheorle bledt wan geval tot geval de gelegenheld te vermijuen dat de staatsralson het automatsch wint van het grondrecht, dat tenslotte net zo zeer deel van de orde ultmalkt, dle woet worden bescherm. Dat van die gelegenheld bij de beoordeling wan de Vexforaungstweus van (aankomende) ambtenaren in het kader van de Radikateneriaes niet zeer enthousiast gebrulk wordt genaakt is een andere kwestie.

Zeer krachtig heeft de wlsselwerklugstheorle ook de trommel geroerd bif conflicten tussen de vrljheid van menlngsulting en het recht lnzake de persoonlijke eer. De beacherming wan de persoonlijke eer 1 s tot een minimum teruggebracht. Als andere elementen van het persoonlijkheidsrecht in het geding $z 1 j n$, heeft de wrijheld van nentngsulting echter winder in de melk te brokkelen. Een erkenning dat bif de horlzontale werklng van de vrl jheld van menlngsulting ook nog andere factoren een rol spelen en dat de bescherming ran mentngeutlingen regenover derden toch van een andere orde $1 \mathrm{~s}$ dan tegenover de stat.

3.8. Het Intemationaal Veranag inzake Burgermechten en Politieke Rechter

3.8.1. Vergelijking tussen art. 5 GG en art. 19 ICCPR

3.8.1.1. De kning van adresaaten

Zowel art. 5 11d 1 GG als art. 19 lid 1 en 2 ICCPR garanderen de vrl theid van mentingsulting alan een leder ("Jeder" respectlevelijk "everyone"). De natlonalitelt van degene, die in de Bondsrepubliek van zijn vritheld van mentngsulting gebrulk makt is dus onder belde regimes in beginsel irrelievant. Desalnilettemin heeft de Bondsrepubliek blj ratiflcatie van het Verdrag het volgende voorbehoud gemaakt: "Acticles 19, 21 and 22 In conjunction with Article 2(1) of the Covenant shall be applifed wthln the scope of article 16 of the convention of 4 November 1950 for the Protection of Human R1ghts and Fundamental Fredoms"(692).

Art. 16 ECRM(693) bepaalt, dat de verdragsstaten door de art. 10 (vritheld van menlingsulting), 11 (recht tot vereniging en tot vergaderlug en betoging) en 14 (nondiscriminatlebegtinse1) ECRM nlet verhinderd worden, de politieke activitelten van bultenlanders an beperkingen te onderwerpen. Het Verdrag bewat een dergelifke bepaling nlet. De Westdultse regering achtte het 
daarom geboden de in art. 16 ECRM gegeven mogelijkheld tot beperking eveneens met betrekking tot de desbetreffende bepalingen wan het Verdrag te laten gelden. Dit om aan de behoefte van de bevolking naar interne velligheld tegemoet te kunnen komen. Verwezen werd door de regerfing naar het verschljnsel terrorlsme en de groelende hoeveelheid politleke organlsaties van buitenlanders in de Bondsrepubliek met hun veelaljdige en onoverzichtelijke activiteiten(694). Bovendien wlde men conflicten tussen de furfdische gelding van de Europese Conventle enerzijids en het Verdrag anderzifds alsmede moellifkheden voor de rechtspraak van de Europese Commissie en het Europese Hof voor de Rechten van de Mens vermifden(695).

Het woorbehoud wil zeggen dat de Westdultse overheld nilet in strijd met haar verplichtingen uit beide verdragen handelt door aparte regels te stellen met betrekking tot de politieke activiteiten van bultenlanders. Het Auständergesetz(696) bevat zo'n regeling. Weliswaar kunnen buitenlanders alle grondrechten ultoefenen, voorzover deze in de grondwet nlet speciaal aan Dultsers $z \perp j n$ voorbehouden(697), maar de polltieke activiteit van buitenlanders mag worden beperkt of verboden, als dat noodzakellk is in het belang van de afweer van storingen van de openbare velligheld of de openbare orde, of in het bellang van de afweer van belemerlugen van de politieke wllsvorming of als andere zwaarwegende belangen dat nodig maken(698). Bovendien is politieke activiteit van buttenlanders onder meer nlet geoorloofd, als deze de freitheittitche demokratische Grundordnung in gevaar brengt (699).

Deze bepalingen worden gezien als algemene wetten in de zin van art. 511 d 2 GG en dus als toelaatbare beperkingen van de vrijheid van meningsulting (700), hoewel men zich ook hier weer kan afvragen hoe het met de formele criterla stat(701). Het voorbehoud bij ratificatie van het Verdrag was nodig, omdat anders het Verdrag op grond van de lex posterlor-regel anders zou hebben gederogeerd aan de bepaling van het Ausländengesetz, die de vrijheid van meningsulting van buitenlanders beperkt $(702)$.

3.8.1.2. De thhoud van de vritheid van meningsuiting Een vergelijking tussen art. 5 lid 1 GG en art. 19 11d 2 ICCPR leert, dat alle in het grondwetsartikel genoemde elementen $\mathrm{in}$ de verdragsbepaling terugkeren. De In art. 19 lid 2 ICCPR gegarandeerde vritheid van mentngsulting omvat de informatlevrijheid en het recht op meningsverbrelding (art. 5 lid 1 eerste $z$ in GG), door middel van de pers of andere media (art. 5 lid 1 tweede $z$ in GG), of in de vorm van kunst, dat in art. 5 
$6 G$ in het derde $11 d$ gegarandeerd wordt. Toegevoegd 18 dat men deze rechten ongeacht grenzen kan uluefenen. Sinds de hervorning van het politieke strafrecht, het arrest van het Bundegverfasangegericht dat de 1 avoer van kranten ult de DDR heeft toegestaan(703) en de afschafing van de controle op ingevoerde flus(704) 13 dit beginsel in de Bondsrepubllek aanvaard ook voor wat betreft informatle, die wit de DDR afkomstig is, hoewel beperkende regelingen op dit punt, zo zly er nog waren, als beperkingen in het belang van de nationalle vel11ghetd of ter bescherming van de openbare orde $4 n$ de $21 \mathrm{n}$ van art. 19 11d 3 ICCPR warschljnifju niet in strijd met het Verdrag zouden $z i \mathrm{In}$.

In art. 19 lid 1 ICCPR wordt het in art. $511 d 1$ GG nlet vermelde recht een mening te koesteren atzonder$11 j k$ vermeld, maar op grond van de stelregel dat de bescherming van het meerdere ook de bescherming wan het mindere omvat en in de erkenning dat zonder vrijheld een menting te koesteren ook geen vrije meningsulting mogelijk is walt dit recht wanzelfsprekend onder de garantie van art. 5 lid I GG(705).

\subsubsection{De beperkingen}

De vil theid van meningsulting kan volgens art. 5 idd 2 GG worden beperkt door de voorschriften van de algemene wetten, de wettelljke beperkingen ter bescherning van de jeugd en door het recht Inzake de persoonlijke eer. Deze beperkingsmoge $11 j k h e d e n$ zijn niet in strijd met art. 19 lid 3 ICCPR.

In art. 19 11d 3 sub a ICCPR wordt het recht inzake de persoonl1jke eer als geoorloofde beperkingsmogellijkheld genoemd, bepalingen ter bescherulng van de feugd worden door de in art. 19 lid 3 sub b ICCPR genoemdie beperkingsmoge11jkheld in het belang van de goede zeden gedekt.

De uraag is of art. 19 lid 3 ICCPR grenzen stelt an de beperking van de vrijheld van meningsufting in de vorm van algemene wetten. Inderdaad $21 \mathrm{Jn}$ alleen algemene wetten, die beperkingen stellen in het belang van de rechten en de goede nam van anderen, van de nationale velligheld of ter bescherming van de openbare orde, de volksgezondhefd of de goede zeden nlet in strifd met art. 19 11d 3 ICCPR, De in deze verdragsbepaling opgesonde gromden 21 Jn dus de enige gemeenschapswarden die tegenover het gebruik wan de viljheld van menlingsulting de voorrang kunnen genleten. Het Is evenwel nlet warschijnlijk, dat gezien de rekbaarheid wan deze begrippen enige bestaande regeling die als algemene wet het grondrecht beperkt in het licht wan art. 19 Iid 3 ICCPR zo smel ongeoor loofd 
Dat geldt evenmin voor de beperking die voor de vrijheld wan menlngsulting voortvioelt ult het princlpe wan de strijdbare democratie (de artt. $911 \mathrm{~d} 2,18 \mathrm{en}$ 21 l1d 2 GG), die fumers als bescherming van de openbare orde kunnen worden gezlen. Bovendien kan een beroep op art. 5 lid 1 ICCPR worden gedaan, dat analoog aan art. 17 ECRM maatregelen ter bescherming van de grondrechten rechtvardigt tegenower hen dle deze grondrechten opzij willem zetten.

\subsubsection{Art. 20 ICCPR}

In tegenstelling tot art. 19 lid 3 ICCRR, dat alleen beperkingsmogeL1jkheden apsomt, brengt art. 20 ICCPR een beperkingsverplichting met zlch mee voor de tot het Verdrag toegetreden staten. Wellswar heeft de Hestdultse regering er tijdente parlementalre behandellng van het Verdrag op gewezen dat deze bepallng onstreden 1 s(706), maar een woot behoud bif de ratificatle is van Westduitse zijde niet gemakt. De Bondsrepubliek gat ervan ult aan de verpllchting tot het verbleden van oor logspropaganda te hebben voldaan door het voorberelden van en het ophitsen tot een a anvalsporlog (par. $80,80 a$ StGB)(707) en het versprelden van propagandamiddelen van ongrondwettige organisaties (par. 86 StGB) door het in art. 9 11d 2 GG opgenomen verbod van verentgingen die gericht zijn tegen de gedachte wan de toenadering tussen de volkeren(708).

De ult het tweede $11 d$ van art. 20 ICCPR voortwloellende verplichting wordt als uitgevoerd beschouwd door de strafbaarheld van volksopruilng (par. 130 stGB - aanval op de menselijke wardigheid van anderen op een wijze die geschikt is de openbare orde te verstoren), verheerlijking van geweld en de ophitsing tot rassenhat (par. 131 StGB) en de bespotting van rellgleuze overtulgingen of wereldbeschouwingen (par 166 StGB) (709).

3.8.2. Het effect van art. 19 ICCPR op de interne mechtesfeer

Als ultoloelsel van de dualistische opvating, die inhoudt dat $1 \mathrm{n}$ verdragen neergelegde regels in de natlonale rechtsorde pas verblndend $21 \mathrm{fn}$ als zif zifn ongezet in nat lonal recht, verkrijgen verdragen in de Bondsrepubliek interne werking door de toesteming van de federale wetgever in de vorm van een federale wet. Door deze in art. 59 11d 2 GG neergelegde pracedure wordt de inhoud van een verdrag getransformeerd in nathonal recht $(710)$, wh autonatisch tot gevolg heeft, dat de burgers zich rechtstreeks op de verdragsbepalingen kuminen beroepen, voorzover deze een self-execu- 
ting karakter hebben(711). De transformatle wan een verdrag in natlonal recht brengt met zlch wee, dat b1j een conflict tussen de verdragsregels en en latere wet de laatste voorrang kr1jgt op grond van het beginsel lex posterior derogat lege priori(712). Een latere wet derogeert alleen dan niet aan eerdere verdragsbepalingen, wanneer deze Verdragsbepalingen tege11jkertijd algemene beginselen van volkenrecht $21 \mathrm{jn}$ (713). Op grond van art. 25 GG zijn algemene beginselen van volkenrecht namelijk automatlsch bestanddeel wan het nationale recht. Deze behoeven dus niet getransformeerd te worden (een monlstisch trekje), hebben voorrang boven normale wetten en creëren onmlddel$11 \mathrm{jke}$ rechten en plichten voor de inwoners van de Bondsrepubliek. De algemene beglnselen van volkenrecht derogeren wellswar an federale wetten, mar niet an de grondwet zelf. Deze kan namelijk alleen weranderd worden door een wet, die de formulering van de grondwet ultdrukke11jk verandert of anvult (art. 791 id 1 GG); een algemeen beginsel wan volkenrecht voldoet ten princlpale niet an deze voorwarde(714). Algemene begInselen van volkenrecht hebben dus met verdragen, die de status van federale wet hebben, gemeen dat ze aan de grondwet ondergeschikt zljn. Gegeven deze constellatle 1 s de interne status van het Verdrag inzake Burgerrechten en Politieke Rechten als volgt te beoordelen.

Door de toestemalngswet van 15 november 1973 is het Verdrag tot bestanddeel van het nationale recht getransformeerd. Voorzover $z 1$ in bepalingen selfexecuting $z 1 j n$, kunmen de Inwoners van de Bondsrepubliek zich er rechtstreeks op beroepen. De rangorde van het Verdrag is gelijk aan die van een federale wet.

Behoren de in het Verdrag gegarandeerde mensenrechtien tot de algemene beginselen wan volkenrecht, dan gentethen zij ex art. 25 GG een verhoogde status en $z 1 j n z 1 j$ in leder geval rechtstreeks toepasibar. Hoewel zulks wel wordt a angenomen(715) $11 \mathrm{jkt}$ het, ook met het oog op de internationale stand wan de mensenrechten, velliger het Verdrag nlet te beschouwen als algemene beginselen van volkenrecht en ze llever te beoordelen op grand van art. 59 11d 2 GG(716).

In dat geval wordt de kwestle van de rechtstreekse toepasbarhe1d van de verdragsbepallngen actuee 1 . Zoals reeds eerder 1 s opgemerkt(717), geeft het Verdrag zelf geen ultslultsel over het al dan niet selfexecuting karakter van de verdragsbepalingen voorzover ze zlch dartoe lenen. Eventin leveren de travaux preparatolres argumenten voor hun rechtstreekse toepasbarheld. Deze hangt aldus uitslutitend af van de 204 omstand1gheld of de Bondsrepub1lek zelf de desbetref- 
fende bepaling self-executing karakter toekent. De constitutionele basis daarwoor is aanwezig(718). Men kan aannemen dat de rechter de rechtstreekse toepasbaarheid wan bepalingen wan het Verdrag zal honoreren wenn Inhalt, zweck und Fassung der elnzelnen Vorschrift nit voller Klarhelt die Annahme zulässt, dass eline solche Wirkung gewollt $\operatorname{sel}^{\prime \prime}(719)$.

Dok het Westdultse lid van het Comite voor de Rechten van de Mens, romuchat, neemt aan dat een leder zich rechtstreeks op de verdragsbepalingen kan beroepen (720). De conclusie $1 \mathrm{~s}$ dat in de Bondsrepubliek art. 19 ICCPR rechtstreeks toepasbaar is.

Ter beantwoording blijft dan nog de onderlinge verhouding tussen art. $5 \mathrm{GG}$, art. 10 ECRM en art. 19 ICCPR. Strikt genomen heeft art. 5 GG als grondwetsbepaling in geval van conflict voorrang boven de belde verdragsbepalingen, terwijl art. 19 ICCPR op zijn beurt aan art. 10 ECRM voorgat op grond van de lex postertor-regel, als men ervan uitgaat dat zowel art. 19 ICCPR als art. 10 ECRM de status van federale wet hebben.

Bestaat er een conflict tussen art. 19 ICCPR en art. 5 GG, dan gat de laatste bepaling in princlpe voor; biedt art. 19 Verdrag echter een grotere rechtsbescherming dan art. 5 GG, dan wordt het conflict volgens het Günstigkeitoprinzip opgelost, wat betekent dat art. 19 ICCPR is toe te passen als dat leidt tot een versterking van de individuele rechtspositie( 721$)$.

\subsubsection{De controle op de naleving van art. 19 ICCPR}

De Bondsrepubliek heeft in 1976 een verklaring ex art. 41 Iid I ICCPR afgegeven, dat $z i j$ het statenklachtrecht erkent. Deze is in 1981 voor nog eens wiff jaar verlengd(722). Tot op heden is van de zifde van een van de andere staten, die verdragspartij zijn en zelf het statenklachtrecht hebben erkend, nog geen enkele maal een klacht tegen de Bondsrepubliek ingediend.

De Bondsrepubliek heeft niet het Facultatleve Protocol inzake het individuele klachtrecht ondertekend. Als reden wordt aangevoerd dat men mogelijke overlapplngen met het rechtsbeschermingssysteem van de Europese Conventie wil voorkomen( 723 ). Met de gelljkwardighefd en de zelfstandigheld van de instanties van de Raad van Europa en het Comite voor de Rechten van de Mensi

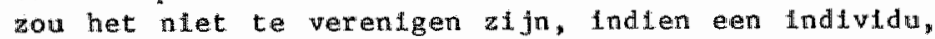
wlens klacht in Straatsburg is afgewezen, vervolgens een klacht bij het Comite zou kunnen indienen(724). Er is ult dien hoofde de voorkeur aan gegeven in plaats vam twee Internationale rechtswegen er slechts eén voor de individu open te stellen. Voor de keuze ge- 
platet, heeft de Bondsrepubliek besloten lifewer het individule klachtrecht voor stratiburg te erkennen, ondat de Europese Conventie een grotere individuele rechtsbescherming zou bieden dan het Verdrag( 725$)$. ondanks genoende bedenklngen is Tomwechat ervoor dat de Bondsrepubliek het Facultatlef Protocol toch ondertekent. Deze dad zou het vertrouwen in de wereldwijde samenwerking op het gebled van de mensenrechten vergroten $(726)$.

Wen korte vergelljking cussen het International Verdrag en de Europese Conventie geeft geen aanlelding te veronderstellen dat de erkenning van het individuelle kachtrecht de Jurldische bescherming van de individu tegenover de Bondsrepubliek wezenlljk zou vergroten. Aan de bescherming van arti. 5 1id $\mathbb{L}$ en 2 GG en $21 j n$ uitleg door de nationale rechter hebben de organen van de Raad van Europa niet veel toe te woegen. In verband wet de vil jheld van menlingsulting (art. 10 ECRM) heeft de Europese Commissie tot dusver slechts énnal een schending door de Bondsrepubliek vastgesteld(727). Tot nu toe heeft de Bondsrepubllek zlch woor het Europese Hof nog niet hoeven te verantwoorden op grond van art. 10 ECRM(728). Art. 10 ECRM wijkt naumelifks af wan art. 19 ICCPR $(729)$. Het enlge opvallende versch11 met betrekking tot de inhoud lis de toevoeglng in art. 10 CRM dat dit artikel niet belet, dat de verdragspartifen radio-omroep, bloscoop- of televisie-ondernemingen kunnen onderwerpen aan een systeem van vergunningen. Maar art. 19 ICCPR makt zo"n vergunningenstelsel ewenmin onmogelijk, omdat dit een geoorloofde beperking $t s$ in verband met de bescherming van de openbare orde (art. 19 lid 3 sub a) (730).

Wel geft art. 10 ECRM meer beperkingsmogelijkheden dan art. 19 lid 3 Verdrag, namelijk tevens "in the interest of ... certitorlal integrity or public safety, for the prevention of disorder and crime, ... for preventing the disclosure af information recelved in confidence, or for maintaining the authority and inpartiality of the judiclary". Men zou deze beperkingen eventueel ander het begrlp openbare orde in art. 19 11d 3 ICCPR kunnen laten wallen. De deskund Igencommlsse van de Raad van Europa was nfet in staat hierover en ultipraak te doen $(731)$.

Tegenover de op het eerste gezicht rulmere beperkingsmogelljkheden, dle art. 10 lld 2 ECRM bledt, staat dat deze slechts geoorloofd zijn voorzover zij noodzake$11 j k$ zijn in een democratische samenleving. Zo" $n$ regtrlctle bewat art. 19 11d 3 ICCPR nlet. Per galdo is het darom moel11.jh vast te stellen, of het reglme wan art. 19 1id 3 ICCPR werkelijk restrlctiever ls dan dat van art. 10 ltd 2 ECRM. Toch begtart de mogelljkheld 
van een discrepantie tussen belde bepallingen. Hoewel ook onder het eventueel restrlctievere regine van art. $1911 d 3$ ICCPR een overtreding van de beperkingen nitet snel zal kunnen worden aangenomen, zou deze discrepantie een reden kunen $z$ ijn het individuele klachtrecht in te poeren. Foor het vraagstuk wan de tolatbarheld wan de artt. 9 11d 2 , 18 en 21 lid 2 GG sperelt de discrepantie overigens geen rol. Deze restricties van de willheld van menlngsulting in het kader van de strildbare democratie vallen onder de beperkingsmoge11jkheden, die belde verdragen gemeenschappelijk hebben.

Aan haar verplichting tot rapportage aan het Comlte voor de Rechten van de Mens ex art. 40 lid 1 ICCPR heeft de Bondsrepubllek door har Initial Report van 25 nowember 1977 voldaan $(732)$. Het werd teven in het land zelf gepubliceerd(733) en bevat 39 bladzijden. Woor wat betreft art 19 ICCPR (734) beperkt het zich alet tot een beschrifving van art. 5 GG, maar refereert het ook aan de belangrijkste ultspraken van Bundesverfacsugggemicht op het gebled van de vritheld van meningsulting(735), de perswrithedd(736) en de omroeprrt theid(737), en staat het stll bif de principiele betekenis van dit grondrecht voor de democratle vanwege zifn rol in de vorming van de publieke opinte (738). Het rapport stelt dat de beperkingen van art. 5 lid 2 GG nlet zover gaan als die van art. 19 idd 3 ICCPR vanwege de Invloed van de wisselwerkingstheorie (739). Zelfkritiek wordt niet geleverd.

Met betrekking tot art. 20 ICCPR wordt in het rapport verwezen naar par. BOa StGB. In verband met het recht tot vereniging (art. 22 ICCPR) worden het SRP- en het KPD-verbod genoend $(740)$.

TIJdens de mondelinge toelichting op het rapport voor het comite benadrukte de vertegenwoordigster van de Bondsrepubllek het belang van te vrije pers als "most effective weapon for controlling governmental author 1ty at al1 levels". Door de pers waren veel ontegelmatigheden blf de overheid blootgelegd(74 1). Dankzij de gedetallleerdhefid van de door de Bondsrepubliek ter beschlkk1ng gestelde gegewens waren de viragen met betrekking tot de artt. 19 en 20 ICCPR van de 21 jde van het comite navenant gedetallleerd. Het comitelid Prado Vetlejo ultte krttlek op de rekbaarheld van het begrlp algemene wetten en vroeg opheldering, wat Verm unglimping des staates und seiner symbote (par. 90a StGB) betekent. Hif ulte de vrees dat deze bepaling te rulm kan worden geInterpreteerd(742). Het comitelid ramopolaky vroeg welke algemene wetten de vrijheld van menfugsulting in concreto beperken en of er wetten a In die het anzien wan de stat beschermen(743). H1 
merkte verder op dat nat zijn menting woorden, die nlet van geweld vergezeld gingen, geen bedreiging poor de nationale velligheld konden betekenen (een vingexwijzlng naar par. 88 a StGB?) (744).

Het oostdultse $11 d$ van het Comitê, Graefrath, w11de weten hoe valk de vritheid van meningsulting was geschonden door het bljhouden van zwarte lifisten van communtsten, personen $1 \mathrm{n}$ het bezt van commun istische lecturur, etcetera. Hij. doelde kennelijk op het bestaan van het vebemwchungsgesetz(745), dat de mogelijkheld biedt de Invoer van communistische lectur in de Bondsrepubliek te controlexen, mar hat niet kan verhinderen. H1j woeg zlch af of er werkelijk vrijheld van mentngsulting en persvrifheld in de Bondsrepubliek bestonden; hij wees op het verschljnsel persconcentratie: was $86 \%$ wan de pers in handen yan én uitgever? $(746)$

Het Comitelid Sir Vincent Evans stelde dat de Bondsrepubllek verder ging dan nodig op grond van hate verplichtingen ult art. 20 lid 2 ICCPR door demagogie te cximlnallseren( 747$)$. Aan een bepaling werd niet gerefereerd, maar wellicht bedolde de vragensteller par. 130 StGB.

Blf de beantwoording van de door het conite over het rapport gestelde vragen gingen de vertegenwoordugers van de Bondsrepubliek nlet op de vrl jheld van meningsutting $\mathbb{1 n}(748)$. Wel merkten zij op dat ze uit tijdsgebrek van een gedetalleerd commentaar afzagen, mar dat een schriftelijke beantwoording zou volgen, Indien gewenst $(749)$. Tot dusver heeft deze nog niet platsgewonden.

De enige referentle an de vrljheld van meningsulting geschledde toen werd ingegaan op het beginsel wan de strijdbare democratie en de spaning die bestond tussen de partijverboden enerzijds en onder meer de vrijheld van menlngsulting anderzijds(750). Overigens lieten de artt. 5, 19 en 22 ICCPR een dergelijke bescherming van de grondrechten door middel van een partijverbod toe( 751$)$, aldus de vertegenmoordigers van de Bondsrepubllek. Verwezen werd naar de klacht die door de KPD in Stratsburg was Ingedlend en daar was afgewen omdat de KPD de dictatur van het proletaraat bepleitte, wat een destructe van vele grondrechten zou betekenen $(752)$.

op grond van een besluit van het comlte uit 1981(753) is de Bondsrepubllek verpllcht wif jaar na de inlevering vam het eerste rapport en vervolgrapport voor te leggen(754). BlJ dle gelegenheld moet speciaal worden Ingegaan op die problemen, die bij de bespreking van het Initial Report in het Comite zijn opgeworpen, maar nlet ult put tend a ijn behandeld (755). 
In het Aanvullend Protocol bij het Grondslagenverdrag hebben de belde Duitse staten afgesproken onderhandelingen te voeren over het wederzijds betrekken wan boeken, tijdschriften, radio- en televisieprodukties. Zoals opgemerkt hebben deze onderhandelingen nog niet tot resultaten geleid. Sinds het begin van de jaren zeventig is er sprake van een vrije informatiestroom vanuit de DDR richting Bondsrepubliek, die gedekt wordt door art. $5 \mathrm{GG}$. De enige nog bestaande belemmering is de controlemogelifkheid op grond van het Vebemachungsgesetz aan de Duits-Duitse grens teneinde geschriften te kunnen tegenhouden, waarvan de Inhoud een overtreding oplevert van een strafvoorschrift dat invoer of distributie in de Bondsrepubliek ult overwegingen van staatsweldigheid verbiedt(756). Het lijkt onwaarschljnlljk dat afspraken tussen de Bondsrepubliek en de DDR op het gebted van de ultwlsseling aan de huldige situatie nog lets kunnen toevoegen. Zulke afspraken hebben echtex desalniettemin het nut, dat $z i j$ een baxriere vormen tegen een eventuele terugkeer naar de toestanden, zoals zif v66r 1968 bestonden. De mogelljkheid tot een terugkeer is immers constitutioneel gezlen nfet uitgesloten, want de hervorningen zijn destijds uitgegaan van de wetgever en niet van het Bundesverfassungsgemicht. De constitutionele rechter beschouwde de toen bestaande regelingen die de informatiestroom uit de DDR beperkten niet als strijd1g met de grondwet ( 757$)$.

De Briefwisseling over de arbeldsmogelljkheden voor fournalisten heeft alleen betekenis voor de Westdultse fournalisten die in de DDR werkzaam $z 1 j n$. Omgekeerd heeft $z 1 \mathrm{j}$ geen praktische betekenis. Journallsten ult de DDR genfeten in de Bondsrepubliek dezelfde grondrechtsbescherming als leder ander individu. Bovendten zijn de beperkende voorschriften jegens bultenlanders ult het Auständergesetz op hen niet van toepassing, omdat DDR-burgers Duitsers zijn in de zin van de grondwet van de Bondsrepubliek(758) en derhalve niet als buttenlanders worden beschouwd. 


\section{Het karakter van de vrijheid van meningsuiting: een vergelijking}

4.1. De democratioche taak van de vrijheid van meningauting in beide Duitse saten

\subsubsection{Premiagen voor en vergetijking}

Als wordt gesproken over de democratsche tak van de vrijheld van meningsulting in belde Dutse staten, mag niet worden vergeten dat het gat on twee verschillewde democrat lebegrippen.

B1j de democratische taak van de vrijheld van meningsulting in de DDR gat het om een materieel democratlebegrip. Onder democratie wardt niet verstaan het voorhanden zijn van een aantal formele kenmerken, maar het voorhanden $z 1 j n$ van een bepaalde matschappijstructurr, namelijk van een samenleving die is gebaseerd op soclalistische productleverhoudingen en op de ultoefening van de politleke macht door de arbeidersiklasse en haar bondgenoten; een samenleving, ingericht in overeensteming met de objecteve wetmatigheden, zoals de leer van het marxlsme-lendnisme die heeft vastgesteld en zoals die worden geInterpreteerd door de SED(1). Een democratische taak houdt derhalve de opdracht in aan de verwezenlijklng van deze materiële kenmerken bil te dragen. De vrijtheld van meningsulting is aan deze opdracht ondergeschikt gemaakt.

Bij de democratische takk van de vrijheld van meningsulting in de Bondsrepublielk Dultsland gat het daarentegen om een formel democratiebegrip. Met democratie wordt nlet bedoeld dat een aantal lnhoudelijke voorwarden moet $z i j n$ verwezenlijkt, mar de term duldt op een aantal formele kenmerken, die aanwezig moeten $z i j n$ om van democratle te kunnen spreken. Deze kenmerken hebben betrekking op de politieke besluitvormingsprocedure $1 \mathrm{n}$ de staat, welke 1 s gebaseerd op meerderhewen, die door vrije verklezingen tot stand zijn gekomen, en op alles wat voor de Instandhouding van deze beslultvormingsprocedure onontbeerlijk $1 \mathrm{~s}$. In het SRP-arrest(2) heeft het Bundesverfaseungagencht de kenmerken opgesond zonder welke die besluitvorning niet kan functioneren. Tezamen vormen alj de frethettthe demokratische Grundominung.

Nu is aok deze formele benadering niet vil 1 van materlele trekken. 21 j produceert wel degelljk inhouden. 
Op de eerste plaats gaan achter formele kenmerken vaak materiele warden schull. Zo behoort tot de in de Westduitse grondwet opgenomen grondrechten, die worden gerekend tot de beginselen die onontbeerlijk $z i j n$ voor het functioneren van de democratische besluitvorming, bi jvoorbeeld ook het eigendomsrecht, een van de klassieke individuele vrijheidsrechten bij uitstek. De erkenning van dit recht heeft een beslissende invloed. op de structuur van de samenleving, doordat zij de basis vormt voor de bestaande eigendomsverhoudingen en de kapitallstische produkt lewijze(3). Het voorbeeld van het eigendomsrecht geeft aan, dat van sommige beginselen, die tot de freiheitiche demokratische Gmundordnung worden gerekend, puur materiele implicathes uftgaan.

Op de tweede plaats is in de Bondsrepubliek het formele democrat lebegrip inzoverre gematerialiseerd, dat de democratische besluitvormingsprocedure zelf tot waarde is verklaard. Bij de instandhouding van die procedure bestat een zelfstandig bellang. Zij is nilet alleen middel, maar ook doel. De democratie is aldus niet louter een voorhanden zijn van formele kenmerken, maar tegelijkertijd inhoud(4). Formeel blifft evenwel ook de waterlële zljde van het democratiebegrip, doordat de inhoud slechts uit procedure bestaat. Men kan daarom volhouden dat het democratlebegrip ondanks tendenzen tot verzelfstandiging een formeel begrip is.

Met betrekking tot de democratische taak van de vrijheld van meningsuiting betekent het felt dat het democratlebegrip in de $D D R$ een materieel en in de Bondsrepubliek een formeel is het volgende.

In de DDR behoren de grondrechten, en dus ook de vrijheld var meningsuiting, zelf niet tot de kenmerken van de soclalistische samenleving, ten behoeve van de opbouw waarvan de vrijheid van meningsuiting een taak te verrichten heeft. De vrijheid van meningsulting behoort dus niet tot de doelen, waarvoor zij moet worden ingezet. Zij is instrument, en ondat zij alleen maar instrument is, wordt zij niet door het doel in bescherning genomen.

In de Bondsrepubllek daarentegen behoort de vrijhetd wan meningsufting, als een wan de grondrechten en als procedurele voorwaarde, tot de kenmerken van de democratie, wartegenover $z i j$ een taak te vervullen heeft. we writheld van meningsulting behoort dus zelf tot de doelen, die door de democratische tak worden nagestreefd. Zij is instrument, maar tegelifk wordt $z 1 j$ als deel van de fretheit tohe demoknatische orundordnung door het doel in bescherming genomen. De strijtbare democratie verplicht de vritheld van meningsui- 

te dragen.

Hoe is die taakvervulling georganiseerd? Hler raken wij een ander principleel verschil tussen het wezen van de democratische taak in de DDR en de Bondsrepubliek. Het verschil vlaeit direct poort ult de exclusief instrumentele visie op de vrlfheid van meningsuiting in de DDR en de middel-doel betekenis van het grondrecht in de Bondsrepubliek.

In de DDR $1 \mathrm{~s}$ de democratische taak positief georganiseerd. De vrijheid van meningsuiting mag uitsluitend worden gebrulkt ten behoeve van de opbouw van de soclalistische democratie. Is dit niet het geval, dan is er geen sprake van een meningsuiting en wordt de uiting vervolgens bestraft als $z 1 j$ in het openbaar gedaan is, genegeerd als zij prive gedaan $15(5)$. De vrl theld van meningsulting en haar democratische taak dekken elkaar volledig: zij gaan in elkaar op. Een logisch resultat van de instrumentele visie.

In de Bondsrepubllek is de democratische taak echter negatief georganiseerd. Het gat er niet om dat de vrijheid van meningsulting uitsluitend zou mogen worden uitgeoefend ten behoeve van het democratische proces, maar juist dat zij 1 n één geval niet mag worden gebruikt, namelijk als het doel van dit gebruik is het democratische proces te doorkruisen of op te heffen. In zo'n geval heeft de staat in het kader van de strijubare democratie het recht te reageren. In alle andere gevallen kan men $z i j n$ recht op vrijheid van meningsulting in beginsel naar elgen belfeven uitoefenen en genlet men bescherming tegen inmenging van overheldswege. Uit deze onderscheiding tussen een gebruik wan het grondrecht, dat de democratie bedreigt, en een gebruik dat de democratie niet bedrelge (onder beide gezichtspunten blijft de ulting bovendien een meningsulting) blijkt de wisselwerking tussen middel en doel. Ondat de vrijheid van meningsuiting zelf deel uitmaakt van de democratie, waartegenover zij een taak te vervullen heeft, kan $z \mathbb{f}$ nfet in haar eigen democratische taak opgaan, dat w11 zeggen niet totaal worden geInstrumentaliseerd, maar bilfft dle democratische taak het karakter van een randvoorwarde behouden. Het tegelijk doel-zijn verhindert de annexatie van het grondrecht door de democratie.

De democratische taak van de vritheld van meningsulting in de DDR bepalt dus de Inhoud van dit grondrecht. De democratische taak in de Bondsrepubliek bepalt niet haar inhoud, maar vormt een beperking van de vrijheid van meningsulting ter wille van het voortbestaan van onder meer het grondrecht zelf.

212 Deze constatering van de principleel andere geaardhetd 
wan de democratische taak in beide staten vormt de premlsse voor de volgende vergelijking.

\subsubsection{Overaenkamst}

Wanut de erkenning van de andere geaardheid kunnen w w well degelijk een overeenkomst vaststellen tussen belde denocratische taken, namel1jk als wij hun werklng abstraheren van het doel warvoor aljworden ingezet. De democratische taak wan de vrltheld van menlngsulting in de DDR dient weliswar ter verdediging van de marxistisch-leministische warden en die in de Bondsrepubliek ter verdediging van de democrat $1-$ sche warden, mar bellde taken dragen dezelfde boodschap uit: systeemveramderende meningsultingen worden in princlpe niet geduld(6). Deze opvatting strookt net met de benadering van de vrijheid van meningsuiting als onvervreendbaar, absoluut recht. In de DDR bestaat die pretentie niet en is de werking van de democratische taak dus logisch. Mar de vrijheld van meningsuiting in de Bondsrepubliek knoopt wel an de westerse traditle vast (7) en daaron kan het niet als vanzelfsprekend worden geaccepteerd dat meningsultingen, die oproepen tot systeemverandering, niet worden geduld. Normaliter behoren oproepen tot systeemverandering vel tat een legitiem gebrulk van de wrijheid van meningsuiting. De enige restrictie in dit opzicht is dat de systeemverandering op vreedzame wijze moet worden nagestreefd(8). Derhalve ls de ult het princtpe van de strijdbare democratie voortvloelende beperking van de vritheld van meningsuiting niet normal.

\subsubsection{Versehtz}

Nu is de Westduitse grondwetgever zeker niet lichtvaraig te werk gegaan. Dat 1 s dan ook het verschil met de DDR, war door het in elkaar woelen van grondrecht en democratische taak de vrijheld van meningsuiting vanult het traditlonele standpunt gezien reeds van te voren 111 usoir is. De conceptie van de strijdbare democrate 19 darentegen de uitdrukking van het besef dat democratische taak en het postulat vam onvervreemdbaarheid van de vritheid van mentngsulting elkar bijten. Daarom zijn speclale warborgen geschapen om te voorkomen dat het erondrecht door de democrat ische taak wordt uitgehold. Niet elke systemveramderende mentingsulting wordt gecrininaliseerd maar alleen die, warult een actieve, strljdbare, agressiewe houding tegenover de bestaande orde spreekt(9). Bovendien kunnen sancties uitsluitend door het Bundesverfaseungsgericht worden ultgesproken(10). Mar deze 
voormarden nemen niet het gevaar wan de democratische taak voor de viljheld van menlngsulting weg. Het absolute harakter is doorbroken en het ristico van een glijdende schaal daardoor automat 1 sch gecreëerd. Reeds de arzeling van het Bundegwerfassungegericht in het geval van de KPD een verbod uit te spreken(11) toont an hoe dubleus en subjectlef een ingrijpen kan zijn. Hitelndelifk werd de agressieve, strijdbare houding van de KPD wit de ldeologische doelstelling van de Hetatur van het proletariat afgeleid, hoewel een ultzlcht op verwezeniljking wan dit doel absoluut niet bescond. Het monopolle van het Bundesverfasaungagericht werd vervolgens uitgehold door de individualise$r$ Ing van het KPD-verbod, zodat veroordellingen door de wrafrechter mogelijk waren, dle aan een verwerking wan de vilitheld van menlagsuiting ex art. 18 GG ge$11 \mathrm{jkstonden}(12)$.

zoals 1 in hoofdstuk 3 is vastgesteld(13), heet de rechtspraak van het Bundeaverfassungsgemicht met betrekking tot de strijdbare dernocatile een opvallende werschulving te zien gegewen. Van methode om de spanning tussen de garantie van de grondrechten en de behoefte an bescherming wan de rechtsorde op te lossen, is de strijdbare democratie tot een zelfstandige norm geworden, tot warde verheven. Door die verzelfstandiglng 1 s verwarloosd dat de strijdbare democratie aok de grondrechten dient te beschermen. In plats daarvan is de verdediging van de bestaande orde sec op de voorgrond gesteld. De verschuiving is met twee bljwerschijnselen gepaard gegaan: het aannemen van een plicht van de burger tot verdediging van de freiheitizche demokratische crundordmung en het gelijkstellen wan kritiek op concrete politieke verhoudingen met kritlek op de freimeititine demokratische Grundordnung. Belde ontwikkelingen zijn in strijd met de oorspronkelijke ultleg van het princlpe van de strijdbare democratie; $z i j$ bevestigen het risico van de glijdende schaal.

Relateren wij deze verschuiving aan de democratische taak, dan blifkt het volgende. De plicht tot verdediging van de frethettiahe demokmatiche Grundorinumg betekent dat de negatieve organdsatle van de vervul11ng wan de democratische tak, een van de elementen die har juist van de democratische taak in de DDR onderscheldde, wordt losgelaten. Dat leddt er toe dat de democratische tak positief georganiseerd raakt. Als deze positivering bovendien is gekoppeld aan de ontwlkkeling, dat kritlek op politieke toestanden wordt gelifkgesteld aan kritiek op het vilje democratische systeem, dan staat niet meer de bescherming van de rechtsorde inclusilef de grondrechten centraal, mar 
de bescherming van de staat, waaraan de vrlitheld van menlingulting ondergeschikt wordt gemakt. Eien zodanige instrumentalisering van de vrifheid wan meningsulting holt de conceptie van de strijdbare democratie zodanig ult, dat afgezien van de te verdedigen warde geen principieel verschll met de democratische taik van het grondrecht in de DDR meer bestart. In beide gevallen is de grondwettelijk gegarandeerde vil theld van meningsuiting van haar absolute gedaante ontdaan. Wel 1 set zo, dat deze posituvering in de rechtspraak van het Bundesverfassungsgemicht geen gevolgen voor alle burgers heett gehad. De gevolgen ziln slechts tot militairen en ambtenaren beperkt gebleven: "Es list deshalb eine Grundpflicht der Soldaten, durch thr gesantes Verhalten fü die Erhaltung der freihelt1chen ordnung elnzutreten"(14); "Vom Beanten wird erwartet, dass er diesen Staat und selne Verfassung als elnen hohen positiven Wert erkennt und anerkennt, fir den einzutreten sich lohnt" (15). Bovendien is de positivering niet zonder echo gebleven. De Radikatenera lass, war de vrljheld van polltieke mentngsulting om de hoek komt kijken, heeft zware kritilek te verduren (16).

Het geldende recht met betrekking tot ambtenaren en mlitalren mag nlet tot algemene veroordelingsmatstaf worden gemakt (al verraadt het wel een zekere menta11teit, die ook elders terug te vinden is). Woor het averige geldt de democratische taak van de vrlitheld van meningsufting in de Bondsrepubliek namelijk in zil n negatleve organisatie, zoals in het beglnsel van de strijdbare democratie neergelegd en warvoor, naar men mag aanmemen, de in het $R P D$-arrest ontwikkelde criteria gelden. Daarmee blifft ook de stelling overelind, dat de democratische taak in de Bondsrepubllek princlpieel verschllt van de democratische taak in de DDR, maar dat $z i j$ tegelijkertijd wel een doorbreking vormt van de opvatting dat de vritheld van meningsulting een onvervreemdbaar recht is. Door die doorbre$\mathrm{king}$ is het $\mathrm{risico}$ van $1 \mathrm{nstrumentalisering} \mathrm{steeds}$ aanwezig*

4.2. Het karakter van de voijhetd wan meningsutting in de beide Duitse staten al gevolg van haar demoeraticolse taak

4.2.1. DDR

Ben karakterisering van de vrifheld van mentngsulting in de DDR levert geen moel11jkheden op, aangezien het karakter van dit grondrecht geheel door de democra- 
tische taak wordt bepaald. De functie van het grondrecht 1 s de ondersteuning van de politiek van partij en stat ter ontwikkellng wan de soclallstische samenleving en van de soctalistische persoonlijkheld. Zorel de ontwlkkeling van de samenleving als van de individu dlent zlch te voltrekken in overeensteming met de objectleve wetmatigheden(17). De vrijheld van meningsulting is volledig gefunctionaliseerd. Het soclalistsche democratlebegr lp in aanmerking genomen kam worden gezegd dat sprake $1 s$ van een demoeratisch-functionele opvatting. Doordat de vrijheld van menlngsulting wordt geneten an de hand van haar belang voor de objectleve orde is zly - in haar democratisch-functionele kwalitelt - objectieve norm. Een subjectiefrechtelijke dimenste wordt het grondrecht onthouden, ook al wordt deze ten aanzien van andere, strikt persoonlijk getinthe grondrechten schoorvotend onderkend (18). Ziji heeft echter geen betrekking op een polltiek grondrecht als de vritheld van meningsulting(19). Ondat de vrijheld van meningsulting een politiek grondrecht is, is zij onderworpen aan het axioma van belangentidentiteit tussen Individu en samenleving, zodat een subjectief moment, dat nilet wordt gedekt door het objectieve ramwerk, zich theoretisch helemal niet kan voordoen. ook ult het gebrulk van de vrijheid van meningsulting voor privedoeleinden kan geen subjectiefrechtelijke dimensie ontspringen, want in de soclalistische wisle is privegebrulk nlet relevant en walt niet onder dit grondrecht (20). Als de individu al th het blikveld verschifnt doordat het grondrecht ook de ontwlkkeling van de soclalistische persoonlijkheld dient, dan heeft dit niets te maken met persoonlijkheidsontploofing in klassleke zin, maax met een ontplooling die past in de soclalistische matischappljuisie, zodat van een echte (onafhankelijke) subjectiviteit niet kan worden gesproken. Dat bewijst het ontbreken van individuele rechtsbescherming met betrekking tot de wrijheld van meningsuitting.

\subsubsection{Bondsrepubtiek Duitstand}

Wij hebben tot dusver gezlen dat vanwege de (negatlef georganiseerde) democratische taak van de writheld van meningsulting in de Bandsrepubliek in dit land de wrijheid van meningiuting net $z 0$ min als onvervreendbaar, absoluut recht kan worden omschreven als in de DDR, ook al staat has relativering dan juist ook in dienst van het behoud van de vrljheld van meningsulting als deel van de frethettiche demokratische Grumardinumg.

216 Binnen de grenzen, die de strijdbare democratie stellt, 
heeft de wrijheld van meningsuiting evenwel het karakter van een Individueel vijheidsrecht in klasslekIiberale zin en kan zij wiet aan een democratische taak onderworpen zijn. Dat volgt uit de definiering van de democratische tak als randvoorwarde; daarin ligt mu juist het verschil met de denocratische taak In de DDR, war grondrecht en taak in elkar opgaan en de taak de inhoud bepaalt.

In hoofdstuk $3(21)$ is echter stilgestaan bij de vraag. in hoeverre de democratische taak nitet tevens haar inwoed eventueel doet gelden binnen de door de strijdbare democratie getrokken grenzen, dus in dat gebled war de vrijheid van mentngsuiting in beginsel naar elgen belleven kan worden uitgeoefend. Wij hebben toen gezien dat het grondrecht, als door de strijdbare democratie te verdedigen warde, behalve bij gebrulk in het spanningsgebied van de strijdbare democratie, tevens zijn objectleve normgehalte doet gelden als dat spanningsgebied niet wordt betreden. Ook dan speelt de warde van de vrljheld van meningsulting als onmisbare factor in het proces wan democratische besluitvorming mee, en wel gefixeerd rond de publieke optnie, die het moet hebben van de vrijheld van meningsulting en dife op haar beurt weer voor de democratie onontbeer 11jk wordt geacht. Vastgesteld is dat, war die factor wordt onderkend, deze een steuntje in de rug van de vrijheid wan meningsuiting kan betekenen, wat des te meer telt angezien veel beperkingen van de vrijheld van meningsulting wellicht ilet zouden bestaan als de democratle niet zo strijdbaar was (22).

Van een democratische taak kan in zulke gevallen ulteraard ndet worden gesproken, hoogstens van een democratische beloning. Stelt men echter, dat het de overheld per definitie niet aangat, op welke manier men zijn grondrecht gebruikt, dan is ook dit stelsel van beloningen een bedrelging van de afweerfunctie van de vrijheld van menlingsulting. Dit als opmerking vooraf.

De door de strijabare democratie getrokken grenzen buiten beschouring gelaten, wordt ondertussen in het theht wan de karakterigering van de vilheld van meningsuting in de DDR toch wel duldelifk, dat het karakter van het grondrecht in de Bondsrepubllek anders geaard 1 s. De werkelijke stuatie 1 s ernttg vertekend door de eenzifdige aandacht, die zowel literatur als rechtsprak besteden an de objectiefrechtoljke $21 \mathrm{jde}$ van de vrlfheid van meningsulting. Men 1 sefascineerd door de schlechthin konstitulerende betekends var de vrifheid van meningsulting voor de democratie. Bij elke gelegenheid wordt dit aspect van het grondrecht als een trofee rondgedragen. Nadere 
analyse van de jurllsprudentle resulteert in en ander beeld. Overeenkomstig het postulaat van de in art. I GG gegarandeerde menselijke wardigheld als doel wan de gehele rechtsorde leidt de objectiefrechtelijke betekenls van de vrljheld van meningsulting geen zelfgtandlg leven. Zif wordt gevoed door de subjectietrechtellijke zijde, door de betekenis van het gromdrecht als Individueel wrijheidsrecht, dat de individuele persoon11jkheldsontplooling dient; zodat ook de beoordeling van de vrijheid van meningsulting als constituante van de objectleve rechtsorde geschieden moet wanuit het perspectief dat dit grondrecht naar elgen believen kan worden uitgeoefend(23). Deze optlek woorkomt een functionalisering van de wrijheid van menlingsulting. Doel is door het benadrukken van de betekenis van het grondrecht voor de democratie de positle van de wril jheld van mentngsulting als afweerrecht te vexsterken. Zonder twijfell is dat gellukt. In de eerste plaats is het werkingsgebled aanzienlijk ultgebreld doordat vanult het objectieve normgehalte aan het grondrecht horizontale werking is verleend (24). In de tweede plaats heeft dat objectieve normgehalte in het vergrote berelk - zowel bij conflicten met de staat als met derden - een verhoging van de status van de vrifheld van meningsuiting bewerkstelligd door middel van de toepassing wan de wisselwerkingstheorie(25), zodat het grondrecht bif de darna plaatsvindende afweging tegen andere belangen neer gewlcht in de schaal legt. Blj conflicten in het hor zontale berelk valt dit vooral op als het de vrljheld van menlngsulting versus de persoonlijke eer betreft; als andere aspectem van het algemene persoonli $₫ k h e l d s-$ recht in het geding zijn heeft de wisselwerkingstheorie geen betekenls(26). Ook blj verticale conflicten Levert de bljzondere betekenis van de viljeid van menlngsulting een welkome ondersteuning ter afweer van Ingrepen van staatswege $(27)$.

ook de lnstitutionele garantie van de perswritheld is niets anders dan een varlant op de behoefte het afweerkarakter van dit grondrecht te versterken. ZelEs het Sptegel-arrest $(28)$, In wellke ultspraak het Bundesberfaceungsgericht alch toch fllnk in de objectiefrechtelifke $21 j d$ wan de persvrijheid verslikte, betekende een versteriking wan de persvrijheid op kosten van de state. Hoewel noet worden vastgesteld, dat Ridder onderschelding tussen private en openbare vrijheld van meningsulting en diens opvattug over de functle van de pers in de staat (29) het Budeaverfasrunggemiaht heeft geinsplreerd blj de ultwerking van de institutionele garante, is de democratisch-func218 thonele opvatting(30) niet gevolgd. Uit de definiering 
van het Instetuut vije pers bijkt dat de perswi jheld ultelndelijk een vwijheld sec is gebleven(31). Wel mordt dle vrijheld sec in het 1 ilcht van de betekents wan de persvrifheid roor de objectleve orde beoordeeld. Deze beoordeling gat echter niet zo ver als in de Institutionele theorie van Baberte(32). Deze stelt de vifheid als institut voorop en stelt de individuele vrltheld daar min of meer in dienst van(33), terw1 11 het Bundesvenfassungsgericht er meet op uit is een evenwicht tussen de Individueie en de institutiorele zijde te zoeken, warbij beide zijden elkar wederzijas beinvloeden en sterken(34). Daardoor blifft de institutionele zelfstandigheld van de pers een an de individuele zijde gerelateerde zelfstandigheid.

Desalniettemin 11 jken bezwaren gepast tegen de gedachtengang van het Bundesverfasiungsgerioht, die achter de 1 in het Spiegel-arrest gebrulkte formuleringen en achter de benadrukking van de openbare tak van de pers schullgaat. Zij tast het bewustzijn an, dat de persurtjheid een individueel vrijheldsrecht is. Dit zou met name moeten worden vermeden met het oog op de reeds bestaande drelgling van functionalisering van de vrifheid van mentngsulting, die van het principe van de strifdbare democratie ultgat.

Tot dusver is een indienststelling van de vritheid van meningsulting volgens oostdults recept door de verankering van de objectiefrechtel1jke zijde wan het grondrecht in de subjectiefrechtelijke zijde echter niet rogelijk geweest.

\subsubsection{Paraztez}

Toch bestaat er een parallel in de wijze, warop in de Bondsrepubliek en de DDR met de vrljheld van meningsutting wordt omgegaan. Dat is de verwarlozing van het privégebruik van het grondrecht.

In de DDR telt alleen de openbare meningsulting; privê-menlingsuitingen zijn volstrekt irrelevant, $z 1 j$ vallem niet eens onder de garantle van art. 27 Verf. om te voorkomen dat meningsuit Ingen dardoor eventuee 1 aan het dictaat wan de democratische taak zouden kunnen worden onttrokken, wordt het begrip openbar zeer exten lief uitgelegd, zodat de mogel1 jkheld on non-conforme meningsultingen ult de prlvesfeer te bestraffen 1 in leder geval gewariborgd blijft( 35$)$.

Art. 5 IId 1 GQ bevat een garantle voor alle mening uitingen; ook het privégebruik wan de vrijheld van menlngsult $1 \mathrm{ng}$ wordt bescherod. De bepallng omvat zelfa het recht geen menlng te ulten(36). Maar 1 s daarom In de Bondsrepubliek de concrete bescherming altijd dezelfide? 
Wh hebben geconstateerd dat de positie van de wryheld van mentugsulting serker is als de objectiefrechtelifke $z i j d e$ in het geding is, dat wil zeggen indien een bijdrage aan de openbar meningsvorming wordt vastgesteld, als het grondrecht in geval wan confllct tegen andere rechtsgoederen moet worden afgewogen. Ten voorkeursbehandeling woor zulke meningsultingen betelkent automatisch een achterstelling wan zulke meningsutingen die geen bijdrage aan de menlingsvorming leveren, de prive-ultingen. Wordt de wheld van meningsulting alleen war gebrulkt in het kader van de lndividuele persoonlijkheidsontplooilng, dan is zij dus nlet zozeer het beschermen ward als wanner $2 \mathrm{lj}$ ook nog of in de eerste plats a an de openbare meningsvorming bljdraagt. Een bewijs dat de whselwerking, die volgens het Bumdeaverfasingsgemicht tussen objectlef- en subjectiefrechtelijke zijde van de vrijheld van meningsulting plaatsvindt $(37)$, niet alleen betekent dat de objectlefrechtelijke zijde de afweerfunctle versterkt, max ook de mate van afweer beinvloedt: hoe meer objectiefrechtelijke relevantie, des te neer afweer.

Men kan dege differentiatie betreuren, andat zij net als de democratische taak lesdt tot een indeling van meningsuitingen in klassen en het absolute karakter van het grondrecht doorbreekt. Men kan zich echter ook op het standpunt stellen dat de differentatie wellswar discrimineert, mar geen nadelige gevolgen voor het privégebrulk van de wrijheid van meningsulting met zich mee brengt. Voor dit soort uitingen geldt immers nog altijd de normale bescherming van art. 5 GG zoals door de grondwetgever vastgesteld, dat wil zeggen als afweerecht net inachtneming van de ult art. 5 ild 2 GG voortvloriende beperkingen, zij het dan zonder de verzachtende werking van de objectleve betekenis voor de desbetreffende meningsulting. Dat is aok genoeg, kan men zeggen, want de vxijheid van meningsuiting is in princlpe nu eenmaal een normal grondrecht dat aan normale beperkingen onderworpen is en bijwoorbeeld nilet ten koste van de persoonlifke eer van andere individuen kan worden uitgeoefend, indacht $1 \mathrm{~g}$ het motto dat de vrijheld van de en ophoudt waar de vrijheld van de ander beglnt. En elgenlijk is het coch al heel mool dat door de horizontale werklng een beroep op de vrijheld van meningsulting in weel gevallen iberhaupt mogelijk is gemakt.

De differentlatie tussen meningsultingen, die wel en die niet aan de menlngsworming bljdragen, kan men dan ook met het oog op het belang van de persoonlljke eer, in leder geval in de privesfeer, accepteren, hoewel de 220 vraag in de lucht blifft hangen, waarom deze redene- 
ring plotseling niet meer opgat als de meningsulting die de persoonlijke eer aantast de openbare mentngsvorming dient.

Problematisch is de differentiatie echter vooral in verband net prive-uitingen, die een overtreding apleveren van voorschriften, die de vrijheid van meningsulting niet in het belang van de persoonlijke eer, maar $1 \mathrm{n}$ het algemeen belang beperken. In dit geval speelt het conflict zich namelijk niet af in een gebled, dat door de horizontale werking nieuw onder de bescherming van de vritheid van meningsulting is gekomen, maar betreft het een klassiek conflict tussen individu en staat. Het is met het absolute karakter van het grondrecht moellijk te verenigen dat een reactle van overheldswege op een meningsulting en de uiteindelijke beslissing ower haar toelatbaarheid c.q. ontoelaatbaarhejd afhankelijk wordt gemakt van het gebruik, namelljk of deze in concreto voor de openbare meningsvorming van beteken is is of niet, met andere woorden: of de democratle er lets aan heeft.

Bovendien bestaat de kans dat de watstelling, of een meningsulting een bijdrage aan de meningsvorming levert, wordt beinvloed door de inhoud van de mentingsuiting.

W1 men de schlechthin konstituiemende betekenis van de vritheid van meningsulting perse tot witing brengen, dan zou het toch loglscher zifn deze waardering niet te beperken tot meningsultingen die een bijdrage aan de openbare meningsvorming leveren, maar alle meningsuitingen in deze wardering te laten delen, want witeindelijk draggt iedere meningsulting, ook degene dle uit privé-overwegingen gedarn 1s, bij tot de vorming van de publieke oplnie. Het is tamelijk kunstmatig om aan te nemen dat de "offentliche geistige Auseinandersetzung" niet ook van prive-uitingen leeft. Elke menlngsuiting is gohtechthin konstituierend, niet slechts als zij uitdrukkelijk als leverancler voor de publieke opinle kan worden geidentificeerd $(38)$.

Op dezelfde veronachtzaming van ult priveoverwegingen gedame meningsultingen is de instltutionele garantie van de perswr 1 jheld terug te voeren. Deze berust op de veronderstelling, dat de objectlefrechtelljke relevantie van meningsuitingen door de pers reeds bif voorbaat vaststaat en dat darom wan hun toelaatbararheld moet worden ultgegaan. Dat betekent geen vrifbrief voor de pers. Ook doax de persvritheld beschermde mentngsultingen worden aan de bekende afweging ondermorpen. Wel is het a ammemen van de objectlefrechtelijke relevantie - vertaald in de openbare taak - 
voldoende reden woor algeweme matregellen ter bescherwing van de 1 infastructur van het gehele perswezen. De institutionele garantie is dan wel officleel een versterking van de perswrijheld als afweerrecht "zil If in werkelijkheld uttsluitend lagegeven door het veronderstelde belang van de persurijheld voor de democratie(39). Z1j loochent het karakter van de persvitheld als individueel vritheldsrecht. De erkening van de objectiefrechtelijke betekenls, verbonden met de benadering van de pers als instituut, doet vollstrekt ut het oog verliezen dat ook lndividuen van de persurtheld gebrulk kunnen maken, bovendien wellicht ook nog om prive-redenen. Het kunstmatige onderscheld tusben meningsultingen die wel en niet wan belang zljo ju voor het functloneren van de democratie wordt door de institutionele garantle versterkt. De ult de institutionele garantie voortviolende privileges en de zorgvuldigheldsplicht laten de mogelijkheid van een eventueel privêgebruik van de persvrijheld bijna tot een soort ridiculiteit uit het verleden verbleken( 40 ). ook de sittliche tuitidee van de vrijheld van meningsuting, de warheldavinding, doet niet vermoeden dat de individuele persoonl1jkheldsontplooling ongeslagen aan kop staat. De wartheld 1, niet zo belangrijk, omdat individuen door de anwarheid in hun waardigheld zouden kunnen wordien aangetast. Nee, eerder is men bang dat anders de voor de democratie onontbeer 11 jke meningsvorming niet optimal zou kumnen functioneren (41).

De vrlitheid van meningsuiting in het algemeen en de persvrifheid in het bijzonder worden beheerst door de democrat 1 che gedachte. Zeker $1 \mathrm{~s}$, dat meningsultingen met een openbaar aspect au eenmal problematischere effecten kunnen hebben dan meningsultingen voor privégebruik, Logisch dat in de rechtspraak en in de 11teratuur dit soort litingen dan ook central stat. Weliswar wordt de gedachte, dat het grondrecht de persoonl1jke ontplooling dient en afweerrecht is, gerespecteerd. De werkelijke belangstelling gaat ondertussen ult nat zijn betekenis voor de democratie. Het grondrecht als objectleve morm leldt een eigen leven; dat at ultelndelijk toch de persoonlijke ontplooling dlent, $11 \mathrm{jkt}$ te worden vergeten. Dan wekt het ook geen verbazing meer, als een rechter opmerkt, dat de onaantastbare kern van het $1 n$ art. 5 ild 1 GG verankerde grondrecht bestat "In der Gewhinlelstumg desjenlgen Mindestmasses an gelstiger Auseinandersetzung, das fux die fretheit liche demokratische statsordnung lebens- 
4.2.4. De vor.jheid van meninguting ats individuele ontplooing en als deel van de objectiene orde

In de Oostdultse visie op de vrijheld van meningsuiting staat de soclalistische samenleving woorop, daarna komt de ontwlkkeling wan de socialistische persoon11 jkheld, zulks in overeensteming met dezelfde objectleve wetmatigheden, die ook de ontwikkeling van de samenleving bepalen.

In de Bondsrepubllek stat de individuele ontplooling van de persoonlijkheld voorop. Dat volgt dringend uit de primaire functie van de vrijheld van meningsuiting als afweerrecht. Voor een deel wordt het belang van de individuele ontplooling evenwel in het licht van het concrete belang voor de democratie beoordeeld. Op meer afweer kan een meningsuiting namelijk rekenen als $z i j$ naast persoonlijkheidsontplooilng ook objectiefrechte11 jk relevent is. Afweer is de primaire functie, naar door haar te koppelen aan de vraag of een meningsulting een bijdrage aan de openbare meningsworming inhoudt, wordt de absoluutheld van de afweer ondergraven.

Duitsland heeft een op de staat gefixeerde traditie. De staat is altijd een zelfstandige grootheld geweest, nooit een afgeleide. Het getuigt van continulteit in het denken dat men er zowel in de DDR als in de Bondsrepubliek moelte mee heeft de individu en zijn ontplooling los te zien van de staat. In de DDR is de persoonlifkheidsontplooing door de staat geannexeerd, blijkens de aldaar aangehangen grondrechtenopvatting. Dat is in de Bondsrepubllek nlet het geva1. Daar is de staat in dienst van de individu gesteld. Maar deze legitimate vanuit de individu makt de state nog ndet tot een afgelelde. Ondat de democratische staatsvorm een onontbeerlijke voorwaarde is voor een optimale individuele ontplooiling, blijft de voedingsbodem voor het ldee dat de staat een zelfstandige factor is aanwezlg. Hoewel de grondrechten verhinderen dat dit ldee praktische consequenties heeft, maakt de leer van de strijdbare democratie het mogelijk dat het idee wakker bilift. De jurlisprudentie met betrekking tot de strijdbare democratie toont aan dat het gevaar niet 11lusoir is, dat de stat zelfstandige betekenis verwerft. De verdediging van de sta.at tegen een "onelgen$11 \mathrm{jk}^{*}$ gebruik wan de grondrechten laat gemakkelljk vergeten dat de stat als democratische orde er juist 1s on die grondrechten te verdedigen.

De belloning van de vrijheld van meningsulting is in de Bondsrepubliek de keerzijde van de medallle, waarvan op de voorkant de strifdbare democratie is ingegrift. ook binnen de grenzen van de strifdbare democratie, 
het gebled war de vitheld wan meningsulting eifenlifk naar elgen belleven kan worden gebrulkt, wordt het grondrecht beoordeeld op $z 1$ jn warde voor hit proces van politieke beslultvorming. De bezorgdheld, die aan de beloning van de vrljheld van meningsulting ten grondslag 11gt, betreft de levensvatbaarheld wan de democratie, ntet de individuele ontplooilng. Als aan de indiwiduele ontplooiling gedacht wordt, dan 1 s dat in felte indirect: de democratie als voorwarde voor Individuele ontplooilng. Door de aandacht woor het middel wordt het doel ook in dit verband verwar$1005 \mathrm{~d}$.

Gelukklg is de afweenfunctie van de vrijheld van meningsulting voldoende ingeburgerd om werkelijk negatheve gevolgen van deze redeneerwijze, uitlopend op een functlonalisering wan het grondrecht, te voorkomen. Negatieve gevolgen op het vlak van de perswrijtheid worden blfwoorbeeld vermeden door het censuurverbod In art. 5 1ld 1 GG. ook al verbledt het alleen censuur vooraf, de warde ervan wordt duidelifk als men het censuurverbod met het vergunningenste 1 sel in de DDR vergelljkt. In de DDR is de ultoefening van de persvrigheld in principe verboden, tenzij zij expldciet $1 \mathrm{~s}$ geoorloofd(43). In de Bondsrepubliek heerst in principe onbeperkte vrijheid, tenzij de uitoefenting expliclet wordt beperkt(4). In geen geval mag de perswrifheld volledig door middel van beperkingen worden ultgehold. Elke beperking $1 \mathrm{~s}$ apart aan toetsing onderhevig en elke beperking moet in het $11 \mathrm{cht}$ van de bijzondere betekenis van de persurifheld worden ultgelegd

In de DDR krijgt de persur the ld bij voorbaat een mullkorf om, om niet te zeggen $1 \mathrm{n}$ het geheel geen kans, terwljl in de Bondsrepubliek elke persuiting mogelijk 1s, met dilen verstande dat de auctor intellectualis er achteraf verantwoordelijk voor kan worden gesteld. Natuur $11 \mathrm{Jk}$ is $\mathrm{d} 1 \mathrm{t}$ censur achteraf. Censur achteraf kan bovendien voor de toekomst preventief werken, zodat $z i j$ indirect ook nog een censuur vooraf kan zij. jn. De term censurur in art. 5 11d 1 GG ("Elne Zensur findet nicht stat" ) is derthalve ongelukklg gekozen. Censuur bestaat alt 1 d. Alleen censuur vooraf is verboden(45). Wat men met de zinsnede: "Bine Zenswr indet nicht statt" in felte bedoelt uit te drukken is He bevestiglng van de afweerfunctle van de persvrijheid. Deze woorden staan ervoor garant, dat bif de persorifheld het aspect van de individuele ontplooling niet verloren kan gan. Zlj maken het definitief onmogelijk de persvilfheid te fumctionaliseren. De onduldelljke formulerlag van de persvrljheld in art. 5 1.d 1 tweede $z$ in $G G$ zou dit anders niet hebben uitgeslo- 
ten.

Het onbetwiste voordeel van dit censuurverbod vooraf is dat elke censunmatregel zelf voorwer v van openbare discusile wordt, hetgeren de moed om bestaande beperkingen te trotseren kan aanwakkeren. De vingerwijzing van het Burdesverfasingegericht naar de schlechthin konstituterende betekenis van de vrijheld van meningsulting heeft dit bewustzijn zonder toljfel gesensiblilseerd. Van een beperkingsautomatisme a la Welmar is geen sprake in de Bondsrepubllek. De afweerfunctie is versterkt.

\subsubsection{Beperikingen en de democratische taak}

Dolk op dit enerzijds volgt een anderzijds. Het censurverbod onderstreept wellswar de afweerfunctie van de vrijheld van meningsuling, maar dat makt een, door de beperkingen ex art. 5 lid 2 GG mogelljk gemakte, censuur achteraf nog niet onproblematisch.

Werpen wij een blik op de beperkingen in het belang van de algemeenheid, dan dulkt de zorg weer op, die an de conceptie van de strijdbare democratie ten grondslag 11gt. De bescherming van de vrlje democratische rechtsorde gat de wetgever ook in het kader van art. $5 \mathrm{GG}$ zeer ter harte. Zie het jarenlange invaerverbod van oostdultse lectur, de keuring van bultenlandse fllms(46), de criminallserlng van natlonat-soclalistische meningsuitingen( 47 ), het bestaan vam een uitvoerlge batterij strafvoorschriften ter bescherming van het aanzien van de rechtsorde, de stact en zijn organen(48) en last but not least de criminalisering van meningsuitingen dle zlch met het verschijnsel geweld bezighoudem(49). Het zijn ten dele zeer vergaande beperkingen (geweest), ingegeven door de angst om het overleven van de democratische staat. Zif zijn uitdrukking van de filosofie achter het princllpe van de strijdbare democratie, dit mal met andere middelen voortgezet.

Hun uitwoerigheid is in tegenspraak met de opvatting dat de democratie het van een vrije discussie moet hebben, zoals ook de implementatie van de beperkingen de vramg opwerpt, wat elgenlifk bescherming behoeft: gaat thet om "Absicherung Irgend edrer", of "ganz spezlli derjenigen politischen ordnung, fux die Melnungs-, Presse- und Informationsfreiheit konstitutiv sind" $(50)$ ?

De voortvarendheld van de wetgever bif het creeren van beperkingen van de vrijheld van meningsulting rot weer enigszins ongedaan gemaakt door de wisselwerkingstheorte, die de rechter hanteert als en meningsuiting in confllict komt met een van de beperkingen en 
wardoor de beperking in kwestie buiten werking word gesteld als de menlngsulting een bifdrage an de vorming van de publieke oplnie levert. Mar als men het met de bijzondere betekenis van de wrljheid van mealngsulting werkell $j \mathrm{k}$ zo ernstig meent 1 ligt het weeleer voor de hand, dat het Bundesverfassungsgericht grmige van de beperkingen uberhaupt niet als in beglnsel geoorloofde beperkingen zou toelaten. Per slot van rekening heeft het $z$ ich competentie gegeven de beperkingen op formele criteria ta: toetsen en ze ongeoorloofd te achten als miet aam zowel de formele als de materiele voorwarden voldaan 1s. Heef het Bundeoverfassurgsgemicht nlet bepalla, dat algemene wetten alleen die wetten zijn, die "nlcht elne Melnung als solche verbleten, die slch nicht gegen dle Aeusserung der Melnumg als solche richten", die vielmehr "dem Schutze eines schlechthin, ohne Ricksicht auf elne bestimnte Melnung, zu schitzenden Rechtsguts dienen", dem Schutze eines Gemeinschaftswerts, der gegenuber der Betätigung der Melnungsfrethelt den Vorrang hat"(51)? B1j velle beperkingen is het werke11jk discutabel of zij niet een menlng als zodanig verbleden en bestaat er aanleidling te veronderstellen dat zij wel degelijk een bepaalde mendng op het oog hebben. Doch het Bundeaverfassungsgeriaht heeft deze criterla niet willen gebruiken en zich volledig laten lelden dow de overtuiging dat elke beperking steeds de bescherming van een Gemeinschaftswert betrof, die voorrang had boven de ultoefeming van de wrijheld van mentngsuiting. Ongetwijfeld is het nlet moelijk zo'n voorrang aan te nemen vanult de wardevoorstellingen van de strljdbare democratie, die leeft van de fllosofie, dat de objectieve vrije democratische rechtsorde ook har portie bescherming behoeft.

Onverbloemd werd dit toegegeven door het Bundeggerichtshof, toen het moest bepalen of de strafbepallingen die nationaal-socialistische meningsultingen verbleden wel geoor loofde beperkingen wan de vrijheid van meningsulting vormen(52). Weliswar betwiffelde het hof of deze beperkingen wel algemene wetten in de $\mathrm{in}$ van art. 5 11d 2 GG waren, maar het stapte daar laconlek over heen met de constatering dat zij werden gerechtwardlgd door de in de strijdbare democratie tot ultdrukking komende behoefte tot bescherming wan de fretheititiche demakntische Grandordnung. Met andere woorden als een beperking wan de vrijheid van meningsuiting echt niet geoorloofd $11 \mathrm{jkt}$ te $\mathrm{zljn}$ wolgens de formele criteria, kan men zlch altljd nog beroepen op het princlpe van de strifdbare democratle on haar 226 toch toelaatbaar te laten zljn. 
Wor een aantal strafyoorschriften bestaat de noodzaak, dat $z 1 j$ algemene wetten in de zin van art. 5 lid 2 GG zijn, natuurlijk a priori niet. Dat zijn die woorschriften die een partijverbod of een verenigingswerbod moeten effectueren en derhalve alleen mogen worden toegepast als een verenigings- c.g. partijverbod is uitgesproken (par. 84, 85 en 86 lid 1 sub 1 tot en met 3 StGB). De toepassing van deze strafvoorschriften wordt rechtstreeks door de artt. 9 lid 2 en 21 IId 2 GG gelegitimeerd.

Enerzijds dus de aan de strijdbare democratie inherente nelging de vrijheid van meningsulting tamelifk woortvarend aan beperkingen te onderwerpen. Anderz1jds juist de poging on door middel van een beroep op de objectiefrechtelifke component van de vrijheid van meningsuiting het grondrecht op te warderen, al gebeurt dat niet langs de hele linie, wat weer tot gevolg heeft dat het privégebruik van de vrijheld van meningsuiting wordt verwarloosd. Deze twee tendenzen doorkruisen elkaar in zekere $z i n$. In de praktijk betekent dat vooral dat door de beloning die van de tweede tendens uitgaat de nadelige gevolgen van de eerste tendens gedeeltelijk weer kumnen worden opgeheven (maar niet, nadat de justitiele raderen in beweging zijn gezet). De erkenning van het objectieve normgehalte van de vrijheld van meningsulting, die aan belde tendenzen ten grondslag. $11 \mathrm{gt}$, leidt aldus in sommige gevallen tot hetzelfde resultat als in de situatie, wanneer de erkenning van de vrijheid van meningsuiting als objectleve norm nlet zou hebben bestaan: enerzijds geen strafrechtelljke beperking, zodat anderz1jds aan een opwaardering van de vrijheld van meningsulting op grond wan haar schlechthin konstituterende betekents ook geen behoefte zou zijn geweest.

\subsubsection{Conctusie}

U1t het voorgaande moge duidelijk $z 1 j n$ geworden, dat de beoordelling van het karakter van de vrijheld van meningsulting in de Bondsrepubliek een gecompliceerde aangelegenhefd is. Dit in tegenstelling tot een beoordeling van het karakter van dit grondrecht in de DDR. De Westduitse 1iteratuur heeft over het algemeen geen moelte met een standpuntbepaling. Weliswaar makt men zich bezorgd over de invloed van de Werttheorie(53) en de institutionele theorie(54) op de wrijhelld van meningsulting, maar bif een inventarisering worden de grenzen, dle de strifdbare democratie aan het grondrecht stelt, als vanzelfsprekendheld geaccepteerd en derhalve niet in de beoordeling betrokken, zodat in de 
Westduitse literatuur de conclusie tenslotte kan zijn dat het grondrecht een individueel vrijheldsrecht, eent afweerrecht is (55).

Maar het is nu julst de strijdbaarheid van de denocrathe en de daarmee verbonden consequentles voor de vrijheld van menfingsulting die een cruclaal gegevent zijn woor een beoordeling van het karakter van de vrl Jheld van menfingsuiting in de Bondsrepubliek. Miet alleen omdat de democratische taak de absolute pretentie van de wrijheld van meningsuiting als onvervreendbaar recht doorbreekt, maar ook omdat de erkenning van het dubbele karakter van de vritheid van meningsulting en de fluatle op haar objectlefrechtelijke component voortspruiten uit dezelfde gedachte wan de strijdbare democratie, de verabsolutering van de freitheitilehe demakratische Grundordnung en de plaats van de grondrechten daarin als objectieve waarden. De vrijheid van meningsuiting is in al haar facetten verstrengeld met de democratische gedachte.

In het voorgaande is geprobeerd een verbinding te leggen tussen de in de Bondsrepubliek negatief geformuleerde democratische taak van de vrijheld van meningsulting en: enerzijds de verregaandheid van de beperkingen waaraan dit grondrecht binnen de door de strijdbare democratie gestelde grenzen (als afweerrecht dus) is onderworpen, anderzifds de opwaardertng die het grondrecht heeft genoten als gevolg van de erkenning van het objectleve normgehalte. Het beeld dat ontstond was een wirwar wan tegenstrifdige tendenzen. Dat beeld laat in leder geval rulmte woor de conclusie dat de garantle van de vrijheid van meningsulting in de Bondsrepubliek van een princlpieel andere orde is dan die in de DDR. Maar tegelijkertijd levert. de confrontatie met de vrijheld van meningsulting im de DDR de constatering op, dat de benadering van de vrijheld van meningsuiting in de Bondsrepubliek zeer ambivalent is. Alle elementen in aanmerking genomen kan niet worden verdedigd dat de vrijheld van meningsuiting in de Bondsrepubliek een onvervreemdbaar, absoluut recht $1 s$, gemeten aan de pretenties van de klassleke 11 berale opvatting over grondrechten. De ultoefening van de vrljheld van meningsuiting mag in de Bondsrepubliek immers niet tegen de democratie gekeerd $z 1 \mathrm{Jn}$. Houdt men zlch aan deze voorwaarde, pas dan is de vrijheid van meningsulting absoluut. Maar dan nog wordt die absoluutheid van binnenuit weer bedrelgd, namelijk via de door de strijdbare democratle geInsplreerde strafrechtelijke beperkingen ex art. 5 lid 2 Gi in het belang van de algemeenheld. Pas een beroep op diezelfde objectlefrechtelijke dimensie, die de vrij228 held van meningsulting in het kader van de strijdbare 
democratie van hat absolute karakter beroof, kan deze bedrelging, die wit art. 5 lid 2 GG voortkome, neutrallseren. Wellswar versterkt deze objectiefrechtelijke dimensie in eerste instantie de afweerfunctie, maar $z$ if verzwakt har tevens, doordat niet alle meningsultingen beloond worden, maar alleen die menungsultingen die aam de openbare meningsvorning bijdragen en het resull taat dus een verdeling van meningsultingen in klassen is.

of de vritheld van meningsulting in de Bondsrepubllek ulteindelijk gebat is bij de erkenning van haar objectiefrechtelijke normgehalte kan hier in het mididen blijven. Deze erkenning hangt samen met spectifleke Duitse historische ervaringen en het kan $z i j n$ dat $z i j$ in de huidige tijd het geëigende middel is om respect voor de jonge democratie te kweken. Wel heeft die erkenning gelesd tot een benadering van de vrijheid van meningsuiting die zo gecompliceerd is en zo veel bijverschijnselen vertoont, dat een jurldische erkenning van het objectleve normgehalte sec, bijwoorbeeld in de context van de internatonale mensentechtendiscussie, niet nastrevenswaardig 11 jkt. Zij ondergraaft de stelling, dat de vrijheid van menlngsulting een onvervreendbaar mensentecht is.

4.3. Het karakter van de vrijheid van meningsuiting in het licht wan het Internationaal Verinag inakke Bur germechten en Politieke Rechten

Op dit punt aangeland is het zinvol zich te bezinnen op de strekking van het International Verdrag Inzake Burgerrechten en Politieke Rechten. Daarvoor verschaft de preambule belangrijke aanknopingspunten. Aan de hand van de preambule kan het doel wan een verdrag worden vastgesteld(56). Volgens de preambule van het Verdrag Inzake Burgerrechten en Politieke Rechten w1 het Verdrag een bijdrage leveren aan de verwezen $11 j-$ king van het 1 deal van de vrije mens, dat will zeggen de mens die staatsburgerifjke en politieke viljheld genter en die vrif is van wrees en gebrek. pit doel $1 \mathrm{~s}$ geformuleerd vanult de overweging, dat de erkenting wan de thherente wardigheid en van de gelijke en onvervreemdbare rechten wan alle leden van de memsengemeenschap grondslag is voor de vrijheid, gerechtigheld en wrede $4 n$ de wereld en dat deze rechten woortvoelen ult de inherente wardigheld van de menselijke persoon. Elke individu bezit dus onverwreendbare rechten als wituloelsel van $z i j n$ inherente wardjgheld. Wit de travaux préparatoires blijkt, dat bij de op- 
stellers var het Verdrag over dit deel van de preambule consensus bestond(57). De geciteerde zimen bevatten een erkening van het oorspronkelifke karakter wan de grondrechten als individuele vrijheldsrechtem. Aldus heeft in de preambule een logische aansluiting plategevonden an de betekenis van de grondrechten, zodis die in de geschiedenis tot uiting is gekomen. Van de Magna Charta tot Martin Luther King, zowel voor Engelse baronnen in de dertiende eeuw als voor de zwarte bewalking van Soweto op de drempel van de eenentwint1gste eeur $z 1 j \mathrm{jn}$ de grondrechten tot op de huidige dag en overal ter wereld, niet alleen in Gdansk, maar ook in onze elgen woonplaats, uitdrukking van de emancipatlestrijd van - al dan niet collectief optredende - individuen tegen dwang, onderdrukking en onverdraagzaamheld van de machthebbers. Altijd werd en wordt gestreden woor de respecterlng van een kern van wardigheld die, zoals de geschledenis leert, universeel wordt beschouwd als inherent aan ledere mens, en warult het onvervreemdbare recht tot ontplooflng van de elgen persoonlijkheld voortvloeit. of die onvervreemdbaarheld nu bewijsbaar is of niet(58), is van minder belang. Dat is een ideologische discussie, die wordt ingehaald door de weerklank, die de clatm in de praktijk bij ontelbare mensen romdom de aarde veroorzaakt.

Er bestaat overigens geen twijfel aan, dat de grondrechten $1 \mathrm{n}$ de loop van de geschiedenis steeds $z 1 j n$ gebruikt als argumenten in een collectleve strifd, die politiek gemotiveerd was. Maar zoals de betekenis wan de grondrechten voor het functioneren van de democratie In werkelijkheid een afgeleide van hun betekenis voor de persoonlifke ontplooling is(59), zo zijn ook de polltieke eiser, ten behoeve warvan de grondrech-

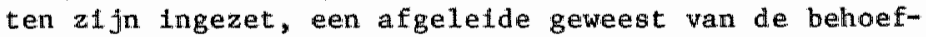
te aan erkenning van de eigen individualiteit. Zelfstandige beteken 1 s voor het objectieve normgehalte vam de grondrechten mag uit de geschiedenis nitet worden afgeleid. Achter de objectleve betekenis gaat steeds de individu schuil.

Utt de ononderbroken ontwikkelingsgang van de grondrechten als middel tot, misschien dikwijls collectief opgeëlste, maar 1 in de grond van de zaak individuele, emanclpate heeft de socialistische grondrechtstheorle zloh losgenalkt. Steunend op de marxistische maatscheppijanalyse wordt als basis voor de huldige afwifling van het karakter van de grondrechten als ind1viduele vrijheldsrechten een fase in de geschiedents genomen, warln de grondrechten inderdaad slechts an bepalde groepen in de samenleving ten goede kwamen en 230 er nog lang geen sprake was van writheld en gelijkheid 
voor ledereen. In de eeste helft van de negentlende eeuw dienden de grondrechten de bielangen van de bourgeolsie. Mar het verheugende is nu fulst, dat die fase alleen mar een schakel in een lange ketting is gebleken. Marz baseerde zijn theorie op wat hij toen wist. Hij wist niet wat - ten dele dankzij hem - na hem zou komen. De emancipatie ging door. Vrijheid werd realitelt voor telkens weer nieuwe groepen. Na het manmelijkce deel van de burgerlijke klasse volgden in ons deel van de wereld andere mannen, daarna ook de voumen. Het emancipatieproces is nog steeds niet afgesloten. Steeds weer grijpen bestaande en nleuwe groepen de kans zich te emanciperen dan wel in gang gezette ontwikkelingen te verdiepen. De grondrechten zijn voor hen het vaandel.

ook het proletariaat, de "doelgroep" van Marx, heeft woor zijn emanclpatie gebrulk gemakt van de grondrechten. Taen Marx en Engels hun opus schreven, oefenden $z i j$ het recht op vrijheid var meningsulting th de traditionele betekenis uit. De emancipatie van menig marxist en arbelder in Europa is dankzij de grondrechten (in hun oorspronkelijke betekenls) tot stand gekomen. Dat $\mathbb{1 n}$ de socialistische staten van het oostblok de grondrechten nu zijn gemonopoliseerd door etn groep, die dit legitimeert door de flxatie op een matschappijbeeld van honderdvijftig jaar geleden, makt de grondrechten nog niet tot grondrechten van een nieuwe kwalitelt, die niets met het begrip te maken zouden hebben, zoals dit in het westen wordt verstan. De grondrechten zijn een in de westerse geschiedenis onderkend en tot bloel gekomen fenomeen. De soclalistische grondrechtstheorle doet niets anders dan dit fenomeen aan de elgen behoeften aan te passen. Dat is een vrij hopeloze aangelegenheid, want het begrip is nu eenmaal. met een eeuwemoude overtuigingskracht verbonden, die berust op indlviduele emancipatie. Tegen deze tendens in gaan betekent onderdrukking en anti-emancipatie( 60$)$.

De soclalistische grondrechtstheorie heeft zlch wellswaar wit de dynamische ontwikkeling van de grondrechten losgemakt, maar dit verandert niets an de hoofdrlchting wan deze stroom. De strom zoekt zijn weg verder en vindt steeds weer nlewwe anhangers.

oolk de preambule van het Internationaal Verdrag inzake Burgerrechten en Polltile Rechten getuigt daarvan. Zij lat bovendien zien dat de stroom universeel 18 * Als de Dostdultse stadtieer van menling $1 \mathrm{~s}$, dat het Verdrag een compromis tussen de traditionele en de soclalistische opwating over grondrechten $\mathbb{H}(61)$, dam geldt dat lin leder geval niet voor de genoemde passage wit de preambule. Deze past ultslutend in de hoofd- 
atroom van de geschledenis van de grondrechten, die voor Mary zijt weg wond en na Karx zijn weg verder heeft gezocht. ZIj vernieut de belofte wan enancipathe en lewert een vruchtbare roedingsbodem foor een strijd, die door het grootste deel van de mensheid altijid nog gestreden moet worden.

Howel ult de preambule van een verdrag geen directe rechten en verplichtingen voor de verdragspartijem voortvloelen, kan zlj van bellang zijn woor de uitleg van de elgenlijke verdragsbepallngen. Art. 31 11 1 van het Weens Verdragenwerdrag bepaalt dat een verdrag te goeder trow moet worden uitgelegd in overeenstemming met de gewone betekents die aan de bewoordingen van het verdrag kan worder gegeven in hun context en In het licht van "object and purpose" van het verdrag. Voor de uitleg van een verdrag is dus niet uitsluitend de tekst van de verdragsbepalingen van belang. De tekst moet worden gezien in zijn context en in het licht van de bedoelingen van het verdrag.

Art. 31 1Id 1 van het Heens Werdragenverdrag bevat aldus een mengeling van tekstuele en teleologische Interpretat lemethoden(62). De teleologische methode is niet alleen mar een additioneel hulpmiddel als de tekstuele methode(63) tekort schiet (64); de bedoelling van een verdrag dient ook reeds bij de uitleg aan de hand wan de tekst zelf te worden betrokken(65).

Voor de uitleg van een verdrag is, zowel als deel van de context(66) als woor het vaststellen van de bedoeIIng(67), de preambule van een verdrag relevant. Doordat de preambule deel uitmakt van het verdrag zelf en derhalve net zo goed als de tekst jurldisch blndend is(68), onderscheldt zij zich bijvoorbeeld van de travaux préparatolres, die ook van belang zijn voor de vaststeliling van de bedoeling van een verdrag, maar die voor de interpretatie eerder van supplementaire betekenis zijn(69).

Uit een en ander volgt, dat de eigen 11 jke verdragsbepalingen, die de jurldisch bindende uitwerking van de erkenning van de inherente wardigheld van de mens in de preambule vormen, en die rechten en verplichtingen voor de verdragsstaten in het leven roepen, vanuit de hlerboven ulteengezette optlek moten worden gelezen. Dat vele van de garanties an beperkingen kunnen worden onderworpen doet a an de zeggingskracht van de preambule niets af. Elke individu makt nu eennal deel ult van een geneenschap, wat betekent dat zowel de rechten van andere individuen als het collectleve belang bepalde grenzen aan de individuele rechten 
De princlpiele vaststelling, dat een vergelljk tussen verschillende belangen noodzakelijk is, stat nlet ter discussie. Wel kan men van inzlcht verschllien hoe dat vergelijk er in concreto dient ult te zien en welke beperkingen in het belang van de rechten van anderem en van het collectief anvaardbaar $z 1 \mathrm{jn}$. Versch1l van mening kan zelfs al bestaan binnen de groep wan landen, war de parlementalre democratie de legitimatie voor het collectlef wormt.

Blijkbaar biedt de wijze van formulering van de individuele rechten en vrijheden in het verdrag ook voldoende rulmte voor landen, die geen demacratische regeringsvorm hebben, om zich er probleimloos mee te kunnen verenigen. De Oosteuropese soclalistische staten zijn tot het Verdrag toegetreden, hoewel zij er geen gehelm van maken dat $21 j$ de opvatting van grondrechten als onverveemdbare rechten niet delen. De in de verschillende verdragsbepalingen opgenomen beperkingsmogelijkheden maken het de sociallstische staten kennel1jk mogelijk de gegarandeerde individuele rechten op een noemer te brengen met de marxistisch-1eninistische leer.

Om ons te bepalien tot art. 19 ICCPR, het voorwerp van onderzoek: de wijze warop de vrljheld van meningsuiting in de DDR is gegarandeerd, vertoont drle discrepanties met art. 19 ICCPR.

In de eerste plaats bevat art. 27 Verf. geen garantle van de Informatievrijheld $(70)$. Hoewel het naturiljk noodzakelijk is de DDR hierop te wjzen, levert een opneming van de informatlevrltheid in de oostdultse grondwet geen verbetering van de bestaande situatie op, zolang de democratische taak van de vrijheld van mendingsuiting gehandhaafd blijft.

Wezenlifker is daarom de constatering van de tweede discrepantie, namell $\mathrm{jk}$ de verstrengeling van garantle en beperking van de vrljheld van meningsulting in art. 27 11d 1 Verf., doordat het grondrecht slechts wordt gegarandeerd, voorzover het in overeenstemming met de beginselen van de constitutie wordt uitgeoefend, terwijl art. 19 ICCPR een duidelljke schelding tussen garantle en beperking verlangt(71). Een opheffing van deze discrepantie leldt echter nog niet tot opheffing van de democratische taak, want zoals wj hebben gezien laten de beperk1ngsmoge11jkheden van art. 19 1ld 3 ICCPR zo"n tak in beginsel toe (72).

De derde discrepantle betreft het verguningenstelsel, maarmee de persvrljheld is genullkorfd. Dit strookt niet met de systematlek van art. 19 ICCPR, die inhoudt: vr1 theid, tenzij. Het vergunningenstelsel leldt namelijk tot: geen vrijheld, tenzij(73). Ongeveer hetzelfde effect als het verguningenstelsel nu heeft, 
mar dan conform art. 19 ICCPR, zou kunnen worden berelkt als het vergunningenstelsel wordt ver wangen door strafrechtelijke beperkingen van de persvritheld lit het belang van de socialistische matschappelijke orde, boven de beperkingen dle tegenwoordig al bestaan wet betrekking tot de vrljheld van meningsulting in het algemeen. Wel zou deze latste verste overheldscontrole lets moellijker maken omdat miet meer a prioI1 wan de onrechtmatigheid van het persprodukt kan worden ultgegaan (zoals onder het verguningenstelsel bly alles wat zonder verguning vermeniguuldigd wordt), maar de onrechtmatigheid pas na inhoudelljke toetsing kan worder vastgesteld.

Het $1 \mathrm{~s}$ nodlg, de DDR er binnen het kader van de bestaande mogelljkheden, dat wil zeggen 1 het Comite voor de Rechten van de Mens, op te wijen dat zijan de verplichtingen ult art. 19 ICCPR op bovengenoende punten niet woldoet. Dat is tot dusver niet gebeurd, dus een vermaning zou al een woorultgang zijn. Toch moet worden aangenomen, dat pogingen om uitsluitend langs deze weg een verbetering van de vrijheid van meningsulting te bewerkstelligen weinig structurele vruchten zullen afwerpen. Art. 19 11d 3 ICCPR bledt te veel ontsnapplngsclausules om het westerse standpunt te kunnen opleggen aan staten, die de marxistischleminlstische opvatting op grondrechten aanhangen. Ook past de DDR art. 27 Verf. uiter $11 \mathrm{jk}$ aan, dan nog verhindert dat niet, dat de vrijheld van meningsutting inhoudelijk wordt bepald door de behoeften van de socialistische samenleving. De democratische taak zal biljwen bestaan.

De enige manter om daarin verandering te brengen, is door te wifzen op het doel wan het verdrag en een beroep te doen op de in de preambule van het verdrag neergelegde erkenning dat ledere mens rechten bezit, die onverureemdbaar zijn. Dat betekent ook dat die rechten infet an een bepalde politieke ideologle mogen worden gekoppeld. Onvervreembbar houdt in dat die rechten inherent zijn aan iedere mens, ongeacht het politleke systeem warin hilj leeft en onafhanke11 jk van dat polltieke systeen. Door zo'n beroep kam de vrljblijvendheld, die art. 19 ICCPR in de praktijk heeft, worden opgeheven en worden voorkomen dat de bepaling wordt lingezet ten behoeve van een gewenst pol1tiek systeem. Pas met het argument van de onvervreendbaarheld in de hand kan wordem hardgemakt dat de 1 fze warop in de DDR de virijheld van menIngsulting is gegarandeerd niet conform de strekking van het Verdrag en van art. 19 ICCPR is.

Aangealen men zich van de effectivitelt van een beroep

234 op de preambule niet te veel mag voorstellen mogen 
statien, die het postulat wan de onwervreemdbaarheid zelf hoog in het vaandel hebben geschreven, het nil bij een eenvoudige verwijzing nam de preambule laten. De enlge wijze on overtulgend op de soclalistische staten in te werken ( $z o$ dat al mogelijk is), is te laten zien dat men deze erkenning van de onvervreendbaarheid zelf serieus neemt.

Dat houdt in dat men moet tonen dat in elgen land de vrijheld van meningsulting onafhankelijk van thet politheke systeem is gegarandeerd. Democratische staten behoren derhalve uiterst terughoudend van de in art. 19 IId 3 ICCPR gegeven beperkingsmogelijkheden (a1 dan niet extra gelegitimeerd door art. 5 lid 1 (CCPR) gebrullk te maken, zeker als het gat om beperkingen die in het belang van de democrate worden gesteld. Bepaalde beperkingen $z i j n$ werkelfjk onontkoombar, bijwoorbeelid die in het belang van de staatsvelifgheid. Ieder land heeft nu eenmal behoefte aan de bewelliging van statsgehelmen, om mar iets te noemen. In zulke gevallen verdient het in de hier verdedigde opvatting evenwel aanbeveling deze beperkingen niet te legitlmeren met een verwijzing naar het belang van de bescherming van de democratte, maar de beperkingen een neutrale legltimatie te geven, omdat zij inherent $z i j n$ aan het bestaan van de staat en niet aan de staatsworm.

Beperkingen in het belang van de rechten van derden leveren geen principièle problemen op, omdat deze rechtstreeks door de menselijke wardigheid van anderen worden gerechtvarardigd.

De stelling dat westerse democratleen ten behoeve van hun eigen geloofwardigheld de garantie van het recht op vrijheld van meningisuiting zo min mogelifk mogen verweven met het eigen politieke systeen ziet niet over het hoofd dat het een naw met het ander samenhangt; de verwezenlijking van de grondrechten brengt exvaringsgewljs een democratische besluitvormingsprocedure met zich mee. Mar door grondrechten en democratle als een onverbrekelijke eenheid te beschowwen en deze eenheld bovendlem jurldisch te bezegelen en te beschermen, zoals in de Bondsrepubliek 1 s gebeurd, wordt een element in de internationale mensenrechtendiscussle ingebracht, dat de eigen overtulgingskracht ondergraaft.

Hoe kan men tegenover het oostblok staan op een werbetering van de mensenrechtensituatie zonder direct in de verdenking te geraken het gehele politieke systeem op te willen blazen, als men steeds de band tussen grondrechten en democratie naar westerse voorstelling en zo benadrukt? Daardoon ontstat de indruk dat het opkomen voor de fundamentele writheden van de bevol- 
king aldaar alleen maar als wig wordt gebruikt om de verhoudingen in de Oostblokstaten te destabiliseren. Dat getuigt niet van acceptatie van het achter het $\mathbb{I} J z e r e n$ Gordijn bestaande systeem. Daardoor wordt het alleen maar moellijker elkaar op basis van gelijkwaardigheid tegemoet te treden. De enige mogelijkheld voor het Westen om verbetering te brengen in de mensenrechtensituatle is tenslotte binnen het kader van de bestaande matschappelijke realiteiten.

De historische ontwikkeling in Duitsland gedurende de eerste helft van de twintigste eeuw, culminerend in de absolute catastrofe van het Derde Rijk, en de daarult voortgekomen traumatische ervaringen in aanmerking genomen, $z \mathbb{1}$ jn de spectale beperkingen van de vrijheld van meningsulting in de Bondsrepubliek in het kader van de strijdbare democratie wellicht te verdedigen en de ultgebrelde strafrechtelijke beperkingen ex art. 5 Iid $2 \mathrm{GG}$, die zijn ingegeven door diezelfde zorg on het behoud van de democratie, misschien te begrijpen. Art. 5 lid I ICCPR bledt voor deze beperkingen bovendien een extra furidisch handvat. Maar vanuit het perspectief van de discusste over de rechten van de mens tussen Oost en West is zowel de beperking van de vrijheid van meningsulting in het kader van de strijdbare democratie als de omvang van de strafrechtelijke bepalingen, die de vrijheid van mentingsuiting binnen de door de strijdbare democratie getrokken grenzen in de Bondsrepubliek beperken, bedenkelijk.

Een grotere terughoudendheid van de wetgever zou de eigen kwetsbaarheid in de internationale discussie verminderen en de overtuigingskracht richting oostblok en met name richting DDR vergroten. De behandeling van het Initiat Report van de Bondsrepubllek voor het Comlte voor de Rechten van de Mens heeft getoond dat de positie van de Bondsrepubliek op het gebied van de vrijheid van meningsuiting $z 0$ sterk niet $18(74)$.

\subsection{Enkele opmerkingen tem aanzien van Nedertand}

De kennis over de democratische tak van de vrijheid van meningsuliting 1 in belde Duitse staten en de uitgangspunten, warmee bij de effectuering van art. 19 ICCPR moet worden rekening gehouden vormen de basis voor een kort ultstapje naar de vrljheld van meningsulting in Nederland ter afsluiting van het onderzoek. Wat voor de Westdultse situatle geldt, geldt ook met betrekking tot Nederland; vanuit het perspectief van het Internattonal Verdrag inzake Burgerrechten en 236 Polltieke Rechten is het noodzakelijk vast te houden 
aan de onwervreemdbaarheld van de wrijheid van meningsulting ter karakterisering van dit grondrecht.

Voor een verhandeling in extenso van de wilye warop dit grondrecht in Nederland is gegarandeerd bestaat geen noodzaak. Men raadplege de recente werken van Boon(75) en Peteng(76). Het gat hier uitsluitend om de vrag, $\mathbb{1} n$ hoeverre in Nederland een verbinding tusisen de wrl theld van menlingsulting en de democratie wordt gelegd.

4.4.1. De stand van de discussie over de grondstag van de writheid van meningsuiting

Ook de Nederlandse rechtswetenschap heeft zich, zlj het op bescheiden schaal, met de karakterisering van de vrijheid van menlngsulting bezig gehouden. Uit de verschillende bijdragen blijkt, dat net als in de Bondsrepubliek de grondslag(77) van de vrijheid van mentngsulting nlet alleen in de fndividu, mar eveneens in de collectiviteit is gezacht.

Dresen meende in 1949 het grondrecht 1 in dienst te moeten stellen van het zedelijk goede en het algemeen welzlin: "Wat met deze beide in strijd 15 , valt niet onder de vrije meningsuiting, het zijn excessen, misbrulken, die geen recht van bestaan hebben, omdat de verhouding middel-doel verbroken is"( 78$)$. Ook volgens Tammes 1 s de vrijheid van meningsuiting niet een recht, dat voortwloeft uit de ard van de menselijke persoon(79), maar hij omschrljft het grondrecht als een matschappelijk belang, warvan de waardering Wisselt nar de omstandigheden van tijd en plaats(80). In de democrat lsche staat is die wardering zeer hoog. Van der Hoeven daarentegen heeft een gemeenschapsbelang als grondslag afgewezen, mar als enige grondslag de individuele persoonlijkheidsontplooilng aanvaard (81). Ook Bowkema nam (in 1966) als enlge grondslag de menselljke persoonlijkheid(82). Wanneer men zou aanvarden dat de vrljheld van menlngsulting an de indivildu wordt toegekend, omdat zo de warheid aan het licht komt, omdat anders de democratische statsvorm onmogelijk ils of omdat dit door het algemeen belang wordt verelst, dreigt valgens hem de indlvidu ten offer te vallen aan de gemeenschap, doordat in de keuze, wat de grondslag van het grondrecht vormt, tevens de matstaf voor de beperking besloten ligt en derhalve beperkingen omwllie van de warheld, de democratie of het algemeen belang toelaatbaar zouden kunnen worden geacht. Neemt men de menselljke persoon$11 \mathrm{jkheid}$ als enlge uitgangspunt, dan bestaat de enlge talk wan de overheld daarin, erwoor te waken dat leder van $z$ iljn vrifheld gebruik kan maken en te verhinderen 
dat anderen dardoor geschaad worden, aldus Boukem (83). Boukema heeft $z i j n$ afijzing van de democratlie als gronds lag wan de vrijheld van meningsulting gebaseerd op $z$ jn observaties van de Westduitse discussie over dit thema. In $z i j n$ boek wijst hij op de gevaren, die het benadrukken van de niet-ladividuele aspection van de or 1 jheld vam meningsulting in de Bondsrepubliek met zich meebrengen, met mame met betrekking tot de peravitheid, warbif reeds in 1966 zo frequent vart de openbare taak van de pers sprake was(84). Verwonder1ijk is het, dat Boukema in zijh onderzoek vrijwel. volledig is voorbijgegaan aan de grenzen die de strijdbare democratle aan de vrijheld wan meningsulting stelt(85), terwlf1 dat toch de meest vergaande beperking in het belang yan de democratie is. KenneIIjtc heeft hif deze beperking als vanzelfsprekendheld aanvaard, wat zijn stelling, dat de menselijke persoonlijkheld het enige uitgangspunt voor de vrijheld wan meningsulting is, enigszins uitholt.

Evenrin kan Domer, blijkens een preadvites voor de Nederlandse Juristen Vereniging uit 1969, warmlopen voor het 1dee, dat de vrijheld van meningsulting aan leder mens, waar en wanneer ook, toekomt als een aangeboren, uit zijn menselijke wardigheld voortvloeiend recht. Hij is van de wardigheid van de mens niet genoeg doordrongen(86). Zljn enthouslasme voor de vrifheid is uitsluitend gegrond op pragmatische overweglingen, namelijk de erwaring met vrijpostigheden, die overheden zich in verleden en heden hebben veroorloofd $c . q$. veroorloven. Dat noodzaakt tot regelingen, wat de overhedd nfet mag(87).

In 1981 heeft Peters de draad weer opgenomen. Met een beroep op Tammes(88) verklaart hij naast de lndividuele persoonlijkheidsontplooilng ook het democratische bestel tot grondslag van de vrijheid van meningsulting (89). Zljn argunenten daarvoor ontleent hij vooral aan de Angelsaksische traditie, die de vrijheld wan meningsulting steeds nauw in verbinding met het polltieke besluitvormingsproces heeft gezien(90). De vrijheld van mentngsulting betekent het recht om mee te praten hoe wij onze samenleving incichten en de mogelifkheid wan de minderheld om zich te laten horen en tot meerderheld uit te groelen, zijns inzlens het "belangrifkste element" van het grondrecht(91). Volgens Peters dienen aan de omstandigheid, dat de vrlutheid wan meningsulting de belangrijkste basis fornt voor de democratische rechtsorde en darmee ook een belangrifke funderling van de overlge vrijheden, conseguenties te worden verbonden. In navolging van Meikzejohn(92) makt hif daarou een onderscheld tussen public speech 238 en private speech(93). Tot de public speech behoren 
die meningsuitingen, die de publieke discussle over publieke aangelegenheden dienen. Op grond van de bijdrage die zij aan het democratische proces leveren maken deze meningsultingen aanspraak op een bevoorrechte positie, dit in tegenstelling tot meningsuitingen die het karakter van private speech hebben. Zij nemen een bijzondere plaats in ten opzichte wan andere belangen, ook als deze eveneens door grondrechten worden beschermd (hoewel die positie in het laatste geval minder absolutut is, bijvoorbeeld als de privacy in het geding is)(94). Deze bewoorrechte positie wordt geconcretiseerd als het om de beoordeling van beperkingen van de vrijheid van meningsuiting gaat: bij een afweging tegen andere belangen mag een meningsuiting, die het karakter van public speech heeft, alleen worden beperkt als er een duidelijk en onmiddeliljk gevaar bestaat voor de aantasting van substantiele belangen (de clear and present danger test) (95).

Opvallend is de paraliel tussen Peterg' redenering en de Westduitse benadering $(96)$. Niet verwonderlijk $1 \mathrm{~s}$ dan ook dat in $z 1 j n$ aanpak hetzelfde discrimlnerende effect zichtbaar wordt, dat wij in de Bondsrepubllek hebben aangetroffen: private speech telt niet zo mee; typisch voor een benadering die niet van de tndividuele ontplooling van de persoonlijkheid uitgaat(97). Peters' benadering is op kritlek gestuit(98), onder meer ondat hij door zijn "eenzijdige belangstelling" voor de vrijheid van meningsulting, waardoor hif "compleet wordt geblologeerd", oplossingen bepleft die "gemakkelijk tot grievend onrechtvaardige resultaten lefden (hetgeen julst in een democratie niet de bedoeling is $)^{\text {n' }}(99)$.

Aan de andere kant is het door Peters gemaakte onderschell tussen private speech en pubtic speech in de rechtspraak niet onbekend. Aan de public speech b1ijkt de rechter middels een beroep op het algemeen belang nog wel eens meer ruimte te geven dan aan de private speech (100).

\subsubsection{Partïjuerboden}

Sinds enige jaren is in Nederland de discussie gaande over de wenselijkheid de wettelijke regeling te verscherpen, dile het mogelifk makt een rechtspersoon te ontbinden, wanneer haar doel of werkzaamheid in str 1 jd 1.s met de openbare orde of de goede zeden, met andere woorden over het vraagstuk van het partijuerbod. Aanlelding is de zorg over de populariteit van enkele politieke partijen - de Nederlandse Volksunle (NWU) en de Centrumpartij - die de rassendiscriminatle propageren, alsmede de kritiek, die de Commissie voor de U1t- 
banning van Rassendiscriminatie in 1979 op de Nederlandse regering heeft geleverd, omdat $z i f$ het woortbestaan van de wWu blifkbaar niet kon verhinderen(101). In eem ultspraak van 8 maart $1978(102)$ had de Amsterdambe Rechtbank de WV namelijk tot werboden vereniging gekwalificeerd wegens haar ijveren voor racistische doelistellingen - de wV bepleitte de uitwijzing van Sur Inamers, Antillianen en buitenlandse werknemers. Om furidisch-technische redenen gelaste de Rechtbank echter niet de ontbinding van de NVu, zodat deze ongestoord kon blijven voortbestaan en haar de inschrijving in het kiesregister, de voorwaarde om aan verklezingen te kunnen deelnemen, niet kon worden geweigerd(103). Art. 4 sub b van het verdrag tot uitbanning van alle vormen van Rassendiscriminatie verplicht de verdragsstaten echter om organisaties, die rassendiscriminatie in de hand werken of daartoe opwekken, onwettig te verklaren en te verbieden(104). Vanult de commissie werd dan ook gesuggereerd dat Nederland aanvullende wettelfjke maatregelen zou menen om aan haar uft het Verdrag voortvloelende verplichtingen te voldoen (105).

Maar zo eenvoudig Iigt de zaak niet. Al is de bestrijding van het racisme een edel doel, dat zeer ernstig moet worden genomen, zadra het middel van een partijverbod daartoe wordt ingezet komen andere principes in het geding. Een partijuerbod raakt de fundamenten van de democratie, doordat het leidt tot beperking wan het kiesrecht, het recht tot vereniging en vergadering en de vrifheid van mentingsuiting. Er moeten dus wel erg zwaarwegende argumenten in het spel zijn on dit middel toe te laten.

De Nederlandse traditie op het vlak van de partijverboden is er een van de ulterste terughoudendheid. Zil is gebaseerd op de opvatting dat het niet aangaat politieke strevingen van een bepaalde politiek-ideologische inhoud te verbieden(106). Een wettelijke regeling die speclaal voorzlet in de mogelljkheid politieke partijen te verblteden heeft niet bestaan. Art. 2 WW van $1855(107)$ verbood alleen verentgingen in het algemeen, die tn strifd waren met de openbare orde. Dat was het geval als het doel van de vereniging was: ongehoorzaamheid aan of overtreding van de wet of een wettelijke verordening, aanranding of bederf der goede zeden, of stoornis in de uitoefening der rechten, van wie het ook zij (art. 3 WWV)(108). Een sanctie tegen de verboden verenigingen bevatte de wet niet. Art. 4 WV hield alleen een sanctie in tegen de leden van een verboden vereniging in de vorn van strafbare deelne240 ming(109). In 1939 werd onder druk van de actuele 
politieke situatie de mogelijkheld van een zelfstandige verbodenverklaring door de rechter opgenomen (110). De regeling van de Wet Verentglng en Vergadering is slechts een maal tegen een politieke parti 1 aangewend, name11jk in 1894 tegen de Soclaal-Democratlsche Bond, en dat ultsluitend omdat deze partij onder meer als doelstelling de onverwerping van de bestaande matschappelijke orde ook met onwettelifke of geweldadige mildelen had(111). Niet de omverwerping van de bestaande matschappelifke orde was een met de openbare orde strijdig doel, mar de wijze, warop men dit doel wllde bereiken. Niet op grond van de Wet Verenlging en Vergaderlng, mar door middel van een apart wetsbesluit is in 1944 de Nationaal-Soclalistische Beweging verboden verklaard en ontbonden. Tevens werden als verboden aangemerkt arganisaties die het streven van de National-Soclalistische Beweglng trachten voort te zetten $(112)$.

Ter uitwoering van het Verdrag tot Uitbanning van alle wormen van Rassendiscriminatie werd in 1971 art. 3 WVV a angevuld met de bepaling dat ook strijdig met de openbare orde was een doelstelling of feftelijke werkzaamheid "gericht op het bedrljven, in stand houden of bevorderen van discriminatie van mensen volgens hun ras". De aanvulling verdween echter weer onder de tafel in het kielzog van de vervanglng van de regeling van de verboden vereniging $1 \mathrm{n}$ de Wet Vereniging en Vergadering door de art. 15 en 16 Boek 2 BW, die bepaLen dat een rechtspersoon verboden 1s, wanneer haar doel of werkzamheid $\mathbb{H}$ strijd $\mathrm{u}_{\mathrm{s}}$ net de openbare orde of de goede zeden en dat de rechtbank een verboden rechtspersoon op vorderlng van het Openbaar Minlsterle kan ontbinden. Dat wil zeggen dat de rechter de vrijheld heeft ontbinding te welgeren.

Naar aanleiding van de uttspraak van de Amsterdamse Rechtbank, waardoor gebleken is dat de muidige wettelijke regeling niet garandeert dat aan de verplichting ex art. 4 van het Verdrag tot Uitbanning van alle vormen van Rassendiscriminatle wordt voldan, en nar anlelding van de krltiek van de Combsle voor de Uitbaning van Rassendiscriminatie op het uit de utspraak voortvloelende betrekkeli jk willekeurige beleld ten adizien van de NWU door de kleswettelljke instanties(113), is een d1scussle op gang gekomen, of wette11Jke stappen dienen te worden ondernomen tenelade te verzekeren dat partifen die rassendiscriminatie bepleften conform de verplichting van art. 4 Verdrag daadwerkelijk worden ontbonden.

Daarachter gat de vrag schull naar de principlele toelaatbarheid van een partijverbod. Omdat de buhoef- 
te an verbindering van rassendiscriminatie de aanleiding is, 15 het 10 glsch, dat de vrag tegen de hierboven geschetate actuele achtergrond is benaderd.

Z1j die een partijverbod onder bepalde omstandigheden toelaatbar achten, ondanks het felt dat een verbod een beperkend efect op bepalde grondrechten heeft, huldigen die mentigg vooral omdat zij het gelljkheidsbeginse1, dat dlscriminatie (niet alleen op grond van ras maar algeneen) verbledt, van een hogere orde achten(114), en nuet 10 de eerse plats omdat zij van mening $21 j n$ dat die partijen, die in hun ogen werboden dienen te worden, er op uit zoudem zijn de bestaande matschappelijke orde omver te werpen(115). Deze invalshoek komt bijwoorbeeld tot witdrukking in Vries" suggestie voor een speciale wet, warmee hij wil berelken dat niet elke organisatie die de democratie wil omverwerpen direct mar wordt verboden, maar slechts die organlsaties die tot doel hebben of wier feltelijke werkzaamheld gericht is op "het bedrijven, in stand houden of bevorderen van elke vorm van onderscheld, uitslulting, beperking of voorkeur op grond van ras, huidskleur, afkomst, of nationale of etnische afstamming, die ten doel heeft of ten gevolge heeft dat de erkenning, het genot of de ultoefening, op grond van geliljkhetd, van de rechten van de mens en de fundamentele vrijheden op politlek, economlsch, social of cultureel gebled, of op andere terrelnen van het openbare leven worden tenlet gedaan of angetast", alsmede - historlsch bepald - organisaties die het streven wan de NSB willien voortzetten(116).

Ook het wetsontwerp dat de Nederlandse regering in dit werband enlge $t 1 j d$ geleden heeft ingedtend(117) heeft dezelfde beperkte bedaeling. Dit ontwerp heft de rechterlijke vrijheid, om een rechtspersoon met een verboderi karakter al dan niet te ontbinden, op. Als doelstelling of werkzamheld van een rechtspersoon in strijd met de openbare orde of met de goede zeden is, is de rechter verplicht haar te verbleden en te ontbinden(118). De voorgestelde wetswijziging komt tegemoet aan de kritlek van de Commissie voor de Ultbanning van Rassendiscriminatie. Veel lost het ontwerp niet op, als het doel 1 s om door mlddel van een verbodlenverklaring bepalde polltieke partijen van verklezlngen ult te slulten, want onder het reglme van de Rieswet ontbreekt een koppeling tussen partijverbod energljs en namsreglstratie en kandidaatstelling voor verkiezlngen anderzdjds (119).

zhet men even af van de actuele anlelding om en partijuerbod ter w1le van de bestrifding van rassen242 discriminatie te aravarden, dan valt het gevar op 
dat zowel de bestaande regeling als het regeringsvoorstel in zich bergen.

De goede zeden als verbodscriterium voor een politieke partij is ten princilpale ondeugdelijk. Terecht merkt het Nederlands Jurlsten Comite voor de Mensenrechten (NJCM) in zijn commentaar bij het wijzigingsvoorstel. van de regering( 120$)$ op, dat dit critertum zo ruim en onbepaald is dat daarmee ledere vanult matschappel1jk oogpunt ongewenste rechtspersoon kan worden verboden en dat het misbruik en willekeur mogelijk makkt. Worden de prevalerende normen en warden in een bepaalde tijd als toetssteen gezien dan hamgt ook partijen als de staatkundig Gereformeerde Part1j, het Gereformeerd Politiek Verbond en de Commulstische Partij Nederland het zwaard van een verbod boven het hoofd.

Vergeleken met zo'n vaag verbodscrilterium als het Nederlandse zijn de Westdultse criterla voor een partijverbod nog hellig! Dat in Nederland desondanks van die vaagheid geen misbruik is gemakt om onwelgevallige partijen te verbleden is miet an de wettelijke regeling te danken, maar uitsluttend aan de liberale polltieke cultuur. Bellekom wil het criterium van de openbare orde opgeven en inruilen voor een regeling analoog aan de Westdultse conceptle van de strijdbare democratie. Hij stelt voor het verboden karakter van polltieke partijen te relateren aan datgene waraan afbreuk wordt of drelgt te worden gedaan: de grondslagen van de 11 berale democratie(121). Het NJCM wijst er echter op dat ook onder gebruikmaking van het Westduitse criterium van de fretheitiche demokratische Grundordnung nog voldoende Wederlandse partijen rljp bl1jven voor een verbod, omdat deze een ander staatsbestel dan het Nederlandse propageren(122).

Niet ledereen 1 is overigens geporteerd voor partijuerboden, zelfs niet als zij zijn bedoeld om partijen die het racisme prediken te verhinderen(123). Het belangrljkste argument wan de tegenstanders $1 s$, dat een partijverbod niet past in de Nederlandse opvatting over democratie. De geschiedenls heeft geleerd dat in Mederland een partijwerbod nlet nodlg 1 is on het systeem te verdedigen. Bovendien 1 s een part 1 jverbod geen effectlef middel, omdat daardoor nog nlet de overtuigling verdwijnt van hen, die zich voor antidemocratische of racistische doelstellingen inzetten. Het stigma van 11 legalitelt kan op hen juist stimulerend werken. Het laten voortbestaan van een partij met zulke abjecte doelstellingen biedt het voordeel dat men haar onschadelijk kan maken door hat in de bestaande structuren in te kapselen.

Voor wat betreft racistische partijen komt daarbij dat 
men zlch beter kan afvragen wardoor de stijgende populariteit wan raclstigche opvatingen wordt veroorrakt. In plate van partijen te verbieden, die misschien zelf wel en nuttige ultaatklep voor bepalde groepen in de samenleving vormen, die zlch door etnishe en culturele minderheden in hun directe woonomgeving bedrelgd volen, rust op de overheid de taak lets an die oorzaken te doen en de omstanditgheden onder de loep te nemen 1 m de wijken van de grote steden war die raclstische opvattingen massaal leven.

Dat een verbod van racistische partijen dwingend zou voortwoelen ult de verplichting ex art, 4 van het Verdrag tot Uitbanning van alle vormen van Rassendiscriminatie schijnt bovendien niet zo zeker te zijn. ledere verdragsstat heeft op grond van art. 4 jo. 5 Verdrag het recht een afweging the verrichten tussen grondrechten als de vrijheld van meningsuiting en het recht tot vereniging enerzljds en het tegengaan van rassendiscriminatle anderzljds(124). Een gezonde aarzeling om aan de wensen van de Commisie tegemoet the komen $1 \mathrm{~s}$ des te meer gerechtvaardigd, omdat de Nederlandge wetgeving nog andere (strafrechtelijke) instrumenten bezit on rassendiscriminatie tegen te gaan. Daarvan is biljkens het NJCM 1 in de laatste tifd bovendien geen gebrulk gemaakt on op te treden tegen de leden van partijen, die door zo"n partijverbod zouden worden getroffen (125).

Ten aanzien van het vraagstuk van het partijuerbod zijn dus verschillende aanpakken moge1ijk. De rechter kan het criterlum van de openbare orde en de goede zeden blyjwen hanteren, al dan niet gekoppeld aan de verplichting verboden rechtspiersonen tevens te ontbladen. Men kan dit criterium vervangen door het criterium van de wrije democrat ische rechtsorde, dat in de Bondsrepubliek wordt gehanteerd. Men kan ook de mogelijkheid van een partijwerbod beperken tot organisaties met racistische of fascistische doelstellingen. Tenslotte kan men de mogelijkheld van een partijverbod ten principale afwijzen. Deelt men dit latste standpunt, dan is het consequent er voor te pleiten de regellng betreffende de verboden rechtspersoon in de art. 15 en 16 Boek 2 BW niet meer op politieke partijen van toepassing te Laten $21 \mathrm{jn}$ *

Wat kan een benaderlng vanult het perspectlef wan de writheid van meningsulting, zoals dat in dit onderzoek 1 ontwikkeld, aan de oplossing van het vraagstuk bi joragen?

Elke opvatting die de mogelljkheld anwardt om een partif te verbleden onder de specifleke voorwarde vam 244 de bescherming wan de democratie, de openbare orde of 
de goede zeden, neent op de koop toe dat aan de vrifheld van meningsuting geweld wordt aangedaan. Een partijwerbod is geen normale beperking van de vritheld van meningsulting. Het voorbeeld van de Bondsrepublilek maakt duidelijk, dat een partijverbod moet worden gerangschlkt onder die matregelen, die reeds vooraf grenzen aan de uitoefening van de vrijheid van meningsulting stellen, en dat een overschrijding van die grenzen als misbruik wan de wrijheld van meningsulting wordt gedefinieerd. Zulke randvoorwarden als een partijuerbod doen afbreuk an het karakter van de vrijheid van menlngsulting als onvervxeemdbaar, in beglnsel absolumt recht, zij relativeren het grondrecht.

Op het niveau van de internationale mensenrechtendiscussle verzwakken zij tegenover staten, die de urijheld van menlingsuiting in dienst van hun elgen matschappelijke orde stellen, het westerse postulaat dat de vrijheid van mentugsulting een onvervreemdbaar recht is, dat ten behoeve van de ontplooling van de Individuele persoonlijkheid gegarandeerd is, zoals ook de preambulle van het Internationaal Verdrag inzake Burgerrechten en Polltieke Rechten zegt.

Als het Westen sterk w11 stan in de internationale discussie moet $z i j$ een jurldische verbinding tussen grondrechten en democratie zoveel mogelifk voorkomen. Dat betekent onder andere dat beperkingen van de vrijheid van meningsultiag ten behoeve van de democratie nitet gewenst zijn. In de Bondsrepubliek bestaat deze verbinding in het kader van de strljdbare democratie op grond van historische ervaringen. De Westduitse historische constellatile ontbreekt in Nederland. De warderelativistische democratie heeft goed gefunctioneerd. Er is geen reden om aan te nemen dat daarin verandering zal komen. Het is daarom helemal nlet nodig door middel van een partijverbod de afweerfunctie van de vrijheid van meningsuiting te ondergraven. Terwlle van de owertuigingskracht in de internationale discussie is het bovendien niet gewenst.

Een verworvenheld van de Westdultse staatsrechtsleer 1 dat 21 f blootlegt dat detocratie dwingend uit het postulaat van de mensel1jke wardigheid en de daarult voortvlaelende ind viduele persoonli jkheldsontplooilng volgt (126). De democratie stat in dienst van de Individuele persoonlijkheid en niet omgekeerd. Dat moet zo blijven. Matregelen ter bescherming van de democratie in het berelk van de grondrechten hebben een voor de grondrechten te aadellge bijwerking om ze gretig te omarmen. Dat toont de Invloed van de gedachte der strijdbare democratle op het Westdultse strafrecht, dat een reeks van voorschriften bevat, die de 
Writheld van meningsulting gevoelig treffen. De vrlheld van meningsuiting is met zulke matregelen miet gedlend.

Het primat van de individuele persoonlljkheidsontplooling - on net een varlatie op peters te spreken (127) - staat een partijuerbod in de weg. Dat betekent In het geheel niet dat men hulpeloos is overgeleverd an racistische meningsaltingen. Vrijheld houdt immers op wart de vrltheld wan anderen begint. De vrijheld van menlingsulting mag worden beperkt, indien de ontploollngswogelljkheden van anderen in het gedrang komen. Bif racistische meningsuitingen is dat zeker het geval. Bepalingen die raclstische meningsuitingen strafbar stellen zijn dan ook geoorloofd, ook al. gebledt de afweerfunctie van de wrifheld van meningsulting ook hier tot terughoudendheid bij de uetgever. Het karakter van de grondrechten als lindividuele vrijhefdsrechten moet de wetgever telkens weer tot extra omzichtigheid aansporen.

Als wlj het werkelijk zo serieus nemen met de stelling dat de vritheld van meningeiting conditlo sine qua non 1 s vor het functioneren van de democratie(128) dan 1 s het in het belang van de democratie om de bestrifding van overtulglingen die een bedrelging vormen van de democratie over te laten an de vrije marktplats van denkbeelden(129). Dat geldt in principe ook voor raclstische overtulgingen, voorzover het belang van de persoonlijkheidsontplooling van derden niet tot beperkingen noopt.

\subsubsection{De individuele ontplooing als entge grondstag}

De vrljheld van meningsulting makt deel uit van een krachtenveld, warin ook andere grondrechten, normen en belangen hun plaats opelsen. Daaronder vindt mea het gelijkheldsbeginsel, het persoonlijkheldsrecht, het algemeen belang, de democratie. Doorploegt men dit krachtenveld vanuit de invalshoek van de vrijheid var meningsulting, dan is de verlelding groot voor dit: grondrecht een bevoorrechte positie te clalmen. Tenbitce 18 het dubbele gewlcht van dit grondrecht onloochenbaar: behalve Individueel vilfheldsrecht ten behoeve wan de ontplooling van de persoonlijkheid ls het tevens een onontbeerlijke factor voor het functioneren van de democratie. Zoals wij hebben gezlen, voor gomigen reden genoeg voor een geprlvilegieerde posttie van de pubtio speech aan de ene kant, voor anderen reden genoeg on de democratle in bescherming te nemen tegen sch1jn-democratisch gebrutk van de vrijheid van menlngsulting met het elgenlijke doel om de democratie 246 te bestrijden aan de andere kant. Enerzijds een beetje 
meer witheld, anderzljds een beetje minder witheld voor de meningsulting. Alles omdat wij het wo goed menen met de democratie, dat spreekt vinzelf. In belde gevallen leldt het trekken van consequenties ult de bifzondere betekenis wan de vri theid van meningsuiting tot ongewenste neveneffecten, het onvervreemdbare karakter van het grondrecht wordt aragetast, zodat men zich kan afwagen: wat schieten wijer nu eigenlijk mee op? Men stelle zlch voor: de een pleit ervoor racistische mentingsultingen als public speech te beschowwen en dus niet klakkeloos te bestraffen, de ander plett ervoor raclstische menlngsultingen, gedaan door een politieke partij, als een indirecte bedrelging van de democratie te bestraffen met een partijverbod. Het trekken van de grenzen voor de vrljheid wan meningsutting begint op deze maniler op een goocheltruc te lijken; men stopt lets in de linkermouw, matim tovert het uit de rechtermouw weer te voorschljn. Een meer eerlijke manier om conflicten op te lossen waarbil de vrijheid wan meningsulting betrokken is, $11 j k t$ mij terug te keren naar de enige werkelijke grondslag van de vritheld van menlingsuiting, de individuele ontplooling. Waarom de enige werkelijke grondslag? Ondat ook de democratie de individuele ontplootIng dient en geen zelfstandige warde vertegenwoordigt. Door te kdezen voor de ene grondslag van de indlviduele ontplooilng wordt het vinden van een oplossing in geval van conflict tussen de vrijheid van meningsuiting en andere rechtsgoederen misschlen niet eenvoudiger, mar wel oprechter.

Door het belang voor de democratie buiten de deur te houden bijvoorbeeld wordt voorkomen dat het altija moeilijke probleem van de afweging tussen twee verschillende grondrechten, zoals tussen de vrijheld van meningsulting enerzijds en het persoonlijkheldsrecht of het gelijkheldsbegingel anderzijds, wordt vertekend en men geen moelte meer doet meerdere belangen werke$11 \mathrm{jk}$ met elkaar te verzoenen. Door zlch te verschuilen achter het belang van de vrijheld van mentigsuiting voor de democratie wordt namelijk gemakshalve vergeten dat ook het gelifkheidsbeginsel en het persooniljkheddsrecht voor de democratie van belang zijn. Wie bewljst elgenlijk dat $21 j$ van minder belang zijn voot de democratie dan de wrijheid van mentigsulting? De denocratle leeft niet van de vrljheld wan meningsulting alleen, $z 1 j$ leeft onder meer ook van da overtulgling dat de individuele persoonlijkheldsontplooing voor allen geldt, wayvan wellswar de vrijheld van menlngsulting een bestanddee $1 \mathrm{is,} \mathrm{mar} \mathrm{ook} \mathrm{de} \mathrm{afwezlg-}$ hell van discriminatile en het gevoel dat de persoon1ijke sfeer gerespecteerd wordt. Het hanteren van het 
belang van de vrl Jheid van meningsuiting voor de demcratie als criterium en hulpmiddel voor conflictoplossing tussen verschlliende grondrechten is een schijnargument. Het verdoezelt dat het in zulke gevallen altijd gaat on een conflict waarblj de persoonlifkheldsontplooling van twee personen in het geding 1 s. De rechter moet zich lets anders laten invallen dan het democrate-argument on de hem voorgelegde conflicten op te lossen. H1j zou bijvoorbeeld meer gewicht kunnen toekennen aan de context, waarin de meningsulting is gedaan en aan de begeleidende onstandigheden (130).

Wilet alleen conflicten tussen twee grondrechten doen zlch voor. De vrijheld van meningsuiting kan ook in conflict raken met andere rechtsnormen, zoals strafen privatrechtelljke regels of voorschriften van locale en provinclale overtheden. Vele van zulke regels, die in concrete gevallen met de vrijheld van meningsulting kunnen botsen, bestaan ten behoeve van het algemeen belang, het algemeen welzifn, bescherming van de (democratische) staat en wat dies meer $z 1 \mathrm{j}$. Woorzover de rechter, die met conflicten tussen de vrlitheld van meningsuiting en andere rechtsnormen geconfronteerd wordt, bevoegd is tot toetsing over te gaan, verdient het naar de hier verdedigde mening aambeveling, niet tot een geprivilegleerde positie var het grondrecht te concluderen op grond van $z 1 j$ in betekenls voor de democratie, maar deze overweging bij de afweglng volledig butten beschouwing te laten.

Ik wil er voor pletten, dat aan de bijzondere betekenis van de viltheid van meningsulting op andere wijze recht wordt gedaan, een wifze, die in overeensteming is met het karakter van het grondrecht als afweerrecht, dat de persoonlijke ontplooling dient, namelijk door het oefenen van meer terughoudendheld door de wetgever als het er om gaat iberhaupt beperkingen van de vrijheid van menlngsulting in het leven te roepen. Terwille van de overtulgingskracht van westelijke deelnemers an de internationale mensenrechtendiscussie is de wetgever verplicht in het bijzonder elke furidische connectle tussen grondrechten en democratie te vernifden, dat wil zeggen dat de wetgever zo min mogelifk tot beperkingen van de vrljheid van meningsuiting dient over te gan, die direct of Indirect de bescherming van de democratie op het oog hebben.

De plicht tot terughoudendheld is des te dwingender, aangezten het de Nederlandse rechter nlet is toegestaan formele wetten an de grondrechten te toetsen, zodat een correctiemogelijkheld ontbreekt. Dit bezwar wordt niet wezenlijk opgeheven door de onstandigheid, 248 dat de rechter wel bewoegd 1 s de formele wet an de 
bepallingen van het Europees Verdrag tot bescherming van de Rechten van de Mens en de Fundamentele Vritheden en het Internationaal Verdrag inzake Burgerrechten en Polftieke Rechten te toetsen, ondat belde verdragen rulme beperkingsmagelijkheden toelaten juist op het gebled, waar de terughoudendheid bepleit wordt.

Nu is het vermogen wan de wetgever, het beperkende effect van een wet op het grondrecht op vrijheld van meningsuiting in de juiste proporties te zien, van nature gelimiteerd. De wetgever kan slechts vooraf en abstract afwegen. Hij heeft daartoe echter niet meer de gelegenheld, als pas aan de hand van een concreet conflict onaanvaardbare repercussies van een bepaalde wet op de vrijheid van meningsulting aan het licht komen. De wetgever kan hoogstens eventueel besluiten de desbetreffende wet weer af te schaffen, mar afgezien van de vraag of dit zo licht zal gebeuren, heeft deze afschaffing op de uxtslag van het concrete confllct geen invloed.

Het zou daarom $z i j n$ aan te bevelen om de Hoge Raad uit te breiden met een constitutionele kamer, die is uitgerust met de competentie formelle wetten aan de in de grondwet gegarandeerde grondrechten te toetsen en ze nietig te verklaren als zij niet met een of meerdere grondrechten verenigbaar zijn. Deze constitutionele kamer zou de geschikte instantle zijn om formele wetten in het licht wan de vrijheld van meningsulting te beoordelen als een concreet conflict daartoe aanleiding geeft. Zij zou kunnen waken over de plicht van de wetgever tot terughoudendheld en kunnen ingrijpen, als de democratie tegenover de vrijheld van meningsulting in bescherming dreigt te worden genomen.

Door vast te houden aan het oorspronkelfjke karakter van de vrijheld van meningsulting en de betekenis van het grondrecht voor het functioneren wan de democratie niet apart te honoreren zou de totale bescherming van de vritheld van meningsuiting worden vergroot.

Weliswaar is het mogelijk, dat in conflicten tussen grondrechten de vrifheld van meningsuiting niet altijd prevaleert in gevallen, dat een beroep op haar objectleve betekenis wel tot privilegering zou leiden, hoewel dat gevolg niet autonatisch behoeft in te treden, ondat ook tot de voorrang van de vrijheld van mentngsuiting zou kunnen worden geconcludeerd op grond van de criteria, die het oorspronkelijke karakter van het grondrecht nlet aantasten. Tegenover de mogel1 jke verzwakking van de vritheid van meningsulting in afzonderlijke gevallen zou echter een principlele versterking staan door ten eerste de afwezigheld van de magelijkheid tot het ultspreken van een partijwerbod en ten tweede het recht van de constitutionele kamer van 
de Hoge Raad or formele wetten an het grondrecht op: vrijheld van meningsulting te toetsen. 
1. Met grondrechten worden in dit onderzoek de klasileke individuele vrijheidsrechten bedoeld. Tenzij ultoruke$11 \mathrm{jk}$ aangegeven wallen onder deze term niet de soclale grondrechten. Grondrechten warop iedere indisidu zich kan beropen, die dus een universeel karakter hebben, $z i j n$ tevens mensenrechter (dit in tegenstelling tot die grondrechten, die alleen burgerrechten zijn, ondat zij uitsluitend aam een personenkring met eem bepalde nathaltreit zijn voorbehouden, zo $\mathrm{k}^{\mathrm{k}}$. Hesse, Grundzuge des Verfassungsrechts der Bundesrepublik Deutschland, 14. Aullage, 1984 Heidelberg/Karlsruhe, p. 115). De term mensenrechten of rechten van de wens wordt in dit onderzoek sleches gebralkt, als in de context het universele karakter van de grondrechten een ultdrukkelijke rol speelt. Vgl, ook M. Kriele, Zur Geschichte der Grundund Menschenrechte, in: Festschrift fur Hans Scupin, 1973 Berlin (W), p. 187 e.v., ad p. 188: "Crundrechte sind positives Recht, Menschenrechte sind Naturcecht".

2. Vg1. A. Bleckmann, Allgemeine Grundrechtslehren, 1979 Köln/Ber $1 \mathrm{ln}(W) /$ Bonn/Minchen, p. 156; K. Grinmer, Demokratie und Grundrechte, 1980 Ber $1 \mathrm{ln}(\mathrm{W}), \mathrm{p} .16, \mathrm{C}$, w. van der Pot, Handboek van het Nederlandse Staatsrecht, bewerkt door A.M. Donner, lle druk, 1983 Zwolle, p. 212 e.v.

3. G. Oestrelch, Geschichte der Menschenrechte und GrundErelhelten in Unriss, 2. Auflage 1978 Bertin (W), P. 39 e.v. . m.n. p. 41 en 51 .

4. E. Kroker/T. Veiter, Rechtspositivismus, Menschenrechte und Souveräntätslehre in verschiedenen Rechtskrelsen, 1976 Wien/Stuttgart, p. 31 .

5. De tekst van beide verdragen is te vinden in Trb. 1969, 99 en Trb. 1969, 100.

6. Art. 1 lid 1 en 2 GG.

7. In deze zin E.W. Böckenförde, Grundrechtstheorte und Grundrechtsinterpretation, 27 .JW 1529 (1974), P. 1537; J. Isensee, Grundrechte und Demokratie, 20 Det Stat 161 (1981), p. 165 .

8. BerfGE $1,14(18)$.

9. BVerfGE 7, $198,(204)$.

10. C. Schmitt, Verfassumgslehre, onveranderde overdruk van 1928,1970 Berlin (W), P. 164 . 
11. BVertog 2, 1 (13).

12. 21. par. 3.2.

13. Hegse (nt, 1), p. 113.

14. K. Hesse, Der Rechtsstat im Verfassungssysten des Grundgesetzes, In: Festgabe fur Rudolf Smend, 1962 Tubingen, p. 71 e.v., ad. p. 85 e.v.

15. Hesse (nt: 1), p. 114 .

16. E'.R* Huber, Biedeutungswandel der Grundrechte, NE 23 Aổ $1(1933)$, p. 79 .

17. Huber (nt: 16), p. 84 .

18. Bỡkenförde (nt. 7), p. 1529 e.v.

19. Vg1. E. Friesenhahn, Der Wandel des Grundrechtsverstännisses, In: Werhandiungen des 50 . Deutschen Juristentages, 1974 Minchen, Band II, P. G 1 e.v., ad p. G I1; K. Kröger, Grundrechtstheorle als Verfassungsproblem, 1978 Baden-Baden.

20. Böckenförde (nt. 7), p. 1535 e.v.; verwezen z1f verder naar Frtesenhahn ( $\mathrm{nt}$. 19), p* G 29 e.v. en F. Dssenbiuh Die Interpretation der Grundrechte in der Rechtsprechung des Bundeswer fassungsgerichts, 29 MJW 2100 (1976), p. 2104 e.v.

21. R. Smend, Verfassung und Verfassumgsrecht, 1928 München/ Lelpzig, p. 18 e.v*

22. Simend (nt. 21), p. 163/164.

23. In: K. Maunz/G. Düig/R. Herzog, Kommentar zum Grundgeset 2 (losbladig), 1968 Munchen (hierna: M/D/H), Art. 1 Rndnr, 1 e.v., m.n. Rndnx. 5; voor een ultvoerige bespreking. H. Willke, Stand und kritik der neteren Grundrechtstheorle, 1975 Berlin (W), p. 24 e.v*

24. M/D/H (nt. 23), Art. 1 Rndnr. 1 en 4 .

25. M/D/H (nt. 23), Art. 1 Rndnr. 10 e.v.

26. BVerfGE 7, $198(205)$.

27. Osisenbuh 1 (nt, 20), p. 2101; vg1. BVerfGe 6, 55 (71).

28. BVerfGE $30,173(188)$.

29. zLe Grimuer (nt. 2), p. 131.

30. BVerfGE 7, $198(295)$.

31. Böickenförde (nt. 7), 1534; vg1. ook E. Denninger, Frelthe1t ordinung - Wertordnung - Pflichtordnung, $30 \mathrm{JZ} 545$ 
$(1975)$

32. Z1e Rleckmon (nt. 2), p. 201; assenbihl (nt. 20), p. 2102.

3. BVerfGE $12,45(51)$.

34. Bleckmann (at. 2), p. 170 e.v. Grimmer (nt. 2), p. 136 e.v.; Ossenbithl (nt. 20), P. 2102 .w.; H.H. Rupp, Fom Wandel der Grundrechte, 101 AöR $161(1976)$, P. 172 e.*.

35. P. Häberle, Die Wesensgehaltsgarantie des Art. 19 Abs. 2 GG, 3. Auflage, 1983 Karlsruhe.

35. Te vinden in de volgende geschriften: Verfassungshehre (at, 10), p. 170 e.v.; Freihaitsrechte und institutionelle Garantien der Relchsverfassung, In: Verfassungsrecht1che Aufsätze aus den Jahren 1924-1954, 1958 BerIin (W), p. 140 e.v. Grundrechte und Grundpfichten, in dezelfde bunde $1, p .181$ e.v.

37. Schmit, Frelheitsrechte und institutionelle Garantien der Reichsverfassung (nt. 36), p. $143 \mathrm{e} \cdot \mathrm{v}$.

38. Id., p. 160 e.v.

39. Id*, p. 166 .

40. Häberle (nt. 35), p. 92 .

4.1. Id., p. 4 .

42. Id., p. 6 .

43. Id., p. 18 e.v.

44. Id.* P. 19. Häberle citeert hier Smend.

45. Id., p. 70 e.v.

46. Id., p. 98.

47. Id., p. 99.

48. Id., p. 71 e.v.

49. Id, P. 102.

50. Id., 101/102.

51. Z1.e ook Haberle (nt. 35), p. 117 .

52. Häberle $(\mathrm{nt}, 35), \mathrm{p}, 163 \mathrm{e} \cdot \mathrm{v}$.

53. Id., p. 207 .

54. BVerfGE $10,118(121)$. 
55. Ygl. Herle (nt. 35), p. 28 .

56. Böckenforde (nt. 7), p. 1533.

57. WI. ook Deminger (nt, 31$), p .547$.

58. Backentorde (nt. 7), p. 1535.

59. Wg1. H.H. Klein, Die Grundrechte in demokratischen Staat, 2. Auflage, 1974 Stuttgart/Berlin(W)/Koln/Mainz, P. 14.

60. BverfGE 14, $21(25)$.

61. 20. kletn $(n+, 59), p .25$.

62. H.K.J. Ridder, Meinungsfrethett, in: F.L. Newmann/H.C. Nipperdey/0. Scheuner (red.), Dhe Grundrechte, Band II, 2. Auflage 1968 Berlin (w), p. 243 e.v.

63. H. Kriger, Allgenelne Staatslehre, 2. Auflage 1966 Stuttgart/Ber In (W)/Köln/Malnz, p. 526 e.v., met name p. 539 e.w.

64. Id., p. 539.

65. In z1jn boek: Grundrechte als Institution, 2. Murlage, 1974 Ber11n (W).

66. Id., P. 23/24. Z1jn theorle begint bif de vaststelling, dat stat en samenleving zlch utt elkar ontwikelen, een differentuêringsproces, dat tot de voruing van een specifiek politiek systeem als zelfistandige communicathesfeer leidt. Dit politieke systeren is het besllutwormingsmechanisme van de samenleving en werkt door zijn functionele spectalisate stablitserend op die samenleving. Tegelijkertijo kan deze differentiëring echter een destablliserende invloed ontwikkelen door een te grote verzelfstandiging, specialisatie en vervxeemding wan de politleke besiultvorming. Om dit gevar te vermijdun

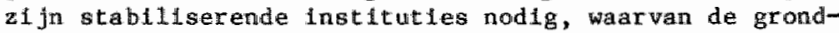
rechten er een zijn. De grondrechten dienen ertoe, het commulcatiesysteem zo te ordenen, dat het voor differentlëring open biljft.

67. Id., p. 23 .

68. Willke (nt. 23), p. 243, ziet o.m. Luhmamns theorte als een bijdrage on "tiber elnen reln personlichkeitsbezogenen Grundrechtsschutz hinausagelangen und die funkt 10 walen und struktureliten Vorausgetzungen elnes wiksamen Ind ividualschut zes elnzubeztehen" .

69. Krifger (nt. 63), p. 543.

70. Isensiev (nt. 7), pw 165.

71. Frtesenhahn (nt. 19), p. G 1 e.v.; Rupp (nt. 34), p. 161 
e. $\%$

72. Tupp (nt: 34), p. 165.

73. 0ssentah $(\mathrm{nt} \cdot 20), \mathrm{p}=2100$.

74. Achterenvolgens: Wilke (nt. 23), E. Grabitz, Freihett und Verfassungstecht, 1976 Tublngen; J. Schwabe, Probleme der Grundrechtsdogmat1k, 1977 Bamberg; Kröger (nt. 19). Bleckmann (nt. 2); Grituer (nt. 2).

75. Vgl. M. Kriele, Enfuhrung in die statslehre, 2. Auflage, 1981 opladen, p. 149 e.v. en 336 e.v.; M. Ratter, Mensch und Geselischaft aus staaticher und wischenstadticher Sicht, In: Festschrift fur Johannes Messner, 1976 Bexlin (W), p. 527 e.v*; R. Wahl, Rechtliche Wirkungen und Funktionen der Grundrechte im deutschen Konstitutionalismus des 19 . Jahrhunderts, 18 Der Stat 321 (1979), P. 321/322. Zle tewens diepgaand: Destreich (nt. 3). p* 39 e.v. en 59 e.v.

76. R. Herzogg, Aligemelne Staatslehre, 1971 Frankfurt(M), p. 363 e.v.

77. Wahl (nt. 75), p. 321.

78. Grimer (nt. 2), p. 38 e.v.; G. Starck, Entwicklung der Grundrechte in Deutschland, in: Gedachtnisschrift fur Christoph Sassen, 1981 Baden-Badea, p. 777 e.v*, ad p. 782 e.v.

79. Wahl (nt. 75), p. 340; wgl. Grimer (nt. 2), p. 55 e.v. en $\mathbb{E} . \mathbb{R}$. Huber, Deutsche Verfassungsgeschichte seit 1789 . Band II, 2. Auflage, 1968 stuttgart, p. 774 e.v.

80. Woor de leer van de staatssouvereindtelt in de 19 e eeww: Grabitz (nt. 74), p. 174 euv.

81. Gritmer (nt. 2), p. 65.

82. P. Laband, Das Staatsrecht des Deutschen Relches, Band I. 2. Auflage, 1888 Freiburg, p. $141 / 142$.

83. Dit aspect woxdt tegenwoordig als enige b11fwende verworvenheld van de toenmalige grondtechtenleer gezlen; vgl. Wall (nt. 75), p. 329 .

84. Voor een attwoerige bespreking: 0estrelch (nt. 3), p. 77 e.

85. G. Jellinek, Systew der subjektiven offentichen Rechte, onveranderde overdruk van 1919, 1964 Aalen, p. 81 e.v.

86. Id, p. 82.

87. Id., p. 86

88. Id. Pa 7. 
89. Woor een uttvoerige bespreking van Jellineks statugleer: Grabltz (nt. 74), p. 3 e.r.

90. VgI. Grimer (nt, 2), p. 91 e.v.

91. Vgl. Grabitz (nt. 74), p. 180 e.v.

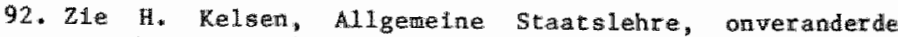
overdruk van 1925, 1966 Bad Homburg/Berltm (b)/Zurich, P. 102 en 107 e.v.

93. VgI. R. Thoma, Das System der subjekt1ven offentlicher Rechte und Pflichten, in: G. Anschutz/R. Thoma (red.), Handbuch desi Deutschen Staatsrechts, Band II, 1932 Tübilngen, p. 607 e.v., ad. P. 619. Vgl. ook E.R. Huber, Deutsche Verfassungsgeschichte selt 1789 , Band VI, 1981 stuttgart, p. 99/100.

94. Smend (nt. 21), p. 161 e.v.

95. Schmitt, Grandrechte und Grundpfilchten (nt. 36), p. 207 e.v.; Verfassungs lehre (nt. 10), p. 163 e.v.

96. Huber (nt, 16), P. 15/16.

97. Vgl. Grimmer (nt. 2), p. 88.

98. Schnitt presenteerde het Derde Rijk als de "nleume rechtsstat", rechtwaardigde de expansionistische aanspraken van HHt ler en de oorlog als middel tot het verwezenlijken van die aanspraken. Hij pollemiseerde tegen de joden. Zie verder: J. Fijalkowski, Dle Wendung zum Fïhrerstaat - Ideologische Komponenten in der politischen Phflosophle Car1 Schmitts, 1958 Köln/Opladen, m.th. de inleiding, p. KITI e.v.

99. Zie Statsrecht der DDR, ultgegeven door Akademe fur Staats- und Rechtswissenschaft der DDR, 1978 Berlin (0), p. 175 e.v.; H. Klenner, Die marxistische Menschenrechtskonzeption, Gedächtnisschrift für Rene Marcic, Band 2, 1974 Berlin (W), p. $793 \mathrm{evv}$.

100. K. Marx, Zur Judenfrage, in: K. Marx/F. Engels, Werke, uitgegeven door: Institut tür Marxismus-Leninismus belda Zentralkonitee der SED, 1957 Berliri (O), Band 1, p. 347 a., w., ad p. 364 .

101. H. Klenner, Studien über dLe Grundrechte, 1964 Berlin (o), p. $14 \mathrm{e} . \mathrm{v}$.

102. H. Klenner (nt. 101), p. 800 .

103. E.W. Böckenförde, Die Rechtsauffassung lm kommunigtischen Stat, 1967 Minchen, p. 44.

104 . Wgl, art. 19 1ld 1 Verf. der DDR.

256 105. K. Sorgentcht/W. Weichelt/T* Riemann/H.J. Senler (red *), 
Verfassung der Dentschen Demokratischen Republik, Band 2. 1969 Berlin (O), P. 15.

106. Wax in het onderzoek het woord "hil $\mathrm{j}^{\text {" }}$ in neutrale zin wordt gebraikt, dient naturlijk "hij of zij" te worden geleath

107. Sorgenicht (nt. 105), p. 107.

108. Trb. 1969, 99.

109. Zle art. 48 11d I ICCPR.

110. Bekanntmachung ther die Ratifikation der Internationalen Konvention vom 16. Dezember 1966 uber zivile und politische Rechted.d. 14-1-1974, GBI./DDR 1974 1, P. 57; BGBI. 1973 II, 1534 .

111. Art. 49 lid 1 ICCPR; vg1. GBI./DDR 1976 I, 108 c.q. BGBI. 1976 II, 1068 .

112. Vg1. GAOR 16th Session 1961-62, Annexes Volune I, Agenda Item 35, p. $5 \mathrm{nr} .30$ en P. $6 \mathrm{nr} .43$ (VN-Document Al 5000); GAOR 16th Session 1961-62, 3rd Comptee, 1073rd Meeting, p. $68 \mathrm{nr} .46 \mathrm{t} / \mathrm{m} 49$.

113: GAOR 16th Session 1961-62, Annexes Volume I, Agenda Item 35, p. $6 / 7 \mathrm{nr} .43 \mathrm{t} / \mathrm{m} 48$ (WN-Document $\mathrm{A} / 5000)$.

114. Id., p. 7/8 nr. 49; Nederland stemde ook tegen.

115. Zi e de diverse voorbehouden in de bundel: Multilateral Treaties, deposited whth the Secretary General; status as at 31 December 1981, VN-Document St/LEG/SER.E/1, p. 118 e.v., bijv. van Frankrijk (p. 12i) en Verenigd Koninkrijk (p. 126).

116. Id., P. 126 .

117. Vgll. GAOR 10th Session 1955, Annexes, Agenda Item 28 (Part II), P. 26 nr. 55 (VN-Document A/2929). Vg1. ook. GAOR 17th Session 1962-63, Annexes Volume II, Agenda Item 43, p. $14 \mathrm{nr} .92 \mathrm{t} / \mathrm{m}, 97$ (VN-Document $\mathrm{A} / 5365$ ): verdere discusste over art. 5 lid 1 ICCPR vond nawelljks meer pllats.

118. "Trb. 1969, 99.

119. Slatacte van de Conferentle over Velligheld en Samenwerking in Europa (CVSE), ondertekend door alle Europese staten behalve Albanlé, alsmede door de Verenlgde staten en Canada. Zle voor de tekst: Verslagen minterie van buiterlandse zaken nr. 115,1976 Den Haag, p. 251 e.w.

120. In het zevende beginsel van de "Verklaring betreffende de beglaselen, die de onderlinge betrekkingen van de deelnemende staten lelden" verklaren de deelnemende staten dat zlj de rechten van de mens en de fundamentele 
writheden wallen eerbledigen en dat zif hur verpluchtungen zullen nakomen zoals die zijo neergelegd in th intermationale verklaringen en overeenkonsten op dit gebled. De vrifheid van meningsulting wordt hiex atre apart genoend. Verder stellien de deelnemende statern zitch Hr de derde mand tot doel de verspreiding van informate van allerlel aad te zullen vergemakkelijken, de sanerwerking op het gebied van de lnformate en de inforiat the-ultwiscling met andere landen te bevorderen en de arbeldsvoorwadrden voor journalisten te verbeteren.

12l. Zij roept geen juridisch bindende rechten en verpllichtugen in het leven ( $R$. Wan Dijk, the final Act of Helsloki - Basis for a Pan-European system?, XI NYIL 97 (1980)* p. $106 \mathrm{e}, \mathrm{v}$.$) . Wel kunnen de gemaakte afspraken$ op andere wijze bindend zijn (Wan Dijk, p. 109). De verklaringen ult internationale overeenkomsten voortvloelende verplichtingen te zullem nakomen heeft tenminste bekrachtigend karakter (vgl. In de DDR-1iteratuur: M. Mohr, Die Grundprinzipten des allgemein-demokrat Ischen Volkerrechts und die Konferenz von Helsink, 22 DAP 2, $24(1977)$, p. 25).

122. Vertrag iber die Grundlagen der Beziehungen zwischen der Bundesrepublik Deutschland under der Deutschen Demokrathschen Republik van $2\lfloor-12-1972$, Gbil./DOR 1973 II, 25 c. q. BGB1. 1973 II, 421 .

123. Zle P. Badura, Verfassung, Stalat und Gesellschaft in der Sicht des Bundesverfassungigerichts, in: Bundeswerfassungsgerticht und Grundgesetz, Zwelter Band, $1976 \mathrm{Tu}-$ bthgen, P. 1 e.v*; G. Roellecke, PrInzlplen der Verfassungstiterpretation fn der Rechtsprechung des Bundeswerfassungsgerichts, in dezelfde uitgave, Zweiter Band, p. 22 e.v.; K. Zweigert/H. Dletrich, Bundesverfassungigericht - Institution mit Zukunft, in: W. Däubler/G. Kise1 (red.), Verfassungsger cht und Polltik, 1979 Reinbek, p. $11 \mathrm{e} \cdot \mathrm{v}$. 


\section{Noten bij hoofdstuk 2}

1. G. H. Hegel, Vor lesungen iber die Philosaphie der Weltgeschichte, Band 1,2. Auflage, 1920 Leifirg.

2. Id., p. 32.

3. Id *, p. 33 .

4. Id., p. 40 .

5. Id., p. 52.

6. Id., p. 51 .

7. F. Engels, Anti-Dihring, in: K. Karx/F. Engels, Werke, ultgegeven door Instcut für Marxismus-Leninismus belm Zentralkomitee der SED, 1957 Berlin (O) (hierna: MEW), Band 20, p* 1 e. $w_{*}$, ad p. 106 .

8. G. Stiehler (red.), Freihelt und Gesellschat - Die Fretheltsauffassung im Marxismus-Lenin1s mus, 1973 Ber $11 \mathrm{n}$ (0), p. 89. Zie verder W. Elchhorn, Demokratie und Fre1helt in der sozialistischen Geselischaft, 31 Einthelt 978 (1976), p. 980; G. Haney, Sozlalistisches Recht und Persönlichkelt, 14 StuR 1977 (1965), P. 187; A. Kosing e.a. Maixistische Phllosophie, 1967 Berlin (0), p. 268 e.v.

9. Kostag (nt. 8), p. 268 e.v. De moodzakellykthe1d houdt nilet in dat de objectleve wetten mechanlsche wetten zija: het mechanlsch determinisme wordt afgeweren. Daarvoor in de plaats treedt het dialectisch determintsme, die de wisselwerking tussen oorzak en werking, noodzakelijkheld en toeval, mogelijkheld en rerkelljkheld benadrukt.

10. R. Havemann, Dialekt1k ohne Dogma?, 1964 Reinbek, p. 104 .

11. $v 1.2 \cdot 2 \cdot 3$.

12. Voor en overzlcht uit 0ostduits zicht: Kosing (nt. 8).

13. K. Marx/F. Engels, Deutsche Ideologie, In: MEW (nt. 7), Band 3, p. 9 e. . ., ad p. 37/38.

14. K. Marx, Manifest der Kommuntstischen Partel, in: MEW (nt. 7), Band 4, P. 459 ,e.v., ad p. 462 e.v.

15. K. Marx, Zur Kritik der polltischen Dekonomie, in: MEW (nt. 7), Band 13, p. 3 e.v., ad p. $8 / 9$. 
16. Id., ad P. 9.

17. Op de arbelid is Marx Ingegaan in zijn Pariser Manuskro te, in: MEW (nt. 7), Ergänzungsband, Erster Tell, p. 465 e.v., ad p. 510 e.v.

18. Id., p. 520 .

19. Kosing (nt. 8), p. 348.

20. H.P* Haldrich, Der Demokratlebegrift der SED, 1980 stutegart, p. 110 .

21. 0. Finger, Die Frethelt der Persönlichkelt, Dzp 397 $(1977), p .408$.

22. Marxistisch-lenindstische Staats- und Rechtistheortie. uttgegeven door Institut fur Theorle des states und des Rechts der Akademie der Wissenschaften der DDR, 3. Huflage, 1980 Berlin (0), p. 394.

23. Programa van de Sozla11stische Etnheltsparte1 Deutschlands van 22-5-1976. Protokoll dex Verhandlungen des IX. Parteltages der SED, deel 2, 1976 Berlin (O), F. 209 .

24. Demokratie, Entwlingsgesetz des sozlalistischen Staates, ultgegeven door lnstitut fur Theorie des Staates und des Rechts der Akademie der Wissenschaften der DuR en Institut fur Staat und Recht der Akademie der Wissenschaften der UdSSR, 1981 Berlin (O), p. 79/80.

25. Ibld. Evenzo: Marxistisch-leninistisch Statg- und Rechtstheorie (nt. 22), p. 393: "Die marxistisch-leninlstische Partel schätzt den fewelligen Entwicklungsatan der Gesellschaft eln, deckt die objektiven Gesetzmässigkelten auf und formuliert Anforderungen, um die objectiven Gesetze auszunutzen".

26. Christ11ch-Demokratische Union (CDU), Libera1-Denokratische Partei Deutschlands (LDPD), National-Denokrat1sche Partel Deutschlands (NDPD) en Diemokratische Bauernparteil Deutschlands (DBD).

27. Waldrich (nt. 20), p. 182 en 184 .

28. Demokratie, Entwicklungsgesetz des sozialistischen Stagtes (nt. 24), p. 85. Vgl. S, Nampe1, Dle sozlalistische Verfassung der DDR, 2. Auflage, 1982 Frankfurt (M), p* $533 / 534$.

29. StLehLer (nt. 8), p. 106.

30. Id*, p. 229 .

31. H. Klenner, Die marxistische Menschenrechtskonzept Ion, In: Gedächendsschrift fur Rene Marclic, Band 2, 197 Berlir $(W)$, p. 793 e.v., ad p. 800 . Vgl. tevens H. KHerimer, Frelheit und Menschenrecht, 38 Einheit 1055 (1983). 
P. 1057: "Beil uns 8 lbt es keine Freiheit fur die Gegner der Freffelt des Volkes".

32. Finger (nt. 21), p. 412.

33. T. Rieman, Dle grosse sozialistische oktoberrevolution - Geburtsitunde der sozlalistischen Menschenrechte, 31 NJ $526(1977)$, p. 528 ; stiehter (nt. 8), p. 230 .

34. GRII./DDR 1949, 5.

35. Verfassung des deutschen Relches van 11-8-1919, RGBL. 1919, 1383; Grundgesetz für die Bundesrepubllk Dentschland van 23-5-1949, BGB1. 1949, 1 .

36. Zaals Mampe1 (nt, 28) antoont.

37. Staatsrecht der DDR, uitgegeven door Akademile für Stats- und Rechtswissenschaft der DDR, 1978 Berlin (0), P. 71.

38. GBI. /DDR 1968 I, 199.

39. $6 \mathrm{b1}$. /DDR 1974 I, 432 .

40. U. Arens, Die andere Fretheit, 1976 Muinchen; H. Kaschkat, Die sozialistischen Grundrechte in der DDR 1976 Wir zburg; Mampel (nt. 28); D. Muller-Römer, Die Grundrechte in Mitteldeutschland, 1965 Köln. Enkele systeenvergelifkende studles: $K$. Löw, Dle Grundrechte - Verständnis und Wirklichkeit in beiden Tellen Deutschlands, 2. Auflage, 1982 München; H. Roggemam, Die Verfassung der DDR, 1970 Opladen, p. 130 e.v*; 4 . Stelger, Ereiheit und Befrelung. Zur Funktion der Grundrechte in der BRD und in der DDR, Politik und Kultur 4, 15 (1976).

41. H. Klenner, Marxismus und Mensehenrechte 1982 Berlin (O); H. Klenner, Studien Wher die Grundrechte, 1964 Berlin (O); E. Poppe (red.), Grundrechte des Birgers in der sozlalistischen Geselischaft, 1980 Berlin (O); E. Poppe, Menschenrechte - eine Klassenfrage, 1971 BerIin (0); K. Sorgenicht/W. Weichelt/T. Riemanm/H.J. Semler (red.), Verfassung der Deutschen Demokratischen Republ1k, Band 2, 1969 Ber1in (0); Staatsrecht der DDR (nt. 37), p. 175 e.v.; Marxistisch-leninistische Staats- und Rechtstheorle (nt. 22), p. 408 e.v.; en vele tijdschriftartikelen.

42. E. Poppe, Gedanken zum Stand der sozlalistischen Grundrechtetheorfe und forschung in der DDR, 24 StuR 1333 (1975).

43. Zie 4.3. Vg1. cevens F.J.M. Feldbrugge, Grondrechten in de Harxistisch-1endnistische rechtsleer, 12 NTRR 91 (1983), m.n. p. 97 e.v., die het loglsche gehalte van de soclalistische grondrechtsopwatting afolist, ondat zif niet ut de marxistisch- leninistische leer zelf volgt, maar en - mislukte - metamorphose is van het in de wes- 
terse geschledents gevormde grondrechtsbegrip.

4.4. Zie 2.3.3.

45. Zo ultdrukkel1 fk: Karxistisch-1eninistische Staats- and Rechtstheorle ( $n t, 22), p, 417$; voor velen: H. Klenmer, Menschenrechte - kilasgenrechte, 32 wJ 284 (1978).

46. K. Marx, Zur Judenfrage, in: MEW (nt. 7), Band 1, p. 347 e.w., ad p. 362. Mars clteert hier B. Baner, Die Judenfrage, 1843 Braunschwetlg, p. $19 / 20$.

47. E. Poppe, Die Bedeutung der Grundrechte uad Grundpflichten des Bürgers 1n der solalist1schen Gesellschaft, 32 NJ 326 (1978), p. 328. Vgl. ook Marxtstisch-lentnistiache Statg- und Rechtstheorte (nt. 22), p. 417 en Stantsrecht der DDR (at. 37), p. $176 \mathrm{e} *$.

48. Cursivering van mij.

49. Zie 2.3.3.

50. VN-Document CCPR/C/1./Add. 13 van 7-7-1977.

51. De bewering, dat dezelfde begrippen 1 in het sociallswe een andere betekenls heblben dan in de westerse rechtswetenschap, makt de communlcatie er overigens niet gemakke11jker op.

52. C. Luge/R. Mand/R. Rost, Sozlalismus und Menschenrechte, 26 stuR 789 (1977), p. 791 en Poppe, Grundrechte des Biturgers (nt. 41), p. 65. Voor een overzicht van de geschiedenis van de grondrechten utt soclalistlsch perspectief leze men $J$. Kuczljnskt, Menschenrechte und Klassenrechte, 1978 Berlin (0). Zle ook Klenner, Studien iber die Grundrechte (nt. 41), p. 14 e.w. Voor de verhouding tussen burgerlijke en marxistische mensenrechter tevens: E. Poppe, Kar1 Marx und die Menschenrechte, 37 NJ $92(1983)$, p. 93 e.v.

53. E. Poppe, Dle pol1tuschen und persönlichen Rechte und Frethelten in System der sozlalistischen Grundrechte, 28 SituR $806(1979), p .812$.

54. Klenmer, Studien uber die Grundrechte (nt. 41), p. 84 .

55. Marxlgetsch-leninistische Stats- und Rechtstheorle (nt. 22), p. 390; Thesen zum Wesen und zur Entwlcklung des sozialist1schen Rechts, 12 StuR 184 I (1963); W. Brugger, Marx und das Rechtswerständnis in der DDR, 22 ROW 101 (1978).

56. Vg1. G. Brunner, Einfihrung in das Recht der DDR, 2. Auflage, 1979 Minchen, p. 2 *

57. Thesen zum Wesen und zur Entwicklung des sozialletischen Rechts: (nt. 55), p. 1846 . 
58. Harxistisch-lenlnistische Staats- und Rechtstheorie (nt. 22), p. 398: "H111 der Arbefterklase kann nur dann Recht werden, went sich die Arbelterklasse unter Finrung Ihrer Partel als stat konstitulert hat und Klassenwillen zum Recht erhebt".

59. Vg1. Brunner (nt. 56), p. 2,

60. Id., p. 3; Marxistisch-leninistische staats- und Rechtstheorle (nt. 22), p. 423 .

61. Marxistisch-Leninist1sche Stats- und Rechtstheorie (nt. 22), P. 425 .

62. W. Buchner-Uhder/E. Poppe/R. Schisseler, Grundrechte und Grundpfichten der Bürger in der DDR, 15 stuR 563 $(1966)$, p. 567 .

63. Klenner, Studlen liber die Grundrechte (nt. 41), p. 11 .

64. K. Marx, Zur Judenfrage, In: MEW (nt. 7), Band 1, p. 347 e.v., ad p. 364 .

65. Ibst.

66. Id., p. 364 e.v.

67. Id., p. 370. Meer over Mar $x^{*}$ opvatt1ng dat mensenrechten de rechten van de bourgeolste waren in: E. Poppe, Marx und (bürger11che) Menschenrechte, 32 StuR 267 (1983). Vg1. tevens Klenner, Harxismus und Menschenrechte (nt. 41), p. 60 e.v.; Poppe, Karl Marx und dle Menschemrechte (nt. 52$)$.

68. Sorgentcht $(\mathrm{nt} .41), \mathrm{p} .15 / 16$.

69. R. Wil1/H.J. W111, 2ur Entwicklung der marxistischLenInlstischen Grundrechtsauffasungen in revolutionären Parteiprogrammen der deutschen Arbelterbewegumg vom "Kommunistischen Manlfest" bis zum Erfurter Programn, Wissenschaftliche Zeltschr 1 ft der Humbold Universitat $z u$ Berlin, Gesellschaft- und Sprachwlisenschaftilche Rethe $2,211(1978)$, p. 212 .

70. Marxistisch-1eninistische Staats- und Rechtstheorie (nt. 22), p. 417 .

71. Klenner, Die marxistische Menschenrechtakonzeption (nt. 31), p. 801 .

72. E. Poppe/R. Schusseler, Sozlallstigche Grundrechte und Grundpflichten der Bürger, 12 stuR 209 (1963), p. 216.

73. Harxistisch-lendnistische Staats- und Rechtstheorie (nt. 22), p. 417 .

74. Poppe, Grundrechte des Burgers (nt. 41), p. 40 e.v. 
75. E. Poppe, Der Verfassungsentwurf und dfe Grundrechte und Grundpllichten der Bürger, 12 stuR 532 (1968), p. 533.

76. Poppe, Grundrechte des Burgers (nt. 41), p. 40 e.v.

77. Stattsecht der DDR (nt. 37), p. 190. Vgl. Klenner, Freiheit und Menschemreeht (nt. 31) * p. 1058 .

78. Bij\%. art. 21 lid 3 Verf.: "Die Verwirklichung dieses Rechts der Mitbestimmig and Mitgestaltung ist zuglelch elne hohe moralische Verpflichtung für feden Bïrger". Dat het bij een morele plicht biljft slutt niet ult; dat de burger die $z \mathbb{1}$ jn plichten nlet warneemt daardoor $z i j \mathrm{j}$ rechten kan verwerken. Een dergelijke dreigling valt af te lezen wit de opmerking in het statsrecht der DDR (nt. 37), $p$. 190, dat de samenleving de lndividu slechts kan beschiermen, Indien deze op zijn beurt ook de samenleving beschermt en sterkt. Zie ook S. Poppe, Grundpiflichten und thr Verhaltnis zu Grundrechten, 32 StuR. $108(1983)$, P. 109 e.v.

79. Statarecht der DDR (nt. 37), p. 185; Poppe, Der Verfassungsentwurf (nt. 75), p. 533; Klenner, studien uber die Grundrechte $(\mathrm{nt}, 41)$, p. 52 .

80. Klenner, Studien uber die Grundrechte (nt. 41), p. 75. Vg1. K. Hofmann/H. Ptischel, Zum Haupt inhalt der Rechte der Bürger in den von sozialistischen Zivllrech der DDR geregelten gesellschaftichen Vexhaltmissen, 10 StuR 1895 (1961), p. 1986; G. Haney, Das Recht des Burgers und die Entfaltung der sozlalistischen Persönlichkelt, 11 StuR 1063 (1962), p. 1079 .

81. Poppe/Schüsseler (nt. 72), p. 219; Bẗchner/Uhder/Poppe/ Schüsseler (nt. 62), p. 569 .

82. Staatsrecht in der DDR (nt. 37), p. 185. Deze formullering keert letterlifk in alle belangrijke publicaties terug. Te optimistisch over de relkwijte van deze erkenning 1s Roggemann (nt. 40), p. 137. Realistischer Mampel (nt. 28), p. 547/548, die benadrukt dat nog geenszins duidelijk is of deze DDR-interpretatle van de subjectleve rechten werkelijk een zelfstandige aanspraak tegenover de overheld creären of daarentegen thet karakter van door de overheld verleende rechten behouden.

83. E. Poppe Dlie politischen und persomifchen Rechte und Fretheiten Im System der sozlalistischen Grundrechte, 28 StuR $806(1979)$, P. 810 .

84. Poppe, Grundrechte des Bürgers (nt. 41), p. 211 .

85. Id., resp. p* 213,215 en 219.

86. A. Zschrledrich, Probleme der jur LstLschen Garantien der grundlegenden Rechte der" Bürger, 22 StuR 1177 (1973).

B7. Voor een overzicht zie G. Brunner, Das System der of- 
fewtich-rechtlichen Rechtsschutzes tn der DDR, In: R. Lange/B. Meissmer/K. Plieyer (red.), Probleme des DDRRechtes, 1973 Koln, $p .81$ e.v. Recenter, mar niet wezenlight veranderd: H. Kaschkat, Der Rechtsschutz des elnzelnen gegen statiches landeln in der DDR, in: R. Westen/B. Meissner (red.), Der Schuti individueller Rechte und Interessen im Recht sozialistischer Staaten, 1980 Baden-Baden, p. 65 e.v.

88. Aldus 0 . Luchterhand, Der Rechtsschutz des einzelnen im Stats- und Verwaltungstecht, in: K. Westen/B. Metssner (red.), Der Sichutz individueller Rechte und Interessen Im Recht soztalistischer Staater, 1980 Baden-Baden, p. 35 e.v. ad . . 51.

89. Zo Luge/Mand/Rost (nt. 52), p. 795.

90. Art. 19 11d 4 GG: "Wird jenand durch die öffentllche Gewalit in selmen Rechee verletzt, so steht ihm der Rechtsweg offen".

91. Poppe, Der Verfassungsentwurf (nt. 75), p. 535.

92. Id. p. $539 / 540$.

93. Statesrecht der DDR (nt, 37), p* 194.

94. E. Poppe/H. Bel1, Das Grundrecht der Melnungs- und Pressefreihelt in der sozlalistischen Verfassung der DDR, 23 NJ $353(1969)$, p. 354 .

95. Klenner, Die marxistische Menschenrechtskonzeption (nt. 31), p. 801 .

96. R. Hieblinger/W. Menzel, Das sozlalistische Grundrecht auf Irele Melnungsäuserung und seine Verwiklichung in der Deutsche Demokratische Repub1ik, habilitatie, 1964 Lelpzig, p. 39. Dit werk is de enige ultgebrelde oostduttse studie over de vrifheld van mentinguiting in de DDR.

97. Sorgenicht (nt. 41), p. 106.

98. Hieblinger/kenzel (nt. 96), p. 45 e.v.

99. Id., p. 4.7/48.

100. Id., p. 40. Evenzo Poppe/Be11 (nt. 94), p. 335/336: "Dawit letztendlich eine rlchtige Melnung entsitehen kann, mus sie stch durch Meinungsstrelt, Kritik und Selbstkritlk heraubliden können. Nur so 1 st elne korrektur möglich und kann sich die Wahrhelt durchsetzen."

101. Klenner, Studlen iber die Grundrechte (nt. 41), p. 113 .

102. Id., p. 115.

103. OG 2-3-1956, ogst 3,316 . 
104. Haney, Sozlaligtischeg Recht und Persönlichkelt (nt. 8), p. 189.

105. Z1e 2.3.3.

106. Heblinger/Menze1 (at. 96), p. 187/188.

107. Poppe, der Verfasiungsentrur (nt. 75), p. 538. Wat in het hiler becowmentarleerde ontwerp nog art. 23 was, is in de wan kracht geworden grondwet art. 27 Verf. geworden.

108. Hebllnger/Menzel (nt. 96), p. 119.

109. Vg1. 2.2.3.

110. Hleblinger/Menzel (nt. 96), p. 122.

111. $21 \mathrm{e} 2.6$.

112. Heblinger/Menzel (nt. 96), p. 123 en 140 .

113. Id., p. 33; Poppe/Be11 (nt. 94), p. 355.

114. Poppe/Be11 (nt. 94), p. 355 .

115. Zte 2.5 .1 .3 .

116. Poppe/Be11 (nt. 94), p. 137.

117. Dat is alle propaganda, die in nam van de wrifheid, de democratle of de menselljkheld bedreven wordt, aldus: statsrecht der DDR (nt. 37), p. 203 .

118. Poppe, Grundrechte des Birgers (nt. 41), p. 143; cursivering van wij. Zle ook PoppefBell (nt. 94), p. 353 ent Sorgenicht (nt. 41), p. 107.

119. R. Havemann, Fragen, Antworten, Fragen, 1970 Mlinchen, p* 260 e.v.

120. Westdultse 11teratuur over dit onderwerp: K.W. Fricke, Polltik und Justiz in der DDR, zur Gesichichte der politischen Verfolgung 1945-1968, 1979 Koln, p. 508 e. v*; S. Mampel, Die Verfasisung der sowjetisch besetzten zone Deutschlands, 2. Auflage, 1966 Frankfurt (M)/ Berlin (W), p 92 e.v.; D. Muller-Romer (nt. 40), p. 132 e.v.; W. Rosenthal, Das nete polltische Strafrecht in der DDR, 1968 Frankfurt (M)/Ber 1 in (W).

121. Strafrecht der Deutschen Demokratischen Republik, Kommentar zum Strafgesetzbuch, ulegegeven door Ministerlum der Just1z und Akademle fü Staats- und Rechtswissengchaft der DDR, 3. Auflage, 1981 Berlin (O), p. 17/18.

122. Id., p. 18 . 
124. Strafrecht, besanderer Teil, ultgegeven door Sektion Rechtswissenschaft der Fumboldt Universite zu Berlin und Akademie fur stats- und Rechtswissenschaft der DDR, 1981 Berlin (0), p. 39.

125. Romtrollratsdirektive 14.38 van $12-10-1946$ (jo. Gesetz 10) betreffende de arrestatie en de bestraffing van oorlogsalisiadigers, national-soclalisten en militaristen, over de internering, de controlie en de bewaking wan potentleel gevaar 11 jke Duftsers. Te vinden in: R. Henken (red.), Sammlung der vom Allierten kontrollrat und der Amerikanigchen Reglerung exlassenen Proklemationen, Gesetze, Verordnungen, Befiehle, Direktiven, Band III, 2, 1946 Stuttgart.

126. StEG van $11-12-1957$, GB.1./DDR $1957 \mathrm{I}, 643$.

127. StGB wan 12-1-1968, GB1./DDR 1968 I, 1.

128. OG $4-10-1950$, OGSt $1,22(40)$.

129. Resp. KG Bernau 26-4-1956, Der schöfe 1956, P. 258; Stc Gross-Ber11n 4-11-1955, UaS III 122 (171); LG Görlltz: 15-5-1951, UaS I $17(12)$. Z1e ook BG Le1palg 28-11-1957, 12 N] $69(1958)$.

130. LG Eberswalde 4-4-1951, UaS 1 i (12).

131. og 4-10-1950, ogst $1,33(41 / 42)$.

1132. LG Potsdan 6-11-1950, UaS I 11 (4); OG 24-8-1951, OGSt 2,214; BG Pocsdam 29-8-1955, Uas III 113 (155).

133. SG Halle $11-7-1954$, UaS III 110 (152).

134. BG Suh1 18-1-1957, UaS III 123 (173).

135. BG Lelpzig 17-4-1953, UaS II 134 (157).

136. Aanklacht of flcler van Justtele Bezirk Erfurt 16-4-1956, BG Erfurt 7-5-1956, UaS III 113 (156).

137. KG Ascherleben 18-3-1957, UaS III $124(176)$.

138. BG Halle 2-4-1953, UaS II 114 (142); BG LeIpzig 20-11955, UaS III 120 (168); BG Dresden 31-5-1957, thaS III $120(169)$.

139. BG Rostock 3-5-1956, VaS III 117 (164).

140. OG 9-6-1953,7 NJ 411 (1953); BG Cottbus 28-2-1955, Uas III 116 (162); KG oranienburg 23-2-1956, Las III 118 $(165)$.

141. OG $4-3-1958,12$ NJ $250(1958)$.

142. BG LEIPZ1g 28-11-1957, UaS CLI 107 (151). 
143. KG Werdau 25-10-1955, UaS III 121 (170).

14.4. GB1./DDR 1979 I, 139. Het eerste StAG dateert van 19-121974; GB1./DDR 1974. I, 591, het tweede StAG van 7-51977; GBI./DDR $1977 \mathrm{I}, 100$.

145. Straftecht, besonderer Te11 (nt. 124), p. 60.

146. BG KarI-Marx-Stadt 16-6-1959, 13 NJ 783 (1959).

147. Strafrecht, besonderer Te11 (nt. 124), pi 61: zie ook OG 21-3-1958, ocst 4, 251 en oG 16-5-1958, OGSt 4, 267.

148. Verleundung (laster) behoort tot de groep van zgn. straftaten tegen de staatsorde, Hetze (ophitsing) daarentegen is een inlsdaad tegen de DDR.

149. OG 5-9-1958, oGSt 5, 302, OG 3-10-1958, OGSt 5, 307; OG 13-1-1959, oGSt 5, 225. ZO'n omstandigheld is bijwoorbeeld, dat de vader wan de verdachte reeds een vijand wan de DDR $i s$, die op grond van hetzelfde dellct al eerder is veroordeeld: $\mathrm{BG}$ Kar 1-Harx-Stadt 16-6-1959, 13 HJ $783(1959)$.

150. OG 16-5-1958, 12 NJ $494(1958)$.

151. Par. 106 11d l StGB, GBI./DDR $1968 \mathrm{I}, \mathbb{1}$ : "Wer mit derm Ziel, die sozfalistische Gesellschaftsordnung der DDR zu schädgen oder gegen ile aufzuzwiegeln ..." (cursivering Van $\mathrm{mij}$ ).

152. 3e StAG, GB1./DDR 1979 I, 139.

153. OG $14-3-1958,12 \mathrm{NJ} 287(1958)$.

154. BG Lelpzig $11-2-1958 * 12$ NJ 177 (1958).

155. OG $31-10-1958$, OGSt 4,277 .

156. Aanklacht offlcler van Justitle Bezlrk Gera 3-6-1958, DdU $4,19$.

157. OG 25-4-1958, OGSt 4,25:4.

158. OG $11-3-1958,12 \mathbb{N J} 323(1958)$.

1159. BBG LeLpzIg 27-1-1962, DdU 6, 11.

160. BG Potsidam 19-1-1962, DdU 6, 10.

161. KG Senfterberg 28-3-1960, UaS 102 (169); StGB Prenzlauerberg 7-4-1960, Ddu 5,7. Vgl. echter Die We1t 3-41976: vrijspraak met verming voor het op de trompet spelen van het Deutschlandlied.

162. OG $14-3-1958,12$ NJ $287(1958) ;$ OC $3-6-1958,12$ NJ 540 $(1958)$; OG 11-7-1958, $12 \mathrm{NJ} 574(1958)$. 
163. BG Magdeburg 1-2-1961 UaS IV 120 (183). Par. 106 Iid 1 sub 5 StGB werd voorafgegaan door par. I9 lid 1 sub 1 StEG (tot 1968) en par. 106 11d l sub 4 StGB (wan 1968 cot 1979).

164. 21. 2.7.

165. of 11-2-1958, ogst 4, 232 .

166. Deze al zeer ruime onschrijuing worde in de rechtspraak oak zeer rutm uitgelegd: OG 3-7-1958, DGST 4, 185; ac $27-9-1961,16 \mathrm{NJ} 131(1962)$.

167. F. Mithlberger, Zum Tatbestand der statsfalndlichen Hetze, 23 NJ 50 (1969).

168. De bouw van de murr had tevens tot gewolg, dat het werzamelen van bostduitse jurlisprudentie door de rechtswetengchap in de Bondsrepubliek moellijker werd. Men rakte voornamelijk angewezen op kranteberlchten en verklaringen van DDR-burgers, dit ook ondat oordelem, wegens Hetze uitgespraken, niet meer in de gepubliceerde jurisprudentfe-ver zamelingen voorkomen. Een belangrifthe informatiebron vormt Amnesty International.

169. Westduitse 1iteratuur hierover: $\mathbb{K} . W$. Frtcke, Vervol1kcomung der "sozlallatischen Gesetzlichkelt"? Erneut Revision des straf- und Strafvollagssechts in der DDR, 10 DA 452 (1977); F.C. Schroeder, Die strafrechts- und Strafprozessrefor der DDR von $1974 / 1975$, 30 NJW 169 $(1977) ; \mathbb{F}^{\circ}$. Schroeder, Die neue Strafrechtsreform der $\mathrm{DDR}_{3} 12 \mathrm{DA} 1064(1979)$.

170. GBL./DDR 1973 II, 25.

171. 2le noot 144 .

172. Pax. 106 11d 1 , StAG van 28-6-1979, GBl./DDR 1979 I, 139.

173. Par. 106 lid 2, StAG van 7-5-1977, GB1./DDR 1977 I, 100.

174. Par. 106 1Hd 2, StAG van 12-1-1968, GB1./DDR 1968 I, 1.

175. Aldus F.C. Schroeder, Dle neue strafrechtsreform der DDR (nt. 169), p. 1070.

176. Exemplartisch is de veroordeling in jul1 1981 van lemant. die een pamflet had samengesteld or $z 1 \mathrm{jn}$ ontevredenheid met de offlciele polltiek in de DDR ult te drukken tot 2 jaar en 3 maanden gevangenisstraf. Bron: Amesty Internationa 1 Index: EUR 22/11/81. d1str.: UA 202/81.

177. Amnesty International Index: EUR 22/01/82, Distr.: NS/ Co, p. 14; vgl. Index: EUR 22/10/81 (geen Ddstr.nr.), P. 6, nrs. 11 en 12 .

178. Amnesty International Index 22/09/84, D1otr.: SC/CO, p.3 
180. In casu naar President Carter en het weekblad Splegel Respectevelijk in: Die gravierendsten Menschencechtoverletzingen in der DDR. Begleitmerlal des DoR-Tetles fur das II. Internationale Sacharov Hear1ng, 1977 Berlin (w), p. 16; en in: Amnesty International Index: EUR 22/ 05/81, D1str. : NS/CO/AD. Vgl. ook het oordeel StG Berlin 17-10-1977 ex par. 106 StGB vanwege het leveren vart matschappljkrttlek in de vorm van gedichten. Bron: Gesamteutsches Inst1tut - Bundesanstalt für gesamtdeutsche Aufgaben, Hest-Berlijn (nawwketriger bronverwelding niet mogelifk).

181. Berliner Morgenpost 3-4-1979.

182. Recente oordelen in: Amnesty International Index: RUR 22/04/81, D1str.: UA 65/81: Index EUR 22/10/81 (geen Detr.nr.), p. 2 nr. 6, p. 3 nr. 7 en nr. 8, p. 4 ar. 9; I. midex EUR 22/09/84, Distr.: SC/CO, p. 4. Frankfurter Allgemelne Zeltung 21-6-1980: veroordeling tot 2 jaar gevangenisstraf woor lemand die zich in zifn emigratleverzoek had beroepen op de Universele Verklaring van de Rechten van de Mens en op de Slotacte van Helsinka. Vgl. het einde van 2.7 .

183. BG Erfurt 6-10-1978. Bron: Gesamtdeutsches Institut (zle de opmerking in nt. 180 ).

184. GB1./DDR 1979 I, 139.

185. Deze twee termen zullen hter bynonlem gebrulkt worden.

186. OGst $4,100$.

187. BG Dresden 2-9-1965, K.W. Fricke (nt. 120), p. 510 .

188. OG 18-10-1957, OGSt, $100(105)$.

189. L. Frenzel, Zur Gese11schaftsgefahrlichkeit der Statswerleundung und zu den Kriterlen threr Festelilung in Einzelfa11, 16 NJ $692(1962)$, p. 698.

190. KG Sangerhausen 13-2-19:58, DdU 4, 9 .

191. KG Dessau 23-4-1958, Ddu 4,5.

192. KG Namburg/Saale 4-8-1958, DdU 4, 7 .

193. KG Bad Langensalza 20-8-1958, UaS IV, 98 (165).

194. KG Bltterfeld 24-11-1960, UaS IV 103 (171).

195. KG Bischofwerda 22-12-1958, UaS IV 99 (166); IWE-Tagesdienst ar. $99 / 1960, p * 1$.

196. OG 11-5-1962, 16 NJ 416 (1962): StGB Prenzlauer Berg I59-1961, DdU 6, 5 . 
197. BG Letpalg 20-5-1959, UaS IV 100 (167). Hoewel zis ontkende werd de verdachte veroordeeld. Han de verklaring van een opgeroepen getuige werd meer warde gehecht ondat deze helder en vooringenomen getulgde (sozialistische Partellichkeit

198. OG 11-5-1962, 16 NT $416(1962)$.

199. StG Gross-Berilin 24-11-1960, Uas IV 104 (172).

200. OG 21-12-1962, OGSt $6,242(244)$ *

201. og $21-12-1962, \operatorname{OgSt} 6,242(246)$.

202. Zle de veroordeling van twee Jonge Westuhtsers wegens kritische uitlatingen bij de dowanecontrole tussen Westen Oost- Berlifn: StGB Prenzlaver Berg 20-6-1967, K. W. Fricke (nt. 120), p. 511. Voor de veroordeling van ween Westuitser tot 10 Jaar ex par. 106 stGB: Berliner Morgenpost 25-9-1982.

203. Zie noot 144 .

204. Par. 220 11d $\mathbb{1}, 2$ en 4, StAG van 28-6-1979, GB1./DDR $19791,139$.

205. Ondat hun dit door het bestaan van het vergunningenstelse1 voor drukwerken onmoge11 jk wordt gemakt; zle 2.6.1.

206. Par. 219 1.1d 2 en 3, StAG van 28-6-1979, GBl./DDR 1979 I. 139 .

207. Neue:s Deutschland 23-5-1979 meldde dit.

208. Dev1sengeretz van 19-12-1973, GB1./DDR 191, 574.

209. Zie de desbetreffende artikelen in de Frankfurter Allgemeine Zeitung 25-5-1979, Frankfurter Rundschau 25-51979, Der Splegel 22, 28-5-1979.

210. Zle het interview met lleym n.a.v. deze nfeuwe wet in: Dex Splegel $44,27-10-1980$, p. 54 e.v.

211. Ber liner Morgenpost 24-3-1981. Vgl. ook de veroordeling van een persoon ex par. 219 StGB, die een Westduttser had geschreven over zlfn plannen de $D D R$ te verlaten: $K G$ Cottbus-Stadt 21-5-1980. Bron: Gesamtdeutsches Institut (zie de opwerkting in nt. 180).

212. Amnesty Internatlonal Index: EUR 22/090/84, DHstr.: SC/ CO. p. $5 / 6$.

213. Befde gevallen In Amesty International Index: EUR 22/ $06 / 84$ (geen Distr.nr.), p. 6.

214. K.H. Baum, Der grosse Schwung der ersten Jahre 1st dahin; Frankfurter Rundschau 25-8-1982, p. 3. 
215. Strafrecht der DDR, Komentar (nt. 121), p. 273.

216. OG $4-10-1950$, OGSE $1,33(41)$.

217. Vgl. 2.5.1.1. V66r 1968 wolgde de strafbarheld ut par. 1911 I sub 1 StEG (nt. 126).

218. Strafrecht der DDR, Komentar (nt, 121), p* 277/278.

219. Id., P. 277. Vgl. bovendien de opmerking in strafrecht, besonderer Tell (nt. 124), p. 31, dat mildrijuen tegen de vrede, de menselifikheld en de mensenrechen principleel te danken $z i j n$ an het mechanlime van het inperia1istlache heerschappljsysteem.

220. Par. 55 11d I AGB van 16-6-1977, GBL./DDR 1977 I, IB5,

221. OG 29-6-1963, naar Mampe1 (nt. 28), p. 709.

222. Recentel1jk een man vamwege het schrijven van een krithsche brief a Erich Honecker. Zle Amesty International Index: EUR 22/05/1981, Distr.: NS/CO/AD. Zle ook mt. 180, dezelfde man die later veroordeeld werd vanwege het schrijuen van een brief aan spiegel.

223. Het Oostduitse recht kent officieel de ambtemarenstatus niet. Gesproken wordt van nedewerkers bif de staatsorganen* Zle de Verordnung uber die pflichten, die Rechte und die Verantwortlichkelt der Mitarbeiter in den Stat organen van 19-12-1969, GBI./DDR 1969 IT, 163 .

224. Staatsrecht der DDR (nt. 37), p. 448.

225. Id., $\mathrm{p} .438$

226. Id., p. 448 .

227. Par. 17 e.v. en par. 21 van de in nt. 223 genoende verordenting *

228. J. Nawrock1, Abkehr von der Partel. Immer mehr Jugend1che in der DDR suchen itren eigenen Weg, Die Zelt 12, $19-3-1982$, p. 9 .

229. SED sleht kleinbürgerliche Friedenssehnsucht, Frankfurter Rundschau 25-3-1982, p. 1.

230. K.H. Batum, Der Gelst zölth, nicht das Zelchen, Frankfurcer Rundschau 29-9-1982, p. 18 .

231. Z1 : Grösste Ausburgerungsaktion ge1t 1976, Der splegel $22,30-5-1983, \mathrm{p} .25 / 26$.

232. Poppe/Be11 (nt. 94$),$ p. 356.

233. F.J. Herrmann, Unsere trele Presse, 31 NDP 1, 5 (1977).

272234 . Vg1. voor de persur thed als klaserecht en overigens 
Hil Halbach, Zur Spezifik des sozlalistischen Journalismus, Hisertatie, 1979 Lelpzig, p. 103 e.V.

235. Id* $p=153$.

236. Poppe/Bell (nt. 94), p. 357.

237. W. Schmidt/E. Hechter, Deffentlichkelt, offentliche Melnumg and statiche oeffentlichkeitsarbeit, 1979 potsdam-Bebelsberg, p. 21 .

238. H. Lange, Pressefreiheit kontra Manipulation, 32 NDP 3 , $21(1978)$.

239. Poppe/Bell (nt. 94), p. 357.

240. Id., P. $357 / 358$.

241. Vg1. par. 106 lifd 1 sub 2 StgB en par. 220 1id 2 SteGB.

242. Poppe, Grundrechte der Bürger (nt. 41), p. 146/147; Poppe/Be11 (nt. 94), p. 356/357; Sorgenicht (nt. 41), p. $109 / 110$.

243. Art. 9 11d 2 Verf, van 1949, GB1./DDR $1949,5$.

244. R. Haventann, Ueber Zensur und Medlen, 9 DA 798 (1976), P. 799 .

245. Par. 2 Verordnung iber die Herausgabe und Herstellung aller perlodisch erschelnenden Presseerzengnisse van 12-4-1962, GB1./ DDR $196211,239$.

246. Op twee ultzonderingen na, dle evenwel via hun uitgeverif door de SED worden gestuurd; zie Mampel (nt* 28), p. 512 .

247. E.M. Herrmann, Zur Theorie und Praxis der Presse in der Sow jetlschen Besatzungszone Deutschlands, 1963 Berlin (Wi), p. 62 .

248. Par. 4 11d 1 Verordaung biber die Unbildung des Allgeme1nen Deutschen Nachrichtendienstes van 1-5-1953, GBI./DDR (le halfjar), 521 .

249. Id., par. B sub a.

250. Par. 9 11d 2 Anordnung Uber das Statut des Allgemeinen Deutsche Nachrichtendienstes $\operatorname{van} 14-7-1966$, GB1./DDR 1966 II, 481 .

251. In de Erste Durchfuhrungsbestimung zur Verordnung iber die Entwicklung fortschrittilcher Literatur wan 13-121951, GBL./ DDR (2de half jaar), 1159.

252. Par. I lid 1. Sinds 1962 komt deze bewoegdheld op grond van par. 4 lid 1 Verordnung tiber dle Herauggabe und herstellung aller perlodisch erscheinenden Fresseerzeugnis- 
Be (nt. 245) toe an het Persbureau wan de voorzitter van de Ministerraad.

253. Id., par. 2 jo. par. 1 Beschluss tiber massnahmen zur Verbesserung der Leltung des Verlagswesens van 28-16$1956,6 B 1 . / D D R \quad 1956$ (2de halfjaar), 549.

254. Par. I Anordnung Hber das Genehmlgungsverfahren fur dle Heratellung von Druck- und Vervielfaltigungserzeugnissen wan $20-7-1959,6 B 1 . / D D R \quad 1959 \mathrm{I}, 640$.

255. Par. 2 11d 1 Anordnung tiber den Vertrieb von Presseerzengm1 sen van 20-11-1975, GB1./DDR 1975 I, 769.

256. Id. " par. 8 11d 1.

257. Id. par. 13 lid 3.

258. Beschluss iber die Blidung des Statichen Komltees fur Rundfunk belm Minlsterrat und des Staatlichen Komitees fitr Fernsehen beim Mintsterrat van $4-9-1968$, GB1./DDR $1968 \mathrm{II}, 837$.

259. Verordnung Hber die Blldung des Stat thchen Rundfunklkomitees vain 14-8-1952, GB1./DDR (2de hall jaar), 733; deze verordening geldt zolang geen mleuwe van kracht geworden $1 \mathrm{~s}$ (art. $\mathrm{g}$ ild $\mathrm{c}$ ).

260. Poppe, Grundrechte des Bügers (nt. 41), p. 143.

261. BG Leipzig 27-y-1962, DdU 6, 11 veroordeelde lemand, die de objectivitelt van de berichtgeving in het SED-partijorgaan Neueg Deutschland in twijfel trok, tat anderhalf jear gevangenti.i.

262. Geclteerd wat Herrmann (nt. 247), p. 37/38.

263. Par. 2 Anordnung viber den Antlquarlatsbuchthandel in der Deutschen Denokratischen Republik van 8-4-1970, GBI./DDR 1970 II, 277. Volgens par. 5 van de oude Anordnung van 20-7-1960 (GB1./ DDR $\$ 960 \mathrm{I}, 442$ ) was dat zelfs verboden voor 11teratuur die "burgerlich-reaktlonäre Ideologien verbreitet oder in anderer Welse den Prinziplen der sozlalistischen Entulcklung widerspricht". In de praktijk behoeft het resultaat nilet anders te $z i j n$.

264. Par. 2 lid 1 Anordnung wber die Arbelt der gewerbluchen Leithbichereien van $1-7-1957,6 B 1 . / D D R ~ 19571,621$.

265. Preambule vam de Verordnung aber die Aufgaben des B1bllotheksystems bel der Gestaltung des entwickelten: geselischaftichen Systems des Sozlalismus in der Deutschen Demokratischen Republik van 31-5-1968, GB1./DDR 1968 II, 565.

266. OG 9-6-1953, 7 NJ 411 (1953). Idem KG Oramienburg 23-21956, UaS III $118(165)$; LG Gör1itz 15-5-1951, UaS I 17 (12). 
267. LG Magdeburg 25-4-1952, UaS II 33 (34). Zle ook BG cottbus 28-2-1955, Jas III $116(162)$.

268. BG Dresden 13-1-1954, UaS II 137 (160).

269. oG 21-11-1958, Der Schoffe 1959 I, p. I/1.

270. OG 8-2-1960, OGSt 5, 339; OG 6-7-1961, OCSt 5, 175; BG Erfurt 19-5-1959, 13 NJ 534 (1959); BG Nagdeburg 4-61953, JaS IL $120(149)$.

271. BG Helle 25-9-1953, UaS II 118 (148); OG 11-2-1958, OGSt 4 , 232; OG 4-3-1958, 12 NJ 250 (1958); BG Hagdeburg 1-21961, UaS IV $120(183)$.

272. Vg1. E. Pleltgen, Die Slcherheit war mit Sicherheit dabe1, die Erfahrungen elnes Korrespondenten in der DDR Die Zeit $34,20-8-1982$, p. 48; E. Bobhme (red..), DeutschDeutsche Presisefrethelt, 1978 Hamburg, p. 30 .

273. Plejtgen (nt. 272).

274. "... eln Fremde Macht, deren Einrichtungen oder Vertreter oder ... elinen Gehelmdienst oder ... andere ausländische organisationen sowle deren Helfer ..."

275. Deze motivering van het oordeel had de verdachte uit het hoofd geleexd, Informationsdienst, uitgegeven door Konitee zur Verteidigung und Verwlrkllchung demokr tischer Rechte und Freitheiten $1 \mathrm{n}$ Ost und West - In garz Deutschland, nr. 26, Junt $1982, \mathrm{p} .13$.

276. 21e het in nt. 275 genoemde tifdschrift, p. 3 e.v.

277. Vg1. 2.5.1.3. Schroeder, Die neue strafrechtsreform der DDR (nt. 169), p. 1076 merke op dat de wetawljzlglng van 1979 zelf moet worden beschouwd als een overtreding wan par. 99 StGB. Erger dan door deze wet kan het anzien wan de DDR in het buitenland niet worden geschaad. Daarow zifn door de invoering van de bepaling de oostdultse autoriteiten zelf als eersten strafbar volgens het nilewre voorschrtft.

278. Vgl. de gevallen Witeland en Lorbeer in Annesty International Index: EUR 22/09/84, Distr : $\mathrm{sC} / \mathrm{CO}, \mathrm{p}, 1 / 2$.

279. J. Göhring/M. Posch (red.), Z1v1lrecht, Te11 1, 1981 Ber Itn (o), p. 34 e.v.

280. Vg1. 2.5.2.

281. Par. 137 t/m 140 StGB c.q. par. 327 ZGB van 19-6-1975, GBH./DDR $1975 \mathrm{I}, 465$.

282. Vg1. par. $111 d 2$ en par. 323 2GB; Grhrting/Posch (nt. $279)$, p. 21 en van dezelfde auteurs: Tell 2, 1981 Ber14n (0), p. $164 / 165$. 
283. Vg1. par. I en 2 StGB; strafrecht der DoR, Kommentar (nt. 121), p. 17 e.w.

284. Strafrecht der DDR, Kommentar (nt. 121), p. 360 .

285. Par. 352 ZGB. Zi.e M. Posch, Schutz des Lebens, der Gesundhelt und des Eigenturi vor Schadenszufugung, 2 . Auflage, 1979 Berlin (O), p. 23 e.v.

286. Zle de tnleiding van I. Fetcher in: K. Marx/F. Engela, Pressefrethelt and Zensur, 1969 Frankfurt $/ M$, p. 15.

287. Marx/Engels, Pressefreihelt und Zensur (nt. 286), p. 73.

288. Id., P. 234 .

289. R. Havemann, Ueber Zensur und Medien, 9 DA 798 (1976).

290. Id., p. 800 .

291. Par, 4 Ausländergesetz van 28-6-1979, GBI./DDR 1979 I, 149; v66r 1979 op grond van par. 3 van een verordenlag: van 14-12-1956, GB1./DDR $1957 \mathrm{I}, 1$.

292. Ibid.

293. Art. 19 Ild I ICCPR wordt van zelfstandlig belang geacht als Indoctrlnatleverbod door A.F.M. Brenninkmel jer, Van drukpersvrijheld tot informatievrijheld, A.R.Koekkoek/ W.Kondjnenbelt/F.C.L.M.Crijns, Grondrechten, commentaar op hoofdstuk I van de herzfiene grondwet, 1982 Ni jmegen, p. 167 e.v., ad p. 187. Het recht on een mening te koesteren 1 s niet onderhevig aan de beperkingen van art. 19 11d 3; vgl. GAOR 10th Session 1955, Annexes, Agenda Item 28 (Part II), P. $50 / 51 \mathrm{mr} .120$ (VN-Document A/2929).

$294 . \mathrm{Vg} 1 \cdot 1.4 \cdot 1 \cdot 2$.

295. Zie ook J. Hacker, Selbstbestimmung, Firelzüglgkeit und Melnungsifelhett nach den Imkraftrreten der UN-Menschenrechtspakte, $24 \mathrm{VN} 77(1976)$, p. 80 e.v.

296. Vg1. $1.4 \cdot 1 \cdot 3$.

297. Vg1. 2.6. en 2.6.1.

298. Idem .

299. Vgl. par. 3 1id 1 Verordnung uber dile herauggabe und Herstellung aller perladisch erschelnenden Presseerzeugnlsse van 12-4-1962, GB1.f DDR 1962 II, 239: "EIne Lizenz kann ertellt werden ..." (cursivering van mif).

300. Vg1. GAOR 10th Session 1955, Annexes, Agenda Iter 28 (Part II), P. $52 \mathrm{nr} \cdot 132$ (VN-Document A/2929).

301. Vg1. GAOR 16th Session 1961-62, Annexes Volume I, Agenda Item 35, p. $4 \mathrm{nr} .23$ (VN-Document A/5000); GAOR 16th 
Session 1961-62, 3rd Comittee, 1072nd Neeting, p. 61 nr. 7 .

302. Vgl. GAOR I6th Sessiton 1961-62, 3rd Committee, 1072nd Meting e.v., p. 61 e.v.

303. S. Mampe1, Die Verwfikllchung der politischen Mensehenrechte in der einfachen Gesetzgebung der DDR? in: $G$. Zieger/G. Brunner/S. Mampl/f. Erwacora, Die Ausubung statilcher Gewalt in 0 st und West nach Inkraftreten der wo-Konvention tiber zivile und politische Rechte, 1978 Heidelberg/Karlsruhe, p. 61 e.v., ad p. 83.

$304 . \lg 1.2 \cdot 5 \cdot 1 \cdot 4 \cdot$

305. Strafrecht der DDR, Kommentar (at. 121), p. 272, c.q. 277.

306. volkerrecht, udtgegeven door Arbeitsgemelnschaft fur Wolkerrecht belm Institut für internationale Bezlehumgen an der Akademie fur Staats- und Rechtswlssengchaft der DDR, Te:1 1, 2. Aurlage, 1981 Berlin (0), p. 58 t. v.

307. Id*, p. 59.

308 . Id., p. 60 .

309. Statsrecht der DDR (nt. 37), p. 227 .

310. Id., p. 228 .

311. Id., p. 227

312. Sorgentcht (nt. 41), p. 23.

313. De term mensenrechten duidt hier niet plotseling op universaliteit en onverwreemdbaarheld, mar betekent "dass der Mensch im Mittelpunkt aller gesellschaftichen Bemithungen steht" (staatsrecht der DDR (nt. 37), p. 184; art. 2 lid 1 Verf.). Alleen de soclalistlsche grondrechten $z$ il $\mathrm{j} n$ daarom mensenrechten in de ware zin des woords, want pas de soclalistische staatsorde makkt het voor de eerste mal In de geschledenls wan de mensheld het 1dea 1 van vrije, gelijke en broederlijk verbonden mensen, de hun persoonlijkhe1d ongehinderd en in harmonte met de matschappelijke belangen ontplooten, mogelijk.

314. Men schroomt er owerigens nlet voor deze conceptie ondanks haar compromiskarakter weer in markistisch-lentnistlsche zin te Interpreteren; vgl. Poppe, Grundrechte der Burger (nt. 41), p. 274 e.v. en H. Klenner, Menschenrechte und volkerrecht, 33 Elnheit 1105 (1978).

315. De zgn. objectieve en subjectleve voorwarden. A. Verdross/B. Slma, Universelles vikerrecht, 1976 Ber11n (*) p. 442. Zie ook A. Koller, Dile unmittelbare Aawendbarkelt volkerrecht1lche Vertrage und des BWG-Vertrages im innerstaatlichen Bere1ch, 1971 Bern, p. $97 / 98$, 
en A Bleckmann, Begriff und Krtcerien der Innerstat$11 \mathrm{chen}$ Hnwendbarkelt vilkerrechtlicher Vertrage, 1970 Berlin (w). D.P. O'Connell, International Law, Valume one, second edition, 1970 London, p. 54 noemt daareate gen maar een criterlum voor het self-executing karakter, nil. of de bepaling "Intended to bind states internally", hetgeen moet orden afgeleld ult de verdragstekst.

316. Koller (nt. 315), P. 98; Bleckmann (nt. 315), p. 306.

317. 0"Conne11 (nt. 315), p. 54 .

318. $\mathrm{Kg} 1.1 .4 .1$.

319. Bundestag-Drucksache $7 / 660$, p. 43 e.w., ad p. $48 / 49$.

320. Art. 32 heens Verdragenwerdrag van 23-5-1969, Trb. 1977, p. 169 .

321. Vg1. GAOR 18th Session 1963-64, Annexes Volume II, Agenda Item 48, p. $16 \mathrm{nr}, 21 \mathrm{t} / \mathrm{m} 23$ (WN-Document A/5655); GAOR 18th Session 1963-64, 3rd Comittee, 1257th Meet lng e.v., P. $237 \mathrm{nr} .4$ e.v. Vgl. verder R. Strelnz, Melnungs- und Informationsfrethelt zwischen $\mathrm{Ost}$ und West, 1981 Ebelsbach/M, p. 30 e.v.

322. Wg1. B. Graefrath, Zu Internationalen Aspekten der Menschenrechtsdiskussion, 32 NJ 329 (1978), p. 330 .

323. Id., P. 331 .

324 . volkerrecht (nt. 306), p. 233.

325. Reapectleveldjk Chr. Tomuschat en B. Graefrath.

326. W. Graf, Zur Arbeit des Menschenrechtskomitees, 23 DAP $4.122(1978), \mathrm{p} .123$.

327. WN-Document CCPR/C/1/Add, 13 van 7-7-1977.

328. Id., p. 8 .

329. Ibid.,; vgli. ook p. 2 .

330. VN-Document CCPR/C/SR.65, p. 10 e.v.

331. WM-Document CCPR/C/SR.67, p. 6.

332. Id., p. 12 .

333. WN-Document CCPR/C/SR.68, p. 1 .

334. Id., p. 9.

335. WN-Document CCPR/C/SR.303; whe voor die trekt wan het besluit (in de thans geldende versle) CCPR/C/19.Rev.1.

336. In VN-Document CCPR/C/28 wordt als datum 4-2-1983 ge- 
noverd.

337. Volgens de tewens in 1981 heralene richt11jnen, aangenomen op 27-7-198I (VN-Document CCPR/C/20, nt. 5 Part II (A) ) Vgl. Chr. Tomuschat, Der Ausschuss fur Menschenrechte - Recht und Praxis, 29 WN 141 (1981), p. 146.

338. WN-Document CCPR/C/28/Add.2 van 14-11-1983.

339. Id., p. 20/21, nr. 111-115.

340. Id., p. 21, ar. 114 *

341. In oktober 1984 had de mondelinge behandeling van het vervolgrapport in het Confte nog niet platsgevonden.

342. Graefrath (nt. 322), p. 331 *

34. 3. GBI./DDR 1973 II, 25.

34. Nr. I, 10, een uttwerking van art. 7 Grondslagenwerdrag.

345. Met de tekst van het Verdrag gepubliceerd, zie nt. 34.

346. Verordnung iber die Tätlgkeft von Publlkationsorganen anderer Staaten und deren Korrespondenten 1r der Deutschen Demokratischen Republik van 21-2-1973, GB1./DDR $19731,99$.

34. I. Id., par. 5 lid 1 .

34.8. Par * 2 Erste Durch fühungsbestumung zur Verordnung aber die Tatigkelt von Pablikationsorganen anderer staten und deren Korrespondenten in der Deutschen Demokrat1schen Republik vam $21-2-1973$, GBl./DDR 1973 I, 100.

349. Bobme ( $n t .272$ ), p. 25; 1d., p. 32: hetzelfde lot ondergIng een correspondent van de omroeporganlsatle ARD ondat hif de opmerking had gemakt dat de oostdultse grenstroepen het strikte bevel hadden op mensen als op hazen te schleten.

3.50. Td., p. $51 / 52$.

351. Vg1. Der splegel 3, 1.7-1-1983, p. 82 e.v.

35. V. 1.7.

353. Durchfithrung best mung zur Verordnung vom 21. Februar 1973 bber die Täligkelt von Publlkationsorganen anderer 5 ta aten und deren Korrespondenten in der Deutschen Demokrat 1 schen Repubilk van $11-4-1979$, GBL./DDR 1979 , 81.

354. Id., par. 311d4.

355. Id. par, 3 lld 1. 
356. U. Rasentath, Wolkerrecht1fchte Beurtellung der nedex DDR-Bestitringung fir Jonmalisten, 12 DA 1174 (1979), P. 1181 .

357. Waar M. Rexin, "Maulkor b fur Korrespondenten", 12 M 449 $(1979)$, p. 450 .

358. $\mathrm{Vg} 1 \cdot 2 \cdot 5 \cdot 1 \cdot 3$.

359. Voor het eret ter gelegentheld van de verklezing van Helmut Kohl tot nleuwe bondskanselier wan de Bondsrepubilek Dultsland. De reactie op deze gebeurtenis vanult de 0ostdutte bevolkfing werden op de Westdultse televtie ultgezonden. Wgl. Frankfurter Rundsichau 30-9-1982, p. 4 .

360. Z1e ook J. Doschner, Zehn Jahre bundesdeutsche Korrespondenten in der DDR, 17 DA 859 (1984). 


\section{Noten bij hoofdstuk 3}

1. Verwezen 21j naar P.J. Boukena, Enkele specten yan de vrl theld van menligsulting in de Duftse Bondsrepubliek en In Nederland, dissertatle V.U., 1966 Amsterdam. De door Boukera gekozen Invalshoek is zodanig, dat de beperklingen die voor de vrl fheid van menlngsulting voortvoelen uit het princlpe van de trifdbare democratie,

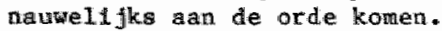

2. É. Bulla, Die Lehre won der streltbaren Demokrat1e, 98 AöR $340(1973)$, p. 342.

3. M. Kutscha, Verfassung und "streltbare Denokratle", $1979 \mathrm{k} / \mathrm{ln}, \mathrm{p} .42 \mathrm{e} \cdot \mathrm{v}$, , die tevens opnerkt (p. 45), dat van een legale machtsovername geen sprake 1 s geweest omdat op het moment van de aanneming wan de macht 1 gingswet de commintische part 1 J (KPD) reeds verboden was, har parlementariers de zetels reeds waren ontmomen en buj de overgeblevenen van een vrije oordeelsvorming nlet gesproken kon worden, aangezlen in de zal gewapende SA-ers a anwezlg waren. Vgl. ook H.A.F.J. Tllborghs, Vifftig faar geleden: de ondergang wan de Weimar-republiek, 58 NJB 415 (1983).

4. Bulla (nt. 2), p. $343 / 344$.

5. Ibld. Vgl, woor een kort overzlicht T. Schmidt, Die Freflett verfassungswidriger Parteien und Verelnigungen, 1983 Berlin (W), p. 36 e.v*

6. Voor het eerst gebruikt in BVerfGE 5, 85 (139).

7. BVerfGE 5, 85 (138); vgl. artikel 30 Unlversele Verklarling van de Rechten van de Mens en artikel 5 van de beide W-Verdragen van 1966, dat de grondrechten niet ter vernletlging van de grondrechten mogen worden gebrulkt. Zle verder $K$. Doehring, Staatsrecht der Bundesrepublik Deutschland, 2. Auflage 1980 Frankturt (M), p. 138 e.v.

8. Voor het vragstuk van de strijdbare deacratio en de fdGo zlj verwezen nar Bulle (nt. 2); C. Gugy, DLe "ineiheltilche demokratische Grundordnung" in der Rechtsprechung des BVerfG, 105 Aod $279(1980) ; \mathrm{J}$. Lameyer, Streltbare Dewokratie, 1978 Berlin (W); A. Sattler, Die rechtllche Bedeutung der Entscheldung fitr die otreltbare Demokratle, 1982 Baden-Baden.

9. BVerfGE $2,1(12)$.

10. BVerfGE 2, $1(12$ e.v.); $5,85(140)$. Zie voor wen be- 
gpreklag van de afzonder Ij jke elementen tevens G. Lastner, Die fretheltiche demokratische Grumordnung, 2. Auf lage $1982 \mathrm{Konigstein} \mathrm{(Ts).}$

11. Op zijn hoogst kunnen wolgens W. Schaltt-Glaeser, Missbrach und Verwikkng won Grundrechten im politiachen Melmungskanp 1968 Bad Homburg, pi. 46 e.v. tot de fdGo die begingelen behoren, die volgens artikel 79 lid 3 GC niet ter dispositle wan de grondwetgewer staan. Dat zou in het ulterste gewal betekenen dat de keuze voor de republikelnse en federale staatsvor evenuin aantastbatar 1s, evenals het zgn. Sozialstaatprinzip (p. 54 met een beroep op BVerfGE 5,85 (198)). Vgl. ook BVerfGe 39. $334 .(349)$.

12. G. Leibholz, Der Begrift der frelheltilchen denokratschen Grundordnung und das Bonner Grundgesetz, 66 DVBl. $554(1951)$.

13. Th. Maunz/G. Dür 1 /R. Herzog, Kommentar zum Grundgeserz (10sblad1g), 1968 München (hierna M/D/H), Axt1kel 18, Rndnr* 48 .

14. Ibid.

15. Zo met name Bulla (nt. 2), p. 350 e.v.

16. Daarentegen wel in een eerder ontwerp, dat $c$ jidens de beraadslaglngen vam de grondwetgevende vergadering als uitgangspunt diende. Zle K. B* von Doeming/R. H. Fussleln/W.Matz, Entstehungsgeschlchte der Artikel de:s Grunfgesetzes, NF 1 JöR $1(1951)$, p. 585 .

17. Schmitt-Glaeser, Missbrach und Verwirkung von Grundrechten Im politischem Meinungskampf (nt. 11), p* 46 e.v.; Bulla (nt. 2), p. 350. Vgl. Dok W.0. Schmitt, Der Begriff der fretheltifichen demokratischen Grundordnung und Artikel 79 Abs. 3 des Grundgesetzes, 18 Dav 433 $(1965)$, p. 438 e.w.

18. Wet van $24-6-1968$, BGB1. $1968 \mathrm{I}, 709 ; \mathrm{gg1}$. Kutscha (nt. 3), P. 108 e.v.

19. Kritisch Bulla (nt, 2), p. 351; hij benadrukt de betekenls van artikel 79 lid. 3 GG als tegen de overheid gertlchte bepaling.

20. Deze tern wordt al 1dentiek met de fdGo beschouw : Schiltt/Glaeser, Missbrawch und Verwlrkung von Grundrechten $1 \mathrm{~m}$ polit dochen Meinungskamp (nt. 11), p. 32; Buil1a (nt. 2), p. 350; M/D/H (nt. 13) Artikel 18, Rndnr. 47. Dok part1jen dle opponeren tegen de gedachte der toenadering tussen de volkeren $z 1 \mathrm{jm}$ volgens artikel 21. Id 2 GG in strijd ret de grondwet.

21. Bulla (nt. 2), p. 354 .

282 22. Voor een overzlcht Sattler (nt. B), p. 17/18. Vgl. ook 
Rutscha (nt. 3), p. $110 / 1 \mathbb{1}$.

23. Zo ook . Stollberg, Die vertassungsrechtilichen Grundlagen des Partelverbots, 1976 Berlin (w), p. 39.

24. BVerfGE 2, 1.

25. BVerfGE 5, 85 .

26. Zie H.A. Lennartz, Zur Rechtsprechung de: Bundesverfassungsgertchts zu den politischen Parcelen, 1982 Munchich, p. 27: drie rechters die an de veroordeling hadden meegewerkt gaven later toe dat het verbod verkeerd was geweest, onder wie Martin Dratin, die naderhand cen voorstander van de opheffing van het verbod. was; vg. M. Drath, Stellungnahme zu Problemen der Fortaver des RPD-Verbots, in: Urted1: KPD-Verbot aufhaben, $1971 \mathrm{köln}$, p. 48 e.v.

$2 \pi$ BVerfGE $2,1(72) ; 5,85(133) ; 20,56(100,108) ; 24$, $260(264) ; 40,287(292) ; 52,63(82)$.

28. BVerfGE $20,56(101)$; vgl. tevens BVerfGE 8,51 (63).

29. BVerfGE $20,56(101)$; zle ook BVerfGE $8,104(113) ; 47$, $130(140)$.

30. BVerfGE 20,56 (101). Daarom is de staat ook nlet cot volledige flnanclering van de partifen verplicht, hoewel het vanwege de openbare taak die de partijen vervullen door hun rol bif de verklezingen wel geoorloofd moet zijn niet alleen voor de verkiezingen zelf, maar ook voor de an de verklezingen deelnemende partijen Van statiwege middelen ter beschikking te stelien (BVerfGE $8,51(63) ; 12,276(280) ; 20,56$ (96 e.v.)) 1 in de vorm van het fiscaal aftrekbaar maken van glften $t$.b.v. partijen (BVerfGE 8,51 (63)) en het vergoeden van de noodzakelljke kosten van een gepaste verklezingsstrifd uit de begroting (BVerfGe 20,56 (97)). Het 1 echter niet geoorloofd substales te verlenen $t . b_{*}$. . het gehelle scala van politiake activitelten: BVerfGe $20,56(97)$.

31. Gesetz uber die politischen Partelen van 24-7-1967, BVBI. 1967 I, 773. Vg1. Par. 2 11d 1. Woor een ultvoerige bespreking: D.J. Elzlnga, De polltteke partif em het constitut lonele recht, 1982 N1 Jmegen, p. 58 e.r.

32. BurerfeE 2,1 (II).

33. BuerfGE 5, $85(134)$.

34. BverfGE 5, 85 (134); wg1. BverfGE 2, 1 (73).

35. BverfG $5,85(134)$.

36. BverfGe $5,85(135)$. 
38. BverfGE 5, 85 (139). Het Bverfo acht het julst dat die burger tegen zlchzelf in bescherming wordt genowem; die opvatting dat de beste garantie noor de democitie tir de gezindheld van de burger ligt in plats van ln de constitutie noent het BverfG "optimlstisch" (p. 136). Whet bepald een blijk van vertrowaen in de elgen bevolkIng.

39. Wameyer (nt. B), p. 41.

40. BverfeE $5,85(141)$ *

41. BwerfGe 5, $85(142)$.

42. BverfGe $5,85(195$ e.v.).

43. BverfGE 5, $85(203$ jo. 199).

44. BverfGE 2, 1 (13); zie H.U. Gallwas, Der Mssbrauch won Grundrechten, 1967 Berlin (W), p. 167.

45. Vgl. BVerwG 34 NJW $1796(1981)$, dat het vexbod van de rechtsextremlatische Wehrsportgruppe Hof fmann bevestelgt; DoehrIng (nt.7), p. 327; Kutscha (nt. 3), p. 118 e. v.

46. Art. 21 11d 2 GG 1s ook t.o.v. art. 18 GG lex specta11s. Voorzover partijen van de th art. $18 \mathrm{GG}$ genoemde grondrechten gebrulk maken, Is art. 21 lid 2 GG wan. toepassing (vgl. Schaltt-Glaeser, Misbrauch und Verwikung won Grundrechten, im polltischen Melnungskampf (nt. 11), p. 234 en M/D/h (nt. 13), Art. 18 Rndnr. 87). De bescherming die een partij $0 . g_{*} \mathrm{~V}_{\mathrm{w}}$ art. 2.1 GG genlet, Btrekt zlch pok ult tot de offlcielle activitelten wau hat functionar1ssen en aanhangers (BverfGE 47, 130 $(139))$. Pas na een partijwerbod kunnen procedures ex art. 18 GG tegen voormalige leden en aanhangers worden aungespannen. Tegen leden en anhangers die onafhanke11 jk van de partif de fidGo bestrijden kan art. 18 GG altifd worden 1ngezet. Het lidmaatschap van een partil beschermt op zichzelf niet tegen een verwerkingsprocedure (BverfGE 11, 282; SchmittGlaeser (nt. I1), p. 242). Voor de onderlinge verhouding tusen de axt. 9. 18 en 21 GG: Gal1was (nt. 44), p. 167 e.v.

47. Wgl. Schmitt-Gideser, Missbrauch und Verwikung won Grundrechten 1m politischen Melnungskarof (nt, 11), P. 123.

4. Id., p. 118/119.

49. Id., p. 119-122.

50. Id., P. 123 .

51. Id., p. 137. 
52. Id., D.. 135/136.

53. Id., P. 128 .

54. Tot twee mal toe is een reeds gelnitleerde procedure die tot een yerwerking moest leiden gestrand wie Bwer fGR 11, 282 en $38,23$.

55. Vgl. Lameger (nt. 8), p. 33 .

56. BverfGE $13,46$.

57. Za Lameyer (nt. 8), p. 44 .

58. BverfGE 13, $46(50)$.

59. BverfGE 25, 44.

60. BverfGE 25, 44 (58).

61. Par. 42 sub I StGB, ondertussen afgeschaft.

62. BverfGE 25, $88(95)$.

63. BverfGE 25,88(100).

64. Reeds H. Coplc, Berufsuerbot und Fressefrethet, $18 \mathrm{JZ}$ 494 (1963), oefende kritlek utt op de ultholling van art. 18 GG door mIdel van het Berufsverbot en art. 21 $11 d 2$ GG.

65. Bver fGE $28,36,(37 / 38)$.

66. BverfGE $28,36(48 / 49)$.

67. BverfGE $28,36(50)$.

68. Bulla (nt. 2), p. 357; Lameyer (nt. 8), p. 52 e.v.

69. Idem BwerfGE 28, 51. Ook hier werd een mi11ta1r er met een verwifaing nar het princlpe van de strijdbare dewocratie van beschuldlgd, kameraden tegen de fidgo op te hitsem, hoerel hij slechts vanwege een bepalde averheldsmatregel tot het niet opvolgen van bevelen had opgeropen.

70. BuerfGE 30 , 1 .

71. Wet $\operatorname{van} 24-6-1968$, BGB1. 1968 I, 709 .

72. BwerfGe 30, 1 (19).

73. BVerforis 39,334 .

74. Op de woorgeschleden1s kan hier ndet ingegaan worden. 2le voor een documentatle $\mathbb{E}$. Denninger (red.), Frelheltliche dewokratioche Grundordnung, Zwelter Te11, 1977. Frankfurt( ()$_{)}$, p. 489 e.v. 
75. Par. 1 Id 1 gub 2 Landesbeamtengesetz in de wer 1 le wam $10-5-1971$, GVBL. 1971, 253.

76. BVerfGE 39,334 (349).

77. BVerfGE $39,334(348)$.

78. BVerfGE $39,334(349$ e.v.).

79. BVerfGE $39,334(353)$.

g0. BVerfole $39,334(359)$.

81. BVerfGR $39,334(368 / 369)$.

82. Afwijzend daarom Lameyer (nt. 8), p. 63.

83. BVerfGE $39,334(367)$. Zie ook 3.6 .6$.

84. Vg1. A. Steimkamm, Nehtübernahme von Verfassungsgegnern in den offentichen Dlenst, Der frelheltiche Rechtsitaat und seine Gegner - Mitel und Grenzen der Abwehr, ultgegeven door Deutache Selktion der Internationalen Juristen-Komission, 1979 Karlsruhe, p. 77 e.v., ad p.96 e.v. De ene rechterlfjke instantie (het BAG) lijkt in de ultleg een tikfe liberaler te $z 1 \mathrm{fn}$ dan de andere (BVerwG). Vgl. enerzijds BAG $29 \mathrm{NJW} 1708$ $(1976) ; 36$ NJW $779(1983) ; 36$ NJW $1812(1983) ; 36$ NJW 1814 (1983) (zie ook LAG Bremen $36 \mathrm{NJW} 1814$ (1983)). Vg1. anderzljds BVerwGE 47,330; 47,$365 ; 52,313 ; 61$, 176 en BVerwG 35 NJW 779 (1982). Een bespreking van de jurisprudentie van het BVerw windt men bij W. Schlck, Zwlschenbalanz in Sachen "Verfassungstreue" der Beamten, 1 WVwZ 161 (1982). Voor de pllicht van trouw van een milita1r, die lid was van de NPD: BVerwG 37 NJW BL3 (1984). Vgl. verder BGH 36 NJW 756 (1983) 757, ultspraak daende in een beroep van eer persoon, dile men had gewelgerd a1s notarls aan te gellen: "Auf elne slch aus der Veroffentlichung des Bewerbers ergebende bloss theoretische Mögl1chke1t, er könne in Verfolgung elnes in unabsehbarer Zeit nicht errelchbaren ziels zu Irgendelnem Zeltpunkt unter 1 rgendwelchen, ntcht näher bestlmbaren Voraussetzungen die verfasisungsmä̀s 1 ge Ordnung der Bundesrepublik Deutschland missachtien, darf die Versagung der Bestellung zum Notar nicht gestitzt werden." Evenuin mag het 1Idmaatschap van een als antIconstitutioneel beschouwde partij een rol apelen th verband met de toelating tot de advocatuur (tenglotte een vrly beroep), zo BWerfG 36 NJW 1535 (1983). In aaslulting op deze ultspraak merkt rechter slmon op, dat van een advocalt niet meer politleke loyaliteit tegenover de fdGo verwacht wag worden dan van ledere andere burger ( $\mathrm{p} .1539$ ). BVerfGE 39, 334 tenslotte 1s bevestigd door BVerfG $34 \mathrm{NJW} 2683$ (1981). Hangezlen een bespreking van de prakt Ijk van de Radikalenerlass buiten het bestek van het onderzoek vall, moet met deze korte orlëtatile worden wolstaan. Voor een wan Nederlandse hand afkomstlge actuele inventarisatie naar 
aanletulng wan enkele cecute utspraken van de Europese Comissie van de rechten van de mens $(9228 / 80$ en 9704/82. van 11-5-1984): Th. L. Bellekom, Berafswerbote en het Europese recht, 9 NJCM-Bullerin $476(1984)$. Wgl. meer spectflek woor de pllcht van trow van ambenaren als beperking van de vid theid wan meningsulting 3.6 .6 .

85. BVerfGE $5,85(139)$.

8.6. $\operatorname{In} 3.6 .6$.

87. Mrletscti: Bulla (nt. 2), p. 355 e.v.: E. Denuinger, Verfassungstreve und Schutz der Verfasing, 37 VWostRL T (1979), p. 17; K. Hesse. Grundzüge des Verfassungsrechts der Bundesrepublik Deutschland, 14 a Auflage 1984 , p. 258 nt. 4; Landeyer (nt. 8), p. 183 e.v., th.n. p. 205. Met de techtspraak van het BVerf $z 1 \mathrm{Jn}$ het onder meer ens: H.H. Klein, Verfassungstreue und Schutz der Verfassung, 37 VWDStRL $53(1979)$, p. 63 e.v.; Sattler (nt. 8), p. 80; R. Stern, Das Staatsrecht der Bundesrepublik Deutschland, Band 1, 1977 Mïnchen, p. 175 (Fg1. In de treede druk (1984) minder explictet p. 196 e.v.). Een tussenstandpunt neent in: T. Schnidt (nt. 5), p. 219 e.v., m.n. p. 226 .

88. Tle Lameyer (nt. 8), P. 86 .

89. BWerfGE $30,33(45)$.

90. BVerfGe 30, $33(46)$. Wgl. ook P. Mäberle, Das Abhörurtel1 des Bundesver fassungsger 1chts, $26 \mathrm{JZ} 145$ (1971), p. 147 .

91. BVerfGE $40,287$.

92. BVerfGE 40, 287 (289).

93. BVerfGE $40,287(293)$.

94. BVerfGE 40, $287(291 / 292)$.

95. 21e ook 3.6.2.

96. Zie verder 3.6 .6 .

97. M. Krtele, Einführung In die Stats lehre, 2. Auflage 1981 , Opladen, p. 335 .

98. BVerfGE 5, 85, (204).

99. Aangenomen wordt dat zij een naturrechtelljke oorsprong hebben, uberpositiv zly, mar hun gelding a an de in de grondwet platisgevonden post tuerlug ontlenen; wgl. Doehriag (nt. 7), P. 129; R* Zlppellus, Allgemelne Staatslehre, 8. Auflage, 1982 Mitichen, p. 314. In de verhoudting tussen art. 2 11d 1 GG en de overige grondrechten wordt art. 2 11d 1 als het subsidielre grondcecht beschouwd: BVerfGE 30, 173, (192), Doehring (nt. 
7), p. $284 / 285$. Vgl, tewens BVer fGE 11,234 (238).

100. De In art. I GG opgenomen beginselen maken deel ult wam de fdGo, die door art. 79 lid 3 GG beschermd wordt.

101. Tot 1976 is 33.707 mal een Verfassungsbeschwerde ingediend, mar een relatiwerling is wel op zijn plazts, gezlen het felt dat $97 \%$ wan de klachten niet tot een van de senaten van het BVerfG doordringt. Zie Chr. Saller, Verfassungseschwerde im Zwilicht, 10 ZRP 303 $(1977)$.

102. BVerfGE $5,85(205)$.

103. BVerfGE 5, $85(205)$.

104. BVerfGE 7,198 (205).

105. Vgl. BVerfGE 7, $198(207)$.

106. Vg1. de bespreking van de Wert theorle in 1.4 .1 .

107. Zle echter 3.8.1.1.

ل08. $M / D / H$ (nt. 13), Art. 5 (Lleferung 20 1982), Rndnr. 40*

109. BVerfGE 7, 198.

110. BVerfGE $7,198(230)$.

111. BVerfge $7,198(205)$.

112. BVerfGE 7, $198(208)$.

113. BVerfGE 7, $198(209 / 210)$.

114. BVerfGE $7,198(208 / 209)$.

115. BVerfGE 7, $198(210)$.

116. BVerfGE $12,113(124 / 125) ; 20,162(176 / 177) ; 21,271$ $(281) ; 25,44(55) ; 27,71(80) ; 27,104(109) ; 28,36$ $(47) ; 28,51(54) ; 28,191(202) ; 35,307(309) ; 42$, $143(150) ; 42,163(169) ; 47,198(232) ; 54,129(136)$; $60,234(240) ; 61,1(10 / 11) ; 62,230(243 / 244) ; 64$ $(108 / 115)$; BVerfG $37 \mathrm{NJW} 1741(1984) 1746$.

117. BVerfGE $7,198(212)$.

118. BVerfG 7, $198(219)$.

119. BVerfGE 7, $198(204)$.

120. BVerfGE 7, 198 (205).

121. BVerfGE 7, 198 (206) met een beroep op G. Dirlg, Fre1zligigkelt, F.L.Neuwann/H.C.N1pperdey/U.Scheuner (red.), D1e Grundrechte, Band II, 2. Auflage, 1968 Berlin (W), 
p. 507 . . ., ad p. 525. Vgl. dau ook toestemend G. Dit $1 \mathrm{~g}$. Zum Luth-Hrtell des Bundesverfassungsgertchts vom 15.1.1958, 11 DöV 194 (1958), p. 196, die in de vermelding van de algemene rechtsbeginselien al invalshoek het bewijs zlet dat het BVerfG rechtstreekse derdenwerking afwijst. Daarentegen zlet H.C. NIpperdey, Soykott und frele Meinungsäusserung, 73 DVBI 445.(1958), p. 4.7 het teruggr 1 jpen op de objekt1ve Wertordnung juist als bewljs voor de erkenning van de rechtstreekse werklng. Vg1. ook H.H. Kleln, Deffentliche und PrIvate Freihe1t, 10 Der Staat 145 (1971), p. $148 / 149$.

122. BVerfGE 7, 198 (207).

123. $M / D / E /(n t .108)$, Art. 5 Rndinr. 29 .

124. BVertEE 25, 256.

125. BVerfGE 25, $256(265)$.

126. BVerfGE 25, 256 (268), Over het vraggstuk betreffende de boycotoproep als meningsulting principleel: P. Lerche, Zur verfassungsgericht11chen Deutung der Melnungsfrelheit, la: Festschrift fir Gebhard Maller, 1970 Tubingen, p. 197 e. W. Het BVerfG heeft onlangs de $11 \mathrm{jm}$ van hel Lith-arrest en het Bunkfuer-arrest bevestlgd Iin BVerfGE 62,230 .

127. Laatstelijk in BWerfGE, 60,234 (239) en 62,230 (242/ 243).

128. 2o de algemene menling; zLe $M / D / H$ (nt. 108), Art. 5, Rndnr. 244 en W. Schmit-Glaeser, DLe Meinungisfetheit in der Rechtsprechung des Bundesverfassungsgertchts, 97 AöR 60 en $276(1972)$, p. 290.

129. Vg1. M/D/H (nt. 108), Art. 5, Rndnr. 244.

130. Par. 823, 826 en 1004 BGB (vgl. BVerfGE 7,198 (211)) en par. 185 e.v. StgB (vg1. BVerfGE 47, 130 (143)). over de civlelrechtelijke bescherming van de persoon1.llke eer: H. Scholler, Presse und Deffentllchkelt, 1967 München, p. 355 e.v*; Over de strafrechtelijke bescherming van de persoonlifke eer: K. Schind, Freihelt der Mefinungsäusserung und strafrechtlicher Ehrenschutz, 1972 tubingen, p. 20 e.v. Zie tevens G. von der Decken, Melnungsausserungs frethelt und Recht der personlichen Ehre, 36 WJW 1400 (1983).

131. Z1e hlervoor $M / D / H$ (nt. 108), Art. 5, Rndnr. 280 e.v. Vg1. het Gesetz uber die Verbreltung fugendgefiahrdender Schriften $\operatorname{van} 29-4-1961$, BGB1, $1961 \mathrm{I}, 497$.

132. RGB1. 1919, 1383.

133. Zo $M / D / H($ nt. 108), Art, 5, Rndnr. 250 .

134. K. Rothenbücher, Das Recht der frelen Melnungsäusse- 
rung, 4 VWDStRL $6(1928)$, p. 20.

135. IbId. Vgl, ook $\mathrm{K}$. Hänzschel, Das Recht der frelen Hesnungsalusserung, in: $G$. Ansehtit $z / R$. Thowa (red.), Handbuch des Deutshen Staatsrechts, Band II, 1932 Tubingen, p: 651 e.v. Voor een ultgebrelde bespreking van de tijdens de Helmar-republlek bestamde opwattingen over het begrip algemene wetten zil verwezen mar $\mathrm{E}$. Schurk, Dex Begriff der "Allgemelnea Gebetze" in Artikel 5 Abchntet 2 des Grundgesetzes, 1970 Berlin $(W)$, p. 43 e.v.

136. Schwark (nt. 135), P. 48 .

137. M/D/A (nt. 108), Art. 5, Rndur. 251 .

138. BVerfGE 7, 19.8 (208).

139. Zaals Kletn, Deffentliche und Private preihelt (nt. $121)$, p. $156 \mathrm{e} . \mathrm{v}$. met en analyse van de travaux priaparatolres aantoont. $M / D / H$ (nt. 108), Art. 5, Rndnr. 252 Q. $v$. daarentegen probeert door middel van de siystematische interpretatiemethode te bewijzen, dat het begrip algemene wetten in de grondwet van 1949 niet hetzelfde kan betekenen als in de grondwet van Welmar, omdat het dan slechts een overbodige herhaling zou zijn van art 19 lid 1 zin $1 \mathrm{GG}$ : "Soweft mach diesem Grundgesetz eln Grundrecht durch Gesetz oder auf Grund elnes Gesetzes elngeschränt werden kann, muss das Gesetz allgemeln und nicht für den Elinzelfall gelten".

140. R. Smend, Das Recht der frellen Melnungsitusiserung, 4 VVDSERL $44(1928)$, p. 52 .

141. Schnitt-Glaeser, Die Mednungsfrethelt in der Rechtsprechung des Bundegverfassungsgerichts (nt. 128), p. 279 noent deze synthese misilukt ondat de belde verwerkte opvattingen niet in elkaars verlengde 11ggen, maar eerder elkar tegengestelde 11 jken te $\mathbf{1}$ jin, angezien de eerste een automatisme invoert, dat smend fuist weer wenst te verhlinderen, met het gevolg dat deze weer geen andacht an de formele criteria schenkt. De prakt 1 jk van het BVerfG 11 jkt Schmitt-Giaeser gelijk te geven: de formele verelsten worden volledig uitgehold, om vervolgens Smends afweging te kunnen vertichten. Zle ook klein, Oeffentliche und Private Fretheit (nt. 121), p. 151 .

142. BVerfGE 7, $198(209)$.

143. Zo La BverfGe 47, 130 (143).

144. BWerfGE 28,36 (47): het le niet de zln van het voorschrift een bepalde mening te verbleden; BVerfGi 28 , 51 (54): de voorschriften grijpen nilet door het verbod van cen bepalde menlng in de vrltheld van mentugsulting in, waar dienen de bescherming van de fdGo en de handheving wan de noodzakelfjke discipline binnen de 
strifdkrachten; 1dem BVerfGE 28,282 (292). De vraag wordt noolt rechtstreeks beantwoord.

145. BWerfog 27, 104 (110), cursivering van m1j; 1 dem BVerfGE 33, $52(66)$ en $47,198(232)$.

146. BVerfGE $21,271(280)$.

147. BVerfGE $7,198(210 / 211)$.

148. BWerfGE $7,198(208 / 209)$.

149. Vg1. K1e1n, Deffentliche und Private Fretheft nt. 121), p. 157 e.v.; $M / D / H$ (nt. 108), Art. 5, Rndnr. 259 e.v.; F. Ossembith1, Versamingsfrethelt und Spontandewonstation, 10 Der Stat $53(1971)$, p. 71 e.v.; Schmitt-Glaeser, Die Metnungsfrethelt in der Rechtsprechung des Bundesverfassungsgeriches (nt. 128), p. 290 e.v.; R. Schnur, Pressefrethelt, 22 VDDStRL 101 (1965), p. 127 .

150. Vg1. Ossenbih1 (nt. 149), p. 73.

151. $M / D / H(n t .108)$, Art. 5, Rndmr. 262 .

152. BVerfGE $7,198(208)$.

153. Ossenbihl (at. 149), p. 79.

154. En daardoor het constitutionele gehalte van de vrifheld van mentngsulting tegenover andere rechtsnormen op de wichtergrond kan treden, wat leldt tot een verzwakklng van het grondrecht, aldus Ossenbihl (nt. 149), p. 74 . H1 1 verliest dan echter ult het oog dat die verzwakking aan art. 5 lid 2 GG inherent $L_{\text {s }}$ en dat het BVerfG juist wil voorkomen dat die verwakking wordt geautomatiseerd.

155. BVerfGE 7, $198(208)$.

156. Vg1. Klein, Oeffent1iche und Private Freihelt (nt. 121), p. 154; M/D/H (nt. 108), Art. 5, Rndar. 267; Schmitt-Glaeser, Die Melnungstreihelt in der Rechtsprechung des Bundesverfassungsger1chts (nt. 128), p. 281 e.v.; Schnur (nt. 149), p. 127 e.v.

157. BVerfGE 7, 198 (208). Vg1. M/D/H (nt. 108), Art. 5, Rndnr. 260 .

158. BVerfGE 7, $198(212)$.

159. K1eln, Deffent1lche und Private Frethelt (nt. 121), p. $\mathbb{1 5 4}$.

160. Zle BVerfGE 9, 162 (164): "offensteht11ch"; BVerfGE 47 , 130 (143). In BVerfGE $42,143(148 / 149)$ heeft het BWerfG zich echter ultdrukkelijk bevoegd verklaard, "dite von den zivilgerlchten vorgenomene Wertung durch 
gelne elgene zu ersetzen", alo de intensitelt wat de achending van de grondrechten bifionder groot 1 s. Deze neeme toe, narmate de ulting meer bljuraagt aan de vorming van de publieke oplale. Het BWerfG kan dus de bevoegdheden van de felteltjke instante an zlchzelf trekken. Vgl. H.J. Paller, Zu den Elngrtffamgllchkelten des Bundegverfassungsgerfethts bei Rügen der Verletzung von Melnungs- und Pressefrethelt, In: Fegschrift fur Martin Löfler, 1980 Kinchem, p. 43 e.** ad p. 46 e. v.

161. K1eln, Oeffentliche und Private Fretheit (nt. 121), p. 155 pleit voor een terugkeer naar de ultieg van de algemene wetten wolgens de tijdens Welmar heersendie opvatting, om daardoor de (abstracte) besilfsingshevoegdheld over het al dan niet geoorloofd achten wain beperkingen van de vritheid wan mentngsulting weer geheel in handen wan de wetgever te lleggen. Hil ziet het verlies van de worspelbaarheld als een te groot bezwaar van de huidige praktijk.

162. Door het apart vermelden wordt de bijzondere waarde wan het recht Inzake de persoonlijke eer beklemtoond, aldus Schmitt-Glaeser, Die Melnungsfrethelt in der Rechtsprechung des Bundesverfassungsgerichts (nt. 128), p. 290.

163. BVerfGR $30,336(348) ; 42,143(150) ; 54,129(136)$.

164. Dat houdt ook het recht in zijn menting nitet te uiten (M/D/H, nt. 108), Art. 5, Rndinr. 40. U1t deze vastitel1 ing kan over 1 gens geen bescherming tegenover de verzameling, opslag en doorgave van persoonsgegevens worden afgeleld: BVerfGE $65,1(40)$.

165. Woorop H.K.J. Ridier, Melnungsfrethelt, L.F. Neumann/ H.C.N1pperdey/U.Scheuner (red.), Die Grundrechte, Band II, 2. Auflage, 1968 Berin (W), p. $243 \mathrm{e.v.,}$, ad p." 264; verder Th.Maunz/R.ZLppelius, Deutsches Staatsrecht, 25. Auflage, 1983 München, p. 170; H. von Mamgoldt/F.Kleln, Das Bonner Grundgesetz, Band I, 2. Auflage, 1966 Berlin (W)/Erankfurt (M), P. 239; U. Scheuner, Presisefrethe1t, 22 VVDStRL 1(1965), P. 64; F. Schneider, Presse- und Metnungsfrethett nach dera Grundgeset $z, 1962$ Minchen, $p .26$ en 30.

166. R1dder (nt. 165), p. 264.

167. B. Ruthers, Persönlitchkelterecht und Melnungskampf, $1 \mathrm{n}:$ Festschrlft fur Martin Loffler, 1980 München, p. 303 e.v., ad p. 307. Wellswar wordt beseft dat ondanks dit criterlum een scherpe afbakening vrljwel niet mogelly 1 s vanwege het gemengde karaikter van vele uitingen. (Rithers, 1 bid.). Het BGH heeft uitgesproken dat genengde wtingen in geval wan toiffel als wardeoordelen kunnen worden besichouwd (GRUR 368 (1969) 370; 555 (1969) 557; 624 (1969) 627), terwlj1 ook van bellang is hoe de geadresseerden de uiting ervaren (GRUR 254 (1970) 255). 
Zile hleronder BVerfGE 61 , 1 .

168. M/D/H (nt. 108), Art. 5, Rndar, 51; E. Friesenhahn, Die Pressefreihelt 1 m Gundrechtssystem des Grundgesetzes, In: Festgabe fiir otto Runze, 1969 Berin (W), P. 21 e.v., ad p. 22; Schaltt-Giaeser, Dile Helnungstelheit In der Rechtsprechung des Bundesverfassungsgerlchts (at. 128), p. 68 e.v.

169. M/D/A (nt. 108), Art* 5, Rndar. 51.

170. Id., Rndur. 54 .

171. II *, Rndnr. 55 .

172. BVerfGE 7, $198(210)$.

173. BVerfGE 61,1 .

174. BVerfGE $61,1(7$ e.v.).

175. BVerfGE 33, 1. (14). Idem BVerfGE 65, 1 (41) en BVerfo $37 \mathrm{NJW} 1741$ (1984) 1746. Vgl. ook BVerfQE 42, 163 (170): wardeoordelen behoeven nlet door feltenmaterlat 1 gestaafd te worden.

176. BVerfít 33, 1 (15).

177. BVerfGE 54,208 (219); curstvering van mij.

178. BVerfGE $61,1(8 / 9)$. Vg1. ook BVerfGE 54, 2018 (219).

179. BVerfGE 60,1 (9); BVerfG 37 NJW $174 \mathbb{1}$ (1984) 1745 . Vg1. ook nt. 167 .

180. Par 186 (Uebele Nachrede, hier noet degene die bepalde felten beweert of verbreldt, die geschlkt zilfn om ilemand verachtelifk te maken of in publieke optnie te vernederen, de wartheid van zijn bewerlng bewljzen), par. 187 (Verleumdung, het tegen beter weten in beweren of verbxelden van een onjulist felt) en par. 187a StGB (Uebele nachrede und Verleumdung gegen Personen des palitischen Lebens).

181. Par. $823,824,826$ (voor wat betreft boycotoproepen) en 1004 BGB.

182. Par. 185 StGB (Belefdigung). Vg1. ook par. 189 StGB (Verungliapfung des Andenkens Verstorbener) en par. 90, $90 a$ en $90 \mathrm{~b}$ StGB; deze laatste bepalingen beschermen het anzien van de atat (z1e 3.6.5.).

183. Par. 823,826 en 1004 BGB.

184. Z1e 3.4.5. en 3.6.1.

185. M/D/A (nt, 108), Art. 5, Rndnr. 55a. 
186. Bverfog 7, $230(234)$

187. BerfGE 47, 198, (233)*

188. BWerfGe 42, $143(151)$. In een op dlezelfde dag gewezen arregt werd wel een rechterlijk yerbod opgehevien, diat allet alleen de letterl1jke herhaling van een wentingsuting verbood, naar ook de herhaling van has substantien BVerfGE 42,163 (168 e.v.).

189. BVerfGe 42, 154 ; af ykende mening bij BVerfGE 42, 143 .

190. Wg1. ook BVerfGE 12, 113 (124 e.W.).

191. BerfoE 42, 154 (161/162).

192. HetfGE 42, $154(161 / 162)$. Vg1, ook BVerfGE 12, 113 $(124$ e.v.).

193. BVerfGE 60, $234(240) ;$ 1den BVerfGE 54,129 (137) en BVerfG 37 NJW $1741(1984) 1746$.

194. BVerfGE 60, $234(241)$. Vg1. BVerfGE $54,129(138 / 139)$ en $61,1(7)$.

195. BVerfGE 7, 198 (212).

196. BVerfGE 7, 198 (219).

197. M.n. BVerfGE 7, 198 (222 e.v.). Vg1. G. Roelecke, Hahrhe1t, Gemelnwohl and Melnungefreitheit, $36 \mathrm{JZ} 688$ $(1981)$. p. 693.

198. BVerfGE 7, $198(230)$.

199. BVerfGE 28,282 .

200. BVerfGE 28, 282 (295).

201. Ridder (nt. 165), p. 263.

202. Ridder (at. 165), p. 265 gat verder; hif stelt als additionele voorwarde dat mentingsultingen warachtig gemeend moeten $z i j n$. Eel onwarachtige meningsulting is geen eningiting ondat nlet het gezegde, mar lets. anders gemeend wordt.

203. Wi. Ruthers (nt. 167), p. 306 e.v.

204. BVertak $12,113$.

205. Zle 3*5.

206. WerfGE 10, $118(121)$

207. BerfGE 12,113 (130) jo. BVerfGE 12, 113 (125) en 10 , 118 (121). Z1e ook 3.5.7.9. 
208. Par. 6, behalve in de perswetten van Ber1ljn en Hessen. De vindplatisen van de perswetten van de deelstaten zift respectievellik: voor Baden-Wurttemberg $(14-1-$ 1964) GBI. 1964, 11; Beleren (3-10-1949) BayBS $1949 \mathrm{I}$, 310; Berlifn (15-6-1965) GmB1. 1965, 744; Bremen (16-31965) GBI. 1965, 63; Hamburg (29-1-1965) GVB.1. 1965, 15; Hessen $(22-2-1966)$ GVBl. 1966, 31; Neder-Saksen (22-3-1965) GVB1. 1965, 9; Noord-R1jinland-Westfalen $(24-5-1966)$ GVB1, 1966, 340; R1jnland-Palte $(14-6-1965)$ GVB1. 1965, 107; Saarland (12-5-1965) Ab1. 1965, 409; Sleeswlk-Holsteln $(19-6-1964)$ GVB1. 1964, 71; teven als bijlagen in M. Loffler, Presserecht, Band II (Dle Landespressegesetze der Bundesrepublik Dentscliland), 2. Auflage, 1968 Mtinchen, p. 506 e.v.

209. Anders valt de formulertug in BVerfGE 54,208 (219/220) en 61,1 (8) wel nlet te liezen.

210. Hesse (nt. 87), p. 152 .

211. BWerfGE 54,208 (219).

212. Vgl. BVerfGE 61,1 (8).

213. Roelecke (nt. 197), p. 694. Wg1. ook Ridder (nt. 165), p. 266 .

214. Vg1. BVerfGe 42, 163 (171), daarmee definitief de in het KPD-arrest (BVerfGE 5, 85 (205)) an dit grondrecht gegeven an verlatend. Daarin werd het belang wan de vrl jheid yan menlngsulting voor de democratle als volgt omschreven: "Ste bewahrt es Insbesondere vor Erstarrung und zelgt dile Fülle der Lösungsaöglichkelten für die Sachprobleme auf". Ze garandeert flexibilitelt en draggt alternatleven aan. Zlj makt de voortdurende menfigsstrijd mogelijk, die het levengelixer van de democratie is.

215. M.u.v. BVerfGE 7, 230; 25, 256; 35, 202; 42, 133 en 62 , 230 .

216. BVerfGE 7, 230 (234); 12, $113(125) ; 24,278(282) ; 25$, $256(264) ; 35,202(221) ; 42,133(139) ; 42,163$ (168); $43,130(137) ; 34,269(282) ; 54,129(136) ; 54,208$ (219); 61, 1 (11); 62, 230 (247). Er bestaat geen adequate Nederlandse vertaling die precles dekt wat met schlechthin konstitulerend wordt uftgedrukt.

217. BVerfGE 42, $163(169)$; cursitering van mij.

218. BVerfGE 28, 36 (48); 1dem BVerfGE 28, 55 (63) en 44 , 197 (203).

219. BVerfGE $10,118(121) ; 20,162(175)$.

220. BVerfGE 12, $205(259 / 260)$.

221. 21e 3.5. 
222. $M / D / H(n t, 108), A r t, 5$, Rane. 81 e. . Zle ook W. Rrafczyk, Ausiand fache Rund funkendungen als "allgemelin zugängliche Quellen" 1m Sinne des Art. 5 Abs. 1 Grundgesetiz, 1983 vituchen, p. 1.4 e.v.

223. Ridder (nt. 165), p. 248: een menlagsulting heeft geen zin alg zij nlet ontwangen ordt.

224 , BWerfGe $27,71(81) ; 27,104(108) ; 28,175(188)$.

225. Een informatiebron s a 1gemeen toegankel1jk als ze "cechnigch geelgnet und bestiumit ist, der Allgemelmheit, d.h. elnem lndividuell alcht bestimbaren Personenkrels, Informationen $z$ us beshafen" (BVerfGE 27,71 (83); 2B, $175(188) ; \mathrm{vg} . \mathrm{M} / \mathrm{D} / \mathrm{R}$ (nt. 108), Art. S. Rudinr. $\left.88 \mathrm{e} . \mathrm{v}_{*}\right)$, zoals kranten en andere massacomunicatiemiddelen.

226. H/D/H (nt. 108), Art. 5, Rndnr. 82 .

227. BiverfGE 27, $71(81)$.

228. BVerfGE $27,71(81)$.

229. BVerfGE 27,71(81). Vgl. Ridder (nt. 165), p. 275.

230. BiverfGE 27, $71(81)$.

231. BVerfGE 27, 71 (81/82). Vg1. ook Schmitt-Glaeser, Dile Melnungsfrethelt in der Rechtsprechung des Bundeswerfassungsgertchts (nt. 128), p. 66.

232. Zue ook Horstpeter Kle1a, Die offentllche Aufgabe der Presse, 1973 Düsseldorf, p. 22 e.v.

233. BVerfGE 8,104 (112).

234. BVerfGE 8, 104, (113).

235. BVerfGE 8, 104 (113). Evenzo BVerfGE 20, $56(98 / 99)$.

236. BVerfGE 8, 104 (113).

237. BNerfge $20,56(98)$.

238. BWerfGE 20, 56 (99).

239. 21.e 3.5.1.

240. BVerfGE 8, $104(112)$.

241. D. Czajka, Pressefrethett und "bffentllche Aufgabe" der Presse, 1968 stuttgart/Berlin (W)/Koln/Mainz, p. 123 e.v., n. p. $125 / 126$.

242. G. Leibholz, Der Strukturwandel der modermen Demokrat1e, 1952 Karleruhe, p. 16 e.v. 
24. Id., p. 17.

244. Ibld:

245. Czajka (nt. 24l), p. 125 .

246. Zle de bespreking van diens opvating in 3.5.2.

247. Wg1. Schnitt-Glaeser, Die Melnungsfretheit in der Rechtsprechung des Bundesverfassungsgerfchts (nt. 128), p. 83.

248. BVerfGE $50,290(337)$.

249. BVerfGE $57,295(319 / 320)$.

250. BVerfGE $10,118(121)$.

251. BVerfGE 12, $113(125)$.

252. BVerfGE 10, 118 (121). Vaste rechtapraak: BVerfGE 12 , $205(260) ; 20,162(176) ; 21,271(279) ; 36,193(204)$; $50,234(240) ; 62,230(243)$.

253. BVerfGE $36 \mathrm{NJW} 1181(1983)$.

254. BVerfGE 10, $118(121)$ en 12, $205(260)$.

255. BVerfGE $12,205(261 / 262)$.

256. BVerfGE $20,162(175) ; 25,256(268) ; 36,193(204)$; $50,234(240)$.

257. BVerfGE $21,271(279) ; 64,108(114)$.

258. BVerfG $37 \mathrm{NJW} \$ 741$ (1984) $\$ 742$. Het betrof de publlcatie door de journalist Ginter Wallraff van het verloop van een redactievergadering bif de Blidzeltung van Axel Springer.

259. BVerfGE 20, $162(175 / 177)$; BVerfG 37 NJW 1741 (1984) 1742 .

260. BVerfGE 10, 118 (121). Deze formuler1ng. keert weex terug in BVerfGE $62,230(243)$.

261. Vg1. Schmit-Glaeser, Dle Melnungsfreiheit in der Rechtsprechung des Bundesverfassungsgerlichts (nt. 128), p. 89 e. $\mathrm{v}$.

262. Naast BVerfGE 10, 118 (121 e.v.) ook 1a BVerfGE 12,113 $(125$ e.v.); 12, $205(259$ e.v.); 20,56 (97).

263. BVertEE 12, $113(126)$.

254. BVerfGE $20,162(175)$.

265. BVerfGE $60,162(174) ; 52,283(286)$. 
266. Lat tell jk BerfGE 50, 234 (239 e. w.) met verdere verwizingen.

267. BVerfGE 12, $113(128)$ : Nin Rahmen der offentliche Autgabe der Pregse die Büger iber offentliche Angelegenhelten zu untertchten".

268. VerfGE 20, $162(174 / 175)$ en (180). Vg1. BVerfGE 57 , $295(319)$.

269. BVerfGE $20,162(175)$.

270. BVerfGR $20,162(221)$.

271. BVerfGE $20,162(175) ; 36,321(340) ; 50,234(239)$.

272. BVerfGE 20,162 (175); BVerfG 37 NJW 1741 (1984) 1742 .

273. De Institutionele opwatting wordt gedeeld door: P. Dagtoglou, Wesen und Grenzen der Pressefrethelt, 1963 stuttgatt, p. 12 e.v*; W. Gelger, Das Grumdrecht der pressefrelhe1t, in: K. Foriter (red.), Die Funktion der Presse 1 demokratischen Stat, 1958 Minchen, p. 9 e.v., ad p. 15; I. Gross, Die Institution Presse, 1971 Berlin (w); Hesse (nt. 87), p. 152 e.w.; p. Lerche, Pressefrelhe1t, In: W.A. Kewen1g (red.), Deutsch-Amerikanisches Verfasingssymposium 1976, 1978 Berlin (W), p. 67 e. $V_{*}$; M. Loffler, Der Verfassungsauftrag der Presse, Modellfall splege1, 1963 Rarlaruhe, p. 2; M. Löffler/R.Ricker, Handbuch des Presserechts, $1978 \mathrm{Min}-$ chen, p. 11 en 44 ; von Mangoldt/Klein (nt. 165), p* 244; Manz/Z1ppe11us (nt. 165), P. 146 en 193; T. Schnelder (nt. 165), p. 134 e.v.; P. Schnelder, Preasefrethelt und Staatssicherhellt, 1968 Mainz, p. 65 (1n mindere ate); U. Scheuner, Die imstitutionellen Garantien dee Grundgesetzes, in: Staatstheorle und Statsrecht, Gesamelte Schr1ften, 1978 Berl1n (W), p. 666 e.v. en Scheuner, Pressefretheit (nt. 165), P. 29 e.v.; D. Stamiler, Die Presse als sozlale und verfassungrechtliche Institution, 1971 Berlin (W); H. Steiger, Inst 1tutionalisterung der Grundrechte?, Im: H. Schelsky (red.), Zur Theorle der Institution, 1970 Disseldorf, p. 110 e.t.

274. Vg1. E. W. Boblenförde, Grundrechtstheorle und Grundrechtsinterpretation, 27 NJW 1529(1974) en in het algeneen 1.2 .1 .

275. Ridder (nt. 165); Scheuner, Die Institutionellen Garattien des Grundgesetzes (nt. 273).

276. Zle met name Stamier (nt. 273), p. 178. e. .

277. Ridder (nt. 165), p. 249 e.v.

278. Id., p. 250 . 
281. Td. " p. 250 en 259.

282. Wd., p. 259. De terminologie 18 ontleend aan G. Jellinek, System der subjektiven öffentlichem Rechte, onveranderde overdruk van 1919, 1964 Aalen, p. 86 e.v." dile de verhouding tussen individu en stat in vier verschllende kwalitelten onderverdeelt, nl. de passleve, de negatieve, de positleve en de actieve status, die resp. de inditidule plicht tegenover de stat, de vrljheld van de staat, aanspraken tegenover de staat en de individuele activiteit in de stat, "der status aktiver Zivität", uitdrukken. Vg1. 1.2.1.

283. Rldder (nt. 165), p. 259, nat Jellinek (nt. 275), p. 87.

284. Id., P. 259 en 269 .

285. Id., p. 257 .

286. Id., p. 289.

287. Id., 2.. 258.

288. Id, p. 261 , analoog aan art. 21 lid 2 GG. Ridder vraagt zich bovendien af of net als in het geval van de piartijen, de bevoegdheld on persorganen te verbleden, die hun taak niet conform hun loyaliteit an de fdco verrichten, uftsluitend aan het $B V e r f G$ dient te worden toegekend (p. 257 nt. 53).

289. Id., p.. 266.

290. Id., p. 259.

291. ld., p. 269; vg1. ook p. 289.

292. Vg1. Horstpeter K1ein (nt. 232), p. 61 .

293. Woor velen: Czajka (nt. 241), p. 136 en Dagtoglou (nt. 273), p. 20; zelfs Stamier (nt. 273), p. 206. Vg1. echter Loffler, Der Verfassungsauftrag der Presse (nt. 273), p. 2, die vaststelt dat de pers "- alhnlich wile de polftischen Parteien - zur unmittelbaren Mitarbelt an State 8 leben berufen ..." 1.

294. M/D/H (nt. 108), Art. 5 Rndnr. 5; Friegemhtha (nt. 168), p, 10 .

295. Dagtoglou (nt. 273), p. 20; Scheuner, Pressefrethett (nt. 273), p. 31; Horatpeter Kleln (nt. 232), p.67.

296. Cza jka (nt. 241), p. 136 .

297. Dagtog1ou (nt. 273), p. 20 . 
298. Id w. 18, 20.

299. Horstpeter Rletn (nt. 232), p. 62.

300. De Belerse Persiet (nt. 208) is als en 1 ge van vroegere datum, n1. $\tan 3-10-1949$.

301. Steeds in par. 3 (nt. 208). Ook het noolt tot wet geworden ontwerp voor eem federale perswet spreekt 4 par. 3 van een openbare taak.

302. Pax. 1., behalve In Beleren en Bremen (nt. 208).

303. Par. 1, Baden-Wirttemberg, Berlijn, Rijnland-Palts, Saarland, Sleeswijk-Holstein. Beteren: par. 3 litd $1:$ "Dile Presse dient dem: denokratlechen Gedanken" (nt. 208).

304. Hamburg (nt. 208).

305. Meder-Saksen (nt. 208).

306. Woord-RL jnland-Westiaten (nt. 208).

307. Berlijn (nt. 208) heeft zlch alet an een definitle gewaagd. Vg1. par. 1.

308. Met $z 0^{\circ} n$ deflultie heeft zelfs Friesenhahn (nt. 168), p. 28 geen moelte, als met tak tenminste functie wordt bedoreld.

309. Libffler, Der Verfassungsauftrag der Presse (nt. 273). P. 2 .

310. Stamier (mt. 273), p. 209 .

311. Schnedder (nt. 165), p. 125 .

31. Gelger (at. 273), p. 30 .

313. Scheumer, Pressefretheit (nt. 165), p. 29/30. Wg1. BVerfGE 20, 162 (175).

314. Mar we1 "Im Interesse dex fir den stat notwendigen Publlzitatsentfaltung" , aldus Löffler/Rlcker (nt. 273), p. 17.

315. U. Scheuner, Privatairtschaft11che struktur und offent11che Aufgabe der Presse, In: Stantatheorie und Stantsrecht, Gesamelte Schriften, 1978 Bierlin (W), p. 759 e.v., ad p. 760; Scheuner, Presefrelhe1t (nt. 165), p. 30; $\mathbb{P}$. Schme1der ( $\mathrm{nt}, 273)$, p. 93; Löffler/Ricker (nt* 273), p. 11, die onderscheldt tussen een openbare takk van dwe pers (als algemen matschappel1jk communteatiemidde1) In soclologlache zin en een taak in constitutoneelrechteligke zin. Zle tevens R. Ricker, Frethelt und Aufgabe der Presse, 1983 Freiburg/Munchen, p. I1 
316. Loffler/Rlcker (at. 273), p. 17, stamiler (at. 273), p* 206.

317. P. Sehnelder (nt. 273), p. 93, 94 e.v.; Loffler/Ricker $(\mathrm{nt}, 273), \mathrm{p} \cdot 18 \mathrm{e} \cdot \mathrm{v}$.

318. Stamier (at. 273), p. 208 .

319. Löfller, Der Verfassungsautrag der presse (nt. 273), P. 4/5; Libfler/Rlcier (nt. 273), P. 19.

320. Whe voor de begripsverwarring die rondom de institutionallsering van de persurt theld is ontstaan: Gross (nt. 273), p. 18; Schnitt-Glaeser, Die Melnungsfrelhelt in der Rechtsprechung des Bundesverfassungsgerlchts (nt. 128), p. 97.

321. Gefger (nt. 273), p. 17.

322. Dagtoglou (nt. 273), p. 16; Gross (nt. 273), p. 24 e.w. Zie Horstpeter Klein (nt. 232), p. 77 .

323. Stamiler (nt. 273), p. 193.

324. Id*, p. 197.

325. Id., p. 205.

326. Id., p. 217. Kritisch $k_{*}$ Nuepliger, Pressefreihelt und Pressevielvalt, 1980 Diessenhofen, p. 92 .

327. Staumler (nt. 273), p. 218 .

328. Id., p. 203*

329. F. Schnelder (nt. 165), p. 113.

330. Id., p. 134 .

331. Dagtoglou (nt. 273), p. 12; Lofflex, Der Verfassungsauftrag der Presse (nt. 273), p. 2; Löffler/Ricker (nt. 273), p. 11; Scheuner, Presiefrelheit (nt. 165), p. 134, 136. Vgl. ook Gelger (nt. 273), p. 15 en P. Lerche, Verfassungstechtil che Fragen zur PressekonzentratIon, 1971 Beriln (W), p. 25 e.v.

33. Dagtoglou (nt. 273), p. 10 .

333. Zo ultrukkel1jk scheuner, Dle 1nstitutionellen Garamtien des Grundgesetzes (nt. 273), p. 673.

334. P. Schilder (nt. 273), p. 62 e.v.

335. BVerfGE $10,118(121)$.

336. Stammler (nt. 273), p. 221; Gross (nt. 273), p. 120 e.v. 
338. Stamler (at, 273), p. 221; "zweck dieser subjektiven Reflexrechte 1 ist fedoch immer nur der Bestandsichute der Inotltut lon" . Daarentegen Lerche, VerfassungsrechtI1che Fragen zur Pressekonzentration (nt. 331), Q. 26, dat de lnstltwtonallserling geen doel op zichzelf $1 . s$, maar witelndelifk de lndiwidu mot dienen.

339. Dagroglou (nt. 273), p. 12; Hesse (nt. 87), p. 153; ran Mangoldt/klein (nt. 165), p. 239; Sicheunex, Pressefrelhelt (nt. 165), p. 63; F. Schnelder (nt. 165), p. 22 e.v., 30,115 .

340. Dagtoglou (nt. 273), p. 13.

341. Vg1. Löfler/Rlcker (at. 273), p. 45 .

34. V. VI. woor dit vraagstuk M/D/H (nt. 108), Art. 5, Rudar. 178 e.v.

343. Vg1. Böckenförde (nt, 274), m.n. P. 1532; Cza jka (nt. 241) , P. 90 e.V.; Frlesenhahn (nt. 168); Y. Hangartuer, Zweckbindung der Frelheltsrechte?, In: Festschrift für Hans Huber, 1981 Bern, p. 377 e.v; Kleln, Oeffentliche und Private Frethedt (nt. 12l), p. 161 e.v.; Horstpeter Kle1n (nt. 232), p. 82 e.v.; E. Kul1, Zur "öffentlichen Aufgabe" grundrechtageschitzter Presse, 1n: Festschrift fur Martin Löfler, 1980 München, p. 187 e.v.; F. Ossenbühl, DLe Interpretation der Grundrechte In der Rechtsprechung des Bundeswerfassungsgertchts, 29 WJW 2100 (1976), p. 2102; Schnitt-Glaeser, Die Meinungsfretheit in der Rechtoprechung des Bundesverfasungsigerichts (nt. 128), p. 102 e.v.; Schnur (nt. 149), p. 113 e.v.

344. Dagtoglou (nt, 273), p. 14 .

345. Schitt-Glaeser, Die Melnungsfreihelt in der Rechtsprechung des Bundesverfassung ager1ehts (nt. 128), p. 105.

346. Duldelljk bl1jkt dit vooral in de analyse van Horstpeter klein (nt. 232). Hij defindeert de openbare takk als "elne an die (Insbesondere bel den Zeltungen beachäftigten) Pressetitigen und den von thrien produzlerten Presselnha1t gerichtete Erwartung ihrer Unwelt, die dle Qualitat der produterten Informationen und deren Wirkung in der und auf die Demokratie becrlffe" (p. 17) uit welke (empirische) definitie het verplichtendie element blifkt.

347. Gross (nt. 273), P. $127 \mathrm{ew}$.

34. F. Friesenhahn (nt. 168), p. $23 \mathrm{e.v.;}$ Horstpeter Kleln (nt. 232), p. 82 e.v. 
350. Czajka (nt. 241), p. 102; Friesenhahn (nt. 168), p. 25.

351. Gzajke (nt. 241), p. 103; sehnur (nt. 149), p. 104. Friesenhahn (nt. 168), p. 24, voegt toe dat ut de ontstansgeschledenis wan art. 5 GG niet blljkt dat de grondwetgewer een andere Inhoud aan het begrip wide geven. Vgl. darvoor: von Doemalng/Fusslein/wht (nt. 16), p. 79 e.v.

352. Vg1. In deze context ook het tussemstandpunt van Herzog in $\mathbb{N} / \mathrm{w} / \mathrm{H}$ (nt. 108), Art. 5, Rndnr. 5 e.v.

353. Horstpeter Kle1n (nt. 232), p. 93.

354. Id., p. 94; 步den Czajka (nt. 241), p. 142 .

355. Schour (nt. 149), P. 117; Herzog noemt een van het oorspronkelijk grondrecht losgekoppelde Instltutlonal1sering een "Taschensplelertriek" (M/D/H (nt. 108), Art. 5. Rndur. 13); voor Stamler aanletding de afwifzing van een zelfstandige institutionele garantie te omschrijwen als "begriffsjurlstische Fetischlerung iberkomaner, liberaler positivistischer Kategorien" (Stamiler (nt. 273), p. 223).

356. Horstpeter Klein (at. 232), p. 92.

357. Schmitt-Glaeser, Die Melnungsfreiheit 1 m der Rechtsprechung des Bundesverfassungsgerichts (nt. 128), p. 117.

358. BVerfGE to, 118 (121); de formulering in BVerfGE 12 , 205 (259) is niet duidelijker.

359. BVerfGE 20,162(175).

360. BVerfGE $20,162(175)$.

361. Vgl. $3.4 \cdot 5 \cdot 2$.

362. BVerfGE $50,234(240)$

363. Rul1 (nt. 343) zlet in BVerfGE 50, 290 in leder geval wel een koerscorrectle van het $B V$ er $f G$.

364. MerfGE 20, $162(174 / 175)$ *

365. BVerfGE 20, $162(178)$.

366. BVerfge $50,234(240)$; tin plats wan over taak wordt ower rol gesproken.

367. Von Mangoldt/Rleln (nt. 165), p. 245.

368. Ibid.

369. BVerfGE 34, 269 (283); BVerfG 37 NJW 1741 (1984) 1742. 
370. In par. 7. Vg1. ook M/D/A (nt. 108) , Art. 5, Rndnr. 129.

371. Löfler/Rlcker (nt. 273), p. 33.

372. BVerfgE 34, $269(283)$.

373. BVerfGE 20, 162 (175/176)*

374. BerfGE 20, 162 (176); vgl. par. 2 van de reglonalle persweten (nt, 208).

375. BVerfGe 20, $162(176)$; V.g1. par. 2 van de reglonale perswetten (nt. 208). Art. 5 lid 1 GG derogeert dan art. 12 l1d I GG, dat de wrijheid van beroepskeuze garandeert: $M / D / H$ (nt. 108), Art. 5, Rndnr. 141 en 142. $\mathrm{Vg} 1$. tevens BVerfGE 50,234 (239) en 52,283 (296 e.v.): de persvr 1 theld beschermt het recht van de ultgever de rlchting wan $21 \mathrm{jn}$ krant te bepalen, te handhaven, te veranderen en te realiseren. Dat betekent ander meer dat de ondernemingsraad op dit punt geen medezeggenschap heeft.

376. Par. 1 11d 4 van de reglonale perswetten (nt. 208).

377. Voor hen die in de journalistlek werkzam waren, was het lidmatschap wan deze organisatle verplicht. Ontbrak de national-soclalistische betrouwbaratheld evenwel, dan werd men als lid gewetgerd en was bljgevolg de toegang tot de journalistiek versperd.

378. Bundesverband Deutscher Zeltungsver leger e.V.; Verband Deutacher Zeftschriften-Verleger e.V.; Deutscher Journalistenverband e.V.; Deutsche Journalistenunion.

379. Zle verder Loffler/Ricker (nt. 273), p. 215 e.w.; R1cker (nt. 315), p. 52 e.v.

380. BVerfGE $20,162(176) ; \mathrm{vg} 1$. ook BVerfGE $50,234(240)$.

381. Bevestlgend Löffler/Rlicker (nt. 273), p. 95. Afwijzend M/D/H (nt. 108), Art. 5, Rndnr. 137; Scheuner, Pressfrethelt (nt. 165), p. 78; Von Mangaldt/Klein (nt. 165), p. $241 \mathrm{e} \cdot \mathrm{v}$.

382. Loffler/R1cker (nt. 273), p. 95.

383. In par. 4 (nt. 208).

384. Par. 4 11d 2 van de perswetten (nt. 208). Volgens de perswet varh Noord-Rijnland-Westfalen bestat in deze gewallen de plicht het veritrekken van informate te welgeren.

385. Zie verder Löfler/Ricker (nt. 273), p. 105 e.v.

386. Buerfor 20, $162(176)$. 
387. Vgl. Lerche, Verfassungsrechtliche Fragen zar Pressekonzentration (nt. 331), p. 21 e.t.; Munz/zippelius (nt. 165), P. 146/147; 1.J. Eapier, Weber Pressefreihellt, 13 Der Stat $399(1974)$, p. 409. Kritlsch tegenaver een beroep op de insticutionele garantie voor dit doe 1: M/D/H (nt. 108), Art. 5, Rndnx. 184; Keln, Deffentliche und private fretheit (nt, 121), p. 161; Botcenforde (nt. 274), P. 1532 .

388. Gesetz gegen Wettbewerbsbeschränkungen van 27-7-1957, BGB1. $1957 \mathrm{I}, 1081$, geldig in de redactie van 3-1-1966. BGBI. $1966 \mathbb{I}, 37$, gew1jzI $22-7-1969$, BGB1. $1969 \mathrm{I}$, 901 en 3-8-1973, BCB1. 1973 I, 917.

389. Pressefusions-Kontrollgesetz van 28-6-1976, BQB1 1976 I, 1697 .

390. Voor een ultgebreide bespreking van de antipersconcentratlewetgeving: Loffler/Rlcker (nt. 273), p. 382 e.v. Volgens W. Möschel, Funktionskontrolle 1 m Presseberelch, $39 \mathrm{JZ} 493$ (1984), m.n. p. 494 e.v.: sluds de inwerkingtreding vat de verscherpte antipersconcentratiewetgewing schijnt de persconcentratie inderdaad, zil het op hoog niveau, te stagneren.

391. Naar Löffler/Rlicker (nt. 273), p. 385. Het betrof dus geen beperking van de perswitheid, mar van de ondernemlngsuritheld.

392. Vgl, Rapler (nt, 387), p. 409.

393. Id., p. 407. Vg1. BVerfGE $21,271(280)$.

394. Volgens de redenering die aok door häberle gevolga wordt; vgl. de bespreking van diens institutionele thearle in 1.2 .1 .

395. M/D/A (nt. 108), Art. 5, Rndnr. 185. Vg1. Frlesienhahn (nt. 168), P. 35 .

396. Friesenhahn (nt. 168), p. 37.

397. BVerfGE 7, $198(209)$.

398. Vg1. Schwark (nt. 135), p. 139.

399. BVerfGE 25, 256 (268), bevestigd In BVerfGE 62, 230.

400. Dat volgt uit de verelsten, die gelden woor algemene wetten 1 in de $z$ in van art. $511 d 26 G ; z 0$ ook par. 1 lid 3 van de reglonalle perqwetten (nt. 208).

401. BWerfGE 36, 321(340).

402. Vg1. BVerfGE 10, 118 (121).

403. BVerfGE $20,162(176) ; 36,193(204) ; 50,234(240)$. 
404 . WerfGE $36,193(204), 64,108(114 / 115), 2$ le voor een gedetall 1eerde bespreking van het verschoningsrecht, Loffler, Presserecht, Band I (Dle Landespressegesetze der Budestepubitk Deutschland), 3. Auflage, 1983 Wiatchen, P. 84 e.v.

405. Gesetz Hber das Zeugniswerwelgerungsrecht der Mitarbelter von Tresse und Rundfunk van 25-7-1975, BGBI $1975 \mathrm{I}$, 1973. Vgl. BVerfGE 36, 193; 36, 314; 38, 103.

406. Par. $5311 d 1$ sub 5 stPo; par. 383 ild 1 sub 5 zPO.

407. Loffler/Ricker (nt. 273), P. 135/136; M. Kohlhaas, Dais Zeugniswerdelger ungerecht des Journallsten, Hn: Pestschrift fur Mortin Loffler, 1980 Wunchen, p. $143 \mathrm{e} . \mathrm{w}$, , ad p. 146/147. Niet van belang 1s, of men door die medewerking inkomen verwerwen wil.

408. BerfGE 21, $271(278 / 279)$. Vgl. Löffler/Ricker (nc. 273 , P. 136 e. . .

409. BVerfGE 64, 108 (115 e.w.).

410. Vgl, par. 138 en 139 stGB.

411. Pat. 97 11d 5 stPo.

412. BVerfE 20, $162(198)$.

413. Par. 97 11d 2 derde zin StPO.

414. Vg1. BVerfGe 20,162 (191 e.v.). Zle verder Loffler/ Ricker (nt. 273), p. 140 e.v.

415. Die volgeng Löffler (Loffler/Rlcker (nt, 273), p. 143) derogeren adan de federale regellng van dezelfde materle In par. $111 \mathrm{~m}$ en $11 \mathrm{ln}$ StPO, die eveneens in $1975 \mathrm{zl} / \mathrm{gh}$ ingevoerd.

416. Vg1. par. $12 \mathrm{t} / \mathrm{m} 18$ van de perswet van Hamburg (nt. 208) en Löffler/flcker (nt. 273), p. 144 e.v.

417. Par. 102 e.v. StPo; vgl. Löffler/R1cker (nt. 266), p. 160.

418. BVerfGE 20, $162(195 / 196)$.

419. In plaats wan de normale ver jaringstermiln wan 10 tot 30 Jaar voor norma le mdrdjuen (Verbrechen, wederrechcelljke handelingen, warop een viljheidsstraf van tenminete 1 jaar staat) bedragt de termijn voor persmisdrilven 1 jaar, voor Pressevergehen (Wergehen $11 \mathrm{fn}$ een aparte categorle delicten, te weten wederrechtelljke handelingen, warop tenmingte een gerlngere vrljheldsstraf of een geldbote staat) is maanden in plaats wan normaliter 3 tot 5 jasr, woot persovertredingen 3 maanden in plats van normalfer 3 tot 6 jaar. 
420. 2le verder Lofflex/Ricker (nt. 273), p. $257 / 258$ en par. 23 van de perswetten (nt. 208).

421. Wet wan 27-1-1977, BGBI. $19771,201$.

422. BVerfGE $20,162(177)$.

423. BGHSt 12, $287\left(293 \mathrm{e} . v_{0}\right) ;$ BVerfGE 12, $113(125 / 126)$.

424. BGHz 31, 308 (312 e.v.); R. Gross, Schranken der Pressefretheit, 94 DVB1 $833(1979)$ * p. 835. Vgl. Das Burgerllche Gesetzbuch, Kommentar, ultgegeven door leden van het Bundesgerichtshof, Band III, I. Tell, 12. Auflage, 1979 Ber11n (W)/New Yark, par. 1004, Rndnr. 149; 0 . Paland, Burger11ches Gesetzbuch, 42. Auflage, 1983 Minchen, par. 824, Rndnr. 6 e.

425. E. Dreher/H. Trönd1e, Strafgesetzbuch, 41. Auflage, 1983 vünchen, p. 896.

426. Vgl. Löffler/Ricker (nt. 273), p. 278/279. Ondat de persvrijheld ook de mededelling van felten bescherat zijn par. 186 e. w woorschriften in de zin van art. 5 III 2 GG die de perswri jheid beperken.

427. Z i.e hieronder $3 \cdot 5 \cdot 7.10$.

428. WVerfGE $20,162(176)$; in deze 21tr ook BVerfGE 36, 193 $(204)$.

429. BVerfGE 12, 113 (130), Zie ook BGW 30 NJW 1288 (1977), 1289 en OLG Düsseldorf 31 NJW 704 (1978).

430. BVerfGE $54,208(220)$.

431. BVerfGE $54,208(219 / 220)$.

432. DverfGE 61, 1(8).

433. Vg1. $3.4 .4 \cdot 2$.

434. Par. 6, behalve Ber11jn en Hessen (nt. 208). De perswet van Beleren (par. 3, 11d 2) spreekt desialniettemin van een warheldspilcht, die echter als zorguidigheldsplicht dient te worden geinterpreteerd, zo $\mathrm{M} / \mathrm{D} / \mathrm{H}$ (nt. 108), Art. 5, Radnr. 145 .

435. Lôf fler, Presserecht (nt. 404), p. 313; vgl. par. 276 $\mathrm{BGB}$.

436. BGH GRUR 147 (1969) 151. Vg1. Löffler, Fresgerecht (nt. $404)$, P. 314 .

437. Zo par. 6 van de reglonale perswetten, behalve Berlijn en Hessen ( $\mathrm{nt}$. 208). Te ver gat dus de opvatting van Gross, "dass die Intention auch objekttver Wahrhelt aller "mitgeteliten "tatsachen stets vorhanden sein muss" (Gross (nt. 273), p. 130). Vgl. Loffler/Ricker (nt. 
273) , p. 2Ll e.*: R1dder (nt. 165), p. 266. Voor eea ultputtende bespreking van de zorgvildigheidsplicht, $H_{\text {: }}$ Loffler, Presiserecht $(\mathrm{nt}, 404)$, m. 313 e.v.

438. Lôfler, pesterecht (nt. 404), p. 310, 313.

439. Wg1. hierboven 3.5.7.8. en Loffler, Presserecht (at * 404), p. $329 / 330$.

440. Par. $10 \mathrm{c} q$. 1.1. wan de perswetten, behalve Baden-Wirttemberg (rit. 208).

4.41. Woor de rechtsprak betreffende de kring van gerechtygden zie R. Damin, Der Gegendarstellungsanspruch lin der Ent wcklung der neueren Rechtsprechung, in: Festschrift für Wartin Löfler, 1980 München, P. 25 e.v*, ad p. 26 e.v.

4.42. Wg1. Damm (nt. 441), D. 30 e.v.

4.43. Meestal wal zelfs blnnen enkele weken gereageerd moeten worden, vgl. Damm (nt. 44I), p. 32 e.u.

4.44. Damm (nt. 441), p. 35 e.v. geeft voorbeelden uit de rechtspraak.

445. Bijwoorbeeld die van Noord-Rijnland-Westfalen (nt. 208).

446. Zie bijvoorbeeld par. 11 litd 3 van de perswet van hamburg. Geen regeling met betrekking tot advertentles kennen Beleren en Hessen (nt. 208). Zle verder Löfflerf Rlcker (nt. 273 ), p. 108 e.v.

447. 21e 3.6.1.1.

448. Löffler, Eresserecht (nt. 404), p. 530 e.v.

449. Vgl. Damm (nt. 441$),$ p. 25.

450. Löfler/RLckex (nt. 273), p. 111/112. In BVerfGE 63, 131 ( 142 ) werd de Gegendarstellungsanspruch echter ult het algemene persoonlfjkheidsrecht afgeleld (zle 3.6 .6 .1$.$) en verkreeg daardoor constitutionele rang. De$ regelling van het recht op antwoord, die de omroepurijheid beperkte, werd nfet als een allgemene wet beschouwd, mar er vond een rechtstreekse afwegling tussen ontoepvrithe1d persoonit jkheidsrecht plaats. Als die afweglng via algenene wet en wilselwerkingtheorle had platagevonden, dan zou de Gegendarstellungsanspewch niet zo'n sterke poistie tegenower de omroepwitheld hebiben greliad.

451. Par. 6 c.q. 7 of 8 van de perswetten (nt. 208). 2te voor de spectale pllchten van de pers verder nog H.D. Jarass, Rechtofragen der Deffentichkeitsarbedt, $34 \mathrm{WH}$ $193(1981)$. 
452. BerfGE 20, 162 .

453. BNerfGE 20, $162(163$ e.F.).

454. Tile voor de achtergronden het Zetr-dossler "Ste kamen bei Wacht und Nebel" Die Zelt $43,22-10-1982$, p. 17 e.v. M1. ook A.Grosser/J.Selfert (red.), Die Splege1Affare, Band I, 1966 Frelburg.

455. Geheifuen waren "Tatsachen, Gegenstände oder Erkenntnisse. \#nsbesondere Schrlften, Zelchnungen, Modelle odet Formeln, oder Nachrlchten daruber, deren Gehelwhaltung vor elner fremden Reglerung fulr das Wohl der Bundesrepublik Deutschland oder elner threr Länder exforderlich 1st"

456. BVerfGe 20, $162(178 \mathrm{e.v.})$.

457. BVerfGE $20,162(186)$.

458. BVerfGE $20,162(177 / 178)$.

459. Par. 100 jo. 99 StGB (oud; te vinden in BGB1 $1951 \mathrm{I}$, $739)$.

460. BVerfGE $20,162(212)$.

461. BVerfGE 20, 162 (178).

462. BVerfGE 20, $162(178)$.

463. Par. $9311 d 1$ StGB, BGBl. 1968 I, 741.

464. Vg1. ook BVerfGE 21, 239 (242 e.v.).

465. Vg1. Böckenförde (nt. 274), p. 1532/1533; klein, Deffentliche und private Frelhelt (nt. 121), p. 159 e.v.; Ossenbihl (at. 343), p. 2103/2104; Schmitt-Glaeser, DIe Melnungstrelhett in der Rechtspechung des Bundesverfassungsgerlchto (nt. 128), thet name p. 97 e.v.

466. Schmitt-Glaeser, Die Melnungsfreihelt in der Rechtsprechung des Bundeswer fassungsgerichts (nt. 128), p. 106 e.v.

467. Id., P. 112.

468. BVERGE $57,295(320)$.

469. BVertaE 12, 205 (261); $31,314(326) ; 59,231$ (257) 258).

470. BVerfGE $35,202(221)$.

471. BWerfGE 12, $113(125)$; Vgh. BWertGE 57, 295(320); 59 , 231 (257).

472. BVerfGE $12,205(261 / 262)$. 
474. BVerfog 57,295 (320).

475. BVerfGE 59, 231 (258); vgL. BVerfGE 52, 283 (296). Z4e yoor de omroepvrijheld verder H.D. Jarass, ole Prelthelt der Massenmedien, 1978 Baden-Baden, fi.n. p. 85 e...; H.H. KIeln, Die Rundfunkfretheit, 1978 Mtinchen, dite ook op de moderne massacommulcatiemiddelen lngat; M/D/G (nt. 108), Art. 5, Rndnr. 193 e.w.; U. Scheuner, Das: Grundrecht der Rundfunkfrethe1t, 1982 Berlin (W).

476. Vg1. $3,4,3$.

477. Vg1. 3.2.6. en 3.2.7.

478. BVerfGE 7, $198(218$ e.*.).

479. BVerfGE $12,113(126 / 127)$.

480. BVerfGE 12, $113(132)$.

481. BVerfGE 12, $113(126)$.

482. BVerfGE 24, 278 (282/283).

483. BVerfGg 42, 163 (171).

484. BVerfGE $54,129(137)$.

485. BVerfGE 12, $113(131 / 132) ; 54,129$ (138); vg1. ook AG stuttgart $14 \mathrm{KJ} 325$ (19.1); LG stutegart $14 \mathrm{KJJ} 328$ (1981); BVerfG 37 WJW 1741 (1984) 1746.

486. BVerfGE $60,234(240 / 241) ; \mathrm{vg} 1.3 .4 * 4.2$.

487. BVerfGE 43, 130 (139).

488. Vg1. BVerfGE 19, 73, (75), war kennelijk geen bljarage a an de openbare meningsvorming geleverd werd. Het hetrof een met veel verbal geweld gevoerde strijd tusisen een stichting ter bevorderling van de wederopbous wan een tad ergen in Dultaland en de efgenaar van een stuk grond, warop deze stlchting een huls had gebourd. Hoewel de stuchting een doel had in dienst van hat algeriene nut, zag geen rechterllyke instante hierin aanletifing de twlst een openbar aspect te verlenem VGI. aok BVerfGg 7, $230(233$ e.v.); hler vormde een door de hunder van een appartement tijdeng de verklezhgsitrijd an de buttenmur opgehangen verklezingsbiljet blijkbar geen bljdrage aan de menlingsworting die het overwegen ward was; de rechter liet het elgendonsrecht van de verhuurder met een beroep op de hulsorde zwarder wegen. F. Maller, Normstruktur und Normativitat, 1966 Berlin (W) $p .210$ e.v. ziet ln dit arrest het bewtjs dat de afweging door volkomen subjectheve opvattingen wordt beheerst. 
aanbrengen van een affiche met de tekst "Kein Startbahn West" an het venster van een gehuurd huls moest door de verhunder worden geduld.

489.

490. Vgl. tevens poor een overgleht van de door de rechtspraak ontwikkelde voorwarden: H. Otto, Ehrenschutz it der polltischen Auseinandersetzung, JR 1 (1983), p. 7; P.J. Tettinger, Der Schutz der persönlichen Ehre in frelen Meinungskampf, $38 \mathrm{JZ} 317$ (1983), p. 321 .

491. BVerfGE 7,198 (212).

492. BVerfGE 61, 1 (11). Vg1. VGH Müchen 37 NJH 1136 (1984): muursch1ldering van het sprookje Roodkapje met R'.J. Strauss als de boze wolf - "Warom heb je zo'n grote wull?" is in de verklezingsstrijd geen belediging wan de Belerse minister-president.

493. ต. Schmitt-Glaeser, Mefrungsereihe1t und Ehrenschutz, $38 \mathrm{JZ} 95(1983)$, p. 98 .

494. Id., p. 95.

495. Voor het eerst in BGHZ 13,334 (338), sindsdlen vaste rechtsprak, vgl. BGHz $81,75(78)$ en voor verdere werwilyzingen $B G F Z 50,133(143)$.

496. Zie the overwegingen in BVerfGE 54, 148 (153/154). Voor een bespreking $W$. Sichmidt, Der verfassungsrechtliche Grundrechtsschutz im dffentlichen Melnungskampf, 33 NJW $2066(1980)$.

497. BVerfGE 54, $148(153)$. Zie verder ln het algemeen, H.E. Brandner, Das allgenetne Persölltchkeltsrecht in der Entwlcklung durch die Rechtsprechung, $38 \mathrm{JZ} 689$ (1983).

498. Vgl. Laffler/Ricker (nt. 273), p. 226. Zie voor de bescherming van het persoonl1jkheidsrecht door het burgerlijke recht tevens R. Wellbrock, Persönllchkeltsschutz und Komunikationsfreihelt, 1982 Baden-Baden.

499. BVerfGE $34,269$.

500. BVerfGE $34,269(282$ e.v*).

501. BHerton $34,269(283)$.

5012. BVextER 35, 202,

503. BVerfoE $35,202(219$ e.w.).

504. BVerfGE 35, 202 (225); vg1. BVerfGE 35, $202(221)$.

505. BVerfGe 35, 202 (225).

506. BWerfGE 63, 132 . 
507. BVerfGe $63,131(142$ e.v.).

5018. BVex $f G E$, 54,208 .

509. BVerEGE 54,208 (219).

510. BVerfGE 54, 208 (219). Vg1. 3.4.4.1.

511. Z1e verder $G$. Roellecke, Melnungskampf und aligenelnes Persönlichkeltsrecht, $35 \mathrm{JZ} 701$ (1980), p. 703.

512. BVerfGE $30,173(191)$.

513. BverfGE 30, 173 (191); Doehr1ng (nt. 7), p. 313 e.v. Vgl. echter T. Wurtenberger, Kunst, Kunstfrelhelt und Staatsverunglimpfung (par.90a StgB), JR 309 (1979), die met een beroep op BVerfGE 33,52 (71) ("Das Schutsgut, das ... der Kunstfretheltgarantie gegenuberstehen könnte, 1st Insibesondere der Bestand der Bundesrepublik Deutschland und ihrer freiheitlichen demokratischen Grundordnumg") in par. 90a, dat het aanzilen van de stat beschernt, een legitleme beperking van de kunstvrljheld ziet, ondat deze bepalling rechtsgoederen van constitutionele rang beschermt. L. Zechlin, Kungtfrelhelt, Strafrecht und Satire, 37 NJW 1091 (1984), p. $1092 / 1093$ is het net deze redenering niet eens. Milt e $1 \mathrm{k}$ strafwoorschrift dat de stat beschermt heeft volgens hem constitutionele rang. Zle ook het elnde van 3.6.5. en VG Köln 36 NJW 1212 (1983).

514. BVerfGE $30,173(192)$ *

515. BVerfGE 30,173 .

516. BVerfGE 30, 173 (193).

517. BWerfGE $30,173(175 / 176)$.

518. BVerfGE $30,173(188 / 189)$.

519. BWerfGE $30,173(190)$.

520. BVerfGE 30, 173 (191).

521. BVerfGE $30,173(193)$ en (195).

522. De aw flkende meningen zijn te vinden in BVerfGE 30 , 200 en 30,221 .

523. BVerfGE 7, $198(212$ e.v.).

524. Zle de Inlelding In: Rlaus Mann, Mephlsto, 1980 Reinbek, P. I e.v.

525. BGH GRUR 210 (1976) 212, Vg1. BGHZ 84, 237 (239): de elsen, die vanwege het persoonlijkheidarecht an de kumstritheld mogen worden gesteld, nemen toe marmate de kunstenaar meer pretendeert an de soclale werke- 
14 theid an te knopen. Volgens ong hamburg 37 Nu 1430 (1984) 131 is bij de afweglng tussen kunsturijheld en persowillikhelistecht tevens wer ever redighelaboginsel van belang, zoals die buj de vrithefd van meningsulting geldt: "In bffentlichen Melnungslampf sind w. therabsetzenden Aeusserumgen gerechtfertlgt, wenn abe elne adaluate Reaktion auf rinen vorausgegungenen extsprechenden Vorgang stmd" 20 ook Zechlln kungtrelhelt, Strafreche und sarte (nt. 513), p. 1093.

526. oLG stuttgart 29 NJW $628(1976) 630$.

527. OLG Kar1aruhe 25 NJW 1810 (1972).

528. Ook otro (nt. 490), p. 10 meent dat de meningsuiting woorop stat, als de kunstenar met zin werk bewnst de politleke discussile 11 belnvloeden en het wetk elgen11.jk als medure poot zijn welng bedoeld is.

529. $\operatorname{Vg} 1 . \operatorname{BgH} 84,237$.

530. Zie voor de problematiek kunst versus memingsulting T. Hutrenberger, Satire und Karikatur in der Rechtsprechung, 36 HW $1144(1983)$. Rritischer: L. Zech Itn, Gerlchtilche Verbote zeltkritscher kunst, $15 \mathrm{KJ} 248$ (1982), die uttrukkelijk arschuw voor het implictet toepassen van de beperkingen ex art. 5 ild 2 GG op de kunetritheld, o.a. door het onderverdelen van en kunstuiting in kanst en niet-kunst.

531. F.C. Schroeder, Der Schutz won Staat and Verfassung im strefrecht, 1970 Mithchen, p. $175 / 176$.

532. A. von Brinneck, Pollttache Jastiz gegen Rommulsten in der Bundesrepublik Deutschland 1949-1968, 1978 FrankEurt(M), p. 71. Voor een ultgebreid overzlcht schroeder (at. 531 ), 178 e.v.

533. Wet van 30-8-1951, BGB1. 1951 $1,739$.

534. Daze intentze werd t1jdens de parlementalre behandelung van het desbetreffende wetsontwerp bijzonder benadwut; vgl, von Bethneck (nt. 532), p. 74 .

535. Zo Schroeder (nt. 531), p. 177 en E.Trager/A.Mayer/A. Krauth, Das neuere Staatsichutagtrafrecht in der Pra$x d s$, In: 25 Jahre Bundesger ichtshof, 1975 Mänchen, p* 227 e.v., ad p. 227 .

536. Gegetu uber das Bundeswertasangager 1 cht van 12-3-1951, BGB1. 1951 I, 243. Door wet van $5-8-1964$, BGBI. $1964 \mathrm{I}$, 593, werden par. $90 \mathrm{a}$ stGB en art. 42 BVerfGG opgeheven en vervangen door een nieuwe par. 90a en 90b stGB, die de schending wan een partijverbod en de oprlchting vath vervangende organiaties c.q. de schending van een werenlgingsverbod gtrafbar stelden.

537. In de versle van de wet van 4-8-1953, BGB1. 1953 $\mathrm{I}$, 
735.

538. Door de in nt. 537 genoende wet.

539. Par $96 \mathrm{a}$ StGB 1 s pas limevoerd door wet wan 30-6-1960, BCB1. $1960 \mathrm{I}, 48$.

540. VgI. BGH HuST II, 159 (183).

541. Wet van 25-6-1968, B6B1. $1968 \mathrm{I}, 741$.

542. Von Bränneck (nt. 532), met name p. $167 \mathrm{e.v.}$

543. Zo BverfGE 25, $44(56)$.

544. BGH HUST $I, 74(96)$; HuST $\mathrm{I}, 108(182)$; vgl. won Brônneck (nt* 532), p. $93 \mathrm{e} \cdot \mathrm{v}$.

545. Von Brïnneck (nt. 532), p. $168 / 169$.

546. Id., $\mathbb{P}$. 172 .

547. Id., p. 173. De gehele dagbladpers uit de DDR viel globaal ook onder par. $97 \mathrm{StGB}$; vgl. OLG Gelle 16 MJW 1369 (1963) en LG Hamburg 20 N.JW 58.2 (1967); verder won Brünneck (nt. 532), p. 169 e.v.

548. Von Brönneck (nt. 532), p. 172 .

549. BGH 13 NJW $1772(1960)$.

550. BGH 18 NJW 1444 (1965) 1445.

551. Von Brinneck (nt. 532), p. 176.

552. Id., D. 177 .

553. BVerfGe $25,44(55 / 56)$.

554. BVerfGE $25,44(58)$.

555. BVerfGE 25,$44 ; 25,64 ; 25,69 ; 25,79 ; 25,88$.

556. 0.g.V. par. 98 1td 2 jo. 86 StGB (oud); vgl. BGH 15 NMW 2019 (1962) en 18 NJW 1973 (1965); von Brünneck (nt. 532), p. 182 .

557. Par. 116 11 4 StgB (oud).

558. BGHSt 19, 245 .

559. BVerfGE 27,71(78 e. $\left.\mathrm{W}_{*}\right)$.

560. BVerfGE 27,71 (85/86). Vg1. BWerfGE 27, 88: ook een op controle berustende vertraglng kân een schending van te in formatiewr theid thouden. 
562. DVerfort 33, 52 .

563. Wet van 24-5-196I, BGBI, $1961 \mathrm{I}, 607$, art. 5, 11d 2.

564. Daarower in BVerfGE 33,78 (88); afwilkende mening bij BVTerfGE 33,52 .

565. BVerfGE 33, 52 (69); de film woet bll jk geven van een atleve, strijabare houding tegenover de fago, als propagandamiddel zijn bedoeld en gevaar opleveren.

566. BVerfGE $33,52(71 / 72) ; 47,198(236)$. 2o ook B. Rieder, Die Zensurbegrife des Art. Il der Welmarer Relchsverfassung und des Art. $5 \mathrm{Abs}$. 1 Sate 3 des Bonner Grundgesetzes, 1970 Berlin (H), P. $142 \mathrm{e}, \mathrm{v}, \mathrm{p} .18 .2$.

567. BVerfGE $33,52(72)$.

56B. BVerfGE 33, 52 (74): "Sle hindert den Verbringenden nicht, den Film der offentlichen Meinungsbildungsprozess vorzufthren"; ook hier wordt weer duidelljk, dat het BVerfG de in art. 5 lid 1 GG gegarandeerde grondrecktex steeds vanult de invalshoek van de publieke opinfle beoordeelt. Vgl. tevens Rleder (nt. 565), p. 155 e.v.

569. BVerfGE 33, $52(73)$.

570. BVerfGE $33,78,(88)$.

571. BVerfGE $33,78,(85 / 86)$.

572. BVerfGE 33, $78(88)$.

573. Wet van 27-2-1974, BGB1. 1974 I, $437(444)$. Vg1. verder G. Hochhelden, Flimzensur, 1n: M.Klenzle/D.Mende (red.), Zensur in der Bundestepubllk, 1981 Munchen/ Wien, p. 188 e.v.

574. BVerfGE 27,88 .

575. Von Britinneck (nt. 532), p. 325.

576. Art. 296 van de wet $\tan 2-3-1974$, BGBl. 1974 I, 469. Dat dit het geval is wordt niet klakkeloos mangenomen; vg1. BGHSt 28,296 .

577. Voor de vraag wat deae clausule precles trhoudt: OLG Hainu 35 NJW $1656(1982) 1657 / 1658$.

578. Ingevoerd bif wet wan 30-6-1960, BGB1. 19601,478 .

579. BGH $31 \mathrm{JZ} 183(1976)$.

580. BGHSt 23, 64 .

581. Trager/Mayer/Krauth (nt. 535), p. 239/240; H.W". Schuldt, Aus der Rechtoprechung des Bundesgertchtshofs 
In Staatsochutzstrafsachen, 33 MDR 705 (1979), p. 705 .

582. Schmidt (nt. 581), p. 705.

583. Een were1ste op grond wan par. 86 1ld 1 StGB. Wgl. BGHSt 29, 73. H. Schuldt, Aus der Rechtsprechung des Bundesgerichtshof in Staatsichutzstrafsachen, 35 MDR 89 (1981), stelt daarow voor par. 86 stG zodanlg te w1 jzigen dat het wel mogel1 jk wordt in dit geval stratrechtelijke stappen te ondernemen.

584. BGH UELA 46, 349.

585. BGH Ufita 46, 349; Bayexlsches obexstes Landesgericht 15 WJW $1878(1962)$.

586. BGH 29 NJW $2271(1976)$.

587. Zo H. Loffler, Presserecht, Band I (Allgenelne Grundlagen , Verfassungs- und Bundesrecht), 2. Anflage, 1969 München, p. 228 .

588. BGHSt $28,394$.

589. D1t volgt uit BGHSt 23,267 .

590. BGHSt 25, 128. Vgl. ook P. Grelser, Verbreltung verfasBungsfelndlicher Propaganda, 25 NJW 1556 (1972); f. Noldeke, Nochmals: NS-Symbole $1 \mathrm{~m}$ politischen Tageskampi, 32 NJW 2119 (1979). Schuldt (nt. 583), p.89 pleit in het kader wan de generale preventle voor het opleggen van meex vrijheldsstraten ter bestrijding van rechtsextremistische mentngsutt ingen.

591. BGHSt $31,383$.

592. BGH 32 HJW 1992 (1979).

593. BGHSE $21,371$.

594. OLG Celle 35 NJW 1545 (1982). Vg1. echter BVerfG 35 NJW $1803(1982)$.

595. BGH $34 \mathrm{JZ} 811(1979)$.

596. Zite 3.6.5.

597. Par. 88a StGB lagevoerd bif thet van 22-4-1976, BGBL. $1976 \mathrm{I}, 1056$; par. 129 atg $\mathrm{Stg}$ Ingevoerd bij wet pan $18-8-1976$, BGB1. $1976 \mathrm{I}, 2181$.

598. BGHSt 28, 26.

599. Bundestag-Drucksache $7 / 3030$, p. 5 en 8 .

600. Bundestag-Drucksache $7 / 4549$, p. 3.

316 601. Zoals een misdriff tegen het leven of tegen de persoon- 
1. Jke vrijhe1d, Landuredesbreuk, roof of brandstichting *

602. BGD1. 1976 I, 1056.

609. Nar S. Cobler, Konzesstonterte Komunikation, in: M. Klenzle/D.Mende, Zensur in der Bundesrepubllk, 1981 Minchen/hlen, p. 90 e.w., ad p. 99.

604. Zie J. Wagner, Drel Jahre Par. 88a StGB - elne Zwischenbalanz, 12 ZRP 280 (1979), p. 281 .

605. Vgl. Bundestag-Drucksache 8/3565, p. 7; Wagner (nt. 604), p. 280; Cobler (nt. 603), p. 101. Een uitspraak wan het BGH is te vinden in 33 NJM 406 (1980).

606. Zie roor een valled18 overzicht van de korte geschiedenis van par. 88a StGB, Wagner (nt. 584), p. 280. Voor de vrijspraak in Dortmind, mar de veroordellng in Keulen van twee boekhandelaars, die geen wan belden van de inhoud van een geschrift op de hoogte waren: 3 . Internat 1 onales Russe11-Tribunal, ultgegeven door Jury, Deutscher Belrat tind Sekretarlat des 3. Internationalen Russel1-Tr1bunals, Band 3, 1979 Berlin (W), p* 58.

607. Wet van 17-8-1981, BGB1. 1981 I, 808 (vg1. BundestagDrucksache 8/3911), samen met de ereneens in 1976 lingevoerde, maar noolt gebrulkte par. 130 a StGB, dat ana$100 \mathrm{~g}$ an par. 88a StGB handleidingen m.b.t. geweldsdeItcten strafbaar stelde, welke geschlkt waren de bereltheld bij anderen te bevorderen zulke delfcten te begaan, bijv. the Anarchist Cookbook (vg1. E. Dreher/H. Trôndle, strafgesetzbuch, 40. Auflage, 1980 Mituchen, p. 651).

608. BGHSt 28, 312 (315). Evenuln was sprake van grondrechtsverwerking ordat de bepaling represslef en ntet prevent lef serkt.

609. Bundestag-Drucksache $8 / 3565 \mathrm{~m} \cdot \mathrm{b} . \mathrm{t}$. par. $88 \mathrm{a}$ StGB.

610. Vg1. G. Grönwald, Meituungsfretheit und Strafrecht, 13 KJ $291(1980), \mathrm{p} .298$ e.W.

611. BGH $13 \mathrm{KJ} 68(1980)$.

612. BGH $31 \mathrm{NJW} 58(1978)$.

613. Aldas Cobler (nt. 603), p. 105.

614. BGH 13 KJ 68 (1980) 72 .

615. Vg1. ook de veroordel1ng ex par. 140 StGB door OLG Braunschwelf 31 . NJW 2044 (1978) wegens het zonder commentar publiceren van en artikel, dat zelf een overtreding van par. 140 StGB tinhoudt.

616. KG Der11n 12-2-1979, naar Cobler (nt. 603), p. 103. 
617.

618. MGASt 29, 258 (269). Vg1. echter BGII 31 WW 58 (1978) 59: het citeren van delen wan het Bomm1-boek in de pers a Is informatleverstrekking of als wardevrlye documentatfe ts geoorloofd, ald duldelijk is dat geen identiflcatie met de schrifver plaataindt.

619. Vg1. G. Krutzk1, "Verungllapfung des Staates und selner Symbole" - Elne Dokumentation zu par. 90a StGB, $14 \mathrm{RJ}$ 294 (1981), p. 295 e.v.

620. Rrutzk1 (nt. 619), p. 297. In de beginjaren van de Bondsrepubliek werd de bepaling echter vooral tegen rechtsextremistische meningsultingen in steliling gebracht. Twee voorbeelden zijn te vinden in BGHSt 3,346 en 7 , 110, die hieronder nog besproken worden. Zile voor de popularitelt van par. 90 StGB in het midden van de Jaren zeventig: 3. Internationales Russel1-Tribuna1 (nt. 606), P. 101 e.v., ad p. 107 e.v.

621. Vgl. Krutzk1 (nt. 619), p. 294 en 314. In beglnsel positief echter F.C. Schroeder, Probleme dex Staatsverumglimpfung, JR 89 (1979). Par. 90a StGB 1s voorwerp van discussie geweest tijdens het Derde Internationale Russelltribunal en ook dar stelde men de constitutionele ondeugdel1jkheld vast; vgl. 3. Internat tonales RussellTrlbunal (nt. 606), p. 110 .

622. BVerfGE 47, 198 (232).

623. Grinwald (nt. 610), p. 295 e.vi; Krutakl (nt. 619), p. 314 .

624. Grünwald (nt. 610), P 295.

625. Krutzk1 (nt. 619), p. 298 e.v.

626. Id* P. 300 .

627. BGASt 6,324 (325); OLG Hamm 30 NJW 1932 (1977).

628. Krutzk1 (nt. 619), p. 307.

629. Vgl * par. $93 \mathrm{StgB}$ (oud) (nt. 537).

630. Grinka1d (nt. 610), p. 296. Vgl. ook H. Cople, Grundgesetz und polftisches Strafrecht never Axt, 1967 Tibingen, p* 90 e.w., p. 109 e.v.

631. Zle OVG Koblenz 30 NJW 970 (1977) en de vrijspraakgevallen, genoend door Krutzk1 (nt. 619), p. 305 nt. 74 en p. $309 \mathrm{nt} .82$.

632. Zie de voorbeelden b11 Krutzk1 (nt. 619), p. 307 e.v.

633. Bverfot 39, $334(359)$. 
634. BaHst 29,50 (53). Zie ook Dreher/Trondle (nt. 425), p. 577 .w. par. 90a HCB.

635. BGHSt $3,346$.

636. BGist $7,110$.

637. BGist 7, 110.

638. Respectievelljk LG Hagen 2-2-1978, nat Krutzkd (nt. 619), P. 304 e.V.: VGH Mannheirn 29 WJW 2177 (1976); AG KöIn 2-12-1974, naar Krutzki (nt.619), p. 310 e.v* 7le werder ook Cobler (nt. 603), p. 95 e.v.

639. Zie: Dokumentation zu den Prozessen wegen des "BubackNachrufs", I1 KJ $280(1978) ; 11 \mathrm{KJ} 432(1978) ; 12 \mathrm{~kJ}$ $312(1979) ; 13$ kal $208(1980)$.

640. LG Göttingen 32 NJW 1558 (1979) 1558.

64 1. LG Göttingen 32 NJW 1558 (1979) 1559*

642. De verklaring is te vinden In: S. Wetterich, Opposition gegen Zensur, in: M.KLenzle/D.Mende, Zensur in der Bundesrepublik, $198 \mathrm{l}$ München/Wten, p. 269 e.w., ad p. 281.

643. LG Götingen 32 NJW 1558 (1979) 1559/1560.

64.4. LG Götingen 32 NJW 1558 (1979) 1560.

645. LG Gattingen 32 NJW 1558 (1979) 1560.

646. Vgl. de documentatle (nt. 639), 11 kJ 280 (1978), p. 281. De mintster van justitie diende tegen alle publicatles een aanklacht in (Wettertch ( $n t .642), p .280$ ).

64.7. Vg1. de Inventarisatle in de documentatie (nt. 639), 11 K.J $280(1978)$, P. $282 / 283$.

648. AG Bonn-2 11 KJ 288 (1978); AG Heldelberg 11 KJ 284 (1978).

649. AG Ditsseldorf 11 KJ 284 (1978).

650. $A G$ Bonn-2 $\Perp$ KJ 288 (1978); AG Bonn-3 $11 \mathrm{KJ} 290$ (1978);

HC Bonn-4 11 KJ 291 (1978) 292 .

551. LG Bonn $11 \mathrm{KJ}$ 433 (1978). Vgl. ook AG Bonm-1 $11 \mathrm{KJ} 288$ (1978).

652. KGe Berlin 11 KJ 293 (1978) 294.

653. AG Bonn-1 11 KJ 288 (1978); LG Bremen 11 KJ 435 (1978); AG Disiseldorf $11 \mathrm{KJ} 284$ (1978).

654. AG Frankfurt II KJ 285 (1978). 
656. LG oldenburg $12 \mathrm{KJ}$ 314 (1979) $315 \mathrm{e}$. v. bevestigd door BGH $13 \mathrm{KJ} 209$ (1980). Schroeder, Probleme der Staatsverunglimpfung (nt. 621), p. 92 betreurt de wrljspraak.

657. LG Oldenburg $12 \mathrm{KJ} 314$ (1979) 315.

658. OLG KOIn 32 NJW 1562 (1979). Evenzo OLG Frankfurt 12 KJ $318(1979) 319$.

659. U. Mickenberger in de documentatie (nt, 639), 12 KJ 312 $(1979), p .320$ o.g.w. BVerfGE $20,162(176)$.

660. BVerfGR 43,130 (139/140).

66L. OLG Köln JR 338 (1979). Anders oordeelde de rechter in en conflict betreffende een sticker, warop de Hessische leew, het wapen van de deelstat hessen, stond afgebeeld met een helm op de kop en een met bloed besmewrde knuppel $\mathbb{1 n}$ de hand. De stlcker was een protest tegen de startbahn West. Het betrof een meningsultiag, die door AG Frankfurt (16-112-1982, Aktenzelchen 50Js $27595 / 82-918 \mathrm{Cs}$ ) met het oog op de betekenis van de ulting voor de meningsvorming toelatbaar werd geacht, mar nlet door de beroepsinstante, LG prankfurt (17-11983, Aktenzelchen 5/31Q617/82); vg1. Würtenberger, Sitire und Karlkatur in der Rechtsprechung (nt. 530), p. 1147. Het artistieke apect speelde kennelifik b1 de beoorteldng geen rol. Zle voor par. 90a StGB als eventuele beperking wan de kunstwritheid Zechlln (nt. 513), p. 1092/1093: de In par. 90a StGB genoende statssymbolen hebben geen constitutionele rang.

662. BVerfgE 33,52 (71). Vgl. ook 3.6.2.

663. AG Glessen $16, \mathbb{1} 8$ en $19-\mathbb{1} \mathbb{1}-1982$, Aktenzelchen 51Ls7Js $1169 / 82$; vg1. Wirtenberger, Sat1re und Karikatur in der Rechtsprechung (nt. 530), p. 1148 .

664. Vaa 19-3-1956, BGB1. 1956 I, 114 .

665. BVerfGE 28, 36. Vg1. 3.2.6.

6616. BVerfGE $28,36(47)$.

667. BVerfGE 28, 36 $(48 / 49)$.

668. BVerfGE 28, $36(49)$.

669. BVerfGE 28, 36 (50).

670. Vgl. Lameyer (nt. 8), p. 50/51.

671. BVerfGE 28, 55 (63).

672. BVerfGE 28,55(64). 
573. Vgl. BVerfGE 28,282 (289 e.v.) i.t.t. BVerwGE 43, 4. Tevens BWerfGE 44, 197 (201 e.w.), zil het hiler wet regengesteld resultat; zie echter de afwijkende mening in BVerfGE 44, 205. Vg1. ook BVerwGE 63, 37. F. T. Schoch, Vexfassungsrechtliche Grundlagen der Elnschriankung polltscher Betrtigung won Soldaten, 108 AöR 215 $(1983), p .227 \mathrm{e} . \mathrm{v}$. pleit er ewenwel voor art. 17a Ild 1 GG als een lex specialls te zien die art. 5 lid 2 GG verdringt, met als gevolg dat de wisselwerkingsheorle v.w.b. de vrl jheld van menlingsulting van militairen buften werking wordt gesteld.

674. BVerfGE 39,334 (367).

675. Vg1. ook 3.2.6. Zie bljwoorbeeld VGH Mannhelm 36 NJW $1215(1983)$.

676. Vg1* de aangehaalde u1tspraken in nt. 84 .

677. Europese Commlsile voor de Rechten van de Mens, Appl1catlon no. 9228/80. De ultsprakk is te vinden la Bellekom (nt. 84), p. 490 e.v. Zle voor de tekst van het Verarag. Trb. 1954,154 .

678. Bellekom (nt. 84), p. $486 / 487$.

679. Application no. $9228 / 80(\mathrm{nt} .677), \mathrm{p} .445 / 496$.

680. Id., p. 494.

681. Id., P. 494/495.

682. Id., p. 494 .

683. Id., p. 496 .

684. Id., p. 500 .

685. Id., p. 501. Vgl. daarentegen de ultopraak in Application no. $9704 / 82$, Bellekom (nt. 84), p. 502 e.v.

686. BVerfGE $39,334(367)$.

687. Zie 3.4.3.2.

688. VG Hamburg 32 NJW $2164(1979)$.

689. VG Ber1in 32 NJW 2629 (1979). Zie verder H.E. Lusken, Zur Melnungs frethet to Sonderstatusverhat tols, 33. NJW 1503 (1980). Voor de veltheld van meningsulting van rechters en hun pllcht tot terughoudendheld: BVerfG 36 NJW 2691 (1983); H. Sendler, Was durfen Rlchter in der oeffentlichke1t sagen? 37 NJW 689 (1984); H.J. Wipfelder, Was darf elm Rlchter sagen? 61 DRIZ 337 (1983). Kitisch jegens een a1 te enthouslaste beperklng van de vrlfheld van meningsulting van ambemaren, rechters, militairen, etcetera: Wöffler, Die Komunikationsfrethelt im Einordnungsverhatitnis, 37 w.JW 1206 (1984). 


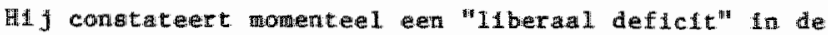
Bondarepubliek ten anzien van deze groepen (p. 1207).

690. Men denke an par. 86a, 88a en 90a StGB.

691. Vg1. 3.6.5.

692. Multhateral Treaties, deposited with the Secretary-General; status as 31 December 1981 , VW-Document St/ LEG/SER.E/1, D. $12 \mathbb{1}$.

693. Tr. 1951, 154.

694. Bundestag-Drucksache $7 / 660$, p. 36 .

695. Ibid.

695. Van 28-4-1965, BGB1. $1965 \mathrm{I}, 353$.

697. Par. 6 11d 1.

698. Par. 6 lid 2.

699. Par. 6 lid 3; of dit het geval is dient te worden bepald aan de hand wan de criterla, dle ten aanzien van art. $2111 d 2$ GG zl jn ontwikeld. Vg1. 3.2.4.2. en A.Kloesel/R.Chrlst, Deutsches Ausianderrecht (Losbladig), 2. Auflage 1980 Stuttgart/Berlin (W)/Köln/Mainz, Kommentar zum Ausiandergesetz, Lieferumg 171981 , p. B.

700. Kloesel/Chrlst (nt. 699), p. 6; OVG Minster 33 NJW 2039 $(1980)$.

701. Vg1. $3.4 \cdot 3 \cdot 1$.

702. Zie 3.8.2. woor een besprek1ng van de lex posterlor-regel.

703. BVerfGE 27,71 .

704. Vg1. 3.6.2.

705. Vg1. Ridder (nt. 165), p. 245/246.

706. Bundestag-Drucksache $7 / 660, p=37$.

707. Hiernee 1 ultwoering gegeven aan art. $26 \mathrm{GG}$, dat het verbod bevat on een aanvalsoorlog woor te berelden.

708. Bundestag-Drucksache $7 / 660$, p. 37.

709. Ibld.

710. I. Seldl-Hohenveldern, Wolkerrecht, 4. Auflage, 1980 Köla/Berlin (W)/Bona/München, p. 53 , D.P. O'Connell, International Law, vollume One, second edition, 1970 London, p. 75 . 
71. Se1dl-Fohenveldern (nt. 710), p. 126. In een deel van de literatur wordt $1 . p . \%$. de transformatieleer de adoptleleer angehangen. In deze visle worden door de toestemulngswet de vertragsbepalingen niet ongezet in national recht, man heeft de coesterningswet later het karakter van een "Awwendungsbefehl", d.w..z. dat de verdragsbepalingen niet de status van een federale wet krifgen, mar dat $21 \mathrm{j}$ met het behoud van hum wolkenrechtelijk karakter intern danwendbaar zijn geworden. (Vgl. Seldi-Hohenveldern (nt. 710), p. 127 e.w.; A. won Ingersleben, Rang und Geltung dex Europalischen Konvention zun Schutze der Menschenrechte und Grund frelheiten in der Bundesrepublik Deutschland, dissertatie, 1967 Bonn, P. 29 en 58, m.b.t. de ECRM; K.J. Partsch, Die Arwendung des volikerrechts lin Innerstatidchen Recht: Ueberprüfung der Transformatlonslehre, in: Berlchte der Deutschen Gesellschaft für Volkerrecht 6, 1964 Karlsruhe, $\mathbb{1} . n$. P. 162). Het gevolg is dat de verdragabepaingen een hogere rangorde dan federale wetten hebben met alle consequentles vandien.

712. BVerfGE 6, 309 (363); Sedd1-Hohenveldern (nt. 710), p. 132.

713. F. Berber, Lehrbuch des Wôlkerrechts, Band I, 2. Auflage 1975 Müruchen, p. 101.

$714 . \quad 1 b i d$.

715. W. Wagner, Die Verwirklichung der Menschenrechte in Pakt der Vereinten Nationen, 1977 Frankfurt(M)/Bern, p. 25.

716. Zo ook de Westduttse regeringsvertegenwoordigster bly de bespreking van het Initial Report van de Bondsrepubliek in het Comles voor de Rechten van de Mens, VN-Document $\mathrm{CCPR} / \mathrm{C} / \mathrm{SR} .96, \mathrm{P} .2$.

717. In 2.10 .2 .

718. zie nt. 716.

719. BGHZ 17, 309 (313), het betrof hiler een privaatrechte11 jke norm. Ygl. A. Bleckmana, Begriff und Kricerlen der Innerstaatlichen Anwendbarkeit völkerrechtlicher Verträge, 1970 Berlin (W), p. 20 .

720. Chr. Tomuschat, Dxe Bundestepublik Deutechland und die Menschenrechtspakte der Verelnten Nationen, 26 VN 1 (1978), P. 4.

721. Ibld.; Berber (nt. 713), p. 103; vg1. BVerfGE 4, 157 $(168)$.

722. Multilateral Treaties (ot.692), p*127.

723. Bundestag-Drucksache $7 / 660, p .27$ en 41. 
724. Gelljkt1jdige behandeling woor elk van belde organen is onmogel1jk ex art. 5 lid 2 sub a Fac.Prot. Trb 1969, 99. Behandeling eerst voor het comite en vervolgens in Straatsburg is niet warschijnlijk wegens de voor Stratuburg geldende voorwarde dat en klacht bunen $z$ es maanden, nadat de nationale rechromidelen $z j n$ ultgeput, moet worden ingedlend (art. 26 ECRM); vgl. Tonus chat (nc. 720), p. 6 .

725. Tomuschat $(\mathrm{at}, 720), \mathrm{p}, 6$.

726. Ib1d.; vgl. H.J. Voge1, Die Menschenrechte in det Bundesrepublik Deutschland, 27 VN $17(1979)$, p. 19.

727. $\mathrm{Vg} 1.3 .6 .6$.

728. Vgl. P. van D1jk/G.J.H. van Hoof, De Europese Conventie in theorte prakt1jk, 2 de druk, 1982 M1 jmegen, p. 352 e.v. Vgl. ook VN-Document CCPR/C/SR.92, p. 5 .

729. Zle voor een vergelljklmg van beide bepalingen het berlcht van de, door het Comté van Ministers van de Raad wan Europa ingestelde, Comulssie van deskundigen van 1-8-1970, te vinden als bljlage in Bundestag-Drucksache $7 / 660$, p. 43 e.v., ad p. 60 e.v.

730. Vg1. GAOR 16th Sesision 1961-1962, Annexes Wolume I, Agenda Item 35, p. 4, nr. 23 (VN-Document A/5000) en $2.10 \cdot 1.3$.

731. Bundestag-Drucksache $7 / 660$ (nt. 729), p. 61 .

732. WN-Document CCPR/C/1/Add. 18 tan 30-11-1977.

733. Der Sichutz der Menschenrechte in der Bundesrepubilike Deutgchland, uftgegeven door het Bundesministerlum der Jugtiz, 1978 Bonn.

734. WH-Document CCPR/C/1/Add. 18, p* 27 e.v.

735. BVerfGE 7, 198 (208)*

736. BVerfoE 12, $113(125)$.

737. BVerfGE 12, $205(261)$.

738. BVerfGE 20, 56 (97/98).

739. HerfGE 7, 198 (207 e.v.).

740. WN-Drocument $\mathrm{CCPR} / \mathrm{C} / 1 / \mathrm{Add}, 18$, p. 30 .

74. VN-Document CCPR/C/SR.92, p. 6.

742. VN-Document CCPR/C/SR. 94, p. 4 .

74. VN-Document CCPR/C/SR.93, P. 11. 
744. Ibid.

745. $\operatorname{Vg1} .3 .6 .2$.

746. VN-Document CCPR/C/SR.92, p. 12 .

74.7. WM-Document CCPR/C/SR.93, p. 13.

74. W. Wocument CCPR/C/SR.96, P. 2 e.v.

749. Id., p. T.

750. Id., D. 3 e.t.

751. Id * P* 4 .

752. Ibld. Vgl. Yearbook of the European Comission of Human Rights $(1955-1956-1957)$, p. $222 \mathrm{e.v} \cdot(250 / 57)$; Van Dujk/Van Hoof (nt. 728), p. 474 .

753. VN-Document CCPR/C/SR. 303; zie voor de tekst van het beslutt (in de thans geldende, geamendeerde versie) CCPR/C/ 19.Rev. 1 .

754. In $V N-D a c u m e n t ~ C C P R / C / 28$ wordt als inleverdatum 3-81983 genoemd. Op 1-10-1984 was het vervolgrapport nog niet verschener.

755. Volgens de in 1981 herzlene richtijnen: VN-Document CCPR/C/20, ar. 5 Part II(a). Vgl. Chr. Tomuschat, Der Ausschuss für Menschenrechte - Recht und Praxis, 29 VN $141(1981), \mathrm{p} .146$.

756. $\mathrm{Vg} 1 \cdot 3 \cdot 6.2$.

757. $\mathrm{gg1} \cdot 3.6 .2$.

753. Art $116 \mathrm{GG}$, BVerfGE 36, 1 (30). Vgl. m.b.t. dit vraagstuk ook de verklarlng van de Bondsrepubllek 1 n samenhang met de brlefwlsseling over de arbeldsmogelljkheden voor journalisten, behorende bij het Grondsilagenverdrag. Ondat DDR-journalisten als Dultsers worden beschouwd, konden ze pas worden toegelaten als lid van de bultenlandse persverentging, nadat deze verenlging haar statuten had veranderd (R. Streinz, Melnungs- und Informationsfretheit zwlschen Ost und West, 1981 Ebels$\operatorname{bach}(\mathrm{M}), p * 174)$. 


\section{Noten bij hoofdstuk 4}

1. $\operatorname{gg} 1.2 .4 \cdot 2$.

2. BVerfGE 2, $1(13)$.

3. Wel merkt art. 12 11d $2 \mathrm{GG}$ op: "Elgentum verpflichtet. Seln Gebrauch soll zuglelch dem Whle der Allgemelnhelt dienen". Dok heeft het BVerfG overwogen dat het elgendomsrecht en andere grondrechten niet onnddellijk eer bepaalde economische orde vastleggen (BVerfGE $4,7(1.7$ e.v.): $\left.50,290\left(336 \mathrm{e} . \mathrm{F}_{\text {. }}\right)\right)$. U1tgangapunt is echter de prive-elgendom. Dat 18 de optlek van warult beperkingen plaatsuinden. Zle verder $K$. Doehring, statarecht der Bundesrepublik Deteschland, 2. Auflage 1980 Frankfurt (M), P. 266 e.v., P. 345 e.w.

4. Vg1. BVerfGE 5*85 (133 e.v.) en 3.2.4.2.

5. Vg1. 2.4.2. en 2.5.1.3.

6. BVerfGE 10, 118 (123): "Das Grundgesetz lässt ... die gegen die frelheltiche demokratische Grundordnung gerichteten politischen Helaungsäusserungen nur soweit zu, als sile dabel wicht selbat gefährdet wird".

7. Vgl. BVerfGE 7, $198(205 / 206)$.

8. Vgl. L.H. Tribe, Amertcæin Constitutional Law, 1978 Mineola N.Y., P. 608 e.v. in het bijzonder ook de afotjkende mening van rechter Branders in whitney versus Callfornla, 274 US $357(1927)$.

9. BVerfGE 5,85(141).

10. Vgl. BVerfGE $10,118(123)$ en art. 211 11d 2 GG.

11. $\operatorname{Vg} 1.3 .2 .3$.

$12 . \mathrm{Vg} 1.3 .2 .6$. en 3.6 .2 .

13. $\mathrm{Vgl} \cdot 3.2 .6$

14. VerfGE $28,36(49)$.

15. BVerfGE $39,334(348)$.

16. $\operatorname{Vgl} 1.3 .2 .6$

17. Vg1. 2.3.3. en 2.4.

326 18. $\operatorname{Vg} 1.2 \cdot 3 \cdot 3$. 
19. Id.

20. 1.2 .4 .2 .

21. In 3.2.7.

22. Zle 3.7. en hlerna onder 4.2.5.

23. $1 \cdot 3 \cdot 4 \cdot 5 \cdot 2$.

24. $V_{g 1} \cdot 3.4 .2$.

25. W $1.3 .4 \cdot 1$. en $3.4 \cdot 3$.

26. 1.3 .6 .1 .1$.

27. Z1e bijwoorbeeld de Mescaleroaffalre, besproken in 3.6 .5 .

28. BVerfGE 20, 162; zie 3.5.7.13.

29. $\operatorname{Vg} 1 \cdot 3.5 .2$.

30. Een bespreking van deze opvatting vindt men in 1.2.1.

31. Vg1. bdfv. BVerfGE 20, $162(175) ; 57,295(319)$.

32. Een bespreking van deze theorle vindt men in 1.2 .1 .

33. Id.; zle w. n. hoofdstuk 1 , nt. 49 en 50 .

34. $\mathrm{Vg} 1.3 .4 \cdot 5 \cdot 2$.

35. Vg1. 2.5.1.3.

36. $\operatorname{Vgl} \cdot 3.4 \cdot 4 \cdot 1$.

37. BVerfGE $57,295(320)$.

38. Zie ook W. Schmitt-Glaeser. Melnungsfretha1t wnd khrenschutz, $38 \mathrm{~J} z 95$ (1983), p. 98, die onder meer zegt: "Gerade für eine frefheitliche demokratische Grundordnung ist beldes gleichermasen wesent lich, dle offentliche ebenso whe die private Melnungsäusserungsfrethelt".

39. $\mathrm{Vgl} \cdot 3.5 .1$.

40. Darmee is aog niet gezegd, dat zif nlet zinvol zouden $21 \mathrm{fn} ; \mathrm{vg} 1.3 .5 .8$.

1. H. $3.4 \cdot 4 \cdot 3$.

42. OWG Mänster 33 NJW $2039(1980)$.

43. Vg1. 2.6. en 2.6.1.

4.4 .61 .3 .5 .7 .1$. 
45. BVerfGE 33, $52(72) ;$ vgl, ook 3.6.2.

4.6. Vig. 3.6.2.

47. Yg. $1.3 .6,3$.

4.8. $\mathrm{Vg} 1.3 .6,5$.

49. $\operatorname{VgI} \cdot 3.6 .4$.

50. BVerfGE 33,78 (85), afw1 jkende meming bij BVerfGE 33 , 52.

51. BVerfGE 7, $198(209 / 210)$.

52. BGHSt 23,$64 ; \operatorname{vgl} 1.3 .6 .3$.

53. Een beapreking van deze theorde vindt inen in 1.2 .1 .

54. Id.: vg 1. bovendien 3.5.

55. Zø E. H. Böcken förde, Grundrechtstheorle und Grundrechtominterpretation, 27 NJW $1529(1974), p * 1537 / 1538$.

56. D.P. O"Conne11, Internationa1 Law, Volume One, second edition, 1970 London, $p, 260$; I. Seld1-Hohenveldern, Völkexrecht, 4. Auflage, $1980 \mathrm{Köln/Berlin(W)/Bonn/Mün-}$ chen, p. 85. Vgl. ICJ-Reporte 1952,175 (196).

57. Vgl. Economie and Soclal Counctl offlclal Records, 14 th Session 1952, Supplement 4, p. $41 \mathrm{nr} .286 \mathrm{t} / \mathrm{m} \mathrm{289}$; vgl. tevens p. $25 \mathrm{nr}$. 162 voor het ontwerp wan het Internathonal Verdrag Inzake Economische, Sociale en Culturele Rechter. Zle ook GAOR 10 th Sesslon 1955, Annexes, Agenda Item 28 (Part I), p. $32 \mathrm{nr} .17 \mathrm{t} / \mathrm{m} 26$ (VN-Document A/ 2929).

58. Vg1. de mening wan A.M. Donner in 4.4.1.

59. Vg1. 3.3., het elnde van 4.4.2. en 4.4.3.

60. Milschien zou het eerlijker zijn, indien de socialistische grondrechtstheorle zou erkennen, dat sommige grondrechten niet met het marxime-leninisme verenigbaar zijn en daarom helemal ntet in de constituties van soclalistische staten zouden moeten worden opgenomen, in plata van ze te garanderen op een wijze, die van het grondrecht nlets meer overlaat; vgl. F.J.M. Feldbrugge, Grondrechten In de marxistisch-1enindstische rechtsleer, 12 NTRR $91(1983)$, p. 98, die meent dat opneming ult propagandaoverwegingen gebeurt, val velgens hem des te meer bewljst, dat het soclalistische grondrechtsbegrip niet meer dan een metamorphose van het traditionelle westerse begrlp 18 .

61. $\operatorname{Vg} 1.2 \cdot 3 \cdot 1$.

62. O"Connel1 (nt. 56), p. 255. Het Heens Verdragenverdrag 
(Trb. 1977, 169) is op 27-1-1980 in werking getreden. Het 1 op grond van art. 4 lleen van toepassing op ver iragen, die na die datum worden afgesloten. Toch is het ook voor de ult leg van het Internationad Verdrag lnzake Burgertechten ien Politiake Rechter relevant, ordat het voor een belangrljk deel als codiflcatie van International gewoonterecht kan forden beschouwd. Volgens het comentaar van de International Law Comission, 61 AJIL 285 (1967), p. 349 e.v., geldt dit voor de bepa1 lingen betreffende de ultleg van verdragen in zeer belangrijke mate. Vgl. p. $349 / 350$ en p. 354 e.v.; het is algemeen geaccepteerd, dat blj de Interpretatla wordt utgegaan van de tekst, dat context en doel van het verdrag daarbl een roll spelen en dat de preambule tot de context behoort.

63. Zie voar eem bespreking van de tekstuele methode F. Berber, Lehrbuch des volkerrechts, Band 1,2 . Auflage 1975 Minchen, p. 478/479; I. Brownlie, Princlples of public Imternational Law, second edition, $1973^{\circ}$ oxford, p. 607 e.v.

64. Die menting is echter wel Berber (nt. 63), p. 479 toegedaan.

65. 0"Connell (nt. 56), p. 255. Zo ook I. Seld1-Hohenveldern (nt. 56), p. 85 .

66. Brownile (nt. 63), p. $607 / 608$.

67. Berber (nt. 63), p. 480 .

68. Vg1. ICJ Reports 1952, 175 (184).

69. Vgl. de vermelding van de eravaux préparatolres als hulpiddel voor de interpretatle in art. 32 Weens Verdragenverdrag.

70. Vg1. 2.7. en 2.10.1.2.

71. Vgl. wat hierower 1s opgemerkt in 2.10.1.3.

72. Id.

73. Id.

74. Vg1. 3.8.3. en zie ook R. Jarosch, Zur Methode des verdeckten Grundrechtsabbaws in der BRD, 25 StuR 74 (1976), p. 82 , die krttiek ultoefent op de beschering wan de vritheld van meningsulting in verband met de conceptie van de strtjdbare democratie.

75. P.J. Boon, Zonder voorafgaande verlof. De writheld van meningsulting in het Nederlandse recht, 3e druk 1983 N1 jmegen. Zie ook A.F.M. Brenninkmeljer, Wan drukperisvritheld tot Informatievr1 theid, A.K.Koekkoek/W. Konlfnenbelt/F.C.L.M.Crijns (red.), Grondrechten, commentaar op hoofdstuk 1 van de herzlene grondwet, 1982 N1jmegen, 
w. 167 e.w.

76. J.A. Peters, Het Primat van de wrifheld wan meningsulthag, 1981 Ni jmegen.

77. Deze term wordt door peters (nt. 76) gebrulkt.

78. P.R.A.P. Dresen, De vrlfe menlngsulting, dissertate V. V.A. . 1949 Amsterdam, p. 61 e.v., 田.n. p. 64.

79. A.J.P. Tammes, Is het gewenst wijalging te brengen in de bestande bepalingen in grondwet en wet betreffemde de vil theld van menlingsulting door middel van drukpers, toneel, film en radio, en $z o$ ja, in welke zin? in: Hande1.1rgen der Nederlandse Jurlsten-Verentging 1949 I, 1949 zwolle, p. 152 e.*., ad p. 153.

80. Ld., p. 158 .

81. J. van der Hoeven, Dlent de uitoefeniag van de grondrechten, welke meningsvorming, meningsulting en informathe betreffen, grondwettel1jk nader te worden geregeld? in: Handellingen der Nederlandse Juristen-Vereniglng 1969 I. twreede stuk, 1969 Zwolle, p. 57 e.v., ad p. $72 / 73$.

82. P.J. Boukema, Enkele aspecten van de vr1 theid van meningsulting in de Duitse Bondsrepubliek en in Nederland, dissertatie V.U., 1966 Ansterdam, p. 102 e.v., m.n. p. 111 .

83. Ibid.

84. Id., p. 266.

85. Ygl. de sumbere opmerkingen in Boukema (nt. 82), p. 84 .

86. A.M. Donner, Dient de uttoefening van de grondrechten, welke meningsworming, menlngsulting en informatle betreffen, grondwettelifk nader te worden geregeld? in: Handellingen der Nederlandse Jur Isten-Verenfging $1969 \mathbb{I}$, tweede stuk, 1969 Zwolle, p. 7 e.v., ad p. 53. Zou men van onvervreendbatheld uitgaan, aldus Donner, dan zouden de grondrechten niet alleen tegenover de staat, maar tegenover ledereen moeten gelden.

8.7. Id., p. $5 \%$.

8.8. Tammes (nt. 79).

89. Peters (nt. 76), p. 2 e.v.

90. Id., p. 4/5. Vg1. ook 1.2.2.

91. Peter (nt. 76), p. 3.

92. Ibld.

93. Id., p. 10, p. $171 e_{*} \mathrm{v}_{*}$ 
94. Id., p. 183 e.v.

95. Id., P. 13, P. 194 e.w.

96. Peters wil zelfs nog werder gam, door te stellen dat ook ondare mededelingen betreffende public speech becherming dienen te genteten. Vgl. Pecers (at: 76), p* 116 en 3.4 .4 .1$.

97. Voor een bespreking van Peters: A. Kors, Het woord vriju1t, 6 NJCM-Bulletin 264 (1981).

98. Zie bifwoorbeeld R. de Winter, De grondslagen van de grondslagen dex vithe:l van meningsulting, 54 NJB 160 $(1979)$, met naschrift van Peters.

99. M.M. Mendel, Geen goede gids, 56 NJB $84 \mathbb{1}(1981), p .841 /$ 842 .

100. Vg1. Peters (nt. 76), p. 88 e.v., m.n. p. 112, Vg1. tevens de argumentatle van de President wan de Masterdamse Rechtbank om een aanklacht af te wlyen, die het voorma1ilge Tweede Kamerlld Imkamp tegen de publleist Brandt Corstlus alias Stoker had ingedlend. Deze had Inkamp onder aanhaling van de rassenwetten var Neurenberg van raclstische opvattengen beschuldigd, nadat Irkamp in een artikel $z i j n$ bezorgdheid had wilgesproken over het sterk dalende aantal geboorten van autachtone Nederlanders en het veel hogere geboorteclffer onder niet-blanken. De rechter oordeelde, dat de ulting van scoker in het algemeen belang was en nlet onnodlg grlevend was gelet op dle ongtandigheid dat Inkamp een publieke flgunr was en gezten de renselijkheid om door krachtdadig woordgebruik de nodige aandacht van het lezend publlek op de kritlek wan Stoker te vestigen; RvdW/KG 1981, 54. Die uitspraak is een erkenning wan de objectieve betekents van de wrijheid van mentingsulting, zoals die Peters voor ogen staat. Zie ook W.J.E.M. van Hövil tot Hesterflier, Vritheld van meningsulting tegen een publieke flguur, 6 NJCM-Bu1letin 302 (1981).

101. C. Flinterman, Nederland op het matje bil de Cammisste voor uftbanning van rassendiscriminatie, 5 NJCM-Bulletin $47(1980)$, p. 49.

102. NJ 1978, 281. Besproken door J.A.0. Eskes, Partifuerbod en kiesrecht, 53 NJB 847 (1978) en door F. Vries, Verbod en ontbinding van racistische organlsat1es, 56 NJB 978 (1981).

103. Zo $H R$ 9-3-1979, WJ 1979, 363.

104. Trb. $1967,48$.

105. Flinterman (nt. 101), p. 49 .

106. Z1e voor een historlsche beschouwing: J.A.0. Eskes, Politleke verenigingsvel theid in Nederland, 5 NJCM-Bulle- 



congt tutitonele recht, 1982 wmegen, p. 119 e.v.

107. De Wet van den $22 \mathrm{sten}$ April 1855 tot regeling en beper$\mathrm{k}$ ing der ultoefenling van het regt van vereenlgling en wergaderlng, Imgedtend bij Koninklljke Boodschap van $25-9-1854$, statablad 32 .

108. Deze crlterla worden besproken door $G$. vam den Dergh, De demacratische staat en nlet-democratische partjen, in: Verboden rechtspersonen, ultgegeven door de NJCM-Boekerif, 1983, Leflen, p. 3 e.v., ad p. 8 e.v.

109. In 1886 vervangen door art. $140 \mathrm{Sr}$.

110. Vgl. E1zInga (nt, 106), p. 123/124.

11. HR 3-12-1894, พ. 6585 .

112. Beglute wan 17-9-1944, houdende vaststelling van thet Besluft Ontbinding Landovertaderlijke organlsatles, $\mathrm{nr}$. E 102 .

113. Eskes (nt. 106), p. 267/268.

114. Zo Vrles (nt. 102) en D.J. Elzinga, Wettelljke regeling racistische partijen dringende noodzaak, Werboden rechtspersonen, uitgegeven door $\mathrm{NJCM}$-Boeker $1 \mathrm{j}, 1983$ Leiden. p. 51 e.v.

115. Tets meer in die richting echter al: Elzlnga (nt. 106), p. 143 e.v. Natul $11 j k$ gat van een beplefting van discrlminatie ladirect wel een gevaar woor het functioneren van de democratie uit; Inzoverre hebben $21 j$, die een schending van het gelljkheldsbeginsel onaanvaardbaar achten, misschien tevens de denocratie op het oog*

116. VrHes (nt. 102), p. 982; een partijuerbod zou bovendien nlet meer door de burgerlijke, maar door de strafrechter moeten worden uitgesproken.

117. Voorstel tat wijziging van enlge bepalingen over verboden rechtspersonen. Biflage Handelingen Tweede Kamer $1981-1982$, nr. $17476, \mathrm{nr} .2$.

118. Voor een besprektng: D.J. Elztnga, De verboden rechtspersioon, 57 MJB 919 (1982).

119. Id., p. 922 .

120. Dit commentar is te vinder in de bundel Verboden rechtspuersonen, ut igegeven door de NJCM-Boeker1j, 1983 Leiden, p. 63 e.v.; hier ad p. 66.

121. Th.L. Bellekom, Part1Jverboden, 1n: A.W.Heringa/R.E. de Winter/w.J.H1teveen (red.), Staatkundig Jaarboek, 1982 Leldien, p. 113 e.v., ad p. 139. Zle tevens de bijdrage wan Bellekom in de discussle over het thema "Botsing van 
Grondrechten" tijdens de Algemene Ledenvergadering van het NJCM op $28-5-1983 ; 8$ NJCM-Bulletin 270 (1983), p. 270 e.n.

122. NJCM-Comentaar (nt. 120), p. 67/68.

123. Wg1. R.E. de Winter, Verbod yoor fascisten, en A.W. Heringa, Vervolglng, racisane effectiever dan verbod Centrum-Partij, in: Verboden rechtspersonen, uitgegeven door de NJCM-Boeker1j, 1983 Lelden, p. 43 e.v. c.q. p. 57 e. .

124. NJCH-commentale (nt. 120), p. 70.

125. Id., p. 72 .

126. Vg1. 3.3.; tevens $\mathbb{R}$. Stern, Das Staatsrecht der Bundesrepublik Deutschland, Band 1, 2. Auflage, 1984 Minchen, p. $572 / 573$.

127. 2le de titel van ijn boek (nt. 76).

128. Zo Brenninkmef jer (nt. 75), p. 168.

129. Vg1. Peters (nt. 76), p. 122.

130. Was de meningsulting ultgelokt door een andere raningsut ing? Vormde zij een adequate reactie? ook op grond van zulke criterta zou Stoker het vam Imkanp hebben gewonnen (vg1. nt, 100). 


\section{Literatuurlijst}

- Areng U., DLe andere Preithelt, 1976 Mtinchen.

- Badura P." Verfassung, Staat und Gesellschaft $1 n$ der Slcht des Bundegver fasingsgerlichts, in: Bundesverfassungsgerlicht und Grundgesetz, Zwelter Band, 1976 Tublingen, p. 1 e.v.

- Be1lekon Th.L., Berufswerbote en het Europese recht, 9 NJCMBullet $476(1924)$.

- Bellekor Th.L., Partijuerboden, in: A.H.Heringa/R.E.de Hinter/ W.J. Wtteveen (red.), staatkundig Jaarboek 1982-1983, 1982 Letiden, p. 113 e.v.

- Berber F., Lehrbuch deg Valkertechts, Band I, 2. Auflage, 1975 Muinchen .

- Bergh G. van den, De democratische staat en nllet-derocrat sche pertiden, 1n: Verboden rechtspersonen, utggegeven door de NJCM-Boeker $1 \mathrm{j}, 1983$ Letden, p. $3 \mathrm{e} . \mathrm{v}$.

- Blekknann A., Begriff und Kriterlen der Innerstaatlichen Anwendbarke1t wölker recht11cher Verträge, 1970 Berlin (W).

- Bleckmann, A., Allgemeine Grundrechtsilehren, $1979 \mathrm{Köln} / \mathrm{Ber}-$ In (W)/Bonn/Minchen.

- Böckenförde E.W., Grundrechtstheorle und Grundrechtsinterpretation, 27 NJW $1529(1974)$ *

- Bốckenförde E.H., Dte Rechtsauffassung 近m kommunlstischen Staat, 1967 Munchen.

- Bôthme E. (red.), Deutsch-deutsche Pressefrelhe1t, 1978 Hamburg.

- Boom P.J., Zonder voorafgaand werlof - De vrijheld van raeningsuting in het Nederlandse recht, 3e druk, 1983 Nifmegen.

- Roukema P.J. Enkele aspecten van de vrijheld van meningsulting in de Duitse Bondarepubliek en in Mederland, dissertate V.U., 1966 Amsterdam.

- Brandner H.E., Das alligemelne Persönllehkeltsrecht in ter Entwlcklung durch die Rechtsprechung, $38 \mathrm{~J} 2689$ (1983).

- Bremninkmeljer A.F.M., Van drukpersurijheld tot fnformatievritheid, in: A.K.Koekkoek/W.Koni jnenbelt/F.C.L.M.Crijins (red.), Grondrechten, comentaar op hoofdstuk 1 van de her le $^{-}$ ne Grondwet, 1982 Nijegen, p. 167 e.w.

- Brownlie I., Princlples of Publlc International Law, second edition, 1973 oxford.

- Brinneck A. von, Pol1tische Justiz gegen Kommuntsten In der Bundestepublik Deutschland 1949-1968, 1978 Frankfurt (M).

- Brugger W., Marx und das Rechtsverständnls tr der DDR, 22 ROW $101(1978)$.

- Brumer G., Enfuhrung In das Recht der DOR, 2. Auflage, 1979 München.

- Humer G., Das Syatem des offentllch-rechtlichen Rechtoschutges lin der DDR, In: R.Lange/B.Melssner/K.Pleyer (red.), Probleme des DDR-Rechtes, 1973 koln, p. 81 e.v.

- Bichner-Uhder W./E.Poppe/R. Schisseler, Grundrechte und Grundpfllchten der Birger in der DDR, 15 St uR $563(1966)$. 
- Bulla E., Die Lehre von der strelcbaren Demokrate, 98 AóR $340(1973)$.

- Cobler Si, Ronzessionlerte Konmulkation, in: M.Kienzle/D. Mende (red.), Zensur ln der Bundesrepublik, 1981 Wünchen/W1en, p. 90 e. $\mathrm{v}$.

- Commentaar van het pederlands Juristen Conlte voor de Mensenrechten blj het ontwerp van wet tat jyziging van enige bepalingen over verboden rechtspersonen, in: Verboden rechtspersonen, ultgegeven door de NJCM-Boekerif, 1983 Lelden, p. 63 e. $v$.

- Coplc H., Berufsuerbot und Pressefreiheit, $18 \mathrm{Jz} 494$ (1963).

- Coplc A., Grundgesetz und politisches Strafrecht neuer Art, 1967 Thiblngen.

- Cajka D." Pressefrethelt und "bffentliche Aufgabe" der Presse, 1968 Stuttgart/Ber lin (W)/Köln/Malnz.

- Dagtoglou P., Wesen und Grenzen der Pressefrethelt, 1963 Stuttgart.

- Damm R. Der Gegendarstellungsanspruch in der Entwicklung der neueren Rechtsprechung, in: Festschrift fur Martin Löff1er, 19:80 München, p. 25 e.v.

- Decken G. von der, Meinungsäusserungsfrethelt und Recht der persönlichen Ehre, 36 NWW 1400 (1983).

- Demokratie, Entwicklungsgesetz des soziallstischen States, ulgegever door Institut fur Theorle des states und des Rechts der Akademie der Wlssenschaften der DDR en Instltut für Stat und Recht der Akaderle der Wissenschaften der UdSSR, 1981. Bier $11 \mathrm{n}(0)$.

- Denulnger E., Frelheltsordnung - Wertordmung - Pflichtordnung, $30 \mathrm{Jz} 545$ (1975).

- Denninger E. (red.). Frelheltilche demokratische Grundordnung, Zwefter Te11, 1977 Frankfurt (M) *

- Denninger E. , Verfasisungstreue und Schutz der Verfassung, 37 WVDSERL 7 (1979).

- Dijk P. van, The Flaal Act of Helsink1 - Basis for a PanEuropean system? XI NYIL 97 (1980).

- DIjk P. van/G.J.H. van Hoof, De Eurapese Conventie in theorie en praktijk, 2e druk, 1982 NLjmegen.

- Doehrting K., Staatsrecht der Bundesrepublik Deutschland, 2. Auflage, 1980 Frankfurt (M).

- Doeming K.B. von/R.W. FUissiein/W.Matz, Entstehungsgeschlchte der Artikel des Grundgesetzes, NF 1 JöR 1 (1951).

- Döschner J., Zehn Jahre bundesdeutsche Korrespondenz In der DDR, 17 DA 859 (1984).

- Dokumente des Unrechts, ultgegeven door Bundesministerium fur Gesamtdeutsche Fragen, 1955-1964 Bonn.

- Donner A.M., Dient de ultoefening van de grondrechten, welke twenlngsvorming, menlngsulting en informatle betreffen, grondwettelijk mader te worden geregeld? in: Handelingen der Nederlandse Jurlsten-Vereniging 1969 I tweede stuk, 1969 Zwolle, p. 7 env.

- Drath M., Stellungmahme zu Problemen der Fortiduer des KPDVerbots, In: Urteil: KPD-Verbot aufheben, 1971 Köln, p. 48 e. v.

- Dreher E./H. Tröndle, Strafgesetzbuch, 41. Auflage, 1983 Munchen . 
- Dresen P.A.A.P., De wije menlngulting, dissertatie U. W.A., 1949 Ansterdan.


Schemer (red.), Die Grudrechte, Band 2, 2. Auflage, 1968 Bierlin (W), p. 507 e.*.

- Dirlg G*, Zum Loth-Urtel1 des Bundesverfassungsger fohts wom 15.1. 1958,11 Dod $194(1958)$.

- Eichhorn W., Demokratle und Fethet in der sozlallstischen Gesellschaft, 31 Einhelt 978 (1976).

- Elzinga D.J., De polutieke partif en het constitutionele recht, 1982 Ni juegen.

- Elzinga D.J. "De verboden rechtspersoon, 57 NJB 919 (1982).

- Elzlnga D.J., Wettelluke regellng rachstische partiden dringende noodaaak, in: Verboden rechtspersonen, wtgegeven door de wJCM-Boeker1J, 1983 Leiden, p. 51 e.v.

- Engels F. Ant1-Dihrling, in: M.Marx/F.Engels, Werke, ultgegeven door Inst tut fur Harxignus-Leninismus bein Zentralkomitee der SED, 1957 Berlln (0), Band 20, p. 1 e.v.

- Eskes J.A.0. Part juerbod en klesrecht, 53 NJB 847 (1978).

- Ekikes J.A.0., Polltieke verenigingswrijheld in Nederland, 5 NuCOY-Bullet 1 a $258(1990)$.

- Rallex H.J., Zu den Elngriffsimglichkeiten des Bundeswerfassungsgerlcht bel Rügen der Verletzung von Melnungs- und Pressefreihelt, In: Restschrift fir Martin Löffler, 1980 München, p. 43 . . . .

- Fastenrath U., volkerrecht1iche Beurtellung der neven DDRBestimmung fuir Journallsten, 12 DA 1174 (1979).

- Feldbrugge F.J.M., Grondrechten in de marxistisch-leninlstische rechtsleer, 12 NTRR 91 (1983).

- F1jalkowsk J* "Die Wendung zum Fuhrerstaat - Idealogische Komponenten in der polttischen Phllosophle Carl Schultts, 1958 Köln/Opladen.

- Finger 0., Dle Fretheft der Persönllchkeit, DZP 397 (1977).

- Filntermar C., Nederland op het matje bij de Commissie voor Uitbanning van Rassendiscrimlnatie, 5 NJCM-Bulletln 47 (1980).

- Frenzel L., Zur Gesellschaftsgefahrlichkelt der staatsverleundung und zu den Kriterien Ihrer Feststellung in Einze1fall, 16 NJ $692(1962)$.

- Frlcke K.W., Polltik und Justiz in der DDR, zur Geschlchte der politischen Werfolgung 1945-1968, 1979 Köln.

- Fricke K.H., Vervollkommung der "sozlalistischen Gesetz-

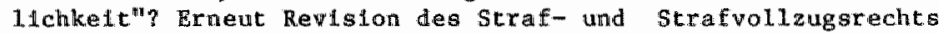
In der DDR, 10 DA $452(1977)$.

- Frosenhahn E. Die Pressefrelheit im Grundrechtssysten des Grundgesetzes, In: Festgabe für otto Kunze, 1969 Berlin (W), p. 24 e.v.

- Fr Lesenhahn E. "Der Wandel des Grundrechtswerstandnisses, in Verhandlungen des 50. Deutschen Jurlstentages, Band II, 1974 Muinchen, $p . G 1$ e.v.

- Gallwas H.U., Der Mlssbrach won Grundrechten, 1967 Berlin (W).

- Geiger W., Des Grundrecht der Pressefrethelt, In: K. Forster (red.), Die Funktion der Presse Im demokratischen Staat, 1958 Minchen, p. 9 e.v. 
- Das Bürgerliche Gesetzbuch, Kommentar, uitgegewem door leden van het Bundesgerichtshof, Band II, 1. Tell, 12. Autiage, 1979 Berlin (W)/New York.

- Göhring J./M.Posch (red.), Zivilrecht, Teil 1, Teil 2, 1981 Berlin (O).

- Grabitz E., Frethelt und Verfassungsrecht, 1976 Tubingen.

- Graefrath B., Zu internationaleu Aspekten der Menschenrechtediskussion, 32 NJ 329 (1978).

- Graf W., Zur Arbeit des Menschenrechtskoniteres, 23 DAP 4, $122(1978)$.

- Greiser P., Verbreltung verfassungsfelndlicher Propaganda,

25 NJW $1556(1972)$.

- Grinmer K., Denokratle und Grundrechte, 1980 Berlin (W).

- Gross I., Die Institucion Presse, 1971 Berlin (H).

- Gross R*, Schranken der Pressefrelhelt, 94 DVBI 833 (1979).

- Grosser A./J.Selfert (red.), Dle Splegel-Affäre, Band I, 1966 relburg.

- Grimwald G., Melnungstrethelt und Straftecht, 13 KJ 291 (1980).

- Gusy C., Dle "Fretheftliche demokratische Grundordnung" in der Rechtsprechung des Bundesverfassungsgertchts, 105 Aở 279 (1980).

- Hacker J., Selbstbestimung, Frellalglgkelt und Melnungsfreihelt nach dem Inkraftereten der UN-Menschenrechtspakte, 24 WN $77(1976)$.

- Räberle P., Das Abhörurtell des Bundesverfassungsgerichts, $26 \mathrm{JZ} 145(197 \mathrm{l})$.

- Haber lle P., Die Wesensgehaltsgarantie des Art. 19 Abs. 2 GG, 3. Auflage, 1983 Karlsruhe.

- Häntzschel K*, Das Recht der freten Meinungsäusserung, $\mathbb{i n}$ : G.Anschütz/R. Thoma (red.), Handbuch des Deutschen Staatsrechts, Band II, 1932 Tubingen, $P .651$ e.v.

- Halbach H., Zur Spezifik des sozlalistischen Journallsmus, dissertatie, 1979 Lelpzig.

- Haney G., Das Recht der Bürger und die tontfaltung der sozlla11 st 1schen Persönlíchkeit, 11 StuR 1063 (1962).

- Haney G., Sozlalistisches Recht und Persönlichke1t, 14 StuR $177(1965)$.

- Hangartner Y., Zweckbindung der Frellheltsrechte? in: Festschrift fur Hans Huber, 1981 Bern, p. 377 e.v*

- Havemann R., Dialektik ohne Dogma? 1964 Relinbek.

- Havemann R., Fragen, Antworten, Fragen, 1970 Minchem *

- Havemann R., Ueber Zensur und Medfen, 9 DA 798 (1976).

- Hegel G.W.F." Vorlesumgen über die Ph1losophle der Weltgeschlchte, Band 1, 2. Auflage, 1920 Le1pzig.

- Her Inga A.W., Vervolglng ractsme effectiewer dan verbod Centrumpart1j, in: Verboden rechtspersonen, ultgegeven door de NJCM-Boeker 1 y, 1983 Leflden, $p=57$ e.v.

- Herrmann E.M., Zur Theorle und Praxis der Presse in der Sowjet1schen Besatzungszone Deutschlands, 1963 Ber11n (W).

- Herrmann F.J., Unsere freie Presse, 31 NDP 1, 5 (1977).

- Herzog R., Allgemelne Staatslehre, 1971 Frankfurt (M).

- Hesse K., Grundzige des Verfassungsrechts der Bundesrepublik Deutschland, 14. Auflage, 1984 Heldelberg/Karlsruhe.

- Hesse K., Der Rechtsstaat in Verfassungssystem des Grundgesetzes, in: Festgabe für Rudolf Smend, 1962 Tubingen, p. 71 e. $v$. 
- Meblinger R./W.Menzel, Das sozlalistische Grundrecht auf frele Metmungsusserung und sielne Veruirkllchumg in der Dentschen Demolkat schen Republik, habllitatle, 964 Leipzig.

- Hochhelden G., Filmzensur, In: M. Rlenzle/D.Mende (red.), Zensur ln der Bundesrepubl1k, 1981 Minchen/WLen, $p .188$ e..

- Hochverrat und Statsgefahrdung, Urtelle des Bundesgerichtshofs, 1957 karlsruhe.

- Mbvel1 tot Westerfier W.J.E.M. van, vrisheid vam meningsulting tegen een publieke figuur, 6 NJCM-Bulletdn 302 (1981).

- Hoeven J. van der, Dient de ultoefening van de grondrechten, welke mengsvorming, meningsulting en informatie betreffen, grondwettell fhe nader te worden geregeld? in: Handelingen der Wederlandse Jurlsten-Veren1g1ng 1969 I tweede stuk, 1969 Zwolle, P. 57 e.v.

- Hofmann K./H. Pischel, Zum Hauptinhalt der Rechte der Burger In den wom sozialfotischen Zlvilrecht der DDR geregelten gesellschaftlichen Verhälenlssen, 10 StuR 1895 (1961).

- Huber E.R.* Bedeutungswandel der Grundrechte, NF 23 Aöll $I$ (1933).

- Huber E.R., Deutsche Verfassungsgeschichte selt 1789, Band II, 2. Auflage, 1968 Stuttgart, Band VI, 1981 Stuttgart.

- Ingergleben A. von, Rang und Geltung der Europäischen Konvention an Schutze der Menschenrechte und Grundfrethettem in der Bundestepublik Deutsehland, dLssertatie, 1967 Bonn.

- Isensee J., Grundrechte und Demokratie, 20 Der Stat 161 (1.981).

- Jarass H.D., Dle Frelhelt der Massenmedien, 1978 Baden-Baden.

- Jarass H.D., Rechtsfragen der Deffentllchkeltsarbeit, 34 NWW $193 .(1981)$.

- Jarosch R., Zur Methode des verdeckten Grundrechtsabbaus in der BRD, 25 StuR 74 (1976).

- Jellinek G., System der subjektiven offentilchen Rechte, onveranderde overdruk van 1919,1964 Aalen.

- Kaschkat H., Dle sozlallstischen Grundrechte in der DDR, 1976 Whit zburg.

- Kaschkat A., Der Rechtsschutz des efnzelnen gegen staat11ches HandeIn in der DDR, In: K. Westen/B.Meissner/F.C.Schroeder (red.), Der Schutz individueller Rechte und Interessen Im Recht soziallstischer Staaten, 1980 Baden-Baden, p. 65 e.v.

- Kelsen $H_{*}$, Allgemeine staatslehre, onveranderde overdruk van 1925, 1966 Bad Homburg/Ber1in (W)/Zirich.

- Klefn H.H., Oeffentilche und pritate Frellhete, 10 Der Staat $145(1971)$.

- Klein H.H., De Gundrechte in demokratischen Stat, 2. Auflage, 1974 Stuttgart/Berlin (W)/Köln/Malnz.

- Kleln H.H., Die Rundfunkfrethett, 1978 München.

- Kletn Ha., Verfassungstreve und Schucz der Verfassung, 37 VNDStRL 53 (1979).

- K1ein Horstpeter, Die bffentliche Aufgabe der Presse, 1973 Düs seldot $\mathrm{f}$.

- Klenner H., Frelhedt und Menschenrecht, 38 Elnhelt 1055 (1983).

- Klenner H*, MarxLsmus und Mensichenrechte, 1982 Ber11n (o). 
- Kenner H., Menschenrechte - Klassenrechte

(1978).

- Klenner H., Menschenrechte und volkerrecht, 33 Elnhe:t 1105 (1978).

- Rlenner H., Die warkistische Menschenrechtskonzeption, in: Gedächtrisschrift fur Rene Marclc, Band 2, 1974 BerIIn (w), p. 793 e. $\mathrm{v}$.

- Kenner H., Studlen uber die Grundrechte, 1964 Berin (0).

- Rloesel A./R.Christ, Deutsches Auslanderrecht (losbladig),

2. Auflage, 1980 Stuttgart/Berl1n (W)/Köln/Malnz *

- Kohlhaas M., Das Zeugniswerwelgerungsrecht des Journalisten, Ln: Festschrift für Martin Loffler, 1980 Minchen, $p$. 143 e.v.

- Koller A., Die wnittelbare Anwendbarkeit völkerrechtllcher Verträge und des EhG-Vertrages in Innerstaatichen Bereich, 1971 Bern.

- Kors A., Het woord vrijult, 6 NJCM-Bulletin 264 (1981).

- Kosing A. (red.), Marxistische Philosophle, 1967 Berlin (0).

- Krafczyk $\omega^{.}$, Auslandlsche Rundfunksendungen as "allgeneia zugängliche Quellen" In Sinne des Art. 5 Abs. I Grundgesetz, 1983 München.

- Kriele M., Einfuhrung in die Statslehre, 2. Auflage, 1981 Opladen.

- Rriele M., Zur Geschichte der Grund- und Menschenrechte, in: Festochrift fur Ulrich Scupin, 1973 Ber1In (W), p. 187 e.v.

- Kröger K., Grundrechtstheor Ise als Verfassungsproblem, 1978 Baden-Baden.

- Kroker E./T.Velter (red.), Rechtsposttivismus, Mensichenrechte und Souweränttätslehre in verschledenen Rechtskreisen, 1976 Wien/Stuttgart.

- Krifger H., Allgemelne Staatslehre, 2. Auflage, 1966 Stuttgart/Berlin (W)/Koln/Malnz.

- Krutzk1 G., "Verunglimpfung des staates und selner Symbole", eime Dokumentation zu Par. 90a StGB, 14 KJ 294 (1981).

- Kuczynsk1 J., Menschenrechte und Klassenrechte, 1978 Ber $11 \mathrm{a}$ (0).

- Rull E., Zur "offentlichen Aufgabe" grundrechtsgeschitzter Presse, In: Festschrift für Martin Löffler, 1980 Minchen, p. 187 e.v.

- Kutscha M., Verfassung und "streltbare Demokratie", 1979 Koln.

- Laband P., Das Staatsrecht des Deutschen Reiches, Band I, 2 . Auflage, 1888 Freiburg.

- Lameyer J., Streltbare Demokratle, 1978 Berlin (W).

- Lange H., Pressefrethelt kontra Manipulation, 32 NDP 3, 21 $(1978)$.

- Latuer G., DLe frelheltliche demokratiche Grundordnung, 2. Aulage, $1982 \mathrm{Könlgst}$ lin/Ts.

- Letbholz G., Der Begriff der frelheltichen demokratigchen Grundordnung und das Bonner Grundgesetz, 66 DWS1 554 (1951).

- Lelbholz 0., Der strukturwandel der modernen Demokrate, 1952 Karlsruhe.

- Lennartz H.A., Zur Rechtsprechung des Bundesverfasungsgerehts zu den politischen Partelen, 1982 Frankfurt.

- Lerche P., Zur verfassungsgerlchtllchen Deutung der Melnungsfrelheit, in: Festschrift ftu Gebhard Muller, 1970 Tubingen, p. 197 e.v. 
- Lerche: P. Verfagungarechtliche Pragen zur Presisekonzentraton, 1971 Berlin (W).

- Lerche P., Pressefrethe1t, In: W. A.Kewenlg (red.), DeutschAmertkant sches Verfassungs 8 ymposium 1976, 1978 Ber1in (W), p. 67 e.

- LI men H.F., Zur Helnungsfrethe1t Im Sonderstatuswerhätnis, 33 NJW 1503 (1980).

- Loffler M., Dle Kommulkationsfrelhelt Lm Enordnungsverhalen18; $37 \mathrm{WJW} 1206(1984)$.

- Löffler M., Presserecht, Band I (Allgemelne Grundlagen, Verfassung- und Bundesrecht), 2. Auflage, 1969 Munchen, Band I (Die Landesprassegesetze der Bundestepublik Deutschland) (voorheen Band TI), 3. Auflage, 1983 Mumchen.

- Loffler M. Der Verfassungsautrag der Presse, Modellfall Splegel, 1963 Karloruhe.

- Loffler M./R.Ricker, Handbuch des Presserechts, 1978 Munchen.

- Lö Ko K., Dle Grundrechte - Verständnis und Wiklichkett in belden Telien Deutschlands, 1977 Munchen.

- Luchterhand 0., Der Rechtsischutz des einzelnen in Staatsund Verwaltungsrecht, in: K. Westen/B. Melssner/F.C. Schroeder (red.), Der Schutz Individueller Rechte und Interessen fur Recht goztallsticher staaten, 1980 Baden-Baden, p. 35 e.v.

- Lugge C./R.Mand/R. Rost, Sozlalismus und Menschenrechte, 26 StuR $789(1977)$.

- Luhmann N., Grundrechte als Inst1tution, 2. Auflage, 1974 Berlin (W).

- Mampel S., Dle sozlallstische Verfassung der DDR, 2. Auflage, 1982 Frankfurt (M).

- Mampel S., Die Verfassung der sowjetischen besetzten zone Deutschlands, 2. Auflage, 1966 Prankurt (M)/Berlin (W).

- Manpel s., DLe Verwirklichung der politischen Menschenrechte In der elnfachen Gesetzgebung der DDR? in: G. zileger/G. Brunner/ S.Mampel/F. Brracora, Die Austibung statlicher Gewalt in Ost und West nach Inkraftreten der WNO-Konvention ther zivile und politische Rechte, 1978 Heldelberg/Karlsrthe, p. 61 e.v.

- Mangoldt H. yon/F.Klefn, Das Bonner Grundgesetz, Band I, 2 . Auflage, 1965 Ber1in. (W)/Erankfurt (M) *

- Marx K., Zur Judenfrage, in: K.Marx/F. Engels, Werke, ultgegeven door Inst thut fur Marxismus-Leninismus befo Zentralkomitee der SED, 1957 Berlin (O), Band $1, p .347$ e.v.

- Mar: K., Zur Kritik der politischen Dekonomle, in: zle boven, Band 13, p. 3 e.v.

- Marx K., Manifest der Kommuistischen Parkel, in: zle boven, Band 4, p. 459 e.v.

- Marx K. , Parlser Manuskripte, in: zle boven, Jrgatizungsband, Erater Tell, p. $465 \mathrm{e}$. v.

- Marx K./R. Engels, Deutsche Ideologle, th: zte boven, Band 3, p. 9 e...

- Marx K./F.Engels, Pressefrelhelt und Zensur, 1969 frankfurt (M).

- Manz R./G.Dur $1 \mathrm{~g} /$ R. Herzog, Kommentar zum Grundgesetz (Losblad 1 g), 1968 Mtunchen.

- Maunz Th./R.zippelius, Deutsches staacsrecht, 2. Auflage, 1982 Minchen.

- Mendel M.M*, Geen goede g1da, 56 NJB 841 (1981). 
- Morschel M., Fustionskontrolle im Presseberelich, $39 \mathrm{JZ} 493$ (1984).

- Mohr M., Die Grundprinziplen des allgemein-denokratischen volkerrechts wad die Konferenz yon Helsiak1, 22 DAP 2, 24 (1977).

- Mulberger * Zum Tatbestand der stagufeindichen Hetze. 23 WJ 50 (1969).

- Miller F., Normstruktur und Normativita, 1966 Berlin (W).

- Muller-Römer D., Die: Grundrechte 1n Mitteldeutschland, 1965 Köln.

- Nipperdey A.C., Boykote und Frelle Melnungsasuserung, 73 DVB1 $445(1958)$.

- Noldeke W., Mochmals: NS-Symbole in polittischem Tageskampf, 32 NJW $2119(1979)$.

- Nuspliger K., Pressefrelheit and Pressevlelfalt, 1980 Diessemhofen.

- O'Connell D.P., International Law, Volume one, second adition, 1970 London.

- Destre1ch G., Geschichte der Menschenrechte und Grundfretheftem Im Umiss, 2. Auflage, 1978 Berlin (W).

- Ossenbithl F., Die Interpretation der Grundrechte in dex Rechtsprechung des Bundeswerfassungsgerichts, 29 MJW 2100 $(1976)$.

- Ossembih1 F., Versamlungsfrethett tnd Spontandemongtration, 10 Der staat $53(1971)$.

- ot to H. Ehrenschutz in der polltischen Ausellnandersetzung, JR $1(1983)$.

- Palandt 0., Burgerliches Gesetzbuch, 42. Auflage, 1983 Minchen.

- Papter H.J., Ueber Pressefrethelt, 13 Der staat 399 (1974).

- Partsch K.G., Die Anwendung des Wolkerrechts im innerstaatlichen Recht: - Ueberprafung der Transformationslehre, in: Berichte der Deutsichen Gesellschaft fur vilkerrecht 6,1964 Rarlsruhe.

- Peters J.A., Het primaat van de vrijheld van meningsuiting. 1981 Nijmegen.

- Pappe E., Die Bedeutung der Grundrechte und Grundpflichtem des Burgers In der sozlalistiachen Gesellschaft, 32 N.J 326 (1978).

- Poppe E. Gedanken zum stand dex sozlalistischen Grundrechtistheorle und -Forschung in der DDR, 24 stuR 1333 (1975).

- Pappe E. (red.), Grundrechte des Birgers In der sozlalistischen Gesellschaft, 1980 Berlin (0).

- Poppe E., Kar1 Marx und dle Menschenrechee, 37 NJ 92 (1983).

- Poppe E., Marx und (burgerliche) Menschenrechte, 32 Stur 267 $(1983)$.

- Poppe E., Mensichenrechte - elne Klassenfrage, 1971 Berdin (O).

- Poppe E., Die politlachen und persönlichen Rechte und Frefheiten im Syster der sozialistischen Grundrechte, 28 stur 806 (1979).

- Poppe E. Der Verfassungsentwurf und die Grundrechte und Grundpflichten der Bürger, 17 StuR 532 (1968). 
- Poppe 2./H. Be11, Das Grundrecht der Mednungs- und Pressefretheit in der sozlallstischen verfassung ter DOR, 23 NJ 353 $(1969)$.

- Eoppe E./E. Schüseler, Soztallstsche Grundrechte und Grundpellchten der Burger, 12 StuR 209 (1963).

- Poppe S., Grundpflichten und thr Verluitnis zu Grundrechten, 32 StuR lOB (1983).

- Posch H. $_{*}$ Schult des lubens, der Gesundhelt und des Elgentums vor Schadenszutugung, 2. Auflage, 1979 Berlin (0).

- Pot C.W. van der, Handboek van het Nederlandse Statsrecht, bewerkt door A.M.Donner, 1 le druk, 1983 zwolle.

- Rexir M., "Maulkorb fur Korrespondenten" 12 DA 449 (1979).

- Rlcker R.. Frethelt und Aufgabe der Presse, 1983 Frelburg/ Munchen .

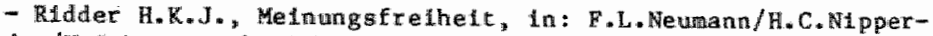
dey/lo. Scheuner (red.), Die Grundrechte, Band 2, 2. Auflage, 1968 Berlin (W), p. 243 e.v.

- Reder B., Die Zensurbegrtffe des Art. 118 Abs. 2 der Welmarer Rellohserfassung und des Art. 5 Abs. I Satz 3 des Bonner Grundgesetzes, 1970 Berlin (W).

- Rlemann T., DLe grosse sozlalistische aktoberrevolution Geburtsstunde det sozfalistachen Menschenrechte, 31 MJ 526 $(1977)$.

- Roellecke G., Melnungskampf und allgemelmes. Persönlichkeltsrecht, $35 \mathrm{JZ} 701(1980)$.

- Raellecke G.., Prinzlplen der Verfassumginterpretation in der Rechtsprechung des Bundesverfassungsgertchts, 1n: Bundesverfassungsgericht und Grundgesetz, Zwelter Band, 1976 Tübingen, p. 22 e.v.

- Roellecke G., Wahrheit, Genednwohl und Melnungsfreihett, 36 J2 $688(1981)$.

- Roggemann H., Die Verfassung der DDR, 1970 Opladen.

- Rosenthal $H_{*}$, Das nese polltiache strafrecht in der DDR, 1968 Erankfurt (M)/Berlin (W).

- Rothenbilcher K., Das Recht der frelen Melnungsäussarung, 4 WWDERL 6 (1928).

- Rotter M., Mensch und Gesel1schaft ausi gtaatlicher und zwischenstaaticher sicht, $1 n$ : Festschrift fir Johannes Messner, 1976 Ber11n (W), p. 527 e.v.

- Rupp H.H., Vom Wandel der Grundrechte, 101 AöR 161 (1976).

- Rïhers B., Persơnllichkeitsrecht und Melnungskanpf, in: Festschrlft für Martin Loffler, 1980 München, p. 303 e.v.

- 3. Internationales Russel1-Tribunal, ultgegeven door Jury, Deutscher Beirat und Sekretariat des 3. Internationalen Rusgel1-Tribunals, Band 3, 1979 Berlin (w).

- Saller C., Verfassungsbeschwerde 1m Ztolel1cht, 10 zRP 303 (1977).

- Sattler A. "Dle rechtilche Bedeutung der Entscheldung fir die steltbare Demokratle, 1982 Baden-Baden.

- Scheuner U., Die institutionellen Garantlen des Grundgesetzer, In: Statstheorle und Staatsrecht, Gesamedte Schrif-

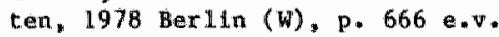

- Scheumer U,, Das Grundrecht der RundfunkfreIhe1t, 1982 BerIn $(w)$.

- Scheuner U., Pressefrelhelt, 22 WWDStR 1 (1965). 
- Scheurer U., Prlvatwirtschaftliche Struktur und offentliche Aufgabe der Presse, In: Staatstheorie und Statsrecht, Gesan melte Schriften, 1978 Berlin (w), p. 759 e.v.

- Schick $W_{*}$. Zwischenbilan in Sachen "Verfassungstreue" der Bearaten, 1 WWw2 161 (1982).

- Schmid K., Frethe1t der Melnungsasserung und strafrechtilcher threnschutz, 1972 Tübingen.

- Schmidt H.W., Aus der Rechtsprechung des Bundesger leht shofs in Staatsschutzstrafsachen, 33 MDR 705 (1979) en 35 MDR 89 (1981).

- Schmidt T*, Die Frelhelt verfassungsidriger Partelen und Vereintgungem, 1983 Berlin (W).

- Schridt Walter, Der verfassungsgerlehtliche Grandrechtsschutz In offentlichen Melnungskampf, 33 NJW 2066 (1980).

- Schmidt Wolfgang/E. Wächter, deffentlichkelt, bffentliche Melnung und staatliche Deffentichkeltsarbeit, 1979 PotsdataBabelsberg.

- Schmict $C$., Freheltsrechte und institutionelle Garantien der Refchsverfassung, In: Verfassungstechtliche Aufsatze aus

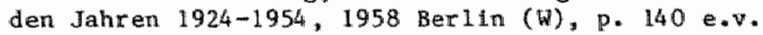

- Schmitt C. Grundrechte und Grundpflichten, in: zie boven, P. 181 e.v.

- Schmite C., Verfassungslehre, onveranderde overdruk van 1928,1970 Berlin (W).

- Schmit W.0. "Der Begriff der freiheltichen derokratischen Grundordmung und Art. 79 Abs. 3 des Grundgesetzes, 18 DoV 433 (1965).

- Schmitt-Glaeser. W. Melnungsfrefhelt und Ehrenschutz, $38 \mathrm{JZ}$ $95(1983)$.

- Schmitt-Glaeser W., Dile Meinungsfrethelt in der Rechtsprechung des Bundesverfassungsgerichts, $97 \mathrm{ABR} 60$ en 276 (1972).

- Schmit-Glaeser W., Missbrauch und Verwikung von Grundrechten im politischen Melnungskampf, 1968 Bad Homburg.

- Schnelder F., Presse- und Meinungsfrelheit nach dem crundgesetz, 1962 München.

- Schnelder P., Pressefrethett und staatsslcherhelt, 1968 MaInz.

- Schnur R., Pressefretheit, 22 WvostRL 101 (1965).

- Schoch F.K., Vertassungorechtliche Grundlagen der Einschränkung poiftischer Betătigung von soldaten, 108 AöR 215 (1983).

- Scholier H., Person und Deffent1ichke1t, 1967 München.

- Schroeder F.C., Probleme der staatsverungllmping, JR 89 (1979).

- Schroeder F.C., Der Schutz von Stat und Verfassung 1 m Strafrecht, 1970 München.

- Schroeder F.C., Die neue strafrechtareform der DDR, 12 DA $1064(1979)$.

- Schroeder F.C., Die strafrechts- und strafprozesgreform der DDR won $1974 / 1975,30$ NJW 169 (1977).

- Der Schutz der Menschenrechte in der Bundesrepublik Deutschland, ultgegeven door Bundesmlntatertun der Justiz, 1978 Bonn.

- Schwabe J., Probleme der Grundrechtsdogmatik, 1977 Bamberg.

- Schwark E., Der Begriff der "Allgemelnen Gesetze" In Artkel

5 Abschnitt 2 des Grundgesetzes, 1970 Berlin (W).

- Seldl-Hohenveldern 1., Volkerrecht, 4. Auflage, $1980 \mathrm{kbln/}$ Ber lin (W)/Bonn/Minchen. 
- Sendler H. Wa durfen Richter ln der beffentichkelt sagen?

37 . $6896(1924)$.

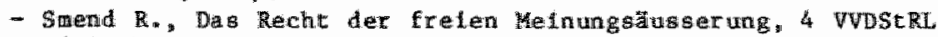
$44(1928)$.

- Saend R., Verfassung und Vertassungstectht, 1928 Munchen

Leipa1g:

- Sorgenlcht K./W. Welchelt/T.MLeman/H.J.Semler (red.). Verfassung der Deutschen. Dewokratishen Republik, Band 2, 1969 Werin $(0)$.

- Starterecht der DDR, uftgegeven door Akademie fur staatsand Rechtswsenschaft der DDR, 1978 Ber11n (0).

- Markistisch-leninistische Stats- und Rechtstheorle, utgegeven door Instlut fur Theorle des States und des Rechts der Akaderle der MLamschatten der DDR, 3. Auflage, 1980 Berlin (O)

- Stamier D., Dle Presse als foxlale und werfassungsrechtilche Institution, 1971 Berlin (W).

- Starck C. Entalcklung der Grundrechte In Deutschland, in: Gedachenisschrift fur Christoph Sassen, 1981 Baden-Baden, p. 777 e.*.

- Stelger B., Frelhelt und Befrelung - Zur Funkton der Grundrechte in der BRD und $4 n$ der DDR, Polltik und Kultur 4 , 15 $(1976)$.

- Stelger H., Instltutionalislerung der Grundrechte? in: H. Schelsky (red.), Zur Theorle der Institution, 1970 Disseldorf, p. 110 e.v.

- Stelnkamm A., Nichtubernahme von Verfassungsgegnern in den affentlichen Dienst, In: Der frelheltileive Rechtsstat und selne Giegner - Mittel und Grenzen der Abwehr, uitgegeven door Deutsche Sektion der Internationalen Jurlsten-Komission, 1979 Karlorwhe, p. 77 e.v.

- Stern K., Da Staatarecht der Bunderrepublik Deutschland, Band 1,1977 en 2 . Auflage 1984 Minchen *

- Stiehler G., (red.), Frethelt und Gesillschaft - Dle Freiheltsauffassung 1 m Marxlsmus-Lentatsmus, 1973 Ber11n (o).

- stollberg F*, Die verfassungarechtichen Grundlagen des Partelverbot: 1976 Ber1in (W).

- Strafreche det Deut schen Demokratischen Republik, Kommentar zum Strafgesetzbuch, uitgegeven door Ministerlutio der Justiz und Akademle für Staats- und Rechtswissenschaft der DDR, 3. Auflage, 1981 Berlin (O).

- Strafrecht, besonderer Te11, witgegeven door Sektion Rechtsmissenschaft der Humboldt Universitat zu Berlin und Akademie fur Staats- und Rechtsulssenschaft der DDR, 1981 Ber lin (O).

- Strelnz R., Melnungs- und Informationsfrethelt zollschen ost und West, 1981 Ebelsbach $(M)$.

- Tames A.J.P., Is het gewenst wijalging te brengen in de bestaande bepalingen in grondwet en wet betreffende de vrijheld van mentingsulting, door riddel van drukpers, toneel, film en radio, en $20 \mathrm{ja}_{\mathrm{a}}$ in welke zin tn: Handelingen der Nederlandse Jur 1 sten-Verentgling $1949 \mathrm{I}, 1949$ zwolle, p. 152 e.v.

- Tetelnger P.J." Der Schutz der persönlichen Ehre 1 frelen Melnungekampf, $38 \mathrm{~J} 2317$ (1983).

- Thesen zum Wesen and zur Encwluklung des sozlalistischen Rechts, 12 Stur $1841(1963)$. 
- Thoma R., Das Systen der subjektiven bffentlichen Rechte und Pfllchten, in: G.Anschitz/R. Thoma (red.). Handbuch des Deutschen Staatsrechts, Band II, 1932 Tublngen, P. 607 e.v.

- Tllborghs H.A.R.I., Vijftig jaar gelleden: de ondergang wan de Weimar-republiek, 58 NJB 415 (1983).

- Tomuschat Chr., Der Ausschuss für Menschenrechte - Recht und Praxis, 29 VN $14 \mathrm{l}(1981)$.

- Tonuschat Chr., Die Bundesrepublik Deutgehland und die Menschenrechtspakte der Wereinten Nationen, 26 VW 1 (1978).

- Trigger E./A.Hayer/H.Krauth, Das neue Staatsschutzotrafrecht in der Praxis, In: 25 Jahre Bundesgerlchtshof, p. $227 \mathrm{e.v}$ *

- Tribe L. A., American Constitutional Lag, 1978 Mineola N.Y.

- Unrecht als Systen, ultgegeven door Bundesministerlum für Gesamtdeutsche Fragen, 1952-1962 Bonn.

- Verdrass A./B.SAma, Dniverselles Volkerrecht, 1976 Ber1in (W).

- Välikerrecht, uttgegeven door Arbeftsgemelnschaft fur volkerrecht befm Institut für Internationale Bezlehungen an der Akadenie für Stats- und Rechtswissenschaft der DDR, Teil $l_{\text {, }}$ 2. Auflage, 1981 Berlin (0).

- Vogel H.J., Dle Menschenrechte in der Bundesrepublik Deutschland, 27 VN 17 (1979).

- Vries F., Verbod en ontbinding van rasclstische organisatees, $56 \mathrm{NJB} 978(1981)$.

- Wagner J., Drei Jahre par. 88a StGB - elne zwlsehenbilanz, 12 ZRP $280(1979)$.

- Wagner W., Die Verwirklichung der Menschenrechte lu Pakt der Verelnten Nationen über bïgerliche und politische Rechte won 16. Dezember 1966, 1m. Grundwertrag und den thn begleitenden Instrumenten, 1977 Frankfurt (M)/Bern.

- Wah1 R., Recht1lche Hirkungen und Funktionen der Grundrecte Im deutschen Konstitutionalimus des 19. Jahrhunderts, 18 Der State $321(1979)$.

- Haldrich H.P., Der Demokratlebegriff der SED, 1980 stut gart.

- Wellbrock R., Persönllchkeltsschutz und Komuntkat lonstre 1heit, 1982 Baden-Baden.

- Wetterlch S., Opposttion gegen Zensur, Ln: M.Kienzle/D.Mende (red.), Zensur in der Bundegrepublik, 1981 Minchen/WLen, p* 269 e.v.

- Wi1l R./H.J.H111, Zur Entwlcklung der marxistisch-lenintst1schen Grundrechtsaufassungen in revolutionären Partelprogramwer der deutschen Arbelterbewegung voli "Komunlstischen Mantfest" bls zum Erfurter Partelprogram, ln: Wissenschaftliche


und Sprachwissensichaftlche Relhe 2,211 (1978).

- W11Hke H., Stand and Kritik der neueren Grundrechtotheorle, 1975 Ber 110 ( (W).

- Whter R.E. de, De grondslagen van de grondslagen der vrijhell wan meningsuiting, 54 NJB 160 (1979).

- Winter R. D. de, Verbod voor fascisten, In: Verboden Rechtspersonen, uitgegeven door de NJCM-Boekerij, 1983 Leiden, p. 43 e.v.

- Wiptelder H.J., Was darf eln Richter sagen? 61 DRIZ 337 (1983). 



ung (Par. 90a StGB), JR 309 (1979).

- Wurtenberger T., Siatre und Karlkatur lin der Rechtsprechung, 36 N.JW 1144 (1983).

- Zechiln L. Kungtfelhe1t, Strafrecht und Satire, 37 NJM $1091(1,984)$.

- Zechlin L*, GerLchtliche Verbote zeltkritlscher Kunst, $15 \mathrm{KJ}$ 248 (1982).

- Zlppeling R., Allgemelne Staatilehre, 8. Auflage, 1982 Minchen.

- Zschledrich A., Probleme der Jurlstischen Garantien der grundlegenden Rechte der Büger, 22 StuR 1177 (1973).

- Zuelgert K./H.DLetrlch, Bundesver fassungsgerlcht - Instituton mit Zukunft? In: Wabuler/G.Kusel (red.), Verfassumggericht und Politik, 1979 Reinbek. 


\section{Rechtspraakregister}

Het rechtspraakreglster verwijst naar de paragrafen, waarin an de witepraken wordt gerefereerd. Alleen gepubliceende uitspraken zijn opgenomen.

A. Bondsrepubliek Duts liand

1. Bundeswenfaesungegeront

Yoor $z$ ver niet anders angegeven is de vindplats: BVerfGE.

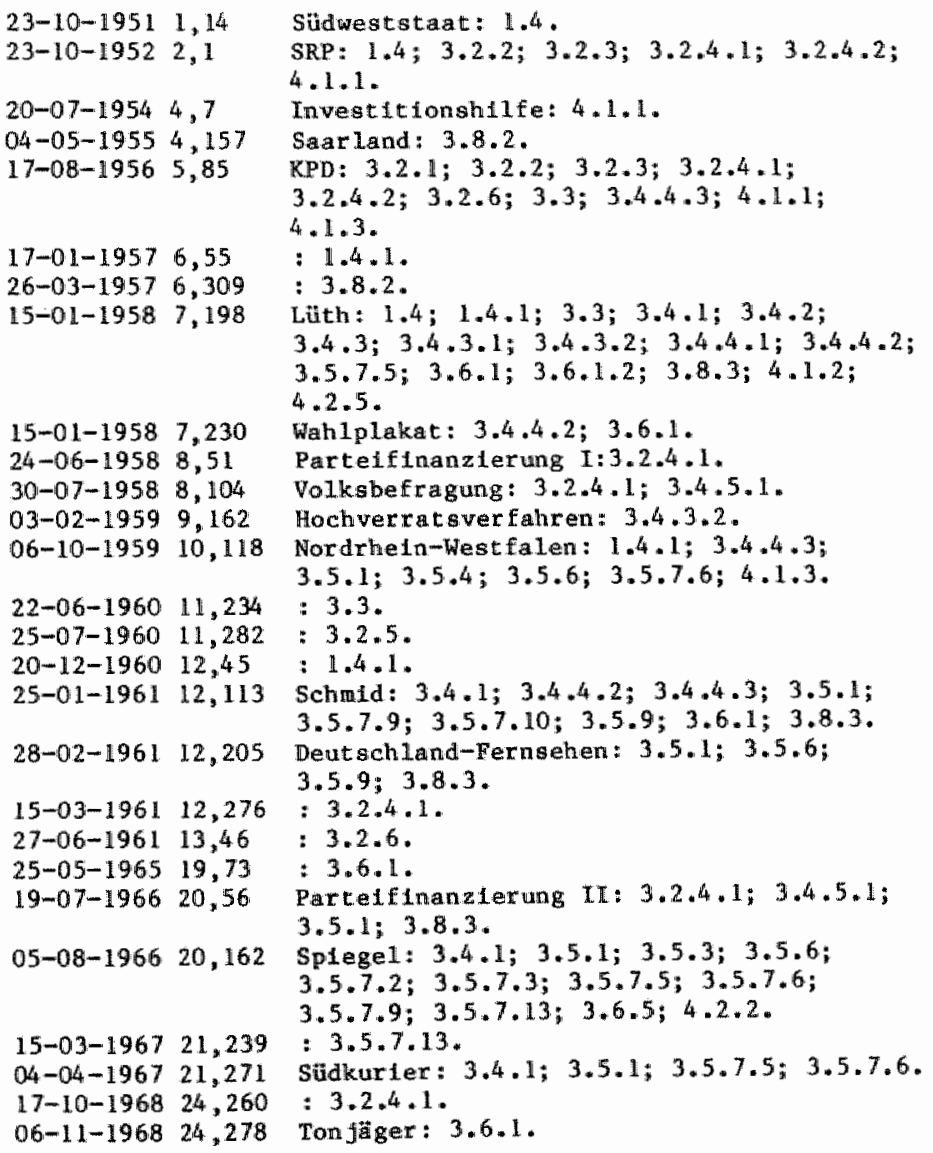


$14-01-196925,44$

$14-01-196925,64$

$14-01-196925,69$

$14-01-196925,79$

$15-01-196925,88$

26-02-1969 25, 256

$03-10-196927,71$

$14-10-196927,88$

$14-10-196927,104$

$18-02-1970 \quad 28,36$

$18-02-1970 \quad 28,51$

$18-02-197028,55$

$15-04-197028,175$

$28-04-1970 \quad 28,191$

$26-05-1970 \quad 28,282$

$15-12-1970 \quad 30,1$

$24-02-1971 \quad 30,173$

23-03-1971 30,336

$27-07-197131,314$

$14-03-197233,1$

$25-04-1972,33,52$

$14-02-1973 \quad 34,269$

05-06-1973 35,202

$27-03-1973 \quad 35,307$

$31-07-1973 \quad 36,1$

$28-1.1-197336,193$

$13-02-1974 \quad 36,314$

$05-03-1974 \quad 36,321$

$02-07-1974 \quad 38,23$

$08-10-1974 \quad 38,103$

$22-0.5-197539,334$

$29-10-197540,287$

$11-05-1976$ \& 2,143

$11-05-1976 \quad 42,163$

$07-12-197643,130$

02-03-1977 44,197

$17-01-1978 \quad 47,130$

$14-02-1978 \& 7,198$

$06-02-1979 \quad 50,234$

01-03-1979 50,290

$24-07-1979 \quad 5,2,63$

$06-11-1979 \quad 52,283$

$13-05-198054,129$

$03-06-1980 \quad 54,148$

$10-06-1980 \quad 54,208$

16-06-1981 57,295

$31-07-1981$ 34 NJW

$13-01-198259,231$

$20-04-1982 \quad 60,234$

$27-04-198235 \mathrm{NJW}$ $22-06-198261,1$
$: 3.2 .6 ; 3.4 .1 ; 3.6 .2$.

$: 3.6 .2$.

$: 3.6 .2$.

: 3.6 .2 .

$: 3.2 .6 ; 3.6 .2$.

1linkfuer: $3.4 .2 ; 3.5 .1 ; 3.5 .7 .5$.

Zeltungen aus der DDR: $3.4 .1 ; 3.4 .5$;

3. 6.2.

* 3.6.2.

$: 3.4 .1 ; 3.4 .3 .1 ; 3.4 .5$.

soldaten: $3.2 .6 ; 3.4 .1 ; 3.4 .3 .1 ; 3.6 .6$. ; 4.1 .3 .

Soldaten: $3.2 .6 ; 3.4 .1 ; 3.4 .3 .1$.

Soldaten: 3.6 .6 .

$: 3.4 .5$.

: 3.4 .4$.

$: 3.4 * 3.1 ; 3.4 .4 .2 ; 3.6 .6 *$

Abhor: $3.2 * 6$.

Mephtsto: $1.4 .1 ; 3.3 ; 3.6 .1 .2$.

$: 3.4 \cdot 3 \cdot 3$.

Unsatzsteuer: 3.5 .9 .

3.4 .4 .1$.

$3.4 .3 .1 ; 3.6 .2 ; 3.6 .5 ; 4.2 .4 ; 4.2 .5$.

Soraya $; 3.5 .7 .1 ; 3.6 .1 .1 ; 4.2 .3$.

Lebach: $3.5 .9 ; 3.6 .1 .1$.

$=3.4 .1$.

*. 3.9.

$: 3.5 .1 ; 3.5 .7 .6 ; 3.5 .7 .9$.

*3.5.7.6.

$: 3.5 .1 ; 3.5 .7 .5$.

$: 3.2 .5$.

$: 3.5 .7 .6$.

Radikalen: $3.2 .2 ; 3.2 .6 ; 3.6 .5 ; 3.6 .6$;

4.1.3.

NPD: $3.2 .4 .1 ; 3.2 .6$.

DGB: $3.4 .1 ; 3.4 .3 .2 ; 3.4 .3 .3 ; 3.4 .4 .2$.

Echtermach: $3.4 .1 ; 3.4 .4 .1 ; 3.4 .4 .2$;

$3.4 .4 .3 ; 3.4 .5 ; 3.6 .1$.

Plugblatt: $3.6 .1 \% 3.6 .5$.

$: 3.6 .6$.

$: 3.2 .4 .1 ; 3.2 .5 ; 3.4 .3 ; 3.4 .3 .1 ; 3.4 .3 .2$.

$: 3.4 .1 ; 3.4 .3 .1 ; 3.4 .4 .2 ; 3.6 .2 ; 3.6 .5$.

kölner Volksblatt: $3.5 .1 ; 3.5 .6 ; 3.5 .7 .3$;

3.5 .7 .6 .

Mitbest1mung: $3.4,5.2 ; 3.5 .6 ; 4.1 .1$.

$: 3.2 .4 .1$.

Tendenzschutz: $3.5 .1 ; 3.5 .7 .3 ; 3.5 .9$.

Kunstkrtt1k: $3.4 .1 ; 3.4 .3 .3 ; 3.4 .4 .2$;

3.6 .1 .

Eppler: 3.6 .1 .1$.

Bơ 11 : $3.4 .4 .1 ; 3.4 .4 .3 ; 3.5 .7 .10 ; 3.6 .1 .1$.

Privat funk in Saar land: $3.4 .5 .2 ; 3.5 .1$;

$3.5 .9 ; 4.2 .2 ; 4.2 .3$.

$2683(1981): 3.2 .6$.

* 3.5.9.

$: 3.4 .1 ; 3.4 .4 .2 ; 3.6 .1$.

$1803(1982): 3.6 .3$.

Melnungsausserung in Wahlkampf: 3.4 .1 ; 
$3.4 .4 .1 ; 3.4 .4 .2 ; 3.4 .4 .3 ; 3.5 .7 .10 ; 3.6 .1$

$15-11-198236$ NJW $1181(1983): 3.4 .2 ; 3.5 .1 ; 3.5 .7 .5$.

$15-11-1982.62,230: 3.4 .1 ; 3.4 .2 ; 3.4 .5 ; 3.5 .1$.

$08-02-198363,131: 3.5 .7 .11 ; 3.6 .1 .1$.

$08-03-198336$ NW $1535(1983): 3.2 .6$.

$10-05-198364.108: 3.4 .1 ; 3.5 .1 ; 3.5 .7 .6$.

$30-08-198336 \mathrm{NJW} 2691 \quad(1983): 3.6 .6$.

15-12-1983 65, 1 Volkszahlungsgesetz: 3.4.4.1.

$25-01-198437$ NJW $1741(1984): 3.4 .1 ; 3.4 .4 .1 ; 3.4 .4 .2$;

$3.5 .1 ; 3.5 .7 .1 ; 3.6 .1$.

\section{Bundesgemichtohof}

$14-10-1952$

$06-05-1954$

25-05-1954

$22-09-1954$

$07-01-1955$

$24-05-1955$

$04-06-1955$

$11-09-1957$

20-01-1959

$22-12-1959$

$25-07-1960$

$13-04-1962$

28-02-1964

$23-02-1965$

$24-06-1965$

$09-08-1965$

15-11-1967

20-03-1968

$29-10-1968$

28-01-1969

20-05-1969

20-06-1969

23-07-1969

$10-12-1969$

29-05-1970

$14-02-1.973$

$03-06-1975$

$17-12-1975$

$08-09-1976$

03-05-1977

09-08-1977

03-0.5-1978

$17-10-1978$

$14-02-1979$

28-02-1979

25-04-1979

20-06-1979

$11-07-1979$

$25-07-1979$

18-09-1979

$03-10-1979$

26-02-1980

$23-04-1980$

26-06-1981
BGHSt 3,346

HuSt 1,74

BGHE 13,334

BCHSt 6,324

BGHSt 7,110

BGHZ 17, 309

HuSt $I, 108$

HuSt II, 159

BGHSt 12,287

BGHZ 31,308

13 NJW 1772 (1960

15 NJW $2019(1962)$

17 NJW 1144 (1964)

I8. NJW 1444 (1965)

18 NJW 1973 (1965)

Ufita 46,349

BGHSt 21,371

BGHZ 50,133

GRLR 147 (1969)

GRUR 368 (1969)

GRUR 555 (1969)

GRUR 624 (1969)

BGHSt 23,64

GRUR 254 (1970)

BGHSt 23,267

BGHSt 25,128

GRUR $210(1976)$

BGHSt 26,258

29 स小 2271 (1976)

30 NJW 1288 (1977)

31 NJH 58 (1978)

BGHSt 28,26

13 KJ 68 (1980)

BGHSt 28,296

BGHSt 28,312

BGHSt 28,394

32 NJW 1992 (1979)

BGHSt 29,50

BGHSt 29,73

$34 \mathrm{JZ} 811$ (1979)

$33 \mathrm{NJW} 406$ (1980)

$13 \mathrm{KJ} 209$ (1980)

BGHSt 29,258

$\mathrm{BGHZ} 81,75$

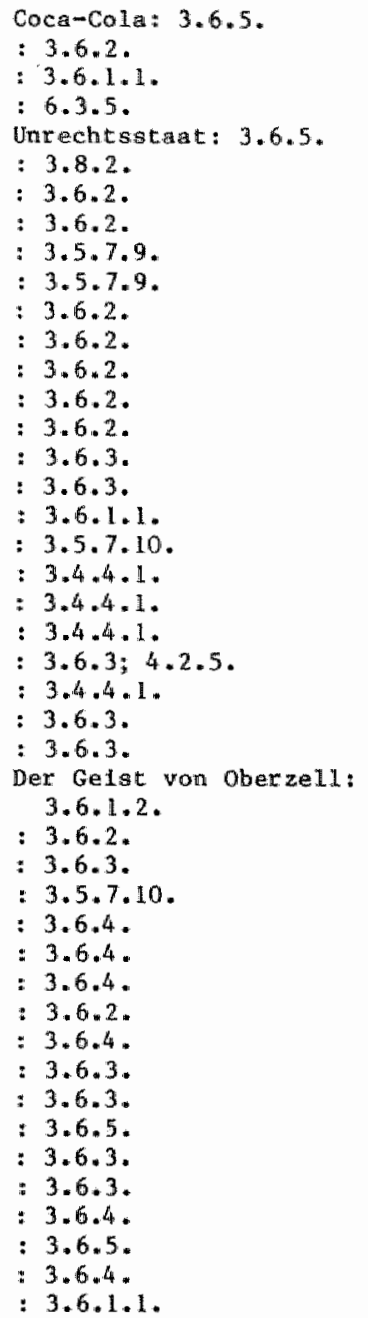




$\begin{array}{lll}08-06-1982 & \text { BGHZ } 84,237 & : 3.6 .1 .2 . \\ 25-10-1982 & 36 \text { NW } 756(1983) & : 3.2 .6 . \\ 25-05-1983 & \text { BGHSt } 31,383 & : 3.6 .3 .\end{array}$

\section{Bayemenes oberates Landergemicht}

$$
\text { 19-07-1962 15 肺 } 1878(1962): 3.6 .3 .
$$

\section{Oberiandeagericht}

\begin{tabular}{|c|c|c|c|c|c|}
\hline Ar angehwe $1 \mathrm{~g}$ & $22-05-1978$ & 31 & NJW & $2044 \quad(1978)$ & $: 3.6 .4$. \\
\hline Celle & $08-03-1963$ & 16 & NJH & $1369(1963)$ & $=3.6 .2$. \\
\hline Cellie & $17-02-1982$ & 35 & NJW & $1545(1982)$ & $: 3.6 .3$. \\
\hline Dusseldorf & $21-12-1977$ & 31 & NJW & $704(1978)$ & $=3.5 \cdot 7 \cdot 10$. \\
\hline Frankfurt & $25-04-1979$ & 12 & $\mathrm{KJ}$ & $318(1979)$ & $=3.6 .5$. \\
\hline Frankfurt & $21-10-1983$ & 37 & $\mathrm{NJW}$ & $1128(1984)$ & $3.6 \cdot 5$ \\
\hline Ha:nburg & $13-05-1983$ & 37 & NJW & $1130(1984)$ & $: 3.6 .1 .2$. \\
\hline Helatum & $02-02-1977$ & 30 & NJit & $1932(1977)$ & $=3.6 .5$. \\
\hline Hatis:BR & $17-03-1982$ & 35 & NWW & $1656(1982)$ & $: 3.6 .2$. \\
\hline Karlisulhe & $01-09-1972$ & 25 & NJW & $1810(1972)$ & $: 3.6 .1 .2$. \\
\hline Koln & $06-06-1978$ & $\mathrm{JR}$ & 338 & $(1979)$ & $: 3 \cdot 6.5$ \\
\hline $\mathrm{KBIn}$ & $02-04-1979$ & 32 & NJW & $1562(1979)$ & $: 3.6 .5$. \\
\hline Stutega & $11-06-1975$ & 29 & NJW & $628(1976)$ & $\begin{array}{l}\text { Wnsere slemens- } \\
\text { Welt: } 3,6,1.2 .\end{array}$ \\
\hline
\end{tabular}

5. Landgemioht

\begin{tabular}{|c|c|c|c|}
\hline Bonm & $23-06-1978$ & $11 \mathrm{~kJ} 433(1978)$ & $=3.6 .5$. \\
\hline Bremen & $28-08-1978$ & $11 \mathrm{KJ} 435(1978)$ & $=3.6 .5$. \\
\hline Bremert & $17-12-1982$ & $36 \mathbb{N J W} 1814 \quad(1983)$ & $: 3.2 .6$ \\
\hline Darmstadt & $01-10-1982$ & 36 NJW $1201(1983)$ & $=3.6 .1$. \\
\hline Gotetugen & $05-04-1978$ & $32 \mathrm{NJW} 1558(1979)$ & $\begin{array}{c}\text { escalero } \\
3.6 .5 .\end{array}$ \\
\hline Hamburg & $27-10-1966$ & $20 \mathrm{NJW} 582 \quad(1967)$ & .6 .2$. \\
\hline Olden burg & $23-02-1979$ & 12 R.J 314 (1979) & 6.5. \\
\hline Stuttgart & $0.5-05-1980$ &  & .6 .1$. \\
\hline
\end{tabular}

6. Amtogeriaht

$\begin{array}{lllllll}\text { Berlin (KGe) } & 10-05-1978 & 11 & \mathrm{KJ} & 293 & (1978) & : 3.6 .5 . \\ \text { Bonn-1 } & 20-12-1977 & 11 \mathrm{KJ} & 288(1978) & : 3.6 .5 . \\ \text { Bonn-2 } & 10-04-1978 & 11 \mathrm{KJ} & 288(1978) & : 3.6 .5 . \\ \text { Bonn-3 } & 14-04-1989 & 11 \mathrm{KJ} & 290(1978) & : 3.6 .5 . \\ \text { Bonn-4 } & 17-04-1978 & 11 \mathrm{KJ} & 291(1978) & : 3.6 .5 . \\ \text { Dusseldorf } & 21-12-1977 & 11 \mathrm{KJ} & 284(1978) & : 3.6 .5 . \\ \text { Frankfurt } & 22-02-1978 & 11 \mathrm{KJ} & 285(1978) & : 3.6 .5 . \\ \text { Heldelberg } & 27-01-1978 & 11 \mathrm{KJ} & 284(1978) & : 3.6 .5 . \\ \text { Scutcgart } & 20-02-1980 & 14 \mathrm{KJ} & 325(1981) & : 3.6 .1 .\end{array}$

7. Bundearabeitegemicht

$\begin{array}{llll}31-01-1976 & 29 \text { NJW } 1708(1976) & : 3.2 .6 \\ 15-07-1976 & 36 \text { NJW } 1812(1983) & : 3.2 .6 * \\ 05-08-1982 & 36 \text { NWW } 779(1983) & : 3.2 .6 * \\ 16-12-1982 & 36 \text { NJW } 1814(1983) & : 3.2 .6 .\end{array}$




\section{Bundesverdaltwnggeriaht}

$\begin{array}{lll}22-05-1965 & \text { BVerWGE } 14,21 & : 1.4 .1 . \\ 11-09-1970 & \text { SVerwGE } 43,48 & : 3.6 .6 . \\ 06-02-1975 & \text { BVerWGE } 47,330 & : 3.2 .6 . \\ 26-03-1975 & \text { BVerWGE } 47,365 & : 3.2 .6 . \\ 22-04-1977 & \text { BVerwGE } 52,313 & ; 3.2 .6 . \\ 12-04-1978 & \text { BVerwGE } 63,37 & : 3.6 .6 . \\ 27-11-1980 & \text { BVerwGE } 61,176 & : 3.2 .6 . \\ 02-12-1980 & 34 \text { NJW } 1796(1981) & : 3.2 .4 .2 . \\ 29-10-1981 & 35 \text { NJW } 779(1982) & : 3.2 .6 . \\ 20-05-1983 & 37 \text { NJW } 813(1984) & : 3.2 .6 .\end{array}$

9. Oberverwaltungagemidht

$\begin{array}{llllll}\text { Koblenz } & 20-09-1976 & 30 \text { NJW } 970(1977) & : 3.6 .5 . \\ \text { Mannhe1m(VGH) } & 22-09-1976 & 29 \text { NJW } 2177(1976) & : 3.6 .5 . \\ \text { Mannhe1n(VGH) } & 26-11-1982 & 36 \text { NJW } 1215(1983) & : 3.6 .6 . \\ \text { Minchen(VGH) } & 04-10-1983 & 37 \text { NJW } 1136(1984) & : 3.6 .1 . \\ \text { Minster } & 19-02-1980 & 33 \text { NJW } 2039(1980): 3.8 .1 .1 ;\end{array}$

10. Vermaltungegeriaht

$\begin{array}{llllll}\text { Berlin } & 20-04-1979 & 32 \text { NJW } 2629(1979) & : 3.6 .6 . \\ \text { Hamburg } & 06-03-1979 & 32 \text { NJW } 2164(1979) & : 3.6 .6 . \\ \text { Köln } & 10-12-1981 & 36 \text { NJW } 1212(1983) & : 3.6 .1 .2 .\end{array}$

B. Dultse Democratische Republiek

1. Oberstes Germicht

\begin{tabular}{|c|c|c|c|c|}
\hline $04-10-1950$ & ogst 1,33 & $:$ & 2.5 .1 .1 & 2.5 .1 .4$. \\
\hline $24-08-1951$ & $\operatorname{agst} 2,214$ & $:$ & 2.5 .1 .1$. & \\
\hline $09-06-1953$ & $7 \mathrm{NJ} 411(1953)$ & : & $2.5 .1 .1 ;$ & 2.7 \\
\hline $02-03-1956$ & $005 \mathrm{~s}, 3,316$ & : & 2.4 .1$. & \\
\hline $18-10-1957$ & DGSt 4,100 & $:$ & 2.5 .1 .3$. & \\
\hline $11-02-1958$ & $\operatorname{OgSt} 4,232$ & : & $2.5 .1 .2 ;$ & 2.7 \\
\hline $04-03-1958$ & 12 NJ $250(1958)$ & $:$ & $2.5 .1 .1 ;$ & 2.7 \\
\hline $11-03-1958$ & $12 \mathrm{NJ} 323(1958)$ & $:$ & 2.5 .1 .2 & \\
\hline $14-03-1958$ & $12 N 287(1958)$ & : & 2.5 .1 .2 & \\
\hline $21-03-1958$ & $\operatorname{OgSt} 4,251$ & : & 2.5 .1 .2$. & \\
\hline $25-04-1958$ & $\operatorname{acsit} 4,254$ & : & 2.5 .1 .2$. & \\
\hline $16-0,5-1958$ & $12 \mathrm{NJ} 494 \quad(1958)$ & : & 2.5 .1 .2 & \\
\hline $16-05-1958$ & $\operatorname{ogsc} 4,267$ & $:$ & 2.5 .1 .2 & \\
\hline $03-06-1958$ & 12 N. $540(1958)$ & : & 2.5 .1 .2$. & \\
\hline $03-07-1958$ & oGSt 4,185 & : & 2.5 .1 .2$. & \\
\hline $11-07-1958$ & ogst 4,190 & $:$ & 2.5 .1 .2$. & \\
\hline $05-09-1958$ & ogst 5,302 & : & 2.5 .1 .2$. & \\
\hline $03-10-1958$ & OGSt 5,307 & : & 2.5 .1 .2$. & \\
\hline $31-10-1958$ & $\operatorname{Ogst} 4,277$ & : & 2.5 .1 .2$. & \\
\hline $21-11-1958$ & Der Schoffe 1959, & $T / 1:$ & 2.7. & \\
\hline $13-01-1959$ & $\operatorname{agst} 5,225$ & ${ }^{*}$ & 2.5 .1 .2$. & \\
\hline $08-02-1960$ & ogst 5,339 & : & 2.7 & \\
\hline $06-07-1967$ & ogst 5,175 & • & 2.7 & \\
\hline $27-09-1961$ & $16 \mathrm{NI} 131 \quad(1962)$ & $:$ & 2.5 .1 .2$. & \\
\hline
\end{tabular}




$\begin{array}{lll}11-05-1962 & 15 \text { Ni } 416(1962) & : 2.5 .1 .3 . \\ 21-12-1962 & \text { ogst } 6,242 & : 2.5 .1 .3 .\end{array}$

\section{Laridgemieht}

\begin{tabular}{|c|c|c|c|}
\hline Bberswade & $04-04-1951$ & $\operatorname{Tas} I 14(10)$ & $: 2.5 .1 .1$. \\
\hline Gotr1t: & $15-05-1951$ & Uas I $17(12)$ & $\begin{array}{l}=2.5 .1 .1 ; \\
2.7 .\end{array}$ \\
\hline $\begin{array}{l}\text { Magdeburg } \\
\text { Potgdan: }\end{array}$ & $\begin{array}{l}25-04-1952 \\
06-11-1950\end{array}$ & $\begin{array}{l}\text { Uas } \text { II } 33(3 / 4) \\
\text { Das I } 11(4)\end{array}$ & $\begin{array}{l}: 2.7 . \\
: 2.5 .1 .1\end{array}$ \\
\hline
\end{tabular}

3. Bezikksgemicht

\begin{tabular}{|c|c|c|c|}
\hline Ber11n (StG) & $a_{4}-11-1955$ & Uas III $122(171)$ & $=2.5 .1 .1$. \\
\hline Derl1a (StG) & $24-11-1960$ & Was IV $104(172)$ & $: 2$ \\
\hline Cottbus & $28-02-1955$ & vas III $116(162)$ & $\begin{aligned}= & 2.5 .1 .1 \\
& 2.7 .\end{aligned}$ \\
\hline Dresder & $13-01-1.954$ & Uas II $137(160)$ & $=2.7$. \\
\hline Dresden & $31-05-1957$ & Vas III $129(169)$ & $: 2.5 .1 .1$. \\
\hline Erfurt & $07-05-1956$ & Was IIL $113(156)$ & $: 2.5 .1$ \\
\hline ferture & $19-05-1959$ & 13 NJ $534(1959)$ & $: 2.7$ \\
\hline Ralle & $02-04-1953$ & Ulas II $114(142)$ & $: 2.5 .1$ \\
\hline Ha1le & $25-09-1953$ & Uas II $118(148)$ & $: 2.7$. \\
\hline Halle: & $11-07-1954$ & das II $110(152)$ & $: 2.5 .1 .1$. \\
\hline Kat $1-\operatorname{Mar} x-$ Stadt & $16-06-1959$ & $13 \mathrm{NJ} 783(1959)$ & $: 2.5 .1 .2$. \\
\hline Letpzigg & $17-04-1953$ & $\operatorname{Uas}$ II $134(157)$ & $: 2.5 .1 .1$. \\
\hline Letpzig & $20-01-1955$ & vas III 120 (168) & $: 2.5 .1 .1$. \\
\hline Le1pzIg & $28-11-1957$ & $\operatorname{Uas} \operatorname{III} 107(151)$ & $: 2.5 .1 .1$. \\
\hline Le1pzig & $28-11-1957$ & 12 NJ $69(1958)$ & $: 2.5 .1 .1$. \\
\hline$L \in 1 p z 1 . g$ & $11-02-1958$ & $12 \mathrm{NJ} 177(1958)$ & $=2.5 .1 .2$. \\
\hline Lefpzig & $20-05-1955$ & La's IV $100(167)$ & $: 2.5$ \\
\hline LeIpzlg & $27-01-1962$ & $\operatorname{DdU} 6,11$ & $\begin{aligned} & 2.5 .1 \\
& 2.7 .\end{aligned}$ \\
\hline Malgdeburg & $04-06-1953$ & Uas IT $120(149)$ & $: 2.7$ \\
\hline Magdeburg & $01-02-1961$ & UaS IV $120(183)$ & $\begin{aligned}= & 2.5 .1 .2 ; \\
& 2.7 .\end{aligned}$ \\
\hline Potsdam & $29-08-1955$ & JaS ILI $113(155)$ & $: 2.5 .1$. \\
\hline Potsdam & $19-01-1962$ & Ded 6,10 & $: 2.5 .1$ \\
\hline Rostack & $03-05-1956$ & Uas III $\mathbb{1 1 7}(164)$ & : \\
\hline $\operatorname{Sun} 1$ & $18-01-1957$ & Uas III $123(173)$ & $: 2.5 .1$ \\
\hline
\end{tabular}

4. Kretsgericht

Ascher leben 18-03-1957

Bad Langensaliza 20-08-1958

Berruau

Buchofswerda

Bitcerteld

Dessau

Naumburg/Salie

Drantenburg

Prenzlauer-

berg (StBG)

Prentiauer -

berg (StBG)

Sangerhausen
$26-04-1956$

$22-12-1958$

$24-11-1960$

$23-04-1958$

$04-08-1958$

$23-02-1956$

$97-04-1960$

$15-09-1961$

13-02-1958

$28-03-1960$
UaS III $124(176): 2.5 .1 .1$. JaS $\mathbb{H} 98(165): 2.5 .1 .3$. Der Schöffe $1956,258: 2.5 .1 .1$. UaS IV $99(166): 2.5 .1 .3$. Uas IV $103(171): 2.5 .1 .3$. Ddu $4,5: 2.5 \cdot 1.3$. DdU $4.7 .7 \quad: 2.5 .1 .3$. UaS III $118(165): 2.5 .1 .1$; 2.7 .

DdU 5,7

$: 2.5 .1 .2$.

Ddu 6,5

Ddu 4,9

Ddu 5,5
$: 2.5 .1 .3$.

: 2.5.1.3.

$: 2.5 .1 .2$. 
C. Nederland

1. Hoge Raad

$03-12-1984$

W. 6585

$09-03-1979$

N 1979,363

$: 4.4 .2$.

:4. 4.2.

2. Rewhbornk

\section{Arosterdam}

(President)

$08-03-1978$ N.J 1978,281

$=4.4 .2$.

Amsterdati

23-04-1981 RvdW/KG 1981, $54: 4.4 .2$.

D. Faad van Europa

Europese Commitie poor de Rechten wan de Mens

$\begin{aligned} 20-07-1957250 / 57 \quad & \text { Xearbook of the European : } 3.8 .3 . \\ & \text { Commlsston of Human R1ghts I } \\ & (1955-1956-1957), p \cdot 222 \text { e.v. }\end{aligned}$

E. Verenigde Waties

Intemationaal Gerechtshof

$\begin{array}{lll}27-08-1952 & \text { ICJ-Reports } & \text { Rights of Nattonals of }: 4.3 . \\ 1952,175 & \text { the United States in } \\ & & \text { Morocco }\end{array}$




\section{Zakenregister}

anbtenaren: $2.5 .2 ; 3.2 .6 ; 3.2 .7 ; 3.6 .6 ; 3.7 ; 4.1 .3$. bultenlanders: $2.10 .1 .1 ; 3.8 .1 .1 ; 3.9$.

censum: $2.6 .1 ; 3.4 ; 3.6 .2 ; 4.2 .4$.

Comfte voor de Rechten van de Mens: $1.4 .1 ; 2.10 .3 ; 3.8 .3$; 4.3 .

democratie

- boctallstische: $1.1 ; 1.3 .2 ; 2.2 .3 ; 4.1 .1$.

- trijalbare: $3.2 ; 3.2 .6 ; 3.6 .6 ; 3.7 ; 3.8 .3 ; 4.1 .1 ; 4.1 .2 ;$ $4.1 .3 ; 4.2 .4 ; 4.2 .5 ; 4.2 .6$.

eer, persoom 11 jke: 1.4.1.2; $2.8 ; 3.4 .1 ; 3.4 .3 ; 3.4 .3 .3 ;$ $3.6 .1 ; 3.6 .1 .1 ; 3.8 .1 .3 ; 4.2 .3$.

enigrat leverzoek: $2.5 .1 .2 ; 2.5 .1 .3 * 2.7$.

grondplichten: 2.3 .3 .

grondrechten

- beperking van: $2.3 .3 ; 2.4 .2 ; 2.10 .1 .3 ; 3.8 .1 .3 ; 4.3$.

- en democratie: $1.1 ; 4.3 ; 4.4 .1 ; 4.4 .3$.

- dubbele karakter: $1.2 .1 ; 3.3 ; 3.4 .5 .2 ; 3.5 .5 ; 3.5 .6$.

- klassenkarakter: 2.3 .1 .

- al subjectleve rechten: $1.2 .1 ; 2.3 .3 ; 3.4 .5 ; 3.5 .5 ; 3.5 .6$; $4.2 .3 ; 4.2 .4$.

- 1.s reflextechten: $1.2 .2 ; 3.5 .1 ; 3.5 .2 ; 3.5 .6$.

- verwerking van. 3.2.5.

grondrechts theorte

- democrat 1 sch-functionele: $1.2 .1 ; \quad 3.5 .2 ; 3.5 .8 ; 4.2 .1$; 4.2 .2 .

- Institutionele: $1.2 .1 ; 3.5 .1 ; 3.5 .3 ; 3.5 .4 ; 3.5 .5 ; 3.5 .7$; $3.5 .7 .5 ; 3.5 .8 ; 4.2 .2 ; 4.2 .3 ; 4.2 .6$.

-klaglek-11berale: $1.1 ; 1.2 ; 2.3 ; 2.3 .3 ; 3.3 ; 4.1 .2 ; 4.1 .3$; $4.2 .2 ; 4.2 .3 ; 4.2 .4 ; 4.2 .6 ; 4.3 ; 4.4 .2 ; 4.4 .3$.

- saclallatische: $1.3 ; 2.3 ; 2.3 .3 ; 2.10 .2 ; 4.2 .1 ; 4.3$.

Gronds lagenverdrag: $1.4 .2 ; 2.11 ; 3.9$.

Informat levr the1d: $1.3 .2 ; 2.7 ; 2.10 .1 .2 ; 2.11 ; 3.4 .5 ; 3.6 .2$; 4.3 .

klachtrecht, Individuee $1: 1.4 .1 .4 ; 2.10 .3 ; 3.8 .3$.

kungtwr1 jheid: $1.2 .1 ; 3.6 .1 .2 ; 3.6 .5$.

materlalime, historisch: $2.2 .2 ; 2.6$.

miltalren: $3.2 .6 ; 3.2 .7 ; 3.6 .6 ; 3.7 ; 4.1 .3$.

naturrecht: $1.1 ; 1.2 ; 1.2 .2 ; 2.3 .1$.

onroepvr1 thetd: $2.6 ; 3.4 .5 ; 3.5 .9$.

oorlogepropaganda: $1.4 .1 .2 ; \quad 2.4 .2 ; \quad 2.5 .1 .4 ; 2.10 .1 .4 ;$

3.8 .1 .4 .

part Jverbod: $3.2 .3 ; 3.2 .4 .2 ; 3.2 .6 ; 3.6 .2 ; 3.8 .3 ; 4.1 .3 ;$

4.4 .2 .

persconcentratie: $2.6 .1 ; 3.5 .7 .5$.

persoon $1 \mathrm{t}$ jkhetdsecht

- algemeen: $3.6 .1 .1 ; 3.6 .1 .2 ; 3.7 ; 4.4 .3$.

- soclal1stinch: 2.3 .3 .

perswr 1 jheld: $2.6 ; 2.10 .1 .3 ; 3.4 .5 ; 3.5 ; 3.6 .1 ; 4.2 .3 ; 4.3$.

recht soederena fweging: $3.4 .1 ; 3.4 .3 .2 ; 3.7$.

Report, Intt1a1: $2.3 .1 ; 2.10 .3 ; 3.8 .3 ; 4.3$. 
Slatacte van Helsinki: 1.4.2.

statsweillgheld: $1.4 .1 .2 ; 3.5 .7 .13 ; 3.6 .2 ; 3.6 .6$.

statenklachtrecht: $1.4 .1 .4 ; 2.10 .3 ; 3.8 .3$.

Verdrag

- Europees Verdrag tot bescherning van de Rechten van de Mens en de Eundarentele Vrijheden: $3.6 .6 ; 3.8 .1 .1 ; 3.8 .2 ; 3.8 .3$; 4.4 .3$.

- International Verdrag Inzake Burgerrechten en Polftieke Rechten: $1.4 .1 ; 2.10 ; 3.8 ; 4.3 ; 4.4 ; 4.4 .3$.

- Verdrag tot Ultbanning van alle vormen van Rassendiscrimina te: 4.4 .2 .

vergunn Ingenstelsel: $2.6 .1 ; 2.10 .1 .3 ; 4.2 .4 ; 4.3$.

waarheidswinding: $2.4 .1 ; 3.4 .4 .1 ; 3.4 .4 .3 ; 3.5 .7 .10$.

Wer cordnung: $1.2 .1 ; 3.2 .2 ; 3.3 ; 3.4 .1 ; 3.4 .2 ; 3.4 .3 .2 ; 3.4 .5$. Wertsystem: $1.2 .1 ; 3.6 .2$.

Wert theorle: $1.2 .1 ; 3.3 ; 4.2 .6$.

wetten, algemene; $3.4 .1 ; 3.4 .3 ; 3.4 .3 .1 ; 3.6 .3 ; 3.6 .4 ; 3.6 .5$; $4 \cdot 2 \cdot 5$.

werking, horizontale: $2.8 ; 3.4 .1 ; 3.4 .2 ; 4.2 .2$.

wisselwerkingstheor 1 e: $3.4 .1 ; 3.4 .3 ; 3.4 .3 .2 ; 3.6 .1 .1 ; 3.7$; 4.2 .2 . 


\section{Zusammenfassung}

Die Funktion der Meinungsfrelhelt in dern belden deutschen Staaten.

In der traditlonellen Auffassung sind die klassischen Grund-

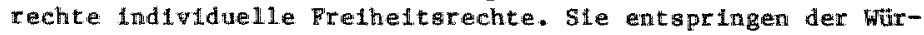
de des Menschen und denen der Individuellen Personllchkeitsentfalcung. Als Abwehrechte sind sie Garantien gegen stat11che EIngriffe. Sile stehen dem Individuum zur frelen Verfügung. Der Individuelle Gebrauch der Grundrechte hat jedoch zugleleh Bedeutung fur das Funktionteren der Demokratie. Das zelgt slch am deutlichsten belm Grundrecht auf freie Melnungsäusugerung. Erst durch die Benutzung dieses Grundrechts funktionlert der demokratische Prozess von Rede und Gegenrede. Wean aber aus der besonderen Bedeutung der Meinungsfre1helt fur die Demokratle verfissungsrechtilche Ronsequenzen gezogen werden, das helsst wenn der Schutz der Melnungsfelhelt bzt. die Intensität dieses Schutzes von gewissen Bedingungen abhäng $1 g$ gemacht wird, besteht die Gefahr, dass dem Charakter des Grundrechts als Abwehrecht Abbruch getan wird. Dle vorllegende Untersuchung beschätigt sich mit der Frage, $a b$ ein solcher Elngeiff in den Charakter des Grundrechts von stateswegen vertretbar 1st, angesichts der Differenzen $2 w 1-$ schen 0st und West uber den Charakter der Grundrechte in der internat Lonalen Menschenrechtsdiskussion.

Auch Im sozlalistischen Staat besteht elne enge Bezlehung zwischen den Grundrechten und der Staatsform, wenglefch es sich hier um eine sozlalistische Grundrechtskonzeption handelt. Elne Auselnandersetzung anlt der Art und Welse, auf der dilese Verblndung im Sozlallsmus gestaltet wird, kenn uns bel der Beantwortung der Frage, ob elne furlstische Anerkennung der Bedeutung der Melnungsfrelheft für die Denokratie zu befüworten 1st, behlifllch selm. Thema dieser Untersuchung ist deshalb die Funktion des Grundrechts der freien Melnungstusserung in der Bundesrepublik Deutschland und in der Deutschen Denokratischen Republik (DDR). Dieser Verglelch garantiert, dass das gesante Spektrum der zur Diskussion stehenden Problematik mesprochen wird.

In der sozlallistischen Avffasisung, wie diese in der DoR vertreten wrd, dienen die Grundrechte nlcht der Abwehr vork vtatitchen Bugriffen, sondern gerade der Elnbezlehung des Individxum: in die Mtigestaltung der sozialist schen GeselIschaftardnung. Ste dienen der Verwliklichung der objektiven Geserzmäsolgkelten des Marxlsmus-Leninlsmus; dlese werden von der Partel der Arbelterklasie festgestellt. In der DDR darf dte Melmungstelhelt nur 1 m Hinbllck auf dieses ziel bentzt werden. Ste erfillt elne demokratische Aufgabe, unter der Berickstchtigung, dass in Sozlialismus Demoktatie eln materleller Begriff ist: Demokratie exlstlert, wenn die Herrschaft 356 der Anbelterklasse uber die Produktlonsmttel hergestelit 
1st. Wur geschitzt sind Melnungsingarungen, die der gesellschaftilchen Funkton des Grandrechts entsprechen, dis helsst dem Aufbau des Sozlialisaus dienen. Folgerichtig werden durch Art. 27 Verf, nur offentliche Melrungsäusserungen geschüt $z^{2}$,

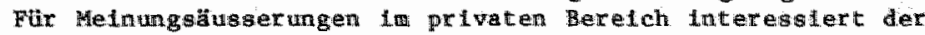
Staat sich im Prinzip alcht. Auch die Presse erfult elne demolkratische Aufgabe. Dle Verantwortung der sozlallstischen Medien ist sogar noch gröser als die derjentgen, die das Grandrecht auf lndwidueller Basis in Anspinch nehmen, wel1 sil die offentliche Melnung gestalten und lenken.

Wer elne Meinung äusert, die nicht mit der demokratischen Aufgabe des Grundrechto überelnstimit, setzt slch der strafrechtlichen Verfolgung aus, meistens wegen statsfelndlicher Hetze oder öffentllcher Herabwürdigung. Darüberhlnaus wird die denokratische Aufgabe der Presse durch eln unfassendes Systen won Genehmigungen gesichert. Nur wer elne statitiche Erlaubuls hat, darf ein Presseorgan grürden. ob elne Genehrigung ertellt wird, llegt ln frelen Ermessen der zustandigen Behorden.

Dile Verfassung der DDR garantiert keine Frelhelt der Informatlon. Nur die Information, die für die Blldung des soztalistischen Bewusstseins unentbehrlich ist, ist gestatet. Allerdings ist das Informationsmonopol der Sozlalistischem Einheitspartel Deutschlands In der Praxis nicht anfrechtituerhalten. Fast iberall in der DDR kann man Radlo- und Fernsehsendungen aus der Bundesrepublik empfangen. Dles lat nicht strafbar. Diese ausland sche Informationsquelle hat in dem letzten Jahren an Bedeutung gewonnen, seft es aufgrund des in 1972 zischen den belden deutschen statten geschlossemen Grundlagenvertrages Rorrespondenten bundesdeutscher Medten gestattet 1st, in der DDR zu arbeiten. Dle Ber 1chterstattung dieser Korrespondenten (in westdeutschen Wedien) über die Verhältulsse in der DDR ist bel DDR-Birgern besonder beliebt.

In der Bundesrepublik ist dle in Art. 5 GG garantierte MeInungsfreiheit an erster Stelle eln Abwehrrecht. Es lat " mit den Worten des Bundesverfassungegertchts, als unittelbarster Ausdruck der menschlichen persönlichkelt in der Gesellschaft etnes der vornehmsten Menschenrechte iberhaupt. Zugleloh ist das Grundrecht jedoch auch gestandtell der objektiven wertordnung, so hat das Bundesverfassungsgertcht festgestellt; für eine frelheitlich-demakratische statsordnumg lat es schlechthin kongtitulerend, denn es ermöglicht erst die ständige gelstige Augelnandersetzung, den Karaf der Melnumgen, der thr Lebenselement ist.

bie objektive Bedeutung des Grundrechts der frelen Melnungsausserung hat sch aut zurel Arten manffertiert.

Erstens hat ste tm Rahmen der streltbaren Denokrat le im Grundgesetz Anerkennung gefunden. Das Grundgesetz hat wh th zu gewlssen unantastbaren Grundwerten der Statisordnung bekant, die entschlossen gegen alle Angriffe von oben und unten verteldigt werden sollen. Elnerselts werden deshalb Elnschränkuggen der polltischen Betatigungsfethelt der Gegner th Kauf genomen. Andwersedes gebletet das Prinzlp der Toleranz, dass mit diesen Elnschränkungen äusserst zur ùckhaltund umgegangen werden soll. Nar die Werte, die fur das Funkt ontreren des denokratischen polltischen Entichelangsprozesses absolut unentbehrlich sind, werden werteldigt. DH.te Werte bllden zu- 
camen die fretheltilche demokratische Grundordung Die Syathese aus dem PrInzlp der Toleranz und dex Bereltschaft zur VerteldLgung der Grundwerte bildet dle atreltbare Demokratie. Diege wetzt num der Inanspruchnahme der Helnungstetheit geWilsm Schramken. Wer das Grundrecht oder einige andere mit dem Grundrecht zusamenhägende, in Art. 18 GG genannt, Grumdrechte zun kapipe gegen die frelheltilche demokratische Grundordnung milibraucht, verwlikt dliese Grundrechte. Auch der Hetrungsefethelt der politischen Partelen sind (tm Art. 21 Abs. 2 GG) Grenzen gesetzt. Sle sind verfassungsidrig, venn te nach thren Zlelen odex nach den Verhalten inrer wnhanger darauf atugehen, die Frelheltiche demokratische Grundordnung zu beelnträchtigen oder zu begeitigen oder den Bestand der Bundesrepubllik zu gefahrden. Für Verelnigungen, die willt Partefen sind, glbt es eine entsprechende Bestim mung. Blsher hat das Bundesverfassungsgericht noch nle elne Verwhong der Meinungsfrethet ausgesprochen. Wohl aber wurden in den Anfangs Jahren der Bundesrepublik die neonazistiche Soztallstische Relchspartel und die Rommuntstsche Partel Deutschlands yon elnem Partelverbot getroffen. Der EInfluss des KPD-Verbotes auf die Individuelle Betätigung der Melnungsfelhelt kam der Verwlrkung glelch. Ir Laufe der Jahre hat die Konzeption der streltbaren Demokratie elne Vervelbatändigung erfahren. Statt eln Versuch zur Lösung der Spannung zwlschen Toleranz und Verteldigungsbereltschaft der Demokratle zu seln, ist die streltbare Demokratie zu elmem Wert an sich geworden. Aus diesem Wert sind neve Verpflichtungen abgeleltet worden. So wird von Beanten und Soldaten erwatet, dass sie Jederzelt aktiv fur die frelheftliche demokratsche Grundordnung eintreten. Wenn bel Beamten oder Anwatern für den offentlichen Dlenst (zum Betsplel aufgrund der M1tgliedschaft elner verfassungstelndlichen Organisation) Zwelfel bestehen, ob sle diese Gewathr bleten können, kann dle Entlassung des Beamten oder Nichteinstellung erfolgen. Dil so verstandene Treuepflicht von Beamten tst elne lm Sinne des Bundeswerfassungsgertchts legale Elmschränkung der Melnungsfrelhelt. Heute witd de Demokratie nicht mehr durch Partelverbote, sondern durch die Trevepflicht der Beamten vertei$\mathrm{d} \lg \mathrm{t}$ *

De finschränkung dex Melnungsfrelhelt im Rahmen der strettbareq Demokratle schwächt den Abwehrcharakter des Grundrechte.

Die zwette Art, In der sich die objektive Bedeutung der Melnungstrelhelt mantestiert, ist eine wom Bundesverfassungsgerlcht beschlossene Aufwertung des Grundrechta, wenn es der Demokratie nitzt. Dles lst der Fall, wenn elne Meinungsausserung zur offentllchen Melnungsbildung belerägt. It Lithurtel1 hat da Bundeswerfassungsgericht elne Methode zur Lösung von Konfllkten zwischen tem Grundrecht und anderen Rechtsgutern

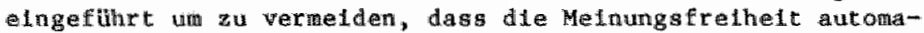
tusch von fligenelner Gesetzen in Sinne des Art. 5 Abs* 2 GG alngeschränkt werden könnte. Bs findet elne Wechselwirkung in dem Stme stat, dass die Gesetze, die die MeInungafrellheit elnschraken dirfen - well sie den schutze elnes Gemelnschaftswertes dilenen, der gegenüber der Betätlgung der Melnungsfethelt den Vorrang hat - , aus der Erkenntnlo der wertsetzenden Bedeutung dieses Grundrechts in fretheltilchen demokratischen staat ausgelegt und so in threr das Grundrecht 
begrenzenden Wirkung selbst wieder elngeschränt werden missen. Whrend der darauf folgenden Gutrerabugăgung In Einzelfall zwischen der Meinungstelheit und dem in Kontlikt dazu stehenden Gemelnschaftswert muss der letztere in der Regel zuribktreten, wenn elne Meinungsăusserung zur Blldung der offentlichen Kefnung belträgt. Die Anerkennung dex objektiven Bedevtung der Melnungs fretheit durch das Bundesverfassungsgrleht hat verschiedene Konsequenzen gehabt. Erstens ist aus der objektiven Bedeutung die Drittwirkung des Grundrechts abgeleltet worden. Zweitens bildet der objektlue Nertgehalt der Meinumgstelheit eln wilkomenes thegengewicht tu dem zahlreichen Einschrankungen, denen die Melinungatretheit ausgesetzt 1st. Das Ausmass dieser Restrlktionen hat selnen Ursprung in dea gletchen Bestreben, die Dentokratle zu schitzen, dem auch der Schwathung des Abwehrcharakters des srundrechts Im Rahmen der streltbaren Demokratie zugrundegelegen hat.

Der Wechselwlikungstheorle ist es zu verdanken, dasis Einschräkumgen der Melnungsfrethelt zun Schutz der Demokratie (zun Belspiel die Strafbarkelt bestimter Melnungsäusserungen, die das Thema Gewalt betreffen, strafrechtliche Elnschrafnkungen zu Schutze des Staates und Elngchränkungen der Melnungsfrelheit von Beamen und Soldaten) nicht zwangs läuflg zum zuricktreten der Meinungsfrelhelt fithren. Drittems hat die Anerkennung der objekt1ven Bedeutung des Grundrechts aber auch daru gefthrt, dass die private Melnungsäusserung der Melnungsăusserung mit öffentllcher Wrikung gegenuber an Gewicht verloren hat. Viertens hat die Bedeutung der Pressefrethelt als 1ndividuelle Persönlichkeitsentfaltung lange zelt aus dem Ange verloren zu gehen gedroht. In Literatur und Rechtsprechung ist von elmer öffentliche Aufgabe der Presge in Hinslcht auf die Melnungsblldung und damit Auf da Funkm tionleren der Demokratle ausgegangen worden. Das Bundeswerfassungsgericht hat deswegen elne institutionelle Garantie der Pressefreihelt fur notwendig gehaiten. Zlel dieser Garantie ist ine verstârkter Schutz des Instituts "Frele Presse" in selner ganzen organisatorlachen und redaktlonellen Breite. Wegen der öffentlichen Aufgabe sind aus der Garantle gewisse privileglen, aber auch ptilchten für die presse abgeleltet worden. Das Bundesverfassungsgerlcht hat die subjektlvrechtliche selte der Pressefrethelt lange zelt vernachlassigt, aber letztlich nicht fillengelassen. Dadurch list elne Funktionalisilerung der Presse In Interesse der Denokratie vermieden worden. Die Ausübung der Pressefreihelt 1st 1 t der Bundesrepublik nach wie vor an keine besondere Bedingung gebunden.

Wicht nur die Einschrănkung der Meinungsfrethett im Rahren der atreltbaren Demokratie, sondern auch die Aufuertung dieges Grundrechts fin Lichte seiner schlechthin konstitulerenden Bedeutung füt die Demokratie ist elne Untergrabung des Verstandnisises der Meinungsfetheit als individuelles Fretheltorecht, well die Intensitat des aktuellen Sichutzes vom Nutzeffekt der Melnungabusgerung auf den demokratischen prozess abliang $1 \mathrm{~g}$ gemacht wixd.

In belden deutschen staten hat das Grundrecht auf frele Meinungsinsserung fne demokratische Aufgabe zu erfullen. Allerdings ist die Qualität der Aufgabe unterschledlich . In der DDR handelt slch um elnen materiellen Demokratte- 
begriff. Die Aufgabe der Melnunggitrelite bezleht sich auf die Werwiklichung materieller Herkmale, die zusamen die aozlal1st


Dhenste des Aufbaus der sozlallstischen Demokratie elngesetzt werden.

In Gegensatz zur DDR handelt es silch 1 d det Bundesrepubilk un elnen formilen Demokratiebegriff. Dle Aufgabe bezleht sich auf die Respekterung gewhser formaler Merkstale, ohne die der demokrat Lche Entscheldungsprozess nicht existieren kann. Ueberdies list die Anfgabe negativ formullert. Sle belnhaltet nicht, dass die Helinugefrelhelt ausschliesslich lim Dienste der Demokratle ausgeilbt werden darf: Das Grundrecht dart dann nilcht benutzt werden, wenn die Melnungsäusserung darauf abzllelt den demokratlschen Prozess zu beelntrachtigen oder zu beseltigen. Dazu komm, dass die Meinungstelheit gelber Tell ist der frelheltilchen demokratischen Grundordnung, die verteldigt wird. Die demokratische Aufgabe stellt elne Rahmenbedingung dar, die auf die Erhaltung der Melnungsfretheit gerlchtet 1 t ; hierrit wird kelnesfalls angestrebt, das Grundrecht zu furktionalisteren.

Trotz der unterschledlichen Formulferung der demokratischen Aufgabe in den belden deutgichen Staten und trotz der unterschledilchen ztelrlchtung - in der DDR geht es um die Verteldigung marxistisch-lenintstischer Werte, In der Bundesinapublik um de Verteldigung des denokratischen Prozesses git es elne Gemelnsamkelt: Sowohl in der DDR als auch in der Bundesrepublik werden Melnungsäusserungen, dle auf eine Aenderung des Systems abzlelen, nicht geduldet.

Die DDR und die Bundesrepubilk sind dem Internatianalen Vertrag iber Bürgerllche und Polltische Rechte belgetreten. Ist die demokratische Aufgabe der Melnungsfrethelt mit den Berst1mmungen dieses Vertrages verelnbar?

Art. 19 Abs 1 und 2 ICCPR beinhaltet elne detallilerte Uaschrelbumg des Grundrechts auf frele Melnungsiusserung, Insbesondere der Informationsfretheit. Abs. 3 desselben Artikels erlaubt Elnschränkungen der Meinungsfrethett in Interesse Drltter, der nationalen Sicherheit, der offentllchen Ordnung, der Volksgesundhelt und der Sitten. Diese Elnschränkungsmöglichkeften bleten staaten mit unterschledicher Gesellschaftostruktur die Gelegenhelt, den konkreten Inha1t des Grundrechts den speziflschen Bedirfnlssen thres systemsinapasisen.

Die demokratische Aufgabe der Metnungstrethelt in der DDR kann wohl als elne erlaubte Elnschränkung im Sinn des Art. 19 Abs. 3 ICCPR gesehen werden. Es müssien aber folgende Bedingungen erfullt sein. Gemäss Art. 19 Abs. 3 ICCPR milssen dinschrakningen durch Gesetz festgelegt werden. Auch mus die Struktur des Axt. 19 ICCPR $\mathbb{1}$ th Auge behalten werden: zwerst wird die Frelhelt festgeste11t, dann werden Einschrenkungen zugestanden; Frethelt tot die Regel, Einschräkungen sind die Ausnahme. Schllesslleh verbletet Art. 5 Abs. 1 ICCPR Elnschrabungen, die so welt gehen, dass dadurch die Fretheft fakt 1 ch a fuehoben wirde. Es lst fraglich, ob Art. 27 Verf. den letzten beiden forderungen Centige lelotet. Ausnahne und Regel sind in der allgemetnen Garantie der Metrungsäusserungsfethelt nicht won elnander getrennt. Der Satz, dass 
Jeder Bürger das Recht hat, "den Grundsätzen dieser Verfas-

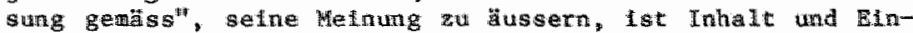
schränkung zugleleh, die Einschränkung bedinge den Inhalt; sle beelntrachtigt die Substanz des Gruntrechts. Auch mit der Bindung der Pressefreihelt an eine Genehnlgungspflicht verstöst die DDR gegen Art. 19. TCCPR. Aufgrund dleser Bestitin mung ist die Ausübung der Pressefrelheit in Pringip erlaubt, kann aber unter bestlmben thstanden elngeschräkt werden. In der DOR ist es genau umgekehrt: Dle Ausibung der Pressefrelhelt ist la Prindp verboten, kanm jedoch genehrigt werden; die Elnschrankung ist also die Regel, die Fretheit ist die Ausnahme.

Die demokratische Aufgabe der Meinungstrelhelt in der Bindesrepublik tst sowohl den Inhalt als auch der for nach elne erlaubte Elaschränkung des Grundrechts in Sinn des Art. 19 Abs. 3 ICCPR. Die Bundesrepublik kann sleh ausserdem auf Art* 5 Abs. I ICCPR berufen. Dleser Artikel verbletet nicht nur dem Staat die Frelhelt sowelt elnzuschränen, dass sle faktlsch aufgehoben wrd, sondern auch Gruppen und Persomen werden Aktivitaten, die die Beseitigung der in Vertrag garantierten Rechte zum Ziel haben, untersagt.

Es 1st Festgestellt worden, dass die Gestaltungswelse der demokratischen Aufgabe $4 n$ der DDR und die Regelung det Fressefrefhelt wicht mit Art. 19 XCCPR verelmbar sind, Die DDR hat nun affgrund des Art. 2 Abs, 2 ICCPR die pellcht, die Gesetzgebung $t$ Art. 19 ICCPR in Elnklang zu bringen, was bisher ntcht geschehen ist. Damit die Birger der DDR In umfassende Nutznlessung von Axt. 19 ICCPR gelamgen, wäre elne Ampassung erforderlich, angeslchts der Tatsache, dass die DDR das Recht des Elnzelnen, slch anf dle dazu geelgneten Bestinungen des Vertrags direkt zu berufen, vernelnt. Dle DDR hat weder das Klagerecht von Staten noch das individuelle klagerecht anerkannt. Sonft rouss die einzige kontrolle uber die Handhabung des Vertrages in der DDR im Menschenrechtskonttee stattinden. Diese Kontralle ist lelder ntcht sehr effektiv, die blsherlge Behandlung der DDR-Berlchterstattung Im Komltee zelgt. Und selbst wenn die DDR dazu gebracht werden könnte, die denokratische Aufgabe der Melnungsfrethett den Anforderungen des Art. 19 ICCPR entsprechend zu regeln, darn noch bllebe die Aufgabe bestehen.

Fine Interpretation der EInzelbestimmungen des Vertrages, die eine solche Aufgabe zulasst, konnte nur durch Verwelsung auf selne Zlelsetzung, die aus der Präambel hervorgeht, vermleden werden. In der Präanbel flndet man dle Anerkennung, dasi die fm Vertrag garantierten Rechte der Würde des Menschen entspringen und dass Jedes Mitglied der Gemelngehatt Her Menschen th gleichen und unverfremdbaren Rechten ausgestattec 1.t. Das Grundrecht auf frele Mellnungsälusserung mus also von der tradtitonellen Grundrechtsaffassung heraus werstanden werden: es dient der Indiwduellen PerönIlchkeitsentfaltumg. Elne Funktionalielerung des Grundrechts, wie dles 1 der DDR durch die demokratische Aufgabe geschleht, ist oit der zlel deg Vertrages nlcht verelmbar. Dieses Argunent wid aelbstverständ1ch nur uberzeugend in die internationale Menschenrechtsdisussion elingebracht und von anderen ernst genonmen werden können, wenn die westlichen Demokratien olbst de traditionelle Auffassung respektieren und befolgen. Aus die- 


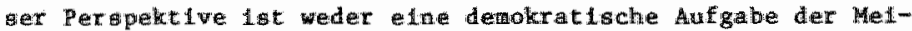
nungfrethet im Rahmen der streltbaren Demokratle akzeptabel, noch rine Prtvlleglerung von Melnungsüuserungen, die der Demokratle nitzlleh stnd, wie dies in der Bundesrepublik der Pall 1st - obwohl vertändlich aufgrund der geschichtlichen Exfarungen und verelinbar mit Art. 19 ICCPR. Solche Elngriffe In die Melnungsfrethet schwehen die Forderung auf Intermatonaler Ebene, das Grundrecht als individuelles Frelheltsrecht zu respektieren.

Aus diesen Grund muss auch 1 a den wederlanden sowoth the Möllchkelt zum Verbot bestmiter polltischer Partelen (selen ale antidemolratisch oder rassistisch) als auch die Privileglerung von Melnungabuserungen, wenn ste der Demokratie dienen - "public speech" - abgew lesen werden. 


\section{Curriculum vitae}

Arjen wan R1jn werd op 6. Jul1. 1956 te Alphen aan den Rijn geboren. Van 1968 tot 1974 bezocht hil het Christell jk Lyceum in deze gemeente. Wa het behalen wan het Gymasium A-diploma studeerde h1j van 1974 tot 1979 Neder lands Recht met Internationaluechtel1jke afstudeerrichting aan de Rijhsundversitelt Utrecht. Vervolgensi was hif als jongerenvertegenwoordiger lid van de Koninkrijksdelegatie nar de 34 ste Algemene Vergadering van de Verenlgde Naties te New York. Na de werwulling van de milltaire dienstplicht verrichte hij van 1981 tot 1983 een promotie-onderzoek an de Rhelnische Friedrich-withelmsUnlversität te Bonn. De auteur is thans werkzaam als journa11 st. 